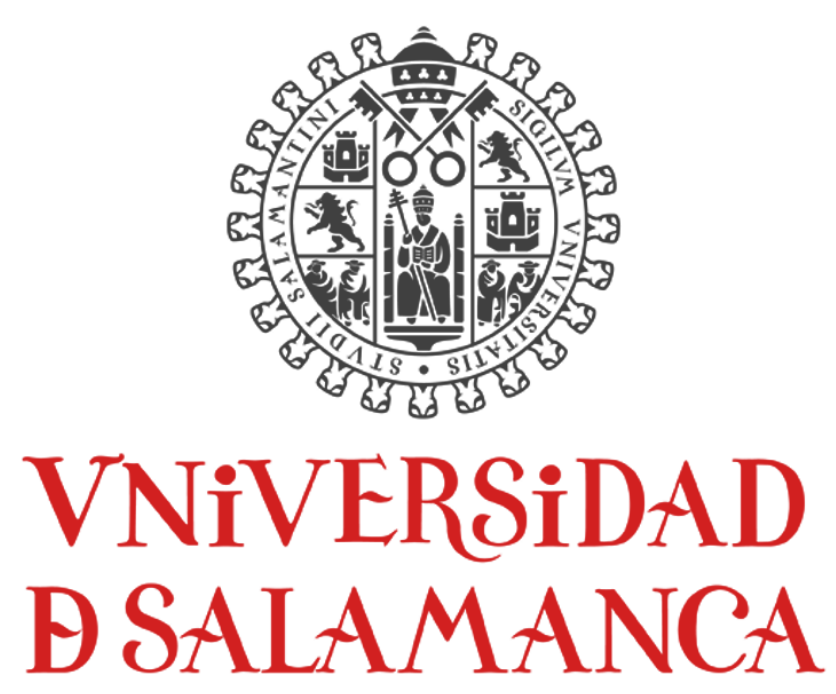

TESIS DOCTORAL

Programa de Doctorado “Pasado y Presente de los Derechos humanos" Facultad de Geografía e Historia

DePartamento de Historia MEdieval, Moderna y CONTEMPoránea

\title{
HISTORIA Y MEMORIA DEL MOVIMIENTO DE DERECHOS HUMANOS DE TUCUMÁN (1977-1999)
}

TRAYECTORIAS MILITANTES DESDE LA DICTADURA A LA LARGA TRANSICIÓN VIGILADA EN EL NOROESTE ARGENTINO

Autor: RUBÉN ISIDORO KOTLER

Directora: Dra. JOSEFINA CUESTA BUSTILlO 
Vo B $^{\circ}$ DIRECTORA DE TESIS:

Fdo.: Dra. Josefina Cuesta Bustillo 


\section{Agradecimientos:}

A Josefina Cuesta por la generosidad permanente. A Pablo Pozzi por el apoyo de siempre. A José María Rodríguez Arias por estar cerca en todo momento. A Walter Soria y al Archivo Histórico de la Universidad Nacional de Tucumán por el apoyo para terminar el trabajo. A José Luis De Pero, por las correcciones. A mis compañeros de la Asociación de Historia Oral de la República Argentina por haber aprendido de ellos. A la Red Latinoamericana de Historia Oral de la cual pude valorizar la importancia de recuperar las voces de nuestros pueblos. A mis hermanos en el afecto: Adolfo y Diego. A mis compañeros de cátedra por la paciencia. A Zulma y Manuel, amigos entrañables que siempre están cerca. A Alejandra García Araoz con quien puedo conversar de estos temas críticamente. A Carol Solís, Cecilia Azconegui, Marianela Scocco, Luciano Alonso y Liliana Barela, con quienes compartimos experiencias en el campo. Un agradecimiento muy especial a los entrevistados cuyos testimonios me enseñaron y señalaron el camino. A los militantes de las organizaciones de derechos humanos de Tucumán cuya historia procuro dar a conocer y cuya memoria obstinada se niega al olvido. 


\section{Dedicatoria}

Dedico esta tesis muy especialmente a mi madre, Sara Silvia Barengols y a la memoria de mi padre, Abraham Kotler, quienes iluminaron el camino de mi carrera y me apoyaron permanentemente. 


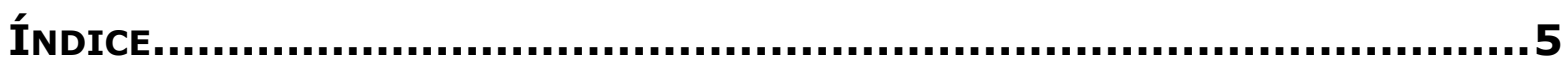

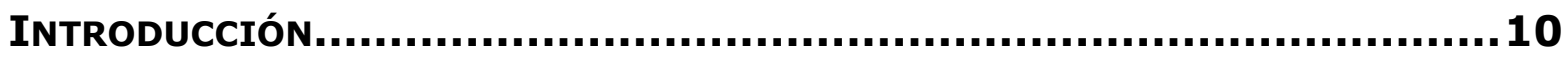

Parte I: Metodología, Fuentes y Memoria....................................26

CAPÍTULO I: ALGUNAS CONSIDERACIONES METODOLÓGICAS..........................27

I.1 Memoria, entrevistas y fuentes orales: Un estado de la cuestión........27

I.2 Una perspectiva desde la historia oral................................... 32

I.3 Las fuentes orales: una valoración de las entrevistas....................46

I.4 Las fuentes primarias escritas..........................................61

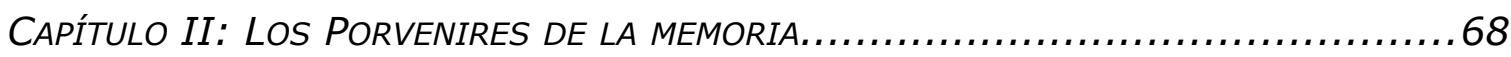

II.1 La Memoria de los "familiares"........................................68

II.2 El pasado traumático entre la memoria y el testimonio....................76

CAPÍTULO III: LOS DERECHOS HUMANOS Y LOS NUEVOS MOVIMIENTOS SOCIALES........79

III.1 Algunos lineamientos teóricos........................................79

III.2 El movimiento de derechos humanos en Argentina: Un estado de la

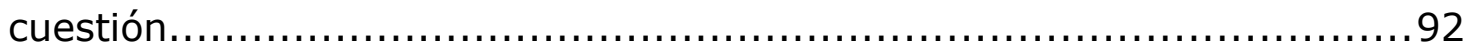

PARTE II: TUCUMÁN EN PERSPECTIVA HISTÓRICA.............................106

CAPÍTULO IV: TUCUMÁN, ENTRE 1966 y 1976.....................................107

IV.1 La antesala del horror.............................................. 107

IV.2 El golpe de Onganía: consideraciones generales.......................111

IV.3 "Tucumán Arde", o la toma de conciencia.............................121

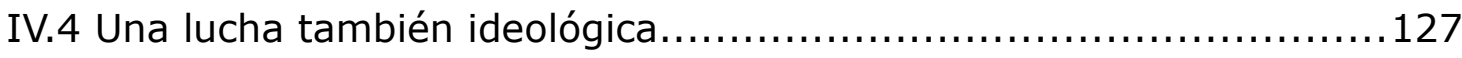

CAPÍTULO V: EL INTERREGNO PERONISTA Y EL OPERATIVO INDEPENDENCIA............132

V.1 La Provincia de Tucumán: de la dictadura a la democracia, a la dictadura.................................................................. 132

V.2 El plan sistemático y la modalidad represiva.............................138

V.3 Algunas precisiones sobre la "última" dictadura militar argentina.....144 
V.4 Acerca de las Prácticas Sociales Genocidas............................ 149

V.5 Las desapariciones forzadas y el circuito represivo en Tucumán.......157

V.6 Las desapariciones en la memoria de los familiares...................161

V.7 "En algo andaban": tipología de los desaparecidos....................174

V.8 La poesía como refugio en el sostenimiento de la Memoria de los desaparecidos............................................................ 180

CAPÍTULO VI: LA IRRUPCIÓN Y DESARROLLO DEL BUSSISMO (1975 - 1999)...........186

VI.1 De la dictadura a la transición $(1975$ - 1983)......................186

VI.2 Evolución del Bussismo desde 1983 hasta $1999 . \ldots \ldots \ldots \ldots \ldots \ldots \ldots \ldots . . \ldots 193$

\section{PARTE III Historia y memoria del Movimiento de DeRechos Humanos} EN TUCUMÁN........................................................................... 200

CAPÍTULO VII LOS ORÍGENES DEL MOVIMIENTO DE DERECHOS HUMANOS EN TUCUMÁN201 VII.1 El surgimiento del Movimiento de DDHH en Argentina...............201 VII.2 Esfera doméstica, ámbito privado..............................213

CAPÍTULO VIII: LOS ORÍGENES DEL MOVIMIENTO DE DERECHOS HUMANOS EN TUCUMÁN:

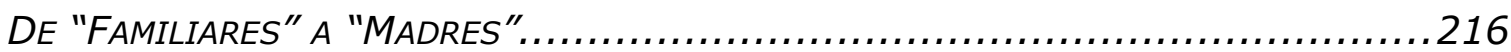

VIII.1 El surgimiento de Familiares de Presos por Razones Políticas.......216 VIII.2 La visita de la Comisión Interamericana de Derechos Humanos. Un punto de inflexión.

VIII.3 De la inmovilidad de Familiares al surgimiento de Madres en Tucumán. La primera ruptura. 230

VIII.4 La aparición de La Asociación de Abogados por los Derechos Humanos y la APDH en la larga transición vigilada.

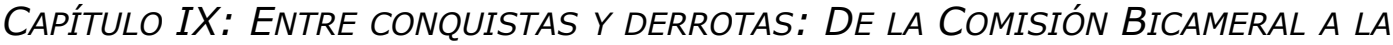

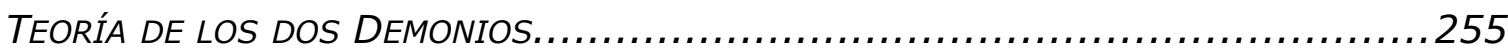

IX.1 La Comisión Bicameral, una experiencia en Tucumán.................255

IX.2 Algunas consideraciones sobre el Informe Bicameral...............266

CAPÍTULO X: ENTRE LA LEGALIDAD Y LA RITUALIDAD...............................280

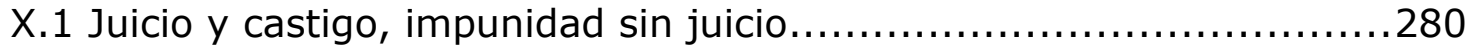

X.2 Punto Final, Obediencia Debida e impunidad adquirida................286

X.3 Del 24 de marzo al 10 de diciembre, lo ritual y lo simbólico...........292 
HISTORIA Y MEMORIA DEL MOVIMIENTO DE DERECHOS HUMANOS DE TUCUMÁN (1977 - 1999) ÍNDICE

Capítulo XI: El mDHT frente al Ascenso del General antonio Domingo Bussi 304

XI.1 Palito "Ortega" o Antonio D. Bussi, y el retroceso del MDHT...........304

XI.2 Entre lo simbólico y lo real: el juicio ético y el retorno del General. 308

XI.3 La Lectura de la "sentencia": lo real y lo simbólico..... 324

CAPÍTUlO XII: H.I.J.O.S., UNA NUEVA GENERACIÓN EN EL MDHT.................333

XII.1 El nacimiento de los "Hijos" ....................................... 333

XII.2 La identidad en la constitución de H.I.J.O.S. Tucumán................342

XII. 3 ¿Aceptar las reparaciones o no aceptarlas? También esa fue la cuestión

CAPÍTULO XIII: LOS '90 y LAS MEMORIAS ENFRENTADAS.......................... 354

XIII. 1 La Justicia llega de allende los mares............................... 354

XIII.2 memorias en pugna en las calles, en los juzgados y en la prensa.357

XIII.3 El primer escrache de H.I.J.O.S. en Tucumán

XIII.4 Un nueva crisis del MDHT y el principio del fin del Bussismo. El camino a una nueva transición

CONCLUSIONES. 387

A MODO DE EPÍLOGO 400

Índice de Abreviaturas. 407

ANEXO DOCUMENTAL 408

Anexo 1 Extracto del expediente judicial con la causa sobre el "Cuerpo de Delegados" de la Facultad de Bioquímica, Química y Farmacia de la Universidad Nacional de Tucumán. 409

Anexo 2 Reproducción del documento elaborado por la Red Nacional de H.I.J.O.S. el 17 de agosto de 1998 en la ciudad de La Plata

Anexo 3 Transcripción del Panfleto entregado por H.I.J.O.S. durante el escrache a Bussi en octubre de 1998.

Anexo 4 Extracto del debate parlamentario del primero de diciembre de 1999 que trató en Cámara de Diputados la impugnación del diploma de Antonio Domingo Bussi y que finalmente le impidió asumir como legislador nacional.

Anexo 5 Extractos de la Impugnación de la candidatura a intendente de 
San Miguel de Tucumán de Antonio D. Bussi por parte de organismos de derechos humanos.

Anexo 6 Documento del 24 de marzo de 2008 consensuado entre todas las organizaciones de derechos humanos de Tucumán.

Anexo 7 CAUSA: G. VARGAS AIGNASSE s/desaparición: "ALEGATO" de Antonio D. Bussi. 451

Anexo 8 Mapa del Noroeste argentino (NOA). 460

\section{FUENTES} 461

LAS ENTREVISTAS 462

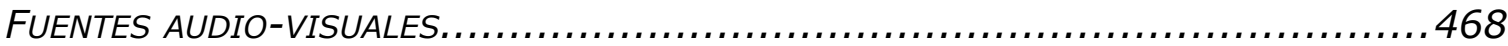

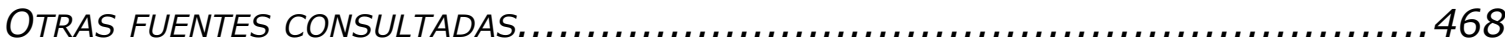

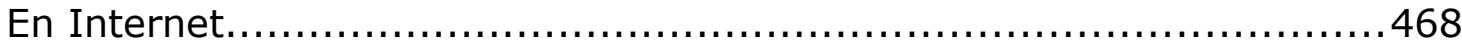

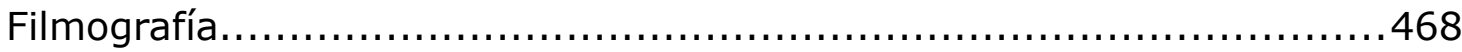

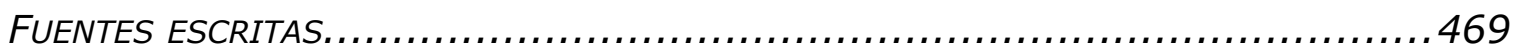

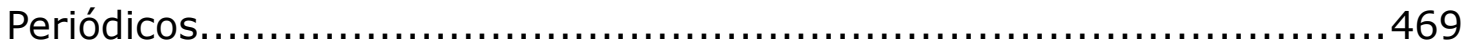

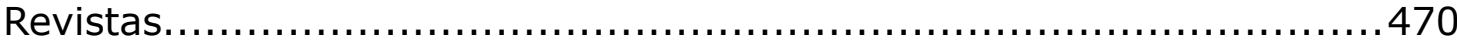

Documentos e informes consultados......................................470

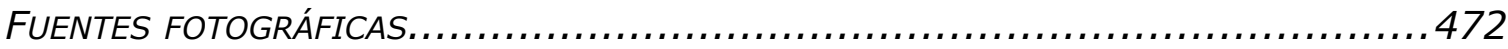

BIBLIOGRAFÍA TEMÁTICA.........................................................480

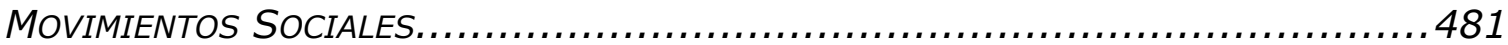

MOVIMIENTO DE DERECHOS HUMANOS............................................4 483

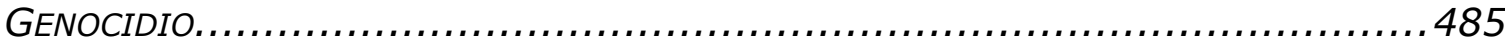

HISTORIA ARGENTINA........................................................... 486

DICTADURA Y TRANSICIÓN EN ARGENTINA..........................................489

DICTADURAS Y TRANSICIONES EN AMÉRICA LATINA.................................496

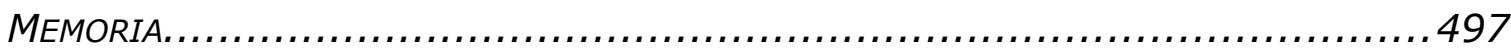

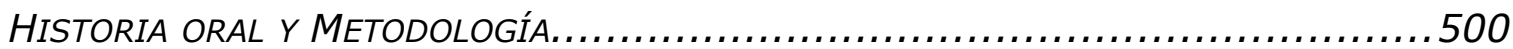




\section{Tu REgRESO*}

Vuelves de la cárcel,

Compañero.

Estás hambriento, herido,

Y con los ojos temblando.

Vuelves de allá,

Donde no sé cuántos días

Has recorrido los tres por tres

Sin el sol

$\mathrm{Ni}$ el amor.

Vuelves de la cárcel,

Compañero,

Con la historia envejecida

De un país prisionero.

Has llegado

Estás entre nosotros

Para decidir el legado

Que nos hizo nuestra gente

Cuando una vez faltabas

Y sin saber por qué.

Por la vuelta, compañero,

Que hay que saber

Que tenemos un nombre

Más allá del silencio.

* Campopiano, Julio César. Secuestrado y desaparecidos a los 18 años, el 21 de octubre de 1976. Alojado en el Arsenal M. de Azcuénaga donde fue visto por última vez. 
INTRODUCCIÓN 
El próximo 10 de diciembre de 2013 se cumplirán 30 años de la reapertura transicional a la democracia institucionalizada en la República Argentina, 30 años desde la asunción del primer presidente constitucionalmente elegido, Raúl Alfonsín, tras la salida del último mandatario de facto, Reinaldo Bignone, después de 7 años de cruenta dictadura. Reflexionar sobre el periodo implica al mismo tiempo bucear en la complejidad de la historia reciente del país y revisar dicho proceso al calor del actual presente imbuido por ese mismo pasado que se procura desentrañar.

Entre 1976 y 1983, gobernó el país la última dictadura militar, heredera de su predecesora, instaurada 10 años antes, en junio de 1966. La dictadura, encabezada por las tres Fuerzas Armadas, implantó por medio del terror un plan económico, social y cultural en el que la matriz neoliberal supuso el eje vertebrador, desestructurando a amplios sectores sociales que se vieron afectados por las medidas impuestas. Por medio de la represión a todo opositor al régimen, el gobierno de facto ${ }^{1}$ aplicó con dureza la imposición de un orden que contribuyó a ampliar las diferencias de clase.

1 Un gobierno de facto (de hecho o non de iure) es aquel que en la práctica ejerce como tal aún no siendo reconocido legalmente. En Argentina es común nombrar a las distintas dictaduras militares con el término de gobierno de facto en contraposición con un gobierno democráticamente elegido por medio de los votos del sistema institucional. Utilizaré por lo tanto este término como sinónimo de gobierno militar o dictadura. 
La transición que se dio paso a partir del 10 de diciembre de 1983 trajo aparejado un conjunto de nuevos problemas y situaciones por las que se vio atravesada la sociedad argentina. Argentina fue el único país que sufrió este tipo de dictaduras en el continente que sentó en el banquillo de los acusados a las máximas esferas del poder militar, responsables de la violación sistemática de los derechos humanos. En contra partida, dicho sector operó sobre el gobierno constitucionalmente elegido en pos de conseguir la amnistía, la cual sería obtenida tras años de presiones en el segundo gobierno constitucional de la transición.

En ese contexto de represión estatal y de una transición vigilada, actuaron en el país un conjunto de organizaciones sociales defensoras de los más elementales derechos humanos. Ante los mecanismos de restricción de las libertades civiles desde el aparato represivo ilegal, se agruparon un conjunto de organizaciones de familiares de víctimas de la represión, que tuvieron una importante presencia en el ámbito público en pos del fin de la cruenta dictadura y por la restitución con vida de los represaliados por cuestiones políticas. Si durante la dictadura este conjunto de organizaciones actuaron con la cautela de saber que el Estado también les vigilaba, la falta de una política en materia de reconocimiento de los principios de "verdad y justicia" durante los primeros años de la transición, les convenció de seguir en la manifestación pública con el mismo espíritu a fin de conseguir sus objetivos, los cuales al mismo tiempo, fueron cambiando en función de los distintos procesos políticos ocurridos en el país.

En los últimos 10 años la transformación operada en materia de revisión de la violación de los derechos humanos en Argentina por parte de los tres gobiernos kirchneristas, contribuyó a variar sustancialmente la forma de ver, analizar y revisar ese pasado, tanto dictatorial como 
transicional, teniendo en cuenta que los procesos judiciales abiertos desde entonces a la fecha en todo el país, vinieron a cumplir con la demanda histórica del movimiento de derechos humanos. Aún con sus limitaciones, que no serán objeto de análisis, el cambio producido en Argentina en la cuestión del reconocimiento del pasado represivo desde el propio Estado ha impactado en el conjunto de militantes de las organizaciones de diferente manera. Es en este panorama en el que me propongo abordar en la presente tesis, una historia y una memoria del movimiento derechos humanos en la provincia de Tucumán, ubicada en el corazón del Noroeste argentino.

Asimismo, en los últimos años se han multiplicado los estudios referidos al movimiento de derechos humanos en la periferia argentina, y ya no es posible hablar de un "movimiento nacional" desde la sola mirada de su desarrollo en la capital del país. Han surgido investigaciones que procuran dar cuenta del devenir histórico de las organizaciones de derechos humanos en provincias como Córdoba, Neuquén, Santa Fe (y las particularidades del caso rosarino), entre las que más se destacan. Otros abordajes han intentado también aprehender como objeto de estudio a grupos de exiliados por razones políticas o bien a colectivos de Familiares exiliados y que contribuyeron a formar organizaciones supranacionales como la Federación Latinoamericana de Asociaciones de Familiares de Detenidos-Desaparecidos (FEDEFAM), fundada en enero de 1981 en Costa Rica.

En este contexto, estudiar a cada colectivo u organización supone establecer las particularidades propias aún en sus fisonomías comunes, siendo el caso más emblemático el de las Madres de desaparecidos, en todas sus vertientes, por la exteriorización que implicó el uso del "pañuelo blanco" como símbolo de lucha. Adentrarme en el movimiento 
de derechos humanos de Tucumán implica la recuperación de una memoria militante que dé cuenta del devenir socio histórico del proceso dictatorial y de la posterior transición democrática desde anclajes meramente locales.

El interés por el objeto de estudio, parte desde la época de mi licenciatura con el inicio de la investigación sobre la historia de la organización Madres de Detenidos-Desaparecidos de la provincia que culminó con la tesina para acceder al grado, defendida en 2002. La continuación y ampliación del estudio referido a todo el movimiento de derechos humanos presume entonces extender la mirada hacia un conjunto de organizaciones que actuaron resistiendo a la dictadura instaurada el 24 de marzo de 1976 y que prosiguieron en su actuación pública durante los años de la larga transición institucionalizada del país en la provincia de Tucumán, una de las más afectadas por el esquema represivo dictatorial.

Mis objetivos en el presente trabajo serán entonces acercarme al estudio del movimiento de derechos humanos de Tucumán desde la experiencia vivida por sus militantes (entendiendo la experiencia en el sentido cómo ha sido desarrollada desde los estudios culturales por Raymond Williams y Edward P. Thompson) por medio de la memoria recuperada a través de testimonios desde la metodología propuesta por la historia oral; analizar las organizaciones de derechos humanos de Tucumán desde la perspectiva sociológica de los nuevos movimientos sociales, buscando comprender las especificidades de este colectivo y, recuperando al mismo tiempo, los clivajes locales que le dieron su fisonomía particular y que nos permite diferenciarlo de otros de similares características en el país; vinculado con lo anterior, deseo indagar los nexos del movimiento de derechos humanos de Tucumán con otros 
movimientos del país, procurando reconstruir las trayectorias personales de sus activistas y los desarrollos generales de cada organización, recorridos que dan al conjunto una coherencia en virtud de la historia provincial; asimismo busco profundizar el análisis del periodo comprendido entre la última dictadura militar y la transición en Tucumán, teniendo en cuenta los escasos trabajos del periodo en cuestión para la provincia norteña y como continuidad de mis trabajos de investigación sobre la historia reciente de la región ${ }^{2}$. Entonces, revisar la historia del movimiento de derechos humanos de Tucumán a partir de la recuperación de una memoria de sus militantes, implica al mismo tiempo aprehender el proceso socio-histórico de la provincia durante el periodo en estudio como adentrarme en lo que le ha sido propio al movimiento: orígenes, desarrollos, acciones, contradicciones, entre otras cuestiones que serán tratadas aquí. Por lo tanto, busco desentrañar cómo, por qué y mediante qué procesos, ha surgido y se ha desarrollado un movimiento de derechos humanos geográficamente localizado, el cual reunió a distintas expresiones entre 1977 y 1999. En definitiva, el interés por ampliar mi investigación hacia el conjunto del movimiento de derechos humanos de Tucumán, tiene que ver con la preocupación de poder comprender cómo afectó la última dictadura militar a la sociedad tucumana y cómo se fue reelaborando un relato de ese pasado dictatorial

2 Procuro aquí profundizar en esta tesis mi trabajo final de tesina, defendida el 9 de julio de 2008 a los fines de obtener la suficiencia investigadora. En aquel trabajo introduje una cantidad de problemas vinculados a la historia y memoria del movimiento de derechos humanos de Tucumán, problemas que serán ampliados en este trabajo con los aportes de nuevas fuentes tanto primarias como secundarias. Asimismo en los últimos años he podido también intercambiar experiencias con colegas que están indagando estas mismas problemáticas pero en distintas provincias, lo que me ha aportado otras miradas y reflexiones sobre un mismo objeto de estudio localizado espacialmente en otras geografías. 
en la transición desde la compleja trama que implicó una apertura institucional atestada de limitaciones.

Desde este último punto pretendo además examinar las relaciones del movimiento de derechos humanos local con una figura "emblemática" de lo que fue la represión dictatorial en Tucumán y que hasta el mismo día de su desaparición física, a fines de 2011, se vio involucrado en todo este proceso, como lo fue Antonio Domingo Bussi, el primer gobernador nombrado por la Junta que ocupó el poder por la fuerza en 1976. Bussi además había emergido como figura política de relevancia en la carrera por la gobernación de la provincia, en la transición, desde fines de los años '80, cuando las distintas políticas de perdón estatal le permitieron participar de la vida democrática del país, sellando su suerte a la casa de gobierno con el triunfo electoral a mediados de 1995. Es así que inquirir sobre los nexos mutuos en los que se construyó una relación conflictiva y compleja entre el militar y las organizaciones de derechos humanos, será un eje fundamental que guiará el trabajo, intentando establecer los puntos de ruptura de lo que algunos sociólogos han denominado "las memorias en conflicto". Me propongo verificar los discursos, las miradas y las acciones que se dieron las organizaciones en la lucha por intentar frenar el avance del Bussismo ${ }^{3}$ y al mismo tiempo las distintas estrategias de las que se sirvieron para sostener el reclamo por verdad y justicia, dos de los motores fundamentales que guiaron a todo el movimiento. La verdad como la revisión misma del pasado reciente y la justicia como aquel mandato ético de lo que no debe repetirse y merece ser sancionado.

3 Bussismo es la forma que adoptó en Tucumán el autoritarismo, referido a determinadas prácticas que partieron desde el propio dictador devenido en político, Antonio D. Bussi. Volveré sobre dicho concepto en el cuerpo del trabajo. 
Mi objetivo central entonces será ubicar los repertorios de acción local y los propios de cada organización y los vehículos que llevan a determinar la conformación de un colectivo mayor englobado en lo que aquí denomino el movimiento de derechos humanos de Tucumán. Memoria e historia no son sinónimos, pero sólo a través de la primera es posible acercarse a la segunda, en relación a los trayectos trazados por los actores sociales, militantes de un movimiento más amplio, que abarcó, en líneas generales, a casi todo el territorio argentino.

La historia del movimiento de derechos humanos en Tucumán si bien hunde sus raíces en la última dictadura militar y en los primeros años de la llamada transición democrática, debe ubicar sus orígenes en los tiempos en que comenzaron a violarse sistemáticamente los derechos fundamentales en la provincia. En este sentido planteo como hipótesis que el Movimiento de Derechos Humanos en Tucumán tiene los umbrales de su nacimiento en 1974 cuando se denuncian los primeros secuestros y se producen las primeras desapariciones forzadas de personas por parte de la conocida Alianza Anticomunista Argentina, (la denominada "Triple $\left.A^{\prime \prime}\right)$ aparato parapolicial que funcionó durante el gobierno de Isabel Martínez de Perón, y, sobre todo a partir de febrero de 1975, cuando se institucionalizó la represión en la provincia con el decreto oficial y secreto del Operativo Independencia que "ordenó" al ejército argentino a realizar operaciones con el firme propósito de terminar con la oposición política y social del régimen.

Aunque la primera organización reconocible en la provincia surge a mediados de 1977, el proceso político que precedió a esta fecha supuso el comienzo del plan sistemático para terminar con la oposición política a un proyecto instaurado en 1966, cuando la dictadura encabezada por el General Juan Carlos Onganía asaltó el poder y destituyó a quien fuera el 
entonces presidente, Arturo Ilia. De estas dos últimas dictaduras militares ${ }^{4}$, se gestó un movimiento de resistencia que reclamaba por las libertades civiles coartadas a partir del esquema represivo previsto por las esferas del poder. Producto de la represión organizada y planificada desde el Estado se produjeron secuestros seguidos por la desaparición de los opositores y comenzó, al mismo tiempo, el reclamo de los familiares por conocer el paradero de los represaliados.

El inicio y la historia del Movimiento de Derechos Humanos de la provincia de Tucumán, a su vez, estará estrechamente vinculado a la historia de lo que denominaré el Bussismo, surgido a fines de 1975, y que podemos situar hasta la actualidad. En este sentido es que, a diferencia de otras organizaciones similares del país, las organizaciones de derechos humanos de Tucumán, centraron sus acciones hacia quien fue el primer gobernador de facto, durante los comienzos de la última dictadura y quien luego ocupó la gobernación de Tucumán, ya en democracia, entre 1995 y 1999. Si durante la dictadura el reclamo consistió en la aparición con vida de sus familiares represaliados, durante la transición en Tucumán, las acciones de las organizaciones de derechos humanos centrarán su mirada en la figura de Bussi con quien confrontará en distintos momentos hasta inclusive los primeros años del nuevo siglo.

Las organizaciones de derechos humanos de la provincia de Tucumán se originaron y desarrollaron sobre clivajes locales y la historia del movimiento debe vincularse de manera directa con lo que fue $y$ simbolizó el Bussismo, tanto durante los años de la represión dictatorial,

4 Cabe recordar que durante el S. XX la Argentina se vio atravesada por seis gobiernos militares que violentaron el orden constitucional, unos más violentos que otros, siendo los dos últimos, el instaurado el 28 de junio de 1966 y el 24 de marzo de 1976, una suerte de continuidad en términos de proyecto económico, social, cultural y político. 
como así también durante los años de la transición, en la que el propio Bussi fue un actor principal en el marco del proceso político provincial.

Es en esas experiencias locales donde hay que buscar los vínculos que se consolidaron en lo que el sociólogo inglés, Raymond Williams, llamó "las estructuras del sentir" y que me permiten entonces hablar de un movimiento social particular, identificable y reconocible en el conjunto de organizaciones que lo componen, con sus rasgos y fisonomías propias y específicas.

Mientras el espacio geográfico de la investigación estará limitado a la provincia de Tucumán, el tiempo estará marcado por las sucesivas etapas del desarrollo de la historia del Movimiento de Derechos Humanos local. Comenzaré abordando de manera general el periodo de la autoproclamada Revolución Argentina, con la dictadura militar que gobernó entre 1966 y 1973, para luego analizar el breve interregno peronista, donde el llamado Operativo Independencia en 1975, resulta un suceso clave en el nacimiento de las primeras organizaciones de derechos humanos.

A continuación me adentraré ya en concreto en las distintas fases que conforman el marco temporal en el que emergieron, desarrollaron y actuaron las diferentes organizaciones de derechos humanos que conforman el colectivo local. Comenzaré con el periodo enmarcado en la última dictadura militar, entre 1976 y 1983, centrándome, sobre todo, en los aspectos autoritarios que afectaron a las estructuras sociales de la provincia y que dieron nacimiento, ya en 1977, a la primera organización de familiares de víctimas represaliadas desaparecidas. Será central aquí el análisis del plan sistemático de desaparición de personas, esquema represivo que comenzó antes de la llegada al poder de la cúpula militar y la memoria de los familiares respecto a dicho pasado. El accionar del 
movimiento en los primeros años del gobierno de facto tuvo que ver entonces con las características que adoptó la represión política con la metodología implementada en la que dar cuenta del circuito represivo resulta imprescindible. Procuraré, en el estudio de este periodo, analizar los cambios desde la constitución de la agrupación de Familiares hasta la primera ruptura producida en su interior, con el desprendimiento, en septiembre de 1981, del grupo de mujeres que conformarán la organización Madres de Detenidos Desaparecidos de Tucumán.

Analizaré posteriormente lo que denomino la larga transición vigilada a la democracia, con sus rasgos y particularidades propias del proceso político provincial, escudriñando las continuidades y rupturas en el accionar del movimiento de derechos humanos, respecto al periodo precedente. Indagaré sobre las características propias de la transición en la provincia. Para esta última etapa el trabajo se dividirá en los tres momentos que dan consistencia a la relación de las actuaciones del movimiento de derechos humanos en relación con el Bussismo: el primero de 1983 a 1987, sub-periodo establecido por la reapertura democrática institucionalizada y donde el eje de campaña y los primeros actos del gobierno provincial se centraron en la cuestión de los derechos humanos. En este lapso para Tucumán fue clave el surgimiento de nuevas organizaciones de derechos humanos y la creación desde el Poder Ejecutivo Provincial de una Comisión parlamentaria local investigadora de las violaciones de derechos humanos en la provincia. Analizaré entonces las implicancias de dicha Comisión en el terreno del movimiento de derechos humanos local desde la articulación en la ayuda prestada por los integrantes de las organizaciones, sobre todo en la recogida de testimonios tanto en la ciudad capital como en el interior provincial, que dio cuenta del horror producido por la represión de los años previos. 
El Juicio a las Juntas completa el panorama de lo que considero una primera victoria política del movimiento, seguida de una primera y compleja derrota del lustro siguiente que dará marco al segundo subperiodo en el abordaje de la historia del movimiento, enmarcado entre 1987 y 1991, con el establecimiento de las leyes de Obediencia Debida y Punto Final y el surgimiento del Bussismo como fuerza política provincial.

Finalmente centraré mi análisis en la década de 1991 a 1999, donde indagaré sobre el fortalecimiento de Antonio D. Bussi como figura política a la par de los avances y retrocesos del movimiento de derechos humanos en el enfrentamiento tanto con el dictador como con su movimiento, el Bussismo, esta vez en el poder.

La clausura temporal del trabajo, en 1999, tiene que ver con dos cuestiones centrales: por un lado, el alejamiento paulatino de Bussi del poder (aunque le hayan sucedido sus hijos en la perpetuidad de su partido político, Fuerza Republicana) y, la nueva fase abierta en el país donde el propio Bussismo se vio comprometido en la caída del ex dictador; por otra parte, con un cambio operado en el movimiento de derechos humanos de la provincia cuya fisonomía, objetivos y espectros fueron mutando en los años sucesivos, sobre todo a partir de la asunción del ex presidente Néstor Kirchner el 25 de mayo de 2003 y las llamadas nuevas políticas de memoria, las cuales abrieron nuevos repertorios de acción pública y una reubicación de los actores sociales que conforman el movimiento de derechos humanos de Tucumán en particular y de toda la Argentina en general.

Los organismos, objeto de esta investigación serán: Familiares de Detenidos Desaparecidos por Razones Políticas, surgido en 1977; Madres de Plaza de Mayo filial Tucumán, que ha sido la forma que ha adoptado el grupo de Madres de Detenidos-Desaparecidos una vez producida la 
ruptura del grupo inicial en 1983; la Asamblea Permanente por los Derechos Humanos (APDH), aparecida en Tucumán en 1984, casi nueve años más tarde que su homónima de Buenos Aires; la Asociación de Abogados por los Derechos Humanos, una agrupación surgida en Tucumán con la transición a la democracia y que ha nucleado a abogados de diferentes extracciones políticas para hacer frente a las demandas de los familiares en la búsqueda de verdad y justicia; finalmente dedicaré un capítulo especial a la organización H.I.J.O.S. cuya aparición pública ha tenido lugar a mediados de los '90, introduciendo al interior del movimiento nuevas miradas, nuevos interrogantes y nuevas acciones que respondían a criterios políticos de la nueva generación de militantes en el campo.

De los dos primeros es posible afirmar que su aparición se vincula estrechamente a una relación entre sí y al mismo tiempo en relación de parentesco con las víctimas de la represión. Por su parte la APDH y la Asociación de Abogados, suponen una relación ligada más a "lo político" desde una mirada tradicional de la definición acerca de lo que implica "la política", debido a la militancia de sus miembros en los partidos tradicionales. Por último el surgimiento de la nueva generación de militantes, en la nucleados en la agrupación H.I.J.O.S., será producto por un lado de la vinculación de sus miembros con la generación que denominaremos "setentista" tiempo, surgirá como herencia lógica generacional de las organizaciones de familiares antes mencionadas.

5 Usaré el término "setentismo" para denominar a una época y a una generación que se vincula con los años '60 y '70, atravesada por dos dictaduras militares y la resistencia, de distintas formas y modalidades, a las mismas. El término no es nuevo y algunos historiadores lo usan para explicitar una modalidad de militancia claramente diferenciada de otros periodos en la historia argentina. 
Lo que vincula a todos los organismos es que se hacen presentes en el espacio público con distintas estrategias y en distintas oportunidades, sobre todo, cada 24 de marzo, cuando se producen las masivas movilizaciones que recuerdan el día del golpe de Estado y cuando confluyen muchas veces en actividades conjuntas, tales como la elaboración de un documento, una solicitada o un manifiesto común. De aquí que sostengamos la última hipótesis acerca del comportamiento de "todo el campo" que conforma el conjunto de las organizaciones de derechos humanos en un "movimiento social" diferenciado, que en las distintas etapas del proceso histórico que va desde 1977 hasta 1999 enfrentó al Bussismo, con menor o mayor presencia en el espacio público.

El trabajo se articulará a partir del testimonio de los militantes de las organizaciones de derechos humanos de Tucumán, siguiendo la metodología propuesta por la Historia Oral $^{6}$, no sin descartar otro tipo de fuentes más tradicionales, como las escritas, y otras menos tradicionales como las imágenes de la época, tanto fotográficas como audiovisuales, las cuales serán objeto de triangulación entre todas ellas.

Vinculado a las entrevistas, la memoria de los testigos resulta de un valor primordial para recuperar la historia del movimiento, en una provincia donde los espacios de expresión de los miembros de las distintas organizaciones se han visto limitados. El testimonio se convierte entonces en una herramienta eficaz para la presente investigación, donde se intenta develar la trama de las memorias enfrentadas entre un

6 Como contribución planeo la construcción de un archivo de la memoria y la palabra sobre los testimonios recogidos en las entrevistas. La propuesta a futuro, vinculada a la tesis, será la elaboración de un sitio web en el que se dispondrán tanto las fuentes encontradas como los testimonios orales, con sus audios originales, y sus respectivas transcripciones, en el intento de socializar la experiencia local con aquellos que deseen adentrarse en la historia reciente de la provincia. 
movimiento que busca establecer criterios de verdad y justicia, y un sistema político y social que permite proyectar y dar cabida a expresiones totalitarias, aún bajo los patrones de la democracia institucional. En ese devenir político histórico se plantean varias etapas, con avances y retrocesos tanto del movimiento de derechos humanos como del propio Bussismo al que se enfrentó dicho movimiento, en una interacción entre unos y otros.

El trabajo se encuadra de esta manera en lo que se conoce como la historia reciente, desafiando las tendencias más tradicionales del quehacer historiográfico. Aquí, los relatos surgidos de las entrevistas vinculan pasado y presente cada vez que los testigos hablan desde la realidad que les toca vivir en el momento de realizarse las entrevistas. En esa reconstrucción, la memoria de un "pasado traumático" juega un rol central en la evocación y reconstrucción de "lo sucedido" por parte de los propios activistas del movimiento.

Busco indagar en los anclajes locales que hacen del movimiento de derechos humanos de Tucumán un movimiento distintivo respecto a otros similares en diferentes regiones del país, analizando sus estrategias tanto en la dictadura como en la larga transición vigilada, analizando desde la subjetividad de sus miembros militantes la percepción del complejo proceso político que les ha tocado atravesar, ubicando, al mismo tiempo, los cambios en su interior en una prolongada existencia plena de triunfos y derrotas políticas, sus prácticas sociales, sus objetivos, los cambios de tales objetivos y cómo han operado en el repertorio de acciones colectivas complejas, en un entramado dialéctico en el que las respuestas dadas supusieron un impacto en el conjunto de la sociedad tucumana. 
Lo temporal, como dije, será entonces uno de los ejes centrales a tener en cuenta en la búsqueda de los cambios no solo de ciertas manifestaciones o actuaciones públicas, sino de la propia percepción individual de una memoria colectiva que reconoce en el pasado cercano, una herencia. El trasvase generacional será determinante para poder comparar organizaciones que han tenido su aparición en la esfera pública en tiempos distintos, como la de Familiares de detenidos desaparecidos por razones políticas, surgido en los prolegómenos de la última dictadura militar y de la generación de los "hijos" de los represaliados, organización vinculada también a los desaparecidos pero que surgen en un momento y un contexto histórico distinto, a mediados de los ' 90 . 
Parte I: Metodología, Fuentes Y

Memoria 


\section{CAPÍtUlo I: Algunas CONSIDERACIONES METOdológiCAS}

"Con el testimonio se abre un proceso
epistemológico, que partiendo de la memoria
declarada, pasa por la archivación de los
documentos y se acaba con la prueba
documental".7

\section{I.1 MemORIA, ENTREVISTAS Y FUENTES ORALES: UN ESTADO DE LA CUESTIÓN}

En este primer apartado estimo conveniente realizar un sucinto estado de la cuestión acerca de los trabajos surgidos desde la perspectiva de la memoria y el uso de las fuentes orales en Argentina, donde los temas vinculados al pasado reciente y a la "memoria" son cada vez más aceptados en los ámbitos académicos y los estudios acerca de la última dictadura militar se han visto reforzados a partir de la metodología propia de la historia oral.

Las investigaciones acerca de la memoria sobre el pasado reciente en Argentina entraron en la academia universitaria en la post dictadura, urgidos por la necesidad y preocupación de revisar lo sucedido en los años de la represión. Si bien las reflexiones encontraron su apoyatura teórica en otros países, pronto las memorias sobre la última dictadura tuvieron vida propia en el país más austral del cono sur. Los temas vinculados al pasado reciente donde el eje memoria se vieron fortalecidos, sobre todo desde la sociología y la antropología, también fueron abordados por los historiadores, que prestaron atención a lo que desde las otras disciplinas se venía indagando.

7 Paul Ricoeur, en Cuesta, Josefina (2008): La odisea de la memoria. Historia de la memoria de España, S. XX, Alianza Editorial, Madrid. P. 128. 
En este sentido han sido pioneros los trabajos sobre memoria de Elizabeth Jelín, impregnados en parte de la tradición de los estudios europeos de Tzvetan Todorov ${ }^{8}$, Maurice Halbwachs ${ }^{9}$ y Paul Ricoeur ${ }^{10}$ entre otros. A los estudios de memoria de Jelín sobre el pasado dictatorial se han sumado los trabajos de Hugo Vezzetti ${ }^{11}$ aportando a la discusión sobre la cuestión de la memoria en relación a las víctimas de la represión ilegal, o las reflexiones de Ludmila Da Silva Catella, destacándose asimismo otra cantidad de investigadores que siguieron las líneas de los sociólogos antes referidos.

Para el caso tucumano, a mediado de los '90, también desde la sociología, los aportes de Emilio Crenzel sobre la década de los '60/'70 y sobre el Bussismo supusieron un importante influjo en quienes buscábamos referencias a la historia reciente de la provincia. Sin embargo, pocos trabajos referenciaban a cuestiones específicamente locales, por el contrario, todos ellos se circunscribían a la ciudad de Buenos Aires. Centraron su preocupación en la capital argentina aunque mencionaran desde lo espacial ciertos clivajes locales, como lo evidencian los trabajos de Crenzel. Es así que aparecieron obras que trataban sobre historias nacionales pero siempre desde la perspectiva de la ciudad de Buenos Aires como eje integrador y poco o nada de atención recibieron las particularidades regionales o provinciales al respecto.

Estas publicaciones corrieron por cuenta de una editorial señera en los temas vinculados a política, historia, sociedad, memoria y movimientos sociales, como es el Centro Editor de América Latina,

8 Todorov, Tzvetan (2000): "Los abusos de la memoria". Editorial Paidós Asterisco.

9 Halbwachs, Maurice (2004): Los marcos sociales de la memoria. Anthropos, Barcelona.

10 Ricoeur, Paul (2003): La memoria, la historia, el olvido, Edit. Trotta, Madrid.

11 Vezzetti, Hugo (2003): Pasado y presente. Guerra, dictadura y sociedad en la Argentina, Edit. S. XXI, Buenos Aires. 
dirigido por Oscar Troncoso. Allí descubrimos los primeros trabajos sobre los autores antes mencionados referidos en particular a la vinculación de la memoria con los llamados nuevos movimientos sociales, como, en el caso que me preocupa en la presente investigación, el movimiento de derechos humanos. ${ }^{12}$ El trabajo de Raúl Veiga, hoy ya un clásico en el estudio del movimiento de derechos humanos, es un buen ejemplo de lo antes dicho ${ }^{13}$. Veiga traza el devenir del movimiento de derechos humanos en Buenos Aires, aunque traslada dicho andamiaje al conjunto del país. Por dar un ejemplo en la tesis de Veiga, menciona al movimiento de Madres de Plaza de Mayo como el que comenzara con la lucha de resistencia a la dictadura cuando en el interior de Argentina en algunos casos concretos, como Tucumán o Neuquén, la misma organización tardara en aparecer y como desprendimiento de otras, sea Familiares para el caso de Tucumán, tal como veremos a lo largo de este trabajo, o de la Asamblea Permanente de Derechos Humanos en Neuquén, sin decir, que por ejemplo, en la provincia de Córdoba no existió una organización de madres de detenidos desaparecidos.

Sobre el desarrollo creciente de la historia oral en Argentina debo indicar el debate del 23 de agosto de 2011 llevado a cabo en el Centro Cultural de la Cooperación. Le mesa de debate versó sobre los orígenes de la historia oral en Argentina y tuvo como participantes a los principales referentes en el campo como ser los historiadores Pablo Pozzi,

12 Si bien, sobre el estado de la cuestión en el tema específico del movimiento de DDHH volveré más adelante en otro capítulo, conviene aquí hacer mención a que alguna de las reflexiones sobre memoria siempre dirigieron su mirada a las organizaciones de derechos humanos. Aunque también es cierto, y hay que mencionarlo, todos ellos, como podremos apreciarlo luego, se referían a la ciudad capital del país. De la periferia argentina poco y nada se había escrito, sobre todo porque hasta bien entrada la transición y, por distintos motivos que no vienen al caso explicar, no eran cuestión de preocupación académica.

13 Veiga, Raúl (1985): Las organizaciones de derechos humanos, Centro Editor de América Latina, Buenos Aires. 
Liliana Barela, Daniel Plotinsky y Mirta Lobato. ${ }^{14} \mathrm{Si}$ bien no hay un consenso sobre los inicios mismos, todos reconocen que fue tras la dictadura militar donde el testimonio oral comenzó a ser utilizado con mayor frecuencia en trabajos de investigación que tenían que ver, justamente, con ese pasado represivo, en aquel entonces, un pasado muy reciente. Sin embargo la historiografía entró tardíamente en la tradición por la recuperación del testimonio y no se consolidó la historia oral como metodología propia hasta los años '90. En este sentido es posible afirmar que no ha sido hasta después del primer encuentro de Historia Oral realizado en Buenos Aires en Octubre de 1993 y los que se siguieron llevando a cabo hasta la actualidad, en que las fuentes orales comenzaron a ser reconocidas como tales dentro de ciertos círculos académicos ${ }^{15}$. "El uso de los testimonios orales en la investigación histórica era, por entonces una metodología novedosa en la Argentina, donde se estaban poniendo en práctica proyectos en diferentes regiones del país, los cuales, en un importante porcentaje, eran llevados adelante con una alta dosis de voluntarismo y esfuerzo individual, y con un escaso basamento teórico por dificultades de acceso a la bibliografía existente en otros países." ${ }^{16}$ Asimismo era costoso también acceder a la tecnología que permitiera el registro testimonial que era principalmente sonoro pues el acceso a filmadoras que registraran también las imágenes era prácticamente imposible.

14 Para ver el debate completo consultar http://www.historiaoralargentina.org/, ¿Dar voz a los sin voz? Los orígenes de la historia oral en Argentina. [Consultado 3 de agosto de 2012].

15 Cabe aclarar que aún hoy existen espacios académicos que siguen desconociendo como válidas las fuentes orales, como así también otro tipo de fuentes que no sean meramente escritas.

16 Memoria del VIII Encuentro Nacional y II Congreso Internacional de Historia Oral de la República Argentina: Las fuentes orales: Su aplicación en educación, investigación y gestión. CD del Encuentro editado por el Instituto Histórico de la Ciudad de Buenos Aires. 
Desde la cinematografía local, y emulando seguramente al documental "Shoah" de Claud Klazman, encontramos producciones como "Cazadores de utopía" dirigida por David Blaustein, estrenada en 1996, y que recupera testimonios de ex militantes de la organización peronista Montoneros en un esfuerzo por exponer al público una imagen hasta ese momento distinta de la que se ofrecía acerca de las opciones político armadas en el país. ${ }^{17}$ Empero el mencionado documental no surgió dentro de un proyecto de historia oral ni se propuso como tal al público.

Sin embargo, el uso del testimonio no era nuevo en la cinematografía documental, pero sí lo era el hecho de involucrar en tales producciones cuestiones referidas a los años '60 y '70, indicando una necesidad de los sobrevivientes de la dictadura de prestar testimonio en ámbitos muy distintos a los judiciales.

Es así como a los trabajos de memoria se sumaron los trabajos a partir de la utilización de las fuentes orales. Entre las principales influencias en materia de historia oral que llegaron a Argentina en los años '80 y '90 se destacan las de los italianos Alessandro Portelli y Luisa Passerini, la catalana Mercedes Vilanova, los ingleses Ronald Grele, Paul Thompson $^{18}$, Alistair Thompson, Steve Brier, el francés Philippe Joutard, entre otros, algunos de los cuales visitaron el país en los sucesivos encuentros de Historia Oral dejando una importante huella en la historiografía local y marcando un camino iniciado en Europa y en Estados Unidos mucho tiempo atrás.

17 Quien ha reflexionado sobre Shoah y el valor de lo testimonial es el historiador Dominick LaCapra, en un intento por poner en cuestión el uso del testimonio de sobrevivientes del holocausto nazi. Los distintos trabajos de LaCapra reflexionan acerca del uso del testimonio en relación a pasados traumáticos y serán citados en esta investigación, ya que algunas de sus reflexiones valen también para el análisis de la recuperación testimonial del pasado represivo en Argentina.

18 Véase sobre aportes de Thompson, Paul (1988): Historia Oral, Edicions Alfons el Magnánim, Valencia. 
De entre quienes realizaron los principales aportes al desarrollo de la Historia Oral en Argentina, cabe mencionar a Dora Schwarztein, quien desde el Programa de Historia Oral de la Universidad de Buenos Aires primero, y desde el Instituto Histórico de la Ciudad de Buenos Aires después, realizó una importante tarea de difusión, enseñanza e incorporación de la historia oral en la academia y en la educación. ${ }^{19}$ Por su parte, conviene destacar los aportes de Hebe Clementi, los cuales resultaron fundamentales para quienes comenzábamos a poner en práctica el uso de las fuentes orales en nuestras pesquisas. Los trabajos y las críticas de Clementi resultaron no solo de inspiración sino de motivación para jóvenes historiadores del interior de Argentina, que mirábamos, como ejemplo, los trabajos realizados en Buenos Aires.

Por todo lo antes dicho es que la presente investigación procura seguir la tradición iniciada en los '90 en este campo desde los usos del testimonio oral como herramienta para la recuperación de la memoria del pasado dictatorial en Tucumán.

\section{2 UNA PERSPECTIVA DESDE LA HISTORIA ORAL}

Eric Hobsbawm afirmaba que cuando comenzó su carrera como joven historiador entrevistando a supervivientes de la Fabian Society de antes de 1914, preguntándoles cuestiones sobre su tiempo, la primera

19 Schwarztein, Dora comp. (1991): La Historia Oral, Centro Editor de América Latina, Buenos Aires; véase también Carnovale, Vera, Lorenz Federico y Pittaluga comps. (2006): Historia, Memoria y Fuentes Orales, CeDinCi Editores, Buenos Aires; Pasquali, Laura comp. (2008): Historia social e historia oral. Experiencias en la historia reciente de Argentina y América Latina, Homo Sapiens ediciones, Rosario; Necoechea, Gerardo y Pozzi Pablo comps. (2008): Cuéntame cómo fue. Introducción a la historia oral, Imago Mundi, Buenos Aires. Sobre los debates referidos a la historia reciente en Argentina se puede consultarse Franco, Marina y Levín, Florencia (2007): Historia reciente. Perspectivas y desafíos para un campo en construcción, Edit. Paidós, Buenos Aires. 
lección que aprendió fue "que ni siquiera valía la pena entrevistarles a menos que averiguase más cosas sobre el tema de la entrevista de las que ellos podían recordar. La segunda lección fue que en lo referente a cualquier hecho que pudiera verificarse de modo independiente, la memoria tendía a fallarles. La tercera lección fue que era inútil tratar de hacerles cambiar sus ideas, ya que éstas se habían formado hacía mucho tiempo y ya eran fijas. (...) Los últimos 30 o 40 años han sido la era más revolucionaria de la historia documentada. Nunca antes el mundo, esto es, las vidas de los hombres y las mujeres que viven en la tierra, se ha visto transformado de modo tan profundo, dramático y extraordinario en un período tan breve. Captar intuitivamente este hecho resulta difícil para las generaciones que no han visto como era antes el mundo"20.

Aunque concuerdo con la segunda y tercera lección que nos entrega el historiador británico, no estoy de acuerdo con la primera. La experiencia de quienes trabajamos con fuentes orales nos indica que aún sin conocer profundamente el pasado que se busca desentrañar en las entrevistas, no sólo no es inútil hacerlas, sino que sirven de necesario primer paso en el camino de indagar qué ha sucedido, cómo ha sido posible y qué percepción tienen los actores sociales de aquello. Concuerdo que a veces la memoria de los entrevistados falla -ya lo recordaba Tucídices-, pero aun así estimo, según mi propia experiencia, que recoger el testimonio de esos actores que han tenido una participación en el pasado se hace fundamental para captar cómo han vivido el suceso, sus puntos de vista y sus análisis, no solo de lo ocurrido, sino también de lo que quisieron que ocurriera. Es así que me parece válida la metodología que nos aporta la historia oral para el

20 Parte de la conferencia ofrecida por el historiador en la Universidad de Londres en 1993 por Eric Hobsbawm., en Hobsbawm, Eric (1998): Sobre la Historia, Edit. Crítica, Barcelona. 
estudio de los movimientos de derechos humanos. En el presente trabajo se plantea una desventaja: ciertamente la que afirma Hobsbawm, en el sentido que el investigador no ha vivido de igual manera el pasado reciente que se busca desentrañar como lo han hecho los actores sociales que han sido entrevistados; sin embargo, lo cierto es que parte de la vida de estos grupos han sido para mí reconocibles por ser contemporáneo de ellos, una ventaja que nos permite, sin lugar a dudas, la historia del tiempo presente.

En este sentido afirma la historiadora Josefina Cuesta que "el historiador faltaría a su tarea si, subyugado por las fuentes orales, sucumbiera a las sirenas de la memoria de otros y cayera en las trampas de la subjetividad. Pero se privaría de un inmenso campo de investigación si se limitara a la estrecha regla de la crítica histórica positivista y rehusara invertir la perspectiva desde un punto de vista hermenéutico: recoger, utilizar e interpretar lo que parece sospechoso en la memoria para contribuir a una historia objetiva de la subjetividad." ${ }^{21}$

Por su parte, sostiene LaCapra que "el testimonio de los sobrevivientes, incluido el proceso mismo de las entrevistas, es en cierta manera un género nuevo que se está haciendo, necesariamente problemático, que tiene consecuencias en la historia oral, especialmente en las áreas de investigación más delicadas. Los historiadores todavía no han elaborado una manera aceptable de "usar" los testimonios, y las profundas diferencias entre el estado y la experiencia de las distintas víctimas, así como entre las diversas respuestas que suscitan no hacen más que complicar su tarea." ${ }^{22}$

21 Cuesta, Josefina (2008): La odisea de la memoria. Historia de la memoria de España, S. XX, Alianza Editorial, Madrid. P. 122

22 LaCapra, Dominick (2005): "Escribir la historia, escribir el trauma, Edit. Nueva Visión, Buenos Aires, Pp. 126 y 127. Si bien es cierto que todavía no hay un acuerdo acabado sobre el "cómo hacer" historia oral, los últimos encuentros 
La decisión sobre la metodología empleada en la presente tesis surge de las propias limitaciones en torno a las fuentes del tema y al periodo abordado. La documentación escrita sobre las organizaciones de derechos humanos de Tucumán, como veremos más adelante, es escasa. La prensa local y nacional poco y nada se ha ocupado de la cobertura de las acciones de tales organizaciones, sobre todo durante el periodo dictatorial, donde, por lo general, acompañaron el discurso castrense del gobierno de facto, haciéndose eco, en la mayoría de los casos, de los partes de prensa oficiales en lo que se refiere a la situación política local. Hoy ya ha quedado demostrado que algunas notas en los periódicos locales referidas a la baja de un militante en "enfrentamientos" con el ejército han sido inventadas desde el Estado militar y los mismos periódicos reproducían los partes de prensa sin confirmar las fuentes ni su contenido. Por lo tanto las manifestaciones, actividades, denuncias, entre otras acciones, solo pueden ser rastreadas a partir de la memoria oral de los propios militantes, quienes, cada uno a su manera, recuerdan hechos, momentos y acciones concretas.

Tampoco las propias organizaciones, sobre todo las surgidas durante la dictadura y en los primeros años de la larga transición vigilada, llevaban constancia escrita de su accionar, con la salvedad de la organización de Madres de Detenidos-Desaparecidos de Tucumán quienes siguieron, durante sus primeros dos años de acción, un libro de actas, registro de sus actividades y discusiones internas. Incluso la organización

académicos internacionales han fijado unas pautas a partir de la recepción de trabajos evaluados y por consensos claramente establecidos sobre "qué es historia oral". En este sentido es posible afirmar que la mera recolección de entrevistas no supone a priori "hacer historia oral" y por el contrario la práctica va más allá del acto de entrevistar sujetos participantes. En este sentido el método historiográfico no difiere del todo cuando incorporamos a los trabajos de investigación histórica fuentes menos tradicionales como las fuentes orales, las imágenes, entre otras. 
mencionada no contaba con una publicación periódica como la que tenían sus pares de Buenos Aires, ni preservaba un archivo propio.

Otro tipo de fuentes menos tradicionales que los documentos escritos, como ser las fotografías, también son, en líneas generales, escasas; no encontrándose, para el periodo dictatorial, imágenes de acciones concretas que permitan hoy evaluar la cantidad de militantes organizados; mucho menos documentos fílmicos como los que podemos encontrar ya en la transición, uno de los cuales forma parte del anexo de la presente tesis. ${ }^{23}$ Tanto las fuentes judiciales como las registradas por una comisión investigadora de la legislatura local, surgieron además, en los primeros años de la transición, a partir de los testimonios de los familiares de afectados por la represión y de la verificación in situ, en algunos casos, de los Ilamados Centros Clandestinos de Detención. Por esto es que la presente investigación se plantea en su metodología el empleo de las técnicas generadas dentro de la Historia Oral por medio de entrevistas a militantes y dirigentes de los organismos de derechos humanos de Tucumán.

Cabe mencionar que no he descartado la búsqueda de archivos y documentos escritos, y las pocas fuentes encontradas me permitieron entonces la corroboración al mismo tiempo, de los testimonios surgidos de las entrevistas. La contemporaneidad de los sujetos participantes posibilita el análisis no solamente de los hechos que muestran los documentos escritos si no que también, partiendo de los mismos

23 Me refiero aquí a una filmación casera de un juicio ético realizado por el movimiento de derechos humanos de Tucumán en junio de 1995 para impugnar la candidatura de quien fuera el gobernador de facto durante la dictadura, Antonio D. Bussi. A este juicio en particular, dedicaré un capítulo en el que abordaré las implicancias del mismo y donde el video en cuestión sirve de fuente documental para la investigación. 
testimonios, es posible corroborar o realizar una lectura crítica de los mismos, desde el hallazgo de tales documentos.

La posibilidad de triangular las fuentes enriquece toda investigación basada en entrevistas, contribuyendo al examen del complejo proceso en estudio y permitiendo reconstruir el pasado, aprehenderlo y comprenderlo. Al mismo tiempo, en el proceso de construcción del relato, la experiencia de los actores participantes, siempre desde un plano subjetivo, suma al dato empírico una realidad que la historiografía tradicional suele descuidar, como ser la estructuras del sentir ${ }^{24}$ de quienes tuvieron un rol protagónico determinado. Como afirma Paul Thompson "la historia oral devuelve la historia a la gente con sus propias palabras. $\mathrm{Y}$ al ofrecer un pasado, también ayuda a encontrar un futuro de elaboración propia (...) le da vida a la propia historia, ampliando así su enfoque. Habla de personajes no sólo extraídos entre los líderes, sino también entre la mayoría desconocida de la gente". ${ }^{25}$ Por su parte Rosa García Orellán reafirma que "los relatos de vida o historias de vida son subjetivos. No es la labor de la persona investigadora perseguir la verdad de dichos relatos, sino penetrar en el entramado de los mismos, donde se construyen y reconstruyen las relaciones sociales $y$, en definitiva, la cultura que está emergiendo a través de la incorporación de experiencias, que la persona muestra en su relato". ${ }^{26}$

La entrevista de historia oral se enmarca siempre en el presente: el de los entrevistados, el del entrevistador y el del tema de investigación, el cual, inevitablemente, está atravesado por esta lógica

24 Williams, Raymond (2000): Marxismo y Literatura, Op. Cit., Pp. 150 a 159.

25 Thompson, Paul (1988): La voz del pasado. Historia Oral, Ediciones Alfons el Magnánim, Valencia. Véase también, Cuesta, Josefina, Op. Cit.

26 García Orellán, Rosa (2012): "De la oralidad a la intención biográfica", en Llona Miren, Entreverse. Teoría y metodología práctica de las fuentes orales, Univ. País Vasco, P.77 
temporal. Los actores sociales entrevistados ya como víctimas, ya como sobrevivientes, ya como familiares de víctimas, hablan desde el presente que les toca vivir con toda la carga emocional tanto de la historia personal que les franquea, como la misma historia del presente en el que viven y en el que, sin lugar a dudas, cifran sus esperanzas o recuestan sus decepciones. Porque, como afirman Camarena y Necoechea, "la historia oral debe rescatar la historicidad del los testimonios. El tiempo es la clave de ese sentido histórico. Corresponde al historiador rescatar el tiempo, introducirlo en la entrevista, y esto es precisamente lo que distingue su labor de otras disciplinas". Y continúan con la reflexión sobre la dimensión temporal afirmando que "el análisis del tiempo no se propone únicamente reconstruir el pasado, aunque esto sea esencial; intenta estudiar cómo se transforma la vida de la gente y cómo ésta narra tales transformaciones". ${ }^{27}$ Afirmo entonces que el tiempo de la entrevista es distinto al tiempo de la narración y ambos deben conjugarse en la compleja trama que se procura reconstruir.

Concluyendo la idea sobre la cuestión temporal, vuelvo a Camarena y Necoechea cuando expresan que "aunque el tiempo siempre está en presente en el acontecer cotidiano, no es un elemento consciente en el curso de la entrevista, ni para el estudioso ni para quien cuenta su vida." Sin embargo, afirman que "la forma en que se maneja el tiempo revela la concepción que de éste tienen ambos protagonistas". ${ }^{28} \mathrm{O}$ como lo refiere Pablo Pozzi 29 "el recuerdo (...) se encuentra en una zona confusa

27 Camarena, Mario y Necoechea Gerardo (2008): Continuidad, ruptura y ciclo en la historia oral, en Pozzi y Necoechea: Cuéntame cómo fue, Edit. Imago Mundi, P. 55.

28 Ibídem.

29 Pozzi hace referencia aquí a las entrevistas que realizó a militantes del PRT-ERP, sin embargo su análisis nos sirve ya que nos acerca a la problemática del tiempo de la entrevista. Sin lugar a dudas la experiencia de entrevistar a militantes de partidos revolucionarios de los '70 es muy distinta a la de entrevistar a 
y contradictoria que combina percepciones actuales con las pasadas y con la experiencia vivida (...) Debido al hecho de que muchos se sienten derrotados, las frustraciones, el dolor y la sensación de pérdida fueron expresadas contradictoriamente con la alegría, la reivindicación del momento (...) Aquí los testimonios dicen mucho más de lo que dicen, verdad que suena de Perogrullo, pero que el investigador debe tener en cuenta, pues no solo nos habla del pasado, sino del propio presente." ${ }^{\prime 30}$

Al hablar de los cambios sociales, Williams explicaba que podían ser de dos maneras: por una parte son cambios de "presencia" y por la otra, "no necesitan esperar una definición, una clasificación o una racionalización antes de ejercer presiones palpables y de establecer límites efectivos sobre la experiencia y sobre la acción". ${ }^{31}$ Según Williams, tales cambios pueden ser definidos como cambios en la "estructura del sentir", por lo tanto, y siguiendo al sociólogo inglés, debemos procurar establecer "los significados y valores tal como son vividos y sentidos activamente; y las relaciones existentes entre ellos y las creencias sistemáticas o formales". ${ }^{32}$ Una alternativa a las estructuras de sentimiento, sería el de las estructuras de la experiencia. Al definir los elementos del testimonio como una estructura, lo podemos observar entonces como "un grupo de relaciones internas específicas, entrelazadas y a la vez en tensión". Sin embargo, como bien indica Williams, "estamos

familiares de víctimas de la dictadura, pero hay un nexo temporal que debe ser analizado y que es común entonces a todas ellas. Esta valoración temporal del momento de la narración (no del momento narrado) es una tarea que todo historiador debe procurar si desea trabajar con fuentes orales.

30 Pozzi, Pablo (2004) Por las sendas argentinas. El PRT-ERP, la guerrilla Marxista. Imago Mundi, Pp. 33 - 34.

31 Williams, Raymond Op. Cit. P. 154.

32 Ibídem. 
definiendo aquí una experiencia social que todavía se halla en proceso, que no siempre es reconocida como social, sino como privada." ${ }^{33}$

Al acercarnos al estudio de movimientos sociales que no han sido masivos, como el que conforman las organizaciones de derechos humanos de Tucumán y que han tenido un objetivo específico al hacer su aparición en la esfera pública, las entrevistas orales nos permiten tener un conocimiento más cabal de su propia existencia y nos permite situar el relato en el tiempo, tanto en el tiempo vivido y experiencial como en el propio tiempo presente del cual surge el relato.

La contemporaneidad de los sujetos participantes permite analizar no solamente los hechos que muestran algunos documentos escritos, sino también la percepción que de los acontecimientos tienen los testigos entrevistados ${ }^{34}$. Cabe recordar que para la historiografía tradicional positivista sólo tenía valor el documento escrito, pero la entrevista oral permite al historiador acercarse a sujetos participantes que no tuvieron suficiente representación en los medios escritos, tanto periodísticos como en otras fuentes oficiales. ${ }^{35}$ Lo antes dicho se verifica con los organismos de Derechos Humanos que, a excepción de momentos específicos como un acto de recuerdo del golpe militar, o una circunstancia particular como

33 Ibídem.

34 Véase en este tema Chartier, Roger (1992): El mundo como representación. Historia cultural: entre práctica y representación, Edit. Gedisa, Barcelona. Para Pablo Pozzi también la representación que los actores sociales se hacen del proceso vivido resulta indispensable para la reconstrucción del relato histórico.

35 Nótese que hoy en día, toda organización tiene su medio de prensa. La aparición de Internet a fines de los años '90 y la popularización de su uso en los últimos años, ha permitido y permite a organizaciones, como las aquí estudiadas, tener su propio espacio de difusión. Un claro ejemplo de esto son los sitios web de las organizaciones de derechos humanos en la que dejan constancia de cada actividad o discurso desde lo visual, lo textual o el hipervínculo, enlazándose unas con otras. El periodo abordado en este trabajo, sin embargo, no cuenta con tal facilidad al acceso documental como lo vengo explicando desde el comienzo. 
ser la sanción de una ley o el juzgamiento de un represor, no han tenido presencia mediática, o si la tuvieron, ésta ha sido escasa.

He buscado aquí por lo tanto indagar por medio de las entrevistas a los militantes, examinando no sólo qué ha ocurrido y cómo ha sido posible el surgimiento de estos grupos sociales, sino también qué percepción tienen o han tenido los testigos ${ }^{36}$ de lo ocurrido, qué quisieron que ocurriera y qué fue lo que realmente ocurrió. Es así como Alessandro Portelli entiende la práctica de la historia oral al asegurar que "no solo nos habla de lo sucedido, sino además acerca de lo que la gente quiso que ocurriera, lo que creía que estaba ocurriendo y lo que realmente ocurrió". ${ }^{37}$ Busco establecer las pautas de la experiencia vivida, analizando por medio de los testimonios los cambios producidos procurando encontrar esas estructuras del sentir de las que habla Williams.

Bidiña sintetiza el problema del trabajo con las fuentes orales y la distinción de éstas con las fuentes escritas al afirmar que "la historia oral tiene un punto de partida muy distinto al de quienes trabajan exclusivamente con fuentes escritas. La práctica de la historia oral comporta una dimensión personal, subjetiva, afectiva, que se despliega en el trabajo de campo y que supone un intercambio constante y un persistente movimiento de roles entre los sujetos involucrados en él, que lo diferencian cualitativamente del trabajo con "fuentes muertas". ${ }^{38}$ Como

36 Hablo de testigos como los entiende Jelín en una de las acepciones en el campo de la historia oral: aquellas personas que han vivido una experiencia y pueden en un momento posterior narrarla, "dar testimonio". Veáse Carnovale, Lorenz y Pittaluga Comps. (2006): Historia, Memoria y Fuentes Orales. Edit. CEDINCI, Buenos Aires.

37 Portelli, Alessandro, Lo que hace diferente a la historia oral, en Schwarzstein, Dora Comp. (1991): "La Historia Oral". Colección, Los fundamentos de las Ciencias del Hombre. Centro Editor de América Latina. Buenos Aires.

38 Bidiña, Ana: "Las fuentes orales: ¿testimonios o testimoniantes? Discurso y representación en la Historia Oral en "VII Encuentro Nacional y I Congreso 
afirma Rosa García Orellán, "como investigadores debemos tener la capacidad de extrañamiento. Ésta constituye una forma de curiosidad que se despierta cuando se descubre que las vidas de las personas, sus formas de entender la realidad y de ponerla en práctica, son diversas." ${ }^{139}$

Por su parte Galasso afirma que la historia oral "ofrece una retroflexibilidad, una posibilidad de proyección del pasado muy fuerte $(\ldots)^{\prime \prime} .{ }^{40} \mathrm{Y}$ es justamente en la proyección del pasado que hacen los actores sociales participantes donde se enriquece el trabajo de la investigación. En esa retro-flexibilidad de los militantes de los organismos de derechos humanos, al ser interpelados sobre su propio pasado y sobre su actuación, procuran, al mismo tiempo, darle un sentido.

Si bien es posible confiar en el relato de un entrevistado, algunas fechas, nombres o sucesos se pierden en el olvido de los actores sociales, entran en contradicción o se vuelven incomprensibles, sobre todo cuando han transcurrido muchos años desde los comienzos de la militancia. Lo que algunos científicos sociales han analizado de las entrevistas y sus resultados al hablar de la memoria, han centrado su atención en su contrapartida, el olvido, y esto se hace evidente en los diálogos. De aquí la importancia de haber rastreado otro tipo de fuentes más tradicionales para una constatación de lo que surge del relato de los testimonios.

Como los olvidos o las distorsiones involuntarias en los relatos de los entrevistados pueden conducirnos al fracaso de la investigación, ha sido importante pensar aquí en un proyecto que ha contemplado los

Internacional de Historial Oral de la República Argentina", Memorias del Congreso.

39 García Orellán, Rosa (2012): De la oralidad a la intención biográfica, en Llona, Miren (coord.): Entreverse. Teoría y metodología de las fuentes orales, Univ. Del País Vasco, P. 74.

40 Galasso, Giuseppe (2001): Nada más que historia. Teoría y Metodología. Edit. Ariel, Barcelona, Pp. 270 a 273. 
relatos orales como un desafío. Como afirma Galasso "no se trata de un nuevo evangelio documental que ha de ser apartado, sino de la necesidad de integrarlo inmediatamente con su código crítico". ${ }^{41}$

La entrevista de Historia Oral es "un producto intelectual compartido mediante el cual se produce conocimiento". ${ }^{42}$ El objetivo de la entrevista es el recuerdo del entrevistado, es uno de los "trabajos de la memoria", y, tal como lo señalaba Schwarzstein, "es la intervención del historiador y lo que éste pone en términos de preguntas (...) lo que sirve como impulsor para la producción de información histórica". ${ }^{43}$ También ésta ha sido una preocupación del Instituto de Historia del Tiempo Presente de París, tal como lo recoge Cuesta donde "la interacción historiador-testigo es una inquietud metodológica cultivada asiduamente: confrontar sistemáticamente los análisis de los historiadores a los testimonios de los grandes actores, (...) esta confrontación ha mostrado que es muy fuerte la curiosidad recíproca entre historiadores y testigos: la confrontación del documento y del testimonio..." ${ }^{\prime 4}$

La investigación para el presente trabajo ha partido de un cuestionario semi-estructurado, adaptado a las necesidades de cada entrevistado según la organización a la que han pertenecido, teniendo en cuenta además quiénes de esos entrevistados se han alejado de la militancia, y quiénes han continuado ocupando un lugar clave dentro del movimiento de derechos humanos al momento de ser interrogados. Aquí es el historiador/entrevistador quien ha dirigido la entrevista de acuerdo

41 Galasso, Giuseppe, Nada más que historia, Op. Cit. Pp. 270 a 273.

42 Schwarzstein, Dora Comp. (1991): "La Historia Oral". Colección, Los fundamentos de las Ciencias del Hombre. Centro Editor de América Latina. Buenos Aires. P. 12.

43 Ibídem.

44 Cuesta, Josefina: "La Historia del Tiempo Presente: estado actual de la cuestión". En Estudia Histórica, Historia Contemporánea, Vol. 4, ediciones de la Universidad de Salamanca, P. 234. 
al interés buscado desde donde ha sido posible construir el objeto de análisis.

Se ha buscado confeccionar un cuestionario base general y sobre ese cuestionario se han elaborado las preguntas propias para cada integrante de los organismos. Tampoco se ha descartado la posibilidad de realizar más de un encuentro con los entrevistados, por lo que algunos testimoniantes han aportado sus experiencias en más de una oportunidad. Sobre esta cuestión he seguido entonces las recomendaciones del propio Thompson quien sugiere que "la mejor manera de empezar trabajos puede ser la realización de entrevistas exploratorias, estructurar un campo y recoger ideas e información". ${ }^{45}$ Siguiendo este camino, el mismo Thompson asegura que es posible debilitar un problema y ubicar los recursos para resolverlo. Es así como para este trabajo tanto la entrevista general de recopilación como la entrevista piloto han resultado de mucha utilidad. ${ }^{46}$ "Si las fuentes orales pueden suministrar realmente información fiable, tratarlas simplemente como un documento más es ignorar su especial valía en tanto que testimonio subjetivo y hablado". ${ }^{47}$ Visto desde esta perspectiva, la cuestión aquí planteada ha sido el escuchar la voz de los sectores subalternos frente a los sectores dominantes, los cuales manejan no sólo la información y su circulación, sino también la valoración de dicha información.

Como asevera Portelli, no existen fuentes orales falsas. Juegan en los testimonios la imaginación, el simbolismo y el deseo. ${ }^{48}$ El olvido o el cambio en la información brindada a partir de testimonios orales, puede

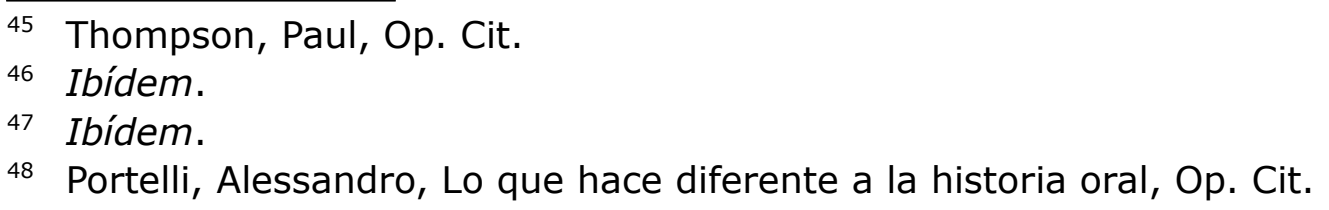


ser interpretado de maneras diferentes, si se realiza un estudio al interior de los relatos mismos. Se olvida o se oculta información por cuestiones que pueden tener que ver con estados emocionales o simplemente por alguna intencionalidad que podría o no detectarse. En este mismo sentido y frente a quienes aducen que los testimonios orales son menos confiables que las fuentes escritas, es posible demostrar que las segundas pueden ser modificadas o resultar apócrifas y por lo tanto dejan de ser creíbles dentro del contexto de una investigación histórica como la presente.

Hay historiadores e historiadoras que desprecian el uso de los testimonios orales olvidando que muchas de sus fuentes son fruto precisamente de eso, de testimonios orales que fueron transcriptos, como puede ser el caso de los registros de un debate parlamentario o los testimonios recogidos de una entrevista publicada en un medio gráfico. ${ }^{49}$ De la misma manera, algunas fuentes escritas, como veremos en otro apartado, son producto también de un testimonio oral. ${ }^{50} \mathrm{Al}$ mismo tiempo los testimonios surgidos a partir de las entrevistas me sirvieron incluso también para corroborar algunos de los datos aportados por las fuentes escritas encontradas. De la experiencia del presente trabajo surge, por ejemplo, que en más de una ocasión se ha podido demostrar que aquello que contaba el entrevistado había sucedido de la manera narrada, comparando ese mismo testimonio con el relato aparecido en la prensa escrita de la época que se intentaba recordar.

Asimismo, determinados procesos han contribuido a disparar los recuerdos de los entrevistados. Lo que Vezzeti menciona como "soportes materiales de la memoria" desde los objetos personales o a la realización

\footnotetext{
49 Ibídem.

50 Me refiero en concreto a las fuentes judiciales o bien a otro tipo de documentos en los que se reproduce sin más el testimonio de quien testifica "algo".
} 
de la entrevista en los lugares donde han transcurrido ciertos sucesos ${ }^{51}$ para ayudar a develar ciertos recuerdos en lo que Thompson, en concordancia con lo sostenido por Vezzetti recomienda, cuando habla de la utilización de "diversas ayudas para la memoria"52 o como los denomina Gerard Namer los "despertadores de la memoria". En este sentido algunos entrevistados hicieron uso de sus archivos personales para recordar algunas de las anécdotas narradas: desde carpetas de recortes de periódicos celosamente custodiados, hasta documentos privados de las organizaciones, han servido para triangular aquí el relato oral con el papel escrito. Cartas, recortes, fotos y objetos personales han servido en más de una entrevista para disparar un recuerdo de un suceso ya lejano en el tiempo, material que ha sido cedido y que ha servido también de documento para corroborar posteriormente si lo narrado era cierto o no.

\section{I.3 LAS FUENTES ORALES: UNA VALORACIÓN DE LAS ENTREVISTAS}

Josefina Cuesta, afirma que la entrevista "es fruto de la superposición y combinación de las diferentes memorias, de las que el sujeto es portador: la memoria personal, social, colectiva y dentro de ésta (...) la familiar, de clase, nacional, política o ideológica". ${ }^{53}$ Al mismo tiempo, citando a Ricoeur y Dulong, recuerda los que suponen, son los componentes esenciales del testimonio, sintetizados en cinco ${ }^{54}$ :

1) "De la aseveración del hecho a la certificación de su autenticidad: 'Yo estaba allí'."

\footnotetext{
51 Hugo Vezzeti: "Un Mapa por trazar", en Revista Puentes. № 1 - Agosto 2000.

52 Thompson, La Voz del pasado. Historia Oral, Op. Cit.

53 Cuesta, Josefina (2008): La odisea de la memoria. Historia de la memoria de España, S. XX, Alianza Editorial, Madrid. P. 128.

54 Ibídem.
} 
Este componente es fácilmente ubicable en los testimonios. Por lo general, encontramos que la mayoría de los relatos utilizan la primera persona, bien del singular, cuando narran una acción individual, o bien del plural, cuando se posicionan dentro de una acción acometida por la organización a la que pertenecían (o pertenecen). La mayoría refiere a hechos concretos de sus vivencias personales. Sucede, incluso, que alguno de los entrevistados ha resguardado consigo una carpeta con documentos personales entre los que se destacan recortes de prensa de la época y van rememorando, a la par que muestran el "documento" donde aparece el registro, que, efectivamente, ellos han sido partícipes, ya porque se los menciona, ya porque aparecen en la fotografía que acompaña a la nota periodística. Estos archivos resultan al mismo tiempo como los soportes materiales de la memoria a los que refiere Hugo Vezzettij ${ }^{55}$, pues en concreto una fecha 0 un lugar termina de precisar el "yo estaba allí" y permite dar mayor veracidad al propio testimonio al tiempo que califica al testimoniante como "válido", pues quién mejor que él, que ha estado allí para certificarlo.

2) "La especificidad del testimonio: 'Yo lo vi'."

El haber estado o el haber sido "testigo ocular"56 hacen que necesariamente el relato pase por la prueba de la comprobación y la aseveración. Esa primera persona se transforma en singular cuando lo individual supera lo colectivo. Igualmente todo relato en primera persona supone la existencia del testigo ocular ya que el haber estado en un determinado hecho o haber sido partícipe del mismo convalida el conjunto del relato más allá de las contradicciones internas del mismo, más allá de ciertas omisiones o equivocaciones. El testimoniante se ubica inmediatamente en el lugar de la acción y transmite, lo más fielmente

55 Vezzetti, Hugo (2000): Un Mapa por trazar, en Revista Puentes. No 1.

56 En los términos expuestos por Josefina Cuesta tomados de Dulong. 
que puede, no solo lo que ha visto, sino su propia experiencia subjetivada, claro está, en la acción de la que ha sido partícipe.

3) "La autodesignación y acreditación: 'Puedes creerme'."

Este componente no suele hacerse explícito, pues toda entrevista es, por lo general, buscada por el historiador y "pautada" entre dos partes. En mi caso, he llegado a mis "testimoniantes" ubicándolos personalmente, en general, estableciendo implícitamente un pacto de credibilidad entre el entrevistador (historiador) y el entrevistado. De todas formas, hay que tener presente que siempre que el entrevistado narra un suceso en particular busca la apoyatura material para que el relato, que podría ser "no creíble", se torne veraz. Los soportes materiales de la memoria, a los que alude Vezzetti, ${ }^{57}$ y sobre los que hablaremos más adelante, se vuelven imprescindibles cuando el relato aparece increíble. Lo veremos cuando citemos algunos fragmentos testimoniales, donde los propios entrevistados recurren a sus documentos personales o refieren sucesos que podrían haber sido publicados en prensa.

4) "Ante la posibilidad de la sospecha, confrontación de testimonios: 'Pregunta a otros'."

Cuando la auto-acreditación planteada en el punto anterior es puesta en duda, asoma en el entrevistado la confrontación con sus pares. Al preguntar a otros o al apoyarse en la posibilidad de la verificación sobre el dato de un lugar o una fecha que no se recuerda, los entrevistados, salvo excepciones, presumen la posibilidad de que el entrevistador pueda preguntar a "otros testigos". Vale aquí el ejemplo de una de las entrevistadas que había puesto como condición para dar su testimonio, hacerlo con un par que corroborara o contrastara su

57 Vezzetti, Hugo (2000): Un Mapa por trazar, Op. Cit. 
testimonio. Incluso, como puede verse en el anexo, un par de entrevistas han sido realizadas a dos personas pertenecientes a una misma organización, entrevista que se vio enriquecida, inclusive, con la discusión entre los relatos sobre la propia percepción del proceso vivido. ${ }^{58}$

5) "La credibilidad y la fiabilidad del testimonio: 'Su mantenimiento a lo largo del tiempo'."

Este último componente es objeto de discusión entre los historiadores orales. Hay quienes sostienen que el sostenimiento del relato en el tiempo, lejos de tornarlo creíble, debe hacernos cuestionarlo, pues puede ser una mera construcción del entrevistado que repetirá durante años para convencerse que ha sido así, como él o ella lo narran, y no de otra manera. En mi opinión, y según veremos en el caso de uno de los testimoniantes, su relato no sólo se ha sostenido, sino que puede verificarse en el tiempo.

Cito aquí un ejemplo de todo lo antes dicho en el testimonio de Carlos Soldati ${ }^{59}$, quien vive en la localidad de Simoca, ubicada en el sur

58 Me refiero en concreto a las entrevistas con Julia Vittar y María Coronel, ambas militantes de la organización HIJOS, como así también a la entrevista realizada a Atilio Castagnaro y María Angélica Mazzamutto, de la organización Asamblea por los Derechos Humanos de Tucumán. Las entrevistas colectivas tienen la ventaja de permitir la apoyatura del recuerdo de unos y otros entrevistados. Cuando, en mi caso, comencé con las primeras pesquisas sobre la historia de las Madres de Detenidos Desaparecidos de Tucumán, recurrí a los talleres de Historia Oral que me permitieron reunir a más de una integrante de la organización, entrevista que con sus pros y sus contras, fueron muy provechosas también en este sentido, el de la credibilidad sostenida por la aseveración de cada testimonio en la afirmación del colectivo.

59 La entrevista a Carlos Soldati ha sido realizada el 1 de diciembre de 2007, días antes de asumir la presidencia de Argentina la esposa del ex presidente Néstor Kirchner. Por este motivo en varias oportunidades, el entrevistado manifiesta abiertamente cierta esperanza que la continuidad en la línea sucesoria en la conducción política del país lleve a buen término algunos de los procesos judiciales contra los responsables de la dictadura. Nuevamente nos merece la pena ubicar en contexto la entrevista. Ocasionalmente he podido cruzarme con Soldati y nunca ha dejado de manifestar su satisfacción por los avances en 
de la provincia de Tucumán, en una finca que pertenecía a sus padres. Tiene a dos de sus hermanos secuestrados y desaparecidos, habiendo sido él mismo secuestrado y objeto de torturas. Desde la desaparición de su segundo hermano, en 1977, ha sido un activo militante en tres de los organismos de derechos humanos de la provincia. Los comienzos de su militancia se ubican en Familiares de Detenidos por Razones Políticas, pasando un tiempo por Madres de Plaza de Mayo desde fines de 1981 y finalmente ha sido uno de los fundadores de la Asamblea Permanente por los Derechos Humanos en Tucumán, el 24 de enero de 1984. He podido entrevistar a Carlos a fines de 2007, unos meses antes del primer juicio contra Bussi, en la causa por la desaparición del ex senador Guillermo Vargas Aignase. ${ }^{60}$ Esta entrevista se dio en el contexto de un punto cumbre de las llamadas políticas de derechos humanos de la administración del ex presidente Kirchner. Como muchos otros activistas del movimiento, Soldati recuerda casi con lujos de detalles las circunstancias del secuestro de su familia, incluidas las del propio. Los cuatro testimonios que cito en el siguiente cuadro se corresponden, en orden cronológico: el primero, recogido por el periódico local, data del 12 de febrero de 1984, cuando la APDH local hacía su presentación pública y Carlos narraba su propio secuestro; el segundo, a instancias de un Juicio Ético contra Bussi ${ }^{11}$ el 19 de junio de 1995, donde fungía de testigo y narraba con precisión las mismas instancias de su secuestro; el tercero de los testimonios se corresponde con la entrevista que le hice el primero de diciembre de 2007, en su hogar; el cuarto es el testimonio que

materia judicial en la provincia, por lo que tras la desilusión de largos años de militancia, hoy ve con expectativas los juicios que se llevan a cabo en la provincia.

60 Juicio que se ha consubstanciado a mediados de 2008.

61 Sobre este Juicio volveré en otro capítulo de esta tesis. 
prestara Carlos como testigo querellante por su secuestro en el juicio de Jefatura, el 31 de marzo de 2010.

\section{Los testimonios de CARlos Soldati}

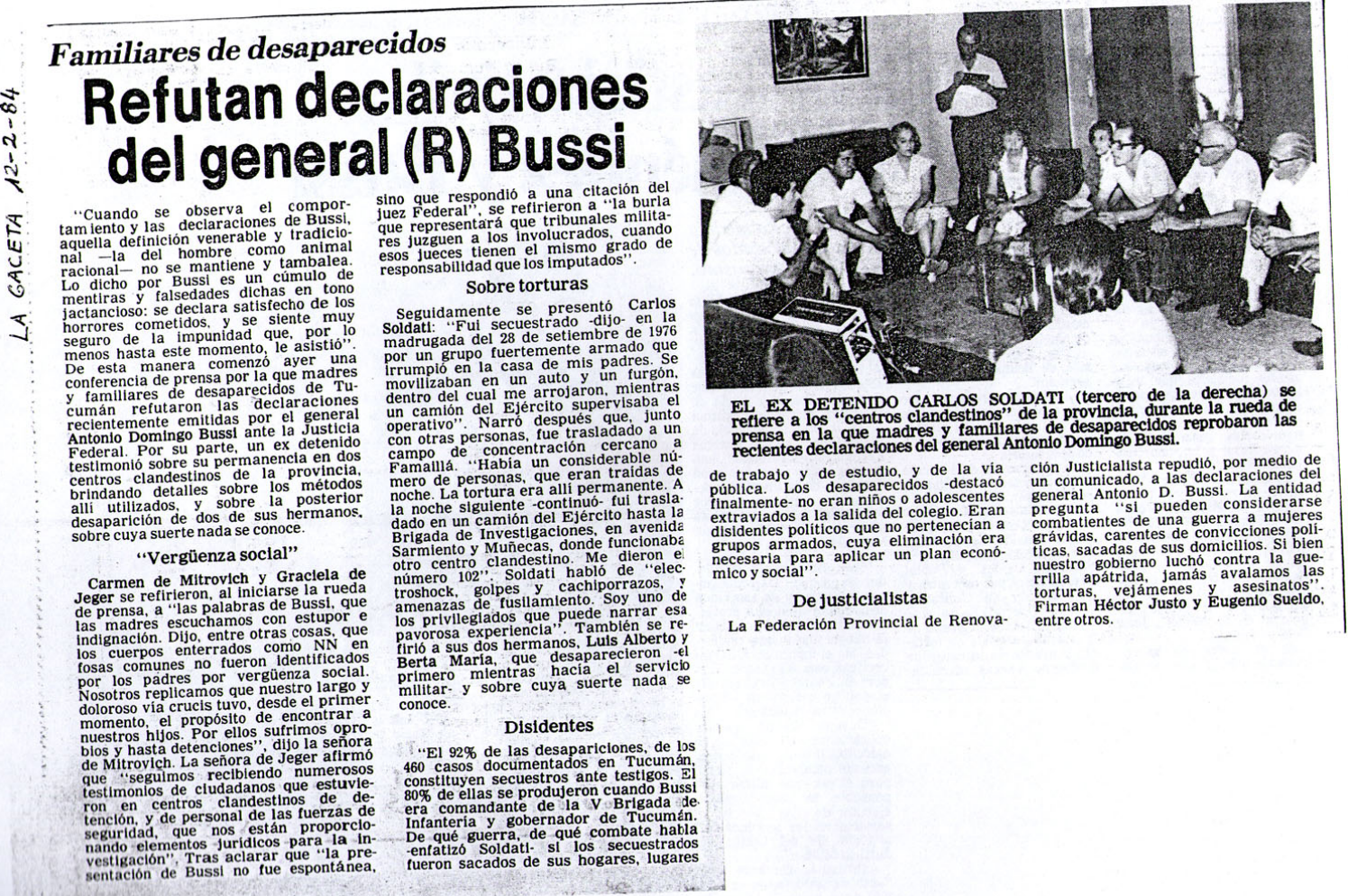

Soldati, como respuesta a Bussi acerca de la existencia de una "guerra" da testimonio a la prensa en la que narra su propio secuestro.

\begin{tabular}{|c|c|c|}
\hline $\begin{array}{c}\text { AÑo DEL } \\
\text { TESTIMONIO }\end{array}$ & $\begin{array}{l}\text { LUGAR DEL } \\
\text { TESTIMONIO }\end{array}$ & TRANSCRIPCIÓN \\
\hline $\begin{array}{c}12 \text { DE } \\
\text { FEBRERO DE } \\
1984\end{array}$ & $\begin{array}{c}\text { LA GACETA } \\
\text { DE TUCUMÁN }\end{array}$ & $\begin{array}{l}\text { «Fui secuestrado en la madrugada del } 28 \\
\text { de septiembre de } 1976 \text { por un grupo } \\
\text { fuertemente armado que irrumpió en la } \\
\text { casa de mis padres. Se movilizaban en un } \\
\text { auto y un furgón dentro del cual me } \\
\text { arrojaron mientras un camión del ejército } \\
\text { supervisaba el operativo. } \\
\text { (Narró luego que fue trasladado a un }\end{array}$ \\
\hline
\end{tabular}




\begin{tabular}{|c|c|c|}
\hline & & $\begin{array}{l}\text { campo de concentración cercano a } \\
\text { Famaillá) } \\
\text { «Había un considerable número de } \\
\text { personas que eran traídas de noche. La } \\
\text { tortura era allí permanente. A la noche } \\
\text { siguiente fui trasladado en un camión del } \\
\text { Ejército hasta la brigada de investigaciones, } \\
\text { en Avenida Sarmiento y Muñecas, donde } \\
\text { funcionaba otro centro clandestino. Me } \\
\text { dieron el número } 102 \ldots\end{array}$ \\
\hline $\begin{array}{l}19 \text { DE JUNIO } \\
\text { DE } 1995\end{array}$ & $\begin{array}{c}\text { JuICIO ÉTICO } \\
\text { A BuSSI }\end{array}$ & $\begin{array}{l}\text { El } 28 \text { de septiembre de 1976, a eso de } \\
\text { las dos y media de la madrugada un grupo } \\
\text { armado de civil, con la cara cubierta, } \\
\text { identificándose como de la policía, entra en } \\
\text { la casa de mis padres, en Manuela Pedraza, } \\
\text { cerca de Simoca. La luz se enciende, yo me } \\
\text { siento sobre la cama y los veo subir por la } \\
\text { escalera, con armas largas, cortas, } \\
\text { linternas, me preguntan a los gritos por mi } \\
\text { nombre, y desde abajo contestan "ese es"... } \\
\text { yo estaba aterrado. "Hay un error, ¿qué } \\
\text { pasa, qué pasa?" El que dirigía el grupo, } \\
\text { que si estaba con la cara descubierta y me } \\
\text { pone la pistola en la cabeza y me dice que } \\
\text { me calle, me amenaza con matarme, me } \\
\text { tira los anteojos y me saca arrastrando de } \\
\text { mi casa. Antes que me pongan la capucha, } \\
\text { alcanzo a ver a un auto al frente de mi casa } \\
\text { y un poco más adelante me tiran en el piso } \\
\text { y me suben a un camión del ejército, con el } \\
\text { sonido característico de los (...) que } \\
\text { supervisaba el operativo. } \\
\text { cuando me tiran en el piso de la } \\
\text { camioneta furgón, veo que hay otra } \\
\text { persona ahí tirada. Tengo la certeza de que } \\
\text { ese muchacho era Pedro Pablo Rodríguez, } \\
\text { que después me entero que unos minutos } \\
\text { antes había sido secuestrado por el mismo }\end{array}$ \\
\hline
\end{tabular}




\begin{tabular}{|c|c|c|}
\hline & & $\begin{array}{l}\text { grupo en Simoca. } \\
\text { La camioneta se toma en dirección } \\
\text { rumbo al norte a toda velocidad, después } \\
\text { de unos minutos, gira hacia el oeste por el } \\
\text { único camino de tierra que conduce hacia } \\
\text { Famaillá y después de unos minutos llego a } \\
\text { destino, me bajan y me introducen en lo } \\
\text { que es un corredor ancho y en una galería } \\
\text { cerrada me tiran al piso. Pude observar ahí } \\
\text { un número considerable de personas } \\
\text { maniatadas, vendadas, que se quejaban. } \\
\text { Enseguida gritos, corridas, ruidos de } \\
\text { motores, pregunto qué pasa, "van a buscar } \\
\text { más gente", me dicen (...) }\end{array}$ \\
\hline $\begin{array}{l}\text { Primero De } \\
\text { DICIEMBRE DE } \\
2007\end{array}$ & $\begin{array}{c}\text { ENTREVISTA } \\
\text { DE HISTORIA } \\
\text { ORAL }\end{array}$ & $\begin{array}{l}\text { «(..) ese mismo año, el } 28 \text { de } \\
\text { septiembre me sacan de esta casa, aquí, de } \\
\text { Manuela Pedraza, un grupo armado, a eso } \\
\text { de las dos de la mañana, que se } \\
\text { desplazaban en un vehículo de la policía, } \\
\text { ellos se identifican verbalmente como de la } \\
\text { policía, estaban de civil, mis padres } \\
\text { estaban aquí, les abren la puerta y bueno... } \\
\text { yo duermo en un altillo, veo que se } \\
\text { enciende la luz, me incorporo sobre la } \\
\text { cama y los veo subir y a los gritos me } \\
\text { preguntan cómo me llamaba y entonces me } \\
\text { sacan arrastrando, me tiran los anteojos, } \\
\text { y... antes de que me colocaran la capucha } \\
\text { veo un automóvil de la policía de aquí a } \\
100 \text { metros, sobre la entrada de la casa y } \\
\text { me tiran en el baúl, en el piso de un furgón } \\
\text { donde había otra persona y partimos a gran } \\
\text { velocidad. Después un vecino cuando yo } \\
\text { aparezco después, me comenta que un } \\
\text { camión del ejército, con el ruido } \\
\text { característico de los (...) que ahí desde la } \\
\text { ruta supervisaba el operativo. Y bueno, } \\
\text { dicen, una frase: "demasiado bueno es }\end{array}$ \\
\hline
\end{tabular}




\begin{tabular}{|c|c|c|}
\hline & & $\begin{array}{l}\text { Videla, ya no quiere más muerte, pero si } \\
\text { están en la joda (ese es el término que } \\
\text { usaban) por mucho tiempo no se va a } \\
\text { saber de ustedes".» } \\
\text { Pregunta: ¿Eso les decían a ustedes } \\
\text { dos? } \\
\text { «A mí y el otro escuchaba, yo ni sabía } \\
\text { quién era. Después me entero, cuando yo } \\
\text { aparezco, de que ese muchacho había sido } \\
\text { secuestrado minutos antes, en Simoca, a } \\
\text { cuatro kilómetros de aquí, y era Pedro } \\
\text { Pablo Rodríguez. Bueno, yo creí que me } \\
\text { mataban, que me hacían descender del } \\
\text { vehículo y me ametrallaban aquí a unos } \\
\text { cuantos kilómetros, pese a que uno está } \\
\text { vendado y tirado, pero por el movimiento } \\
\text { del cuerpo sé que el vehículo toma } \\
\text { dirección norte y luego de unos minutos } \\
\text { dobla hacia la izquierda, (...) levantan a } \\
\text { otro en el camino también, secuestran a } \\
\text { otra persona, ya éramos tres y llego a un } \\
\text { lugar que después ubico como Famaillá, } \\
\text { pero me bajan como a una especie de } \\
\text { galería cubierta donde había muchas } \\
\text { personas, así, vendadas y maniatadas (...)» }\end{array}$ \\
\hline $\begin{array}{c}31 \text { DE MARZO } \\
\text { DE } \\
2010\end{array}$ & $\begin{array}{l}\text { JUICIO DE } \\
\text { JEFATURA }\end{array}$ & $\begin{array}{l}\text { «El } 28 \text { de septiembre del año 1976, a } \\
\text { eso de las dos y media de la madrugada, } \\
\text { un grupo numeroso, entre } 15 \text { y } 20 \\
\text { personas, llegan a la casa de mis padres, } \\
\text { en Manuela Pedraza, cerca de Simoca, } \\
\text { "iabran la puerta, es la policía!", gritan; mi } \\
\text { mamá, asustada, les abre la puerta de la } \\
\text { galería del fondo y entran, con armas, con } \\
\text { linternas, con la cara cubierta con medias y } \\
\text { pañuelos, se notaba que eran personas } \\
\text { jóvenes, menos una, que actuaba a cara } \\
\text { descubierta y con una pistola en la mano, } \\
\text { era el que dirigía el grupo, recorren las }\end{array}$ \\
\hline
\end{tabular}




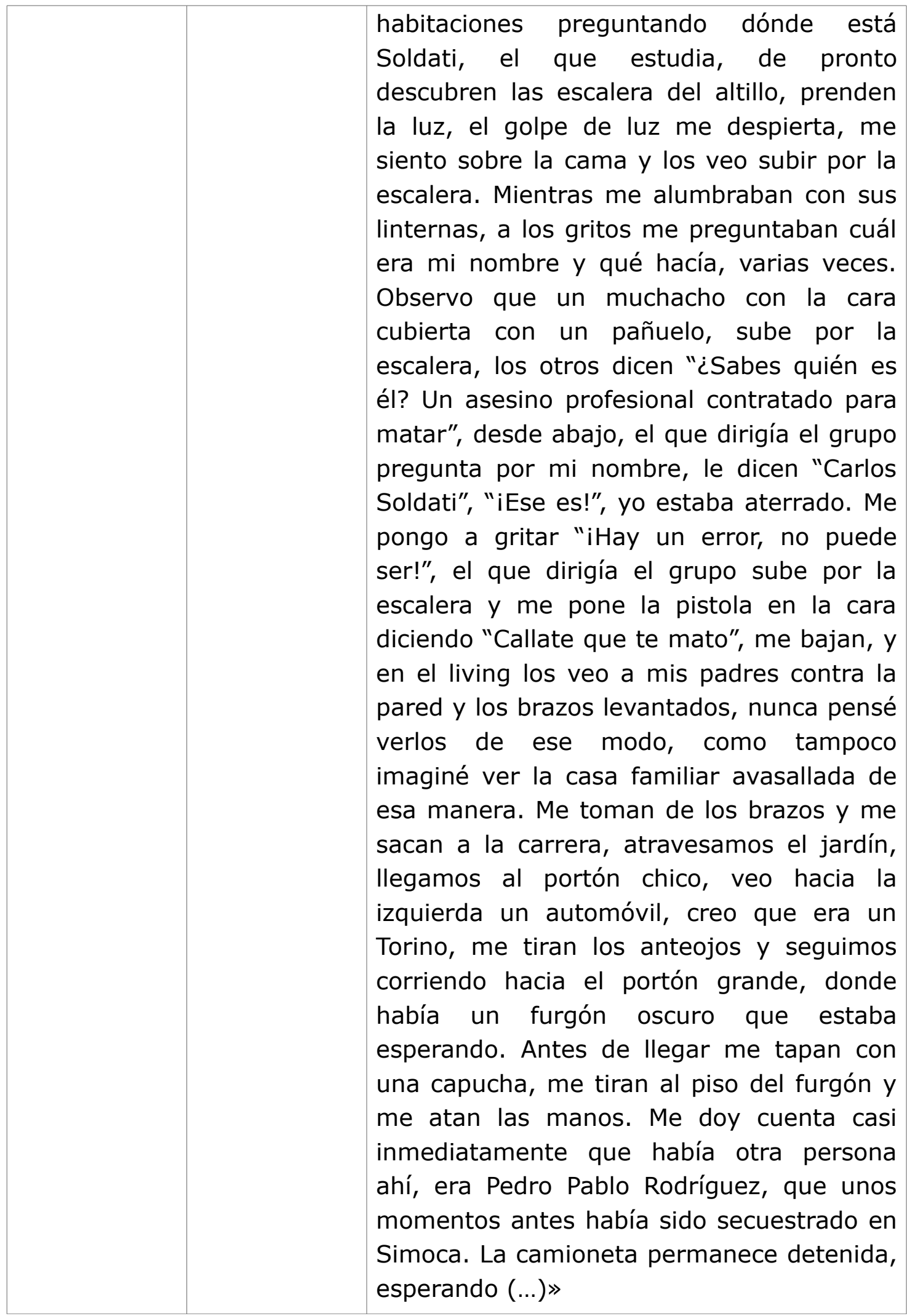


La discusión sobre la cuestión de la repetición y la perdurabilidad del testimonio a lo largo del tiempo, como dije, no es nueva y sigue sin ser resuelta. ${ }^{62}$

Josefina Cuesta explica que el mantenimiento del relato a lo largo del tiempo es lo que le daría credibilidad y fiabilidad. La catedrática explica entonces que "además de la corroboración horizontal, sincrónica, de los otros testigos, el testimonio puede apoyarse en su propia corroboración a través del tiempo, en su permanencia en la diacronía". ${ }^{63}$

En todo caso resulta conveniente, como ya mencioné, el entrecruzamiento de fuentes: contrastar todos los relatos y buscar la correlación entre lo que se dice y lo que suponemos realmente ocurrió, en los términos planteados por Alessandro Portelli, y es lo que he procurado en esta pesquisa. No me he quedado con aquello que se presenta repetitivo en ciertos relatos, sino en la búsqueda por encontrar los puntos de veracidad y credibilidad en los mismos, por indagar sus rupturas como así también las contradicciones internas que hacen al testimonio, por un lado, y a la apreciación personal y subjetiva que de los acontecimientos vividos tienen los sujetos sociales, percepción que no siempre es lineal aunque el investigador procure encontrar la coherencia interna del relato narrado.

62 Esto se puso en evidencia en el debate producido en el marco del encuentro de Historia Oral de la República Argentina, en 2009, en la mesa donde debatíamos los temas referidos a las pesquisas vinculadas al pasado dictatorial. El tema no es menor, ya que algunos historiadores sostienen que nuestra tarea en la investigación con las entrevistas debe procurar romper el discurso al interior del testimonio de los entrevistados y encontrar esas contradicciones y fisuras que harán del testimonio, no una fuente creíble, pero sí una fuente que necesariamente debe ser estudiada hermenéuticamente. Sobre la fiabilidad del testimonio véase, LaCapdra, Dominick (2001): Escribir la historia, escribir el trauma, Nueva visión, Buenos Aires, Capítulo III.

63 Cuesta, Josefina. La Odisea de la Memoria. Historia de la memoria en España, S XX. Edit. Alianza. Madrid. 2009. P. 131. 
Como asegura Portelli "las fuentes escritas y orales no son mutuamente excluyentes. Tienen características comunes así como autónomas y funciones específicas que sólo cada una puede cumplir". ${ }^{64}$

Considero necesario en este punto analizar el proceso de realización de las entrevistas para el presente trabajo. Para el periodo abordado entre 1966 y 1976, he recurrido a un fondo documental de la investigación desarrollada para la concreción de la producción audiovisual "El Tucumanazo"65, donde se destacan los testimonios de militantes del movimiento obrero y estudiantil de esos años. La importancia de dichos testimonios, como veremos más adelante, tiene que ver con que pertenecen al conjunto de la generación víctima de la represión de la última dictadura militar. Los fragmentos testimoniales escogidos dan cuenta no solo de los procesos vivenciados por estos militantes, sino de sus impresiones y miradas a partir de la experiencia que les ha tocado vivir. Aquellas entrevistas fueron hechas en el año 2004, en los inicios del gobierno del ex presidente Néstor Kirchner, en paralelo, cuando se abría en el país, con una nueva revisión del pasado dictatorial en Argentina, con la implementación, todavía en sus inicios, de las llamadas políticas de derechos humanos y que en definitiva implicaron el comienzo del juzgamiento a los responsables de los crímenes de Lesa Humanidad. La necesidad de incluir en este trabajo, alguno de estos testimonios, se fundamenta en la razón que la historia de la militancia setentista se vincula directamente con el proceso político y social de Tucumán abierto en 1974 y que desembocaría en el último golpe militar y sus consecuencias. No se puede comprender la ferocidad de la represión

64 Portelli, Alessandro: Lo que hace diferente a la Historia Oral, en Schwarzstein, Dora Comp. (1991): "La Historia Oral". Colección, Los fundamentos de las Ciencias del Hombre. Centro Editor de América Latina. Buenos Aires. 
estatal desatada durante el último gobierno de facto (y aún antes), si no se comprende qué ha sucedido en los años previos. ${ }^{66}$

Sobre el conjunto de entrevistas a los militantes de las organizaciones de derechos humanos, en su mayoría fueron efectuadas entre septiembre y diciembre de 2007, siendo alguna de ellas realizadas con posterioridad. Los entrevistados son ex dirigentes de algunos de los organismos de derechos humanos como así también militantes activos dentro del movimiento. Tres de las entrevistas citadas han sido realizadas hace más de 10 años con motivo de la investigación sobre el movimiento de Madres de Detenidos Desaparecidos de Tucumán, punto de partida desde el cual surgió la necesidad de continuar indagando sobre el movimiento de derechos humanos en su conjunto, en una región como Tucumán. Estas entrevistas guardadas en un archivo personal han estado realizadas a distintas integrantes del movimiento de Madres de desaparecidos de la provincia, y sirven también como fuentes para la presente investigación sobre el conjunto de las organizaciones de derechos humanos. Estas últimas entrevistas no serán tampoco presentadas en el anexo documental, ya que, si bien sirven a la presente pesquisa, no forman parte directa de la misma.

Entre los militantes de las organizaciones de derechos humanos entrevistados se encuentran dirigentes y militantes de base de Familiares de Detenidos por Razones Políticas, miembros de la Asamblea Permanente por los Derechos Humanos de Tucumán, otros militantes del

66 No se incorpora en anexo los testimonios mencionados aunque fragmentos de los mismos serán reproducidos a los fines de la pesquisa. Si bien, como digo, no forman parte del corpus documental reunido para este trabajo, su cita se hace indispensable para comprender la etapa inmediata anterior a la última dictadura siguiendo, además, con la metodología de la historia oral, esencial en este trabajo. En cambio como anexo documental de la tesis se presentará al final, un DVD con los audios completos de las entrevistas realizadas sí, para la tesis. 
movimiento de Madres de Plaza de Mayo filial Tucumán, miembros de H.I.J.O.S., entre otros.

Una cuestión que considero necesaria precisar es la actual coyuntura política de Argentina con los juicios abiertos a la sazón de la administración del ex presidente Néstor Kirchner y continuada por la actual presidente Cristina Fernández. Esta coyuntura ha convencido a una amplia mayoría de militantes del movimiento social en estudio de que por fin se ha roto el cerco de impunidad abierto después de que se sancionaran las leyes de Obediencia Debida y Punto Final en 1987 y los indultos en 1990.

Por esta razón, es importante tener en cuenta que en los relatos de los entrevistados se producen una amalgama entre el pasado reciente con el presente que les toca vivir, es decir, que de los relatos se deduce una desilusión hacia el pasado vivido, donde algunos hitos son vivenciados como verdaderas derrotas políticas, y donde el presente abierto tiene la esperanza de ver al fin cumplidos algunos de los objetivos, después de casi 30 años de militancia. ${ }^{67}$

Las sentencias a cadena perpetua por genocidio contra el ex policía bonaerense, Miguel Etchecolatz y el cura castrense Von Wernich, producidas en 2006 y 2007 respectivamente, y los juicios que en estos momentos se llevan a cabo en todo el país, incluso en Tucumán, son

67 Al momento de escribir este trabajo ya se resolvieron en la provincia de Tucumán dos juicios por violación de los derechos humanos en la provincia, con sentencia firme. El primero en 2008, en la causa por la desaparición del ex senador Guillermo Vargas Aignase y cuyo fallo también servirá de fuente documental para la tesis; y el segundo, el primer juicio por Centro Clandestino de Detención, la ex Jefatura de Policía y que involucró, de una u otra forma, a los mismos actores sociales de la presente tesis. Por este motivo también, parte de los relatos surgidos del proceso oral del juicio, serán mencionados en el trabajo. Lo que cabe aclarar es que todas las entrevistas fueron realizadas antes de sustanciarse ambas instancias judiciales. 
circunstancias que se ven reflejadas en los testimonios de los militantes de las organizaciones, a la vez que la impunidad que les ha acompañado va dejando lugar a la justicia o, dicho de otra manera, van encontrando la luz de los principios buscados históricamente por el movimiento de derechos humanos de "Verdad" y "Juicio y Castigo" que analizaré a lo largo de todo el trabajo. Por este motivo es imprescindible, en la tarea de historiar, tener en cuenta estos factores fundamentales del nuevo escenario político abierto en 2003 que implica ir más allá en el análisis de los relatos, sobre aquello que los testimoniantes dicen, pero también sobre aquello que callan.

Algunas de las entrevistas abren dudas, por cuanto el paso del testigo por una organización ha sido breve. Otros testimonios reflejan incertidumbres propias de quien narra un suceso acaecido hace más de 30 años. Lo que importa en estos casos no ha sido tanto el dato certero como la percepción que los entrevistados tienen desde el presente sobre su experiencia vivida, entendiendo la historia oral como lo afirmaba más arriba, en el sentido que la entiende Portelli. Lo significativo en la realización de las entrevistas, en todo caso, es la posibilidad que tuve de poder contar con nuevas fuentes para el periodo en estudio, y conservar a futuro el acervo testimonial que pueda servir de fuente para otros investigadores, puesto que muchos de los miembros de estas organizaciones son ya personas mayores, incluso algunas de las personas entrevistadas han fallecido; es mi interés, además, poner a resguardo sus narraciones con el trabajo de investigación presente. ${ }^{68}$

68 Véase el listado completo de los entrevistados al final de este trabajo entre las páginas 162 a 164 . 


\section{I.4 LAS FUENTES PRIMARIAS ESCRITAS}

La información documental escrita que se puede recabar para un estudio de estos movimientos es escasa. Algunos, como el caso de las Madres de desaparecidos de Tucumán han ido siguiendo periódicamente un libro de actas, mientras que otros militantes han guardado los recortes de periódicos u otros objetos personales en una caja o carpeta, pero, en general, la mayoría no han dejado huella escrita alguna. En todo caso, la documentación privada contribuye a nuevos hallazgos pero, en muchas ocasiones, no se tratan de documentos oficiales, ni siquiera de las organizaciones en estudio.

Otro inconveniente surge al rastrear noticias referidas a las acciones de estas organizaciones en la prensa local, que no ha reflejado de manera profunda y constante dichas actuaciones. Aunque existen algunas notas de prensa, en los últimos años de la dictadura y los primeros años de la transición democráticas, la prensa local daba muy poca cobertura a las acciones de los organismos de derechos humanos. Más allá de la propia rutina periodística, como la cobertura de algunas marchas o manifestaciones públicas, los medios locales, sobre todo $\mathrm{La}$ Gaceta de Tucumán, el periódico de mayor tirada en la provincia, daba escasa cobertura de las actividades del movimiento y sólo publicaba alguna noticia cuando algún referente nacional visitaba la provincia, o bien cuando alguna cuestión vinculada a la justicia comprometía a los represores y recibía por lo tanto la opinión de los dirigentes de los organismos de derechos humanos. Por lo tanto, la presencia de estas organizaciones en los medios periodísticos es escasa.

Aún cuando la prensa escrita haya mostrado algunas actividades del movimiento, muchos de sus rasgos no son reflejados allí, y reconstruir la historia por medio de lo que ha aparecido sólo en los 
periódicos resulta un imposible. No obstante, y aún sabiendo las dificultades que supone encontrar documentación escrita, presento en este trabajo el resultado de una búsqueda exhaustiva de fuentes escritas que, de alguna manera, contribuyen a confirmar o rechazar aquello que los testigos afirman en los testimonios.

Sobre las fuentes escritas del periodo, incluso cuando sea insuficiente, sigue siendo la prensa escrita de la época una fuente distinguida donde encontrar ciertas informaciones. Ya desde la crisis de la dictadura, sobre todo desde la derrota de la Guerra de Malvinas, desde mediados de 1982, y con un cierto debilitamiento del gobierno de facto, comienzan a aparecer algunas notas específicas de acciones concretas públicas del movimiento. Desde la apertura institucionalizada del país, sobre todo desde mediados de 1983, al comienzo de la campaña electoral previa a las elecciones de la apertura democrática, la prensa empieza a prestar mayor atención a actividades concretas, que tienen que ver con la visita de algún referente nacional a la provincia o a alguna acción del movimiento local de impacto, como una marcha, un ayuno o las declaraciones de determinados actores. Lo que sí es común al periodo dictatorial es la publicación de solicitadas, sobre todo en periódicos de gran tirada como Clarín, y donde el aporte monetario de los propios familiares sirvió para denunciar públicamente las desapariciones.

Distinto es lo que ocurre durante la larga transición vigilada, sobre todo desde fines de los años ' 80 y a lo largo de los años ' 90 , donde no solo la prensa local, sino también la nacional ${ }^{69}$ ha dado mayor

69 Me refiero a prensa escrita nacional a los periódicos de mayor tirada y con alcance de distribución en todo el país, especialmente Clarín y ya, desde 1987, con el surgimiento del diario Página 12, medio que ha prestado especial atención al tema del pasado dictatorial en todo el territorio nacional. En menor medida el diario La Nación, también ha tenido algunas referencias sobre lo ocurrido en Tucumán. 
importancia a los temas referidos a las luchas del movimiento de derechos humanos, sobre todo, como ya veremos en otro capítulo de este trabajo, con el surgimiento del Bussismo en democracia y las distintas elecciones que tuvieron como figura "destacada" al principal responsable de la represión dictatorial en Tucumán, Antonio Domingo Bussi. Las miradas de la prensa, tanto local como nacional, pronto se fijaron en lo que ocurría en Tucumán dado lo inédito de que un ex gobernador de facto tuviera participación en la vida política de la provincia. Es por este motivo, y no por otro, que los medios de prensa nacionales comenzaron a poner su atención en el proceso tucumano y, en particular, al desarrollo local de las acciones de las organizaciones de derechos humanos. En adición a esto, La Gaceta también comenzó a prestar mayor atención a las acciones del movimiento local, no tanto por su simpatía con las organizaciones que lo componían, sino por ser notas centrales del quehacer político local. Es así como, de la prensa escrita de finales de los '80 y sobre todo de los '90, encontramos mayores referencias a las antes indicadas.

Igualmente conviene una nueva digresión para explicar que aún cuando nos encontramos con notas de prensa, éstas deben leerse siempre con atención, ya que los medios hegemónicos locales y nacionales respondían al discurso dominante y el énfasis puesto en las noticias tenían que ver, sobre todo durante la dictadura militar, con los partes oficiales o con los filtros propios que impuso el gobierno militar a partir de cierta censura. En muchos casos la información sobre el movimiento de derechos humanos, como toda actividad que supusiera una resistencia a la propia dictadura, circuló subterráneamente, fuera de los circuitos tradicionales. Un buen ejemplo de esto que afirmo ha sido la Agencia Clandestina de Noticias (ANCLA), que llevó adelante el periodista 
desaparecido Rodolfo Walsh ${ }^{70}$, como estrategia comunicacional contrahegemónica. Hay que tener en cuenta, como también explicaré más adelante, que en Tucumán el control dictatorial era mucho más férreo que en otras regiones y esto impidió, en muchas ocasiones, que las organizaciones hicieran públicas sus manifestaciones por la aparición de los desaparecidos.

A los comunicados de prensa o las noticias aparecidas en los medios gráficos se deben agregar en la mención de las fuentes escritas los documentos personales. Si bien éstos no abundan, algunas cartas, poemas o notas escritas por los propios militantes me han sido entregadas como parte del acervo que constituye la historia misma del movimiento. En algunos casos se trata de apuntes tomados por los activistas en reuniones, en otros, de manuscritos con sus sensaciones sobre determinados acontecimientos. Sin embargo, tampoco este tipo de documentación es abundante ya que muchos militantes no han conservado "sus papeles" o bien no les han dado la importancia que se merecían.

De los documentos oficiales algunos revisten mayor importancia para el presente trabajo y valen destacarse no solo como tales sino que merecen, y será objeto de análisis, la explicación de cómo han sido confeccionados. Tal es el caso del Informe de la Comisión Bicameral Investigadora de los Crímenes de Lesa Humanidad realizado en Tucumán, un documento elaborado a partir de las denuncias recibidas por los parlamentarios locales luego que el Poder Ejecutivo provincial, en los primeros meses de la transición, decidiera su creación. Si bien el informe más reconocido a nivel nacional ha sido el Informe elaborado por la

70 Sobre la experiencia de contra información de Walsh léase Vinelli, Natalia (2002): ANCLA, una experiencia de comunicación clandestina orientada por Rodolfo Walsh, Edit. La Rosa Blindada, Buenos Aires. 
Comisión Nacional de Desapariciones de Personas (CONADEP), el Informe de la Bicameral, como lo explicaré más adelante, reviste un carácter especial dado que ha sido uno de los dos informes elaborados por una comisión parlamentaria, único en el país, junto a la provincia de Chaco. Asimismo, y dado el presente en el que este trabajo se elabora, las presentaciones judiciales y las sentencias elaboradas por los tribunales orales sobre los juicios recientemente llevados a cabo en la provincia de Tucumán, servirán como fuentes tenidas en cuenta, a la vez que los mismos dan fe de la represión estatal y parapolicial de los años dictatoriales.

Otros documentos encontrados y que sirven al presente trabajo son los informes y resoluciones de la Universidad Nacional de Tucumán, institución que se vio doblemente comprometida durante los años de la dictadura: por un parte, y como será explicado luego, un sector importante de la comunidad universitaria fue víctima de la represión dictatorial; por otra parte, otro sector, aunque relativamente menor, colaboró decididamente con los dictadores y sus representantes locales, desde su intervención misma hasta el funcionamiento de una central de inteligencia en la propia sede del Rectorado. Asimismo, durante la transición, la comunidad universitaria jugó un papel central en el esclarecimiento del pasado represivo nombrando comisiones investigadoras y contribuyendo sus miembros en las investigaciones de la comisión bicameral provincial. En este sentido, algunas resoluciones del consejo directivo forman parte también del corpus de fuentes escritas que presento en el trabajo y que me han servido decididamente para analizar el papel jugado por la casa de estudios en el periodo en cuestión.

A los documentos antes mencionados, se suman otras fuentes de no menor jerarquía a la luz de los primeros juicios llevados a cabo en la 
provincia de Tucumán. Me refiero en concreto a las sentencias condenatorias por el juicio en la desaparición del ex Senador Guillermo Vargas Aignase y que dictaminara la culpabilidad de, entre otros, el propio Antonio D. Bussi.

La segunda sentencia en cuestión es la que dictaminó la responsabilidad y culpabilidad de antiguos miembros de las fuerzas de seguridad local en la investigación sobre el centro clandestino de detención, la ex Jefatura de Policía local, que funcionó como campo de concentración donde los desaparecidos eran llevados en primera instancia antes de su disposición final. Ambas sentencias contribuyen a esclarecer aún más no sólo las responsabilidades militares en el esquema represivo local, sino, y sobre todo, a establecer mayores precisiones sobre cómo funcionaba dicho esquema. Si bien en el presente trabajo no propongo, desde esta perspectiva, indagar sobre dicho esquema represivo, la documentación escrita surgida de ambos casos resulta reveladora sobre lo ocurrido en Tucumán. Asimismo incorporo como fuente documental los fundamentos del Tribunal Federal para elevar la causa sobre el Operativo Independencia a juicio, fundamentos que se difundieron en diciembre de 2012 por los medios de prensa. Dicho documento resulta de un incalculable valor, no sólo jurídico, sino también testimonial, pues, en las interpretaciones de los jueces actuantes, se determina el comienzo del esquema represivo en Tucumán situándolo en 1975, es decir, un año antes del último asalto de los militares al poder.

Un párrafo aparte merecen los testimonios producidos a instancias de ambos juicios recogidos, en líneas generales, por los medios de prensa local $^{71}$. Si bien las fuentes judiciales resultan de un valor

71 Cabe mencionar que en los últimos años los medios de prensa se han multiplicado, sobre todo tras la aparición de las nuevas tecnologías que permitió, entre otras cosas, el surgimiento de una cantidad importante de medios digitales 
documental incalculable, no dan cuenta, por ejemplo, de las acciones acometidas por los miembros de las organizaciones de derechos humanos a lo largo de toda su historia, siendo que muchos testigos en las distintas causas pertenecen a dichos organismos. Está claro que lo que busca el tribunal es saber qué ha ocurrido en torno al esquema represivo en Tucumán y no tanto cuál es el devenir histórico de unas organizaciones que remontan sus orígenes a ese pasado dictatorial del que se indaga. Si bien el testimonio de un familiar de víctimas de la represión dictatorial narrará lo que le ha tocado vivenciar a partir de la desaparición del ser querido, el tribunal no ahondará en detalles de las acciones llevadas a cabo para su aparición. Es aquí donde choca el principio de verdad y justicia con un claro límite, pues no es papel del tribunal que juzga establecer criterios históricos sobre el pasado reciente sino el establecimiento de los criterios de verdad seguido de justicia. En este sentido los testimonios y sentencias a instancias del aparato judicial tendrán el valor de la objetividad, aquello que empíricamente se puede corroborar para el establecimiento de la sentencia, y no tanto el plano de las subjetividades, de la experiencia vivida por los familiares, que es, en definitiva, lo que busco establecer en este trabajo.

locales que han puesto cierto énfasis en la cobertura mediática de los juicios aquí mencionados. 


\section{CAPÍtulo II: Los PoRVENIRES de LA MEMORIA}

\section{II.1 La Memoria de los "Familiares"}

"Todo está guardado en la memoria, sueño de la vida y de la historia". ${ }^{72}$

El tema de la memoria ocupa un lugar central en la historia oral y, en el presente trabajo, es uno de los ejes fundamentales a tener en cuenta. En las entrevistas apelamos al recuerdo del entrevistado y en esa construcción encontramos a la memoria en permanente conflicto. Según Cuesta "la memoria, en el sentido más simple del término, es la presencia del pasado"73. $\mathrm{Y}$ siguiendo a $\mathrm{H}$. Rousso agrega que "es una reconstrucción psíquica e intelectual que supone, de hecho una representación selectiva del pasado que no es nunca el del individuo solo, sino el de un individuo inserto en un contexto familiar, social y nacional" ${ }^{\prime 74}$.

En trabajos de investigación, donde el testimonios es una de las fuentes fundamentales, producto de la entrevista, la memoria es un proceso compartido entre el historiador / entrevistador y el actor participante / entrevistado. El primero busca por medio de preguntas activar la memoria del entrevistado, quien en un múltiple esfuerzo por evocar el pasado, intenta decir qué ha pasado, qué ha querido él que pasara y cómo analiza lo sucedido. El relato oral acompaña la evocación de los acontecimientos por medio del recuerdo del entrevistado. La

\footnotetext{
72 Gieco, León (2002): La Memoria, del CD Bandidos Rurales, EMI.

73 Cuesta, Josefina (1996): "De la Memoria a la Historia", en Entre el pasado y el presente. Historia y memoria, Universidad Nacional de Educación a distancia, Madrid.

74 Ibídem.
} 
dualidad memoria-olvido es clave cuando se los vincula a experiencias traumáticas colectivas de represión o aniquilamiento, cuando se trata de catástrofes sociales o colectivas. ${ }^{75}$

Vale aquí un nuevo paréntesis para mencionar dos debates en el campo académico que luego se vieron traducidos en dos obras bibliográficas que recogen lo fundamental de la discusión en torno a la dualidad "memoria - olvido" y que demuestran la creciente preocupación por comprender y aprehender el fenómeno en sus dos caras. El primero "Usos del olvido"76, recoge las exposiciones del coloquio de Royaumont en el que pensadores como Yerushalmi, Loraux, Mommsen, Milner y Vattimo exponen de manera provocativa las reflexiones en torno a un tema tan sensible para el historiador como el olvido, siempre en contrapartida con la memoria. El segundo de ellos, a mi modo de ver mucho más provocativo, interpela a los historiadores a partir del Foro Internacional sobre "memoria e historia" Ilevado a cabo en 1998 y convocado por la Academia Universal de las Culturas donde pensadores como Ricoeur, Kristeva, Xinegjian, Eco y otros se preguntan "¿Por qué recordar?"77. Ambas discusiones discurren entonces entre los usos del olvido y las necesidades del recuerdo atravesadas, todas las exposiciones, en el neurálgico asunto de la memoria.

Sobre ésta cuestión, y en concreto en Argentina, Elizabeth Jelín, al referirse a los grupos oprimidos, silenciados y discriminados de una sociedad, país o región, considera que "la memoria tiene un papel altamente significativo como mecanismo cultural para fortalecer el

75 Ibídem. Quien ha trabajado sobre dichos traumas, al hablar de los efectos Psicológicos de la represión, fue el equipo de Asistencia Psicológica de Madres de Plaza de Mayo y cualquiera que quisiera tratar dicho tema debe consultar en Kordon, Diana y Edelman, Lucila y otros (1986): "Efectos psicológicos de la represión política". Ed. Sudamericana / Planeta. Buenos Aires.

76 AAVV (1998): Usos del olvido, Ediciones Nueva Visión, Buenos Aires.

77 AAVV (2007): ¿Por qué recordar?, Edit. Granica, Buenos Aires. 
sentido de pertenencia"78, al mismo tiempo que se asocia con lo que Todorov llama "la resistencia antitotalitaria". ${ }^{79}$ Vezzetti sostiene que "la referencia a la memoria supone alguna forma de recuperación del pasado en la que nos sentimos involucrados", ${ }^{80} \mathrm{y}$ agrega que lo que se recuerda es un pasado que de alguna manera se vincula con el presente. La memoria es para Vezzetti "una práctica social" y a su vez requiere de "soportes materiales"81, sobre los que ya he hecho mención. Como vemos, en la Argentina post dictatorial la memoria está íntimamente relacionada a los efectos represivos del pasado reciente y la preocupación de los especialistas tienen que ver con la recuperación de ese pasado por una parte, y de su apropiación por parte de quienes han sufrido la represión y sus familiares, que atravesados por un hecho traumático, debieron enfrentar a las políticas estatales de la transición que de una u otra forma invitaban al conjunto social al olvido.

Para Vezzeti, entonces, no se trata de formas mentales sino de marcos materiales, ya que antes de estar presente en la mente de los hombres y mujeres que participaron de los acontecimientos, se encuentra en aquello que es material: ceremonias, libros, películas, monumentos, lugares, etc. La posibilidad de traer al presente aquello que está situado en el pasado requiere de actores, voluntad de hacerlo, tiempo y recursos. ${ }^{82}$

Vezzetti considera que "...la causa de la memoria depende de la fuerza y la perdurabilidad de estos soportes y de una acción que sea capaz de renovar su impacto sobre el espíritu público. En la fuerza y los

\footnotetext{
78 Jelín, Elizabeth: Memorias en conflicto. Revista "Puentes". № 1 - Agosto 2000.

79 Tzvetan, Todorov (2000): "Los abusos de la memoria". Editorial Paidós Asterisco.

80 Vezzetti, Hugo: Un Mapa por trazar. Revista "Puentes". N 1 - Agosto 2000.

81 Ibídem.

82 Ibídem.
} 
contenidos de la memoria se relacionan y se entrecruzan el pasado y el presente". ${ }^{83}$

Esta opinión es igualmente sostenida por L' Hoste, quien refiriéndose a las Madres de Plaza de Mayo, sostiene que "ocupan un lugar geográfico en la comunidad, la Plaza de Mayo, histórica plaza, lugar de convocatoria del pueblo (...) Marcharán con las fotos de sus H.I.J.O.S., concretizando sus presencias. Llevarán el pañuelo-pañal en una evocación de la unidad madre-hijo primaria". ${ }^{84}$ Es posible afirmar esto también de todas las demás organizaciones de derechos humanos que han actuado y que aún hoy actúan en la esfera del ámbito público. La marcha de los 24 de marzo en Tucumán se ha convertido, en este sentido, en el escenario vivo de esa presencia, donde las memorias en conflictos juegan un papel central en la disputa por quién ocupa un lugar en el palco y desde dónde hablará cada uno. Lo que nunca falta son las fotos de los desaparecidos. La colectividad se debate con la individualidad y si bien todas las organizaciones buscan recordar el pasado, cada una lo hace desde su lugar, desde su posición.

$\mathrm{Si}$, como afirman algunos historiadores, "toda memoria es memoria colectiva" ${ }^{185}$, todos los 24 de marzo son, en Tucumán, el ámbito donde la colectividad se vive plenamente en el recuerdo del pasado. No me extenderé sobre esta cuestión que ha sido ampliamente debatida, debido a la extensión del presente trabajo, pero sí debo advertir que este será uno de los temas claves que guiará la investigación.

Una cuestión que resulta entonces conveniente exponer es que la memoria tiene además sus marcas territoriales, ocupa un espacio

83 Ibídem.

84 Kordon, Diana y Edelman, Lucila y otros (1986): "Efectos psicológicos de la represión política". Ed. Sudamericana / Planeta. Buenos Aires.

85 Cuesta, Op. Cit. Véase en este sentido los aportes de Halbwachs, Maurice (2011): La memoria colectiva, Miño Dávila Editores, Buenos Aires. 
público, un espacio que supone una batalla por la lectura que se hace del mismo pasado en disputa. En Tucumán, el escenario público siempre fue una zona de reconocimiento de pujas políticas, donde no sólo las calles fueron testigos de los enfrentamientos entre el llamado campo popular y las fuerzas del régimen o de gobiernos elegidos por medio del voto, sino que además, la disputa se hizo evidente en otros espacios más específicos como la Universidad, los comedores universitarios o, por ejemplo, en distintos bares tradicionales de la provincia donde las tertulias políticas de todo el arco opositor al régimen liberal eran convocantes para la discusión. Con nostalgia, algunos ex militantes recuerdan y narran las discusiones políticas en sitios como "La Cosechera" o "El Buen Gusto", dos cafés tradicionales de Tucumán, hoy ya desaparecidos. La marcación de estos escenarios por parte del MDHT ante determinadas fechas conmemorativas o la imposición del nombre en el callejero por parte de las autoridades gubernamentales durante la transición, evidenció que aquellas marcas de las que hace mención Vezzetti, también tuvieron su punto de disputa en la provincia.

Para el MDHT el espacio público fue un escenario de disputa permanente y aún hoy lo sigue siendo, no sólo durante la dictadura, cuando sus militantes decidieron romper el cerco y pasaron a la movilización callejera, como venía sucediendo en Buenos Aires desde la aparición de las primeras rondas de las Madres de Plaza de Mayo en abril de 1977. También, a lo largo de la transición vigilada, como mecanismo de reconocimiento colectivo de una acción directa por ocupar la calle y la plaza el MDHT le disputó a los poderes de turno el espacio público en acciones bien concretas. Al transcurrir los últimos años de la última dictadura militar, la ocupación de las calles por parte del MDHT se hizo más evidente en la cantidad de manifestaciones sobre todo en 
determinados momentos vinculados a la liturgia impuesta desde las mismas organizaciones que conforman el conjunto. Más adelante centramos nuestra mirada en las marchas y otras prácticas del 24 de marzo, pero mencionarlas ahora supone adelantar una hipótesis, y es la que define al espacio público como un espacio de disputa de las memorias eminentemente políticas. La colocación de placas conmemorativas en espacios significativos por algún acontecimiento determinado involucra, hasta el presente, una acción en la que las organizaciones procuraron reafirmar su memoria respecto al pasado disputado. El "aquí sucedió" irrumpe como una estrategia comunicativa al conjunto social para prevenir que lo traumático de la represión puede volver a suceder, aunque lo deseable sea que el "nunca más" suceda, parafraseando al título del informe de la CONADEP.

Más adelante podremos observar acciones concretas de la utilización del espacio público como escenario de las memorias en disputa. Lo que conviene en todo caso aclarar aquí, es que dichas memorias no sólo son representaciones simbólicas por medio de distintas manifestaciones ni una recuperación desde lo testimonial, sino que configuran materialidades espaciales que definen una narrativa hacia el pasado sobre el que se procura establecer la verdad por principio y la justicia como valor de aquello que fue pero que no debe repetirse nunca más.

En este sentido otra dimensión a tener en cuenta en el estudio de la memoria es su dimensión ética y el compromiso moral de quienes recuerdan. Refiriéndose a la memoria de la dictadura militar argentina, Vezzetti sostiene que su construcción es compleja, ya que se trata de "una memoria cargada sobre todo con la evocación de lo que no debe 
repetirse", ${ }^{86}$ es decir, está aludiendo a la cuestión de la ética en la reconstrucción del pasado, lo mismo que ocurriera, por ejemplo, en la Alemania del post nazismo. En esta línea de análisis, Dreizik habla del compromiso moral hacia ese pasado y sostiene que "estamos llamados a responder por, y somos responsables de, acciones que no hemos cometido y que tuvieron lugar en un tiempo que no es el nuestro". ${ }^{87}$

Para el caso de los entrevistados en este trabajo, el compromiso moral asumido no es solo con "el pasado" sino con todo lo que ese pasado encierra, en particular con los familiares que se encuentran desaparecidos. Si bien los familiares buscan el establecimiento de la verdad, el sostener el recuerdo implica la perseverancia, desde una razón moral, de la búsqueda en el tiempo, en primera instancia una búsqueda del familiar $y$, en segunda instancia, ante la presunción de la muerte de los desaparecidos, la búsqueda de justicia ante el crimen cometido.

Pero las memorias aparecen al mismo tiempo contradictorias, en conflicto, en una tensión. Jelín indica que "siempre habrá otras historias, otras memorias y otras interpretaciones alternativas". ${ }^{88}$ Justamente en esas diferencias es donde deseo indagar al entrevistar a los actores que participan o han participado en cada uno de los organismos de derechos humanos. Esto implica ver a la memoria como un espacio de lucha política que en ocasiones se torna en una batalla contra el olvido, ${ }^{89}$ pero que al mismo tiempo define una concepción actual de mundo y siempre en perspectiva del futuro.

Nuevamente vuelvo a la idea de aquello que no debe repetirse "nunca más". Esa lucha o conflicto puede darse en el interior de un 86 Vezzetti, Hugo: Un Mapa por trazar. Revista "Puentes". N 1 - Agosto 2000.

87 Dreizik, Pablo M. Comp. (2001): "La Memoria de las cenizas". Editado por la Dirección Nacional de Patrimonios, Museos y Artes. Buenos Aires.

88 Jelín, Elizabeth: Memorias en conflicto. Revista "Puentes". N 1 - Agosto 2000.

89 Ibídem. 
mismo grupo, tal como les sucedió a las Madres de DetenidosDesaparecidos de Tucumán, no sólo en el momento mismo de su división a finales de 1983, sino en el hecho de recordar las causas de la separación. En Tucumán, las tensiones se tornan acto cada vez que se producen las marchas del 24 de marzo o cada vez que se debe consensuar una acción unitaria, notando además que esto ha sido así desde los orígenes mismos del movimiento. Dicha dinámica confrontativa es propia de todo movimiento social, no es exclusiva del movimiento de Derechos Humanos y supone tensiones que pueden aflorar en ciertos momentos históricos. Quién ocupa el palco central, quién elabora el documento que será leído, quién expresa la voluntad de los desaparecidos, son algunas de las cuestiones que se observan en esa disputa por la memoria año tras año.

Retomo en este punto el ejemplo de la división de Madres de detenidos desaparecidos, donde algunas militantes hacen un determinado balance sobre las causas de la división del grupo, visión que no es compartida por todas las mujeres. Mientras algunas plantean los factores externos como la intromisión de referentes bonaerenses en cuestiones locales, otras recriminan a sus compañeras ciertas decisiones de intransigencia. ${ }^{90}$ Sin embargo, lo común a todas las integrantes de "Madres" de desaparecidos, más allá de su propia visión y de las contradicciones aparentes, es que existe en ellas una necesidad de recordar el pasado anterior, la desaparición de sus hijos o hermanos, y la modalidad permanente de su búsqueda. Sin embargo, aquello que es un derecho, como ser el acto de recordar, en el contexto de una tragedia seguida de un trauma social, como la ocurrida en Argentina, se convierte en un deber: acordarse y dar testimonio de aquello que no debe volver a

90 Kotler, Rubén, Los Movimientos Sociales: Formas de resistencia a la dictadura, Op. Cit. 
ocurrir. ${ }^{91}$ Nuevamente, el acto de recordar supone la conjugación del pasado con el futuro, mediada por el presente que recuerda.

\section{II.2 EL PASADO TRAUMÁTICO ENTRE LA MEMORIA Y EL TESTIMONIO}

Una cuestión no menor sobre las entrevistas del presente trabajo es que refieren, como expresé más arriba, a un pasado traumático, vinculado al Estado represivo. La experiencia vivida por la mayoría de los entrevistados, tiene que ver con la desaparición de un familiar y su búsqueda, con la propia persecución política, con auto-exilios y hasta con la propia detención y tortura, como en el caso ya mencionado de Carlos Soldati. En este sentido, las entrevistas de historia oral reunidas en este trabajo suponen en su estructura interna, cuestiones intrínsecas de un pasado dictatorial y represivo, con toda la carga que ello implica. Hasta no hace muchos años, y por motivos que explicaremos a lo largo del trabajo, el miedo todavía les impedía a los familiares narrar el horror vivido y no fue tarea sencilla conseguir que algunos familiares aceptaran ser entrevistados. La tarea de entrevistar, para el historiador, en estos casos, resulta compleja, al tiempo que supone un desafío.

Quien más ha reflexionado sobre los testimonios referidos a pasados traumáticos es el historiador Dominick LaCapra. ${ }^{92} \mathrm{Si}$ bien LaCapra centra el objeto de sus análisis en los testimonios de los sobrevivientes de los campos de concentración en la Alemania Nazi, algunas de sus reflexiones sirven para dar cuenta sobre cómo operan determinadas situaciones verificables no sólo en el resultado de las entrevistas, sino también durante el desarrollo de las mismas e incluso

91 Tzvetan, Todorov, Los abusos de la memoria, Op. Cit.

92 Véase LaCapdra, Dominick (2001): Escribir la historia, escribir el trauma, Nueva visión, Buenos Aires. Del mismo autor, (2008): Representar el Holocausto. Historia, Teoría, Trauma, Prometeo, Buenos Aires; LaCapra, D (2008): Historia y memoria después de Auschwitz, Prometeo - UNTREF, Buenos Aires. 
antes, cuando uno procura contactar a los entrevistados. Quizás deba afirmar aquí que la mejor entrevista es aquella que no pude concretar, cuando contacté con quien había sido la primera presidente de la organización de Familiares de Detenidos Desaparecidos por Razones Políticas en Tucumán, Carmen de Mitrovich. Todos la nombraban, e incluso aparece dando su testimonio en el Juicio Ético mencionado más arriba donde el mismo Carlos Soldati prestó declaración. Al concertar la entrevista con Carmen en un primer momento había accedido a ser entrevistada, tuvimos un charla informal de presentación en la que comenzó a narrar la desaparición de su hija hasta quebrarse y echar a llorar. Quedamos en que yo la llamaría para concertar la entrevista, pero luego, días más tarde, me llamó ella misma para disculparse, que por razones de salud no podía darme su testimonio.

La negación a dar testimonio, los olvidos, las omisiones, las interrupciones en los relatos seguidos por la tristeza del rememorar un hecho del pasado traumático que sigue presente, la ausencia del duelo impedido por la desaparición de los cuerpos de los represaliados, son cuestiones determinantes en los relatos y deben ser tenidos en cuenta, no sólo al momento de realizar la entrevista misma, sino también, y sobre todo, a la hora de analizar lo que el testimonio dice, lo que oculta, lo que calla o tergiversa y los silencios, esas pausas que muchas veces no son valoradas por los historiadores orales, y pueden decirnos mucho más que las palabras.

Para LaCapra, quien da el testimonio vuelve a vivir el horror al afirmar que "en la memoria traumática, el acontecimiento queda registrado e incluso se lo puede volver a vivir en el presente, a veces de manera compulsiva y repetitiva. ${ }^{\prime \prime 3}$ En el caso de las causas judiciales un

93 LaCapdra, Dominick (2001): Escribir la historia, escribir el trauma, Op. Cit. Pp. 107 y 108. 
equipo de psicólogos acompaña a los testigos en el camino de la testificación, lo que no sucede cuando el historiador avanza en una entrevista. LaCapra explica que es posible "que en ese proceso no intervenga una rememoración dirigida y consciente. Sin embargo, el acontecimiento vuelve en las pesadillas, en escenas que reaparecen vívidamente sin intervención de la voluntad, en ataques de angustia y en otras intrusiones repetitivas que son características de un andamiaje despótico". ${ }^{94} \mathrm{Y}$ esto es verificable en el acto mismo del testimoniar.

En más de una entrevista tuve que interrumpir el cuestionario pues los testigos se angustiaban, lloraban y hasta se ahogaban. Sobre todo sucede cuando narraban la manera en cómo sus familiares habían sido secuestrados o la expectativa perdida de saber dónde está el cuerpo para la elaboración del duelo e incluso cuando explicaban las expectativas de justicia que con el tiempo se habían ido desvaneciendo. Debe quedar claro que la función del historiador no es la función del psicoanalista y es lo que intenta establecer, en las diferencias, el historiador estadounidense cuando afirma que historiadores y psicoanalistas, suelen hablar un idioma distinto. ${ }^{95}$ La entrevista de historia oral, en este caso, nunca será liberadora ni podrá prometerle al testigo una salida del trauma pero, LaCapra insiste que "como aspecto de la elaboración del pasado, el recuerdo implica volver allá y estar aquí simultáneamente, y ser capaz de distinguir esos dos tiempos sin dicotomizarlos. En otras palabras, se recuerda lo que sucedió entonces sin perder la noción de que se vive y se actúa en el ahora, aun cuando en cierta medida quizá se vuelva a vivir todavía compulsivamente el pasado o a ser poseído por él." ${ }^{\prime 96}$

\footnotetext{
Ibídem.

Ibídem.

Ibídem.
} 


\section{CAPÍTULO III: LOS DERECHOS HUMANOS Y LOS NUEVOS MOVIMIENTOS SOCIALES}

\section{III.1 Algunos Lineamientos teóRICOS}

Luego de explicar la metodología empleada en este trabajo, estimo conveniente exponer cómo entiendo al movimiento de derechos humanos de Tucumán en el marco de la teoría sociológica sobre los movimientos sociales. Entendiendo que las organizaciones que conforman el colectivo local han conformado un todo organizado a pesar de la autonomía con la que se actuó cada organismo, el trabajo del conjunto se vio enmarcado dentro de la acción colectiva. Es así como los aportes desde la sociología me han permitido comprender y aprehender mi objeto de estudio como un todo que por momento se vio cohesionado a pesar de las diferencias $y$ tensiones propias de todo movimiento social complejo.

Como afirman Pedro Ibarra y Benjamín Tejerina, "a lo largo de los últimos años las formas tradicionales de movilización han experimentado grandes cambios hasta el punto de que muchos analistas se preguntan si no estaremos asistiendo al nacimiento de un nuevo modelo de acción colectiva". ${ }^{97}$ Lo que busco en el presente trabajo es entender el Movimiento de Derechos Humanos dentro de lo que la sociología ha dado en llamar los Nuevos Movimientos Sociales (NMS), nuevas formas de acción colectiva surgidas en Argentina durante la última dictadura militar y que, a lo largo de los años '70 y ya durante la larga transición vigilada

97 Ibarra, Pedro, Tejerina, Benjamín editores (1998): Los Movimientos Sociales. Transformaciones Políticas y cambio cultural, Edit. Trotta, Valladolid, Pp. 10 a 12. 
desde 1983, se han erigido como resistencia y respuesta a la represión, que dejó un saldo de 30.000 detenidos desaparecidos en el país.

En un marco de mayor amplitud, tomo para su estudio a un gran conjunto de organizaciones de derechos humanos de las que iré marcando diferencias y similitudes, pero que, sin embargo, serán analizadas aquí en como un colectivo que denomino Movimiento de Derechos Humanos de Tucumán ${ }^{98}$. Busco establecer los nexos que las organizaciones locales han entretejido entre sí y con sus homónimas de otras regiones o provincias, alguna de las cuales se han destacado por su actuación espacial en la capital del país, Buenos Aires.

La violación sistemática de los derechos humanos en Argentina, en general, y en Tucumán, en particular, ha dado como resultado la aparición de nuevos actores sociales cuya participación se ha visto limitada por la clausura de los canales tradicionales de expresión política, como ser los partidos políticos, las instancias institucionales como el parlamento o los tribunales, y que, por medio de la movilización pública, encontraron nuevas válvulas de escape para llevar adelante sus reclamos. ${ }^{99}$

Si la dictadura instaurada el 24 de marzo de 1976 pretendió "aniquilar" a todo actor social opositor al régimen liberal instaurado diez años antes, vio nacer, por el contrario, a un nuevo sujeto de oposición que, ligado directa o indirectamente a los represaliados, encontró una nueva forma de enfrentar a los represores, constituyéndose en organizaciones hasta el momento novedosas.

98 A partir de ahora llamaré al Movimiento de Derechos Humanos de Tucumán con las siglas MDHT.

99 Para Tucumán véase Kotler, Rubén (2006): Los Movimientos Sociales: formas de Resistencia a la dictadura. Madres de Detenidos Desaparecidos de Tucumán, Op. Cit. 
Cabe mencionar en este punto que si bien los inicios del movimiento se remontan a los comienzos de la última dictadura militar, su continuidad en el tiempo y su andar en la transición institucional del país, supone un abanico de preguntas sobre unas organizaciones que fueron mutando, según mis hipótesis, y por lo tanto cada periodo de su accionar debe ser comprendido en el marco político del desarrollo histórico de la provincia en estudio. La dictadura supuso un marco de inflexión para el surgimiento de tales organizaciones vinculadas, en principio, con lazos de sangre con los represaliados, pero al mismo tiempo, el no cumplimiento de los objetivos del movimiento no sólo hizo que sus acciones no llegaran a su fin al momento de la apertura democrática institucionalizada, sino que, por el contrario, se dieran nuevas formas y estrategias de acción, apareciendo incluso nuevas organizaciones que dieron vida al movimiento en su conjunto.

Al remitirnos al surgimiento del movimiento de derechos humanos, asoma la idea de la "determinación", planteada por el sociólogo inglés Raymond Williams. En 1980 Raymond Williams publica "Marxismo y Literatura" donde postula que no son "'la base" y "la superestructura" las que necesitan ser estudiadas, sino los verdaderos procesos específicos e indisolubles dentro de los cuales, desde un punto de vista marxista, la relación decisiva es la expresada por la compleja idea de la determinación."100

Williams expresó que en el marco de la teoría cultural marxista no existe problema más difícil que el de la "determinación" explicando que "el sentido fundamental del término "determinar" es "fijar términos o fijar límites" e implica por lo tanto poner un límite, poner fin a alguna acción que resulta problemática. Se pone el énfasis en la idea de la acción

100 Williams, Raymond (2000): Marxismo y Literatura, Ediciones Península, Barcelona. Pp. 102 a 108. 
directa: "Somos nosotros mismos quienes producimos nuestra historia". ${ }^{101}$ Las condiciones y los supuestos "definidos" u "objetivos", por lo tanto, son términos que califican esta acción: es verdaderamente la "determinación" como "fijación de límites". Sin embargo para Williams, en la práctica, la determinación nunca es solamente la fijación de límites sino también el ejercicio de presiones. Sobre este principio buscaré establecer cuál ha sido la determinación y qué límites han sido sobre los que ha ejercido presión el accionar del movimiento de derechos humanos en la provincia argentina de Tucumán tanto en dictadura como en la larga transición vigilada.

Dirá entonces Williams que "...la realidad de la determinación es el establecimiento de límites y el forjamiento de presiones, dentro de los cuales las variables prácticas sociales son profundamente afectadas pero nunca necesariamente controladas". ${ }^{102}$ Es en contextos represivos donde quizás este juego dialéctico encuentra mayor claridad. En América Latina distintos regímenes dictatoriales establecieron rígidos límites de acción, fijando severas normas y duros castigos a quienes procuraran "subvertir" dichos límites. Los castigos tenían que ver no solo con la cárcel sino también con distintas formas represivas que iban desde el secuestro clandestino, la tortura en centros de detención ilegales hasta la desaparición física misma de los individuos considerados "subversivos". Al denominar subversivo como el blanco de ataque el régimen dejó abierto un amplio abanico de posibles sectores sobre los cuales fijar los límites que además supusieron la barrera moral entre el bien y el mal. La dictadura materializó distintas herramientas para la fijación de dichos

${ }_{101}$ Williams, Raymond (2000): Marxismo y Literatura, Op. Cit. P. 103 a 105. 102 Ibídem. 
límites entre los que la desaparición forzada fue una de ellas pero no la única. ${ }^{103}$

A los límites del poder dominante, distintos grupos de resistencia comenzaron a ejercer presiones. Agrupaciones que reunían a familiares de las víctimas empezaron tempranamente a manifestarse contra el régimen no solo en el afán de conseguir la aparición con vida de sus seres queridos sino también reclamando la apertura democrática, el final de esos "rígidos" límites establecidos, en términos de Williams.

Sin embargo la respuesta a los "límites" fijados por la dictadura no fue igual en todo el continente latinoamericano ni dentro de la propia República Argentina; las presiones se hicieron sentir de manera desigual según la región o provincia. Cuanto más rígido fueron establecidos los límites por parte del régimen, más tardíamente aparecieron los grupos de presión. Es al menos lo que se puede observar para el caso de la provincia de Tucumán, una de las más afectadas por las medidas de la dictadura y donde los controles sociales fueron de los más férreos en todo el país, controles que como ya expresé, se hicieron sentir con dureza incluso antes de instaurado el gobierno de facto.

Es necesario clarificar algunas cuestiones referidas a la idea de "determinación" planteada por Williams en el dialéctico proceso de "fijación de límites" y el "forjamiento de las presiones". Dentro de un proceso social, las determinaciones, que pueden ser experimentadas

${ }_{103}$ Cabe aclarar que el método represivo argentino siguió la doctrina de la Escuela Francesa en la denominada lucha antisubversiva. Véase en este sentido Péries, Gabriel La doctrina militar contrainsurgente como fuente normativa de un poder de facto exterminador basado en la excepcionalidad; Ranalletti, Mario Contrainsurgencia, catolicismo intransigente y extremismo de derecha en la formación militar argentina. Influencias francesas en los orígenes del terrorismo de Estado (1955-1976); ambos capítulos en Feierstein, Daniel (2009): Terrorismo de Estado y Genocidio en América Latina, Edit. Prometeo y EDUNTREF, Buenos Aires, Pp. 221 a 249. 
individualmente pero que son siempre actos sociales, son realmente y con frecuencia, formaciones sociales específicas, mantienen relaciones muy complejas con las determinaciones negativas, que son experimentadas como límites, puesto que en modo alguno son sólo presiones contra los límites, aunque éstos son de fundamental importancia. Asimismo entiende Williams que con frecuencia son presiones derivadas de la formación y el impulso de un modo social dado. Son además, presiones ejercidas por formaciones nuevas con sus requerimientos e intenciones todavía por realizar.

Basta mirar como ejemplo el surgimiento y la acción de los llamados nuevos movimientos sociales, surgidos tras la Segunda Guerra Mundial en un contexto de expansión del capitalismo. Estos nuevos movimientos plantearon una serie de presiones o demandas al sistema imperante para la transformación del modelo con diferentes posicionamientos. Grupos ecologistas, feministas, la llamada nueva izquierda en sus distintas vertientes, son algunos de los ejemplos posibles de ser examinados y tanto la sociología como la historiografía han centrado sus miradas en ellos, como organizaciones constitutivas de la historia contemporánea en el llamado mundo occidental.

Williams explica entonces que la "sociedad" nunca es solo una "cáscara muerta" que limita la realización social e individual. Es siempre un proceso constitutivo con presiones muy poderosas que se expresan en las formaciones culturales, económicas y políticas y que, para asumir la verdadera dimensión de lo "constitutivo", son internalizadas y convertidas en "voluntades individuales". La determinación de este tipo -un proceso de límites y presiones complejo e interrelacionado- se halla en el propio 
proceso social en su totalidad, no en un abstracto "modo de producción" ni en una "psicología" abstracta. ${ }^{104}$

Hablar de movimiento social es referirse entonces a acciones conflictivas que buscan la transformación de las relaciones sociales de dominación que se ejercen sobre los principales recursos culturales, la producción y el conocimiento. Dichos conflictos pueden conducir a una ruptura del sistema político o a reformas institucionales y se manifiestan cotidianamente en las formas de organización social y cultural, en las relaciones de autoridad. Un movimiento social es la acción conflictiva por la cual, las orientaciones culturales son transformadas en formas de organización social, que son definidas por normas culturales generales y relaciones de dominación social. ${ }^{105}$ Dicho en los términos explicados por Williams, una resistencia a la determinación impuesta por los poderes hegemónicos o dominantes.

Un movimiento social no puede existir sin una cierta conciencia de sí mismo, aunque esto no implica que pueda organizarse y pensarse directamente sobre un proyecto político distinto del tradicional. ${ }^{106}$ De aquí surge entonces la necesidad de observar qué entendemos por política. Según Luis Sánchez Agesta, se pueden definir como políticos "los procesos, acciones o instituciones que definen polémicamente un orden vinculante de la convivencia que realice al bien público". ${ }^{107}$ El traslado del reclamo de los militantes de las organizaciones de derechos humanos por la aparición de los represaliados al espacio público, ha transformado un reclamo personal o individual en social, haciendo extensiva sus

\footnotetext{
104 Williams, Op. Cit.

105 Touraine, Alain (1984): "Los Movimientos Sociales". Ed. Almagesto, Buenos Aires.

106 Ibídem.

107 Sánchez Agesta, Luis (1972): Principios de teoría política, Editorial Nacional, Madrid.
} 
demandas a otros asuntos de la vida institucional del país. Según Hannah Arendt, la política es una necesidad ineludible para la vida humana, tanto individual como social. Puesto que el hombre no es autárquico, sino que depende en su existencia de otros, el cuidado de ésta debe concernir a todos, sin lo cual la convivencia sería imposible. Misión y fin de la política es asegurar la vida en el sentido más amplio. Es la política quien hace posible al individuo perseguir en paz y tranquilidad sus fines. ${ }^{108}$

La idea de política está directamente vinculada a las ideas de poder, conflicto y fines que se consideran de bien público. En este sentido, el MDHT ha desafiado el poder del Estado, ocupando un espacio público determinado, realizando presentaciones judiciales, actos públicos, manifestaciones y otras expresiones, y todo esto ha convertido invariablemente la lucha del movimiento en política. Estas afirmaciones llevan a una nueva manera de relacionar tanto lo político y lo social como la vida privada y el mundo público, en la cual las prácticas sociales cotidianas se incluyen junto a lo ideológico y lo institucional - político tradicionalmente establecido. En dictadura la confrontación se hace más evidente, buscando romper los límites impuestos por la dictadura, siempre en los términos planteados por Williams. A lo largo de la transición, si bien el repertorio de demandas se ve modificado, y las acciones y estrategias cambian, la disputa de lo público sigue vigente en el amplio espectro de las organizaciones que conforman el movimiento, tanto las más antiguas, como las nuevas, surgidas de la apertura institucionalizada del país.

Desde una mirada que tome en cuenta la crisis social e institucional de un país, como la que ha atravesado a Argentina en los años '70, se podrá comprender a los movimientos sociales como nuevas 108 Birulés, Fina (1997): Hannah Arendt ¿qué es la política? Ed. Paidós, Barcelona, P. 67. 
formas de hacer política, nuevas instancias de participación pública y de nuevas relaciones sociales y de poder. Es posible entonces afirmar que los nuevos movimientos sociales surgen en momentos en que los canales tradicionales por los que se rigen las sociedades occidentales contemporáneas están clausurados 0 han entrado en crisis, ${ }^{109}$ generándose nuevas formas de socialización, nuevas redes sociales y nuevos sujetos políticos, que, participando al margen de las instituciones, buscan establecer relaciones de fuerza con las autoridades, sean estas dictatoriales o democráticas.

Aunque los actores que conforman los llamados nuevos movimientos sociales alcancen una conciencia de sí mismos y de las organizaciones que les nuclean, pueden surgir más o menos espontáneos y pueden construir en el transcurso de su existencia una identidad y una dinámica propias que los distinga de otros movimientos, de diferentes o similares características. No es lo mismo hablar del movimiento obrero argentino o hablar de la llamada nueva izquierda surgida en los años '60, que hablar del movimiento de derechos humanos, cada uno de los cuales se rige por dinámicas diferenciadas, aunque en algunas instancias puedan coincidir en la acción, pero aún así los objetivos de unos y otros serán claramente distintos.

Al acercarme al análisis de las estrategias de comportamiento de los nuevos movimientos sociales, puedo observar cuatro etapas diferenciadas, a partir de las cuales es posible establecer criterios propios para el estudio de cada uno de ellos.

La primera etapa es la del surgimiento del movimiento, el origen del mismo y la relación con el contexto donde nacen. Para el MDHT es posible afirmar que nace del contexto de la última dictadura militar, 109 Véase Jelín, Elizabeth (1989): Los nuevos movimientos sociales, Centro editor de América Latina, Buenos Aires. 
aunque las semillas de lo que será esta fuerza motor comienzan a germinar durante el interregno democrático entre 1973 y 1976, y aún antes, cobrando mayor fuerza e impulso a partir de la transición a la democracia en diciembre de 1983, cuando verán aparecer nuevas organizaciones dentro del Movimiento. Por lo tanto los orígenes los situaré en el periodo 1973 - 1981, pudiendo enmarcar el nacimiento a mediados de 1977 con la aparición del primer grupo de familiares de detenidos por razones políticas.

La segunda etapa tiene que ver con el desarrollo del movimiento, con el reconocimiento por parte de la sociedad de su existencia, y la interacción con otros movimientos similares o bien por medio de su accionar autónomo e independiente. Situaré esta etapa después desde 1981, cuando la organización de Familiares de Desaparecidos por Razones Políticas, sufra su primera fractura con la aparición de Madres de Detenidos Desaparecidos, un desprendimiento del primero y que supuso una estrategia de acción novedosa como las rondas de los jueves o el uso del pañuelo blanco distintivo de las Madres de Plaza de Mayo en Buenos Aires. Esta fase inaugurada hacia fines de la dictadura, llega hasta mediado de los '90, cuando el movimiento crezca con la aparición incluso de nuevas organizaciones que lo van a integrar, punto predominante de su accionar, el año 1995 con la aparición de los "H.I.J.O.S." y el ascenso del Bussismo como fuerza política "democrática".

Una tercera etapa estaría dada por la crisis interna del movimiento que conlleva fracturas o divisiones internas por distintas razones o bien a la ruptura del mismo. El enfrentamiento con el Bussismo desde la llegada al poder provincial del ex dictador por medio de elecciones, implicó al mismo tiempo una profundización de las acciones del conjunto de las organizaciones como su propio desgaste. 
Esta tercera etapa, tal como mostraré más adelante, conduce a un cuarto momento en el que, si bien el movimiento no desaparece, sufrirá transformaciones que harán que su constitución y fisonomía, sean completamente distintas. ${ }^{110}$ No será parte de este trabajo ubicar dichas transformaciones que se producirán hacia los primeros años del nuevo siglo, sin embargo, merecen ser contempladas como un final de época, coincidente además con el final del Bussismo en el poder, con la nueva administración política surgida tras la crisis de representatividad en el país en 2001 y con la llega de Néstor Kirchner al gobierno en 2003, donde la causa de la revisión del pasado dictatorial en Argentina cobró un nuevo impulso y donde además se redefinieron las acciones y los actores en juego en dicha situación.

Si bien es cierto que el MDHT ha vivido constantes fracturas y divisiones, hay que decir también que ha engendrado nuevas agrupaciones ya en la transición democrática, algunas de éstas, como la Asociación de Abogados por los derechos humanos, que ha tenido una breve pero intensa vida dentro del movimiento, otros han surgido a mediados de los '90, dándole nuevo impulso y nuevas dinámicas de acción, como es H.I.J.O.S. ${ }^{111}$

Los movimientos sociales, a su vez, están relacionados directamente con lo que la sociología ha dado en llamar el cambio social. ${ }^{112}$ Desde esta óptica es posible afirmar que la presencia de estos

110 Sztompka, Piotr (1995): "Sociología del Cambio Social". Ed. Alianza, Madrid, Pp. 315 a 321.

111 La sigla H.I.J.O.S. significa: Hijos por la Identidad y la Justicia contra el Olvido y el Silencio; sobre esta agrupación volveré más adelante.

112 Sztompka, Piotr, Sociología del Cambio Social, Op. Cit. No forma parte de este trabajo analizar el concepto de cambio social, pero si conviene explicar brevemente a que se refiere Sztompka cuando habla del mismo. Puede implicar la introducción de algo que falta (Un nuevo gobierno, nuevas costumbres y leyes, o instituciones), en un aspecto positivo, o bien, detener, evitar o contrarrestar cambios resultantes tanto de procesos no conectados con los 
movimientos sociales tiene que ver directamente con la caída de un régimen, un gobierno o un sistema político, económico, social y cultural, o también están relacionados con la posibilidad de evitar que se produzcan tales cambios 0 disrupciones. ${ }^{113}$ La edificación de un movimiento social es "una acción de extrema libertad colectiva"114 aún cuando su surgimiento se dé en un contexto dictatorial, siendo esa libertad colectiva la que desafía al régimen, erigiéndose el movimiento en demandante de transformaciones y de un cambio social.

Aunque me refiero en la presente pesquisa a un movimiento de derechos humanos, estimo necesario una digresión para explicar que las organizaciones en estudio sostienen una idea "limitada" del concepto derechos humanos. En primer lugar al hablar de movimientos sociales propiamente defensores de derechos humanos, hay que afirmar que la mayoría de las veces estos nacen del traslado de un drama personal, individual, como puede ser el caso de la desaparición de un familiar detenido ilegalmente, al ámbito de lo social y público ${ }^{115}$. Ese traslado implica la conversión de aquello que supone una catástrofe privada en una cuestión social y, por lo tanto, cualquier reclamo ya no será privado ni será meramente individual o de un grupo de personas, sino que se transformará en una cuestión que deba ser canalizada y atendida por el conjunto de la sociedad. ${ }^{116}$ Como afirma Marysa Navarro lo personal

movimientos sociales, en su aspecto negativo. La relación entre los movimientos sociales y el cambio puede ser directa si tenemos en cuenta la posibilidad o no que dichos movimientos puedan tener para producirlo.

113 Véase Sztompka, Piotr, Sociología del Cambio Social, Op. Cit.

114 Ibarra, Pedro, Tejerina, Benjamín, Los Movimientos Sociales, Op. Cit. P. 12.

115 Para un análisis más detallado de la cuestión Espacio Público y Espacio Privado, Véase Arendt Hannah (1998): La Condición Humana, Edit. Paidós, Barcelona, Cap. II, Pp. 37 a 95.

116 Véase Calderón, Fernando (1986): "Los movimientos sociales ante la crisis". Editado por la Universidad de las Naciones Unidas (UNU) y CLACSO. Bs. As. 
también es político ${ }^{117}$, y lo personal tratado en un colectivo genera conflictos y tensiones, por lo que el movimiento social puede, asociado con las cuatro etapas determinadas por Sztompka, "discutir y cambiar los medios de actuación, las formas de tomas de decisiones, incrementar o reducir sus posibilidades de participación de sus miembros o intensificar en cierto momento sus reivindicaciones o bien reforzar los rasgos de su identidad. ${ }^{118}$ Una vez más retomo la idea de la determinación de Williams para resolver el grado de activación política según cada momento histórico en el que el movimiento va a sostener su presencia pública / política.

Para introducir en el estudio de los nuevos movimientos sociales es necesario centrarse en lo que le es propio: la espontaneidad, la noinstitucionalización (en tanto forma organizativa distinta de un organismo oficial del Estado), la ambigüedad de demandas, los sentidos contradictorios y multifacéticos. Estos aspectos deben ser considerados especialmente desde la acción y prácticas colectivas, más que desde propuestas ideológicas o aparatos institucionales.

Considero entonces a los nuevos movimientos sociales como indicadores de la existencia de conflictos entre actores colectivos, en los cuales se pone en cuestión el sistema de relaciones sociales. ${ }^{119}$ En este sentido "los movimientos sociales no son fenómenos residuales del desarrollo o manifestaciones de descontento de las categorías marginales. No son sólo el producto de la crisis, ni los últimos efectos de una sociedad que muere. Por el contrario, son los signos de aquello que está naciendo." ${ }^{120}$ En síntesis, se puede afirmar como lo hacen Tejerina e

117 Eckstein, Susan coord. (2001): Poder y protesta popular. Movimientos Sociales Latinoamericanos, Edit. Siglo XXI, México. Pp. 274.

118 Ibarra, Pedro, Tejerina, Benjamín, Los Movimientos Sociales, Op. Cit. P. 13.

119 Jelin, Elizabeth, Los Nuevos Movimientos Sociales, Op. Cit.

${ }^{120}$ Ibídem. 
Ibarra, que los movimientos sociales "eran y son una predeterminada forma de canalizar conflictos en la modernidad." ${ }^{121}$

\section{III.2 El MOVIMIENTO DE DERECHOS HUMANOS EN ARGENTINA: Un ESTADO DE LA CUESTIÓN}

En este punto considero necesario un balance sobre lo ya indagado respecto al movimiento de derechos humanos en Argentina en general y en el interior del país en particular. En los primeros años de la transición algunos trabajos abordaron el estudio de las organizaciones de derechos humanos desde la sociología, dando cuenta de una "historia nacional" de dichas organizaciones que congregaba a una serie de estudios que referían, en la mayoría de los casos, a la provincia de Buenos Aires, extrapolando a todo el país una historia "nacional" que se suponía respondía a la existencia de un vasto movimiento social organizado en todo el territorio. Lejos de ser así, los estudios se centraron en las organizaciones de derechos humanos surgidas en la capital del país y daban cuenta sobre los derroteros o clivajes de la capital sin tener en cuenta las particularidades locales, provinciales o regionales. Sucedía esto mismo con prácticamente todos los estudios referidos al periodo dictatorial e incluso anterior, atando la suerte de los estudios generales a las vicisitudes de la provincia de Buenos Aires o a la de la capital del país. ${ }^{122}$

Quien más ha trabajado las cuestiones de los nuevos movimientos sociales en general y el movimiento de derechos humanos en particular

\footnotetext{
${ }^{121}$ Ibarra, Pedro, Tejerina, Benjamín, Los Movimientos Sociales, Op. Cit. P. 13.

122 Conviene aclarar aquí que cuando hablo de Buenos Aires me refiero a la capital argentina, a menos que aclare que me refiero a la provincia que lleva el mismo nombre. En líneas generales es posible afirmar que la realidad de Buenos Aires provincia suele diferir a la realidad de la ciudad capital, en cuyo centro se encuentran las principales instancias administrativas nacionales.
} 
vinculados a los temas de la memoria en relación con la etapa de la última dictadura militar y la transición democrática ha sido Elizabeth Jelin, cuyos principales aportes a los estudios de estos temas aún hoy siguen siendo materia de consulta obligada. ${ }^{123}$ De los trabajos pioneros en el campo, editados por el Centro Editor de América Latina sobre el Movimiento de derechos humanos, se destacan de otras publicaciones, ya que la mencionada editorial ha sido señera en la publicación de investigaciones monográficas referidas a la última dictadura, todavía en los comienzos de la transición, apostando por autores como Raúl Veiga, María Sonderéguer, María Inés González Bombal y la misma Elizabeth Jelín. ${ }^{124}$ Veiga ha sido el primero en concebir una historia general del movimiento de derechos humanos y su obra introductoria es consulta obligada para todo aquel que desee involucrarse en el estudio de la cuestión. El trabajo de Veiga es hoy uno de los clásicos en la materia en Argentina por lo que merece mención aparte.

Desde la perspectiva de las relaciones de parentesco, el trabajo de Judith Filc, publicado en 1997, resulta un aporte fundamental en el estudio de la relación entre familia y dictadura, a la luz de los discursos tanto oficiales como de los llamados sectores populares. ${ }^{125}$ Otros trabajos aparecidos después de terminada la dictadura tienen que ver con ensayos periodísticos más que con investigaciones académicas rigurosas. Uno de

${ }^{123}$ Véase entre otros trabajos de Jelín, Elizabeth (1987): Movimientos Sociales y Democracia Emergente, Centro Editor de América Latina, Buenos Aires, T. 1 y 2; (2002): Los trabajos de la memoria, Edit. S. XXI, Buenos Aires; (2002) Los Archivos de la Represión: Documentos, Memoria y Verdad, Edit. S. XXI, Buenos Aires; (2005) "Los Derechos Humanos, entre el Estado y la sociedad", en Suriano, Juan: Nueva Historia Argentina, Edit. Sudamericana, Buenos Aires.

124 Véase Jelín, Elizabeth, Los movimientos sociales, Op. Cit. y Veiga, Raúl (1985): Las organizaciones de derechos humanos, Centro Editor de América Latina, Buenos Aires.

125 Filc, Judith (1997): Entre el parentesco y la política. Familia y dictadura, 1976 1983, Edit. Biblos, Buenos Aires. 
los primeros libros sobre el movimiento de Madres de Plaza de Mayo fue el realizado por el periodista Jean Pierre Bousquet, y que todavía hoy resulta una publicación referencial de consulta. ${ }^{126}$ Otra contribución al estudio de los organismos de derechos humanos lo ha brindado Marysa Navarro en un capítulo a su cargo sobre el movimiento de Madres de Plaza de Mayo, dentro de un trabajo mayor compilado por Susan Eckstein. La virtud del trabajo de Eckstein ha sido reunir distintas visiones sobre un panorama general de los nuevos movimientos sociales en América Latina, un estudio comparativo que permite conseguir una visión más amplia de la materia en el continente. ${ }^{127}$

Las investigaciones referidas al movimiento de derechos humanos, exclusivamente en el interior del país, son de reciente aparición en la historiografía argentina. Se destacan entre estos trabajos sin dudas los de Luciano Alonso, quien dedica gran parte de sus investigaciones a la historia de las organizaciones de derechos humanos de Santa Fé, imbricando además, la historia local a la historia del movimiento nacional en clave comparada. Los trabajos de Alonso en este sentido nos sirven además de guía en la formulación de las necesidades de observar a las organizaciones de derechos humanos dentro del conjunto de un movimiento, pero con las particularidades de cada una. Sobre la provincia de Santa Fé propiamente la síntesis de su obra se concentra en el libro de reciente publicación que da cuenta de la historia del movimiento santafesino. ${ }^{128}$

${ }^{126}$ Bousquet, Jean Pierre (1983): Las locas de la Plaza de Mayo, El Cid Editor, Buenos Aires.

127 Eckstein, Susan (2001): Poder y protesta popular. Movimientos sociales latinoamericanos. Edit. S. XXI, México.

128 De Alonso, Luciano véase: Defensa de los derechos humanos y cultura política: entre Argentina y Madrid, 1975-2005, edición on line de la Universidad Internacional de Andalucía (UNIA, Santa María de La Rábida / Sevilla, 2010), [http://dspace.unia.es/handle/10334/187] y del mismo autor: Luchas en plazas 
Para el caso del interior santafesino se destacan los trabajos referidos a las Madres de la Plaza 25 de mayo de la ciudad de Rosario, donde principalmente Marianela Scocco ha hecho un abordaje en el estudio sobre dicha organización y Cristina Viano ha publicado algunas entrevistas a distintas madres que conforman el movimiento. Si bien, sobre el caso rosarino el trabajo más importante hoy se ha traducido en un material audiovisual ${ }^{129}$, la recuperación de la memoria de las militantes del movimiento de Madres permite adentrarnos en la perspectiva comparada del movimiento, toda vez que otros trabajos sobre la misma organización se sintetizan en la diferentes producciones monográficas en otras provincias, como en el caso de Neuquén, donde Cecilia Azconegui narra el derrotero de las madres en aquella provincia sureña. ${ }^{130}$ También Carol Solís, en sus estudios sobre el caso del movimiento de derechos humanos en la provincia de Córdoba, apela a menudo, como lo hace Alonso, a las comparaciones y busca en sus trabajos los nexos constitutivos de cada una de las organizaciones surgidas en el ámbito local y nacional.

$\mathrm{Si}$ bien en todos los casos encontramos similitudes, los procesos locales se circunscriben a anclajes propios, donde la historia previa de cada provincia o región trajo aparejada el surgimiento de tales o cuales organizaciones, en tales o cuales períodos o momentos, por lo que vacías de sueños. Movimiento de derechos humanos, orden local y acción antisistémica en Santa Fe, Prohistoria Ediciones, Rosario, premio Espacio Santafesino 2010, Prohistoria Ediciones, Rosario.

129 Magliocca, Eugenio (2011) "Arderá la memoria. La historia de las Madres de Plaza 25 de Mayo de Rosario, del grupo de apoyo a Madres de Rosario, DVD.

130 Véase de Azconegui, Cecilia De madres de desaparecidos a Madres de Plaza de Mayo 1976-1983 en Orietta Favaro y Graciela Iuorno (eds.) (2010): El 'arcón' de la Historia Reciente en la Norpatagonia argentina: Articulaciones de poder, actores y espacios de conflicto, 1983-2003, Edit. Biblos, Buenos Aires. Y "Las políticas de Derechos Humanos de Argentina y Chile y su impacto en las víctimas", Revista América Latina, Nro. 8, Universidad Arcis, 2do. Semestre del 2008-1er Semestre 2009. 
aprehender el origen y evolución de cada regional resulta de fundamental importancia para la compresión de los desarrollos locales de cada organismo y en definitiva del movimiento en su conjunto.

La pregunta que surge en alguno de estos trabajos como inquietud común a todos ellos es si es posible determinar la existencia de un movimiento nacional de derechos humanos o si por el contrario estamos en presencia de historias locales / regionales que no implican en una sumatoria de experiencias, un solo movimiento nacional. Lo que queda claro de la revisión de los autores mencionados, es que no es posible explicitar una historia nacional del movimiento de derechos humanos solo desde la experiencia porteña.

La historia escrita en y desde Buenos Aires no es una síntesis de un desarrollo nacional ni puede suponer la aparición de otros fenómenos periféricos como mera imitación del fenómeno capitalino. Dicho de otro modo, lo que me motiva la necesidad de adentrarme en los puntos de comparación sobre el origen y desarrollo del movimiento de derechos humanos en Argentina, es la inquietud acerca de la posibilidad de encontrar para todo el territorio nacional una historia global que explique la existencia de un solo movimiento de derechos humanos que sea integrador. En general, lo que se venía encontrando hasta bien entrada la primera década del 2000 eran trabajos que referenciaban a una historia nacional pero que sin embargo, como apunta Alonso, respondían al desarrollo de las organizaciones en Buenos Aires y La Plata, sin tener en cuenta las historias locales de otras regiones periféricas, más alejadas de la capital. ${ }^{131}$

Por ejemplo, para el caso del surgimiento del movimiento en Santa Fé, Luciano Alonso explica que "en principio, las agrupaciones que

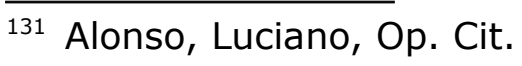


se constituyeron fueron menos y lo hicieron más tarde (respecto a otras regiones del país). Familiares se formó entre 1977 y 1979, la Asamblea Permanente por los Derechos Humanos hacia 1981 y el Movimiento Ecuménico por los Derechos Humanos recién en 1983. La Liga Argentina por los Derechos del Hombre apareció frecuente pero aleatoriamente durante todo el período dictatorial, sin que pueda distinguírsela claramente de la conducción del Partido Comunista local, en tanto que la agrupación Madres no se formaría hasta 1987. Eso no supone de ninguna manera que no existieran grupos e individuos que realizaran acciones en defensa de los derechos humanos con anterioridad, o que incluso algunas agrupaciones no trataran de conformarse con anterioridad-como el MEDH, que había intentado hacerlo en 1978- pero la constitución del colectivo fue muy débil y laxa hasta muy avanzada la dictadura."132

Mientras que, para la provincia de Neuquén, según lo indagado por Cecilia Azconegui, "en los primeros años de reclamos y oposición las madres no tuvieron una voz que las diferenciara del resto de los miembros de la APDH o de la Comisión de Familiares de detenidos y desaparecidos que también trabajaba en la región. Junto a ellos comenzaron las primeras manifestaciones públicas que enmascaraban su contenido político en el ropaje religioso. El obispado cobijaba a la naciente resistencia en tanto que las prácticas religiosas tradicionales como la misa, la peregrinación y la procesión fueron tomando un cariz netamente político (Mombello, 2003). Así nacieron desde 1977 como espacios de denuncia y oración las Marchas de la Fe, con motivo de la

132 Alonso, Luciano (2008): El surgimiento del movimiento argentino por los derechos humanos en perspectiva comparada, en revista digital de la escuela de historia - unr / año 1 - n 1 / Rosario, 2008, ISSN 1851-992X. Véase del mismo autor Luchas en plazas vacías de sueños. Movimiento de derechos humanos (...) Op. Cit. y Razones, modos y efectos de una historia del movimiento por los derechos humanos, en Cernadas, Jorge y Lvovich, Daniel (2010): Historia ¿Para qué? Revisitas a una vieja pregunta, Edit. Prometeo, Cap. 7. 
celebración de la Navidad y las Marchas por la Vida, en ocasión de la celebración secular del día de la madre, y se resignificaron procesiones como el via crucis de Pascua. Esas oportunidades en las que las madres marchaban junto con los creyentes y los no tanto (aquellos que concurrían sólo para expresarse y denunciar) se convertían en actos de denuncia donde se pedía por los desaparecidos y se intentaba concienciar a la mayor cantidad de gente posible. Esas marchas y procesiones formaban parte de una política del disfraz y del anonimato que se ejercía públicamente pero que estaba hecha para contener un doble significado y para proteger la identidad de los actores." ${ }^{133}$

Sobre Rosario se destaca una producción general que cruza las vertientes entre sociedad, represión y dictadura. El trabajo de Gabriela Águila, resulta revelador sobre un panorama general de la dictadura en la ciudad santafesina pero explica muy poco la resistencia de las organizaciones de derechos humanos, a las cuales no les dedica más que un par de páginas. ${ }^{134}$ En este sentido arrojan mayor claridad respecto al movimiento de derechos humanos en el espacio rosarino los aportes de Scocco y Viano. Este último se ha introducido en el tema entrevistando a una de las integrantes del movimiento de Madres de la plaza 25 de Mayo, Herminia, parte de una historia de vida como metodología, para explicar la trayectoria militante de una Madre que, emulando a las Madres de Plaza de Mayo, concretó su militancia recurriendo a repertorios similares, como las rondas en la plaza o el uso del pañuelo blanco. ${ }^{135}$ Más

133 Azconegui, Cecilia (2009): Madres, militantes o resistentes. La definición de identidades en el movimiento de derechos humanos en el Alto Valle de Río Negro y Neuquén (1976-1983), presentado en Primer Congreso Nacional Sobre Protesta Social, Acción Colectiva y Movimientos Sociales, Buenos Aires.

134 Águila, Gabriela (2008): Dictadura, represión y sociedad en Rosario, 1976/1983. Un estudio sobre la represión y los comportamientos y actitudes sociales en dictadura, Prometeo, Buenos Aires.

135 Viano, Cristina (2008): Mujeres y movimientos sociales: un acercamiento al 
abarcadores resultan los trabajos de Marianela Scocco, de los cuales ha surgido una producción audiovisual que cuenta con los testimonios del colectivo de Madres de la Plaza 25 de Mayo recurriendo también a la metodología de la historia oral para recuperar la memoria de un grupo de mujeres, sus trayectorias y los repertorios de su militancia, atravesados, todos ellos, por sus propias historias de vida. En otros trabajos Scocco examina a la filial local de las Abuelas de Plaza de Mayo, en un intento de recuperar la memoria más amplia del movimiento de derechos humanos de Rosario, al tiempo que profundiza en el estudio de los orígenes de Madres de la plaza 25 de Mayo. ${ }^{136}$ En el caso de la ciudad santafecina de Rosario, como se dio en otras regiones del país, las organizaciones si bien adoptaron los usos del movimiento en Buenos Aires, pronto se distinguieron por sus particularidades que son claramente visibles, como en el caso de las "Madres". En Rosario, a diferencia de la capital argentina, las mujeres que conformaron la organización se denominaron "Madres de la plaza 25 de Mayo" en clara referencia a las marchas que estas mujeres hacían en la plaza principal de la ciudad. Si bien adoptaron, como todas, el uso del pañuelo blanco en las manifestaciones, lo importante de recalcar aquí es que la identidad local se impuso por sobre una identificación global o de índole nacional, lo que explica los anclajes locales para el desarrollo del movimiento en la ciudad de Rosario.

Para el caso cordobés, Carol Solís explicita que "en el cruce de esta historia previa y la nueva metodología del terror se inscribe la

movimiento de Madres de Plaza de Mayo desde una historia de vida, en Necoechea, G., Mastrángelo, M. y otros: Historia Oral y Militancia política en México y en Argentina, Edit. El Colectivo - UBA, Buenos Aires.

136 Magliocca, Eugenio: Arderá la Memoria, Documental; Cit. Scocco, Marianela (2011): "La historia de una búsqueda. Darwinia Gallicchio, Madre y Abuela de Plaza 25 de Mayo de Rosario", Ponencia presentada en las XIII Jornadas Interescuelas Departamentos de Historia, Catamarca. 
génesis de los organismos de defensa de derechos humanos. Con una dinámica similar a otras grandes ciudades del país, en Córdoba fue más tardía para los organismos la posibilidad de inscribir públicamente sus reclamos. Hacia el final del período dictatorial encontramos ya formado y activo un grupo de organizaciones que aglutinan tanto desde adscripciones biológicas como desde otras profesionales, políticas o religiosas. Nos referimos a Familiares de Desaparecidos y Detenidos por Razones Políticas (FDDRP), Asamblea Permanente por los Derechos Humanos (APDH), Servicio de Paz y Justicia de América Latina (SERPAJ), Liga Argentina por los Derechos del Hombre (L.A.D.H), Movimiento Ecuménico por los Derechos Humanos (MEDH) y Familiares de Presos y Desaparecidos Peronistas (que posteriormente desaparece como referencia). En el caso de las Abuelas de Plaza de Mayo Filial Córdoba (APM), durante la dictadura algunas de ellas activaron dentro de Familiares y otras, al principio, mantuvieron vínculos con la organización de Buenos Aires. Aparecieron con ese nombre ya avanzado 1983, lo que confirma que tal situación de injusticia era previamente cobijada dentro de otros colectivos. ${ }^{137}$ Como veremos más adelante, tanto en Córdoba, como sucedió en Tucumán, la ola represiva estatal y paraestatal, se profundizó luego de producidas unas series de revueltas obrero estudiantiles tras la instauración de la dictadura de 1966.

Con respecto a la región Noroeste de la República Argentina, son todavía más escasos los trabajos que desarrollan la temática del movimiento de derechos humanos. De las provincias norteñas de Salta y Jujuy se destacan dos trabajos. El primero de ellos, es un compilatorio que recoge testimonios y documentos sobre la represión dictatorial en la

137 Solís, Ana Carol (2011): Los derechos humanos en la inmediata posdictadura. (Córdoba, 1983-1987) en Revista ESTUDIOS - N 25 -ISSN 0328-185X (EneroJunio 2011) 83- 100. 
provincia de Salta elaborado por Lucrecia Barquet y Raquel Adet y editado por la universidad de esa provincia. ${ }^{138}$ El compilatorio reúne, entre otros documentos, una síntesis del informe de la Comisión Nacional sobre Desaparición de Personas (CONADEP) referido a la provincia de Salta, algunos casos locales emblemáticos, recortes periodísticos que refieren a la represión dictatorial y distintos testimonios de represaliados. No deja de ser un compilatorio de fuentes que requerirán, en un futuro cercano, un estudio más profundo de lo que implicó la represión en aquella provincia.

En la provincia de Jujuy, cabe mencionar un trabajo periodístico de Reynaldo Castro que reúne entre otros, ensayos y testimonios sobre lo que implicó la represión en aquella provincia. ${ }^{139}$ El trabajo, editado por la propia universidad local, ofrece algunos testimonios de conjunto, no es más que otro compilatorio que no consigue explicar de conjunto, qué pasó en Jujuy, provincia que además, también sufrió duramente la represión de la última dictadura militar. Vinculado a la fábrica azucarera de Ledesma, quizás el hecho más notorio sea lo que se conoce como "la noche del apagón". En la noche del 27 de julio de 1976 las dictadura cortó el suministro eléctrico en todo el departamento de Ledesma, en la provincia de Jujuy, mientras policías, gendarmes, militares y capataces de la empresa Ledesma allanaron y saquearon viviendas en Libertador General San Martín y Calilegua. En vehículos de la propia empresa se secuestraron a más de 400 trabajadores, estudiantes y profesionales siendo llevados a galpones de mantenimiento de la fábrica azucarera, donde permanecieron secuestrados durante días en condiciones infrahumanas. Del total de detenidos, 30 permanecen en calidad de

\footnotetext{
138 Barquet Lucrecia y Adet, Raquel (2011): La represión en Salta, 1970 - 1983. Testimonios y documentos. EUNSA, Salta.

139 Castro, Reynaldo (2008): Con vida los llevaron. Memorias de madres y familiares de detenidos-desaparecidos de San Salvador de Jujuy, Argentina. EdiUnJu, Jujuy.
} 
desaparecidos, entre ellos, el alcalde de la localidad de Ledesma, el médico Luis Arédez. Su esposa, Olga Márquez de Arédez, fue una de las militantes del movimiento de Madres de Plaza de Mayo de Jujuy, hasta el día de su muerte el 17 de marzo de $2005 .{ }^{140}$

El caso de Aredez y su lucha en Jujuy fue emblemático no sólo en la provincia, sino en el conjunto de provincias que conforman la región Noroeste y donde desde Tucumán, las organizaciones locales, miraron siempre lo sucedido en las vecinas Jujuy, Salta y Santiago del Estero, sobre todo. Lo que implicó la militancia de Olga en el movimiento de Madres de Plaza de Mayo fue sintetizado por la contratapa del diario Página 12 por el periodista Luis Brushtein al afirmar que "La casa de Olga en Ledesma era una romería durante los días de la Marcha de los Apagones. Madres e HIJOS de todo el país se alojaban allí y se cocinaban grandes ollas de locro y docenas de empanadas. Habían sido muchos años de soledad, de dolor y humillación y la marcha era su victoria, la confirmación del valor de la dignidad, de que no estaba sola y de que el reclamo de justicia era algo más que una locura desgarradora. Ya enferma, en las últimas marchas caminaba con un barbijo para evitar la ceniza." ${ }^{\prime 141}$

En concreto, y para el caso que me ocupa en este trabajo, la provincia de Tucumán, los aportes ya citados de Emilio Crenzel han sido fundamentales, sobre todo en lo que se refiere al conocimiento de la época previa al último golpe de Estado, con su trabajo sobre las rebeliones obrero estudiantiles conocidas como "El Tucumanazo", o bien

140 Sobre el fallecimiento de Olga Aredez Léase la contratapa del diario Página 12: http://www.pagina12.com.ar/diario/contratapa/13-48592-2005-03-18.html [Consultado 30 de marzo de 2012]. Sobre la historia de la noche del apagón y la militancia de Olga Aredez, el documental de Eduardo Aliverti, "Sol de Noche", ofrece desde el testimonio, un documento invalorable, en el que se entrevista tanto a la propia Olga como a su entorno.

${ }^{141}$ Ibídem. 
de la etapa del llamado "Bussismo en democracia" con su libro "Memorias Enfrentadas, el Voto a Bussi en Tucumán". ${ }^{142}$ Otros trabajos de Crenzel, del tipo monográfico, dan cuentas parciales de sus investigaciones acerca del proceso político vivido en Tucumán ligado al Bussismo y las representaciones sociales que sobre el fenómeno se dieron distintos sectores sociales, votantes y no votantes del propio ex represor Antonio Domingo Bussi en las diferentes contiendas electorales en la que se presentó como candidato. El impacto por ver una figura controvertida, responsable de la represión en Tucumán, reconvertida en representante del pueblo en distintas elecciones tanto locales como nacionales, llamó la atención no solo de Crenzel sino también de otros especialistas, entre las que cabe destacar, la filósofa tucumana Dolores Marcos, quien en un breve trabajo desarrolla la cuestión del autoritarismo vivido en la provincia y sus marcas de representación. ${ }^{143}$ Como vemos, desde la historiografía es pobre el abordaje sobre el periodo dictatorial y transicional, aunque el fenómeno tucumano ha sido materia de preocupación de sociólogos y filósofos, el fenómeno tucumano.

Del periodo tanto inmediato anterior como posterior a la muerte de Perón y a la crisis desatada por el aumento de la oleada represiva, los aportes de la socióloga Inés Izaguirre y su equipo resultan fundamentales en la caracterización no solo de la implementación de las nuevas políticas ultra liberales desde 1966, sino y sobre todo en la respuesta de los denominados sectores populares a tales políticas y la consecuente represión estatal a las luchas obrero - estudiantiles de la década de los '70. Una síntesis de todo lo trabajado por Izaguirre se condensa en una

142 Véase los trabajos de Crenzel (2001): El Tucumanazo, 1969 - 1974, Facultad de Filosofía y Letras de la UNT; del mismo autor (2001): Memorias enfrentadas: El voto a Bussi en Tucumán, Colección Diálogos, UNT, Tucumán.

143 Marcos, Dolores (2006): Asedio a la democracia. Perfiles del autoritarismo en el NOA, Facultad de Filosofía y Letras de la UNT, Tucumán. 
obra recientemente publicada en la que cuantifica el número de víctimas de la represión estatal y paraestatal de aquellos años. ${ }^{144}$

Del trabajo referido coordinado por Inés Izaguirre, el capítulo 9 elaborado por Matías Artese y Gabriela Rofinelli, "Guerra y Genocidio en Tucumán", ${ }^{145}$ es el que más aporta en la investigación que me ocupa, pues avanza en la explicación territorial específica del caso tucumano. Sobre la caracterización planteada por Artese y Rofinelli volveremos más adelante, sin embargo, cabe referir que además de la mencionada síntesis, estos autores han venido trabajando en la cuantificación de los represaliados en Tucumán a partir de los datos obtenidos por los registros de la Asamblea Permanente por los Derechos Humanos.

Desde la historiografía local, el periodo no ha sido abordado aún lo suficiente. El historiador tucumano, Roberto Pucci ha publicado un trabajo que se enmarca en el periodo anterior a la última dictadura, atendiendo a la desestructuración que provocaron las medidas de la dictadura militar instaurada en $1966 .{ }^{146}$ Pucci no ha tenido en cuenta, sin embargo, cómo afectaron dichas medidas al conjunto de la población ni explicita la respuesta que los sectores populares se dieron como mecanismo de defensa de los avasallamientos de la dictadura militar, como tampoco ofrece mayores explicaciones del complejo proceso abierto en la provincia tras el retorno de Perón, el interregno democrático institucionalizado entre 1973 - 1976 y lo que implicó el terror de esos años y con posterioridad al último asalto del poder de los militares. Del periodo de la última dictadura en concreto, tampoco existen trabajos integrales que

${ }^{144}$ Izaguirre, Inés Comp. (2010): Lucha de clases, Guerra civil y Genocidio en la Argentina 1973 - 1983. Antecedentes, desarrollo, complicidades. EUDEBA, Buenos Aires.

145 Op. Cit. Pp. 311 a 337.

146 Pucci, Roberto (2007): Historia de la destrucción de una provincia. Tucumán 1966, Ediciones del Pago Chico, Buenos Aires. 
den cuenta del desarrollo del llamado Proceso de Reorganización Nacional. Del periodo setentista en Tucumán debo sí mencionar el documental realizado por $\mathrm{mi}$ junto a Diego Heluani sobre los "Tucumanazos" y que recupera un material de archivo audiovisual inédito en la provincia. ${ }^{147}$

Sobre el estudio del movimiento de derechos humanos local en concreto, mis estudios han sido los únicos aportes realizados hasta el momento, referenciados, muchos de los trabajos realizados, incluida la presente tesis, en los aportes de historiadores de otras regiones del país, ya mencionados más arriba. Sin embargo, la piedra basal para la actual investigación, ha sido sin dudas mi tesis de licenciatura, estudio sobre la organización de Madres de Detenidos-Desaparecidos de Tucumán, posteriormente publicada por el Programa de Historia Oral de la Universidad de Buenos Aires. Ya en los últimos años, los distintos trabajos del tipo monográfico, presentados en diferentes encuentros académicos, terminaron de configurar un mapa por trazar y en el que la presente tesis procura dar marco y cierre, abordando, como dije, la historia del movimiento de derechos humanos a partir de la recuperación de la memoria de sus activistas.

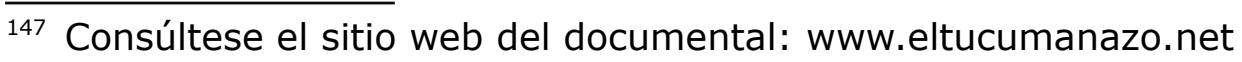


PARTE II: TuCumÁn En PERSPeCtIVA HISTÓRICA 


\section{CAPÍtUlo IV: TuCuMÁn, entre 1966 Y 1976}

\section{IV.1 LA ANTESALA DEL HORROR}

Para entender los motivos del último golpe militar en Argentina es necesario aprehender y comprender lo sucedido en la década que le antecedió. Por este motivo, abordaré aquí la lo que implicó la década 1966 - 1976, denominada también "década setentista" y que diera a lugar el término "setentismo", el cual refiere al conjunto de prácticas estatales y sus consecuentes respuestas sociales en el intento de imposición de un sistema social, político, económico y cultural ultra liberal. ${ }^{148}$

Aunque de manera somera, percibir lo que implicó la década de los '70, nos ayudará a un mejor análisis no solo del periodo dictatorial, sino de las marcas que dejó a su paso la instauración de lo que Guillermo

${ }^{148}$ Los testimonios que se citan en el presente apartado corresponden a otra investigación realizada por mí que dio lugar a un documental sobre los años '70 en Tucumán y que describe el periodo en cuestión, la década de los '70, antesala del último gobierno militar instaurado en marzo de 1976. Las citas corresponden a fragmentos de las entrevistas realizadas a miembros del movimiento obrero estudiantil de esos años, la generación, como veremos en el trabajo, de los "desaparecidos". No presento, como mencioné antes, ni el audio ni su transcripción completa pues si bien estas fuentes sirven también para explicar el contexto previo anterior al último gobierno militar, no forma parte de la presente investigación. Sin embargo, los fragmentos testimoniales aquí presentados sirven al conjunto del trabajo, para explicar la percepción que tienen hoy los actores sociales que participaron de las revueltas obrero estudiantiles y que dio paso a la represión dictatorial de los años subsiguientes. Se han trabajado los testimonios orales de la misma manera que lo explicitado en el capítulo sobre la metodología empleada. 
O'donnell denominó «El Estado Burocrático-Autoritario» ${ }^{149}$ y en concreto, sus implicancias en la provincia de Tucumán.

Como veremos más adelante, lo que denominaré la década 1966 - $1976^{150}$, se presenta fundamental incluso en la constitución de los imaginarios creados por alguna de las organizaciones de derechos humanos, pues los represaliados del periodo siguiente, por un lado, son los actores sociales que jugaron un rol protagónico en el enfrentamiento de la dictadura impuesta en 1966, y por otro, son los familiares directos de quienes conformaron el conjunto de organizaciones de familiares de víctimas de la última dictadura militar. Será además crucial en la conformación de una de esas organizaciones de derechos humanos surgidas a mediados de los años '90, como H.I.J.O.S., que reunió, entre otros, a los hijos de los desaparecidos. Lo que sigue entonces procura desentrañar no solo las causas de la última dictadura militar y cómo afectó este proceso a la provincia de Tucumán, sino que sirve de nexo para comprender el desarrollo ulterior del movimiento de derechos humanos en la región norteña.

149 O'Donnell, Guillermo (2009): El Estado burocrático autoritario, Prometeo, Buenos Aires.

150 Algunos autores mencionan a los diez años que van desde 1966 a 1976, como la "década de los '70". Esta aclaración es conveniente no solo a los fines prácticos de la decisión temporal por denominarla de esta manera, sino porque supone toda una idea referida a un periodo que se vio envuelto por dos dictaduras militares y un cambio de paradigma en la respuesta de los sectores afectados por esos Estados represivos, muy distinto a los golpes militares anteriores que sufrió el país. Setentistas además se denomina a la generación de obreros y estudiantes que resistieron los embates de ambas dictaduras. Léase, por ejemplo, Pozzi, Pablo y Schneider Alejandro: Los Setentistas, EUDEBA, Buenos Aires Anzorena, Oscar (1998): Tiempo de Violencia y Utopía. Del golpe de Onganía al golpe de Videla", Ediciones del pensamiento nacional, Buenos Aires. Para el mismo periodo Izaguire, Inés y otros (2010): Lucha de clases, guerra civil y genocidio en la Argentina. 1973 - 1983, Edit. EUDEBA. 
La década que va desde 1966 a 1976 marcó, en ese contexto, la implementación del Estado burocrático autoritario, y como lógica respuesta, el auge y apogeo de las luchas de los sectores populares en todo el país. ${ }^{151}$ El proceso iniciado el 28 de Junio de 1966 con el golpe militar que depuso al gobierno constitucionalmente elegido del presidente Arturo Illia, impuso al General Juan Carlos Onganía como presidente de facto, acentuando al mismo tiempo las contradicciones de clase. El programa económico liberal implementado por la dictadura habría de impactar fuertemente en los sectores obreros y en un importante sector de la clase media, sobre todo en los estudiantes universitarios, que a partir de algunas medidas en contra de la autonomía universitaria comenzaron a tomar conciencia y decidieron, de conjunto, enfrentar abiertamente al régimen impuesto y sus políticas que claramente afectaban sus intereses.

En un contexto particular, la provincia de Tucumán fue uno de los blancos elegidos por la dictadura en la implementación de medidas regresivas por parte del dictador Juan Carlos Onganía, siendo una de las más castigadas dentro del conjunto del país. El cierre de 14 fábricas azucareras, principal industria y motor de la economía provincial, tras su intervención en 1966, la injerencia en la Universidad Nacional de Tucumán, y otras disposiciones del gobierno de facto, golpearon duramente la estructura social, económica y cultural de la provincia, convirtiéndose en una de las de mayor número de movilizaciones y alzamientos tanto urbano como rural, en una combinación de sectores que podría caracterizarse como una alianza obrero - estudiantil. ${ }^{152}$

${ }^{151}$ Para una mayor caracterización del periodo se recomienda: Izaguire, Inés y otros Op. Cit.; Crenzel, Emilio (2001) El Tucumanazo, Op. Cit; Heluani Diego (2007): "El Tucumanazo, un documental necesario", de Cine Independiente Producciones.

152 Crenzel, Emilio (1997): El Tucumanazo, Edición Facultad de Filosofía y Letras de 
Los Tucumanazos de mayo de 1969, noviembre de 1970 y junio de 1972, como fueron denominados tres momentos en ese proceso de movilizaciones populares contra la dictadura instaurada en 1966, se inscribieron en el marco de otros movimientos de protesta obrero estudiantiles que se produjeron en casi todo el territorio argentino en los años '70, donde se destaca el Cordobazo, producido el 29 de mayo de 1969, como la mayor movilización de masas en Argentina, ocurrida en la ciudad de Córdoba, pero que tuvo sus réplicas en otras provincias del interior del país.

Los Tucumanazos, además de remitir a la idea de los tres movimientos de protesta mencionados, también consignan a las diferentes visiones que de ese proceso tienen hoy quienes han participado en él. Estos momentos del proceso histórico son el primero en mayo de 1969, paralelo al Cordobazo y que incluso se sitúa días antes en el Jardín de la República. ${ }^{153}$ Sobre éste existe una controversia, pues la mayor parte de la biblioteca no lo considera tal a pesar de quedar demostrada la elevada participación obrera en las zonas de las fábricas afectadas por el cierre, y la importante magnitud de la movilización estudiantil en el centro de la ciudad ${ }^{154}$; luego, en noviembre de 1970, se

la UNT, Tucumán, Pp. 23 a 57.

153 "El Jardín de la República" es como es llamada la provincia de Tucumán por tener un clima subtropical con una importante vegetación. Utilizamos esta expresión además como símbolo de lo que supuso el "florecer" de la participación política en esos años.

${ }^{154}$ Un ejemplo de dicha negación es lo que postula Mariano Millán, para quien en el '69 tucumano no hubo "conducción obrera" que merezca denominar a las revueltas de ese año un primer Tucumanazo, aún cuando queda demostrada la alta conflictividad incluso en los meses previos en las zonas de las fábricas azucareras cerradas y al papel que le cupo al gremio de los trabajadores del azúcar, la FOTIA, en estos casos, reconocida por el propio sociólogo. Léase Millán, Mariano (2012): El movimiento estudiantil tucumano: Del golpe de Onganía al Cordobazo (junio de 1966 - mayo de 1969) EN http://movestudiantil.com.ar/cuartas-jornadas-trabajos/Mesa\%202/Millan.pdf [Consultado por última vez en diciembre de 2012]. 
produce lo que clásicamente se conoce como el Tucumanazo, estudiantes universitarios toman la ciudad de Tucumán con barricadas en defensa del comedor universitario conectando con una huelga general de la Confederación General del Trabajo (CGT); finalmente, como tercer y último momento de ese proceso de lucha se distingue el denominado Quintazo, de Junio de 1972, una protesta estudiantil que ganó en dimensión por la toma de un predio universitario que congregaba a una cantidad de facultades. Si bien los tres movimientos responden a la misma lógica de enfrentamientos a la dictadura de entonces, cada uno supuso particularidades y diferencias.

En el testimonio de los militantes que han participado en aquellos sucesos encontramos contradicciones que develan la conflictividad de esos años. Lo que observamos a partir de la narración de quienes han participado de los "Tucumanazos" es una dualidad que recorre lo colectivo del movimiento y las actuaciones individuales de los dirigentes sociales, en donde es posible reconstruir el entramado político y social de las diferentes etapas del proceso que va desde 1969 hasta 1972.

\section{IV.2 EL GOLPE DE ONGANÍA: CONSIDERACIONES GENERALES}

El 28 de junio de 1966 se produjo un golpe militar que derrocó al gobierno de Arturo Illia. Asumió entonces la presidencia del país el General ( $R$ ) Juan Carlos Onganía. Las Fuerzas Armadas al frente de lo que autoproclamaron como "La Revolución Argentina", destituyeron al presidente y su vice y a todos los gobernadores del país, disolvieron el Congreso Nacional y las Legislaturas provinciales, separaron de sus cargos a los miembros de la Corte Suprema de Justicia y disolvieron los Partidos Políticos. El golpe contó con el apoyo de la Iglesia Católica, 
miembros del sindicalismo más conservador y amplios sectores de clases medias.

Podríamos sintetizar las características de la dictadura de 1966 siguiendo a Guillermo O'Donnell en su identificación del Estado Burocrático-Autoritario:

1. El respaldo y organización de la dominación por medio de la estructura de clases, siendo su base social dominante la burguesía.

2. La especialidad de su poder es la coacción y lo que algunos llamaron la normalización de la economía, que implicó la instauración de las medidas liberales aplicadas desde los comienzos mismos de la dictadura instaurada en 1966 y continuada, por parte de Martínez de Hoz, como Ministro de Economía de la dictadura de 1976. En Tucumán dicha normalización supuso, entre otras medidas, el cierre de 14 fábricas azucareras, principal motor de la economía local y que significó para la provincia una desarticulación social en los pueblos del interior. Cuestiones ambas que se cumplen con la instauración del orden en la sociedad, que no es otra cosa que la figura que se presentaba a través de los medios sobre la necesidad de restablecer cierto orden perdido y de terminar con el caos causado por la subversión y la guerrilla.

3. La exclusión de la participación en la vida política de sectores populares, anteriormente activos. ${ }^{155}$ Tal como mostraré, la última dictadura militar supuso, en este orden, la continuidad de la que le precedió, aunque la represión más feroz a la resistencia contra dictatorial, comenzara, sin embargo, durante el interregno constitucional entre 1973 y 1976. A partir de 1974 ya se denuncian las primeras desapariciones forzadas de personas.

155 Véase Petras, James (1993): Clase, Estado y Poder en el tercer mundo. Casos de conflictos de clases en América Latina, Fondo de cultura económica, Buenos Aires. 
4. La exclusión implicó además la supresión de la ciudadanía por medio de la liquidación de las instituciones tradicionales, junto a la negación de lo popular. El Estado se colocó como si estuviera frente a una nación enferma, un cuerpo al que había que extirparle el cáncer que avanzaba. La propaganda de la época mostraba un país enfermo por el marxismo internacional y por lo tanto, desde la narrativa oficial, había que curarlo. Esto, que en términos metafóricos puede resultar ilustrativo de los alcances de la represión, en el balance final, se observa claramente que se trató de "aniquilar" ideológica pero sobre todo físicamente a todo opositor al régimen.

5. Este Estado implica también un sistema de exclusión económica sobre todo de los sectores populares, ya que promueve un patrón de acumulación de capital en favor de los grandes grupos concentrados de la economía, es decir del capital privado. Para el caso de Tucumán, claramente, a favor de las grandes industrias azucareras, cuestión que se constata con el cierre de las fábricas de menor producción.

6. Promueve, además, una mayor internacionalización de la estructura productiva, que entraña un nuevo desborde de la sociedad civil respecto del ámbito territorial y de relaciones sociales que se pretende acotar.

7. También, este Estado intenta despolitizar el tratamiento de cuestiones sociales. En este punto es importante tener presente a los diferentes grupos y movimientos que se alzaron durante el período para manifestar su oposición al régimen, tal como lo veremos en el presente capítulo.

8. En concordancia con lo expresado por Elizabeth Jelín o Marysa Navarro, el politólogo también considera que la dictadura instaurada en 
1966 supuso el cierre de los canales democráticos de acceso al gobierno. ${ }^{156}$

Sobre las características del golpe de Onganía existe una extensa bibliografía, pero considero que lo apuntado acerca del Estado Burocrático-Autoritario resulta comprensible, por lo que no me detendré en este punto en detalle, ya que tampoco supone el objetivo de la presente pesquisa. Sólo mencionaré aquellas políticas que afectaron particularmente a Tucumán para mostrar la crisis estructural producida en torno a las medidas adoptadas por el gobierno nacional y provincial y observar cómo se desataron las fuerzas opositoras al régimen a partir de las mismas. ${ }^{157}$ Lo cierto es que el nuevo golpe militar vino a implementar una política ultraliberal que favorecía a sectores del llamado stablishment económico nacional e internacional (Sobre todo recibió el apoyo de sectores agropecuarios e industriales). El contexto de la Revolución Argentina, fue la guerra fría, dominada por lo que se conoce como "La Doctrina de Seguridad Nacional", que pretendió combatir al comunismo internacional para apuntalar el proyecto liberal y que se consolidó a partir de los distintos golpes militares en todo el continente latinoamericano.

156 O'Donnell, Guillermo (1997): Contrapuntos. Ensayos escogidos sobre autoritarismo y democratización, Op. Cit. Es interesante recalcar que los puntos expresados por autor sobre el Estado Autoritario, coinciden con los puntos propuestos por Raimond Aron, citado por Touraine en ¿Qué es la democracia? A su vez de una u otra manera quienes han analizado el interior de los diferentes regímenes militares de Latinoamérica en el último cuarto del $S$ XX podrán observar una similitud semejante entre cada uno de ellos y que tiene que ver con un contexto global mayor. Un hilo conductor para entender dicha cuestión pueden ser los archivos que han aparecido en los últimos años sobre el Plan Cóndor y que reflejan no sólo la colaboración entre los diferentes gobiernos militares de la región, sino también la participación abierta de EE.UU.

157 Sobre el desarrollo del golpe de 1966 se puede consultar: Anzorena, Oscar (1998): Tiempo de Violencia y Utopía... Op. Cit.; Bonavena, Pablo y otros (1998): Orígenes y desarrollo de la guerra civil en la Argentina, 1966 - 1976. EUDEBA, Buenos Aires, y De Riz, Liliana (2000): Historia Argentina, Tomo 8: La política en suspenso, 1966/1976. Editorial Paidós, Buenos Aires. 
En última instancia, el propósito del gobierno encabezado por Onganía era la asignación de recursos para el área moderna y transnacional de la economía con la supuesta idea de producir un salto cualitativo y cuantitativo en el país. La concentración económica y política del régimen privilegió a las grandes industrias y las inversiones extranjeras en detrimento del comercio y la pequeña industria. Por lo tanto, en un plano general afectó al conjunto de actores económicos sobre todo del interior, quitándole al mismo tiempo poder y recursos a los obreros y a sus sindicatos, que fueron incorporados al sistema siendo intervenidos o directamente clausurados ${ }^{158}$.

Al mismo tiempo, se acentuaron las contradicciones de clases y se produjo a lo largo del período 1966 - 1976 una profundización de la lucha popular contra el régimen que sólo pudo ser derrotada desde febrero de 1975, a partir del llamado Operativo Independencia ${ }^{159}$, que tuvo por objetivo terminar con la oposición popular de toda índole, tanto en el campo de la lucha armada, como con la oposición política e intelectual, como lo veremos más adelante. En este contexto, la dictadura instaurada el 24 de marzo de 1976 procuró terminar el trabajo iniciado por Onganía y sus sucesores.

El golpe de Onganía marcó en Tucumán el fin del mandato del gobernador Lázaro Barbieri, haciéndose cargo del gobierno interinamente el Comandante de la V Brigada de la Infantería Gral Delfor Félix Elías Otero, siendo sucedido con posterioridad por Carlos Imbaud, como interventor local de la dictadura.

La provincia de Tucumán fue siempre un polo de atención y de preocupación para el gobierno de facto de Onganía. Con motivo de

158 James, Daniel (2003): "Nueva Historia Argentina". Tomo 9, Cap. 4. Editorial Sudamericana, Bs. As.

159 Más adelante volveré sobre el Operativo Independencia. 
cumplirse el 150 aniversario de la Independencia Argentina, el 9 de julio de 1966, el dictador viajó a Tucumán para presidir los actos centrales frente a dirigentes de la FOTIA ${ }^{160}$ (la Federación de Obra de Trabajadores de la Industria Azucarera) donde realizó un anuncio que trazaba el rumbo de lo que sería la política que asumía el nuevo gobierno: "La espada de la revolución se desencadenaría sobre Tucumán, para transformarlo de manera revolucionaria". ${ }^{161}$ Como veremos a lo largo de todo este trabajo, las palabras del dictador sonarían proféticas a la luz del pasado reciente, cuando observemos que efectivamente la fórmula para la implementación de las políticas establecidas por los centros de poder, solo serían posible por medio de la violencia que supone el uso de la "espada" como herramienta para su protección.

Hasta ese momento, el golpe no ofrecía mayores resistencias entre algunos sectores de clase media. Héctor Marteau, uno de los dirigentes estudiantiles durante los llamados Tucumazos recuerda las instancias del golpe de la siguiente manera:

«El golpe se da el 28 de junio. El 9 de julio, (...) se hace el desfile tradicional nacional en Tucumán, y va Onganía con

${ }^{160}$ La FOTIA fue uno de los gremios más combativos en aquellos años y sus dirigentes fueron blanco de la represión de la última dictadura militar, a muchos de los cuales se secuestró e hizo desaparecer hasta el día de hoy. Cabe mencionar además que el 9 de julio es una fecha emblemática para la provincia pues en 1816 se declaró en Tucumán, la independencia del país. El 9 de julio siempre fue una fecha que convocó a los gobernantes nacionales para centralizar los actos y lanzar sus proclamas, como lo hizo el propio dictador Onganía. Incluso, durante la última dictadura militar, el gobierno de facto provincial estableció un slogan que resultó operativo a los fines represivos del propio Estado, al decir que Tucumán se había convertido en "Cuna de la independencia y en sepulcro de la subversión", como observaremos más adelante. Lo notorio en todo caso es que ya en 1966, las autoridades militares eligieron a Tucumán para anunciar lo que sería su política económica y sería la misma provincia, en 1975, 10 años después, la playa de cabecera desde la cual la siguiente dictadura militar lanzaría su plan sistemático de represión.

${ }^{161}$ Crenzel, Emilio(1997): El Tucumanazo, Op. Cit. 
toda la fanfarria nacional, desfile de aviones, granaderos y los estudiantes nos preparábamos para repudiar la dictadura militar, el golpe militar, sabiendo que había cierto compromiso de muchos sectores de poder como la dictadura que estaban haciendo pero no medíamos el alcance de su presencia cuando fuimos esa mañana a la calle, a la avenida Aconquija, donde se realizaba el desfile principal, nuestra sorpresa fue que éramos una minoría absoluta a los cientos de estudiantes, porque decenas de miles de tucumanos aclamaban la dictadura, pero decenas de miles, toda la avenida Aconquija aclamaba a Onganía». ${ }^{162}$

Las medidas del Poder Ejecutivo Nacional afectaron particularmente a la provincia y el objetivo fijado para la transformación económica produjo una concentración económica en los grupos dominantes y una desestructuración social de los trabajadores. La política que afectó a la industria azucarera y la intervención de la Universidad Nacional de Tucumán - UNT - fueron dos medidas que a la postre se volverían en contra del régimen y de sus representantes locales.

En lo que se refiere a la Universidad Nacional de Tucumán (UNT), la intervención producida a partir del decreto - ley 16.912, del 29 de julio de 1966, produjo un proceso de resistencia y de lucha contra el régimen dentro del estudiantado, sector que hasta ese momento no había rechazado. La supresión de la autonomía universitaria, ganada después de largos años de lucha estudiantil, se veía quebrantada y la defensa del comedor estudiantil en Tucumán habría de ser un factor de permanente conflicto no sólo dentro del marco universitario sino también en las calles de Tucumán. La amenaza del cierre de los "comedores y residencias" universitarias, era motivo de preocupación pues éstos les permitían a los

162 Testimonio de Héctor Marteau (ex dirigente estudiantil durante el Tucumanazo de noviembre de 1970) [Entrevista realizada por el autor]. 
estudiantes que llegaban desde el interior de otras provincias, o de regiones vecinas a Tucumán, comer y alojarse por poco dinero y les permitía continuar con sus estudios. Sin embargo, la dictadura de 1966 pronto apuntó su mirada a los comedores y residencias pues allí los jóvenes no solo comían o se albergaban sino que eran espacios de socialización y sobre todo de discusión y participación política.

La juventud desde entonces comenzó a involucrarse en cuestiones políticas, a militar en un sentido amplio del término, realizando trabajo de base y tomando conciencia con el transcurrir de los conflictos. La influencia de lo que Hilb y Lutzky denominan "La Nueva Izquierda"163 fue fundamental, pues numerosos jóvenes pasaron a integrar incluso alguno de los grupos políticos que optaron por la vía armada en el país. A Tucumán llegaron, por esos años, numerosos dirigentes nacionales con la idea de armar y conducir a los grupos locales. El contacto entre las diferentes universidades era constante, en un diálogo fluido, y las manifestaciones de apoyo entre una $y$ otras a veces determinaron el devenir de la lucha. También la solidaridad con la clase trabajadora fue en constante crecimiento en el encuentro que habría de determinar el enfrentamiento entre estos dos sectores con las fuerzas del régimen.

En cuanto a la crisis azucarera el golpe de gracia lo produjo el gobierno nacional cuando decidió, unilateralmente, intervenir primero algunas fábricas azucareras, sobre todo a aquellas que consideraba un freno al desarrollo económico, apostando luego por su posterior cierre. El intento de implementar lo que se dio en llamar el Operativo Tucumán ${ }^{164}$, 163 Hilb, Claudia y Lutzky, Daniel (1984): "La nueva izquierda argentina: 1960 1980". Centro Editor de América Latina, Buenos Aires.

164 El Operativo Tucumán supuso la implementación de una serie de medidas a fin de favorecer la instalación de nuevas industrias que absorbieran la mano de obra desocupada dejada por el cierre de los ingenios, sin embargo esta medida nunca logró recomponer el cuadro de crisis social y económica que supuso el cierre de los ingenios. 
no logró recomponer el cuadro social que produjo la desocupación entonces producida.

El 22 de Agosto de 1966 por medio de la sanción del decreto - ley 16926, se intervinieron 8 ingenios, llegando con el tiempo a ser 14 las plantas intervenidas. Según el gobierno de Onganía se ponía en marcha en la provincia de Tucumán un nuevo programa de reestructuración "agro - industrial", que debía atraer al mismo tiempo capitales nacionales e internacionales para la instalación de nuevas y más modernas industrias, que habrían de ocupar la mano de obra desocupada por la industria azucarera. El proceso al final del camino implicó el cierre de 11 de los 14 ingenios intervenidos, generándose una desocupación que a su vez produjo una desestructuración de la clase trabajadora de Tucumán. Los ingenios que cerraron fueron en general los de menor promedio diario efectivo de molienda y los de menor producción azucarera. ${ }^{165}$ Este cierre todavía está grabado en la memoria de los ex trabajadores de las fábricas azucareras y uno de ellos, Hugo Figueroa, de la localidad sureña de Villa Quinteros así lo recuerda:

« ...y el cierre del ingenio se produce porque el gobierno de la nación decía que había poca producción azúcar, pero resulta que después del cierre de los ingenios, faltaban ingenios para que muelan toda la caña que tenía Tucumán y cierran ¿14?, ¿15?, 11 porque el 10 ingenio que cierran es el Santa Ana, Santa Ana... ${ }^{166}$

La desocupación aumentó a niveles insostenibles provocando incluso que varios miles de trabajadores tuvieran que migrar hacia otras ${ }_{165}$ Crenzel, Emilio: El Tucumanazo. Op. Cit.

166 Testimonio de Hugo Figueroa, ex trabajador del Ingenio Villa Quinteros cerrado en 1966. [Entrevista realizada por el autor]. Véase Kotler, Rubén (2012): "Villa Quinteros se rebela: el Tucumanazo de 1969 y la lucha contra el cierre de los ingenios", en Revista Historia, Voces y Memoria N 04 del Programa de Historia Oral de la Universidad de Buenos Aires, Pp. 171 a 199. 
regiones del país como "trabajadores golondrinas". Se estima que el número de desocupados en esa época osciló entre 150.000 y $200.000^{167}$.

El mismo Figueroa explica:

«En esa época, yo te digo, incorporando las zonas aledañas como la Florida, Amberes, que la gente se ha ido después del cierre del ingenio, porque ya no tenía trabajo, y yo pienso que arriba de los $4.000 \ldots \gg^{168}$

Para comprender mejor el proceso algunos datos ayudan a completar el entramado que muestran de manera más acabada la cuestión aquí planteada. Con una superficie de poco más de 22.000 kilómetros cuadrados, Tucumán contaba para 1970 con 766.000 habitantes, de los cuales más del $40 \%$ residían en San Miguel, la capital. ${ }^{169}$ Las empresas instaladas en Tucumán no alcanzaron a cubrir entonces el cupo de mano de obra desempleada que había dejado el cierre de los ingenios.

La crisis estructural desatada provocó, por lo tanto, una profundización en las contradicciones de clase por un lado, y una mayor presencia de conflictos tanto urbanos como rurales. Crenzel ha cuantificado el nivel de conflictividad entre 1969 y 1972 y con los datos aportados se puede concluir que a mayor profundización de la crisis se

167 Algunos testimonios hablan incluso de 250.000 tucumanos que debieron abandonar la provincia. En todo caso lo importante es tener en cuenta que más allá de los números, se encuentran miles de historias personales de los obreros y sus familiares que debieron buscar otros horizontes o bien nuevas actividades económicas a fin de satisfacer sus necesidades básicas.

168 Testimonio de Hugo Figueroa.

169 Para profundizar sobre la la estructura económica de Tucumán en torno a la producción del azúcar: Crenzel, Emilio, Op. Cit; Murmis, Miguel, Carlos Waisman (1969): Monoproducción agroindustrial, crisis y clase obrera; la industria Azucarera tucumana; Sigal, Silvia (1970): Crisis y conciencia obrera: la industria azucarera tucumana. 
produce una mayor desestructuración social que lleva entonces a un aumento de los conflictos. ${ }^{170}$

\section{IV.3 "TuCUMÁN ARDE"171, O LA TOMA DE CONCIENCIA}

A partir de la crisis producida en lo político, económico y social es que los sectores directamente afectados por las diferentes medidas del régimen se plantearon como alternativa enfrentar al gobierno abiertamente en las calles. Cerrados los canales tradicionales de manifestación, la política adquiere características novedosas. La violencia como recurso de manifestación política es la vía que le quedó como alternativa a los sectores populares para oponerse al gobierno, el que a su vez también debe recurrir a la violencia para reprimir dichas manifestaciones.

Es posible plantear que en Tucumán, al igual que en otras zonas del país, se produjera una toma de conciencia en algunos sectores medios urbanos y en la clase obrera en particular tal, que les permitió a obreros y estudiantes pasar de la discusión teórica a la acción. No es exagerado decir, por lo tanto, que el campo popular entre 1968 y 1975 se encontraba en un proceso prerrevolucionario ${ }^{172}$, donde las fuerzas del

170 Crenzel, El Tucumanazo, Op. Cit.

171 Tucumán Arde fue el nombre que recibió una muestra plástica itinerante realizada por artistas de la ciudad de Rosario apoyados por distintos intelectuales en el que se ponía de manifiesto la crisis provocada por las políticas económicas y sociales en la provincia de Tucumán por parte del gobierno de facto encabezado por Juan Carlos Onganía.

172 Si bien es cierto que la década de los '70 marca el auge y apogeo de la lucha de clases en Argentina, no podemos afirmar, para el caso tucumano, que estemos en presencia de un proceso revolucionario. Tema de discusión si lo fue o no, existen elementos fácticos que me permiten sostener que sólo se trató de un proceso prerrevolucionario y donde las fuerzas del campo popular eran tan heterogéneas como sus mismos propósitos. Algunas organizaciones plantearon abiertamente la vía armada para la toma del poder, mientras que otras discutieron profundamente si la opción armada era la correcta. Para el caso de las manifestaciones de los Tucumanazos, sin embargo, los comienzos de la 
régimen recurrieron a la represión violenta de cada manifestación, de cada pueblada, de cada rebelión o revuelta, tanto urbana como rural, para proseguir con el plan de implementación de las políticas ya mencionadas. En algunas provincias del país se produjo entonces una especie de alianza de dos sectores que serán los protagonistas de las luchas de aquellos años. Tanto el movimiento estudiantil, eminentemente de clase media, como la clase trabajadora, participaron en diverso grado y de acuerdo a cada momento y situación, en ese proceso prerrevolucionario.

Para esta provincia es factible destacar tres períodos en el proceso de luchas. De las entrevistas realizadas a integrantes del movimiento obrero y estudiantil ${ }^{173}$ de Tucumán, es posible afirmar que se puede hablar de "tres Tucumanazos"174.

Carlos Zamorano, ex dirigente estudiantil de esos años y miembro del Partido Comunista Argentino explica sobre "los Tucumanazos":

«...cuando decimos Tucumanazo, decimos que había una pueblada en San Miguel de Tucumán, otra en Concepción, en

rebelión estudiantil fue, como mencionan algunos autores, un movimiento reformista que se fue radicalizando, buscando en principio la restitución de los derechos conculcados por la dictadura instaurada en junio de 1966 . Sobre el periodo y como ya indiqué, son todavía escasas las investigaciones que puedan echar luz sobre un proceso histórico sumamente complejo. Sin embargo vale insistir que sin comprender este periodo resulta dificultoso abordar la etapa subsiguiente y los avatares que tuvo que soportar la sociedad tucumana a partir de la profundización de la represión dictatorial en todas sus formas.

173 Las entrevistas mencionadas fueron realizadas entre el año 2004 y 2005 en el marco del proyecto de la realización del documental "El Tucumanazo" dirigido por Diego Heluani. El conjunto de testimonios allí recogidos dan cuenta del proceso histórico abierto en 1966 con el golpe de Juan Carlos Onganía y centra su mirada en los sucesos denominados Tucumanazos.

174 Para una tipificación de estos movimientos denominados "Azos" ver Beba Balvé y Beatriz Balvé (1989): "El '69, Huelga política de masas", Editorial Contrapunto, Buenos Aires, y Bonavena, pablo y otros (1998): Orígenes y desarrollo de la guerra civil en la Argentina, 1966 - 1976. EUDEBA, Buenos Aires. 
Monteros, otra en Aguilares, otra en Villa Alberdi, era contemporáneo en toda la provincia, no era en una sola ciudad o en la capital que eso sería interesante conversar con la gente de Monteros, conversar con la gente de Concepción para ver la participación de otros que no han llegado a ser tan notorios como personas individuales porque eran ciudades más chicas nada más, pero fue muy importante... $\gg^{175}$

En Tucumán cada uno de los momentos de la lucha, estuvo signado por una profundización de las diferencias de clase y quienes participaban en los enfrentamientos eran sectores proletarios, estudiantes de clases medias y medias bajas, y, si bien parte de la población de la capital provinciana acompañó cada protesta callejera, nunca se involucró más allá del apoyo que según el momento era mayor o menor, de acuerdo a la represión sufrida por los manifestantes. De hecho, los estudiantes y los obreros del azúcar enfrentaron como en un campo de batalla a las fuerzas del régimen con los elementos que tenían a mano. Ejemplo de esto es la anécdota relatada por Ángela Nassif, ex dirigente estudiantil de esos años, en la que da cuenta de cómo enfrentaban a la policía:

«Hay un momento, ya no me acuerdo exactamente en qué fecha, que la Policía Provincial es totalmente rebasada, llegan Brigadas de la Federal, especialmente motociclistas, preparados para la lucha de calle que habían hecho el día anterior una exhibición de su destreza y de su poder para amedrentarnos, donde iban en la moto, atrás iba parado otro con látigo, lanza gases y demás, entonces nosotros pensamos que podíamos hacer contra eso. Y a la altura de lo que ahora sería el viejo Concejo Deliberante, cruzamos una tanza, ellos

$\overline{175}$ Testimonio de Carlos Zamorano, dirigente del Partido Comunista. [Entrevista realizada por el autor]. 
venian formados en cuña y nosotros sabiendo como reaccionaban hicimos un acto relámpago en la esquina, a 20 metros de donde habíamos colocado la tanza y por supuesto, tiramos volantes, tiramos las bombas de estruendo y ellos avanzaron a atacar, nos dieron la orden de retroceder y nosotros amagamos con avanzar y ellos dieron la orden de avanzar y avanzaron y les dio a donde habíamos calculado, no en el cuello, en la mitad del pecho, con lo cual cayeron las 10 primeras motos y se armo un escándalo, pero además fue el hazmerreír de la población.» ${ }^{176}$

Los testimonios de aquellos años no solo dan cuenta de lo ocurrido, sino también de cómo lo perciben hoy, quienes además, ya entrada la última dictadura militar, sufrieron en carne propia la represión por haber participado justamente en estas revueltas populares. Sobre esto volveré más adelante.

Una segunda cuestión que estimo necesaria tratar, es lo relacionado con la idea que también en Tucumán se estaba llevando a cabo un proceso prerrevolucionario. Si bien algunos de los enfrentamientos fueron espontáneos, no por eso debemos afirmar que todo el movimiento carecía de dirección y estaba falto de una ideología ${ }^{177}$. De hecho es factible comprobar la plena conciencia que aquella era una lucha revolucionaria, a partir del análisis de los testimonios recogidos. Desde el comienzo mismo del proceso de lucha, iniciado en 1968, en algunas localidades del interior de la provincia, hasta su inicio de mayor virulencia en mayo de 1969, la idea de la transformación social estaba

176 Entrevista a Ángela Nassif, dirigente del Partido Comunista Revolucionario (PCR) [Entrevista realizada por el autor].

177 Este es un punto de controversia incluso entre los propios militantes. Algunos testimonios ponen en duda que hubiera una conducción unificada y destacan que la ausencia de dicha conducción le quitaría el posible carácter revolucionario del proceso. 
presente en los actores sociales. Las evidencias en este punto son contundentes, desde el desarrollo de la muestra artística "Tucumán $\operatorname{Arde}^{\prime 178}$, hasta las homilías de los sacerdotes del movimiento tercermundista, y las declaraciones de los dirigentes estudiantiles así lo manifiestan.

En un contexto más amplio, la lucha de clases producida no sólo en Tucumán, sino también en el resto del país, estaba influenciada por movimientos internacionales más importantes, desde la revolución cubana, la figura del Che Guevara como emblema de la guerrilla, pasando por el mayo francés y sus consignas, hasta manifestaciones estudiantiles y obreras en todo el continente latinoamericano de idéntica magnitud.

En este punto considero necesario responder a dos cuestiones planteadas por Mark A. Healey, quien sostiene "que el epicentro de la ola de protesta de mayo de 1969 no fueron los clausurados ingenios de Tucumán, símbolos de un país en colapso, sino las fábricas de Córdoba, verdadero motor del proyecto económico del gobierno"179. Si bien es cierto que por la magnitud del enfrentamiento y por el resultado posterior del mismo, el Cordobazo quedó como el auge de la lucha de aquellos años, sostener que Tucumán no fue el epicentro de la lucha es desconocer que en esa provincia las manifestaciones obreras con toma de ingenios y retención a modo de rehenes de empresarios, y puebladas de gran magnitud, han sido la antesala de un proceso de lucha social que culmina con manifestaciones diarias en el centro de la ciudad, en algunos casos violentamente reprimidas. Es necesario mencionar acá las

\footnotetext{
178 Sobre la muestra Tucumán Arde y el estado del arte en esos años léase Longoni, Ana y Mestman, Mariano (2008): Del Di Tella a "Tucumán Arde". Vanguardia artística y política en el 68 argentino, EUDEBA, Buenos Aires.

179 James, Daniel, Op. Cit.
} 
puebladas de Bella Vista enero de 1969, y la de Villa Quinteros en Abril de 1969, donde no sólo el pueblo salió a la calle a enfrentarse con las fuerzas del régimen. En cada uno de los casos mencionados la solidaridad llegó incluso de la mano de los sacerdotes tercermundistas, que tenían un trabajo de base muy importante en los pueblos del interior de la provincia.

Así también lo expresan algunos testimonios, como el del ex militante del Partido Revolucionario de los Trabajadores (PRT) ${ }^{180}$ en la corriente la Verdad, Carlos "el chino" Moya:

«Este ensayo general del '69, nos va a permitir estar presentes en los '70 y el vínculo con el movimiento obrero era con algunos contactos que nos habían quedado del viejo trabajo político... alguna gente del ingenio San José; tratar de ayudar desde afuera cuando había conflictos como por ejemplo el de villa quinteros, que íbamos de observadores, a ayudar o los primeros despelotes en Bella Vista...» ${ }^{181}$

Por otro lado tampoco estoy de acuerdo cuando Healey sostiene que el motor de las protestas en Tucumán fueron los estudiantes universitarios y secundarios siendo su escenario fundamental la ciudad de san Miguel de Tucumán. Si bien es cierto que el epicentro de la protesta fue el centro de la capital provinciana, no es menos cierto que grandes focos de lucha y conflicto se desarrollaron en el interior, como en los casos arriba mencionados de Bella Vista, Villa Quinteros, a los que se tendría que sumar, por ejemplo, Tafí Viejo, entre otras localidades.

${ }^{180}$ El Partido Revolucionario de los Trabajadores sufrió una fractura en su interior. Por un lado el PRT combatiente que optó por la lucha armada, y por el otro, el PRT la Verdad alejado de la vía armada para llegar al poder.

181 Entrevista a Carlos Moya, ex dirigente del PRT La Verdad. [Entrevista realizada por el autor]. 
La mancomunión entre estudiantes y obreros no sólo se deduce de los testimonios de los dirigentes, sino también, de las lecturas de los diarios de la época, tanto nacionales como locales, e incluso en alguna de las publicaciones periódicas. En este mismo sentido Crenzel cuantifica a los participantes de cada uno de los movimientos que enmarcan el Tucumanazo, al mismo que consigue desarrollar en su estudio cuáles son los sectores que componen cada uno de los ciclos de protesta. En los tres momentos destacados también por el trabajo de Crenzel los obreros ocupan un lugar central junto a los estudiantes, siendo el momento de mayor presencia noviembre de $1970 .^{182}$

En una extensa nota dedicada al levantamiento de Villa Quinteros, el 13 de mayo de 1969, la revista bonaerense, Primera Plana, rescataba los testimonios de obreros de aquella localidad sureña de la provincia. Martín Dip, abogado y asesor de una comisión pro Defensa del ingenio San Ramón, destacaba que "El Operativo es un fracaso (...); pocos jornales en el mes y un salario menor al legal, demoras en el pago, fuentes de trabajo alejadas de los pueblos". 183

\section{IV.4 UNA LUCHA TAMBIÉN IDEOLÓGICA}

En el transcurso de la lucha de clases se planteó desde el comienzo la lucha ideológica, lo que permite tener una idea cabal acerca de qué sectores estaban enfrentados en el período. Por un lado, el oficialismo, representado por el gobernador Roberto Avellaneda en Tucumán en el año 1969, acentuaba el catolicismo de ultraderecha asistiendo a los "Cursillos de Cristiandad" que se desarrollaban en Tucumán y que tenían su origen en la España franquista. Por otro lado, la

182 Para una tipología de los actores que participan en el Tucumanazo se puede consultar: Crenzel, Emilio: El Tucumanazo, Op. Cit.

183 Primera Plana, Número 333 del 13 de mayo de 1969. Véase Kotler, Rubén (2012): Villa Quinteros se rebela: el Tucumanazo de 1969... Op. Cit. 
Iglesia sufría en 1968 una fractura en su interior con la separación de un grupo de sacerdotes que habrían de conformar el Movimiento de Sacerdotes para el Tercer Mundo. Una de las provincias donde más se evidencia dicha ruptura es Tucumán, donde los Cursillos por un lado mostraban la ideología de las clases dominantes, y por otro, trece curas de la provincia se convertían en los representantes de los Sacerdotes tercermundistas, que tuvieron gran participación en las manifestaciones y mucha presencia en el interior, realizando un trabajo de base muy importante en los pueblos donde habían sido cerradas las fábricas azucareras.

Uno de los curas del movimiento de Sacerdotes para el Tercer Mundo fue Juan Ferrante, quien reconoce la importante presencia del movimiento en Tucumán:

«...toda esa gente era la que conforma toda una especie de grupo grande, unos veintipico de componentes que son los que van a conformar todo ese grupo del Tercer Mundo que era muy numeroso en Tucumán, prácticamente era bastante importante.»184

Con motivo de celebrarse una misa en homenaje a los estudiantes muertos en Corrientes y en Rosario, durante los días previos al Cordobazo, en mayo de 1969, Ferrante pronunció la siguiente homilía:

«Hoy los cristianos tenemos que dar testimonio en las enseñanzas de Cristo para que el combate que libran los estudiantes no sean en vano, pues si queremos hacer una revolución, tenemos que hacerla hasta el fin, y si caen algunos, que su sangre sea la semilla liberadora. Se dirá que instrumentamos la misa. Estamos aquí porque los cristianos

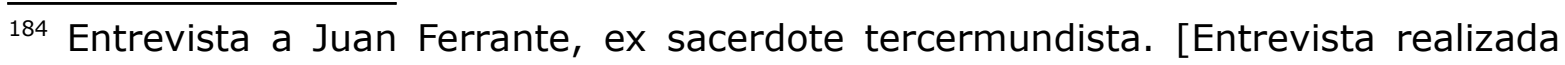
por el autor]. 
no podemos estar ajenos al compromiso del hombre que busca crear una sociedad fraternal y justa. Cristo liberó a los oprimidos del faraón. Hoy hay muchos faraones de los cuales los hombres buscan liberarse. El espíritu guiará a los hombres hacia su liberación total. Los cristianos no deben desoír el llamado de liberación de los pobres, porque Cristo es el Dios de los pobres y los pobres deben liberarse para liberar a otros. ${ }^{185}$

No quedan dudas por lo tanto, que a la lucha política que implicaba el uso de la violencia como legítimo recurso (en la visión tanto del gobierno de facto como de los sectores sociales afectados por las medidas del régimen militar) y a la profundización de la crisis estructural del sistema económico, vino a sumarse el factor ideológico, como resultado de la misma lucha entre dos sectores que cada vez se hacían más identificables. El régimen por un lado y la utilización del monopolio de la fuerza para reprimir todo intento de rebelión, los sectores populares, por el otro, que se debatían entre los levantamientos urbanos y rurales y la lucha armada como vehículo para la resolución del conflicto que culminara en una revolución social. ${ }^{186}$ Claramente el proyecto de los segundos, si bien era amplio y heterogéneo se planteaba como una alternativa a la imposición de las medidas ultra-liberales de la dictadura instaurada en junio de 1966. Si bien en líneas generales puedo decir que

185 La Gaceta de Tucumán, 26 de mayo de 1969.

${ }^{186}$ Cabe aclarar que lo que denominamos aquí "sectores populares" resulta de unas heterogéneas composiciones de organizaciones políticas, gremiales y estudiantiles, que por momentos confluían en determinadas luchas pero que, en su seno, planteaban distintas respuestas y estrategias de acción. Por ejemplo, estuvieron las organizaciones políticas como Montoneros, de extracción peronista o ERP, del marxismo que planteaban la lucha armada como válida para enfrentar al sistema, y otras organizaciones como podían ser el Partido Comunista Revolucionario de orientación marxista maoísta o el propio Partido Comunista Argentino, ligado a la Unión Soviética, que planteaban sus diferencias en el uso de las armas como vía de respuesta a la represión estatal. 
el proyecto social de los sectores populares tendía al socialismo (con la diferencia de miradas que podía tener cada grupo político) no existía un plan unificado de todo el campo ni mucho menos una idea acabada de conjunto sobre el cambio pretendido. Cada organización se dio un programa y acorde a él unas estrategias de acción que con mayor o menor eficacia pusieron en juego durante los '70.

Visto desde el presente, este proceso de luchas sociales plantea una serie de cuestiones que se vinculan con el estudio de aquellos años. El devenir de la historia personal de cada uno de los militantes que han tenido cierta participación en alguno de los tres Tucumanazos, las contradicciones propia de los actores sociales y de la propia historia del país, los olvidos, tanto los personales como los colectivos, la influencia de los medios masivos de comunicación en la formación de la opinión pública sobre los '70, entre otras cuestiones, asumen en los testimonios datos reveladores que indican lo contradictorio del propio proceso histórico. Entre lo individual de las acciones y lo colectivo del movimiento se desenvuelve una trama que solo es posible rastrear a través del testimonio de los ex militantes setentistas.

En el terreno de verse aplacadas las formulaciones políticas que apelaban a la violencia, la dictadura instaurada en 1966 entraba hacia 1972 en un cono de sombras. El fortalecimiento sobre el posible retorno de Perón generaba también conflictos y contradicciones no solo en el poder, sino en las distintas facciones que operaban en Argentina. Ya no sólo era el campo popular en su conjunto contra las fuerzas de la dictadura instaurada algunos años antes, sino que era la discusión sobre el poder, sobre el tipo de sociedad que debería resultar del alejamiento de los militares del poder. 
Comprender además esta generación de militancia resulta clave para la comprensión posterior del movimiento de derechos humanos. En primer lugar, porque es la generación que se vio afectada directamente por la represión militar que se profundizó, como veremos más adelante, a partir de febrero de 1975, con el Operativo Independencia; en segundo lugar, porque son los familiares afectados directos, que darán origen, con la represión sufrida, a la aparición en escena, desde 1977 en adelante, de las organizaciones de familiares de represaliados políticos en todas sus variantes; en tercer lugar, y esto también será motivo de análisis más adelante, será la generación sobre la que se referenciará una de las organizaciones de derechos humanos surgida a mediados de los '90, H.I.J.O.S., que nucleaba a los hijos e hijas de los afectados directos por la última dictadura militar. 


\section{CAPÍtulo V: El interRegno Peronista y el Operativo INDEPENDENCIA}

\section{V.1 La Provincia de Tucumán: de la dictadura a la democracia, a la DICTADURA}

Terminados los convulsionados procesos del Tucumanzo y tras el retorno de Perón, se abría en Argentina en general, y en Tucumán en particular, una nueva coyuntura. Lejos de aplacarse las manifestaciones de protesta, los actores sociales en juego radicalizaron sus discursos y prácticas. Un claro ejemplo de esto, fue la última gran huelga de la FOTIA, perfectamente retratada por el periodista Marcos Taire ${ }^{187}$ y que da cuenta que lejos de traer la pacificación al país, el interregno peronista contribuyó a la exacerbación de las prácticas y discursos, al decantarse su líder, Juan Domingo Perón, por el ala derecha dentro del propio peronismo.

En un principio, comenzaron a operar con mayor actividad las organizaciones de izquierda que optaron por la vía armada para el cambio social, entre las que cabría destacar a Montoneros, de extracción peronista, y al Partido Revolucionario de los Trabajadores y su brazo armado, el Ejército Revolucionario del Pueblo (PRT - ERP), de extracción marxista. Estas organizaciones político armadas, entendieron que el regreso de Perón no brindaba una salida a la revolución deseada. Sobre el periodo en cuestión existe una vasta literatura, aunque quizás todavía insuficiente, sobre todo en lo que hace a la historia tucumana. Sobre el

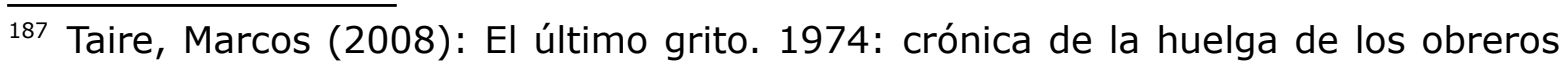
tucumanos de la FOTIA, Ediciones del Pago Chico, Buenos Aires. 
periodo, Pablo Pozzi y Alejandro Schneider contabilizaron 17 organizaciones armadas de relevancia, destacándose las mencionadas anteriormente. ${ }^{188}$ En Tucumán el PRT - ERP decidió a fines de 1974 la instalación en sus montes de una guerrilla rural, creyendo que el pueblo acompañaría a la revolución por la vía armada.

En paralelo, a la vuelta de Perón a la Argentina y tras su llegada al poder, el movimiento peronista tuvo un corrimiento hacia la derecha, como ya dijimos, por medio de José López Rega, mano derecha del propio Perón y uno de los promotores del grupo parapolicial, la denominada "Triple A", (Alianza Anticomunista Argentina) que comenzó a perseguir a opositores de izquierda desde 1974. A la muerte de Perón y tras la sucesión de su viuda, Estela Martínez de Perón, López Rega tuvo un influjo particular sobre la presidente.

Como concluye Pablo Bonavena su caracterización del periodo estando Perón en el exilio operó tanto a su derecha como a su izquierda, complejizándose el panorama político nacional. Según el sociólogo "el armado político que propició Perón no tenía otro destino posible que su estallido. La táctica de aglomerar fuerzas políticas y sociales tan distintas con un difuso programa reformista de borrosos límites ideológicos le permitió engrosar el caudal de votos al peronismo, pero al costo de no poder gobernar."189

\footnotetext{
188 Véase Véase Pozzi Pablo (2004): "Por las sendas argentinas...", El PRT-ERP, la guerrilla marxista, Imago Mundi, Buenos Aires y Pozzi, Pablo y Schneider, Alejandro (2000): Los Setentistas, Izquierda y clase Obrera (1969 - 1976), EUDEBA, Buenos Aires.

189 Bonavena, Pablo (2010) Guerra contra el campo popular en los '70: Juan Domingo Perón, la depuración ideológica y la ofensiva de los gobernadores en Izaguirre, Inés (2010): Lucha de clases, guerra civil y genocidio en la Argentina. 1973 - 1983. Antecedentes, desarrollo y complicidades, EUDEBA, Buenos Aires, Pp. 228 a 235.
} 
Coincido entonces con la caracterización realizada por Pisani, Jemio y Rauch cuando plantean para el periodo transicional de una dictadura a la otra, con el interregno peronista entre 1973 y 1976, que "la alteración de las relaciones de fuerzas que posibilitó la perpetración del golpe de Estado ${ }^{190}$ fue el resultado de una combinación de estrategias políticas, en el sentido estricto del término, con estrategias políticomilitares tendientes a fracturar la embrionaria articulación entre las fuerzas revolucionarias y las organizaciones de base. Aunque no siguieron un proceso lineal, estas acciones tuvieron como efecto de conjunto la aniquilación de aquellas mediaciones políticas (sindicatos, comisiones obreras, movimientos políticos, movimientos armados, movimientos barriales o estudiantiles) que constituían el principal obstáculo a la imposición del nuevo modelo socioeconómico."191

Como apunta Inés Izaguirre "en el mes de septiembre (de 1974) el Poder Ejecutivo envía al Congreso Nacional un proyecto de ley que resulta aprobado en 48 horas por ambas cámaras y es sancionado el 28 de septiembre de 1974 como ley número 20.840 de "Seguridad Nacional", que reprimía "los intentos de alterar o suprimir el orden constitucional y la paz social de la Nación". 192 Para la socióloga, dicha ley fue el punto de inicio del Operativo Independencia ya que a partir de la misma el ejército comenzó con sus preparativos como informa en su diario quien estuvo al mando en la primera etapa del Operativo, el General Acdel Vilas.

La represión estatal tuvo en todo el proceso anteriormente desarrollado, tres etapas diferenciadas: la primera consistió en el uso de

190 El golpe del 24 de marzo de 1976.

191 Pisani, Alejandra, Rauch, Magdalena y Jemio, Ana Sofía: Construcciones de sentido en las explicaciones sobre el proceso genocida en Tucumán en los discursos de sobrevivientes de Famaillá. 1975-1983, Mimeo.

192 Izaguirre, Inés, Op. Cit. Pp. 112 a 114. 
la fuerza paramilitar ejercida por la Triple A con José López Rega a la cabeza desde 1974, cuando se reportan las primeras desapariciones forzadas de personas y la elaboración de listas negras que incluían no solo a activistas políticos, sindicales y estudiantiles, sino también a intelectuales, miembros de las universidades, periodistas, etc; la segunda con la implementación del Ilamado Operativo Independencia, una operación militar bajo las órdenes legales de la presidencia desde febrero de 1975 con la idea de "combatir" a la guerrilla instalada en los montes tucumanos; la tercera fase, la de mayor ferocidad, se concreto con el alzamiento militar del 24 de marzo de 1976 y donde las fuerzas represivas actuaron a discreción sobre todo el conjunto de la población.

Con la ley 20.840, la presidente Martínez de Perón, firmó el decreto secreto 261 que daba inicio a las operaciones militares el 5 de febrero de 1975. Sobre el Operativo Independencia afirman González y González que "los (...) decretos de 1975 lograron devolver al centro de la escena a las Fuerzas Armadas para encargarse de la lucha contra la subversión, pese a que ya en ese momento el poder militar de la guerrilla había mermado considerablemente. Pero la magnificación de los acontecimientos tucumanos, que fueron elevados a la categoría de "guerra contrainsurgente", sumado a la impotencia y corrupción política y a la presión sindical, convirtieron a un momento difícil en un golpe de Estado latente. Hay quienes dicen que pudo haberse evitado con elecciones anticipadas, pero el golpe ya estaba en marcha y el motivo real era imponer un modelo económico como el que se siguió. Guillermo Walter Klein, mano derecha de Alfredo Martínez de $\mathrm{Hoz}$, ministro de Economía del gobierno militar iniciado en 1976, diría: "Ella [la política económica] era incompatible con cualquier sistema democrático y sólo aplicable si la respaldaba un gobierno de facto". ${ }^{193} \mathrm{Y}$ continúan explicando ${ }^{193}$ Clarín, 5 de octubre de 1980, citado en José Luis D’Andrea Mohr (1998): El 
que "aunque el capitalismo argentino nunca fue un ejemplo de unión, siempre que sus intereses necesitaron el disciplinamiento de los subordinados para ejercer una conducción general de una economía a su servicio, supieron actuar mancomunadamente, con el fondo de un golpe militar, y el predominio de las fracciones vinculadas al capital transnacional. ${ }^{\prime 194}$

Dicho en otros términos, la estrategia estuvo centrada en una operatoria de hostigamiento llevada adelante fundamentalmente por la Triple A, tendiente al debilitamiento de los lazos construidos entre el movimiento sindical, el estudiantil, los movimientos barriales y las organizaciones armadas de izquierda, que va producir un escisión entre el movimiento popular y las organizaciones políticas, en particular las armadas, alianza que fue tejiéndose desde el golpe de Onganía anteriormente descrito.

Para las sociólogas antes citadas, "el Operativo Independencia, iniciado en febrero de 1975, supuso un salto cualitativo respecto de la doble estrategia (...) de repliegue político y concentración de fuerzas en el ámbito militar, adoptada por los sectores dominantes para lograr el fraccionamiento de los sectores populares y la legitimación del posterior aniquilamiento. Esta transformación supone que el Estado vuelve a asumir abiertamente en su carácter institucional la dirección de las acciones represivas, hasta entonces desplegadas a través de los grupos

Escuadrón Perdido, Editorial Planeta, Buenos Aires, P. 27.

194 González Tizón, Hilda y González Roque (2003): Tucumán, el entramado represivo (1975 - 1978), en AAVV: Construcción de la memoria, EUDEBA, Buenos Aires, Pp.195 y 196. Para un estudio más exhaustivo sobre el Operativo Independencia consúltese: Crenzel, Emilio (2001): Memorias Enfrentadas: El voto a Bussi en Tucumán, Colección Diálogos, Universidad Nacional de Tucumán; Rofinelli, Gabriela: una periodización del genocidio argentino (Tucumán 1975 1983), en Fermentum - Revista de Sociología y Antropología de Venezuela, No 46., Feierstein, Daniel (2007): El Genocidio como práctica social, Fondo de Cultura Económica, Buenos Aires. 
paramilitares". 195 Según las hipótesis aquí sustentadas el "cambio no se produjo abruptamente. Es posible dar cuenta de ciertos elementos que gradualmente, y sobre la base del éxito de la estrategia anterior, van expresando un progresivo desplazamiento de la alianza de clases en el Estado hacia una ofensiva represiva abierta. Entre los elementos más significativos que dan cuenta de este desplazamiento se puede mencionar la sanción de la mencionada Ley 20.840, de Seguridad Nacional (1974).."196 Por lo tanto, lo que notamos para el periodo de recrudecimiento de la represión estatal y paraestatal es que el cambio implicó en primer lugar una etapa de hostigamiento, implementada por el Comando Restaurador del Norte, enrolado en la Triple A, al mando del comisario Roberto Albornoz y otros grupos paramilitares creados a instancias de Luciano Benjamín Menéndez, cuyo objetivo central -aunque no el único- fue desmontar las articulaciones existentes entre el Ejército Revolucionario del Pueblo (ERP) y la fuerza social de la que formaba parte; a una etapa de aniquilación material, a cargo del ejército, que comienza con el Operativo independencia desplegado a través de una ocupación militar en parte del territorio tucumano, cuyo centro de operaciones se ubicó en el departamento de Famaillá ${ }^{197}$, agregan, además, que "así como a nivel nacional, en Tucumán también es posible dar cuenta de ciertos elementos que marcan una avanzada progresiva hacia una ofensiva represiva asumida abiertamente por el Estado, que se

195 Pisani, Rauch y Jemio, Op. Cit.

196 Ibídem.

197 Cabe mencionar que tanto Pisani como Jemio trabajaron con posterioridad en el marco del proyecto de investigación sobre el Genocidio en Tucumán, relevando 40 testimonios a sobrevivientes de la localidad tucumana de Famaillá. Dicho archivo testimonial da cuenta de cómo han sufrido las consecuencias de la represión militar del Operativo Independencia, no solamente militantes de la zona, sino los propios vecinos. Una copia del mencionado acervo testimonial se encuentra en poder del Archivo Histórico de la Universidad Nacional de Tucumán, fuente además, consultada para la presente tesis. 
HISTORIA Y MEMORIA DEL MOVIMIENTO DE DERECHOS HUMANOS DE TUCUMÁN (1977 - 1999)

CAPÍTULO V: EL INTERREGNO PERONISTA Y EL OPERATIVO INDEPENDENCIA

desarrolla al compás de los cambios de las relaciones de fuerza que se producían tanto a nivel nacional como provincial y que pueden entenderse como expresión de los mismos." ${ }^{198}$

\section{V.2 EL PLAN SISTEMÁTICO Y LA MODALIDAD REPRESIVA}

Tal como venimos apreciando, las primeras persecuciones políticas, las primeras desapariciones forzadas de personas y los primeros Centros Clandestinos de Detención $(C C D)^{199}$ han tenido lugar en la provincia de Tucumán desde fines de 1974 y comienzos de 1975, con el establecimiento del Operativo Independencia. La intervención del ejército en un operativo avalado legalmente por el Estado, ${ }^{200}$ implicó por primera vez la implementación de torturas y la desaparición sistemática de personas, prácticas que se aplicaron en todo el país, de manera planificada, metódica e ilegal, después de producirse el golpe el 24 de

198 Pisani, Jemio y Rauch Op. Cit., Mimeo. La escalada represiva es explicada no solo por estas autoras sino que además otros trabajos dan cuenta del avance represivo del Estado con distintas acciones. No vamos a detenernos en estos puntos pero si mencionar que para terminar de comprender la complejidad del periodo conviene leer los trabajos de Inés Izaguirre, Pablo Ponavena, Matías Artese, Gabriela Rofineli o Marcos Taire, que nos ayudan a comprender, desde una mirada cuantitativa, cuáles fueron los blancos de ataque de esa represión, a quiénes ha apuntado el régimen para "su aniquilamiento" y sus objetivos. Los distintos trabajos mencionados explican, de diferentes maneras, cómo la provincia de Tucumán se transformó en blanco, durante el interregno de la democracia institucionalizada en manos del peronismo (1973 - 1976), de la escalada represiva que terminará de arraigarse tras el golpe del 24 de marzo de 1976.

199 Véase el anexo documental número 5, en el que se detallan cada uno de los Centros Clandestinos de Detención que funcionaron en Tucumán.

200 López Echagüe, Hernán (1991): El enigma del General Bussi, Edit. Sudamericana, Buenos Aires; AAVV (2003): Construcción de la Memoria, Edit. EUDEBA, Buenos Aires. Rofinelli, Gabriela: una periodización del genocidio argentino (Tucumán 1975 - 1983), Op. Cit; Artese, Matías y Rofinelli, Gabriela: Responsabilidad Civil y genocidio. Tucumán en años del Operativo Independencia (1975 - 1976), en Documentos de Jóvenes Investigadores del Instituto Gino Germani de la Universidad de Buenos Aires. 
marzo de 1976. En este sentido el informe de la CONADEP ${ }^{201}$ expresa que "a la provincia de Tucumán le cupo el siniestro privilegio de haber inaugurado la 'institución' CCD, como una de las herramientas fundamentales del sistema de represión montado en la Argentina"202. Entre 1974 y 1978 funcionaron catorce CCD, llegando a ser treinta y tres durante el período dictatorial. La Escuelita de Famaillá fue, en el circuito represivo tucumano, el primer centro de detención ilegal que funcionó en todo el país. ${ }^{203}$

El decreto sancionado de manera secreta por el Poder Ejecutivo a cargo de Isabel Martínez de Perón, establecía que dada "las actividades que elementos subversivos desarrollan en la Provincia de Tucumán y la necesidad de adoptar medidas adecuadas para su erradicación" se ordenaba:

Artículo $1^{\circ}$ : El Comando General del Ejército procederá a ejecutar las operaciones militares que sean necesarias a efectos de neutralizar y/o aniquilar el accionar de los elementos subversivos que actúan en la Provincia de Tucumán.

201 La CONADEP ha sido la Comisión Nacional sobre Desaparición de Personas creada por el gobierno de Alfonsín para recoger los testimonios de los represaliados durante el gobierno militar. Dicha comisión ha estado presidida por el escritor Ernesto Sábato y ha recibido la crítica de algunos organismos de derechos humanos, quienes exigían al gobierno radical la conformación de una comisión bicameral nacional que investigara los crímenes de Lesa Humanidad.

202 Informe de la CONADEP (1998), Edit. EUDEBA, Buenos Aires, Pp. 213 a 217; véase también el Informe de la Comisión Bicameral Investigadora de las Violaciones de Derechos Humanos en la Provincia de Tucumán. IEPALA, Salamanca, 1991.

203 El informe de la Bicameral y el informe de la CONADEP ofrecen un completo panorama sobre el asunto de los Centros Clandestinos de Detención (CCD). El primero de los informes se centra en Tucumán y aporta un valioso documento que refleja la crueldad del sistema represivo en la provincia. La CONADEP, que recogió testimonios del informe de la Bicameral provincial, dedica uno de sus capítulos a los Centros de Detención ilegal en Tucumán (como del resto de provincias argentinas). 
Artículo 2: El Ministerio del Interior pondrá a disposición y bajo control operacional del Comando General del Ejército los efectivos y medios de la Policía Federal que le sean requeridos a través del Ministerio de Defensa, para su empleo en las operaciones a que se hace referencia en el artículo $1^{\circ}$.

Artículo $3^{\circ}$ : El Ministerio del Interior requerirá al Poder Ejecutivo de la Provincia de Tucumán que proporcione y coloque bajo control operacional el personal y los medios policiales que le sean solicitados por el Ministerio de Defensa (Comando General del Ejército), para su empleo en las operaciones precitadas.

Artículo 4 ${ }^{\circ}$ : El Ministerio de Defensa adoptará las medidas pertinentes a efectos de que los Comandos Generales de la Armada y la Fuerza Aérea presten a requerimiento del Comando General del Ejército el apoyo necesario de empleo de medios para las operaciones.

Artículo 5: El Ministerio de Bienestar Social desarrollará, en Coordinación con el Ministerio de Defensa (Comando General del Ejército), las operaciones de acción cívica que sean necesarias sobre la población afectada por las operaciones militares.

Artículo $6^{\circ}$ : La Secretaría de Prensa y Difusión de la Presidencia de la Nación desarrollará a indicación del Ministerio de Defensa (Comando General del Ejército), las operaciones de acción sicológica concurrentes que le sean requeridas.

Artículo $7^{\circ}$ : El gasto que demande el cumplimiento de la misión encomendada por el presente Decreto hasta la suma de pesos CUARENTA MILLONES será incorporado a la 
Jurisdicción 46, Comando General del Ejército, correspondiente al Presupuesto del año 1975. 204

Si en algunas esferas del ejército se esgrimía el argumento de la instalación de la guerrilla en los montes tucumanos para desatar la cruenta represión, no caben dudas, sobre todo después de los últimos estudios en la materia, que el plan pretendía "aniquilar"205 a todo el movimiento popular opositor al régimen ultraliberal instaurado unos años antes con el golpe militar de Juan Carlos Onganía en junio de 1966. Emparentado con el término aniquilación, la palabra subversión y subversivo adquiere mayor connotación, toda vez que el accionar subversivo es el punto de mira de las operaciones del ejército en Tucumán.

Pero ¿quiénes eran los subversivos que pretendía neutralizar o aniquilar, como consta en el decreto, el gobierno constitucional de Isabel Martínez de Perón? Feierstein explica que cuando se habla de subversión "es claro que no se está haciendo referencia sólo a los miembros de la izquierda revolucionaria armada, sino a un grupo más amplio de población". ${ }^{206}$ Entonces el sociólogo agrega que "el concepto de

${ }^{204}$ Decreto Secreto No 261. El decreto llevaba la firma de María Estela de Perón Presidente de la Nación; Alberto L. Rocamora - Ministro del Interior e interino de Justicia; Oscar Ivanissevich: Ministro de Educación; Alberto J. Vignes: Ministro de Relaciones Exteriores y Culto; Adolfo M. Savino: Ministro de Defensa; José López Rega: Ministro de Bienestar Social; Alfredo Gómez Morales: Ministro de Economía; Y Ricardo Otero: Ministro de Trabajo.

205 Utilizo aquí el término aniquilamiento que es como define el Estado argentino la política represiva comenzada en febrero de 1975 con el Operativo Independencia. En el artículo primero del decreto 261, firmado por la entonces presidenta Isabel Martínez de Perón expresaba literalmente que: "El Comando General del Ejército procederá a ejecutar las operaciones militares que sean necesarias a efectos de neutralizar y/o aniquilar el accionar de los elementos subversivos que actúan en la Provincia de Tucumán".

206 Feierstein, Daniel (2007): El Genocidio como práctica Social, Fondo de Cultura Económica, Buenos Aires. P. 312. 
delincuencia subversiva hace referencia a una modalidad de práctica social que, definida por los propios perpetradores, se centra en un modo de encarar la realidad y las relaciones con los otros, uno que incluso puede ser rastreado en las políticas dirigidas a niños y adolescentes, como sugieren las acciones de la dictadura en el campo de la educación". ${ }^{207}$

El número de desapariciones ocurridas durante el Operativo Independencia entre febrero y diciembre de 1975, según las denuncias efectuadas ante la CONADEP, fue de 114 personas. ${ }^{208}$ Según un estudio realizado por Gónzalez y González Tizón, entre febrero de 1975 y marzo de 1976 se produjeron 358 detenciones seguidas de desapariciones de personas en la provincia de Tucumán ${ }^{209}$. El accionar represivo estaba entonces a cargo del general Acdel Edgardo Vilas quien, en cumplimiento de las funciones encomendadas y aún antes de asumir Antonio Domingo Bussi como interventor de Tucumán -abril de 1976-, ya había anulado en su capacidad de combate y prácticamente extinguido al Ejército Revolucionario del Pueblo (ERP), que operó en la zona selvática de Tucumán con un contingente compuesto, según un documento que el propio Ejército atribuye al ERP, por tan solo 35 efectivos y que, de acuerdo con lo estimado por la propia Jefatura de Inteligencia del Estado Mayor General del Ejército, estaba integrado por un número que variaba entre 120 y 160 personas. ${ }^{210}$

Según afirma Pucci "el operativo militar iniciado en febrero de 1975 comenzó con allanamientos, detenciones masivas y secuestros de

\footnotetext{
207 Ibídem, P. 314.

208 Ibídem.

209 AAVV ( 2003) Construcción de la Memoria, Eudeba, Buenos Aires.

210 Documento: Impugnación de la candidatura de Bussi a la intendencia de San Miguel de Tucumán presentada por los organismos de DDHH de Tucumán en 2003. Véase en Anexo documental número 5.
} 
activistas y pobladores en la ciudad capital y en toda la zona de Famaillá, Monteros y Santa Lucía, y con una ola de atentados contra los domicilios de dirigentes y abogados defensores de los derechos humanos, como en los casos de Angel Pizarello, Juan Carlos Ponssa y Gerardo Maxud, entre otros. Una treintena de integrantes de la Triple $A^{211}$, encubiertos como funcionarios del Ministerio de Bienestar Social, arribaron a Tucumán con José López Rega para sumarse a la represión, amparados por los decretos secretos de Isabel Perón, que disponían la participación de ese ministerio en el denominado Operativo Independencia." ${ }^{212}$

Por lo tanto, cuando se produjo el último golpe militar en la República Argentina que destituyó a la presidenta en el ejercicio del poder, la represión ilegal y parapolicial ya estaba afectando a grandes sectores sociales, en su mayoría activistas sociales, militantes obreros y estudiantiles. El golpe solo puso de pretexto la falaz excusa de pretender combatir a la guerrilla, que para diciembre de 1975, como se dijo, ya estaba incapacitada para accionar. De hecho, en su "diario de campaña" quien iniciara las "operaciones militares" durante la primera etapa del Operativo Independencia, Adel Vilas sostenía: "En medio del cariño de sus habitantes y el respeto de los soldados, dejé Tucumán el 21 de diciembre de 1975, próxima la Navidad. El "Operativo Independencia", si bien no había terminado, era un éxito completo. La subversión armada había sido total y completamente derrotada por un Ejército que luego de cien años de paz demostraba su capacidad de combate. La mayor satisfacción fue recibir días después, ya estando en la capital federal, el

${ }^{211}$ Junto a la implementación del Operativo Independencia ya venía actuando de manera ilegal la Triple A (Alianza Anticomunista Argentina), grupo parapolicial que respondía a las órdenes de José López Rega, mano derecha de Isabel M. de Perón.

212 Pucci, Roberto (2007): Historia de la destrucción de una provincia. Tucumán 1966, Ediciones del Pago Chico, Buenos Aires. 
llamado del general Bussi, quien me dijo: «Vilas, Ud. no me ha dejado nada por hacer»."213

Puedo entonces concluir, como afirma López Echagüe, que "la denominada Operación Independencia encierra un indescifrable enigma, por lo demás, de ser temido por la sociedad argentina en su conjunto: es posible señalar con exactitud la fecha de su inicio pero resulta dificultoso (...) establecer la de su finalización." ${ }^{214}$

\section{V.3 Algunas PReCisiones SOBRe LA "ÚLtima" dictadURA MilitaR ARGENTINA}

"Fue cuando se callaron las iglesias, fue cuando el fútbol se lo comió todo, que los padres palotinos y Angelelli, dejaron su sangre en el lodo".215

Algunos autores consideran que el Gobierno Militar instaurado el 24 de marzo de 1976 fue una representación y continuidad del Estado burocrático-autoritario, abierto con el golpe del 28 de junio de $1966^{216}$ cuyos criterios han sido ya esbozados con anterioridad.

El Estado, por medio de este último asalto de los militares al poder, establecía una vez más la frontera de lo moral y lo no moral, aquello que estaba permitido y aquello que estaba prohibido, lo que representaba la cultura oficial y lo que representa a la cultura falsa, importada de ideologías foráneas distintas a la civilización occidental y

${ }^{213}$ Vilas, Acdel: Tucumán, enero a diciembre de 1975 en www.nuncamas.org. [Consultado de la web por última vez en diciembre de 2006].

${ }^{214}$ López Echagüe, Hernán: El Enigma del general Bussi, Op. Cit. P. 216.

215 Gieco, León, La memoria, (Del CD Bandidos Rurales).

216 O'Donnell, Guillermo (1997): Contrapuntos. Ensayos escogidos sobre autoritarismo y democratización. Ed. Paidós. Buenos Aires, P. 75. 
cristiana, erigiéndose el mismo Estado en salvaguardia de lo moral y desconociendo a todo lo demás. ${ }^{217}$

En un contexto de mayor amplitud, el golpe de estado del 24 de marzo de 1976 en Argentina se dio dentro de lo que se conoció como la Doctrina de Seguridad Nacional y el establecimiento del Plan Cóndor, un operativo sostenido por el Departamento de Estado Americano que consistió en una colaboración entre las diferentes dictaduras latinoamericanas en cuanto al manejo de información, implementación de los distintos regímenes, ayuda en el secuestro de personas, etc. Un plan elaborado y apoyado por Estados Unidos, que se extendió incluso fuera de nuestro continente. Es importante recordar aquí que la Escuela de Panamá sirvió de base de entrenamiento a soldados latinoamericanos, entre los que se encontraban, por ejemplo, el General Antonio Domingo Bussi. ${ }^{218}$

"El Plan Cóndor fue la coordinación que establecieron clandestinamente los servicios de inteligencia de las dictaduras sudamericanas durante los años setenta y ochenta para eliminar a todos aquellos que consideraban enemigos de los regímenes militares allí donde estuvieran. A causa del Plan Cóndor, las fronteras de las distintas naciones bajo regímenes militares quedaron abolidas: nadie estaba seguro aunque hubiera dejado su patria. El Cóndor creó una suerte de 'espacio Schengen' para la persecución de los opositores donde no existía el derecho internacional, ni los convenios de extradición, ni los tribunales de justicia, ni los derechos humanos, ni la piedad, ni la presunción de inocencia: bastó una Ilamada telefónica para convertirse en una víctima de un

217 Avellaneda, Andrés: "Censura, autoritarismo y cultura argentina, 1960-1983". Centro editor de América latina, Bs. As. , 1989, P. 20.

218 Martín de Pozuelo, Eduardo y Tarín, Santiago (1999): España Acusa, Ed. Plaza Janés, Barcelona. 
secuestro, de un cruce furtivo de aduanas o para ser asesinado". ${ }^{219}$

Es así como el autoproclamado Proceso de Reorganización Nacional (P.R.N.) encabezado por las tres Fuerzas Armadas, en marzo de 1976, vino a completar el mandato del gobierno militar que le antecedió entre 1966 y 1973 y buscó eliminar a toda oposición política, social y cultural del sistema que se intentaba implementar en Argentina ${ }^{220}$. El plan implicaba entonces derrotar finalmente a los movimientos de protesta obrero estudiantiles de fines de los años '60 y comienzo de los '70 contra la dictadura de Onganía, que habían reagrupado a sectores medios y medios bajos en protestas tanto urbanas como rurales contra las medidas ultraliberales que intentaba aplicar el llamado establishment por medio del ejército a punta de fusiles. ${ }^{221}$

Según Petras y coincidiendo con O'Donnell y con Pozzi, el golpe desató fuerzas y políticas que desarraigaron las instituciones y las relaciones establecidas durante la mayor parte del S. XX en la República Argentina. El objetivo principal del Gobierno de facto fue "la transformación del obstáculo principal para la expansión del capital: la clase trabajadora organizada y dotada de conciencia clasista". 222 El mecanismo para lograrlo fue la implementación del terror, como técnica

\section{${ }^{219}$ Ibídem.}

220 Pozzi, Pablo y Schneider, Alejandro: Los Setentistas. Izquierda y Clase obrera: 1969 - 1976, Op. Cit.

${ }^{221}$ En Tucumán el ciclo de protesta de fines de los sesenta y comienzo de los setenta recibió el nombre de "Tucumanazo", ciclo de protestas que se dieron lugar en todo el país y cuyo punto culmine fue el Cordobazo en Mayo de 1969. Para ampliar sobre el periodo véase: Crenzel, Emilio (1997): El Tucumanazo, Facultad de Filosofía Y Letras de la Universidad Nacional de Tucumán; y Kotler, Rubén: "El Tucumanazo, los Tucumanazos 1969 - 1972, Memorias enfrentadas: entre lo colectivo y lo individual", en Memorias del congreso Inter-escuelas / Departamentos de Historia 2007.

222 Petras, James: Clase, Estado y Poder en el tercer mundo. Casos de conflictos de clases en América Latina. Fondo de Cultura Económica, Buenos Aires, 1993. 
para poder abolir de manera sistemática la memoria de la solidaridad y de los lazos sociales dentro de la clase trabajadora, instaurando los sentimientos de subordinación, respecto a la clase dominante. ${ }^{223}$

Siguiendo a Pozzi y a Schneider "la Argentina cambió entre 1976 y 1999 hasta tal punto que el panorama político actual sería irreconocible hace 25 años. Pero esa visión no considera que el golpe se dio por los errores de la izquierda sino por sus aciertos, invirtiendo las hipótesis clásicamente aceptadas. La izquierda, hasta bien entrado los años 70, había crecido en número, avanzado en experiencia y, sobre todo, venía profundizando sus vínculos con la clase obrera como nunca antes en la historia argentina, incluyendo la década de 1930 (...) En ese sentido el golpe de Estado de 1976 puede ser concebido como un ataque a la clase obrera politizada por la izquierda..."224

La abogada responsable de llevar adelante alguna de las causas contra los represores en Tucumán, Laura Figueroa, asegura que:

«...si bien en Argentina hubo diversos grupos que tomaron las armas, de acuerdo a sus criterios políticos, no todos los desaparecidos pertenecieron a los grupos armados; en nuestro país hubo genocidio, de lo contrario, estaríamos hablando, como hizo el gobierno radical, de dos grupos de violencia, uno de derecha y uno de izquierda; en el país hubo genocidio, que significa, que no solamente hubo persecución política a un grupo determinado que había tomado las armas, sino a todo grupo opositor o persona opositora al régimen militar de esa época y diríamos a partir del año 1975.»225

223 Ibídem.

${ }^{224}$ Pozzi, Pablo y Schneider, Alejandro (2000): Los Setentistas. Izquierda y Clase Obrera: 1969 - 1976, Op. Cit.

225 Testimonio de Laura Figueroa, abogada defensora de los derechos humanos en la provincia de Tucumán [Entrevista realizada en Tucumán el 22 de noviembre de 2007 por el autor]. 
Estas cuestiones se vinculan directamente con lo que se conoce en Argentina como "Teoría de los dos demonios"226, donde se procuró, una vez reinstalada la democracia en 1983, equiparar el accionar de la guerrilla con el terrorismo estatal. Acerca de la teoría de los dos demonios, Feierstein sostiene que la idea fue impuesta por parte del gobierno de Alfonsín (con un claro guiño de la dictadura saliente) y uno de los mecanismos usados para este fin ha sido el informe de la CONADEP, cuyo prólogo a cargo del escritor Ernesto Sábato, fue pieza clave del andamiaje. Para el sociólogo, al hablar de "dos terrores simétricos: uno de derecha, otro de izquierda", dejaba a la sociedad lejos del conflicto de los años '70. ${ }^{227}$ Sobre esta cuestión volveré más adelante ya que merece un análisis más minucioso, por cuanto la teoría de los Dos Demonios afectó a importantes sectores sociales y fue uno de los motores de la lucha del movimiento de derechos humanos en la necesidad de trasmitir al resto de la sociedad que no era posible equiparar el accionar del Estado con el accionar de los grupos opositores al régimen.

La política represiva llevada a cabo por el último gobierno de facto se asentó entonces en una metodología cuyas características fueron sintetizadas en el informe de la Comisión Bicameral investigadora de los crímenes de Lesa Humanidad en la provincia de Tucumán: el secreto, la clandestinidad y la impunidad.

- El secreto remite al uso del aparato represivo de las FFAA, desde la inteligencia hasta la ejecución de los diferentes operativos. Incluyó también muchos de los llamados "enfrentamientos abiertos" entre

${ }^{226}$ Véase Barrio Terol, José Manuel (2005): Insurgencia y Represión. Acerca de la teoría de los dos demonios, en Historia Actual On line, No 8. http://www.historia-actual.com/hao/pbhao.asp [Web consultada por última vez en marzo de 2008].

${ }^{227}$ Feierstein, Daniel: El Genocidio como práctica social, Op. Cit. 
el ejército o la policía y los subversivos, los cuales respondían, en realidad, a una planificación previa, concebida en la ilegalidad. De esta manera, la prensa local podía hacer alusión a "enfrentamientos" para referirse a aquellas muertes cuyas causas fueran dudosas. ${ }^{228}$

- La clandestinidad era una práctica, tanto en lo que se refería a la identidad de los integrantes de las fuerzas de seguridad, como al destino final de los desaparecidos.

- La impunidad era la condición necesaria para la continuidad de la represión ilegal. El sistema le garantizaba no sólo el aparato estatal a los autores de dichos crímenes, sino también una protección fundamental a la hora de ejecutarlos. En este punto se puede decir que la Iglesia Oficial fue no sólo complaciente con el Estado sino en muchos casos cómplice de estas acciones ilegales. ${ }^{229}$ Sintetizando en palabras de Roberto Pucci, del total de crímenes registrados, entre secuestros y desapariciones de personas ocurridos en la provincia, cerca de un 40 por ciento fueron cometidos antes del golpe militar. ${ }^{230}$

\section{V.4 Acerca de las Prácticas Sociales Genocidas}

Como afirma Daniel Feierstein, "en el genocidio social se describe la necesidad de dar cuenta de un momento posterior al exterminio del siguiente modo: Las prácticas sociales genocidas no culminan con su realización material (es decir, en el aniquilamiento material de una serie de fracciones sociales vistas como amenazantes y construidas como

\footnotetext{
${ }^{228}$ Informe de la Comisión Bicameral. Op. Cit.

229 Ibídem.

230 Pucci, Roberto (2007): Historia de la destrucción de una provincia, Op. Cit. P. 343.
} 
"otredad negativa"), sino que se realizan en el ámbito simbólico e ideológico, en los modos de representar y narrar dicha experiencia traumática". ${ }^{231}$

Antes de adentrarme en la cuestión de los desaparecidos, como uno de los núcleos centrales del presente trabajo, considero apropiado analizar aquello que el sociólogo ha dado en llamar la "práctica social genocida"232. Así como comienza a ser aceptado por la academia la hipótesis que sugiere que en Argentina se ha producido entre 1975 y 1983 un genocidio, no es menos cierto que desde algunas latitudes esta cuestión todavía es resistida en el análisis. En un trabajo de reciente aparición, Feierstein realiza una síntesis de sus estudios relativos a las prácticas sociales genocidas comparando el genocidio judío en la Alemania nazi con lo que él considera otro genocidio, perpetrado en Argentina entre 1975 y 1983, desde una triple visión filosófica, sociológica y jurídica. Otros autores argentinos han retomado la visión del sociólogo, contemporáneo además, de los fallos dictaminados por la justicia contra dos represores de la última dictadura militar: el ex Director General de Investigaciones de la Policía bonaerense, Miguel Etchecolatz y el cura castrense Christian Federico Von Wernich.

Sobre el primero, la sentencia en su contra ha sentado precedente, no sólo en el ámbito de la justicia y los juicios que se llevan a cabo contra los represores de la última dictadura, sino que también sirven de argumentos para quienes sostienen que desde el comienzo de Operativo Independencia y hasta el final de la dictadura se desarrolló en Argentina un proceso genocida. El 19 de Septiembre de 2006 Etchecolatz era condenado a reclusión perpetua en el fallo del Tribunal Federal No 1

\footnotetext{
${ }^{231}$ Feierstein, Daniel (2012): Memorias y representaciones. Sobre la elaboración del genocidio, Fondo de Cultura Económica, Buenos Aires, Pp. 180 - 182.

${ }^{232}$ Feierstein, Daniel, El Genocidio como práctica social, Op. Cit.
} 
de La Plata que incorporó la figura jurídica de genocidio por primera vez. ${ }^{233}$

Sobre Von Wernich, el fallo de la causa 2.506/07 también lo acusa por el delito de genocidio, amparándose esta vez en la sentencia contra Miguel Etchecolatz, que sirve, como ya dije, de antecedente de esta y otras causas, como la que tuvo bajo proceso al represor de Tucumán, Antonio Domingo Bussi. En una parte de la sentencia condenatoria al cura castrense se establece que "el genocidio es un proceso y como tal se debe entender, tiene una preparación, un desarrollo y una legitimación posterior. Todo el que participa en alguna de estas etapas es cómplice y autor de este genocidio y tiene un rol muy importante aquel que lo justifique ideológicamente". 234

En la sentencia a reclusión perpetua se menciona que varios testigos relataron durante el transcurso de las audiencias, cómo Von Wernich les aconsejaba hablar, colaborar, y justificaba el rol de los represores diciendo que lo hacían por Dios y por la Patria. Al mismo tiempo, el fallo procura establecer una tipificación sobre la dictadura al afirmar que ésta se "autodenominó "Proceso de Reorganización Nacional" porque sus objetivos no se agotaban en los aspectos económicos y políticos, sino que perseguía un quiebre y una reconstitución de todas las relaciones, de la moral, de la ideología, de la familia y las instituciones; allí el rol de la Iglesia se volvió fundamental, incluso el método de exterminio basado en arrojar personas vivas al mar "había sido

${ }^{233}$ Fallo de la sentencia a Reclusión Perpetua contra Miguel Osvaldo Etchecolatz por Genocidio. Causa 2251/06. Véase Clarín, 20 de Junio de 2006 y Página 12, 20 de junio de 2006.

${ }^{234}$ Fallo contra el cura castrense Christian Federico Von Wernich en el que se le sentencia a reclusión perpetua por el crimen de genocidio en la ciudad de La Plata. Causa 2506/07. 
consultado con la jerarquía eclesiástica, que lo aprobó por considerarlo una forma cristiana de muerte". ${ }^{235}$

Siguiendo en esta línea, los jueces expresan que en "la Argentina no hubo una represión indiscriminada sino discriminada; el aniquilamiento no fue casual ni irracional, se trató de la destrucción sistemática de una parte sustancial de un grupo nacional que había desarrollado determinadas formas de organización y de participación. Terminar, cortar con esa participación, con esa organización, fue uno de los objetivos a más largo plazo que se propuso la dictadura y que hasta el día de hoy padecemos". ${ }^{236}$

Lo que se intenta demostrar, en última instancia, por medio del fallo, es la intencionalidad claramente política que tenía Von Wernich en su accionar, en un contexto estructural que no remitían a "hechos aislados sino que eran parte de un plan sistemático en el cual a él le tocaba ser un engranaje fundamental en una única maquinaria genocida que actuaba en todo el país". ${ }^{237}$ El fallo entiende por esta razón, que el caso del cura no se trata de un simple partícipe sino que se lo menciona como autor del genocidio desarrollado, por lo que la sentencia a reclusión perpetua quedaba firmemente argumentada. ${ }^{238}$

Ya en 1995 los organismos de derechos humanos de Tucumán denunciaban que en la provincia había habido un genocidio y que su responsable había sido el que por aquel entonces era candidato a gobernador Antonio Domingo Bussi. En la sentencia de un juicio ético llevado a cabo por el movimiento, se manifestaba comprobado "que entre los años 1975 y 1977 se ha ocasionado en la provincia de Tucumán un

\footnotetext{
${ }^{235}$ Ibídem.

236 Ibídem.

237 Ibídem.

${ }^{238}$ Ibídem.
} 
genocidio, del cual resulta - entre otros - muy especialmente imputado quien fuera Comandante de las operaciones antipopulares primero, y Gobernador de facto después Antonio Domingo Bussi". ${ }^{239} \mathrm{Si}$ bien por aquel entonces lejos estaba la posibilidad que Bussi fuera juzgado por genocidio, los organismos ya denunciaban que en la provincia se había intentado eliminar un grupo determinado por medio del plan sistemático de represión de las fuerzas del orden, y apuntaban contra el general retirado como uno de los principales responsables. Sobre el Juicio Ético volveré más adelante, sin embargo, considero necesario expresar aquí que en 1995 todavía no había madurado la idea de que en Argentina durante los años de la represión había sucedido un genocidio. La primera en hablar en estos términos en Tucumán desde una perspectiva jurídica ha sido Laura Figueroa, una de las abogadas más activas en materia de los juicios contra los represores. En este sentido, la abogada explicaba:

«Una de las tareas que he sostenido hasta hoy ha sido el de poder establecer cuál ha sido el circuito de muerte en Tucumán. Esto ha sido un trabajo monstruoso. Con la colaboración de Viviana Vicente, de H.I.J.O.S., estando ella recién recibida armamos la causa del Operativo Independencia, que era una materia pendiente, cosa que pude sistematizar recién en el año 2003 más o menos. Creo que desde el año 2003 hasta ahora creo que he podido determinar con precisión el circuito de muerte después de tantos años de investigación. Esto llevaría a afianzar el procesamiento de genocidio.»

Pregunta: ¿Qué significa decir circuito de muerte?

${ }^{239}$ De la sentencia del Tribunal del Juicio Ético contra Bussi llevado a cabo el 19 de junio de 1995. 
«Antes nosotros teníamos una noción muy dividida o estanca, es decir, decíamos por ejemplo: Centro Jefatura ${ }^{240}$, Centro Escuelita, como si fuera algo aislado. Sabíamos que de Jefatura iban a cualquier Centro, sabíamos que de Nueva Baviera iban a Arsenales. Lo que nos faltaba determinar entonces era el Circuito de muerte, es decir, si pasaban por Jefatura, a dónde eran trasladados (los detenidos) y a dónde terminaban. Porque no tanto importaba si de jefatura pasaban a Nueva Baviera, al Motel o al Reformatorio, sino determinar cuál era el destino final. Es decir, cuáles fueron los Centros "chupaderos"241 y cuáles eran los Centros de "exterminio". En todos los Centros hubieron muertos por tortura, pero no en todos los Centros hubieron ejecuciones masivas, y esto recién ahora lo estoy pudiendo determinar.»

Pregunta: ¿Cuándo se incorpora a las causas la figura de genocidio?

«Yo siempre hablé de genocidio y consigo que recién este año después de la sentencia a Etchecolatz, al día siguiente pido que en la indagatoria por los delitos en Arsenal, se haga en el marco del delito de Genocidio. Mi desesperación en el año 2005 era perfeccionar la sistematización de las pruebas en Arsenal para poder demostrar que realmente fue un genocidio, pero no solamente por la cantidad de muertes sino, yo, dentro de lo que es Arsenal determiné por "grupos de víctimas", por ejemplo, yo he dividido: estudiantes de la

240 Centro hace alusión a los Centros Clandestinos de Detención. La Jefatura de policía o la Escuelita de Famaillá, fueron dos de los más de treinta CCD que funcionaron en Tucumán entre 1975 y 1983.

241 Los chupaderos suponen aquellos CCD donde eran alojados temporalmente las víctimas tras el secuestro inicial. No necesariamente en el primer Centro de detención los desaparecidos eran asesinados. Como se sabe, en Buenos Aires, una de las prácticas del gobierno militar era arrojar los cuerpos, aún con vida, al Río de la Plata. 
facultad de Medicina, de Derecho, de Filosofía, los que venían de Santiago del Estero, obreros del Ingenio San Juan, obreros del ingenio Concepción, etc, entonces yo lo que puedo determinar, es uno de los requisitos que piden en la convención es que realmente se trató de un grupo sustancial que tenía que ser destruido total o parcialmente. Entonces el juez no ha tenido otra alternativa que aceptar el procesamiento (de Bussi) por genocidio, con semejante anexo que es la sistematización de las pruebas más el contenido de la sentencia de Etchecolatz (...) para no caben dudas que desde enero de 1976 hubo un solo lugar de exterminio (en Tucumán), que fue Arsenales, más allá que como digo, hubieran muertes en otros lados. $\gg^{242}$

Siguiendo esta línea de análisis Feierstein asegura que "los secuestros selectivos producidos por las organizaciones paramilitares tenían el claro objetivo de eliminar a aquellas personas capaces de articular sus movimientos políticos (gremiales, barriales, sociales, estudiantiles) con las organizaciones de izquierda $-y$, en particular con la izquierda armada, aunque no solamente- aquellos militantes con capacidad no sólo de "pegar el salto político", sino fundamentalmente de lograr que sus propios colectivos "pegaran dicho salto". 243 Sobre el proceso tucumano en la conformación de una tipología sobre el enemigo a aniquilar, es posible detectar la propaganda publicada por el estado provincial ya en manos de Antonio Domingo Bussi, en el diario La Gaceta de Tucumán durante el año 1976:

\section{«Atención tucumano}

Preste atención y colabore si comprueba:

\footnotetext{
242 Testimonio de Laura Figueroa [Entrevista realizada por el autor en Tucumán en noviembre de 2007]

${ }^{243}$ Feierstein, Daniel, El Genocidio como práctica social, Op. Cit.
} 
-Que en su barrio, pueblo o paraje se radican personas jóvenes sin hijos de corta edad;

-Que esas parejas no mantienen relación con el vecindario;

-Que no se les conoce familiares;

-Que no sabe a qué se dedican ni en qué trabajan.

Porque esas personas pueden estar atentando contra su seguridad, la de su familia y la del país (...) $)^{244}$

De esta manera quedaba configurado el retrato de los subversivos que el Estado pretendía aniquilar, la forma en cómo se trasmitía al resto de la sociedad lo que Feierstein denomina las "prácticas sociales genocidas". Ese fue el objetivo al que apuntó la dictadura militar entre 1976 y 1983 en la práctica de la desaparición forzada de personas. Como apunta Alejandro Horowicz "la ideología de la seguridad nacional, la ideología del enemigo interno, no es el resultado de una importación teórica del reino militar, sino re-traducción militar de un conflicto objetivo: o ellos o nosotros." 245

244 López Echagüe, Hernán, El enigma del General, Op. Cit., P. 164.

245 Horowicz, Alejandro (1985): Los cuatro Peronismos, Edit. Legasa, Buenos Aires. 


\section{V.5 LAS DESAPARICIONES FORZADAS Y EL CIRCUITO REPRESIVO EN TUCUMÁN}

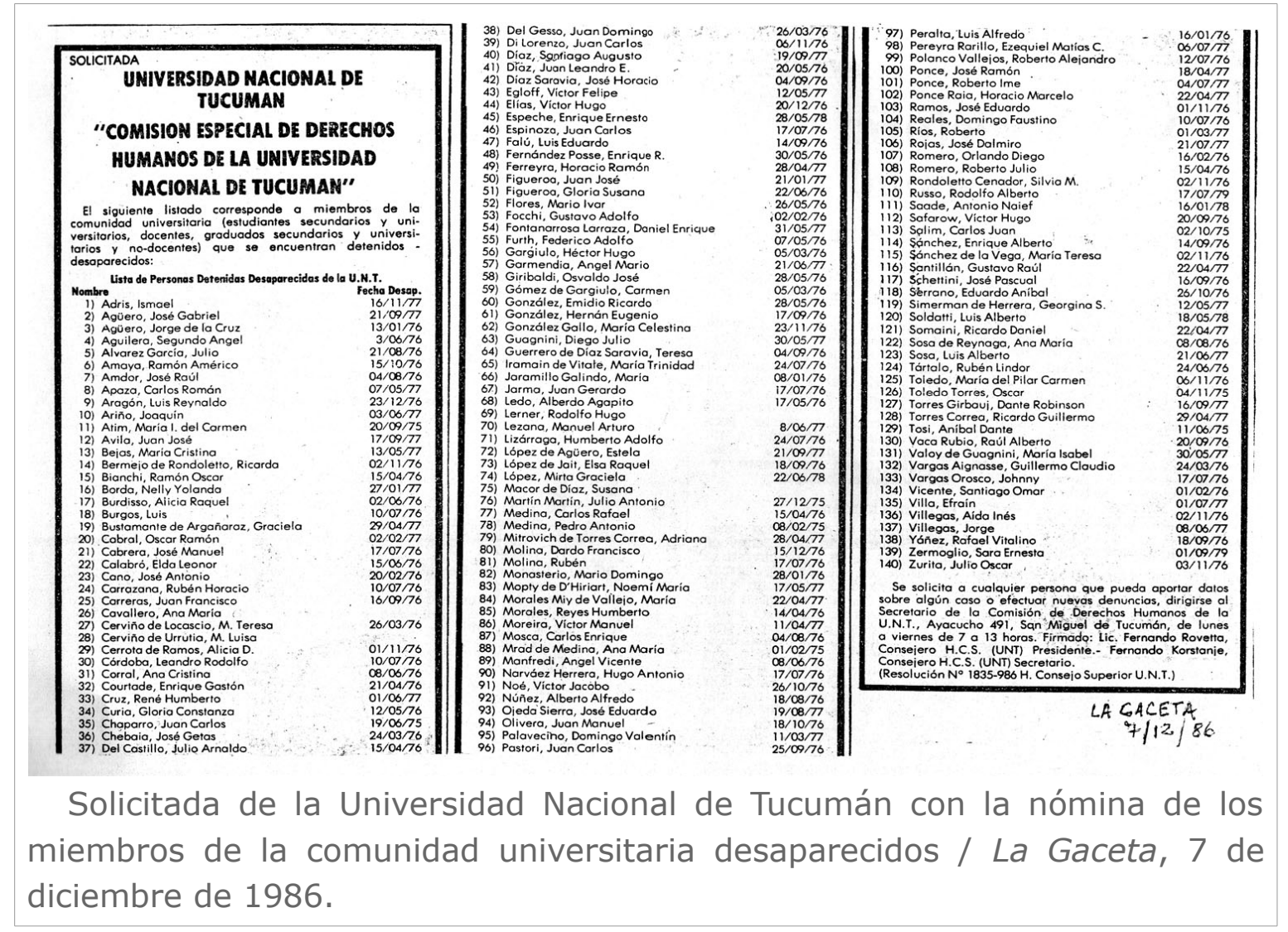

El escritor argentino Julio Córtazar expresaba en enero de 1981 lo siguiente: "Pienso que todos (...) coincidirán conmigo en que cada vez que a través de testimonios personales o de documentos tomamos contacto con la cuestión de los desaparecidos en la Argentina o en otros países sudamericanos, el sentimiento que se manifiesta casi de inmediato es el de lo diabólico (...), es imposible enfrentar el hecho de las desapariciones sin que algo de nosotros sienta la presencia de un elemento infrahumano, de una fuerza que parece venir de las profundidades, de esos abismos donde inevitablemente la imaginación termina por situar a todos aquellos que han desaparecido". ${ }^{246}$

${ }^{246}$ Extracto del discurso del escritor Julio Cortázar en el Coloquio de París reunido del 31 de enero al $1^{\circ}$ de febrero de 1981, donde se debatió la cuestión de la violación de los derechos humanos en Argentina. Publicado en Mignone, Emilio y 
De la ilegalidad de las detenciones aparece la figura del desaparecido que se vincula directamente con la conformación de muchas organizaciones de derechos humanos, en particular con aquellos organismos que tienen que ver con la relación de parentesco con los represaliados, como Madres de Plaza de Mayo, Familiares de Detenidos y Desaparecidos por Razones Políticas, Abuelas de Plaza de Mayo e H.I.J.O.S.

El "desaparecido" es una nueva figura jurídica que nace en la República Argentina, producto de la represión estatal. La política represiva llevada a cabo por el proceso militar y explicada más arriba en la trilogía: secreto, clandestinidad e impunidad, sin los cuales no hubiera sido posible hacer desaparecer de manera sistemática a miles de opositores políticos. Los organismos de DDHH trabajaron para conseguir llenar el vacío legal que implicó la falta de una figura jurídica que contemplara al "desaparecido". En este mismo sentido, Laura Figueroa sostiene que:

«Los organismos de derechos humanos consiguen una gran victoria, y es que el Estado argentino promulgue una ley, que es la ley 24.321, donde se reconoce por primera vez la figura jurídica del desaparecido, y eso trae un alivio en las cosas cotidianas del familiar desde la Patria Potestad, desde una casa que había que vender, cosas cotidianas como esas pero que enredaron año tras año a toda una familia, porque generalmente la familia se negaba a hacer la presunción del fallecimiento porque para nosotros, los organismos de derechos humanos, no están fallecidos, siguen estando desaparecidos, hasta que no aparezca realmente el cuerpo y

Conte MC Donnell, Augusto (2006): Estrategia represiva de la dictadura militar. La doctrina del paralelismo global, Edit. Colihue, Buenos Aires. 
se lo identifique que pertenece a tal persona, esa persona sigue desaparecida... $\gg^{247}$

Para algunos sectores de la sociedad, era una cuestión prioritaria instaurar un orden mientras que los desaparecidos eran un dato menor. Desde la propaganda oficial se insistió que era necesario extirpar el cáncer de la subversión, y por lo tanto no se cuestionaba los métodos utilizados por las FFAA. La consigna del "por algo será", se constituyó para esos sectores en una premisa que explicaba la desaparición y no sólo no se cuestionó el golpe militar, sino que fue apoyado abiertamente, aún a sabiendas del horror que producía. De esta manera los militares legitimaron su accionar e incluso la Iglesia avaló y justificó en más de una ocasión la represión, la tortura y la desaparición de personas. ${ }^{248}$

Según Isidoro Cheresky, sólo un reducido número de personas, especialmente familiares de desaparecidos, pudieron atravesar la puerta de sus casas para salir a reclamar por los detenidos ilegales frente a los órganos estatales. Una compleja tensión se planteó entre los familiares y el gobierno, por el comportamiento de éste último de desentenderse del problema, negándolo, o bien responsabilizando de los crímenes a sectores particulares, ajenos al Estado. ${ }^{249}$

247 Entrevista a Nelly de Bianchi y Laura Figueroa, realizada el 10 de Octubre de 1996 en el marco del estudio sobre el movimiento de Madres de Detenidos Desaparecidos de Tucumán. La entrevista se encuentra alojada en el Archivo Histórico de la Universidad Nacional de Tucumán. [Entrevista realizada por el autor].

248 Véase Mignone, Emilio (1999): "Iglesia y dictadura. El papel de la Iglesia a la luz de sus relaciones con el régimen militar". Edit. La Página y Universidad de Quilmes, Buenos Aires. Aquí el autor recorre minuciosamente la relación entre la institución eclesiástica y el poder político en Argentina, y demuestra con sobrado material documental el rol jugado por ésta durante el período en cuestión. No obstante hubo sectores eclesiásticos no sólo no apoyaron el golpe y las prácticas represivas, sino que se opusieron a ella. Algunos curas como es caso de Angelelli fueron desaparecidos.

249 Cheresky, Isidoro, La inadmisible desaparición de personas, Op. Cit. El autor aborda la cuestión de los desaparecidos de forma más acabada, y logra 
Las desapariciones fueron, entonces, el motivo de la presencia del movimiento de derechos humanos en el espacio público. Movimiento tan amplio que abarcaba tanto a familiares de los desaparecidos, como otras organizaciones que sin estar vinculadas directamente a los represaliados, se solidarizaba y comprendía el drama que la nueva situación generaba. Esta nueva condición de las personas que no estaban ni detenidas ni muertas, sino desparecidas, impactó psicológicamente en los familiares. En este sentido el Equipo de Asistencia Psicológica de Madres de Plaza de Mayo realizó acciones que nos permiten tener una idea más o menos acabada sobre el efecto que produjeron esas desapariciones.

La desaparición planteó, y aún hoy plantea, un desafío enorme porque implica una inconclusión de historias individuales y familiares más allá de las certezas sobre el fin de las personas desaparecidas. ${ }^{250}$

Asimismo, la mayor dificultad del equipo de ayuda psicológica fue cómo presentar al desaparecido, que en tanto ausente involuntario era alguien que no estaba presente, pero tampoco muerto. Según L' Hoste, esta cuestión desencadenó en las madres afectadas dos conflictos centrales, uno referido a la del sujeto responsable de la desaparición "y otro en lo que atañe al destino del propio desaparecido". 251 Esta misma autora sostiene que sobre estas dos temáticas gira el accionar y búsqueda de las madres actuando en espacios diversos, como el sociopolítico y el subjetivo. Esto último vale también para el conjunto de

presentar todos los conflictos que generó y genera dicha cuestión. No me detendré en cada uno de esos aspectos ya que no forma parte de este trabajo.

${ }^{250}$ Ibídem. Sobre el modus operandi del Estado acerca de la desaparición de personas existe en la actualidad una variada documentación, registro y detalle acerca de los operativos. Desde los ya citados informes (CONADEP y Bicameral de Tucumán) hasta diferentes archivos personales y públicos, como el publicado por el Centro de estudios Legales y Sociales "El secuestro como método de detención" de 1982 y otros.

${ }^{251}$ Kordon, Diana y Edelman, Lucila. Op. Cit. 
organizaciones que componen el amplio abanico del movimiento de derechos humanos.

Está nueva categoría de existencia, el desaparecido, es caracterizada como la "presencia del ausente desaparecido", y que se internaliza de manera diferente en cada individuo. ${ }^{252}$ En este sentido L' Hoste considera que durante el período de la dictadura se planteó una lucha entre la visión del Estado y la que se construye en una parte de la sociedad. Mientras el primero trató de imponer una categoría de entidad o existencia, señalándolo como "muerto en enfrentamiento terroristadelincuente", usando códigos propios de la guerra, como una forma de legalizar y legitimar el accionar estatal, las Madres de Plaza de Mayo opusieron una nueva legalidad que se expresa al enunciar "no murieron en guerra - no murieron - no están de viaje - los hicieron desaparecer". ${ }^{253}$

\section{V.6 LAS DESAPARICIONES EN LA MEMORIA DE LOS FAMILIARES}

Uno de los testimonios que narra con mayor crudeza la modalidad represiva y el formato de la desaparición forzada, es el de Felicidad Carrera, quien recuerda las circunstancias sobre el secuestro de su hermano, Juan. ${ }^{254}$

El secuestro de Juan se produjo en el ámbito mismo de una sede universitaria, único caso que se constata en Tucumán, sobre la desaparición de un estudiante desde dentro de un edificio educativo.

252 Ibídem.

253 Ibídem.

${ }^{254}$ El caso de Juan aparece públicamente por primera vez en el Informe de la Comisión Bicameral Investigadora donde aparece no solo el testimonio de Felicidad, su hermana, sino de otros testigos de la causa, Página 264. En anexo documental número 1 presento extracto de la causa por la desaparición del cuerpo de delegados de la Facultad de Bioquímica con los casos de Juan Carreras y Enrique Sánchez. 
Además, este caso resulta significativo por dos motivos: en primer lugar Juan es oriundo de la localidad de Belén, un pueblo de la vecina provincia de Catamarca, de la cual se confirman tres desapariciones, dos de las cuales se producen en Tucumán; segundo, Juan formaba parte del llamado cuerpo de delegados de la carrera de Bioquímica, que era la modalidad organizativa que se dieron en los años 70 los estudiantes universitarios. El cuerpo de delegados representaba a los estudiantes a modo de sindicato estudiantil. Es importante destacar estos aspectos para observar la ferocidad del plan represivo por un lado, y para poder tener una idea real del poder que implicó la represión en todo el territorio estatal. Conviene recordar en este punto que la represión fue particularmente dura, como ya expresé, con dos sectores claramente identificables como ser trabajadores, incluido los dirigentes sindicales o representantes gremiales, como también estudiantes, porción joven de la población involucrada en las rebeliones estudiantiles de los años 70 .

A continuación presentamos la entrevista con Felicidad en la que narra con lujo de detalles el secuestro de su hermano Juan ${ }^{255}$ :

Pregunta: Cuénteme sobre el secuestro de Juan

Felicidad: «Bueno, lo del secuestro de Juan, el está acá por que viene cuatro días antes del 16,11 o 12 de septiembre... a Juan el 2 de mayo del ' 76 lo buscan en esta casa que te digo de Chacabuco $445^{256}$, él no estaba, estaba durmiendo en la casa de una abuela, le roban todo lo de valor que tenía.»

Pregunta: ¿usted sabía de esta...?

255 Para el caso que nos ocupa del testimonio que sigue, una nueva digresión conviene hacer aquí, ya que la segunda persona desaparecida de Belén es Yolanda Borda, quien también formaba parte del cuerpo de delegados de la misma facultad que Juan. En el caso de Yolanda, la joven estudiante fue secuestrada en la misma localidad de Belén, como único y emblemático caso de una desaparición en aquel pueblo catamarqueño.

${ }^{256}$ Es la dirección de la residencia universitaria donde residía Juan en Tucumán. 
Felicidad: «No, yo me entero al otro día.»

Pregunta: ¿Nunca le sugirió que se fuera?

Felicidad: «Hasta ese momento nunca.»

Pregunta: ¿Pero cuando usted se entera, no le advierte?

Felicidad: «Cuando lo buscan le roban hasta los despertadores viejos, lo llevo hasta la casa de mi tío que vivía en la calle Lavalle 650 (a la vuelta de la Chacabuco), y ahí estábamos en la gran duda si decir que vaya o acompañarlo y presentarse en alguna dependencia del Ejército o la policía porque los changos ${ }^{257}$ no sabían si había sido del Ejército o de la policía los que habían allanado, los que han asaltado esa noche la casa. Mi tío decía que era mejor que no lo encuentren, al fin no se presentó, y yo lo llevo a Catamarca, a Belén, digamos a los 2 o 3 días, me acuerdo que en el ómnibus iban 2 personas que yo siempre pienso que eran personas que nos iban siguiendo o por lo menos algo sabían del asunto o capaz no, porque la paranoia te hace ver cosas irreales.

Bueno, llegamos a Belén el 5 o 6 de mayo y él se queda, él le ayudaba a mi tío en la farmacia y le gustaba mucho cazar, entonces salían en el invierno a cazar, con un grupo de amigos y unas personas grandes.

$Y$ en septiembre cuando el censo ese que se hace en la universidad, también era la duda, viene o no viene, pero no fue una discusión, no, viene, además, por ahí me contaron cuando yo estaba acá en ese momento, que por ahí unos de la familia decían pero para que se va a ir y él decía "yo me tengo que ir a censar porque quiero rendir el 16", entonces justo fue ahí, el censo, no sé cuantos días antes y el examen el 16, el busca a un amigo que también rendía esa materia,

${ }^{257}$ Chango es un modismo norteño que significa chavales. 
que estaría más preparado, que es Enrique Sánchez, también un desaparecido de bioquímica, lo llama para que le dé una mano porque rendían fisiología, el titular de la cátedra era el profesor Francisco Barbieri, una eminencia reconocida a nivel mundial. El día antes, yo vivía en un departamento, Enrique va y le estaba explicando cosas y quedan, esa conversación la escuche yo, que le dice: "bueno, mañana nos encontramos en la esquina de la facultad". Se va Enrique y yo lo acompaño a tomar el ómnibus 10 que se iba a la casa de mi abuela, de manera que él cuando va a rendir el día 16, él llegó a esa esquina y Enrique no estaba, no sé, pero estoy segura que fue así, Enrique no estaba por que lo habían llevado los militantes...»

Pregunta: ¿Y qué pasó?

Felicidad: «Y ahí pasa lo peor, lo más macabro, una de las cosas más terribles, a la siesta, porque rendían a la tarde, suponte que el examen habría sido a las 4 o 5 de la tarde, como todos los amigos y compañeros de casa de Juan vivían ahí, uno de ellos casualmente, Belicho ${ }^{258}$ salían caminando por la vereda entre la casa y la facultad, mira un auto estacionado casi frente a la facultad, un Peugeot blanco y lo ve a Enrique Sánchez que lo conocía porque frecuentaba la casa y lo saluda, y él (por Enrique) no contestaba, entonces se dice, "qué le pasa a este", y él ha pensado, "lo he saludado y a gatas ${ }^{259}$ me ha mirado", por supuesto que con el tiempo nos enteramos que hicieron que Enrique lo entregue a Juan, desde qué hora y cuántas horas estuvo en ese auto no sé, de manera que Juan entró a la facultad sin duda sorprendido porque no lo vio a Enrique, yo pienso que ya la tenía rendida a esa materia, y bueno era la materia que se rendía escrita y

258 Belicho es la forma en que llaman a los oriundos de Belén.

259 A gatas es una expresión argentina que indica apenas o con dificultad. 
en ese momento el titular de la cátedra no era el Dr. Barbieri, era la Dra. Brauckman, con quien tuve a posteriori algunas conversaciones. Uno de los ayudantes era de apellido Del Río, bioquímico, que yo no sé si vive acá, pero yo hablé con él, (...) y bueno, el relato que te voy a hacer ahora es el contado por la Dra. Brauckman y por el muchacho Del Río. Era en el primer piso, estaban terminando casi de rendir cuando se acercan 3 o 4 personas, preguntaron si estaba rindiendo Juan Carreras, la Dra. dijo que los vio e inmediatamente pensó todo, y dijo sí, dice que ella, mientras, hablaba con los otros ayudantes, y empezaron a pensar, ¿Cómo lo sacamos de acá? La pared es muy alta, no va a poder salir...»

Pregunta: ¿Eso fue en la (calle) Chacabuco?

Felicidad: «Sí, en la Chacabuco. Si lo sacamos por la ventana de atrás de alguna forma lo van a ver, dice que ella es como que ha perdido el conocimiento con respecto a todo lo que ha ocurrido entre ese instante que preguntan por él y el momento en que ella se entera - que fue abajo- que se lo llevan, eso fue terrible, además dice que la inquietud de Juan desde el momento que siente que lo nombran hasta que entrega el examen era terrible, a tal punto que le va mal en el examen porque dice que, vos sabes que no lo he querido ver, en un momento no me acuerdo quién me lo quiso mostrar al examen, en la facultad, dice que a partir del momento que él escucha que lo buscan ya son rayas las que él escribe, claro, él ya no escribe nada por el temor que el tenía, eso también me contó un compañero que estaba a la par de él rindiendo, Nadim Neme, que tiene un negocio acá a la vuelta...»

Pregunta: ¿Había mucha gente rindiendo? 
Felicidad: «Eran muchos los que estaban rindiendo, eran varios...»

Pregunta: O sea que también, si se hubieran levantado todos a lo mejor...

Felicidad: «Bueno ya no podes decir porque como nunca te imaginabas nada en esa época, nunca pensabas que era terrible lo que estaba pasando, si la familia se hubiera imaginado mínimamente algo, jamás se lo deja venir, vos te has fijado que es toda una melange de cosas así espantosas, y bueno, Juan fue el último en entregar la hoja, detalle contado por la Dra. brauckmann, claro, no la quería entregar porque no se quería ir, porque él sabía que lo estaban esperando. A Juan lo agarran en la puerta del aula de donde había rendido, bajan las escaleras y cuando iban en el hall saliendo, nadie sabe decir si eran 203 , con camperas, que nadie sabe decir si llevaban armas o no, claro, porque además nadie los miraba puntualmente a ellos ${ }^{260}$, pero se encontraron en el hall con el profesor Francisco Barbieri, murió con un Alzheimer terrible hará como 10 años, Juan lo mira al profesor y le dice: "profesor haga algo para que no me lleven", por supuesto que este hombre no pudo hacer nada y él me contó después: "lo que le ha pasado a Carreras marca un antes y un después en mi vida, porque yo no podía hacer nada, no sabía qué hacer, yo he tenido pesadillas después de eso, he tenido grandes culpas porque creo que algo podría haber hecho, pero bueno no he hecho nada", decía él, bueno lo sacan y lo suben al Peugeot ese y nunca más, cuando... $\gg^{261}$

260 A los secuestradores.

${ }^{261}$ Entrevista a Felicidad Carreras, ex miembro de Familiares. [Entrevista realizada por el autor en 2008] 
Las referencias de Felicidad, como la del resto de entrevistados que narran las desapariciones de sus familiares, tienen que ver con las investigaciones personales que cada uno de ellos hicieron para dar con el paradero de los desaparecidos. En el caso de Felicidad, lo que sigue de su narración, tiene que ver con la trayectoria de su propia militancia en Familiares de Desaparecidos pero con gestiones personales para encontrar a su hermano. En ese derrotero fue que consiguió entablar un diálogo con los testigos presenciales del secuestro de Juan, quienes le contaban a su vez, cada uno, sus puntos de vista.

Felicidad narra con certeza lo que a ella misma le han contado los profesores y amigos de Juan, en un intento por resolver cómo sucedió la desaparición del hermano, procurando reconstruir el rompecabezas. La escena si bien parece increíble, su relato se torna verídico desde la convicción misma de las referencias que ella indica como testigos presenciales de la desaparición de su hermano. Nuevamente podemos verificar en su narración los componentes del relato, a los que aludíamos al comienzo del trabajo. Por momentos, la voz de Felicidad está atravesada por el llanto, y esto mismo ocurre con todos los familiares entrevistados que reviven en primera persona el trauma.

El siguiente relato se corresponde a Carlos Soldati, activo militante en el campo del movimiento de derechos humanos. Carlos, como dije en otro apartado de este trabajo, tiene a dos de sus hermanos desaparecidos y él mismo ha sufrido el secuestro y la tortura. Desde la desaparición de su segundo hermano, en 1977, ha sido un activo militante en tres de los organismos de derechos humanos de la provincia. Su comienzo en este tipo de militancia se ubica en Familiares de Detenidos por Razones Políticas, pasando un tiempo por Madres de Plaza de Mayo y finalmente ha sido uno de los fundadores de la Asamblea 
Permanente por los Derechos Humanos en Tucumán el 24 de enero de 1984. Hoy ya está alejado de aquella militancia y en su testimonio se deja fluir cierta desilusión después de tantos años. Soldati recuerda casi con lujos de detalles las instancias del secuestro de su familia, incluido el propio. Es así como recuerda la desaparición de su hermana, Berta María:

«En el año 1976, ya con Bussi gobernador, me encuentro un día trabajando aquí en una grúa como balancero, en la finca de mis padres y nos llega la noticia que una de mis hermanas, Berta María, que era trabajadora social y trabajaba en el Instituto de Psicopedagogía "Jean Piaget", en la calle San Juan al 800, había sido secuestrada. Militaba en el Peronismo de Base, haciendo trabajo en las villas miserias $^{262}$. Era el 6 de julio del año '76. Gente de civil, armada, que irrumpió ahí en el lugar a eso de las diez, diez y media de la mañana y no se sabía nada, y ya a esta altura, por supuesto, las noticias sobre gente que desaparecía se sabía, no con total precisión qué suerte corrían. Antes, en el año 1975, en febrero, había sido secuestrado aquí a la salida de Simoca, un compañero mío de la carrera de Filosofía, Pedro Medina. Pedro había militado en la Juventud Peronista. También en una camioneta de civil y nunca se supo de él. En la época del Operativo Independencia que empieza el 10 de febrero de 1975 con el general Vilas. (...) Y uno se enteraba. A aquel lo secuestraron y no se sabía que pasaba. El ejército controlando los caminos, el acceso a los pueblos, y entonces me entero yo... me llega la noticia que mi hermana había sido secuestrada. Y era poco y nada lo que se podía hacer. Uno queda estremecido y conmocionado sin poder hacer nada, sin saber a quién recurrir, pensando que en algún lugar está. Ese

262 Villas Miserias es lo que en España se conocen como "Chabolas". 
mismo año, el 28 de septiembre, me sacan de esta casa, aquí en Manuela Pedraza. ${ }^{263}$

Los testimonios de Felicidad y Carlos son idénticos al de muchos otros familiares: cuentan con detalles la desaparición de su ser querido, de acuerdo a los relatos que les han llegado. Todos aseguran que al recibir la noticia no sabían nada sobre el secuestro de la víctima. Con el tiempo y por medio de los relatos de quienes estaban con los secuestrados, los familiares fueron haciéndose la idea de cómo había sido el secuestro y cual podría haber sido el destino final.

Sobre el vínculo de los desaparecidos, desde los relatos que se reconstruyen a partir del relato de otros, la imagen que se configura en algunos casos es la de un cuento que otros les cuentan. Dicha relación sucede sobre todo en la nueva generación de militantes del campo de los derechos humanos, como el caso de HIJOS y sobre el que volveré en un capítulo aparte, pero que en este caso estimo necesario adelantar, para terminar de explicar cómo ha sido esa relación traumática. Entonces, el relato de Susana Salvatierra, ex integrante de H.I.J.O.S. Tucumán y ex militante de un partido de izquierda de extracción trotskista, sirve a los fines de poder clarificar lo que implica para la psiquis de los familiares, la desaparición forzada, aún cuando el paso del tiempo terminó con la presunción de muerte. El padre de Susana había sido un renombrado dirigente apodado "el trosco Salvatierra" por su militancia en los años '60 y '70 en un partido trotskista. Susana, sin saberlo, había heredado la militancia de su propio padre al activar ella misma en un partido con las características del que había militado el "trosco". Las imágenes que ella tiene de su padre son difusas y las obtuvo a partir de los relatos que

\footnotetext{
263 Testimonio de Carlos Soldati [Entrevista realizada por el autor en diciembre de 2007]. "Manuela Pedraza" es una de las localidades que conforman la región de Simoca, donde está ubicada la casa de Carlos Soldati.
} 
gente cercana al joven secuestrado le trasmiten. Sobre esas imágenes manifiesta:

«Yo había pasado ya por la militancia, pero en esa militancia había conocido a gente que lo había conocido a mi papá. La historia de mi papá la fui conociendo de a poco. Después de 1983, me empezaron a llamar la atención las marchas, empecé a ir, sabía más o menos la historia de mi papá, pero no era todavía demasiado abierto el contar en dónde estaba, en qué organización, y nada de eso, ni hablarlo tan abiertamente, no era muy habitual. Después lo fui conociendo (a mi papá) a partir de mi militancia política. Yo militaba en el M.A.S. ${ }^{264}$ y ahí estuve militando un buen tiempo, hasta 1989, creo. A partir de ahí fui conociendo a algunos de los que lo conocían a mi papá que tampoco sé en qué términos lo conocían, como que la parte esta de la reconstrucción de la historia estaba medio tapada, pero no era lo que me movía básicamente a militar (en el MAS). Incluso el tema de enterarme después que a mi papá le decían el "Trosco" por ejemplo y que yo estaba en un partido trotskista era como raro. Había toda una recreación en mi cabeza de lo que supuestamente él podría haber sido y que se ha ido completando con mi militancia en H.I.J.O.S.. Muchos de los padres de los que estaban en H.I.J.O.S. Io conocían a mi viejo, entonces cada uno me ha ido aportando distintas cosas como para poder ir haciéndome una imagen de él. Hay una parte en donde más allá que los hayas conocido o no, dependiendo de la edad, de tu viejo o tu vieja desaparecidos son un cuento... un cuento que te cuentan, y cada vez que te encontrás con alguien te recrean ese cuento.

264 MAS: Movimiento Al Socialismo. Partido político de izquierda de extracción Trotskista. 
Por eso fue muy fuerte para mí haberlo visto en la película. ${ }^{265}$ Hay recuerdos de mi infancia que no sé si son sueños que yo tuve cuando era chica o si realmente había pasado...»266

El cuento del que habla Susana es el cuento que, sobre todo los hijos, tienen de los padres desaparecidos. Pero es el cuento diabólico, al decir de Cortázar, que tienen los otros familiares que a partir de 1977 salen como movimiento a reclamar la aparición con vida. En este sentido las palabras de Carlos Soldati ${ }^{267}$, refuerzan esta idea:

«...y el convencimiento que en materia de derechos humanos ya no está esa confrontación con los que ocupan la casa de gobierno, digamos con el gobierno nacional sino saber de alguien que está respondiendo a las exigencias que durante larguísimos años uno tuvo. Esto último del parque de la memoria en la Costanera Norte, yo he ido muy poco a Buenos Aires, así que no ubico el lugar (...) y sin embargo empiezo a sentir esa necesidad (breve pausa en la que el entrevistado solloza) de ir ahí y ver el nombre de mi hermano, es como esa presencia material que nos ha sido

265 Susana refiere al estreno del documental "El Tucumanazo", mencionado anteriormente. En el documental se recupera un fragmento de archivo audiovisual en el que aparece el padre de Susana, el "Trosco" Salvatierra, leyendo una lista de estudiantes liberados luego de una refriega con las fuerzas del régimen durante la dictadura de Onganía. La entrevista con Susana ocurrió unos días después del mencionado estreno y las referencias al documental fueron inevitables, sobre todo al repasar la sensación que le generó el ver una filmación de su padre y nada menos que en un acto de militancia.

266 Testimonio de Susana Salvatierra [Entrevista realizada el 29 de noviembre de 2007].

267 Este testimonio viene teñido del dramatismo que el propio Soldati le imprime, cuando en un momento se quiebra y se le escapan algunas lágrimas. Estas lágrimas son recurrentes en todos los testimonios en los que se alude o bien al secuestro y posterior desaparición de la persona o bien cuando el testigo cuenta alguna anécdota sobre el desaparecido. Suelen interpelar a quienes le hacen la entrevista, como buscando que el entrevistador se haga eco y resuelva de alguna forma el drama, que a más de 30 años de la desaparición se vive con la misma intensidad. 
negada porque no tenemos el cuerpo y que también antes se dio con un árbol en el bosque de la memoria allá, en el cerro de San Javier ${ }^{268}$, en esos lugares como sustituto, como Ilenando esa presencia del cuerpo que nos falta...»269

La necesidad de ver materializado el cuerpo de sus hermanos es, para Soldati, la necesidad de encontrar sentido al cuento que le contaron a Susana sobre su padre, la ausencia del desaparecido, seguida de la certeza de la presunción de muerte, y ésta, seguida de una falta de duelo imposible de elaborar.

Crenzel explica que "la práctica sistemática de las desapariciones a partir del golpe de Estado (...), supuso dos cambios radicales con respecto a los grados y formas que había asumido la intensa violencia política que experimentó Argentina durante el siglo XX. En primer lugar, a diferencia de la represión contra opositores políticos o militantes sindicales del pasado, las desapariciones objetivaron el desenvolvimiento desde el Estado de una decisión de exterminio. En segundo lugar, comportaron la emergencia de una forma novedosa de la muerte por causas políticas, su práctica clandestina. Estas particularidades, diferenciaron al caso argentino, incluso, del resto de las dictaduras que, en los años setenta, se establecieron en los países de la región."270

Uno de los planteos centrales de todo el movimiento de derechos humanos en Argentina exigía, durante la dictadura y en los primeros años de la transición, la "Aparición con Vida" y tenía que ver con lo que Jelin expresa cuando afirma que era ahí "donde se construía el sentido de

${ }^{268}$ El Bosque de la Memoria fue inaugurado en el año 1996 por iniciativa de la Asamblea Permanente por los Derechos Humanos de Tucumán.

269 Testimonio de Carlos Soldati [Entrevista realizada el 1 de diciembre de 2007].

${ }^{270}$ Crenzel, Emilio (2007): Dictadura y Desapariciones en Argentina: Memoria, conocimiento, y reconocimiento del crimen, en Intersticios, Revista Sociológica de Pensamiento Crítico, Vol. 1, No 2, en www.intersticios.es (Consultado en enero de 2008). 
la lucha, en medio de (...) una lucha por el sentido. ¿Qué pedir? ¿Qué reclamar? ¿Cómo presentar lo que se sabía? Ninguna consigna iguala a la de "Aparición con Vida" en su carga emotiva, en su significado político, en su valor estratégico". ${ }^{271}$

Sobre el sostenimiento de la consigna "Aparición con Vida" que se mantuvo a lo largo de los primeros años de la transición y que fue discutida largamente por el movimiento, Sara Mrad explica desde Madres la postura que las llevó a seguir sosteniéndola:

«Son cinco consignas básicas que no abandonamos nunca las Madres: Aparición con Vida, Juicios y Castigo y cárcel a los genocidas, no a la exhumación de cadáveres, no a las reparaciones económicas y no a los homenajes póstumos. Con lo de Aparición con vida es duro, porque si uno reconoce que está muerto, es uno el que tiene que ir al juez a dar por muerto al familiar desaparecido y te preguntan en qué época cree que su hijo ha muerto para darte el certificado de defunción... uno los mata, es terrible (...) y la Aparición con vida lo seguimos sosteniendo porque es una forma de decirle al Estado que se haga cargo de los desaparecidos, que nosotros no los damos por muertos, que si se los llevaron con vida hay responsables... ${ }^{272}$

La discusión sobre qué incluir en un documento, qué consignas deben ser mencionadas y cuáles deben dejar de introducirse no es un tema menor, sobre todo cuando llega el momento del consenso entre todos los organismos en la organización del acto público. La misma Sara lo expresa:

271 Jelin, Elizabeth (2005): Los derechos humanos, entre el Estado y la Sociedad", en Suriano, Juan comp.: Nueva Historia Argentina, T. 10: "Dictadura y Democracia (1976 - 2001), Edit. Sudamericana, Buenos Aires.

272 Testimonio de Sara Mrad [Entrevista realizada por el autor el 2 de noviembre de 2007]. 
«Estas divergencias se manifiestan con más fuerza durante la transición. Las consignas que más dificultades trajeron fueron "Juicio y castigo" y "Aparición con Vida", porque algunos las sentían como consignas sin salida posible, y muchos en el movimiento de derechos humanos no querían acorralar al gobierno de manera tan cruda». ${ }^{273}$

Las divergencias de las que refiere Sara son además las que en determinados momentos hizo que el propio movimiento se fracturara, que alguno de sus activistas dejara de participar en determinadas acciones o que las distintas organizaciones que lo componen se reacomodaran en el tiempo, aceptando que la desaparición de los secuestrados, implicaba sin más, la desaparición física definitiva, esto es, la presunción de la muerte.

\section{V.7 "EN ALGO ANDABAN": TIPOLOGÍA DE LOS DESAPARECIDOS}

Se repetía con frecuencia, en la mayoría de los testimonios, la presunción de "inocencia" de los desaparecidos, quienes, a su vez, habrían sido víctimas de la locura criminal del ejército sin ninguna causa o razón que la justificara. En todo caso, algunos familiares repiten que, de haber cometido algún delito los represaliados, debieron haber sido juzgados por el Estado. Al margen de las consideraciones personales de los familiares, resulta necesario responder cómo se conformó el grupo de los desaparecidos, víctimas de la represión ilegal paraestatal y estatal. Un cuadro elaborado por los sociólogos González y González ayuda a la compresión de cómo estaba conformado el grupo en Tucumán de acuerdo a la franja etaria y la ocupación:

${ }^{273}$ Ibídem. 


\begin{tabular}{|c|c|c|}
\hline \multicolumn{3}{|c|}{$\begin{array}{l}\text { CUADRO NÚMERO 2: TUCUMÁN 1975-78 - DISTRIBUCIÓN } \\
\text { DE LOS HECHOS SEGÚN INSERCIÓN OCUPACIONAL DE LOS } \\
\text { SECUESTRADOS. }\end{array}$} \\
\hline \multicolumn{2}{|c|}{ OCUPACIONES } & TOTAL N \% \\
\hline \multirow{2}{*}{$\begin{array}{l}\text { PROFESIONES } \\
\text { LIBERALES* }\end{array}$} & ABOGADOS & 817.1 \\
\hline & $\begin{array}{l}\text { OTRAS } \\
\text { PROFESIONES } \\
\text { LIBERALES }\end{array}$ & 474.1 \\
\hline \multicolumn{2}{|c|}{ EMPLEADOS } & 23120.3 \\
\hline \multicolumn{2}{|c|}{$\begin{array}{l}\text { COMERCIANTES E } \\
\text { INDUSTRIALES }\end{array}$} & 332.8 \\
\hline \multicolumn{2}{|c|}{ ObReros } & 46841.0 \\
\hline \multicolumn{2}{|c|}{ ESTUDIANTES } & 23120.3 \\
\hline \multicolumn{2}{|c|}{$\begin{array}{c}\text { OTRAS OCUPACIONES NO } \\
\text { REMUNERADAS }\end{array}$} & 504.4 \\
\hline \multicolumn{2}{|c|}{ TOTAL } & $1141 * * 100.0$ \\
\hline
\end{tabular}

La conclusión a la que arriban los sociólogos, luego de observar la franja que se corresponde con cada grupo de desaparecidos, indica que la "mayor cantidad de hechos involucró a obreros (41\%). Es decir, las bases del movimiento obrero fueron las que resultaron el blanco principal de la ofensiva represiva, en esto coinciden varias investigaciones sobre el tema." ${ }^{275}$ A los obreros les siguen en orden de importancia numérica estudiantes y empleados, con un $20,3 \%$ cada uno. (...) $Y$, continuando a los anteriores en importancia una gran cantidad de hechos estuvieron relacionados con la profesión de abogado (7.1\%)."276

Cabe mencionar aquí una segunda reflexión que nos merece el cuadro anteriormente citado y es la conexión entre los desaparecidos con la historia inmediata, precedente del comienzo de la represión a gran

\footnotetext{
${ }^{274}$ Gónzalez y Gónzalez Op. Cit. P.212.

275 Ibídem.

${ }^{276}$ Ibídem.
} 
escala en Tucumán, en febrero de 1975, que es el periodo comprendido entre la instauración de la dictadura de Juan Carlos Onganía, a la cual ya me he referido, y los levantamientos populares conocidos como los Tucumanazos, explicados en otro apartado del presente trabajo. Lo que ilustra el periodo, cosa que también se ve reflejada en el cuadro precedente, es que justamente la represión apuntó a desmantelar todo nicho de rebelión popular expresado en los trabajadores, sobre todo de las fábricas azucareras cerradas y los estudiantes de una universidad intervenida por la dictadura militar.

De los primeros no sólo desaparecieron trabajadores rasos, sino que, sobre todo, fueron represaliados los trabajadores más combativos del movimiento, entre ellos una gran cantidad de dirigentes sindicales. Esto además se verifica a partir de los testimonios de sobrevivientes en algunas zonas como Famaillá, del que dan cuenta el Grupo de Investigación sobre el Genocidio en Tucumán (el GIGET). La mayor parte de los desaparecidos pertenece entonces a trabajadores de la industria azucarera local.

En el caso del estudiantado, según lo reflejan las cifras, ellos fueron el blanco elegido por ser los "dueños" de las principales protestas en el centro de la ciudad capital, el sector que venía, indudablemente, creciendo en el nivel subjetivo de la conciencia y con un grado creciente de politización el cual se observaba no solo en los centros estudiantiles de las distintas facultades que componían la universidad sino por su incorporación a distintos partidos de izquierda, armados o no, y que los llevaba a militar más allá del ámbito universitario. Ya mencioné al Cuerpo de Delegados de la Facultad de Bioquímica, como ejemplo de los que se pueden mencionar una cantidad de casos. Algunos estudiantes, amén de su participación como delegados estudiantiles pertenecían al mismo 
tiempo a partidos de izquierda o hacían trabajos de base, lo que los convertía en el blanco elegido por la represión.

Por otra parte, la mayoría de los desaparecidos lejos estaban de las organizaciones político-militares, lo que desnuda una vez más la falacia de la dictadura auto justificada en la necesidad de "combatir a la guerrilla".

Retomo aquí la idea delimitada en el capítulo VI.4 sobre las prácticas sociales genocidas. El 27 de diciembre de 2012 la Justicia Federal anunciaba la elevación a juicio de la causa sobre el Operativo Independencia. Como hecho inédito en las causas que se siguen en la provincia, el tribunal citando al Daniel Feierstein afirma "coincidir con el sector doctrinario que considera que la caracterización de "grupo nacional" es válida para analizar los hechos sucedidos en Argentina, dado que los perpetradores se propusieron destruir un determinado tramado de las relaciones sociales en un Estado para producir una modificación lo suficientemente sustancial que alteró la vida en su conjunto. Analizando la inclusión del término "en todo o en parte" emergente de la definición de la Convención de 1948, es posible sostener que el grupo nacional argentino ha sido aniquilado "en parte" y en una parte lo suficientemente sustancial como para alterar las relaciones sociales al interior de la propia nación."277

De este modo, el tribunal explica que "las Fuerzas Armadas al momento de los hechos, identificó y definió un grupo de población como "la subversión". Dicho conglomerado estaba compuesto principalmente por obreros y jornaleros del interior de la provincia (alrededor de 70 casos), sus familiares directos (alrededor de 43 casos) dirigentes sindicales y gremiales (alrededor de 40 casos) comerciantes y personas 277 Causa: 401015/2004, Operativo Independencia (1975/marzo de 1976) Expte. $401015 / 04$ y $401016 / 04$ y conexas. 
de oficio del interior de la provincia (alrededor de 20 casos), empleados públicos (alrededor de 20 casos) profesionales (alrededor de 12 casos)."278 Volvamos nuevamente a repasar en número cómo afectó la represión dictatorial a los distintos sectores que conforman, lo que la justicia denomina "el grupo" (de afectados). A continuación reafirma el tribunal que "lo que tuvo en común la mayor parte de dicho grupo (alrededor del $60 \%$ de las víctimas) fue su supuesta afinidad con el pensamiento "marxista" o "comunista", desde la perspectiva de los perpetradores, en tanto defendían los derechos de los trabajadores o de la población más empobrecida, y con ello ponían en riesgo el plan económico y social que éstos pretendían implementar para el país una vez que derrocaran al gobierno constitucional vigente." ${ }^{279}$ Una vez más vemos aquí como los tribunales comienzan a cambiar la mirada sobre la composición del grupo denominado "subversivo" por la dictadura al tiempo de explicar doctrinariamente que el plan represivo se trató de un genocidio.

Como prueba de lo considerado, corresponde citar la Orden denominada "La rebelión. Plan del Ejército contribuyente al plan de seguridad nacional", dictada el 9 de enero de 1976 por el Ejército Argentino, cuya finalidad fue el establecimiento de "las operaciones necesarias para asegurar la destitución del gobierno y facilitar la asunción del gobierno militar mediante: ... la detención de personas del ámbito político, económico y jurídico que deban ser juzgadas. La determinación del grupo a detener incluía expresamente a dirigentes políticos, gremiales, funcionarios públicos y delincuentes económicos y subversivos". (Cfr. Causa "Vargas Aignasse", Sentencia de fecha 15 de agosto de 2004, Exma. Cámara de Apelaciones de Tucumán).

\footnotetext{
278 Ibídem.

279 Ibídem.
} 
Se considera, por consiguiente, que durante el Operativo Independencia (1975/1976), las fuerzas armadas y de seguridad intentaron destruir total o parcialmente a una parte sustancial del grupo nacional argentino, mediante la matanza de miembros del grupo, lesión grave a la integridad física o mental de los miembros del grupo, sometimiento intencional del grupo a condiciones de existencia que habrían de acarrear su destrucción física, total o parcial.

Que las formas utilizadas para desmembrar y aniquilar el grupo de ciudadanos seleccionados fueron los secuestros, el interrogatorio bajo tormentos, la clandestinidad y la eliminación de las víctimas. Tal metodología fue implementada en la provincia de Tucumán para luego ser trasladada a todo el territorio de la Nación y prolongada en el tiempo, luego del golpe de estado de marzo de 1976.

Que tales circunstancias se encontrarían corroboradas por numerosas pruebas, correspondiendo destacar un informe elaborado por Alberto Luis Cattaneo agregado en la causa caratulada "Vargas Aignasse Guillermo s/ secuestro y desaparición" (Expte Nro 262/76), en el que consigna, entre las diversas acciones a realizar de particular significación para el "hecho político" a concretar, la orden emitida por la Junta de Comandantes Generales de "detener a partir del día ' $D$ ' a la hora ' $\mathrm{H}^{\prime \prime}$ ' a todas aquellas personas que signifiquen un peligro cierto para el desarrollo de las acciones militares necesarias para la toma del poder. En el mismo documento se determino las "caracterización" de las personas a detener, las "prioridades", la constitución de "equipos especiales militares" y/o "comisiones especiales" para su ejecución y los "lugares de detención" de dichas personas. (fs 60/64 de la causa citada). 
Desde tales evidencias puedo concluir que la "reorganización nacional" buscada por la dictadura desde su propia denominación como "Proceso de Reorganización Nacional", no se inicia en marzo de 1976 sino que data de mucho tiempo antes (desde la dictadura de Onaganía) y nunca se agotó en su sentido político sino que perseguía un quiebre y una trasfiguración total de los modos de construcción de identidades al interior del territorio, una reconstrucción de las relaciones sociales que afectaba la moral, la ideología, la familia y las instituciones. Es decir que no se trató solamente de eliminar a quienes integraban una o varias fuerzas políticas, se intentaba transformar a la sociedad toda, aniquilando a quienes encarnaban un modo de construcción de identidad social y eliminando -material y simbólicamente- la posibilidad de pensarse socialmente de otro modo.

\section{V.8 La poesía como Refugio en el SOStenimiento de la Memoria de los DESAPARECIDOS}

"Existe porque lo busco

Existe porque perdura

Subsiste porque ¿lo encontraré?"280

Una de las manifestaciones que se ha reiterado en algunos familiares de desaparecidos es la de plasmar en verso el trauma personal / familiar. El escribir las sensaciones de ese trauma ha sido, en algunos casos, recurrente, y tiene que ver además con un espíritu de época. En definitiva se trataba de poder compartir con otros las sensaciones personales, colectivizando un drama particular y trasladándolo al conjunto social. El caso más notable seguramente es el del poeta Juan Gelman, reconocido en el mundo de las letras pero además en su incansable búsqueda de su nuera desaparecida. En los casos que

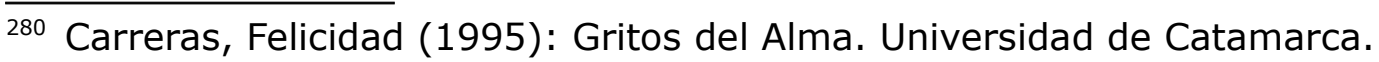


mencionaremos a continuación no se trata de escritores o poetas profesionales, sino de familiares que han buscado refugio en las letras para compartir, de uno u otro modo, el trauma familiar. Recuperamos entonces dos de esos poemas que conforman además de una fuente más para su análisis, una fuente novedosa que aporta al conjunto de "lo testimonial", la memoria de los familiares sobre los desaparecidos. El primero, escrito por Felicidad Carreras, hermana de Juan, estudiante catamarqueño desaparecido del ámbito universitario a quien referimos en el apartado anterior:

A Juan ${ }^{281}$

Quiero saber

A dónde llevar

Las flores en septiembre

A dónde derramar

Más lágrimas

Que mojen tu tumba

Quiero saber

A dónde partir

Con tu recuerdo

Quiero saber

Qué tiempo recorrer

Para seguir sintiendo

Tu tan eterna ausencia

El segundo de los poemas es el que escribió Berta Notari de Soldati, madre de Berta y Luis, los hermanos desaparecidos de Carlos Soldati: ${ }^{282}$

${ }^{281}$ Ibídem.

${ }^{282}$ Este poema me fue entregado por Carlos en el momento de hacerle la 


\section{Perdón}

Perdón Berta María y Luis Alberto

Perdón por enseñarles a sufrir

El hambre y la injusticia del hermano,

Por el cual tuvieron que morir.

Perdón porque en el alba de la vida

Entre lágrimas tuvieron que partir

Soñando con un mundo de justicia

Que nunca llegarán a compartir

Perdón porque de niños aprendieron

Del hogar, de la casa, del jardín

A vivir la pobreza de los otros,

A llorar y también a sonreír.

Perdón hijitos míos, porque vieron

A sus padres sin dobleces convivir

Y enseñarles la honradez como brújula,

Que les marque la ruta por seguir.

Y pidamos perdón al Padre Eterno

Por dejarnos por ahí... tu mandato sin cumplir

Pero enseñando a todos los hermanos

Al Dios de los humildes bendecir.

entrevista. La copia impresa del poema fue entregado en el Juicio Ético a Bussi, el 19 de junio de 1995 sobre el cual desarrollaré el capítulo XI.2. 
Si el primer poema se refiere a la ausencia del hermano desaparecido y a la impotencia de no tener un lugar dónde llevar las flores y la imposibilidad del luto, ante la presunción de la muerte, el segundo poema refiere a la educación recibida por los desaparecidos en el seno del hogar materno. Del primero podemos entonces inferir que el sentimiento de no saber dónde están los cuerpos replica en los familiares que no pueden elaborar el luto aún sabiendo que los desaparecidos no se encuentran con vida. Conviene entonces recordar aquí la discusión al interior del MDHT sobre la consigna "aparición con vida" que hasta los primeros años de la transición se sostuvo vigente. Si bien la presunción de la muerte de los familiares se hizo presente, sobre todo ante la invisibilidad de los cuerpos, levantar la consigna de la aparición con vida suponía interpelar al Estado como máximo responsable de las desapariciones forzadas.

El segundo poema implica desde la percepción personal de quién lo escribe asumir "la responsabilidad" por la educación dada en el hogar. La propaganda de la dictadura responsabilizaba, sobre todo, a los padres de la educación recibida por los hijos desaparecidos, los cuales a su vez se involucraban en política por esa misma educación recibida. La propaganda dictatorial interpelaba desde los medios de comunicación, directamente a los padres, interrogándolos acerca de su conocimiento sobre las actividades políticas o sociales de sus hijos. La madre de Berta María y Luis Soldati asume "su responsabilidad" en la educación, una educación basada en la solidaridad y el sufrimiento personal ante las injusticias que sufren los otros, sobre todo por los pobres. En este sentido, es pertinente mencionar que no hay autoinculpación sino la asunción que el compromiso por el sufrimiento del otro fue lo que en definitiva les llevó, en primer lugar, a involucrarse en alguna 
manifestación política y, en segundo lugar, que dicha participación les provocó el castigo dictatorial que terminó en secuestro y desaparición. Si los dictadores le preguntaran a la autora del poema sobre su conocimiento de las actividades de sus hijos, seguramente ella respondería afirmativamente, consciente que los valores dados en el hogar generaron una conciencia que los llevó a la militancia.

Aquí considero oportuno, entonces, hacer una doble mención en relación a los poemas citados: en primer lugar si bien son escritos como testimonio del dolor personal, sus mensajes caminan en la misma dirección de los testimonios dados por otros familiares en las entrevistas, es decir que no resultan contradictorios de la angustia por no saber qué fue de los desaparecidos; por otra parte, el tener la completa seguridad que la desaparición se produjo por la militancia política. En segundo lugar los poemas nos permiten apreciar, desde marcos culturales propios, la percepción que tuvieron (o tienen) los mismos familiares y la necesidad de dar a conocer públicamente, el padecimiento personal, haciendo al mismo tiempo una transferencia a los social, convirtiendo el dolor individual en responsabilidad colectiva. Si las Madres de Plaza de Mayo habían asumido lo que ellas denominaban "la socialización de la maternidad", nombrando no a cada uno de sus hijos sino a los 30.000 desaparecidos, estas dos mujeres, tanto Felicidad como Berta, transfieren el dolor personal y lo transforman en dolor colectivo socializándolo por medio del verso. De esta manera se explica, por ejemplo, que Berta Nortari, autora del segundo poema, decida imprimirlo y repartirlo a instancias de una actividad pública del MDHT. Si bien la madre de los hermanos Soldati no ha participado activamente en el movimiento, como sí lo hizo su hijo Carlos, la expresión del poema y su difusión en un momento particular presupone la necesidad de dar a conocer su caso y 
de buscar la justicia ausente al tiempo que le dice a la sociedad: estos desaparecidos también son hijos del conjunto. Queda claro entonces que no existe una sola manera de dar testimonio y que la literatura, liberadora en algunos casos, ayudó a expresar el dolor de los familiares al tiempo que permitió su socialización. Los que no pudieron, por distintos motivos, involucrarse en la militancia en las organizaciones de derechos humanos, buscaron otras instancias de participación desde la que pudieran manifestar la memoria sobre los desaparecidos, presente, pero al mismo tiempo conflictiva. 


\section{CAPÍTULO VI: LA IRRUPCIÓN Y DESARROLLO DEL BUSSISMO (1975 - 1999)}

"Hay un viejo podrido que quemó el jardín florido y tiene un hijo imbécil con la cara de asesino". ${ }^{283}$

\section{VI.1 De LA DICTADURA A LA TRANSICIÓN (1975 - 1983)}

Tucumán se convirtió en un caso paradigmático de estudio, sobre todo desde la sociología, donde existen numerosos trabajos dedicados a la cuestión ${ }^{284}$, por haberse elegido allí como gobernador en octubre de 1995, por medio del voto democrático, al ex dictador Antonio Domingo Bussi. A lo largo de los años '90, el Bussismo ${ }^{285}$ no dejó de crecer en número como fuerza política organizada alrededor del partido que fundara el ex gobernador de facto, Antonio Domingo Bussi, "Fuerza Republicana", y que habría de obtener en distintas elecciones, tanto provinciales como nacionales, un importante caudal de votos ${ }^{286}$.

La ley de Punto Final decretada por el gobierno Radical de Raúl Alfonsín en 1986, había beneficiado al propio Bussi, quien vio cómo el

283 Gieco, León (2001): El ídolo de los quemados, del CD Bandidos Rurales, EMI.

${ }^{284}$ Sociólogos vinculados al Centro de Investigaciones Gino Germani, en la Universidad de Buenos Aires, han sido los que más se interesaron por el caso tucumano en relación a la dictadura y al Bussismo. Así como mencionamos a Inés Izaguirre y todo su equipo de colaboradores, quizás el que más se destaca por la continuidad en su línea de investigación respecto al fenómeno del Bussismo propiamente sea Emilio Crenzel. Véase del último autor: El voto a Bussi en Tucumán. Op. Cit.

285 Aunque volveré luego sobre el término Bussismo, conviene decir aquí que ha sido la manera en la que el autoritarismo adoptó en la provincia de Tucumán a partir de las prácticas arbitrarias del propio Bussi.

${ }^{286}$ Crenzel, Emilio, El Voto a Bussi en Tucumán, Op. Cit.; López Echagüe, Hernán, El Enigma del General, Op. Cit. 
juicio que lo imputaba como autor de delitos de Lesa Humanidad quedaba sin efecto y esto le habilitaba para participar en la vida política de la provincia como candidato en elecciones democráticas dentro del marco constitucional. ${ }^{287}$

Con motivo del retorno a la esfera pública de Bussi, ya como General retirado, López Echagüe concluía meses antes de la elección para gobernador en 1991, cuando el represor se presentaba como candidato por primera vez que "el retorno del general, responsable de la más cruenta etapa de este operativo ${ }^{288}$ solo sirve para acrecentar dicho misterio (sobre el final del Operativo, que en palabras de Bussi no llegaría a su fin hasta que no quede ningún "delincuente en Tucumán") y hacer eterno el temor. Pues ¿qué es un delincuente para el general? ¿Qué futuro propone...?"289 Estos eran algunos de los interrogantes que se planteaban a comienzo de los '90 ante la posibilidad cada vez más cierta del regreso de Bussi, esta vez despojado del traje militar.

A partir de estas premisas se hace imperativo estudiar el caso tucumano con mayor profundidad. Pocos son los estudios académicos que dan cuenta del devenir político de una provincia en la que ha comenzado lo que hoy podemos denominar el genocidio argentino y en la que la desordenada transición a la democracia, teñida de continuismo, ha permitido consagrar gobernador a quien era acusado como responsable máximo de los delitos de Lesa Humanidad. Se trata, por lo tanto, de quitar el velo y arrojar luz al pasado reciente de Tucumán, como un factor clave en el desarrollo de la historia reciente de Argentina. No se puede comprender sino, como una provincia donde han tenido lugar uno

\footnotetext{
287 Díaz Clodrero, José L. y Abella, Mónica (1987): Punto Final. Amnistía o voluntad Popular, Puntosur Editores, Buenos Aires.

288 Referido al Operativo Independencia.

${ }^{289}$ López Echagüe, Hernán: El Enigma del general Bussi, Op. Cit. P. 216.
} 
de los más importantes movimientos de resistencia antitotalitaria que ha incluido a importantes sectores sociales, cambie radicalmente años más tarde y elija como mandatario a un ex gobernador de facto, responsable de la vida y la muerte de los ciudadanos. Lo que se busca entonces es dar respuesta a la pregunta de Cómo ha sido esto posible, pregunta que por otra parte, desde el fin de la Segunda Guerra Mundial, se ha planteado la academia sobre el nazismo.

La historia de los organismos de derechos humanos en Tucumán, como ya dije, está íntimamente ligada a la historia de lo que aquí denominaré el "Bussismo". Estimo por lo tanto conveniente realizar una breve caracterización sobre lo que entiendo por Bussismo. No es posible desvincular la historia política de la provincia, y dentro de ella al Bussismo, de la propia historia de las organizaciones, ya que desde antes de concretarse el golpe de marzo de 1976, Antonio Domingo Bussi tiene fuerte presencia en la vida cotidiana de Tucumán y su sociedad, y la seguirá teniendo una vez producida la transición a la democracia.

Denomino Bussismo a la forma que tomó en la provincia de Tucumán una idea del autoritarismo, es decir, que cuando menciono al Bussismo hago referencias a determinadas prácticas claramente autoritarias. El Bussismo implica pensar tanto en la propia persona del represor Antonio Domingo Bussi y del partido que él mismo ha creado, Fuerza Republicana, y que desde 1987 se ha presentado en todas las elecciones provinciales y nacionales con distinta suerte, así como también a determinadas formas de vínculos sociales, culturales y prácticas políticas.

Nacido en la provincia de Entre Ríos, Bussi había comenzado su carrera militar con 17 años, al ingresar en el Colegio Militar quedando su suerte atada a la provincia de Tucumán en diciembre de 1975, cuando, 
después de ser ascendido a general de Brigada, fue nombrado sucesor del General Acdel Vilas para continuar al frente de las acciones del ya mencionado Operativo Independencia. Tras el golpe del 24 de Marzo de 1976, Bussi ha sido designado gobernador de facto por la Junta militar, cargo que ha ocupado hasta finales de 1977.290

Ya retirado del ejército en 1981, había sido acusado por crímenes de Lesa Humanidad durante los juicios abiertos en 1985. En el Informe de la Comisión Bicameral ${ }^{291}$ se asegura que la gestión de Bussi ha estado rodeada de un "vasto aparato represivo, que orientaba su verdadero accionar a arrasar con las dirigencias sindicales, políticas y estudiantiles", recordando que, si bien Bussi afirmó en 1975, al asumir el mando del Operativo Independencia, que "la guerrilla ya estaba derrotada", el número de víctimas se incrementó sensiblemente a partir de su asunción como gobernador el 24 de marzo de 1976". ${ }^{292}$ Por lo tanto el informe de la Comisión Bicameral provincial asegura que a Bussi le caben "las responsabilidades por la violación de los más elementales derechos fundamentales". ${ }^{293}$

En una presentación ante la justicia, algunos organismos de derechos humanos impugnaron la candidatura de Bussi como intendente de la capital provincial, San Miguel de Tucumán, en junio de 2003. ${ }^{294}$ Allí

\footnotetext{
290 Marcos, Dolores (2005): "Liderazgos autoritarios en el noroeste argentino: el caso Bussi en Tucumán", en Reflexión Política, año 7, No 13, IEP - UNAB, Bogotá, López Echagüe, Hernán, El Enigma del General, Op. Cit. Véase documento Impugnación de la Candidatura de Bussi a la intendencia de Tucumán, Anexo documental 5.

291 Kotler, Rubén (2007): "Análisis del Informe de la Comisión Bicameral Investigadora de las Violaciones de los DDHH en la Provincia de Tucumán (1974 -1983)", en Revista Prohistoria No 11, Primavera 2007, Rosario.

292 Informe de la Comisión Bicameral Investigadora de las Violaciones de los Derechos Humanos en Tucumán, IEPALA, Salamanca, 1991.

293 Ibídem.

294 Intendente es el nombre que recibe la figura del alcalde en Argentina.
} 
se detallan algunas de las acciones del general retirado que según estiman las organizaciones que iniciaron la demanda, le convertían en "inhábil moral" para ejercer cualquier cargo público. ${ }^{295}$

Según la presentación mencionada, "Bussi fue uno de los máximos responsables del Operativo Independencia a fines de 1975, cuando en el gobierno de Isabel de Perón movilizó a las Fuerzas Armadas con la excusa de 'combatir a la guerrilla'. Eso marcó el inicio del Terrorismo de Estado, que se profundizó con el Golpe de Estado en marzo de 1976. Desde abril de 1976 hasta 1977 ocupó la gobernación de Tucumán y a partir de febrero de 1980 fue comandante del III Cuerpo de Ejército y como jefe de la Zona III dirigió todas las operaciones militares en las provincias de Córdoba, Mendoza, Catamarca, San Luis, San Juan, Salta, La Rioja, Jujuy, Tucumán y Santiago del Estero. Desde 1975 a 1981, Bussi tuvo a su cargo los centros clandestinos de detención y las cárceles, donde detentó el poder de decisión sobre la vida y la muerte de miles de personas". ${ }^{296}$ Además de estos crímenes que se le imputaban a Bussi, los organismos agregaban como ejemplos las siguientes causas por las que también había sido cuestionado y por las que en sus últimos años de vida había sido procesado: Imputado en juicios por secuestro, ocultamiento y cambio de identidad de menores, delitos no amparados por las leyes de obediencia debida (23.521), la causa por la apropiación de menores que tiene en su poder el juez Bagnasco; la reivindicación del

295 Véase el anexo documental número 5, donde las organizaciones ANDHES, APDH y el CELS, detallan, en una síntesis histórica todos los cargos que se le imputaban a Bussi y que, en términos legales, lo inhabilitaban moralmente, para ejercer cargos políticos, a pesar que el mismo ya había ocupado cargos legislativos y ejecutivos, como ser la propia gobernación de Tucumán entre 1995 y 1999.

296 Documento de Impugnación a la candidatura de Bussi a la intendencia de San Miguel de Tucumán. Léase un fragmento del documento de impugnación en el anexo documental número 5 . 
"terrorismo de estado" por parte del ex general, prueba de ello lo constituye la declaración que realizara en el diario La Gaceta del 20 de noviembre de 1999, en la que impunemente expresó: "...no se puede desconocer la Operación Independencia que es el único éxito de las armas de la Argentina en el siglo que finaliza"; ${ }^{297}$ y la obstrucción de Bussi en la acción de la justicia para poder determinar la suerte corrida por los desaparecidos.

Para el periodo dictatorial es posible sintetizar las actuaciones de Bussi en dos expresiones que provienen de ámbitos distintos. La primera es una nota escrita por el periodista Horacio Verbitsky quien expresa que "la Comisión Bicameral Investigadora formada en 1984 compiló una nómina de 507 secuestros durante la guerra sucia en Tucumán: 387 personas detenidas desaparecidas, otras 96 que luego recuperaron su libertad y 24 cuyos cadáveres fueron recuperados. El 68 por ciento de los 507 secuestros se produjeron en 1976 y 1977, mientras Bussi fue interventor federal y jefe militar de la provincia, una concentración de poder absoluto que no ocurrió en ningún otro lugar del país". ${ }^{298}$

La segunda es el testimonio del ex conscripto Omar Torres quien deja constancia de las ejecuciones que el propio Bussi realizaba a los presos políticos. El relato de Torres afirma lo siguiente:

«Una vez vi cómo un detenido desnudo era enterrado vivo, dejándole solamente la cabeza afuera del pozo, apisonando la tierra después de mojarla para compactarla; esto duraba 48 horas. Ocasionaba calambres muy dolorosos y afecciones a la piel. En dos oportunidades presencié fusilamientos en este campo, el que efectuaba el primer disparo era el General Antonio Bussi. Después hacía participar en el mismo a todos

297 La Gaceta, 20 de noviembre de 1999.

298 Página 12, 6 de Junio de 1999. 
los oficiales de mayor jerarquía. El lugar de las ejecuciones estaba ubicado a unos 300 o 400 metros de la Compañía de Arsenales, monte adentro. Se tendía un cordón de seguridad a los 20 metros y otro a unos 100 metros del lugar. Los disparos se hacían con pistolas calibres $9 \mathrm{~mm} 011,25 \mathrm{~mm}$, siempre entre las 23 y 23.30 horas. Cada quince días se asesinaban entre 15 ० 20 personas». ${ }^{299}$

Si bien el testimonio de Torres ha sido recogido por primera vez en el Informe de la CONADEP, ha servido de prueba argumental para procesar al general retirado. Asimismo el testimonio de Torres ha sido ampliamente difundido por parte de los organismos de derechos humanos en algunos de las manifestaciones públicas difundiendo gigantografías con sus dichos a modo de denuncia pública y social.

299 Testimonio de Omar Eduardo Torres a la Comisión Nacional de Desaparición de Personas - Legajo Nº 6667. 


\section{"Acá hubo una guerra y en ella sólo existen muertos en combate"}

\section{Sostuvo en rueda de prensa el general de división (RE) Antonio Domingo Bussi, al referirse a su presentación ante la Justicia}

"Acá se llevó a cabo una guerra donde se jugó nada más y nada menos que el destino de la República. Yo he respondido a una requisitoria de los señores jueces conforme al carácter y con las limitaciones propias de las operaciones militares que se realizaron en la provincia de Tucuman". Tal lo expresado por el general de division (RE) Antonio Domingo Bussi, en una reunion de prensa realizada en un hotel centrico y en la que se explico su diligencia ante los jueces federales de Tucuman, que analizan denuncias por personas desaparecidas. Aslmismo se refirió a diferentes aspectos del accionar de las fuerzas de segurdad en ocasión de las acciones antisubversivas.

\section{Orden constitucional}

El general Bussi. que vestía su uniforme militar. sostuvo que las "fuerzas legales (Ejército, Armada Aeronautica, policias y demas efectivos de seguridad en cumplimiento de una mision del goblerno constipolonal de aquel entonces, que avalaron los tres poderes del Estado, respondio con operaciones milita-

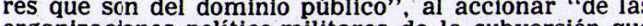
inaracos comunis y internacion comunlsmo interna de algunos de nuestros comprovincianos". Explicó que "se llevó a cabo una guerra con metodologias y fines bien diferentes. La subversión metodologias y thes blen diferentes. La subversion cancias y complica gunes por ese tipo de cancian modificar las estructuras dol acciones, que raron raos descon rar caos, desconcertar a los que plensan, excitar a los fura fuerza. En ese acclonar los subversivos no respetaron legales, mo la legales, con la orden superior del goblerno constiEjército llevaron a cabo operaciones clásicas que son propias del Ejército". "Yo les recuerdo -siguió-, cómo la subversión con grupos seudomilitares de guerrilleros 0 terroristas ideológicamente fanatizados, cometieron todo tipo de atentados, sabotajes, secuestros con torturas y cautiverio, operando pueblo' aguantaderos, refugios, cuevas y hasta casas de citas. forme mejor conviniera a sus intereses, luego de extorsionar a sus famillares", sus int El que no mata, muere

Subrayó que "en la guerra no existe represión,

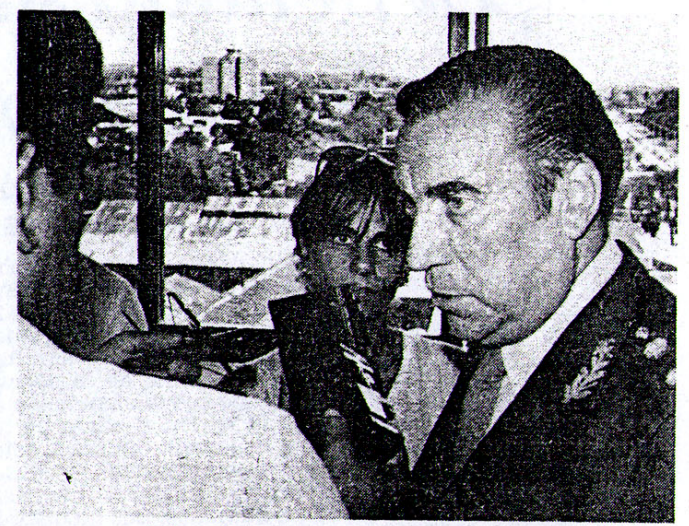

EL GENERAL BUSSI formula declaraciones a periodistas en un hotel céntrico, antes de regresar a Buenos Aires.

existen operaciones militares. Muertos por asesinato no existen en la guerra, existen muertos por combate. En la guerra no hay ese tipo de figuras delictivas. En la guerra hay operaciones militares, hay bajas en comare, hay persecucion. En la guerra el limite de las armas no táctico pós en la guerra, el que no mata, muere...

Mas adelante explico que "el accionar solapado de los subverstros, sus campañas psicológicas de inconvierte a en refugio táctico residenclas de la cludad o el monte nabia que ectuar operillajes, comi de all que a veces la persona que no este mente lo cuerr planteado con guerra planteado por la subversion y crea que fue un hechos delictivos captura de un delincuente y te pron dellncuente subversivo con un secuestro no son talde presentar como desaparecidos a quienes subversion cidos en los términos en que se los quiere reclamar muertos cn combate"

El general Bussl regresó ayer a Buenos Aires.

Bussi sosteniendo a la prensa su versión sobre la guerra para justificar la represión estatal de la dictadura. Bussi no abandonaría nunca estas hipótesis / La Gaceta, 10 de febrero de 1984.

Según lo demuestra Crenzel, "la transición no supuso un corte automático y generalizado en las formas de sociabilidad, en los valores y las conductas de la población, cuando el momento dictatorial dejó lugar 
al momento constitucional en la vida política argentina en $1983^{\prime \prime 300}$. En este sentido, el ascenso del Bussismo en la transición es uno de los elementos más importantes para evidenciar la idea de Crenzel sobre la transición. Bussi nunca se contradijo sobre sus actuaciones durante su estancia en Tucumán, al mando del operativo militar primero, y como gobernador de facto después. En una conferencia de prensa el 9 de febrero de 1984, es decir dos meses después de haber asumido Raúl Alfonsín como presidente constitucional, Bussi sostuvo la hipótesis de la guerra, teoría sustentada por el ejército en su conjunto. Afirmó que en Tucumán se había librado una guerra "donde se decidió el destino de la República. En ella hubo dos bandos y dos métodos, el practicado por la guerrilla del comunismo internacional (...) La subversión llevó a cabo una guerra sucia, buscando modificar la estructura del Estado y dentro del caos confundir a los que piensan excitar a los cobardes doblegar a los tibios. Fundamentalmente para conquistar el poder y desprestigiar a las Fuerzas Armadas". ${ }^{301}$ La postura de Bussi era, en definitiva, la posición de la mayoría de los altos mandos del ejército, y esta tesis sería refrendada durante el juicio a las juntas, un año después ${ }^{302}$. Asimismo Bussi nunca cambió el discurso, basta leer, por ejemplo, lo que en su descargo por el juicio por la desaparición del ex senador provincia, Guillermo Vargas Aignase, declaraba el militar retirado cuando afirmaba:

«La experiencia adquirida me permitió comprender este horroroso fenómeno de la guerra, para enfrentar al flagelo de la subversión en el "epicentro" mismo del accionar subversivo nacional (Tucumán), acompañado y apoyado por la inmensa mayoría del pueblo tucumano -"objetivo inicial" y víctima de

\footnotetext{
300 Crenzel, Emilio (2001): El voto a Bussi en Tucumán, Op. Cit.

301 Diario La Tarde, 9 de febrero de 1984.

302 Véase Bignone, Reynaldo (1992): El último de facto. La liquidación del proceso. Memoria y Testimonio. Ed. Planeta. Buenos Aires.
} 
la agresión apátrida- que vio y sufrió, en vivo y en directo, más que ningún otro argentino, el temor y el terror; la seguridad de sus vidas; y la pérdida de sus patrimonios; convirtiéndose -de hecho- en el factor determinante de la victoria político-militar de mi gestión. Los tucumanos de la década del 70, son testigos insobornables de la GUERRA que vivió Tucumán y de la conducta de sus Fuerzas Armadas; muy pocos pueden negar hoy este "hecho" y de los miedos y horrores que producían las "bandas de delincuentes terroristas" que asolaban la Provincia, con su secuela de muertos, desaparecidos, secuestrados, atentados, etc. ${ }^{303}$

Una de las más arduas tareas del movimiento de derechos humanos, en este sentido, era, por un lado, la lucha ideológica que debía procurar llegar a la sociedad con otro discurso, por otro lado, la de defender la postura de las víctimas, ya que, en su mayoría, los desaparecidos no eran integrantes de los grupos armados, sobre todo, cuando Bussi asume el máximo poder en Tucumán. En este sentido, el contra-discurso de los organismos no se hacía esperar. A los dichos anteriores del general retirado a la prensa, el movimiento respondió replicando que "lo dicho por Bussi es un cúmulo de mentiras y falsedades dichas en tono jactancioso: se declara satisfecho de los horrores

${ }^{303}$ Léase en anexo documental número 7 el descargo de Bussi en su alegato durante el juicio sobre la desaparición del senador Guillermo Vargas Aignase. Bussi siempre esgrimió el argumento de la guerra para legitimar la represión y la desaparición forzada de personas. En este sentido revisar sus declaraciones durante los primeros años de la transición y compararlas con sus últimas manifestaciones públicas ya sea a la prensa o en las instancias judiciales es rever el pensamiento militar que siempre sostuvo desde que le fuera entregado el mando del Operativo Independencia en diciembre de 1975. El mesianismo bélico de Bussi no es propio del ex gobernador de facto sino de prácticamente toda la superioridad militar implicada en los juicios de Lesa Humanidad que recorren hoy la República Argentina. 
cometidos, y se siente muy seguro de la impunidad que, por lo menos hasta este momento, le asistió". ${ }^{304}$

Es así como esa transición marcó entonces la suerte del propio Bussismo y su participación ya en democracia no es menos cuestionada por los organismos de derechos humanos. Desde 1983 hasta el final de su mandato como gobernador electo por medio de los votos en 1999, es posible seguir el devenir político de Bussi en el entramado social de la provincia. Siendo acusado en 1984 por la justicia civil que sentó en el banquillo de los acusados a la cúpula de las Tres Fuerzas Armadas que usurparon el poder en 1976, se vio beneficiado por las llamadas leyes de impunidad de la administración del presidente Raúl Alfonsín. Con la sanción de Ley de Punto Final en 1986 se supuso el final de los juicios que se le seguían por los crímenes cometidos. Aunque la condena judicial en aquellos años no llegaba para el General retirado, la condena social le habría de perseguir constantemente por medio del accionar del movimiento de derechos humanos, que ató a su suerte a la carrera política de Bussi.

Sobre el surgimiento y presencia de Bussi en el escenario político de Tucumán, Dolores Marcos procura responder a la pregunta "¿Quiénes apoyaron el regreso de Bussi a la política local?" afirmando que junto a la dirigencia del partido Bandera Blanca, liderado por un abogado de ideas de ultra derecha, Ezequiel Ávila Gallo, apoyaron a Bussi "una serie de personajes asociados a la industria azucarera y a otras industrias locales, los mismos que habían colaborado económicamente con la administración Bussi durante la dictadura, quienes pusieron a disposición del general sus recursos y sus influencias. Políticamente, la élite asociada a esos circuitos comprometió su ayuda y su compromiso con la causa que haría regresar

$\overline{304}$ Diario La Gaceta, 12 de febrero de 1984. 
a Bussi al mando de la provincia. Un año más tarde, y tras su ruptura con el líder de Defensa Provincial Bandera Blanca, Bussi funda su propia estructura partidaria: Fuerza Republicana, que tan sólo un año después cuenta con 70.000 afiliados". ${ }^{305}$ Fuerza Republicana ${ }^{306}$ se estableció como partido político provincial el 4 de julio de 1988. En los primeros tiempos Bussi procuró constituir su partido en una fuerza política nacional o conformar un frente de partidos provinciales conservadores, consiguiendo así importantes acuerdos de adhesión en algunas provincias de la región como en Jujuy, Salta y Santiago de Estero, quedando con el tiempo limitado su centro de actuación exclusivamente en la provincia de Tucumán. ${ }^{307}$ Siguiendo a Marcos sostiene que "tanto en sus declaraciones de principios, como en los mensajes de campaña, (...) Bussi y su partido han tomado la moralización de la sociedad y la política como bandera y consigna, en una especie de cruzada moral contra la dirigencia de los partidos tradicionales." ${ }^{\prime \prime 30}$

Sin embargo el tiempo demostraría que el Bussi de la democracia se comportaba de la misma manera que los políticos tradicionales. Una vieja idea que los militares podían hacer cualquier cosa menos robar ${ }^{309}$,

305 Marcos, Dolores (2005): "Liderazgos autoritarios en el noroeste argentino: el caso Bussi en Tucumán", en Reflexión Política, año 7, No 13, IEP - UNAB, Bogotá.

306 A Partir de ahora denominaré a Fuerza Republicana como FR.

307 Marcos, Dolores: Liderazgos Autoritario, Op. Cit.

308 Ibídem.

${ }^{309}$ La idea que se expresa aquí tiene que ver con una imagen del saber popular que aflora en momentos donde algún político es sospechado de corrupción. El dicho que afirma "roba, pero hace" sirve de legitimación que permite a algunos sectores sostener a determinados personajes de la política tradicional valorando la praxis en beneficio del común. En el caso de los militares la premisa pareció ser que podían violar los más elementales derechos humanos aún cuando dicha violación fuera en el supuesto beneficio de las mayorías. De ahí que muchos votantes de Bussi justificaran su voto en el "quehacer" del general retirado basado, sobre todo, en su honestidad. La aparición de una cuenta en Suiza no declarada puso en cuestión incluso esta veta del ex represor aún cuando desde 
quedaba en desuso cuando se le descubriera a Bussi, entonces gobernador elegido, el 13 de febrero de 1998, una cuenta secreta en Suiza no declarada. Bussi sería sometido a un juicio político que lo mantendría alejado de la gobernación de Tucumán por dos meses entre abril y junio de 1998, pero, sin embargo, sería absuelto por el tribunal legislativo que lo acusaba. Mientras se ejecutaba el juicio político en su contra, algunos militantes del MDHT sostenían con indignación la repulsa contra el poder legislativo de la provincia, ya que Bussi sería juzgado por robo y no por los crímenes de Lesa Humanidad que se le acusaba. Una nota aparecida en un diario de Buenos Aires daba cuenta de que "el incremento patrimonial de Bussi se produjo cuando era gobernador de facto de Tucumán."310

Estas son algunas de las incidencias del devenir político de Bussi y su partido FR. Sintetizando entonces lo actuado por Bussi en el periodo democrático retomo la enumeración que los organismos de derechos humanos de Tucumán han elaborado con motivo de la impugnación de la candidatura del general retirado a la intendencia capitalina provincial:

- El haber incurrido en "falsedad ideológica" en su declaración jurada patrimonial, presentada en la cámara de diputados ya que no ha incluido cuentas bancarias secretas en el exterior (circunstancia que llevó a un tribunal de honor del ejercito Argentino a considerar su conducta como perjudicial al prestigio de esa institución).

- La presunción de enriquecimiento ilícito por la compraventa de varias propiedades, a partir de 1976, que se tramita en la Justicia Federal.

las organizaciones de derechos humanos también se lo denunciaba.

310 Página 12 del 27 de marzo de 1998. 
- El juicio Político que se siguió como Gobernador de Tucumán, con resultado mayoritariamente favorable a su destitución, pero que no se efectivizó por falta de un voto para reunir los dos tercios de votos de los miembros presentes de la Legislatura, conforme lo establece la Constitución de Tucumán, por el año 1997. 311

311 Documento de Impugnación de la Candidatura de Bussi a la intendencia de San Miguel de Tucumán. En anexo documental número 5. 
PARTE III HISTORIA Y MEMORIA DEL Movimiento de Derechos Humanos 


\title{
CAPÍtUlo VII LOS ORÍGENES DEL MOVIMIENTO DE DERECHOS HUMANOS EN TUCUMÁN
}

\author{
"Los desaparecidos que se buscan con el \\ color de sus nacimientos, el hambre y la \\ abundancia que se juntan, el mal trato con su \\ mal recuerdo. $1 / 312$
}

\section{VII.1 El SURgimiento Del Movimiento De DDHH en ARgentinA.}

Si bien la historia general de los organismos de derechos humanos de Argentina ${ }^{313}$ no forma parte de este trabajo, considero necesario realizar una breve mención de éstos en el ámbito nacional ${ }^{314}$. En muchos casos la actuación de dichos organismos ha influido en el desarrollo de los movimientos provinciales. Luego de mencionar y explicar la clausura democrática después del golpe de estado del 24 de marzo de 1976, e incluso antes, es necesario precisar que el escenario del surgimiento de las organizaciones de derechos humanos se da como consecuencia lógica

312 Gieco, León, La memoria, Op. Cit.

313 Para una historia de los organismos de derechos humanos léase, Veiga, Raúl (1985): Las organizaciones de derechos humanos, Biblioteca Política Argentina, Centro Editor de América Latina, Buenos Aires.

${ }^{314}$ Cuando mencione a los organismos a nivel nacional, estaré haciendo referencia a la actuación que dichos organismos han tenido y tienen en la capital argentina. Cabe destacar que si bien en las provincias los organismos de derechos humanos aparecen actuando de manera autónoma e independiente, muchas veces lo hacen subordinando sus decisiones a las tomadas en Buenos Aires, allí donde funcionan como si fueran sedes centrales. Un caso paradigmático en este sentido es el movimiento de Madres de Plaza de Mayo, que en Tucumán adhiere al nombre del organismo su filiación con el organismo porteño, es decir que si bien reconoce su libertad de acción, depende directamente de las decisiones a nivel nacional. No ocurre lo mismo con la agrupación H.I.J.O.S., que si bien se conforma a partir de 1995 como red nacional, cada filial mantiene la autonomía en la forma de interactuar y no depende de un lineamiento central. 
del aumento en la oleada represiva en todo el país. Marysa Navarro afirma que "el vacío creado por la falta de instituciones mediadoras fue llenado gradualmente por las organizaciones de derechos humanos"315. Si bien en parte lo que afirma Navarro es cierto, dichos organismos compartieron en variadas oportunidades el espacio público con otras organizaciones, como las sindicales o las partidarias, la búsqueda de los desaparecidos hizo que el movimiento de derechos humanos adquiriera notoriedad en la lucha contra la dictadura. Jelín explica que "durante la dictadura, el movimiento de derechos humanos se constituyó en un movimiento social casi paradigmático: la solidaridad interna, el conflicto frente a un opositor reconocido, el cuestionamiento de los límites del sistema, estaban claramente presentes. El movimiento planteaba una oposición profunda y frontal a los principios éticos de la organización social y política del gobierno militar". ${ }^{316}$ Para Bombal y Sonderéguer durante los años del llamado Proceso "se había ido gestando, y había ido operando políticamente, un movimiento que reclamaba por la plena vigencia de los derechos humanos. Ante la violación de los más elementales - entre ellos, el derecho a la vida - el movimiento fue la respuesta de una sociedad que se veía vulnerada. Temprana fue su oposición al régimen militar como clara su consigna principal: Aparición con vida y juicio y castigo a los culpables, sostenida en un contexto de absoluta interdicción de las garantías individuales y de violación del orden jurídico." ${ }^{317}$

315 Navarro, Marysa, Lo Personal es Político, Op. Cit. P. 280.

316 Jelin, Elizabeth comp. (1987): Movimientos sociales y democracia emergente, T. 1., Centro Editor de América Latina, Buenos Aires.

317 González Bombal, María Inés y Sondereguer, María: Derechos Humanos y Democracia, en Jelin, Elizabeth, Movimientos Sociales y democracia emergente, Op. Cit. 
Como afirma Luciano Alonso "...no es inútil advertir que las grandes matrices de comprensión se basan casi siempre en el estudio de las experiencias de la ciudad capital de la Argentina, Buenos Aires, y de conglomerados urbanos cercanos como La Plata. Se dispone de escasos estudios socio-históricos acerca de otras regiones o ciudades, y aquí cabe destacar los de Silvina Oviedo y Carol Solís para Córdoba y de Rubén Kotler para Tucumán. Adicionalmente, el movimiento en defensa de los derechos humanos violados en Argentina tuvo una extensión muy superior a la del territorio nacional en tanto muchos grupos de exiliados realizaron actividades similares y vinculadas. De la creciente literatura sobre el exilio, los trabajos de Silvina Jensen sobre Barcelona, Marina Franco sobre Francia, Guillermo Mira Delli-Zotti sobre Madrid o Pablo Yankelevich sobre México, entre otros, van aportando nuevas miradas sobre las acciones pro derechos humanos de argentinos radicados en esas latitudes. ${ }^{\prime 318}$

Según Alonso estamos ante una situación paradójica. "Las descripciones e interpretaciones generales sobre el movimiento argentino por los derechos humanos se sostienen abrumadoramente en los estudios sobre una región particular del país -por cierto, la más importante por su centralidad política y su trascendencia en diversos sentidos- en tanto apenas se dispone de indagaciones sobre los tiempos, modos de constitución, acciones e impactos del actor colectivo en otras localidades. Lo que hasta ahora se viene presentando como la historia del movimiento argentino $o$ en Argentina -distinción para nada ociosa- parece en realidad el traslado de la experiencia capitalina al nivel de representación del Estado nacional." ${ }^{\prime 319}$

\footnotetext{
318 Alonso, Luciano (2008) El surgimiento del movimiento argentino por los derechos humanos en perspectiva comparada, en Revista digital de la escuela de historia - UNR / año 1 - n 1 / Rosario, 2008.

319 Ibídem.
} 
Coincido con el historiador santafesino en el sentido de la necesidad de comenzar, entonces, con "ejercicios sistemáticos de comparación respecto de las formas que asumió el movimiento por los derechos humanos en diversas sedes, lo que permitiría descentrar el eje Buenos Aires - La Plata y apreciar de modo más completo las diferentes experiencias históricas." ${ }^{\prime \prime 20}$

Algunas de las organizaciones que componen el vasto movimiento, sin embargo eran de antigua data, como la Liga por los Derechos del Hombre, emparentada al Partido Comunista Argentino. ${ }^{321}$ La Liga, como es llamada tradicionalmente, había sido creada el 20 de diciembre de 1937 durante una reunión convocada por la comisión Pro Amnistía de los presos políticos y exiliados de América, llevada a cabo en el salón de actos del diario "Crítica". 322 Durante los años más duros de la última dictadura militar, e incluso antes, la Liga había creado una comisión de apoyo a los familiares de los presos políticos.

Otros organismos de más reciente aparición remontan sus orígenes a mediado de los años '70, bien durante la dictadura encabezada por Videla o incluso antes, durante el interregno democrático de Isabel de Perón, cuando comienza la represión a la oposición política de manera sistemática y avalada por el Estado. Una de las organizaciones de relevancia pública ha sido, y aún hoy continúa siendo, la Asamblea Permanente por los Derechos Humanos (APDH), el organismo por cuyas características se presenta como el "más político" de todos, ya que muchos de sus miembros pertenecían a algunos de los partidos

320 Ibídem.

${ }^{321}$ Navarro, Marysa, Lo personal es Político, Op. Cit. P. 281. Algunos miembros de la Liga manifiestan que es falaz sostener que la misma ha surgido como un órgano del Partido Comunista para defender sólo a los miembros de ese partido. Es así como lo sostiene, por ejemplo, uno de sus dirigentes históricos, Carlos Zamorano.

322 Veiga, Raúl, Las organizaciones de derechos humanos, Op. Cit. P. 112. 
tradicionales, como es el caso del ex presidente Raúl Alfonsín, miembro de la Unión Cívica Radical y que presidiera la APDH durante los primeros años de la transición. Como afirma Veiga, "entre todos los organismos de derechos humanos, la APDH, es única en su variedad ideológica, política y sectorial". ${ }^{323}$ La APDH había sido creada en Buenos Aires el 18 de diciembre de 1975 después de una reunión realizada en la Casa Nasareth con la idea de "promover la real vigencia de los derechos humanos". ${ }^{324}$ Como veremos más adelante, y dadas las dinámicas locales, la APDH tendrá un derrotero particular en cada región o provincia, emergiendo en Tucumán, recién a comienzos de 1984. En Nequén, por ejemplo, formaban parte de la APDH, las madres de los desaparecidos neuquinos quienes se separarían de la misma para conformar el núcleo local de Madres de Plaza de Mayo. 325

Otra de las organizaciones que constituyen el llamado movimiento de derechos humanos, es el Movimiento Ecuménico por los Derechos Humanos (MEDH), cuya aparición en la escena pública se sitúa en febrero de 1976 (un mes antes del golpe), y que se planteaba, en sus orígenes, crítico hacia la Iglesia Católica, siendo algunos de sus miembros, incluso, ex integrantes del movimiento de Sacerdotes por el Tercer Mundo.

El Servicio de Paz y Justicia (SERPAJ) es una institución latinoamericana que si bien sus orígenes se remontan a mediados de los años '50, tomó relevancia en 1980 cuando uno de sus más destacados miembros, Adolfo Pérez Esquivel, recibiera el premio Nóbel de la Paz, siendo incluso este nombramiento un golpe de efecto para la dictadura,

323 Ibídem.

324 Ibídem.

325 Léase Azconegui, Cecilia (2009): Madres, militantes o resistentes. La definición de identidades en el movimiento de derechos humanos en el Alto Valle de Río Negro y Neuquén (1976-1983). Ponencia presentada en el Primer Congreso Nacional Sobre Protesta Social, Acción Colectiva y Movimientos sociales en la Universidad de Buenos Aires. En Actas del Congreso. 
ya que el dirigente del SERPAJ galardonado, había sido secuestrado y había estado detenido durante casi dos años.

A partir de 1977 se crean en Buenos Aires los distintos organismos que por su filiación con los represaliados tomaron el nombre de cada movimiento: Madres de Plaza de Mayo, Familiares de detenidos desaparecidos por Razones Políticas, Abuelas de Plaza de Mayo y, a mediados de los años '90, H.I.J.O.S..

En Abril de 1977 un grupo de 14 mujeres funda el Movimiento de Madres de Plaza de Mayo. La mayoría de estas mujeres nunca habían participado en política y no tenían ninguna presencia pública. Con la desaparición de sus hijos estas "madres" salieron a la calle a buscar a los desaparecidos inaugurando quizás una de las formas más novedosas de militar y hacer política, como sería con el paso del tiempo las rondas alrededor de la pirámide de la plaza que le daba el nombre a la organización. Comenzaron a reconocerse unas a otras en las oficinas públicas, despachos de abogados, ministerios, iglesias, etc., allí donde recurrían para pedir información o buscar algún dato de sus hijos desaparecidos. Con el tiempo decidieron que lo mejor era agruparse y establecieron como mecanismo de distinción, el uso de un pañuelo blanco que les permitiera reconocerse en los encuentros públicos. Con el tiempo el pañuelo se convertiría en todo un símbolo más allá de las instancias nacionales y se argumentaría que éste representaba el pañal de los hijos desaparecidos.

De los comienzos, Navarro explica que "la idea de ir a la Plaza de Mayo en una época en la que las manifestaciones de cualquier clase estaban prohibidas atemorizó a muchas mujeres. Su vida como esposas y madres no las había preparado para quebrantar la ley y manifestarse 
frente a la Casa Rosada ${ }^{326}$ bien custodiada, en donde no se había llevado a cabo ninguna manifestación desde el golpe militar". 327

Si bien es cierto que el miedo paralizó a muchas mujeres, no es menos cierto que de algunos testimonios se deduce que éstas mujeres si bien sentían temor, había un mandato materno más fuerte que las impulsaba a salir al espacio público en búsqueda de sus hijos secuestrados. Como veremos en el caso tucumano, la inacción pública fue lo que hizo tomar la decisión a un grupo de mujeres de separarse de Familiares y salir a marchar en las rondas de los días jueves en la plaza principal. Los comienzos de las rondas de Madres tiene que ver con que se reunían en las inmediaciones de la pirámide de la Plaza de Mayo y la policía les impedía que siguieran congregándose, ya que estaba en plena vigencia el estado de sitio y las asambleas y reuniones estaban prohibidas. De esta manera decidieron comenzar a caminar alrededor de la Monumento de la Plaza y si bien este acto desafiante también les costaría algún tipo de castigo ${ }^{328}$ no dejaron de dar vueltas alrededor de la pirámide cada jueves, convirtiéndose esta actividad en una de las principales manifestaciones del movimiento hasta la actualidad.

De idéntica manera, las Madres del interior del país que fueron agrupándose también adoptaron las plazas principales de las capitales de provincia para manifestarse en ronda contra el gobierno de turno. Con el tiempo se consolidó un movimiento nacional adoptando la metodología de las Ilamadas Marchas de Resistencia, convocadas una vez por año en la

326 La Casa Rosada es la Casa de gobierno ubicada frente a la Plaza de Mayo. Que las Madres marcharan allí suponía un abierto desafío a la dictadura militar.

327 Navarro, Marysa, Lo personal es Político, Op. Cit. Véase también Bousquet, Jean Pierre (1983): Las Locas de la Plaza de Mayo, El Cid Editor, Buenos Aires.

${ }^{328}$ Algunas integrantes del movimiento han sido secuestradas y se encuentran desaparecidas, entre ellas, una de sus fundadoras, Azucena Villaflor de Devicenti, secuestrada el 10 de diciembre de 1977 y cuyos restos han sido recientemente encontrados. 
Plaza de Mayo durante las 24 horas de un día completo. Por lo tanto dos símbolos identifican históricamente a este movimiento en cualquiera de sus vertientes: la manifestación en el ámbito público y los pañuelos blancos.

En 1986 el organismo de las Madres en Buenos Aires se habría de dividir en Madres de Plaza de Mayo, liderado hasta la actualidad por Hebe de Bonafini, y el Movimiento de Madres de Plaza de Mayo Línea Fundadora, cuyas miembros han sido críticas con los postulados intransigentes del primero. En su carta fundacional, la "Línea Fundadora" de Madres expresaba su desacuerdo con Hebe de Bonafini con el siguiente enunciado: "la escisión del movimiento se produjo después de haber enfrentado juntas los peores años de la dictadura. Fue motivada por graves disidencias con relación a un necesario cambio en la metodología de nuestra lucha bajo un gobierno constitucional y por profundas discrepancias frente al avance de una creciente e inaceptable actitud autoritaria y de marcado personalismo, que impedía una concepción democrática de la convivencia hacia el interior de nuestro movimiento de derechos humanos". 329

Por su parte, Abuelas de Plaza de Mayo se conformó como agrupación formal recién en 1983, sin embargo, ya tenían presencia pública, al igual que Madres, desde 1977. Inicialmente estaba compuesta esta agrupación por madres de desaparecidos, que se habían dedicado exclusivamente al reclamo, investigación y búsqueda de los hijos de secuestrados nacidos en cautiverio y entregados en adopción, esto es, a sus nietos. La diferencia en los objetivos de encontrar los nietos vivos hace que este organismo tome distancia de otros movimientos que con el paso del tiempo reconocerán la presunción de muerte de los

329 Véase Kotler, Rubén, Los movimientos sociales, formas de Resistencia a la Dictadura, Op. Cit. 
desaparecidos. Según expresó Estela Carlotto, presidenta del organismo: "los niños también están desaparecidos, pero a diferencia de los adultos posiblemente estemos caminando alrededor de ellos y no los veamos". 330

Casi simultáneamente con la aparición de Madres y Abuelas, surge Familiares de Desaparecidos por Razones Políticas, un organismo que toma carácter orgánico en Septiembre de 1977, después de una Asamblea en la que se reúnen aquellos militantes que ya se reconocían de haber pasado por despachos y secretarías en búsqueda de los desaparecidos. ${ }^{331}$ Después de pedir asesoramiento legal a la Liga, ésta les ofrece un espacio físico donde reunirse. La presentación de un petitorio el 14 de octubre de 1977, reclamando la búsqueda de los ciudadanos ilegalmente detenidos, la liberación de los presos sin causas ni procesos y la posibilidad de salir del país de los detenidos a disposición del Poder Ejecutivo Nacional (P.E.N.), sirve de marco como primera aparición pública de la organización. ${ }^{332}$ El nombre del grupo ya es una declaración de principios y establece los objetivos que le han movido su organización: "Familiares de Desaparecidos (no sólo éramos madres, sino también esposo/as, hermano/as, hijo/as) y Detenidos (luchábamos también por la libertad de los presos) por Razones políticas (éramos totalmente conscientes de la militancia de nuestros desaparecidos). ${ }^{333}$

Ilda Velasco es una de las fundadoras de Familiares de Detenidos por Razones Políticas en la Ciudad de Buenos Aires y recuerda que el organismo comenzó a activar en 1976:

«A mi hija la secuestran el 29 de agosto de 1976. A partir de ahí fui a la Liga, que es otro organismo, la Liga por los

\footnotetext{
330 Veiga, Raúl, El Movimiento de derechos humanos, Op. Cit. P. 62.

331 Familiares de Desaparecidos (2006): La lucha que reivindica la lucha", editado por el Instituto Espacio para la Memoria, Buenos Aires.

332 Veiga, Raúl, El Movimiento de derechos humanos, Op. Cit.

333 Familiares de Desaparecidos, Op. Cit.
} 
Derechos del Hombre y ellos nos dieron un espacio, donde funcionaban en aquel entonces, en la calle Esmeralda noventa y pico, no recuerdo bien. Después la Liga se traslada a la sede en Avenida Corrientes, y la gente que iba a hacer las denuncias a la Liga fuimos allí, y ellos fueron los que nos propusieron que nos agrupáramos como organismo. Entonces éramos... no se cuantos seríamos, seis o siete personas, entre los que se encontraba un matrimonio de apellido Orfanó, y bueno nos conformamos como Familiares, el nombre nuestro fue desde el comienzo, porque decíamos que éramos porque en esa época no era fácil decir: familiares de detenidos desaparecidos por razones políticas, el nuestro fue el único organismo que reconoció que nuestros H.I.J.O.S. estaban desaparecidos por ser militantes, más allá de lo que sean, pero eran militantes políticos.» ${ }^{334}$

Una frase abrevia la idea que Velasco tiene de Familiares y las posibles distinciones con Madres de Plaza de Mayo:

«Yo también soy una madre, pero sin pañuelo.»335

Las diferencias entre un organismo y otro son más profundas que el mero hecho de portar un pañuelo, al fin y al cabo una simbología externa, aunque no es menos cierto que el movimiento de derechos humanos en su conjunto no sería el mismo sin la presencia de los pañuelos en los actos públicos, cuestión reconocida incluso por alguno de sus miembros. ${ }^{336} \mathrm{Si}$ bien cada uno de estos organismos actuaba desde

334 Testimonio de Ilda Velasco [Entrevista realizada por el autor el 4 de Octubre de 2007 en la ciudad de Buenos Aires].

335 Ibídem.

336 Algunas diferencias políticas entre los organismos se dejan entrever de las entrevistas realizadas a sus miembros. En algunos casos y ante el grabador apagado reconocen diferencias personales muy profundas y los cuestionamientos suelen exceder la mera denuncia política. En una de las entrevistas a una integrante del movimiento de Madres de Plaza de Mayo de Tucumán, ésta reconocía fuera de micrófono: "lo que sucede es que necesitan el pañuelo blanco 
sus orígenes hasta la actualidad con principios propios y con autonomía en la toma de decisiones, no es menos cierto que dichas divisiones les llevaron a participar, en determinadas ocasiones, en acciones conjuntas, dejando de lado las diferencias que les separaban y buscando la concreción de aquellos objetivos que les eran históricamente comunes. Un ejemplo de esto ha sido una solicitada realizada en forma colectiva entre Familiares y Madres de Plaza de Mayo con motivo del día internacional de los derechos humanos, el 10 de diciembre de 1977, una de las primeras actuaciones públicas incluso del organismo que nuclea a los familiares de los represaliados.

Otra manifestación conjunta que demuestra la solidaridad entre los organismos ha sido expuesta con motivo de la visita de la Comisión Interamericana de Derechos Humanos (CIDH) en septiembre de 1979. Ante la víspera de la llegada de la Comisión, las oficinas de la Asamblea Permanente, la Liga, el Movimiento Ecuménico y la Comisión de Familiares fueron allanadas. Los expedientes y una petición que había sido redactada para ser entregada a la Comisión Interamericana fueron recogidos". ${ }^{337}$ Sin embargo, y a pesar del clima represivo, los organismos continuaron recogiendo pruebas para llevar al organismo internacional que se acercaba al país para investigar las violaciones a los derechos humanos. Es así como el 19 de septiembre de ese año 1979 se realiza una movilización hacia la plaza de Mayo para entregar al gobierno militar un petitorio avalado por 27.000 firmas.

en la plaza", esto para explicar una pelea personal con la dirigente de otro organismo pero que no pasaba a mayores por la posibilidad que Madres rompiera con la organización del acto central y no concurriera. La ausencia de Madres de Plaza de Mayo (en cualquiera de sus vertientes) implica sin más la ausencia de los pañuelos que identifican al movimiento de derechos humanos en su conjunto.

337 Navarro, Marysa, Lo personal es Político, op. Cit. 
$\mathrm{Si}$ en dictadura los organismos de derechos humanos han interactuado entre ellos en variadas ocasiones, también lo han hecho durante la transición, sobre todo en lo que se refiere a los actos de recuerdo del golpe, como los que se realizan todos los años el 24 de marzo. Sin embargo, y a pesar de existir elementos comunes entre todas las organizaciones, importantes diferencias políticas les separan, y estas se han evidenciado sobre todo desde diciembre de 1983 después del triunfo del presidente Raúl Alfonsín en las urnas. Una cuestión ha sido enfrentar al régimen dictatorial con un objetivo claro, y otra muy distinta era plantear una acción en un gobierno como el radical que dividía aguas. En este sentido Jelin expresa que "la transición a la democracia significó un desafío importante" para los organismos de derechos humanos, ya que la nueva coyuntura "hacía suyos los principios ideológicos rectores del movimiento en lo referente a los fundamentos éticos del Estado". 338

En algunos casos se produjeron fracturas internas dentro de una misma organización, como la división sufrida en el movimiento de Madres de Plaza de Mayo, tal como ha sido mencionado antes en este trabajo. Graciela Fernández Meijide, ex miembro de la APDH, expresaba a comienzos de los '80 que "las diferencias con otros organismos se ha ido marcando cada vez más" y que para la APDH era más fácil acordar ciertas tácticas con aquellos organismos que se planteaban la realidad del cambio en el trabajo en dictadura con respecto al trabajo en democracia, que con aquellas organizaciones que no se lo planteaban. ${ }^{339}$ Tanto la alusión de Fernández Meijide, como la del movimiento de Madres de Plaza de Mayo Línea Fundadora, están estrechamente vinculadas a la presidenta de la Asociación Madres de Plaza de Mayo Hebe de Bonafini, que siempre se mostró mucho más intransigente a la hora de aceptar las

338 Jelín, Elizabeth: Movimientos sociales y democracia emergente, Op. Cit. P. 14.

339 Veiga, Raúl, El Movimiento de derechos humanos, Op. Cit. P. 123. 
políticas estatales aún en gobiernos constitucionales. Con estas líneas estimo que se puede tener una apreciación clara del desarrollo del Movimiento de derechos humanos a nivel nacional. Como el objetivo de la presente investigación es centrar el análisis del movimiento en Tucumán, lo que sigue es entonces la historia de los organismos y su actuación en la provincia norteña.

\section{2 ESFERA DOMÉSTICA, ÁMBITO PRIVADO}

Un tema que se plantea cuando se abordan trabajos referidos al surgimiento de las organizaciones de derechos humanos en contextos de dictaduras, es la triple cara de un mismo sitial: la esfera pública versus la esfera doméstica, y en ella, el ámbito de lo privado.

Una primera distinción que se hace necesario destacar es la diferencia entre el ámbito doméstico y el espacio privado. Algunos autores señalan que el espacio doméstico es la esfera del hogar, reservado para el género femenino y distinguen a éste del plano personal o privado. Mientras la esfera pública, como ámbito de lo político, quedaba tradicionalmente referido a la participación del género masculino, en un sistema androcéntrico de dominación. ${ }^{340}$ El surgimiento de organizaciones de derechos humanos conformados principalmente por mujeres, sobre todo en las organizaciones que se definieron sanguíneamente por su relación con los desaparecidos, como Familiares o Madres, plantean nuevos interrogantes en lo que se refiere a la división entre el ámbito público / político y el doméstico / privado: por un lado, la reconfiguración de las fronteras entre las esferas pública y domésticas y entre esta última y la privada, y por otro, la conformación de estos grupos autónomos, con

\footnotetext{
340 Para un análisis más detallado de esta cuestión véase Filc, Judith (1997): Entre el parentesco y la política. Familia y Dictadura, 1976 - 1983, Edit. Biblos, Buenos Aires.
} 
una identidad propia, desafiando al Estado, participando de la política de manera novedosa, impulsando nuevas prácticas sociales, en definitiva, en palabras de Marysa Navarro, transformando lo personal y privado, incluido en la esfera doméstica, en político y público.

Si bien al comenzar la dictadura las Fuerzas Armadas afirmaban que por cuestiones de seguridad era necesario que la ciudadanía se quedara en sus respectivos hogares, el planteo resultaba contradictorio, ya que la mayoría de los operativos se llevaban a cabo irrumpiendo en las casas de las víctimas. Nadie se encontraba a salvo, aún quedándose puertas adentro del hogar. Es factible observar aquí la progresiva disolución del espacio limítrofe entre lo público - doméstico a medida que avanzaba el régimen dictatorial.

También las madres, abuelas y hermanas de los desaparecidos rompieron con la misma dicotomía público-privado. En una sociedad tradicionalmente androcéntrica como la Argentina, quebrantar ese límite implicó, por lo tanto, romper con un orden natural esgrimido por la propaganda oficial, en donde la zona representada por el hogar, era privativo de las mujeres, quienes, al mismo tiempo, tenían vedado el acceso al espacio público, ámbito de la política y exclusivo de los hombres.

Tanto las madres, las hermanas y las abuelas de los desaparecidos sin proponérselo explícitamente consiguieron lo que algunos movimientos feministas planteaban desde hacía mucho tiempo, es decir, la posibilidad de salir a la calle y participar plenamente de lo político. No de lo político desde una mirada tradicional sino de plena participación por la lucha en la conquista de ciertos derechos conculcados por la propia dictadura. $Y$ no sólo lograron eso, sino que al mismo tiempo, generaron una forma nueva y original de hacer política, una 
novedosa manera de ejercitar los derechos de participación de la "cosa pública". Dejaron "las tareas propias del hogar", las tareas domésticas propiamente, para ocupar las plazas, las iglesias, los ministerios y otros escenarios de diversas luchas sociales, y hacer de éstos su lugar de reunión. En Buenos Aires para el Movimiento de Madres, fue la Plaza de Mayo, en Tucumán fueron las iglesias, en un primer momento, para luego adoptar las rondas de los jueves en el caso de las Madres de Desaparecidos.

Las rondas en Tucumán se realizaban alrededor de la Plaza Independencia, plaza principal de la provincia y que representa o simboliza el ámbito del poder político, toda vez que la misma está circundada por la Casa de Gobierno y la Catedral. La Plaza Independencia se convertía entonces en un nuevo escenario ocupado por estas organizaciones para medirse y hacer un balance de fuerza con el régimen dictatorial primero, y con el gobierno constitucional provincial después. A lo largo de toda la historia del movimiento local de derechos humanos y hacia el conjunto de organizaciones políticas, sindicales y de otras índole, la plaza principal siempre fue escenario de disputa política frente a los poderes constituidos, de manera democrática cuando se realizaban las elecciones, pero también, y sobre todo, en momentos donde el poder dictatorial ocupaba de facto los espacios de gobernación. 
CAPÍtUlO VIII: LOS ORÍGENES DEL MOVIMIENTO DE DERECHOS humanos en Tucumán: De "Familiares"a "MadRes"

VIII.1 El surgimiento de familiares de Presos por Razones Políticas

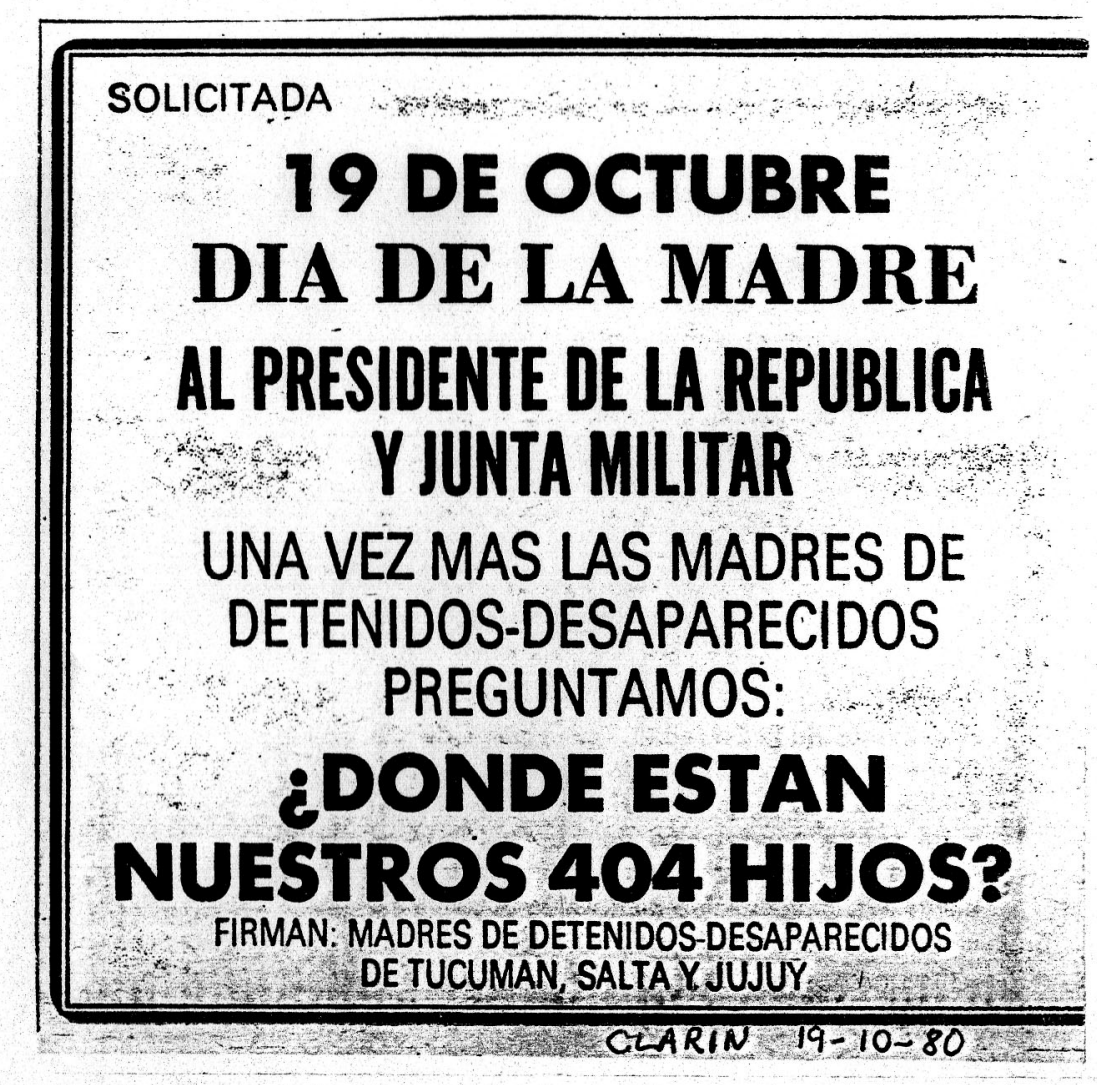

Solicitada en el diario Clarín firmada por "Madres de DetenidosDesaparecidos del NOA / Clarín 19 de octubre de 1980.

Si la historia de los organismos de derechos humanos a nivel nacional está en estrecha vinculación con la última dictadura militar, mucho más lo estará el movimiento en Tucumán, cuyo nacimiento hay que ligarlo además al comienzo del plan sistemático de represión 
establecido, tal como ya se ha explicado en otro capítulo de este trabajo, en febrero de 1975 con la implementación del Operativo Independencia.

Sin embargo, aun cuando las primeras desapariciones forzadas de personas comenzaron a producirse a fines de 1974, no será hasta 1977 en que Familiares de Detenidos y Desaparecidos por Razones Políticas haga su aparición en la esfera pública. Si bien no hay una fecha concreta que nos permita relacionarla con su fundación, de acuerdo a los testimonios, entre agosto y septiembre de ese año comienza a estructurarse una forma de organización con las reuniones que los familiares de los represaliados mantenían en la Iglesia del Sagrado Corazón de Jesús, ubicada en la calle Chacabuco al 500 de la ciudad capital. El espacio era cedido por el obispado local, con la idea de que los Familiares no hicieran públicas sus denuncias.

Entre los activistas que se destacaban de aquellas reuniones hay que mencionar a Carmen de Mitrovich, quien fue la primera presidenta del organismo y tal vez la figura más renombrada por los militantes de aquella época. También conviene destacar la participación de Vilma de Ribero muy activa en la militancia de Familiares, y a Carlos Soldati, quien, además, ha militado en años posteriores tanto en Madres de Detenidos Desaparecidos como en la Asamblea Permanente por los Derechos Humanos de Tucumán, siendo uno de sus miembros fundadores. Estos han sido algunas de las más de 300 personas que semanalmente se encontraban en la Iglesia para mantener reuniones, discutir estrategias, recibir a nuevos familiares y planificar las acciones. Este grupo de Familiares mantuvo, además, importantes vínculos con su homónimo de Buenos Aires y con otros organismos de derechos humanos que comenzaban a hacer su aparición pública en otras provincias vecinas 
a Tucumán, como el movimiento de Familiares de la provincia de Jujuy o de Santiago del Estero ${ }^{341}$.

De los comienzos, Carlos Soldati ${ }^{342}$ recuerda:

«Cuando desaparece mi hermano en mayo de 1978, nos llega una invitación para una primera misa con Familiares, a fines de junio, no recuerdo si fue por el 20 o el 18 de junio, en la Iglesia del Sagrado Corazón, en la calle Chacabuco al 500. Entonces la Iglesia estaba llena de familiares y recién me pongo en contacto con la gente y es el comienzo de la organización del grupo de Familiares. Estaban la señora Carmen de Mitrovich, Ibáñez, se me van muchos nombres con los cuales nos vimos todos los años siguientes en una intensa militancia, pero había muchísima gente...»

Pregunta: ¿De tu familia, va alguien más a esas reuniones o solamente vos?

«Sólo voy yo, soy yo únicamente. Uno sentía miedo, pero era tal el impacto por la desaparición de mi hermano que uno decide ya pese a los riesgos que pudiera correr, buscarlo con desesperación.»343

No todos los componentes de una misma familia de víctimas de la represión asistían a las reuniones de las organizaciones por variados motivos. En el caso de Soldati, vivir en la periferia de la provincia, a casi 100 kilómetros de la capital, y tener entonces que trasladarse semanalmente, suponía una contrariedad; en otros casos se volcaban a las reuniones las madres de las víctimas, pues los padres seguían con sus

\footnotetext{
341 Tanto Santiago del Estero, como Jujuy, Salta, Catamarca y la Rioja, conforman, junto con Tucumán, la región del Noroeste Argentino. Véase el Anexo 8.

342 Testimonio de Carlos Soldati. Ex militante de Familiares de Detenidos, Madres de Detenidos Desaparecidos de Tucumán, y APDH.

343 Testimonio de Carlos Soldati.
} 
obligaciones laborales para llevar el sustento al hogar y no les dejaba tiempo de asistir a las reuniones.

En general, la división interna en cada hogar suponía entonces una manera de división del trabajo, donde los padres continuaban siendo el sostén de la familia a través del trabajo, y a las madres les quedaba como tarea la búsqueda de los desaparecidos por medio de las distintas gestiones en la que se incluía la participación en las reuniones de familiares. En el caso de los componentes más jóvenes de las familias, cuyos desaparecidos eran los hermanos, se planteaba una problemática particular. A éstos se les impedía asistir a las reuniones de los organismos por varios motivos: para preservarlos, ya que al ser jóvenes eran un blanco elegido por la represión, tal como podemos comprobarlo en el caso del propio Soldati, secuestrado y torturado, pero, al mismo tiempo, por la desconfianza que suscitaba la presencia de jóvenes en las reuniones tal como rememora Sara Mrad: ${ }^{344}$

«Mi paso por Familiares fue muy breve porque en realidad yo tenía ganas de participar más, pero por otro lado tenía la presión y el miedo de mi mamá, que me decía que no vaya siempre y por ahí nos turnábamos... o íbamos juntas o nos turnábamos. Por momentos incluso parecía que en Familiares se olvidaban de haberme visto con mi mamá porque cuando yo llegaba sola me miraban con cierta desconfianza porque era joven. Yo en esa época, cuando la secuestran a mi hermana, tenía 24 años y cuando iba a Familiares tendría 27 o 28 años. Y a mí me impactaba por ahí... bueno, me acuerdo de una reunión en la que llegamos nosotros y no había llegado Carmen de Mitrovich todavía, ella era la que

\footnotetext{
${ }^{344}$ Presidenta de Madres de Plaza de Mayo filial Tucumán.
} 
organizaba las reuniones... había una comisión ya, un grupo...»

Pregunta: ¿Esto en qué año fue?

Sara: «Debe haber sido en el año '78, porque en el '79 me entero que había ya una división aunque no muy clara de Madres, porque en esos años todavía las Madres seguían participando de las reuniones de Familiares, pero hacían reuniones paralelas. Pero volviendo a la llegada de Carmen me impactó cómo entró. En la reunión debe haber habido unas cincuenta personas... todo esto era en un salón que tenían al lado de la Iglesia del Sagrado Corazón. Entonces te decía, Carmen Mitrovich entró como esas maestras de escuela, autoritaria, hablando muy fuerte y dando órdenes. Y a mí me impactó porque había mucha gente del interior y he sentido como una cosa muy autoritaria. Pero de todas formas uno seguí yendo, o seguía estando en contacto con ellos, porque era una forma de tener conexión con todos los que nos pasaba lo mismo...» ${ }^{345}$

Con el transcurrir de los primeros meses "Familiares" comienza a afianzarse en las acciones que llevaban a cabo. Sus integrantes viajaban al interior de la provincia a recoger testimonios de otros familiares de represaliados que por miedo, por la distancia con la capital o por incompatibilidad de horarios, no se acercaban a denunciar la desaparición del ser querido. El miedo, según se desprende del testimonio de los miembros de la organización, era lo que más pesaba para impedir muchas veces que una madre denunciara la desaparición de un hijo, o que una esposa reconociera el secuestro de su marido. Aún así las reuniones semanales en la Iglesia del Sagrado Corazón eran

345 Testimonio de Sara Mrad [Entrevista realizada por el autor en Tucumán el 5 de diciembre de 2007]. 
multitudinarias y tendían a crecer en los primeros años. De las reuniones, Soldati explica:

«Una vez se nos acercó un señor de la Liga ${ }^{346}$, se presenta y nos dice, una opinión que también repetían alguno de los familiares, de que se pensaba que la mayoría de los secuestrados estaba con vida, y que estaban en cárceles secretas y que había que empezar a tramitar para recuperarlos y también había que moverse con prudencia. Desde ahí arrancan las reuniones semanales de los días martes y ahí comienza toda una campaña de recoger datos, los testimonios, la lista empieza a hacerse cada vez más larga...»

Pregunta: ¿Había más gente del interior de la provincia?

«Había gente del interior que también fue arrimándose, de pueblitos del interior, sí. Y bueno, éramos muchos y la lista creció hasta los cuatrocientos y tantos desaparecidos...» ${ }^{347}$

Si bien me es imposible, con los documentos y testimonios con los que cuento, establecer un número certero de asistentes a las reuniones, dado el número de desaparecidos y la crueldad de la represión, no es exagerado decir que muy posiblemente participaban cerca de 300 o más personas, en reuniones lideradas por unos pocos pero que congregaban a una multitud con el afán de informarse, participar de las acciones públicas o bien para proponer nuevas acciones.

Los viajes a Buenos Aires comenzaron también a hacerse cada vez más frecuentes desde Familiares, ya sean para visitar algún ministerio en búsqueda de información sobre los desaparecidos, como así también para

\footnotetext{
${ }^{346}$ En referencia a la Liga por los Derechos del Hombre sobre la cual ya hice mención más arriba.

347 Testimonio de Carlos Soldati.
} 
unirse a las organizaciones de derechos humanos en la Capital del país, sea para la publicación de alguna solicitada en un diario de tirada nacional o sea para entablar un vínculo que les permita una mayor eficacia en la acción. Tampoco hay que dejar de mencionar las acciones individuales que en muchos casos eran resueltas por los propios familiares al visitar un ministerio o procurar entrevistarse con un miembro de la Iglesia oficial como gestión particular. Aunque la organización se planteaba acciones colectivas, el hecho de no obtener respuesta, hizo que muchos militantes, ante la desesperación por conseguir información acerca de su familiar desaparecido, concretaran acciones individuales.

Se buscaba poder recabar todo tipo de información de donde fuera posible y fortalecer los vínculos entre los distintos organismos destinados a la acción pública. En Buenos Aires, si bien la dictadura mantenía cierto cerco a estas organizaciones, había mayor libertad de acción que en Tucumán, donde los controles dictatoriales y represivos eran más férreos todavía. De este modo, por ejemplo, era más sencillo publicar una solicitada colectiva en un medio de prensa porteño que en uno local y es lo que podemos apreciar en la imagen de abajo. La Solicitada en cuestión ponía negro sobre blanco el nombre de los desaparecidos en Tucumán al tiempo de interpelar a la Junta Militar gobernante exigiendo conocer el paradero. La denuncia en concreto de esta solicitada menciona, en las vísperas de la Navidad de 1981, 412 desaparecidos y está firmada por Familiares de la provincia. 
HISTORIA Y MEMORIA DEL MOVIMIENTO DE DERECHOS HUMANOS DE TUCUMÁN (1977 - 1999)

CAPÍTULO VIII: LOS ORÍGENES DEL MOVIMIENTO DE DERECHOS HUMANOS EN TUCUMÁN: DE

"FAMILIARES" A "MADRES"

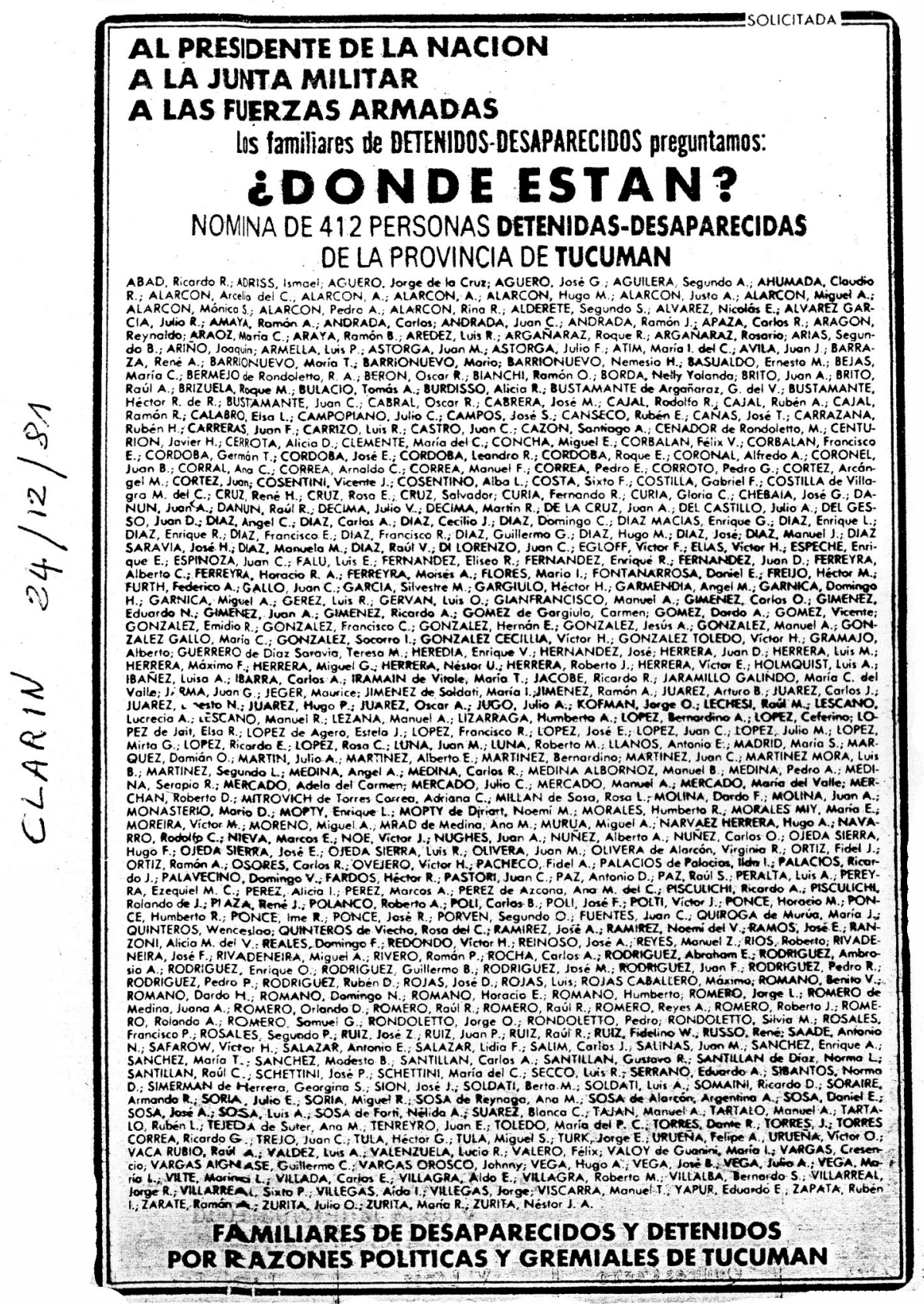

Solicitada en el diario Clarín firmada por "Familiares de DetenidosDesaparecidos" de Tucumán con nómina de los represaliados / Clarín, 24 de diciembre de 1981. 
De los viajes que Familiares realiza a la Capital, Soldati explica lo siguiente:

«En el año 1978 viajamos a Buenos Aires para entrevistarnos con los organismos, llegamos también al ministerio del Interior, a la policía Federal, a la Liga Argentina, a la Asamblea, la Cruz Roja, llevando nuestros datos, nuestros testimonios. En la policía Federal nos decía eso, que se iban a empezar a publicar las listas a medida que la gente empiece a aparecer, entonces es la gran expectativa, todavía no nos movilizábamos, simplemente era recoger datos, enviar notas, al ministro del interior, al Obispo, Jaime Nevares, a Monseñor Zaspe...» ${ }^{348}$

Una frase del refranero popular de aquellos años en Tucumán explica con certeza el clima represivo y de miedo que se vivía: "Sonríe, Bussi te ignora". Esta afirmación implicaba que si las fuerzas del orden, encarnadas en la figura del dictador, desconocían las actividades de los ciudadanos, nada había que temer. Sin embargo, los familiares, activos militantes en la búsqueda de los detenidos desaparecidos, estaban permanentemente expuestos a persecuciones, amenazas e incluso al secuestro mismo para atemorizarlos y paralizarlos en la búsqueda. Alguno de los entrevistados sostiene, en este sentido, que tenían la sensación de haber sido vigilados en la Iglesia donde se congregaban y que en variadas ocasiones sospechaban que sus charlas eran escuchadas por medio de micrófonos ocultos en el interior de la sala de reunión.

Es así como transcurrieron los primeros años de acción, en los que no faltaron disputas internas, acciones públicas que, aunque limitadas, comenzaban a emular a las realizadas en la ciudad de Buenos Aires. De todas formas, no sería hasta bien entrado 1981 en que el movimiento ${ }^{348}$ Testimonio de Carlos Soldati. 
tucumano especifique acciones de exposición públicas concretas como las rondas alrededor de la plaza pública. En este sentido, como veremos más adelante, la ruptura al interior de Familiares, tendrá entre sus principales causas, la decisión de no marchar en Plaza Independencia semanalmente, como lo hacían las Madres en la capital.

\section{VIII.2 LA VISITA de LA Comisión InTERAMERICANA de DeRechos Humanos. UN PUNTO DE INFLEXIÓN}

1979 fue un año clave para el MDHT por la visita de la Comisión Interamericana de Derechos Humanos de la Organización de Estados Americanos $(\mathrm{CIDH})$ que resultaría de trascendental importancia tanto para la coyuntura local del propio movimiento como para el desarrollo de la dictadura ${ }^{349}$.

Según consta en el propio informe de la Comisión, el Estado argentino "por nota de 18 de diciembre de 1978, extendió a la misma una invitación para realizar esta observación in loco, en un todo de acuerdo con las normas reglamentarias pertinentes, la cual originalmente se fijó, de común acuerdo, para el mes de mayo de 1979". ${ }^{350}$ Sin embargo, en razón de los cambios que se produjeron en la $\mathrm{CIDH}$ como consecuencia de la entrada en vigencia de la Convención Americana sobre Derechos Humanos, fue necesario aplazar esta visita, la cual se efectuó en definitiva entre el 6 y el 20 de septiembre de 1979. El organismo internacional estaba constituido por juristas de todo el continente elegidos por sus antecedentes en el campo de la defensa de los derechos humanos.

\footnotetext{
349 http://www.cidh.org/countryrep/Argentina80sp/introduccion.htm\#B. [Artículo consultado en febrero de 2008].

350 Ibídem.
} 
Si bien los militantes expresan que la inspección de dicha comisión había sido importante para poder denunciar internacionalmente lo que sucedía en el país, tienen la sospecha de que la llegada de sus integrantes, en realidad, aceleró el proceso de desaparición de sus familiares ya que la dictadura procuró borrar las posibles huellas de los detenidos ilegalmente. En este sentido un dato importante es la sanción de la Ley 22.068, previa a la visita de la Comisión, por medio de la cual se establecía la presunción de fallecimiento de los desaparecidos. ${ }^{351}$ Los abogados que llevan hoy las causas por los crímenes de la dictadura, presumen (aún hoy esto es materia de investigación) que la mayoría de las desapariciones finales de los detenidos se produjeron, por lo menos en Tucumán, meses antes del arribo a la provincia de la Comisión. Es lo que busca establecer, por ejemplo, la abogada Laura Figueroa, cuando manifiesta la necesidad de revelar el circuito de muerte en Tucumán, es decir, saber a ciencia cierta dónde fueron ejecutados los detenidos y en qué momento.

Sobre la visita de la Comisión de la OEA, Soldati expone:

«...vino la Comisión de la OEA en el año 1979, con mucha esperanza, porque hasta aquí no se sabía nada, para ver si con el contacto con el gobierno ellos podían averiguar algo, tener alguna noticia sobre los desaparecidos. Vino un grupo a Tucumán, recogió las denuncias, y se fueron. En realidad la visita de la Comisión de la OEA sirvió para dar espacio en los diarios el tema de los desaparecidos, porque hasta ese momento en los diarios poco y nada se decía, y aquí en Tucumán nada, en La Gaceta. Eso sí, se conoció el problema,

351 Sonderégtuer, Maria (1985): Aparición con Vida (El movimiento de derechos humanos en Argentina), en Jelín Elizabeth: Los nuevos movimientos sociales, Op. Cit. 
ya nadie podía ignorar eso, porque apareció en los titulares de los diarios, pero desde la expectativa que uno tenía, de aparición con vida, la visita de la OEA fue el golpe duro que recibimos porque encontraron cárceles secretas, lugares clandestinos de detención pero... vacíos, entonces ya comenzó a crecer esa sospecha y ese temor que siempre estaba que pudieran no estar vivos los desaparecidos. ${ }^{352}$

Vilma Ibáñez por su parte no esconde las expectativas que había generado la visita Internacional de la Comisión Interamericana:

«Si bien yo personalmente tenía esperanzas cuando fue lo de la OEA que vino acá a la calle Crisóstomo Álvarez y 9 de Julio, al Hotel Versalles, recuerdo que decían que había micrófonos ahí, aunque después para mi ha sido todo una mentira eso, para mi que fue todo un engaño... $>^{353}$

Esta misma idea sostiene Ricardo Arédez Márquez, hijo de Olga Márquez de Arédez, integrante del movimiento de Madres de Desaparecidos de la provincia de Jujuy, quien en una carta expresaba que la "presencia de funcionarios de la empresa Ledesma ${ }^{354}$, convenció de que no sería fácil nuestra presentación, el miedo era general, y más aún cuando detectamos que nos estaban filmando desde una de las ventanas de un conocido hotel a todos los que estábamos en la fila, por

352 Testimonio de Carlos Soldati.

353 Testimonio de Vilma Ibáñez [Entrevista realizada por el autor en Tucumán el 22 de noviembre de 2007].

354 Ledesma es una de las más importantes fábricas azucareras del Noroeste argentino, ubicada en la provincia de Jujuy, donde se vivió una feroz represión durante la dictadura militar. En un operativo que se conoce como la noche del apagón, fue secuestrado y desaparecido el esposo de Olga Márquez de Arédez. Esto impulsó a la mujer a militar en el movimiento de Madres de Plaza de Mayo de Jujuy. 
supuesto que esto lo denunciamos a los abogados de la CIDH, y ellos se metieron al hotel y responsabilizaron a sus dueños de esta acción." ${ }^{355}$

Rosa Nassif, explica sobre la llegada de la OEA:

«En Buenos Aires hubo una idea que los desaparecidos estaban vivos hasta que llegó la OEA. Lo que pasa es que la venida de la OEA precipita la liquidación después... es que cuando llega la OEA la dictadura tenía el temor o la idea de que podía haber inspecciones, hasta ahora hay algunos relatos de gente, sobre todo los de la ESMA, que a algunos se los dejaba salir y volver, es decir que estaban vivos, y hay un momento en que deciden que hay que liquidarlos y que debían desaparecer, no podía haber pruebas de la existencia de campos de concentración. Lo de la OEA en ese momento fue muy importante, es decir se centró el debate de los organismos de si se podían aprovechar las contradicciones que había en ese momento entre el gobierno de Carter y la dictadura, que tenía un peso muy importante el sector vinculado a los rusos en ese momento... nosotros empujamos a aprovechar esas contradicciones y es la primera vez que a nivel internacional quedan registros que aquí había desaparecidos. ${ }^{356}$

De la percepción que los propios militantes tienen lo más importante que dejó la visita de la Comisión de la OEA al país han sido sus conclusiones sobre la violación sistemática de los derechos humanos desde comenzada la dictadura militar y una nueva posibilidad de difundir

${ }^{355}$ Extracto de la carta leída por Ricardo Arédez Márquez en la marcha a 29 años de "La Noche del Apagón", el 28 de julio de 2005, hijo de Olga Márquez de Arédez, integrante de Madres de Plaza de Mayo de Jujuy y fallecida un año antes. En www.segundoenfoque.com.ar/palabrasaredez.doc (Artículo consultado en febrero de 2008).

356 Testimonio de Rosa Nassif [Entrevista realizada por el autor el 6 de diciembre de 2007]. 
en el exterior lo que sucedía en Argentina y los crímenes del Proceso. El número total de denuncias que recibió durante su estancia en Argentina fue de 5.580, de las cuales 4.153 eran nuevas denuncias y 1.261 comunicaciones se referían a casos ya registrados y que estaban en trámite. ${ }^{357}$ La Comisión establecía una serie de recomendaciones que por su tenor eran rechazadas por el gobierno militar. ${ }^{358}$ Entre los principales planteos de la $\mathrm{CIDH}$ se destacan la necesidad de investigación, enjuiciamiento y sanción de los responsables de las muertes, información sobre el destino de los desaparecidos, la investigación de las denuncias de torturas y sanción de los responsables, como así también el restablecimiento de una extensa lista de las libertades civiles y políticas. ${ }^{359}$

357 Informe de la Comisión Interamericana de Derechos Humanos de la Organización de Estados Americanos (OEA) del 14 de diciembre de 1979. http://www.cidh.org/countryrep/Argentina80sp/indice.htm

[Documento consultado en enero de 2008].

358 Sonderégtuer, Maria, Aparición con Vida, Op. Cit.

359 http://www.cidh.org/countryrep/Argentina80sp/. 
HISTORIA Y MEMORIA DEL MOVIMIENTO DE DERECHOS HUMANOS DE TUCUMÁN (1977 - 1999)

CAPÍTULO VIII: LOS ORÍGENES DEL MOVIMIENTO DE DERECHOS HUMANOS EN TUCUMÁN: DE

"FAMILIARES" A "MADRES"

\section{VIII.3 De LA INMOVILIDAD de FAMILIARES AL SURGIMIENTO DE MADRES EN} TUCUMÁN. LA PRIMERA RUPTURA

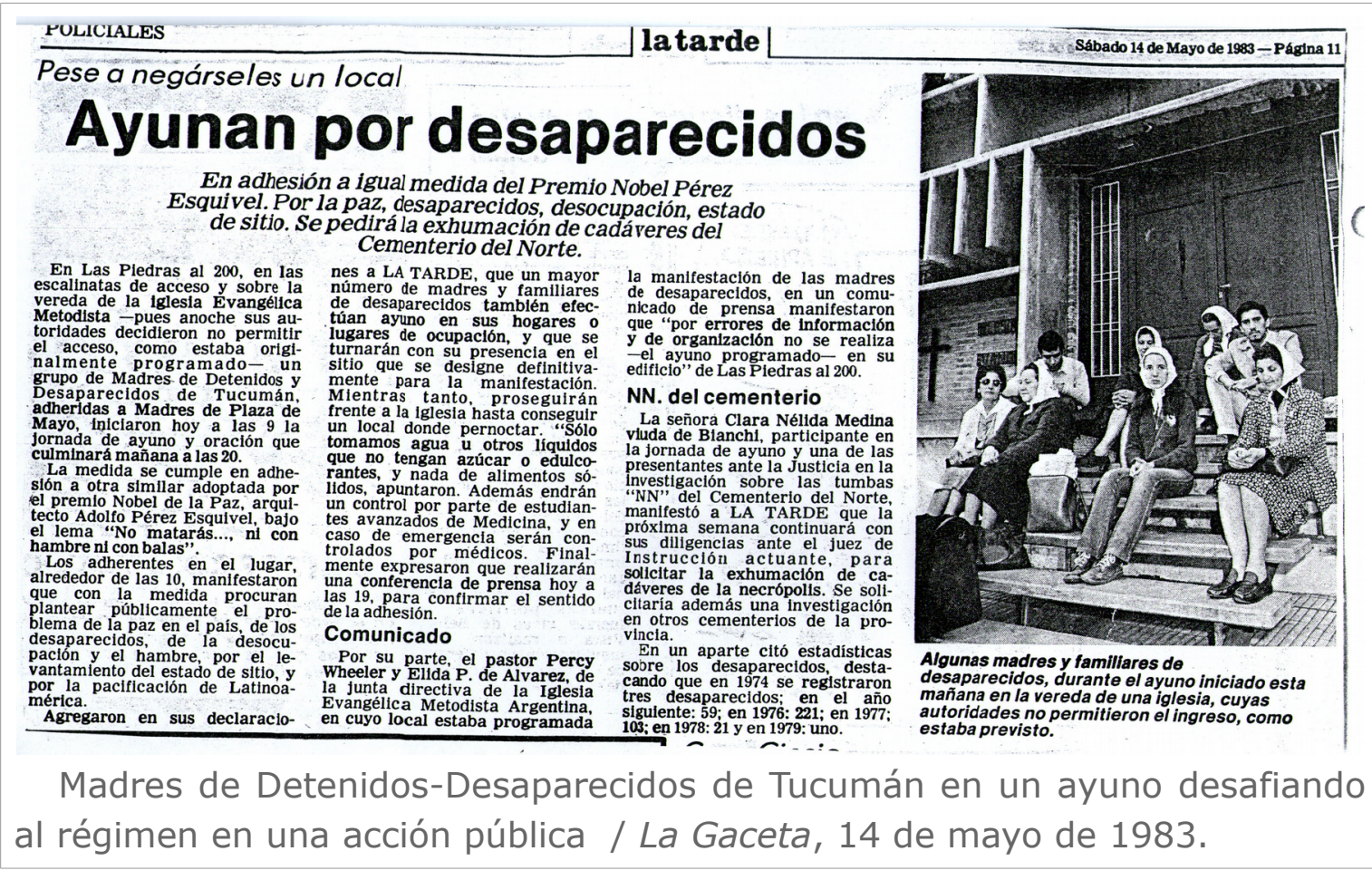

Si las expectativas de los miembros de Familiares sobre la posible aparición con vida se diluía en la "presunción de muerte" de los secuestrados, muchos de sus integrantes comenzaron a realizar planteos internos respecto de la inmovilidad del organismo, que, con el comienzo de la década del '80 y animados por las manifestaciones públicas de Madres de Plaza de Mayo en Buenos Aires, provocará una primera fractura interior. Esta división de Familiares en Tucumán se concretará durante 1981, tomando forma una nueva agrupación que seguía los pasos de Madres de Plaza de Mayo, liderada en la capital del país por Hebe de Bonafini.

El 10 de septiembre de 1981 quedó oficialmente constituido el Movimiento de Madres de Detenidos - Desaparecidos de Tucumán, un 
grupo de mujeres que alejadas de Familiares comienza a reunirse semanalmente en la Iglesia de Fátima, acogidas por su cura, el Padre "Lalo" Amato Pérez. ${ }^{360}$ En el documento de su fundación, tras situar sus orígenes en el grupo que se reunía en la Iglesia del Sagrado Corazón, este nuevo organismo explicaba los motivos de su separación, en relación a Familiares, afirmando que según transcurría el tiempo y al ver "la total ineficacia de su accionar" se fueron desalentando ${ }^{361}$.

El documento continúa afirmando:

"Nos sustrajo de él la valiente y esclarecida actuación de las Madres de Plaza de Mayo con las que nos pusimos en contacto. Los actos y tareas que Ilevaban a cabo, la lectura de sus publicaciones nos hizo ver que coincidíamos en nuestros propósitos así como en cuáles eran los medios más eficaces para llevarlos a cabo. Decidimos sumar nuestros esfuerzos a los suyos colaborando en todo lo que nos permitían nuestros medios y la distancia, como hasta aquí lo hicimos. Pero convencidas de que un mal Nacional debe suscitar con el propósito de remediarlo, un accionar también Nacional al margen del cual no quede ninguna zona del país, hemos resuelto constituir esta comisión en Tucumán que se propone trabajar al unísono con las Asociación Madres de Plaza de Mayo que su posición será la hasta ahora sustentada."362

Con respecto a las diferencias aludidas entre Familiares y Madres en Tucumán, Sara Mrad explica su visión:

\footnotetext{
360 Sobre la historia de este movimiento léase Kotler, Rubén, Los movimiento sociales, formas de resistencia a la dictadura, Op. Cit.

361 Acta fundacional del Movimiento de Madres de Detenidos Desaparecidos de Tucumán.

362 Acta Fundacional, Cit.
} 
«Como en Buenos Aires, las madres somos más de lo callejero, de lo público que de lo administrativo burocrático, y las otras organizaciones no, y ya para esa época las Madres empezábamos a indicar la lucha de los desaparecidos, empezábamos ya a plantear el reconocerlos como revolucionarios como luchadores populares y que otras organizaciones por ahí todavía tenían miedo de decir, no si mi hijo era un luchador, en general, hasta ese momento, primaba esto que no hacían nada. ${ }^{363}$

En algunos casos, los integrantes de una misma familia se dividían, y mientras algunos seguían reuniéndose en la Iglesia del Sagrado Corazón, otros decidieron concurrir a las reuniones de las Madres. Es el caso de la propia Sara, cuya hermana desaparecida, motivó que tanto su madre como ella misma militaran en ambas agrupaciones. Lo paradójico es que mientras la madre de Sara continuaba asistiendo a las reuniones de Familiares, por una decisión política, su hija decidió comenzar a encontrarse con el grupo de Madres que frecuentaban la iglesia de Fátima. Esto lo explica ella misma:

«Cuando comenzamos a sentir más la disconformidad acá, y empezamos a ver todas las actividades de Madres allá en Buenos Aires, se empieza a querer salir a la calle y se arma otro grupo paralelo porque Familiares no salía a la calle. La

363 Testimonio de Sara Mrad. Nótese que en el testimonio, Sara habla de la organización en Buenos Aires como posicionándose ella misma dentro de dicha organización. La primera vez que entrevisté a Sara, con motivo de mi investigación sobre Madres de Desaparecidos de Tucumán, en 1997, se posicionaba como miembro de la organización local. 10 años después, y tras quedar ella sola sosteniendo la filial tucumana, como filial de las Madres de Buenos Aires, parte de su discurso cambió y ahora refiere a la organización porteña, haciendo una traslación geográfica de su propia experiencia. El "nosotras" es ahora para Sara, la experiencia de las madres en Buenos Aires, en un claro gesto de identificación con la organización central de la cual ella misma depende. 
única salida a la calle que recuerdo como Familiares y que no fue salida a la calle, fue cuando vino la Comisión de la OEA en 1979, esa es la que yo recuerdo. Por ahí Marta Rondoletto me habló de una marcha en 1978, yo no me recuerdo de que hayan hecho ninguna marcha, no recuerdo una actividad pública de Familiares, tanto que cuando nosotras las planteábamos, ellos tenían mucho recelo en salir. Por miedo por un lado, y por resistencia a la posición de Madres por otro. Mi mamá sin embargo seguía yendo a las reuniones de Familiares y yo iba a las reuniones de Madres. Igual mi mamá cuando había alguna actividad de Madres, ella se ponía el pañuelo y todo, ella también tenía su pañuelo blanco... lo que pasa con mi mamá es que ella era como muy retraída y como que al tener ella una estructura de familia bastante patriarcal, además que mi papá siempre le decía como ella iba a andar en la calle, entonces ella como que se debatía entre lo que le dictaba su corazón y lo que mi papá un poco, la sometía de alguna manera... y bueno, le costó mucho romper...»364

Una vez más vemos aquí que el recuerdo del pasado está teñido del propio presente de los activistas. Por una parte Sara reprocha el hecho de que Familiares, en sus primeros años, no se manifestara públicamente al tiempo de dejar en claro que fue motivo suficiente para separarse y conformar una nueva organización que recuperara la tradición de Madres en Buenos Aires. Por otra parte, lo que refleja el testimonio precedente es el equilibrio que se daba en cada familia donde, como ya expresé anteriormente, las divisiones de tareas estaban claramente establecidas.

Otro de los militantes que dejará desilusionado Familiares, será Carlos Soldati quien recuerda su paso a Madres: 
«En Familiares llega un momento, no recuerdo bien en qué año, puede haber sido quizás año 1980 o 1981 que me voy de Familiares, yo estaba a cargo de la recepción de todos los testimonios, teníamos las reuniones semanales, pero yo quería ir un poco más allá de las notas y de las misas, entonces salir a la calle y manifestar y ahí nos pedían prudencia, pero también creo que era la línea de la Liga Argentina por los Derechos del Hombre, es decir, nos acogían, nos respaldaba, nos apoyaba, pero que había que ser prudentes y que todo a su tiempo, porque pese a todo lo que estaba ocurriendo, Videla era el general democrático entre comillas, o el menos malo, y que había que cuidarse del golpe pinochetista, de un Benjamín Menéndez o de un Juárez Mason, y no complicar las cosas... entonces nos demoraban en la salida. En una marcha por la vida en el año 1982 finalmente salimos, pero ya a esta altura yo estaba en el grupo de Madres, que era un grupo muy pequeño y menos organizado que el grupo de familiares, en definitiva, yo termino yéndome, pero trabajando en estrecho contacto con todos. ${ }^{365}$

La incorporación de Soldati, como la de otros miembros en el movimiento de Madres de Detenidos Desaparecidos de Tucumán, se produce el 30 de abril de 1982 y es cuando el grupo adherido a Madres de Plaza de Mayo conseguía aumentar sus miembros, lo que equivalía, en definitiva, a capacidad organizativa. ${ }^{366}$

Algunos miembros de los partidos de izquierda también colaboraron, en esos años, con esta línea de Madres, ya por afinidad política, ya por coincidencias en las acciones públicas. Ángela Nassif, 365 Testimonio de Carlos Soldati.

366 Libro de Actas del Movimiento de Madres de Detenidos Desaparecidos. Acta número 27. 
dirigente del Partido Comunista Revolucionario, había tenido hacia fines de los años '60 y comienzos de los '70 una activa participación en los movimientos de protesta obrero estudiantil de los Tucumanazos, ya mencionados. A comienzo de los '80, Ángela se convierte desde el mismo partido en el cual militaba en una de las más activas colaboradoras de Madres de Detenidos Desaparecidos.

Nassif recuerda que su paso por Madres se debía a la escasez en el número de militantes con que contaba el organismo y, sobre todo, por la afinidad ideológica:

«Cuando vino la comisión de la OEA yo trabajaba con la que ahora es presidenta de Madres de Plaza de Mayo, Sarita Mrad y con Carlos Soldati. Con ellos recorrimos el interior para recoger testimonios porque la gente no venía a la ciudad. Entonces viajábamos al interior de la provincia tomando testimonios directos de la gente. La gente tenía mucho miedo de venir a hacer la denuncia». 367

Tras la derrota militar en la guerra de Malvinas, el clima político argentino se fue distendiendo, producto del ciclo de crisis económica junto a los cada vez más constantes reclamos de los sindicatos que dejaban al descubierto las insolvencias del gobierno de facto. La guerra en Malvinas había sido un fatal intento de fuga hacia delante por parte del entonces presidente de facto Leopoldo F. Galtieri que no hizo sino poner en evidencia las falencias del régimen. Esta distensión permitió una mayor apertura en el movimiento de derechos humanos y así como Madres rompe con Familiares en la necesidad de una mayor presencia pública, también comienzan a plantearse nuevas estrategias vinculadas con el enfrentamiento directo a la dictadura. Aunque el miedo no había

367 Testimonio de Ángela Nassif, ex dirigente del Partido Comunista Revolucionario [Entrevista realizada por el autor el 6 de diciembre de 2007]. 
desaparecido, a mediados de 1982 Madres de Detenidos - Desaparecidos de Tucumán muestra entonces una mayor ocupación del espacio público, quedando al fin institucionalizadas las rondas en la Plaza Independencia.

Esta ocupación de la plaza pública, además, sirvió para que otros miembros de Familiares decidieran concurrir a las reuniones del nuevo organismo, marcándose cada vez más las diferencias, quizás no tanto políticas, como si estratégicas y de metodología en la acción. Las diferencias políticas y de acción, que se irán profundizando junto a las líneas de trabajo de Madres y de Familiares, si bien por momentos se conjugan, en realidad recorren un camino casi paralelo. Como ya dije, uno de los motivos de la división había sido la falta de presencia pública de Familiares.

Un claro ejemplo de estas diferencias se observa ante la visita a Tucumán del dirigente del Servicio de Paz y Justicia (SERPAJ) Adolfo Pérez Esquivel. En el marco de dicha visita, el 12 de noviembre de 1982 se organizan las actividades de la jornada que finaliza con un acto público en el Club Estudiantes. Aunque se coordinan algunas actividades con Familiares, Madres denuncia en una reunión que el organismo que se reúne en la Iglesia del Sagrado Corazón está de acuerdo en asistir a los actos públicos pero no en participar de la difusión previa con "volanteadas ${ }^{368}$ y pegatinas en el centro de la ciudad." Las Madres resumían su queja afirmando que toda la difusión correría a cuenta de ellas y el SERPAJ sin colaboración de Familiares. ${ }^{369}$

Aunque las salidas a la calle en Tucumán se hacían más complicadas que en Buenos Aires por el control de la dictadura en la

\footnotetext{
368 El término volanteada es ampliamente utilizado por militantes y hace referencia a la entrega en la vía pública de panfletos o también llamados volantes.

369 Acta Número 31, Libro de Actas, Cit.
} 
provincia, esto no atemorizaba al organismo de Madres para buscar una acción distinta a la de Familiares. Sobre la visita de Pérez Esquivel en concreto Nassif explicaba que:

«Cuando se hace la visita de Pérez Esquivel, esto ya en el año ' 82 , se hizo una movilización muy grande de la gente y él -refiriéndose al premio Nóbel de la Paz - no quiso participar de la marcha». ${ }^{370}$

En una reunión posterior, el 2 de diciembre, con motivo de organizarse el acto del 10 de diciembre, por el día de los derechos humanos, Madres expresa que Familiares intentaba modificar el programa previsto, por expresa directiva de su presidenta, Carmen de Mitrovich, para dejar de lado la marcha, una vez concluida la misa, y que las organizaciones de derechos humanos se dirijan directamente al Club Huracán BB donde se desarrollaría un acto público convocado por el Partido Comunista. Por lo tanto Madres decidió entonces no renunciar a organizar la manifestación pública, aún en el caso de tener que realizarla en soledad, pero sin cerrar la vía de negociación con el otro organismo, tratando de persuadirles en la necesidad de participar. El 9 de diciembre, es decir, un día antes de la celebración del acto por el día de los derechos humanos, Madres reiteraba su intención de realizar la manifestación, tal y como finalmente ocurrió. ${ }^{371}$

370 Testimonio de Ángela Nassif.

371 Acta Número 34 y 35, Libro de Actas, Cit. 
HISTORIA Y MEMORIA DEL MOVIMIENTO DE DERECHOS HUMANOS DE TUCUMÁN (1977 - 1999)

CAPÍTULO VIII: LOS ORÍGENES DEL MOVIMIENTO DE DERECHOS HUMANOS EN TUCUMÁN: DE

"FAMILIARES" A "MADRES"

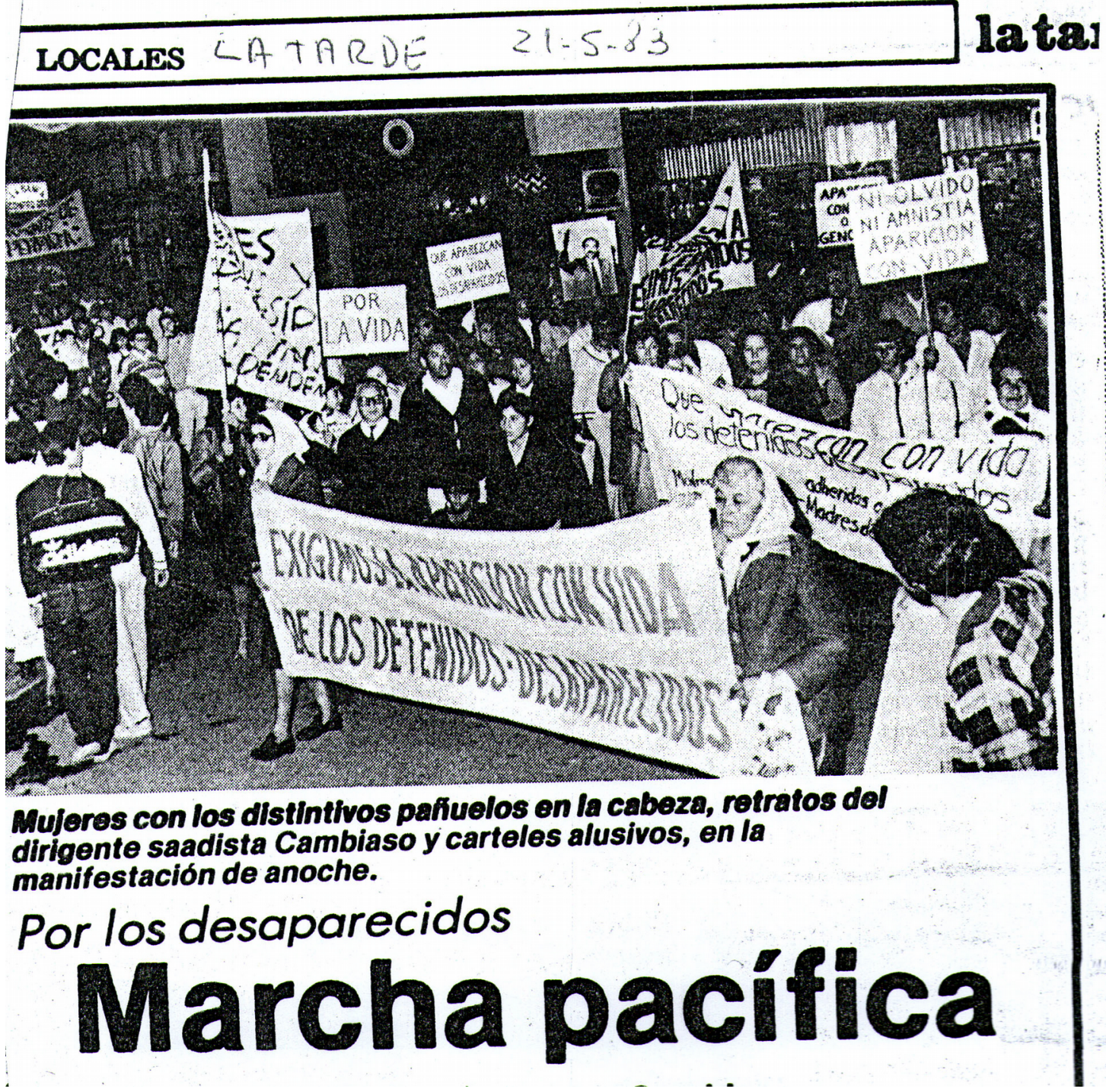

En un clima de distención de la dictadura el movimiento de derechos humanos de Tucumán se manifiesta públicamente / La Tarde, 21 de mayo de 1983.

El clima de distensión se observa también por la intensa actividad política a lo largo y ancho de todo el país, cuando después de la derrota en Malvinas comienza a hablarse de la transición. La dictadura, que había apostado fuerte por perpetuarse en el poder, de repente se veía acorralada y deslegitimada en su accionar. Una de las campañas que más 
recordarán los militantes, sobre todo de Madres, es aquella que decía: "Las Malvinas son argentinas, los Desaparecidos también", dejando en claro la posición del organismo sobre la derrota militar en el intento de recuperar las islas, y que no debía cejar en el reclamo central del movimiento: la aparición con vida de los desaparecidos.

La visita a Tucumán de Raúl Alfonsín como presidente de la APDH y candidato del Partido Radical a la presidencia del país, el 14 de octubre de 1982, fortalecía al MDHT, dándole un espaldarazo y volviendo a poner sobre el debate público la necesidad de volcar el reclamo por los principios de "verdad y justicia" y de "aparición con vida", que, tanto desde Madres como desde Familiares, se levantaban como banderas. Ante la presencia de los familiares, Alfonsín lanzaba en Tucumán a modo de proclama lo que serían sus principales consignas ante la campaña electoral del año siguiente:

«Un país en el cual no se hace justicia es un país que no tiene futuro, que está quebrado en el fundamento mismo de su existencia (...) A esta altura ya no buscamos mera información, como un intento de brindar consuelo a una familia, y pasemos a otra cosa. Nosotros pedimos justicia, y justicia es una noción muy rica. Significa, para el caso de los desaparecidos: Si están con vida, si hay uno con vida, que se le deje en libertad. Si están muertos, que se investigue, se juzgue, y se sancione a los responsables». ${ }^{372}$

Los dichos de Alfonsín generaban gran expectativa en el movimiento de Tucumán, esperanzas que cuatro años después, con la sanción de las Leyes de Punto Final y Obediencia Debida se darían contra una pared y serían vistas como una claudicación del dirigente radical. De

372 Periódico Renovación, órgano del Partido Unión Cívica Radical, 15 de Octubre de 1982. 
lo que queda del año 1982 y la primera parte de 1983, el movimiento repetirá una y otra vez las marchas encabezadas por Madres en reclamo por los desaparecidos aunque a diferencia de los años anteriores, éstas marchas serían secundadas por las juventudes políticas que poco a poco comenzaban a tener nuevamente protagonismo en los centros estudiantiles de las distintas facultades.

Sobre este periodo de transición Vilma Ribero de Ibáñez recuerda:

«Teníamos esperanza con Alfonsín, teníamos esperanzas... pero después vinieron las leyes y Menem y fracaso tras fracaso...» $\gg^{373}$

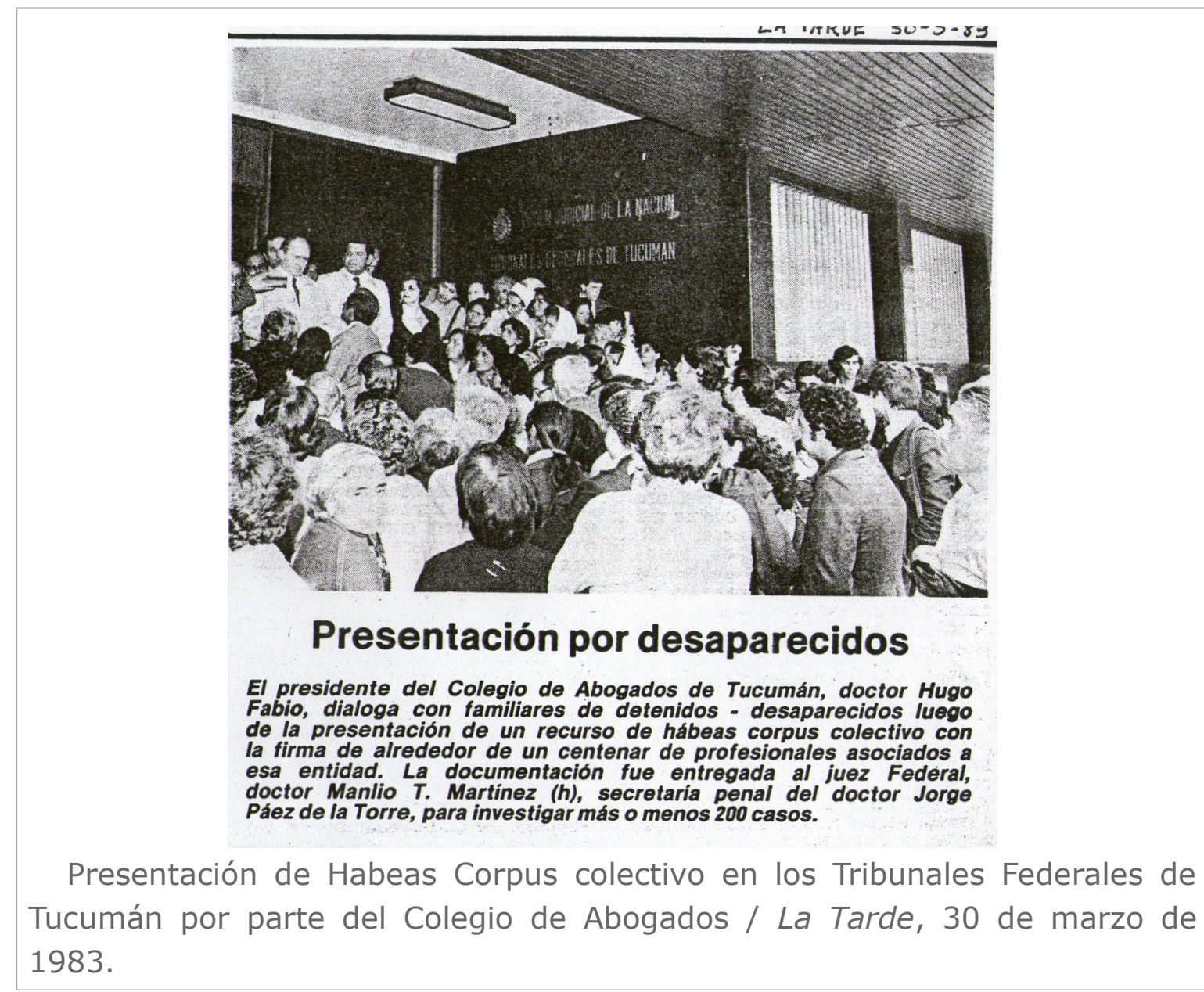

373 Testimonio de Vilma Ibáñez [Entrevista realizada por el autor el 22 de noviembre de 2007]. 


\section{VIII.4 La aparición de La Asociación de Abogados por los Derechos}

\section{HUMANOS Y LA APDH EN LA LARGA TRANSICIÓN VIGILADA}

\section{Homenaje a abogados}

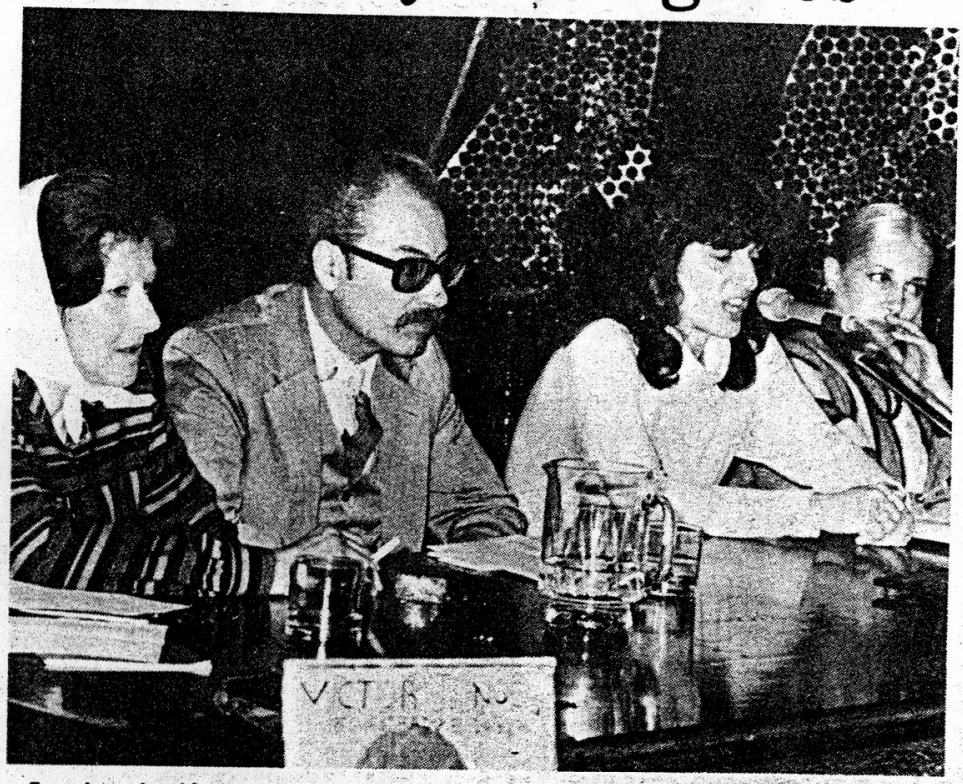

La Asociación de Abogados por los Derechos Humanos efectú profesionales del foro tucumano, muertos y desaparecidos los recordación formo parte de los actos de la Semana del Abogado.

$$
\angle A \text { GACETA } \quad 8-9-84
$$

La Asociación de Abogados por los Derechos Humanos rinden homenaje a sus colegas represaliados/ La Gaceta, 8 de septiembre de 1984.

La apertura democrática no solo no contribuyó a acercar más a los organismos entre sí, sino que las diferencias se evidenciaron mucho más aún. Aparecieron nuevas organizaciones en Tucumán como la Asociación de Abogados por los Derechos Humanos y la Asamblea Permanente por los Derechos Humanos (APDH), que, si bien respondía a los criterios de su homónima de Buenos Aires, no dejaba de actuar según los criterios propios de sus integrantes locales. 
El grupo de Abogados por los Derechos Humanos se constituyó en Tucumán el 10 de diciembre de 1983, día en que asumía la presidencia del país Raúl Alfonsín y que daba comienzo a la llamada transición democrática.

Laura Figueroa, una de las fundadoras del grupo, recuerda sus inicios:

«Cuando me recibo, mi objetivo era ser abogada laboralista, defensora de los sectores obreros, y de esa manera poner a disposición de uno de los sectores más castigados, que es la clase obrera, el título que la Universidad me daba. Yo me recibo de abogada en 1981, todavía bajo el proceso militar y empiezo a hacer mi especialidad en derecho laboral, había comenzado a incursionar ya en casos cuando viene a Tucumán Luis Zamora, que era miembro del CELS ${ }^{374}$ en Buenos Aires, entonces los organismos de derechos humanos piden acá una entrevista con Luis Zamora, que en ese momento era candidato a presidente por el $\mathrm{MAS}^{375}$ y le piden que se formara en Tucumán algo parecido al CELS. Zamora dice que no era posible y yo justo estaba en el local del MAS y me llaman para decirme que los organismos estaban planteando esto. Los que yo recuerdo que estaban Carmen de Mitrovich, de Familiares de Desaparecidos y Presos por Razones Políticas, también si no recuerdo mal estaba Graciela González, estaban Pascual Ariño y Dardo Molina, que eran afectados porque uno es hermano y el otro es hijo de desaparecidos, y honestamente no recuerdo a más nadie; se que eran varios. Entonces Luis Zamora, en un acto poco democrático me tira al ruedo de que yo agarre la posta

374 El CELS es el Centro de Estudios Legales y Sociales, muy vinculado al movimiento de derechos humanos.

375 MAS, partido de extracción trotskista: Movimiento Al Socialismo. 
y la verdad que no estaba en mis cálculos políticos el trabajar sobre este tema, más allá que yo, como todo militante, estaba consubstanciada y en lo que podía participaba de actividades. Las organizaciones que estaban presentes me dijeron que tratara de organizar algo en Tucumán, así es como tomo contacto con algunos abogados, y me acuerdo perfectamente cuando hablo con dos abogadas, una es Liliana Vitar, actual camarista de la provincia, y Alicia Noli, actual jueza Federal, y me dicen: justo estábamos nosotras en lo mismo, estábamos pensando formar algo. Ahí se había comprometido también Pascual Ariño que también es abogado, aunque nunca llevó ninguna causa salvo la de su hermano, y llegamos a juntar 22 abogados y logramos largar la Asociación de Abogados por los Derechos Humanos de Tucumán el 10 de diciembre de 1983 haciendo coincidir con el día internacional de los derechos humanos». ${ }^{376}$

Del grupo inicial de 22 abogados, también formó parte la actual jueza Alicia Sánchez de Noli, quien junto a Liliana Vitar quedarían trabajando casi en exclusividad, poco tiempo después de organizada la Asociación, una vez alejados de la agrupación inicial el resto de abogados.

376 Testimonio de Laura Fiegueroa [Entrevista realizada por el autor el 22 de diciembre de 2007]. 


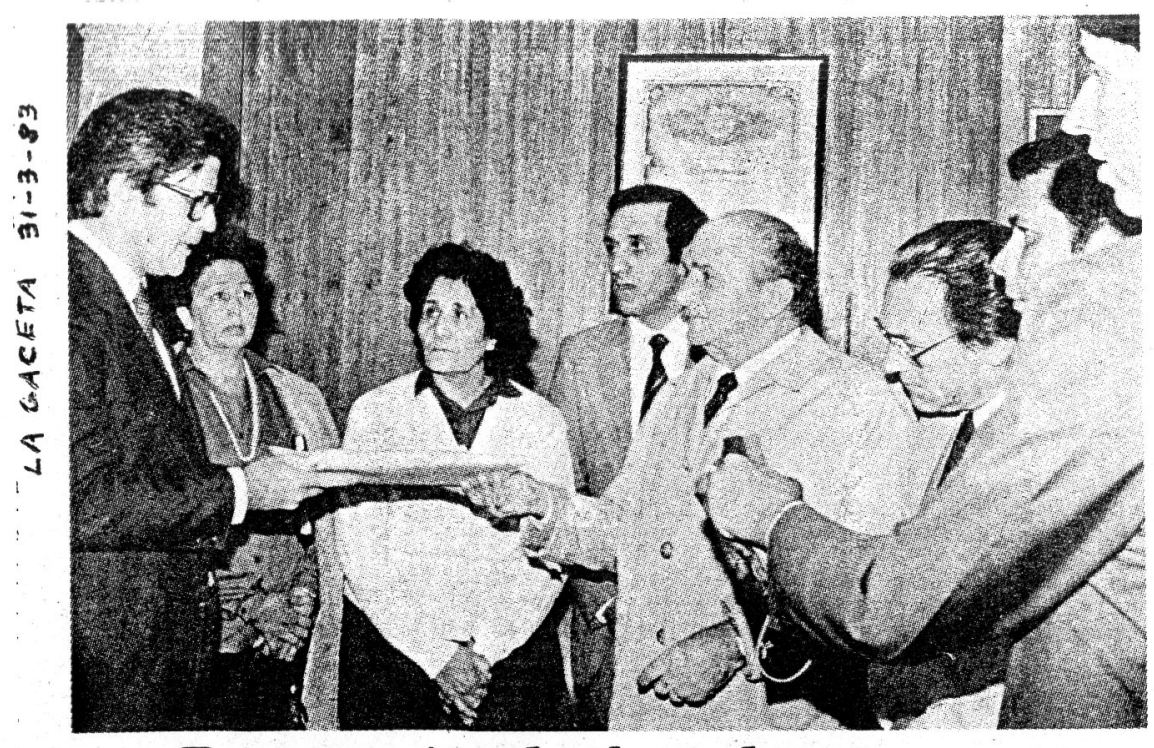

\section{Presentación de abogados}

Miembros del Colegio de Abogados, encabezados por el titular, doctor Hugo $\mathrm{Fablo}$, entregan al juez federal $\mathrm{N}^{\circ} 1$ doctor Manlio $\mathrm{T}$.

Martínez (h), un recurso de hábeas corpus por desaparecidos. En

la puerta de los tribunales federales se reunieron numerosos

familiares de desaparecidos, quilenes conversaron con las autori-

dades del órgano colegiado, poco después de la presentación.

Presentación de Habeas Corpus colectivo en los Tribunales Federales de Tucumán por parte del Colegio de Abogados / La Gaceta, 31de marzo de 1983.

Ya en 1975, Noli había comenzado a reunirse con algunos familiares de represaliados políticos con motivo del secuestro de su hermano. En 1976 es detenido y desaparecido su marido, por lo cual ella debe exiliarse en Buenos Aires primero y en Córdoba después. Durante los años de ese exilio "de cabotaje", como ella misma lo define, mantiene vínculos con Familiares de Desaparecidos, sobre todo durante su estancia en Córdoba. Regresa a Tucumán en el año 1982 y ella es una de las que propone la formación del grupo de abogados:

«Ya con el deshielo de la dictadura, después del desastre de Malvinas, comenzamos a reunirnos en el año 1983 algunos abogados jóvenes en torno al Colegio de Abogados, cuyo presidente era el Dr. Hugo Fabio, y el nos invita a que nos 
reunamos para darnos protección porque éramos muy inseguros; es más, algunos colegas en esa época, a los que habíamos estado exiliados, por ejemplo, colegas que habían estado trabajando en el Estado o que no habían sufrido ningún tipo de persecución, nos miraban con algún recelo, y bueno, el Dr. Fabio nos ofrece la sede del Colegio, y ahí convocamos a la primera reunión de la Asociación de Abogados por los derechos humanos a fines del '83. Era algo totalmente local y te diría que en las primeras reuniones éramos unos 20 abogados. Mucha gente joven, gente que venía de las juventudes políticas, de distintos partidos, por la primavera alfonsinista, la recuperación de la democracia, el Estado de derecho, etc., muy ligado a la necesidad de hacer un reconocimiento a los derechos humanos». 377

Lo que queda claro es que la Asociación de Abogados surge de dos vertientes que por distintos motivos y necesidades variadas, se juntan. Por un lado la figura de Laura Figueroa y la herencia del dirigente nacional del Partido MAS, Luis Zamora, y por otra parte, la de Alicia Noli, cuya filiación con familiares desaparecidos le llevan a conformar un organismo que si bien en su composición era muy distinto del resto, en los primeros años de la transición tuvo una destacada participación, sobre todo en la investigación de los crímenes de Lesa Humanidad ocurridos en la provincia. Una de las tareas fundamentales de esta Asociación fue sin lugar a dudas su colaboración con la Comisión Bicameral Investigadora de las Violaciones de los Derechos Humanos creada en 1984, por orden del Poder Ejecutivo Provincial. ${ }^{378}$

\footnotetext{
377 Testimonio de Alicia Noli [Entrevista realizada por el autor el 28 de noviembre de 2007].

378 Sobre esta Comisión parlamentaria volveré en el capítulo IX porque merece una mención especial en este trabajo.
} 
Por su parte, el papel de Hugo Fabio y su compromiso con los derechos humanos, como presidente del Colegio de Abogados de Tucumán, se explica a partir del secuestro de su hija que había estado detenida en el Centro Clandestino Arsenal Miguel de Azcuénaga, siendo liberada tiempo después. Era entonces una persona afín al MDHT y conocía perfectamente la temática.

Sobre el trabajo de la Asociación, Figueroa explica:

«En el Colegio (de Abogados) comenzamos a recibir a los familiares. Era impresionante la cantidad de gente que se arrimaba y nosotros levantando testimonios y viendo. Con mucha dureza teniendo que explicarles que comenzaríamos por las causas de las que tuviéramos más elementos probatorios, que eso por supuesto le produjo a los familiares mucha angustia al comienzo y después lo entendieron, pero ese criterio fue válido porque nos permitió presentar en la justicia y abrir un camino con elementos que la justicia... bueno, en ese momento los jueces habían sido nombrados por la dictadura, entonces teníamos que ir pisando fuerte. En un año habíamos presentado bastantes causas que eso nos permitió posicionarnos y éramos el único grupo de abogados de Tucumán que llevábamos causas. ${ }^{379}$

Transcurrido el año 1984, muchos integrantes de la Asociación de Abogados se alejan de la misma por diferentes cuestiones y quedan trabajando las tres abogadas que con el tiempo serían recordadas como las abogadas por los derechos humanos: Laura Figueroa, Alicia Noli y Liliana Vitar.

$\overline{379}$ Testimonio de Laura Figueroa. 
Figueroa lo explica diciendo:

«Después del año '84 quedamos solo tres abogadas, el famoso triunvirato, que ha sido un triunvirato muy fuerte y lo concreto es que se ocupó un espacio que golpeó muy fuerte dentro del Poder Judicial, a tal punto que Bussi nos dijo que éramos las tres lobas que aullábamos en los pasillos de tribunales. Esa expresión todavía es recordada por la gente de la época, lo dijo en las radios, en todos lados... no nos nombró, pero nos dijo: que sigan aullando las lobas por los pasillos de tribunales. $\gg^{380}$

El alejamiento de la mayoría de los abogados que conformaban la organización y las diferencias entre las abogadas restantes, sería motivo más que suficiente para que la asociación no prosperara aunque hoy, en el recuerdo de los "viejos militantes" del MDHT, todavía perviven las acciones que llevaron adelante en la defensa de los derechos humanos y en el esclarecimiento de lo ocurrido durante la dictadura.

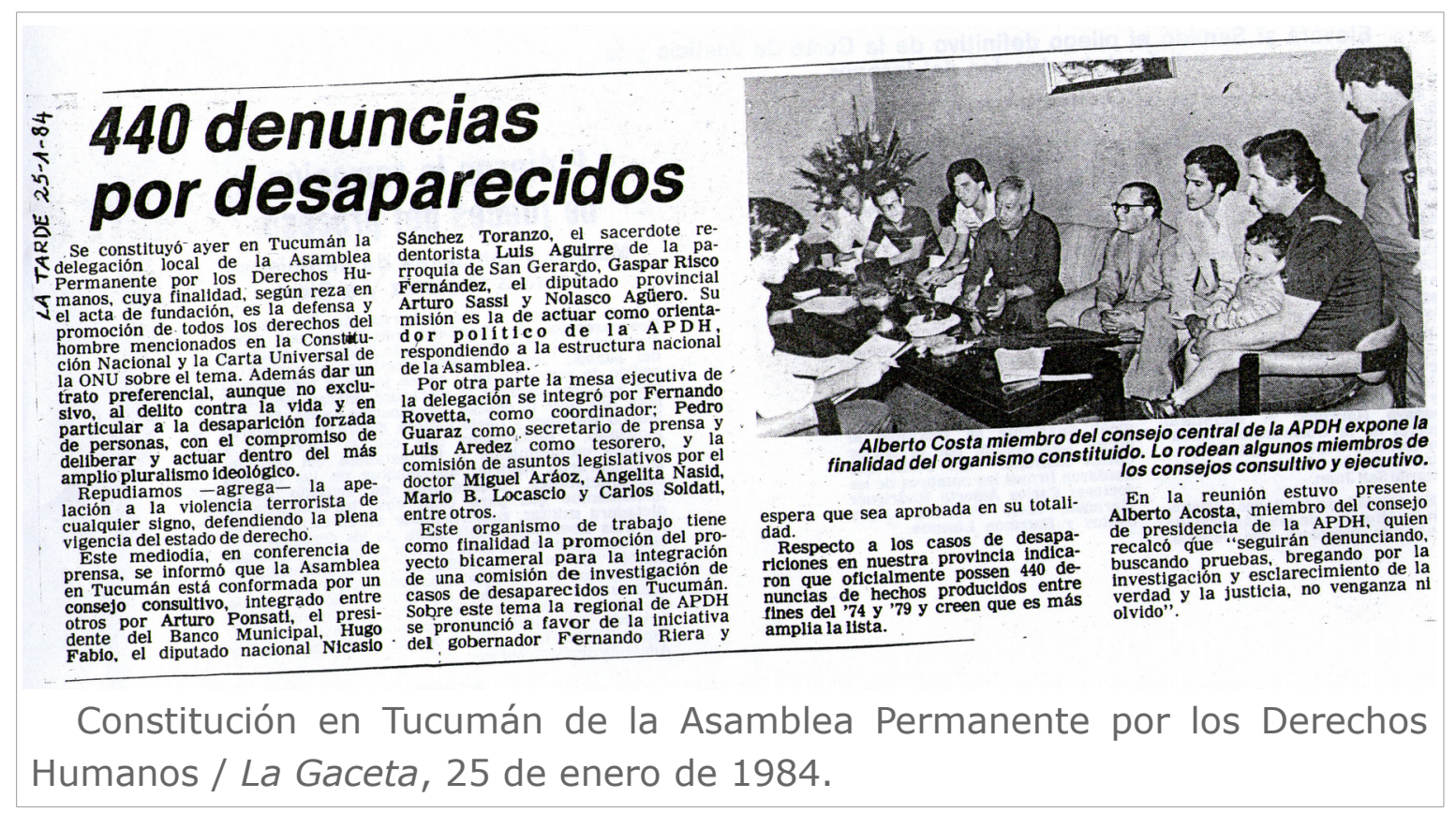

380 Ibídem. 
Casi paralelamente a la formación de la Asociación de Abogados por los Derechos Humanos surge, el 25 de enero de 1984, la Asamblea Permanente por los Derechos Humanos en la provincia de Tucumán. Si bien el organismo aparece tardíamente en la provincia norteña, existían ya tareas de coordinación entre los futuros miembros de la Asamblea y los dirigentes del organismo en Buenos Aires por medio de la celebración de algunas reuniones periódicas.

Del acta de su fundación surge el objetivo de la APDH local en concordancia con su central en Buenos Aires: "la defensa y promoción de los derechos del hombre mencionados en la Constitución Nacional y la Carta Universal de la ONU sobre el tema. Además dar un trato preferencial, aunque no exclusivo, al delito contra la vida y en particular a la desaparición forzada de personas, con el compromiso de deliberar y actuar dentro del más amplio pluralismo ideológico." ${ }^{381}$

En el acta fundacional citada por el diario La Tarde, puede verse también una referencia a la idea que supuso para la APDH la participación de los grupos armados en los años precedentes. La teoría de los dos demonios, sobre la que volveré más adelante, se encarnaba también en la Asamblea local, recogiendo el espíritu del organismo presidido a nivel nacional por Alfonsín. El párrafo más sugerente en este sentido es el que sostiene: "repudiamos la apelación a la violencia terrorista de cualquier signo, defendiendo la plena vigencia del estado de derecho". ${ }^{382}$

Nassif ha sido una de las cofundadoras de la APDH y recuerda su creación después de la visita de uno de los miembros de la APDH Buenos Aires, Carlos Auyero:

381 Diario La Tarde de Tucumán, 25 de enero de 1984.

382 Ibídem. 
«Viene Auyero de Buenos Aires a Tucumán y empieza a buscar a dirigentes políticos y se forma primero lo que era un Consejo Consultivo, porque desde su propia organización era antidemocrática, formada con lo que ellos llamaban personalidades. El organismo no estaba formado por afectados directos de la represión. Creo que en Buenos Aires tampoco. Acá se arma una dirección de eso en 1984. Entre otros estaba Soldati, Rovetta, que juega un papel muy importante en la formación de la APDH, él era de la Democracia Cristiana, Atilio Castagnaro del Partido Intransigente, Ponsatti que estaba en el consejo Consultivo, Guerrero, el Chino Robles, era muy amplio, y nosotros queríamos que sea lo más amplio posible.» ${ }^{383}$

Atilio Castagnaro, presidente de la APDH Tucumán ${ }^{384}$, entra como miembro del organismo en 1985. Su militancia política se vinculaba al Partido Intransigente (PI) y pasa a integrar parte de la comisión directiva de la Asamblea. Castagnaro recuerda que:

«En aquellos años yo militaba en el Partido Intransigente y la APDH aquí en Tucumán estaba constituida por miembros de distintos partidos políticos, entre ellos el PI y yo era el que iba a la APDH en nombre de ese partido. En Tucumán tiene la APDH una fundación muy parecida al de Buenos Aires (...) Supongo que en Tucumán ha comenzado más tarde porque la represión ha sido muy severa que comienza en 1974 $1975 \gg .^{385}$

\footnotetext{
383 Testimonio de Ángela Nassif.

384 Testimonio de Atilio Castagnaro al momento de ser entrevistado, en 2007, era el presidente de la APDH Tucumán y continúa siéndolo. [Entrevista realizada por el autor el 13 de noviembre de 2007 en Tucumán].

385 Testimonio de Atilio Castagnaro.
} 
Otros integrantes del consejo consultivo de la naciente Asamblea tucumana fueron Hugo Fabio (además presidente del colegio de abogados de la provincia, que tenía, como ya dije, importantes vínculos con el movimiento de derechos humanos), el sacerdote redentorista de la parroquia de San Gerardo, Luis Aguirre, el filósofo Gaspar Risco Fernández, entre otros. La mesa ejecutiva estaba integrada, además de Rovetta, por Pedro Guaraz, Luis Arédez y la completaban Miguel Aráoz, la propia Ángela Nassif y Carlos Soldati.

La APDH por sus propias características, permitía participar a gente que estando vinculada a los partidos políticos, sobre todo de izquierda o centro izquierda, no podían acceder fácilmente a los organismos vinculados con la filiación de los desaparecidos. La desconfianza se basaba en el hecho de que en los años de la dictadura no habían faltado casos de militares infiltrados en el movimiento, siendo uno de los más destacados el de Alfredo Astiz, un hombre de la Marina, quien haciéndose pasar por familiar de una víctima en Buenos Aires, se acercó a Madres de Plaza de Mayo e hizo desaparecer, entre otras, a Azucena Villaflor, una de las fundadoras del organismo porteño. ${ }^{386}$

Sobre las dificultades de involucrarse en las organizaciones no teniendo familiares represaliados, Ángela Nassif explica:

«No era fácil entrar en los organismos y más si no tenías un familiar desaparecido. Esto generaba mucha desconfianza. Lo primero que tenías que explicar quién eras y por qué querías entrar. Lo segundo era por qué estabas viva. $Y$ yo les decía que era porque tenía suerte, no se me ocurría decir otra

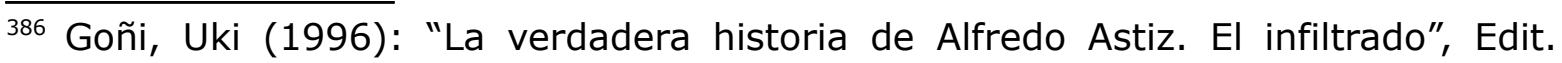
Sudamericana, Buenos Aires. 
cosa, entonces tenías que andar explicando cosas tan absurdas como esas». ${ }^{387}$

El tema de la desconfianza parece recurrente en algunos testimonios, sobre todo de quienes han querido colaborar en el movimiento de derechos humanos pero que no tenían ningún familiar desaparecido. Feierstein ha analizado el tema de la desconfianza a partir de las relaciones sociales que se veían quebrantadas, como un mecanismo que servía al propio engranaje del aparato represivo. El sociólogo afirma que "la desconfianza resultó uno de los modos más eficaces para clausurar las relaciones de reciprocidad y solidaridad. No es posible construir una política crítica o contestataria desde la desconfianza, y de dicha imposibilidad da cuenta la absoluta desestructuración de las fuerzas contestatarias durante la década del ochenta y del noventa". ${ }^{388}$ Habría que agregar que esto ha ocurrido desde los inicios mismos del movimiento de derechos humanos, de ahí también en parte, la fragmentación en tantas organizaciones que no han sido capaces de articular acciones conjuntas de manera más decisiva para hacer frente a objetivos comunes. En este sentido la aparición de organismos como la APDH en Tucumán, permitía participar en la defensa de los derechos humanos a actores que no tenían cabida en los organismos vinculados desde el punto de vista de la relación de parentesco con los represaliados.

Para Carlos Soldati:

«La APDH aparece con una problemática mayor, surgiendo por un tema prioritario, la cuestión de los presos políticos y sobre todo la de los desaparecidos. Se incorporan profesionales, algunos eran estudiantes de filosofía,

387 Testimonio de Ángela Nassif.

388 Feierstein, Daniel, El Genocidio como práctica social, Op. Cit. 
abogados, psicólogos... y bueno, era otro estilo y otra manera. Uno estaba muy jugado en el reclamo por los desaparecidos (...) se incorpora formando el Consejo de la Asamblea gente que era reconocida a nivel político, por ejemplo, aquí estaba Arturo Ponsatti, de la Democracia Cristiana, estaba alguna gente del peronismo, estaba Succar, del socialismo popular, estaban algunos profesores y gente como Antonio Guerrero que era peronista. ${ }^{389}$

La misma pluralidad pretendida en el acta fundacional de la Asamblea, si bien le daba una apertura mayor que la de cualquier otra organización, por las mismas diferencias habría de provocarle con el tiempo alguna crisis interna teniendo en cuenta que en más de una oportunidad les llegaba el reclamo de la central de Buenos Aires por sostener en la provincia posturas distintas a las posiciones mantenidas en la capital. Hay que recordar que la APDH era un organismo con fuertes vinculaciones con el radicalismo y se expresaba, tal como ya se dijo más arriba, en las ideas de su máximo referente y presidente del país. De esta manera la APDH estaba integrada sobre todo por políticos locales, intelectuales y militantes del movimiento que no tenían filiación alguna con los represaliados. Tanto la Asamblea como la Asociación de Abogados y otros organismos menores, ampliaron el espectro del movimiento en Tucumán, abriendo el abanico a todo el marco social de participación en el cuestionamiento del pasado reciente del país en general y de la provincia en particular.

Las organizaciones como la APDH o la Asociación de abogados tuvieron entre sus principales retos hacerse eco del mandato del primer gobernador de la transición en la provincia, Fernando Pedro Riera, del Partido Justicialista (PJ), y gestionar, junto a los otros organismos de 389 Testimonio de Carlos Soldati. 
derechos humanos de Tucumán, la formación de la Comisión Bicameral Investigadora de las violaciones a los derechos humanos que habría de concretarse en el transcurso de ese año 1984. En la primera rueda de prensa convocada el 25 de enero, denunciaban la desaparición de 440 personas entre 1974 y 1979.

Los militantes vivían muy de cerca el proceso político y, tras seis años de una cruenta dictadura militar, sentían como una victoria política el haber conseguido que desde las instituciones del propio Estado se pudiera elaborar un informe parlamentario. Los organismos experimentaban la transición como parte de una lucha, en la que la tarea de unos y otros había sido fundamental para el advenimiento del estado de derecho. Sin embargo, si la aparición de los organismos se vincula con la desaparición de los militantes sociales de los años '70, ciertamente algunos hitos en la historia del país son vividos como verdaderas derrotas políticas.

Mientras las promesas de Alfonsín sobre el tema de los derechos humanos habían generado ciertas expectativas, éstas pronto se diluían al ver que no sólo no se conseguía una comisión parlamentaria nacional que se hiciera responsable de la investigación de los crímenes cometidos, sino que veían en el informe de la CONADEP cierta desilusión, al observar cómo, a pesar de la lucha, triunfaba la línea teórica en la que se equiparaba a víctimas y victimarios, en lo que se conoce como la Teoría de los Dos Demonios. Esta claudicación de Alfonsín, como es sentida por los militantes del movimiento, tendrá su máxima expresión en las llamadas leyes de impunidad, donde se disolverían las esperanzas de que la justicia avanzara en el procesamiento y juzgamiento de todos los responsables de los crímenes de Lesa Humanidad. Así la transición avanzaba más lenta que rápida y las organizaciones sentirán en carne 
propia estos retrocesos. Como afirma Feierstein "los organismos (...) fueron quienes, durante más de tres décadas de post genocidio, encabezaron la confrontación con alguna de las consecuencias de las prácticas sociales genocidas, en particular, a través de los avatares de la lucha contra la impunidad". 390

390 Feierstein, Daniel, Las prácticas sociales genocidas, Op. Cit. 


\title{
CAPÍTULO IX: ENTRE CONQUISTAS Y DERROTAS: DE LA
}

\section{Comisión Bicameral a la TeORÍa de los dos Demonios}

\author{
"A Tucumán le corresponde el triste y \\ doloroso papel de convertirse en campo de \\ experimentación de aberrantes técnicas \\ represivas, aplicadas por algunos jefes militares \\ y policiales". 391
}

\section{IX.1 LA COMISIÓN BICAMERAL, UNA EXPERIENCIA EN TUCUMÁN}

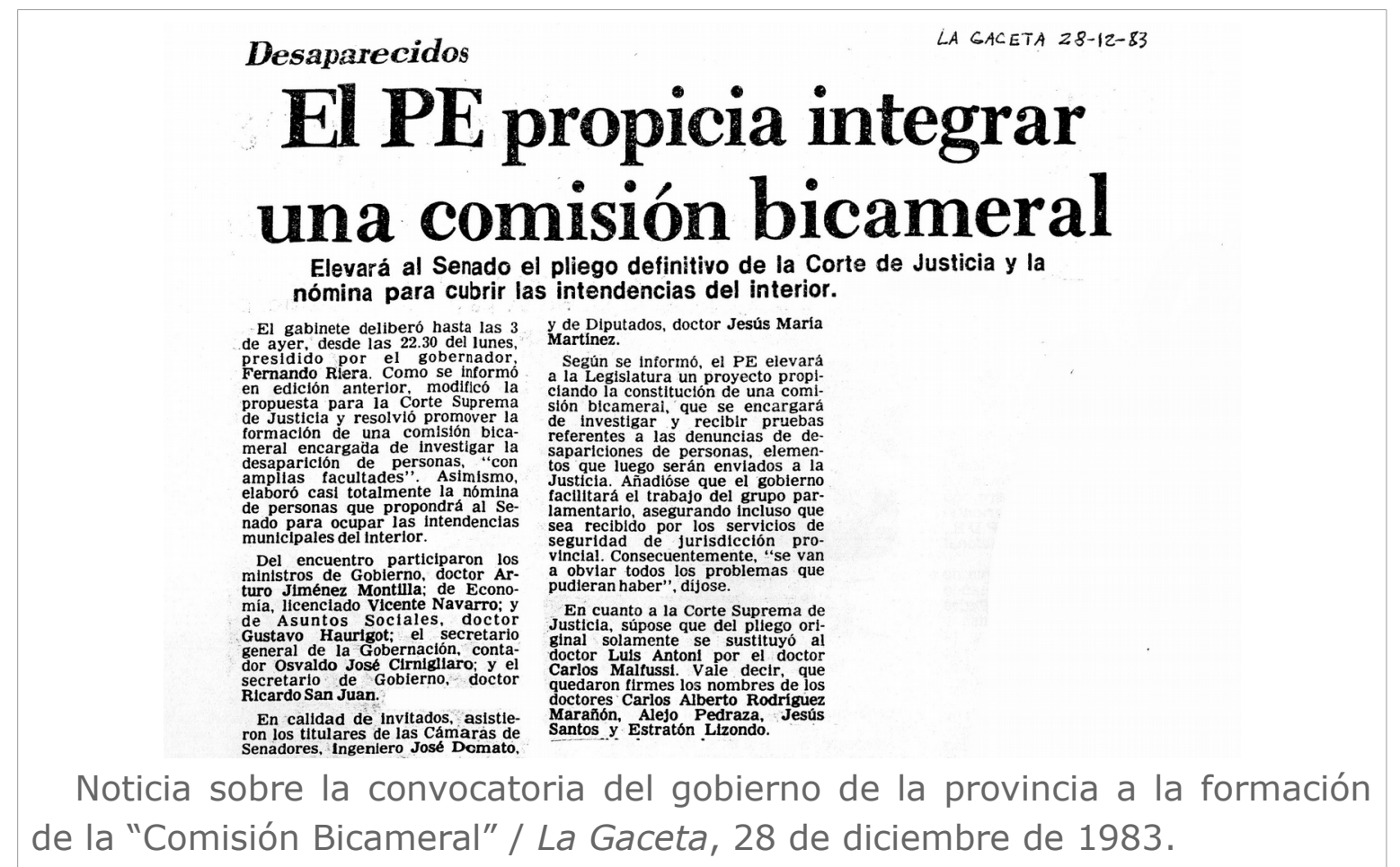

La conformación en Tucumán de la Comisión Bicameral Investigadora de las Violaciones de los derechos humanos supuso un salto importante en la revisión del pasado dictatorial en la provincia. ${ }^{392}$ En

${ }^{391}$ Informe de la Comisión Bicameral Investigadora de las violaciones a los derechos humanos en Tucumán, P. 24.

392 Para un análisis más detallado de la Comisión Bicameral véase Kotler, Rubén 
1983, una vez restablecida la democracia, los organismos de derechos humanos comenzaron a exigir al gobierno de Raúl Alfonsín la disposición de una comisión bicameral a nivel nacional que investigara la violación sistemática de los derechos fundamentales en Argentina. Entonces, el presidente Alfonsín, delegó la responsabilidad de elaborar un informe a partir de las denuncias recibidas, a una comisión de notables presidida por el escritor Ernesto Sábato ${ }^{393}$. Como es sabido, de esta manera nació la Comisión Nacional sobre la Desaparición de Personas (CONADEP), que elaboró el informe "Nunca Más". Esto generó la primera crisis en el seno de la APDH, porque si bien muchos de sus integrantes aceptaron de buen agrado la conformación de la mencionada comisión de notables, muchos, sobre todo los integrantes del interior, y, para el caso que nos ocupa, Tucumán, estuvieron en desacuerdo y llegaron a alejarse del organismo por estas discrepancias. A su vez, la APDH fue uno de los pocos que preservó su apoyo al presidente radical, no sólo en torno a la Comisión Sábato, sino también a la llamada teoría de los dos demonios.

Una de las organizaciones que más insistió en la necesidad de crear una comisión parlamentaria ha sido, sin lugar a dudas, Madres de Plaza de Mayo. Hebe de Bonafini, presidenta de la organización, explicaba los motivos por el cual no aceptaron formar parte de la CONADEP:

«...No le vamos a firmar un cheque en blanco a Alfonsín, no le vamos a firmar un cheque en blanco, decíamos nosotras. Quedaban todavía muchas expectativas sobre lo que muchos

(2007): Análisis del Informe de la Comisión Bicameral Investigadora de las Violaciones de los DDHH en la provincia de Tucumán (1974 - 1983), en Prohistoria No, Año 11, primavera 2007, Rosario.

393 Vezzetti, Hugo(2003): Pasado y presente. Guerra, dictadura y sociedad en la Argentina, Edit. S. XXI, Buenos Aires, p. 112, Véase también Crenzel, Emilio (2007): Dos prólogos para un mismo informe. El Nunca Más y la memoria de las desapariciones, en Prohistoria No 11, Primavera 2007, Rosario. 
suponían que podía hacer el gobierno radical. Y fue muy duro para las Madres tomar esa decisión; a las contradicciones de algunas se sumaban las presiones muy fuertes sobre todas nosotras. Lo que pasa es que ustedes piden demasiado, nos decían, hay que valorarlo como un paso positivo. Pero nosotras no nos dejamos entrampar y seguimos exigiendo la formación de la Bicameral, en lugar de esa comisión de "notables" sin poder de resolución.» 394

En el mismo sentido de Bonafini se pronunciaron otras organizaciones de derechos humanos como el Servicios de Paz y Justicia (SERPAJ), dirigido, como ya dije, por Adolfo Pérez Esquivel. El premio Nóbel, en una entrevista casi 20 años después de ver la luz pública el informe de la CONADEP, recordaba su posición respecto a la Comisión Sábato afirmando que:

«...a Alfonsín le dije que no iba a integrar la CONADEP porque yo decía que había que mandar todo a la Justicia Federal. Como él no aceptó, no participé de la Comisión. Cada uno tiene que tomar decisiones en la vida y ninguna es gratuita. Tenemos que profundizar el diálogo y ver cómo seguir construyendo en vez de dividir los organismos». 395

Sobre el conflicto que supuso la delegación de la investigación del pasado reciente del país en la CONADEP, Soldati expresa:

«En Tucumán aparece la Comisión Bicameral (de la provincia) y no una comisión de notables. Desde Madres se impulsaba la comisión bicameral y la CONADEP no era

394 Diogo, Alejandro (1988): Conversando con las Madres de Plaza de Mayo. Hebe, Memoria y Esperanza, Ediciones Dialéctica, Buenos Aires, P. 155; Carrizo, Raúl, Condición humana y enunciación ética. Su expresión en las prácticas y discursos de la Asociación, Madres de Plaza de Mayo, Mimeo.

395 Entrevista a Adolfo Pérez Esquivel el 6 de abril de 2006 en www.lavaca.org [Consultado por última vez en marzo de 2008]. 
valorada suficientemente, entonces eso creaba... esas diferencias creaban algunas distancias y dificultad para que se sumaran grupos políticos o juventudes políticas a nuestros reclamos, como la juventud radical, porque se partía de la idea de que, como depositario de la voluntad popular, el Congreso tenía que hacerse cargo y no una comisión de notables y como que desde el Congreso iba a tener mayor fuerza, eran cosas que se discutían y uno seguía la consigna de las Madres...»396

En Tucumán, muchos miembros del movimiento, en concordancia con las figuras nacionales, se mostraban igualmente reticentes con la CONADEP. Es el caso, por ejemplo, de Laura Figueroa, quien sostiene la idea que la Comisión se establece como una estrategia del gobierno de Alfonsín de centralizar las denuncias y poner un punto final a la investigación. Esto se evidenciaría para la abogada, incluso en el nombre que el informe recibió tiempo después: "El Nunca Más", como una forma de cerrar toda la investigación allí.

A pesar de las críticas de que pudiera haber sido objeto la Comisión Sábato para ser apoyada por algunos organismos y objetada por otros, las contradicciones sobre su aceptación o su rechazo surgían en el seno mismo del movimiento. Por ejemplo, aún cuando el propio Carlos Soldati pudiera expresar que seguía las consignas de Madres de Plaza de Mayo en cuanto al rechazo de la CONADEP, la posibilidad de dar testimonio no le impidió acompañar a quienes fueron a Tucumán a recoger datos de las víctimas del terrorismo de Estado. La percepción sobre el valor de lo realizado por esa comisión, tiene que ver en todo caso con las experiencias personales de los afectados, al momento de buscar un lugar donde dejar asentada su experiencia que, todavía en 396 Testimonio de Carlos Soldati. 
aquellos incipientes años de transición, resultaba traumática. Así lo manifiesta Carlos Soldati:

«Después viene lo de la CONADEP y ahí yo termino de reconocer el lugar donde estuve secuestrado, en la Jefatura de Policía, también fuimos a Famaillá, se reconoció La Escuelita, aunque yo pienso que estuve ahí, no en La Escuelita, sino en el ex ingenio Nueva Baviera donde funcionaba una base del ejército cuando me secuestran en el año 1976.» ${ }^{397}$

La idea queda sintetizada en una frase en la que finalmente Soldati reconoce:

«...la CONADEP también sirvió para que se conociera la verdad.»

En este sentido Sara Mrad explica que:

«Si bien Madres de Plaza de Mayo se opuso a la CONADEP y a las presentaciones individuales, muchas madres en Tucumán prestaron declaración en la Bicameral y esos testimonios pasaron después a la CONADEP, claro que esto generó mucha polémica». ${ }^{398}$

397 Testimonio de Carlos Soldati.

398 Testimonio de Sara Mrad. 


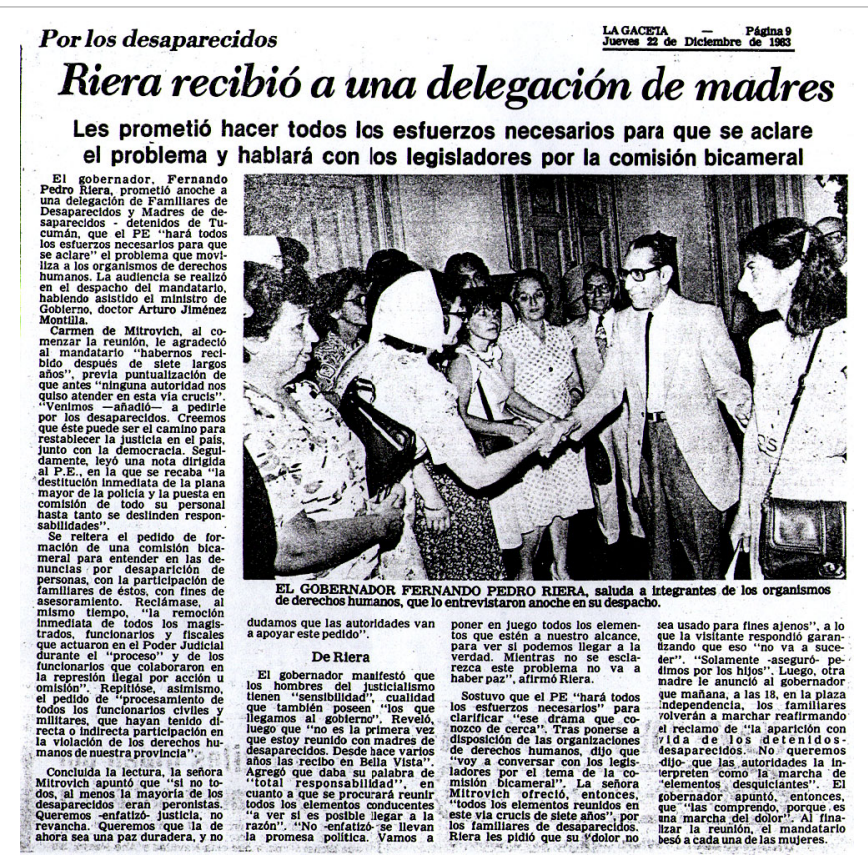

El gobernador de Tucumán recientemente elegido, Fernando Riera, recibe a Familiares y Madres con la promesa de convocar a una comisión bicameral. / La Gaceta, 22 de diciembre de 1983.

El gobierno de Tucumán, a diferencia de la administración nacional, promovió casi desde su asunción la creación de la comisión parlamentaria en la provincia. El 21 de diciembre el entonces gobernador de la provincia, Fernando Riera, de extracción peronista, le otorgaba audiencia a un grupo de familiares de desaparecidos y se comprometía a impulsar la Comisión parlamentaria que investigara los crímenes de Lesa Humanidad. Lideraba la congregación Carmen de Mitrovich, presidenta de Familiares y quien llevaba entonces la voz cantante del grupo. Riera, en declaraciones al periódico local reconocía que durante la dictadura él mismo ya había recibido en su domicilio, en la localidad sureña de Bella Vista, a familiares de víctimas de la represión dictatorial y les había dado su palabra que haría lo que estuviera a su alcance para colaborar con ellos. La mutua colaboración ofrecida por unos y otros, más la presión ejercida por el movimiento de derechos humanos local, determinó que 
Riera finalmente impulsara la comisión parlamentaria. ${ }^{399}$ Es así como el 27 de diciembre de 1983 el Poder Ejecutivo provincial resolvió propiciar la conformación de una delegación parlamentaria con representantes de las dos cámaras ${ }^{400}$.

Según la crónica periodística, la decisión del gobierno local de crear la comisión parlamentaria había sido comunicada a los organismos por el propio gobernador electo Fernando Riera, comunicación que fue bien acogida por la mayoría de sus miembros ${ }^{401}$. Fue así como nació la ley provincial 5.599 que impulsaba la creación de dicha comisión y que tuvo a su cargo la recepción de denuncias de las víctimas, tanto en la ciudad capital como en el interior, la entrevista con los organismos de derechos humanos, la inspección conforme a la denuncia recibida, el secuestro de libros en las distintas seccionales de la policía y del ejército, la citación a los presuntos responsables, entre otras diligencias. El mensaje del Poder Ejecutivo provincial invocaba el deber del gobierno de posibilitar la investigación junto al castigo de responsables y culpables "de los excesos cometidos". ${ }^{402}$ Tras un largo debate parlamentario quedaba sancionada la ley y se publicaba en el Boletín Oficial de la provincia el 22 de febrero de 1984.403

399 La Gaceta, 22 de diciembre de 1983.

400 En 1983 la provincia contaba con un parlamento bicameral compuesto por una Cámara de diputados y una Cámara de Senadores (Dicha composición bicameral fue sustituida por una sola Cámara legislativa tras la reforma de la Constitución provincial en 1991). Pero Tucumán no fue la única provincia en la que se formó una comisión parlamentaria local. En la provincia de Chaco, por ejemplo, una Comisión de Derechos Humanos de la Cámara de Diputados también ha elaborado un informe similar al Informe de la Comisión Bicameral de Tucumán.

401 La Gaceta, 28 de diciembre de 2003.

402 Informe de la Comisión Bicameral Investigadora de las Violaciones de Derechos Humanos en la Provincia de Tucumán. IEPALA, Salamanca, 1991, p. 3

${ }^{403}$ Boletín Oficial de la Provincia de Tucumán, 22 de febrero de 1984. 
En la investigación efectuada por los legisladores tuvieron una participación destacada los integrantes de la Asociación de Abogados que, como representantes legales de los familiares, contribuyeron a dar pruebas y a acercar posiciones.

Figueroa, crítica, reflexiona sobre esa participación:

«Yo participaba en off, seguía trabajando llevando mis causas, porque creía que el eje central debía estar centrado en la justicia y por eso hubo dos abogadas que trabajaron y asesoraron casi a tiempo completo a la Comisión Bicameral. El informe de la Bicameral fue un informe importante porque desde una institución estatal de mayoría peronista, y ya sabemos que el partido Justicialista había apoyado al Operativo Independencia, saca un informe, si bien recortado, pero importante porque fue por lo menos un paso, de que la violencia había comenzado desde el Estado en el año 1974, aunque lo haya dicho en una sola frase, eso significa una victoria de quienes estábamos trabajando en la temática. ${ }^{404}$ Por su parte Alicia Noli, quien sí acepta colaborar con la Comisión, recuerda:

«En 1984 Tucumán tiene una de las comisiones de la verdad más importante del país, que es la Comisión Bicameral por los derechos humanos. Informalmente Liliana Vittar y yo empezamos a trabajar desde el comienzo porque los organismos presionan y lo obtienen de los legisladores provinciales, en ese momento la legislatura era bicameral, que trabajara gente de los organismos con ellos y los legisladores aceptan que ingresen dos abogados. Empezamos primero informalmente (...) y después estuvimos contratadas, yo contratada con sueldo de la legislatura, debo haber estado

\footnotetext{
404 Testimonio de Laura Figueroa.
} 
tres meses en el staff de la legislatura, pero en realidad trabajamos desde el comienzo del informe, un año al menos, hasta que sale el informe definitivo. ${ }^{405}$

Noli, a diferencia de Figueroa, reivindica el trabajo de la CONADEP e insiste en el papel que jugó para el esclarecimiento de la verdad. Reconoce que en aquellos años sí se pedía una comisión legislativa porque se suponía que el poder del parlamento elegido era mucho más representativo que el Poder Ejecutivo, que había formado la Comisión de notables. Sobre el trabajo de la Bicameral tucumana en concreto, Noli dice:

«La comisión sí trabaja coordinando algunas cuestiones, nosotros viajamos con algunos legisladores a Buenos Aires a trabajar con la CONADEP para intercambiar información. En el año 1984, ellos vienen acá, tomamos declaraciones y es cierto que queda mucha gente que no denuncia, gente con miedo que después con los años se fueron acercando y fueron bajando la barrera, o que venían, hacían la denuncia y se iban con sus miedos a cuesta, con su terror a cuesta, porque Tucumán ha sido una provincia especialmente castigada.» ${ }^{406}$

En la introducción del Informe se explicitaba el objetivo de la comisión de "garantizar el interés civil de toda la población, en satisfacer el esclarecimiento de los trágicos episodios en que desaparecieron gran cantidad de personas $^{\prime 407}$. Se consideraba apropiado por lo tanto constituir la comisión, formada por diputados y senadores locales, como representantes del pueblo de la provincia. El texto además señala que la

\footnotetext{
405 Testimonio de Alicia Noli, ex integrante de la Asociación de Abogados por los Derechos Humanos de Tucumán y actual Jueza Federal [Entrevista realizada por el autor en 2007].

406 Ibídem.

407 Informe de la Comisión Bicameral, Op. Cit. P. 3.
} 
mencionada comisión habría de constituirse en un complemento del accionar judicial y establecía al mismo tiempo las funciones de ésta.

Hugo Vezzetti en referencia al informe de la CONADEP explica que se había convertido en un "soporte material y práctico que no sólo recuperaba sino propiamente rectificaba la significación de ese pasado". ${ }^{408}$ Este mismo concepto es válido entonces para el Informe de la Bicameral en Tucumán, donde también hubo una necesidad de rectificar lo actuado por el Estado en la ilegalidad de un gobierno ilegal e ilegítimo.

Si bien la formación de la Comisión provincial difería de la CONADEP nacional, en cuanto a que la primera estaba conformada por miembros de un poder del Estado, el espíritu en la recolección de los testimonios era el mismo y todo el material reunido por la Bicameral de Tucumán pasó a formar parte del corpus reunido por la CONADEP. Esto, al menos, es lo que no duda en manifestar Sara Mrad:

«Cuando se hace la Comisión Bicameral aumentan el número de denuncias. La gente empieza como a tener más confianza, y yo no se, creo, no te sabría decir exactamente, habría que verlo en el informe, creo que ellos llegan a recolectar ochocientas y tantas denuncias. Entregamos como Madres las denuncias que teníamos pero no participamos de la Comisión. Sí, algunas personas han ido a título personal a testimoniar, otras no. Después, la Comisión Bicameral con todos los informes que tenían entregó la documentación a todos los organismos. Pero todas las denuncias que habían ahí, han ido a parar a la CONADEP.»409

\footnotetext{
408 Vezzetti, Hugo, Pasado y Presente, Op. Cit. P. 136.

409 Testimonio de Sara Mrad.
} 


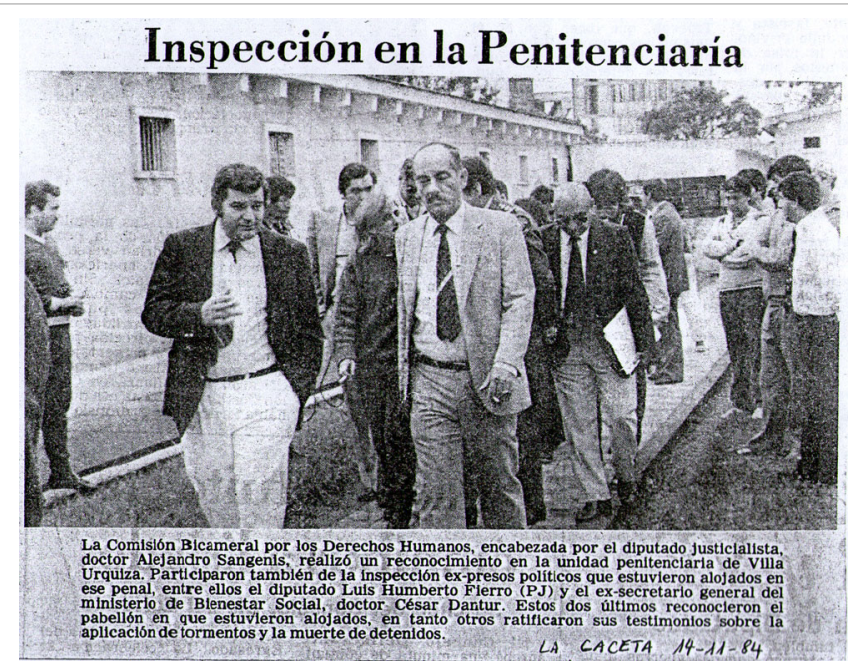

Miembros de la Comisión Bicameral Investigadora de las Violaciones a los Derechos Humanos inspeccionan la Cárcel de Villa Urquiza donde estuvieron detenidos presos políticos / La Gaceta, 14 de noviembre de 1984.

La conformación de la Comisión Bicameral es vivida hoy por los distintos militantes del movimiento de derechos humanos como una victoria política, como una consecución de los organismos, de su presión en los poderes institucionales, sin el cual no hubiera sido posible que se concretara. El informe final sería publicado en el año 1991 gracias a las gestiones que Atilio Castagnaro pudo realizar en España durante los años en que había estado viviendo en la península, esto implica que también la difusión del contenido de la investigación corrió por cuenta de los activos del movimiento de derechos humanos de la provincia. Según recuerda Castagnaro:

«A fines de los ' 80 me voy a España y ahí me junto con un grupo de exiliados tucumanos, entre ellos el que más me acuerdo, porque era tucumano, el resto eran todos argentinos de todos lados, es Ernesto Rosenberg, médico ginecólogo, que ya estaba metido en el Partido Obrero y que venía del trostkismo, y ahí fundamos lo que se llamó la AAPDH en España, que tenía otra significación: Asociación Argentina Pro 
Derechos Humanos, y esa fue la que inició los juicios en España, tanto contra Pinochet como contra los dictadores argentinos, incluido el Bussismo. Ahí formamos esa Asociación (...) fue en los años en el que el Bussismo empezaba a crecer y buscábamos dinero para hacer carteles y mandarle a los compañeros acá, para mostrar lo que era Bussi, etc, y ahí imprimimos el libro de la Bicameral, en el '91, con la ayuda del IEPALA, que es el Instituto de Estudios Políticos para América Latina...» ${ }^{410}$

Si bien es cierto que el espíritu de la comisión bicameral era el mismo de la comisión presidida a nivel nacional por Sábato, el hecho que el Estado provincial decidiera asumir la responsabilidad de investigar establece una notable diferencia. El Estado se hacía cargo de la responsabilidad de poner una luz de esclarecimiento sobre un pasado que lo involucra directamente. Más allá de las competencias de unos y otros, en Tucumán, la Comisión tendría legitimidad ya que estaba conformada por los legisladores.

La idea de dar conocimiento público sobre lo acontecido en el pasado reciente era la misma. Se refuerza de esta manera la idea sostenida por Vezzetti en cuanto a constituirse el documento final elaborado en soporte material de la memoria.

\section{IX.2 ALgUnAS CONSIDERACIONES SOBRE EL INFORME BICAMERAL}

Estimo conveniente plantear aquí algunas cuestiones que surgen de la lectura del Informe de la Comisión Bicameral Investigadora de las Violaciones de Derechos Humanos en la Provincia de Tucumán. En primer término, hay que tener presente que es un informe político y que un informe sobre las violaciones de los derechos humanos comience con un 410 Testimonio de Atilio Castagnaro. 
análisis político habla a las claras que el resultado de la investigación era (y es) de interés público, ya que la represión estatal había afectado a un importante sector de la sociedad. La administración provincial asumió la cuestión política al expresar que "es deber inexcusable del gobierno popular y democrático, posibilitar la investigación, y en su caso, el castigo de los responsables y culpables, de los excesos cometidos so pretexto de la represión del terrorismo y la subversión. Todos los sectores políticos y el pueblo lo reclaman, y el Gobierno, surgido de la voluntad soberana del pueblo, debe ser sensible a tales reclamos de justicia, posibilitando que sean los representantes del pueblo, los que tengan a su cargo reunir todos los elementos, para que la Justicia, como órgano natural del Estado, determine los casos de delitos y violación a los derechos humanos, cometidos al margen de la ley y que deben ser reprochados por ésta y por el pueblo todo, que espera salgan a la luz todos los excesos cometidos y aparezcan los desaparecidos cuyas ausencias angustian a familiares y amigos" ${ }^{\prime \prime 11}$.

Algunas consideraciones expresadas en el Informe reflejan profundas contradicciones en cuanto a ciertas actuaciones de la dirigencia política que estuvo al frente del país en los primeros años de la transición democrática.

Retomo entonces uno de los conceptos reiterados una y otra vez por la comisión, cuando se refiere a los crímenes cometidos por la dictadura. Habla de excesos y no de crímenes. Aunque la palabra crimen pudiera aparecer mencionada, el concepto exceso no sólo minimiza la responsabilidad política en la represión, sino que desvía la atención de la opinión pública. Además los parlamentarios expresan que "no han

${ }^{411}$ Informe de la Comisión Bicameral Investigadora de las Violaciones de los Derechos Humanos en Tucumán, Op. Cit. P. 3. 
emitido juicio alguno que no fuera competencia de la comisión, dejando para la Justicia la calificación y el juzgamiento, conforme a derecho, de las causas que le han remitido"412. También decidieron hacer explícita la condena de los crímenes, con lo cual, si bien asumen desde el estado el papel que les confiere el Poder Ejecutivo para investigar, ponen cierta distancia con los responsables de las violaciones a los derechos humanos. Están diciendo claramente: fueron ellos y no nosotros, fue el poder usurpado por los militares y no como expresión del deseo de la voluntad popular.

Aunque el informe deja entrever que no todos los legisladores estaban de acuerdo con la creación de la comisión, se cuidan en expresar que a todos les animó el mismo espíritu ${ }^{413}$ que es, en este caso, el de la condena de las violaciones a los derechos humanos en la provincia. En este sentido al ser aprobado el informe por los legisladores, uno de los representantes de la Comisión, Armando Baunaly del Partido Justicialista, se encargó de dejar en claro que el "informe no juzga ni condena a nadie, sino que es una enumeración de hechos..." ${ }^{414}$

Uno de los temas centrales que cruza la investigación de estos temas es qué se entiende por derechos humanos: bien sea la sola revisión del pasado dictatorial, o bien la cuestión de los desaparecidos o bien una referencia al sistema económico y social que del golpe militar se evidencia. Los parlamentarios se pronuncian explícitamente sobre el concepto que entendían por derechos humanos citando, por ejemplo, las declaraciones de los derechos del hombre y del ciudadano de la Francia revolucionaria de 1879 o algunos principios establecidos por la religión católica apostólica romana para denostar los delitos de Lesa Humanidad 412 Informe, Op. Cit. P. 4.

413 Ibídem.

414 Diario La Gaceta, 22 diciembre de 1984. 
cometidos por los militares. La conclusión a la que había arribado la Comisión bicameral fue que: "en su expresión más conocida, la violación de los Derechos Humanos, designa todo lo que los argentinos vimos en algún momento de auge de la brutalidad terrorista, incorporado a lo cotidiano y que el citado informe de la OEA enumeró escrupulosamente" ${ }^{\prime 415}$. En la enumeración de los derechos fundamentales violentados en el país se consolida el argumento de la Comisión: El derecho a la Vida, con las muertes ilegales y las desapariciones; el derecho a la Libertad Personal, con las detenciones indiscriminadas y arbitrarias, la limitación del derecho de opción y la prolongada permanencia de asilados; el derecho a la Seguridad e Integridad Personal, con las torturas, tratos crueles, inhumanos y degradantes; el derecho a la Justicia y al Proceso Regular; el derecho a la Libertad de Opinión, Expresión e Información, la Suspensión de los Derechos Laborales y Políticos; las Restricciones a Actividades Religiosas y al Accionar de los Organismos de Derechos Humanos. ${ }^{416}$ Lo que sugiere esta lista en todo caso, es que en Argentina en general, y en Tucumán en particular, se habían violado los Derechos fundamentales establecidos en la Carta de los Derechos Humanos declarada por la Organización de Naciones Unidas el 10 de Diciembre de 1948. Se habían violado entonces, lo que algunos autores han denominado los Derechos Humanos de primera y segunda generación.

La Comisión centró su preocupación en las desapariciones forzadas de personas, preocupación central de los propios organismos de derechos humanos, que buscaban establecer el paradero o el destino final de sus familiares desaparecidos. Asegura al respecto que "el mundo

${ }^{415}$ Informe Comisión Bicameral, Op. Cit. P. 29.

416 Ibídem. 
entero ha adoptado la palabra Desaparecidos, sin ser traducida a ningún idioma"417.

Retomo en este punto uno de los temas anteriormente planteados y es el referido a la llamada teoría de los "Dos Demonios". Ampliamente discutida en el seno del movimiento de derechos humanos, la idea de que el terrorismo de Estado era equiparable a la acción de las organizaciones armadas produjo cierto rechazo en algunos sectores sociales que estimaron que tal comparación no era dable y por lo tanto la desdeñaron.

En Tucumán se debatió mucho sobre si aceptar la hipótesis estatal o rechazarla. En este sentido, si bien el informe Sábato ofrece una teorización en la que se iguala el accionar de la guerrilla con la represión estatal, el mismo lenguaje será utilizado por los legisladores que emitieron el informe provincial bicameral.

Sobre la idea de los dos demonios, Barrio Terol explica que la misma "se ha utilizado para, si no justificar, sí al menos querer dar una explicación simplista al advenimiento del golpe del general Videla y la consiguiente dictadura conocida en Argentina como el Proceso. La teoría de los dos demonios viene a decir lo siguiente: la serie de acciones violentas cometidas por los grupos de ultraizquierda que operaban en el territorio argentino durante la etapa antes citada, fundamentalmente a cargo del sector del peronismo conocido como Montoneros, así como también por el marxista Ejército Revolucionario del Pueblo o ERP, pueden catalogarse como uno de los demonios. Y por otra parte, las acciones de la ultraderecha, como la Alianza Anticomunista Argentina o AAA, más conocida como la Triple A (alentadas desde atrás por el ministro de Bienestar Social, José López Rega) son el otro demonio, junto a la represión indiscriminada ejercida durante el Proceso, que de esta manera ${ }^{417}$ Informe, Op. Cit. P. 29. 
y según esta argumentación devino a la vez demonio y consecuencia inevitable de la situación de desorden anterior, es decir del otro demonio". ${ }^{418}$ Su hipótesis, sostiene el mismo autor, "no intenta dar una justificación ideológica a la alteración del orden constitucional llevada a cabo por Videla, Viola, Galtieri, Massera, etc., sino tan sólo dar un soporte exculpatorio a la sociedad en general, por la mayor o menor pasividad durante el Proceso." ${ }^{419}$

Otra explicación más precisa y que ayuda a comprender el efecto que generó la teoría de los Dos Demonios en la sociedad argentina de la transición es la que describe Feierstein en su análisis acerca de cómo la sociedad quedaba al margen de la disputa en los años dictatoriales, como si fuera inocente de cargo y culpa. Dirá entonces el sociólogo que "la articulación entre la negación de la identidad y la transferencia de la culpa opera en el caso argentino del siguiente modo: el "demonio de izquierda" provocó con su accionar contestataria la reacción desmesurada de un poder militar que, en lugar de reprimirlo con la fuerza de la ley, se desbordó, iniciando un baño de sangre donde la mayoría de las víctimas fueron inocentes." ${ }^{1420}$ En esta misma dirección apunta Crenzel al analizar el prólogo del informe de la CONADEP cuando sostiene que el mismo "propone un "nosotros" externo a toda violencia, una "comunidad imaginada" de ciudadanos ajenos a las divisiones y enfrentamientos." ${ }^{421}$

Ciertamente la teoría pareció calar hondo en algunos sectores sociales que entendían que la dictadura militar y todo su horror se había desatado pura y exclusivamente por culpa del accionar de los grupos

${ }^{418}$ Barrio Terol, José Manuel (2005): Insurgencia y represión. Acerca de la teoría de los dos demonios. En Historia Actual On Line, No 8. http://www.historiaactual.com/hao [Consultado en línea por última vez en enero 2008].

${ }^{419}$ Ibídem.

${ }^{420}$ Feierstein, Daniel, El Genocidio como práctica Social, Op. Cit. P. 342.

${ }^{421}$ Crenzel, Emilio, Dos prólogos para un mismo informe, Op. Cit. 
armados y no con la intención de frenar un movimiento social más profundo y que abarcaba a sectores más amplios y heterogéneos. Incluso algunos partidos de izquierda se aventuraron en reproducir este discurso, y lo que se observa es la presunción de la responsabilidad de los grupos armados en el accionar represivo estatal. Esto puede graficarse ampliamente en el testimonio de Ángela Nassif, miembro del Partido Comunista Revolucionario, quien asume esta posición, no al extremo de equiparar una y otra violencia, pero sí de echar ciertas culpas a la izquierda armada sobre la represión:

«Creo que hay un mal balance de todo lo que fue la lucha de la época previa al golpe y sobre todo la de los grupos armados, donde mucha gente se sintió la mortadela de un sándwich. Objetivamente lo fueron, porque estos muchachos se equivocaron desde el punto de vista político en el blanco, porque el blanco no era el gobierno constitucional de la Isabel como ellos pusieron, además tené en cuenta que vos estás en una de las provincias más peronistas, donde la gente luchó mucho por la vuelta de Perón y ellos instalaron la guerrilla contra Perón por lo tanto no podían tener el apoyo de la población nunca con esa línea. Se equivocaron en la línea y en la forma de la lucha armada, es lo que mucha gente te decía cuando le tomabas el testimonio sobre todo en Santa Lucía, ellos vienen y tienen con que irse y nosotros nos quedamos aquí, en la misma casa, en el mismo trabajo, los chicos en la misma escuela, y esto les daba miedo porque la represalia era contra el pueblo. Venía después el ejército donde ellos (los militantes de las organizaciones armadas) había ido a comprar cigarrillos y los detenían, hacían desaparecer al quiosco. $\gg^{422}$

$\overline{422}$ Testimonio de Ángela Nassif. 
Esta interpretación ha sido ampliamente difundida y ha contribuido también a trasmitir la idea de un pueblo inocente víctima de las dos violencias. Se asume que no es posible ver a un pueblo inocente ni poner el justificativo de la represión estatal a partir de los grupos armados y pensar en una sociedad al margen de los conflictos políticos y sociales. En esta misma línea se expresan las ideas de Pablo Pozzi y Alejandro Schneider, para quienes el alto nivel de conciencia de clase de parte del pueblo, el crecimiento de la fuerza popular y el avance contestatario de amplios sectores sociales había sido el propósito de la represión estatal a través del gobierno constitucional en 1975 y con el gobierno de las tres fuerzas armadas a partir del golpe militar. ${ }^{423}$

Algunos militantes de los años setenta también presumen que esa fuerza social organizada era el blanco de la represión, y no solamente los grupos armados. Es el caso del testimonio de Marcos Taire, quien al recordar los efectos que supuso la serie de levantamientos populares en la provincia entre 1969 y $1972^{424}$, afirma:

«Pero bueno, a pesar de eso la lucha duró varios días, fue heroica realmente, el estudiantado tucumano sobre todo, tuvo un comportamiento heroico, yo creo que estos antecedentes, esta heroicidad que tuvo el estudiantado tucumano pesaron muchísimo en el futuro inmediato, en los años '75 y '76 para el odio que tuvo después la represión de la dictadura, primero el operativo independencia y después la dictadura para masacrar al estudiantado tucumano como lo

423 Pozzi, Pablo y Schneider, Alejandro (2002): Los Setentistas. Izquierda y Clase Obrera: 1969 - 1976, Op. Cit.

${ }^{424}$ Se hace referencia aquí a los distintos Tucumanazos, rebeliones obrero estudiantiles que al igual que el Cordobazo o el Rosariazo, generaron una importante conciencia de clase en amplios sectores de clase media y en los trabajadores, en el caso de Tucumán, de las fábricas azucareras. 
hicieron. Este... hace poco me comentaron de un trabajo, de un sociólogo porteño, que estudió los porcentuales de desaparecidos del estudiantado argentino, y el estudiantado de Tucumán ocupa el primer lugar en porcentuales, de acuerdo a la cantidad de estudiantes de la universidad y de nivel secundario entre los desaparecidos en Argentina. Creo que tiene mucho que ver con ese odio que se engendró en la represión a raíz de estos actos heroicos que había tenido el estudiantado tucumano en los primeros años '70.» ${ }^{425}$

Por otra parte cabe volver a recordar aquí que para diciembre de 1975 (tres meses antes de producirse el golpe que derroca a la esposa de Perón) la guerrilla ya había sido derrotada y el mayor número de represaliados se produjo desde entonces, siendo en su mayoría dirigentes estudiantiles, obreros y defensores de los derechos humanos, como lo menciono en otro capítulo de este trabajo.

Lo que se hace necesario precisar en este punto es cómo reciben la teoría de los dos demonios los organismos y qué percepción tienen de la misma. Todos los entrevistados afirman que en cada organismo se discutía ampliamente la tesis pronunciada por el escritor Ernesto Sábato en el prólogo de la CONADEP, y en la mayoría de los casos la tendencia era al rechazo. Quienes tienen familiares desaparecidos admiten la militancia de los mismos, y aseguran que por esa actividad política es que los hicieron desaparecer. Si bien H.I.J.O.S. entra tarde en este debate, conforme se constituía la agrupación a mediado de los '90, no dejaban de debatir también esta cuestión. Es decir, la teoría de los Dos Demonios no solo dividió aguas, sino que hasta el día de hoy sigue siendo tema de controversial debate.

425 Testimonio de Marcos Taire [Entrevistado por el autor en Buenos Aires en agosto de 2004]. 
Uno de los que se opuso a la idea de los dos demonios es Carlos Soldati ${ }^{426}$ :

«Los desaparecidos fueron sacados indefensos de sus casas, llevados a campos de concentración, torturados y muertos». 427

Si bien es cierto que H.I.J.O.S. aparecerá en la escena pública muchos años después de estas primeras discusiones sobre la llamada Teoría de los Dos Demonios, no les impedirá discutirla. Abro aquí un necesario paréntesis para dar cuenta de algunos testimonios de H.I.J.O.S. Tucumán, ya que la discusión acerca de la equiparación de dos formas de terrorismo, uno de derecha y otro de izquierda, sacudió en más de una oportunidad a la agrupación, ya que el debate se centraba en la historia política de sus padres desaparecidos.

Muchos hijos de activistas secuestrados no conocían la historia de militancia de sus padres y sólo con la entrada en la agrupación comenzaron a averiguar el motivo o el pretexto por el cual la represión ilegal había cargado contra éstos. Muchos descubrieron tardíamente que sus padres habían pertenecido a tal o cual agrupación armada, y comenzaron a hacerse planteos sobre su propia historia, lo que les afectó profundamente. Estimo oportuno, por lo tanto, hacer una digresión en este apartado para reflejar, de acuerdo con los testimonios recogidos, las ideas que de la tesis de los dos demonios se tenían.

${ }^{426}$ El testimonio de Soldati en este punto se torna vital, por cuanto tiene dos hermanos desaparecidos y él mismo ha sufrido en carne propia el secuestro, la detención y la tortura. No niega la militancia de su hermana Berta María, quien trabajaba en el Peronismo de Base o el trabajo de su hermano en las asociaciones de colegios universitarios. En el presente testimonio Soldati se detiene en un comentario de Bussi aparecido en el diario La Gaceta de Tucumán en el año 1984, donde el general retirado expresaba que lo sucedido desde 1975 hasta 1983 había sido una guerra.

427 Testimonio de Carlos Soldati. 
H.I.J.O.S. si bien discutió ampliamente esta cuestión, ha rechazado siempre la postura esgrimida en el prólogo del informe Nunca Más. De alguna manera lo que se reproduce en las discusiones va más allá de la teoría en sí. Se plantean controversias sobre su propia historia, sobre la historia de la militancia de los padres, de la historia política del país y, en definitiva, también la cuestión de la violencia como arma política. Muchos integrantes de H.I.J.O.S. fueron haciendo su propia experiencia en la formación de una idea cabal sobre la propia historia, negada hasta el momento en que comienzan a encontrarse. Pocos hijos de desaparecidos pueden contar con el conocimiento cierto de la historia de sus padres, ya que desde el miedo, la vergüenza o el ocultamiento desconocían en qué actividades estaban involucrados.

María Coronel, junto a su hermana, Lucía, han sido miembros fundantes de H.I.J.O.S. Tucumán. Sobre la discusión de los dos demonios María explica:

«Hemos tenido discusiones muy fuertes al principio, porque la crianza pesa mucho cuando vos tenés que afrontar tu historia y aunque sea la historia de tus viejos. Yo me he criado con una abuela que jamás me ha negado la militancia de mis viejos con todas las letras, de cosa que yo no entendía, yo no entendía que eran los Montoneros, pero ella me decía que mi papá había sido Montonero y que yo debía estar orgullosa y no te tiene que dar vergüenza eso, y hasta incluso hablar de la desaparición, de la desaparición que en ese momento era algo que yo tampoco entendía pero sabía que mi mamá estaba desaparecida... eso nos ha pesado mucho a nosotros para tener una cuestión de plantarte con respecto al respeto que vos tenías con la militancia de tu viejo, no con lo que era la lucha armada, que la lucha armada 
tiene que ver con otro análisis del momento, era muy difícil, y sigue siendo muy difícil analizar desde los '90 lo que era la década del '70 y para nosotros era también empezar de cero. $Y$ hemos tenido agarradas tremendas, pero terribles, de chicos que, bueno con el tiempo me da gracia, porque hemos ido descubriendo que sus padres si estaban en organizaciones armadas y ellos creían que no y cómo pesaba eso, pesaba el creer que tu viejo nunca había tocado un arma a la hora de la discusión...» ${ }^{428}$

Viviana Vicente entró en la agrupación tardíamente, sin embargo, también plantea la cuestión de los Dos Demonios, lo que refleja que el tema siguió siendo cuestión de discusión a lo largo de la historia H.I.J.O.S:

«Sobre los dos demonios lo que nos pasó a nosotros, lo que pasó aquí en Tucumán, fue ir a charlas a las escuelas y jamás asumíamos la identidad política de nuestros viejos en un principio ¿Pero por qué? Porque vos decías, si, mi viejo fue Montonero y te tildaban de terrorista y claro, salías del paso, como hizo una vez Gargiulo ${ }^{429}$, está bien, matar está mal, mate quien mate, pero bueno, era ponernos un poco... hay un contexto histórico, era como muy difícil eso, tenerlo cerrado nosotros y después traducirlo en un colegio secundario, si lo haces hoy posiblemente lo reciben de una mejor manera, pero no es lo mismo que hacerlo con Bussi en el gobierno, ir a los colegios y hablar para que esté este hijo de puta ahí, legitimado por el voto popular o ir y decir: un genocida no puede ser gobernador... $\gg^{430}$

428 Testimonio de María Coronel [Entrevista realizada por el autor el 29 de noviembre de 2007].

429 Pablo Gargiulo fue otro militante de H.I.J.O.S. Tucumán.

430 Testimonio de Viviana Vicente [Entrevista realizada por el autor el 12 de noviembre de 2007]. 
Por su parte Susana Salvatierra, quien también ingresa desde los inicios, recuerda estas discusiones explicando el impacto que produjo en ella el hecho de encontrar otros compañeros que relataban con toda naturalidad la militancia de los padres en alguna de las organizaciones armadas:

«Yo me acuerdo que una de las cosas que más me impresionó cuando entré en H.I.J.O.S. fue escuchar a María y a Lucía que abiertamente decían que sus padres eran Montoneros y que habían muerto, su papá en combate y su mamá en la ESMA, a mi me parecía asombroso, y después escucharlas decir lo mismo fuera de H.I.J.O.S., entonces ahí ya me parecía increíble...»

\section{Pregunta: ¿En qué sentido?}

«Que era la primera vez que escuchaba decir a alguien: mi papá fue Montonero con ese orgullo, era la primera vez... entonces yo decía ¿Y mi papá qué fue? Y ahí empecé a averiguar, muchos de nosotros no sabía ni en qué circunstancias ni el destino final (de los padres desaparecidos), algunos hemos empezado a conocer el destino final después (...) pero bueno, el contexto de ellas les ha permitido decir eso. $\mathrm{Y}$ no todos podían, porque todavía estaban una serie de discusiones pendientes, como teoría de los dos demonios, había como muchas cosas...»

Pregunta: ¿Y eso lo discutían...?

«Y terminaban saliendo en las reuniones esas discusiones inevitablemente...» ${ }^{431}$

Llegado a este punto hago propias las ideas de Feierstein para quien es inevitable remarcar el destacado rol jugado por el movimiento ${ }^{431}$ Testimonio de Susana Salvatierra [Entrevista realizada por el autor el 29 de noviembre de 2007]. 
de derechos humanos "en el intento de conformar una percepción contra hegemónica de los hechos. Y, pese a todo, conscientemente o en forma apenas inconsciente, dejando la lucha tan sólo en manos de los abogados (que en la visión positivista resultan los únicos que saben) se priorizó en lo jurídico la lucha material (la posibilidad efectiva de que los perpetradores fueran a la cárcel) por la lucha simbólica (el derecho como productor de verdad, como sanción colectiva de modos de representar el pasado)". 432 También será por este motivo que muchos de los integrantes de la generación joven de este movimiento, encarnada en H.I.J.O.S., habían decidido estudiar derecho y buscar los cauces legales para cumplimentar el objetivo sin depender de terceros. El discurso contra hegemónico del que habla el sociólogo ha sido la batalla librada para responder a la teoría de los dos demonios. Así es como lo explica Julia Vitar, militante de H.I.J.O.S., al concluir que:

«Es algo que trabajamos desde la organización, el posicionamiento de la teoría de los Dos Demonios, y las piedras basales de la teoría de los dos demonios, que son las leyes de Obediencia debida, Punto final y toda esa política de derechos humanos que tiene Alfonsín que intenta asentar esa versión de la historia de los hechos y era uno de los puntos básicos de nuestra organización, la pelea contra las leyes y combatir la teoría de los dos demonios y explicar por qué lo que pasó ha sido un plan sistemático de violación a los derechos humanos y que no era una guerra en la que habían dos grupos que contendían sino que había un Estado que estaba dispuesto a violar los derechos de las personas... ${ }^{433}$

432 Feierstein, Daniel, El Genocidio como práctica social, Op. Cit. Pág. 345.

433 Testimonio de Julia Vitar [Entrevista realizada por el autor el 31 de octubre de 2007]. 


\section{Se realizó una marcha por los desaparecidos}

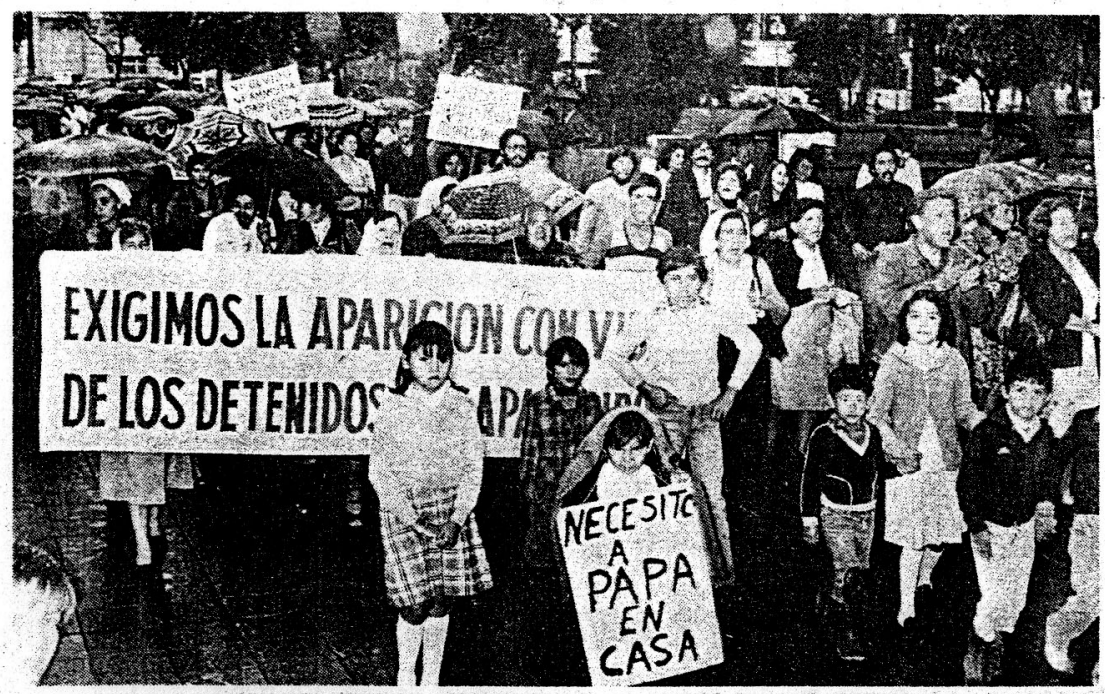

NINOS CON CARTELES que los Identifican como hijos de desaparecidos encabezan la marcha que se realizo ayer.

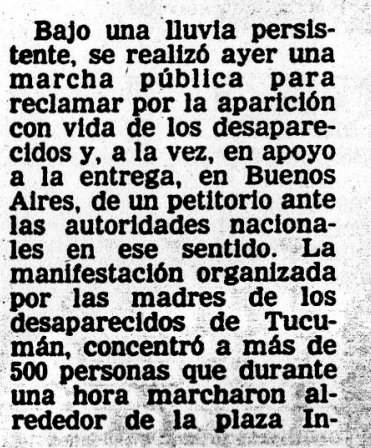

ก. - n

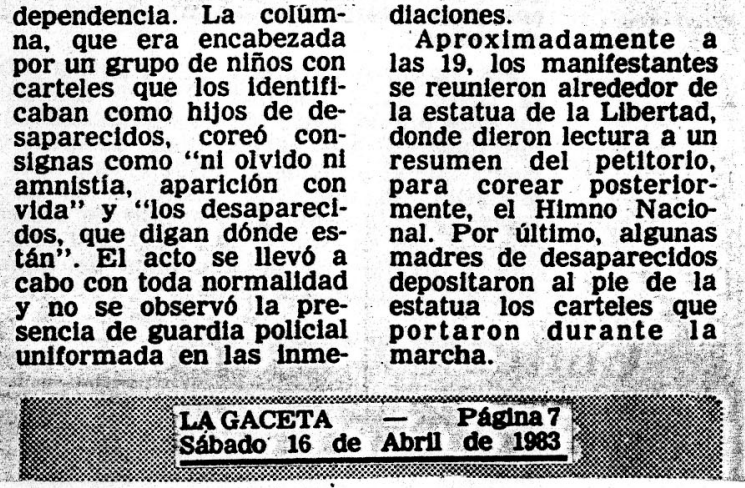

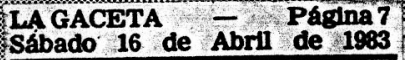

Marcha de organizaciones de derechos humanos de Tucumán exigiendo "aparición con vida de los desaparecidos" / La Gaceta, 16 de abril de 1983. 
A los cinco días de haber asumido la presidencia del país, el 15 de diciembre de 1983, Alfonsín sancionó los decretos 157 y 158 por medio de los cuales se ordenaba enjuiciar a los dirigentes de las organizaciones armadas: el Ejército Revolucionario del Pueblo (ERP) y Montoneros, y el procesamiento a las tres juntas militares que gobernaron el país desde el golpe militar hasta la Guerra de las Malvinas. Por este motivo digo que se comenzaba a cumplir con parte de lo prometido en la campaña electoral. Una de las principales críticas que recibiría la administración radical se sustentaba en que no podía juzgar en pie de igualdad a las organizaciones armadas que a los miembros de las juntas militares, tema tratado ya en el apartado anterior, donde la teoría de los dos demonios comenzaba a operar desde el propio Estado y se vería ratificada al hacerse entrega del informe de la CONADEP. Como ya dije, 1984 había transcurrido con cierta confianza por parte del movimiento de derechos humanos por cuanto el principio de verdad parecía quedar establecido en la revisión del pasado reciente, sin embargo el valor de justicia todavía quedaba lejos del panorama político del país. Entre el 22 de abril y el 14 de agosto de 1985 se realizaron las audiencias públicas en las que declararon 833 personas. Las atrocidades que revelaron muchos de esos testimonios resultaron un duro golpe para parte de la ciudadanía que se enteraba por vez primera el horror de los crímenes cometidos por los represores. ${ }^{434}$

Entre el 11 y el 18 de septiembre de 1985 el fiscal Julio César Strassera realizó el alegato de la fiscalía, que luego sería considerado como una pieza jurídica histórica. La fiscalía consideraba que la responsabilidad por cada delito debía ser compartida por los miembros de

\footnotetext{
${ }^{434}$ Para un análisis más detallado del proceso de juzgamiento a los responsables de las Tres Fuerzas Armadas léase Nino, Carlos (2006): Juicio al mal absoluto, Editorial Ariel, Buenos Aires.
} 
cada junta a la que se le había probado la participación. Finalmente, el tribunal no aceptó este criterio sosteniendo que las responsabilidades debían ser asignadas por cada fuerza armada, lo que produjo una considerable reducción de las penas para los miembros de la Fuerza Aérea. Sobre estos juicios, Feierstein sostiene que "se estructuraron a partir de la sumatoria de delitos individuales (...) cometidos contra sujetos individuales". ${ }^{435}$ Citando al jurista Eduardo Barcesat, el sociólogo expresa que en su opinión se debió haber abierto una causa por genocidio pero que esta idea fue desechada "ante el claro carácter político de la matanza y la dificultad de encuadrar los hechos en la calificación de genocidio de la Convención para la Sanción y la Prevención del delito de Genocidio". ${ }^{436}$

Como ya manifesté anteriormente, juristas tucumanos como Laura Figueroa sostenían tempranamente estas mismas ideas compartidas inconscientemente por los organismos de derechos humanos. ${ }^{437}$ Las llamadas leyes de impunidad que habrían de ser sancionadas dos años después, fueron de alguna manera explicitadas por el fiscal de la causa en el alegato del juicio. Entonces Julio Strassera cerró su alegato con esta frase: «Señores jueces: quiero renunciar expresamente a toda pretensión de originalidad para cerrar esta requisitoria. Quiero utilizar una frase que no me pertenece, porque pertenece ya a todo el pueblo argentino. Señores jueces: "Nunca más"».

Del modo en que expuse, la interpretación del "nunca más", que además dio nombre al informe de la CONADEP, suponía una clausura en el proceso que debería haber terminado con el castigo de "todos" los

\footnotetext{
${ }^{435}$ Feierstein, Daniel, El Genocidio como práctica social, Op. Cit. P. 345.

${ }^{436}$ Ibídem.

${ }^{437}$ En un panfleto firmado por Madres y Familiares de Desaparecidos de Tucumán, se cierra con una frase contundente: Aparecen con vida o es Genocidio.
} 
responsables, tal como lo exigían los organismos. El juicio dejó en claro que sólo se juzgaba a las cúpulas militares quedando al margen de los juicios de 1985 los rangos inferiores del ejército. Algunas organizaciones veían que los juicios a la Junta militar tenían sus limitaciones y las sospechas acerca del alcance de las políticas revisoras del pasado dictatorial de la administración de Alfonsín, en el principio de justicia, fue develado dos años después con las sanciones de las llamadas leyes de impunidad: Punto Final en diciembre de 1986 y Obediencia Debida en junio de 1987. En este sentido la evaluación que hacen, a más de 20 años de llevado a cabo el juicio a las Juntas, por casi todos los miembros del MDHT coincide con las apreciaciones de Julia Vitar, quien sostiene:

«El juicio a las Juntas y la CONADEP son dos instancias donde se sostiene la teoría de los dos demonios. El juicio a las Juntas es aberrante, inclusive la cuestión discursiva y todo entonces obviamente cala muy profundo en la percepción en la construcción social de la memoria de lo qué ha sido la dictadura y obviamente los "H.I.J.O.S." no escapamos a eso...» $\gg^{438}$

El proceso político desde la transición hasta la sanción de las leyes de impunidad es vivido por las organizaciones de derechos humanos de Argentina como una gran derrota política, la segunda desde la conformación de la CONADEP, en la cual advertían como se diluían las pretensiones del movimiento de conseguir establecer la verdad en primer término, y la justicia seguida de la condena real a los responsables de la represión dictatorial como segundo y necesario paso. A las marchas de los 24 de marzo o del 10 de diciembre se añadían las innumerables movilizaciones para pedir la nulidad de las leyes llamadas de impunidad

\footnotetext{
438 Testimonio de Julia Vitar.
} 
por el movimiento en todo el país. ${ }^{439}$ Por otra parte, este punto de inflexión afectó particularmente al MDHT que además de vivir en sintonía con el movimiento nacional, sentía que la provincia había retrocedido en cuanto a la defensa de los derechos fundamentales se refería por cuanto en esos años habrían de ver surgir con fuerza al Bussismo.

Un párrafo aparte merece la defensa de quienes han sido juzgados en estas instancias en 1985. El discurso siempre era el mismo: se había tratado de una guerra, y los actos develados debían ser considerados como circunstancias inevitables de toda guerra. Como vemos, desde el final del periodo dictatorial, los represores se ampararon siempre en la excusa bélica, en el servicio brindado a la patria y que en toda guerra se cometen "excesos". Algunos sectores cercanos a los partidos políticos tradicionales también vieron al proceso dictatorial como una guerra. Uno de quienes más han sostenido esta tesis en Tucumán es el propio General retirado Antonio Domingo Bussi, como he podido comprobar en otro apartado de este trabajo, tesis ampliamente rechazadas por el movimiento de derechos humanos. Carlos Soldati reflexiona entonces:

«Nada justifica esta atrocidad, ni siquiera el argumento de una pretendida guerra, aún la guerra tiene sus reglas de respeto al prisionero. Pero si fueron sacados indefensos de sus casas, nos preguntábamos y es lo que insistimos siempre, ¿dónde está la guerra, dónde está la guerra? Ese caballito de batalla con el que pretendieron justificar lo injustificable...» ${ }^{440}$

\footnotetext{
439 Ya desde 1983 el movimiento se movilizaba en contra de la ley de amnistía. En estas manifestaciones se convocaba a toda la ciudadanía y si bien los oradores centrales eran los miembros de los organismos de derechos humanos, los partidos de izquierda sumaban su voz y a sus militantes, conformándose una nueva identidad en estos actos que ya no solo pertenecían a los familiares de los afectados por el terrorismo estatal.

440 Testimonio de Carlos Soldati.
} 
Sobre los alcances del juicio a las Juntas, Alicia Noli también realiza su propio balance:

«Lo interesante del juicio a las Juntas y del punto trece de la sentencia que mandaba a juzgar a todos los inferiores, pero después la reforma del código de la justicia militar, el mandato a que las causas pasaran al Estado Mayor Conjunto, el acompañar a familiares en estas cuestiones humillantes de que fueran a declarar al comando $y$ no donde funciona tribunales, que la corte no entiende porque (entre comillas) tiene que poner una placa enorme ahí de desagravio, porque además de ahí salían grupos de asaltos, grupos de tareas, bueno, acompañar al familiar a que el juez de instrucción (...) y después la ley de los 60 días de caducidad que fue la Ley de Punto Final, la Cámara Federal de Tucumán que resolvió girar las causas el día 59 a la provincia de Córdoba...»

Pregunta: ¿Ustedes creían que a partir del juicio a las juntas se iban a juzgar a los cuadros inferiores?

«El punto trece del juicio a las juntas mandaba a continuar... por un lado deja establecido que fue un plan sistemático, deja establecido el concepto de terrorismo de Estado y que fue un plan de represión sistemático acorde a la doctrina de Seguridad Nacional, etc. etc., el juzgamiento que hace, es de alguna manera un juzgamiento criminal y político, por el rol que tenían y por eso la doctrina que aplican, es la doctrina que permite aprehender a los aparatos de organización de poder, la doctrina de Roxin, entonces logra el juzgamiento nada más que de la Junta, pero el punto trece de la sentencia, manda seguir el juzgamiento a todos los responsables inferiores... lo que pasa es que después viene todo esto, de las leyes de Obediencia Debida y Punto Final. Lo que pasa es que cuando va la causa -de Bussi- a Córdoba, 
viajamos las tres, Liliana, Laura y yo, nos entrevistamos con María Elva Martínez a quien le pedimos que la siga en Córdoba, constituimos domicilio en el estudio de ella y bueno, la cosa era muy desesperanzadora porque la Cámara de Córdoba tenía un solo día y resuelve hacer urgente las citaciones para dejarlo incriminado a Bussi, pero no puede ahondar más. La recibe el último día girada por la Cámara de Tucumán...» ${ }^{441}$

\section{X.2 Punto Final, Obediencia Debida e impunidad adQuirida}

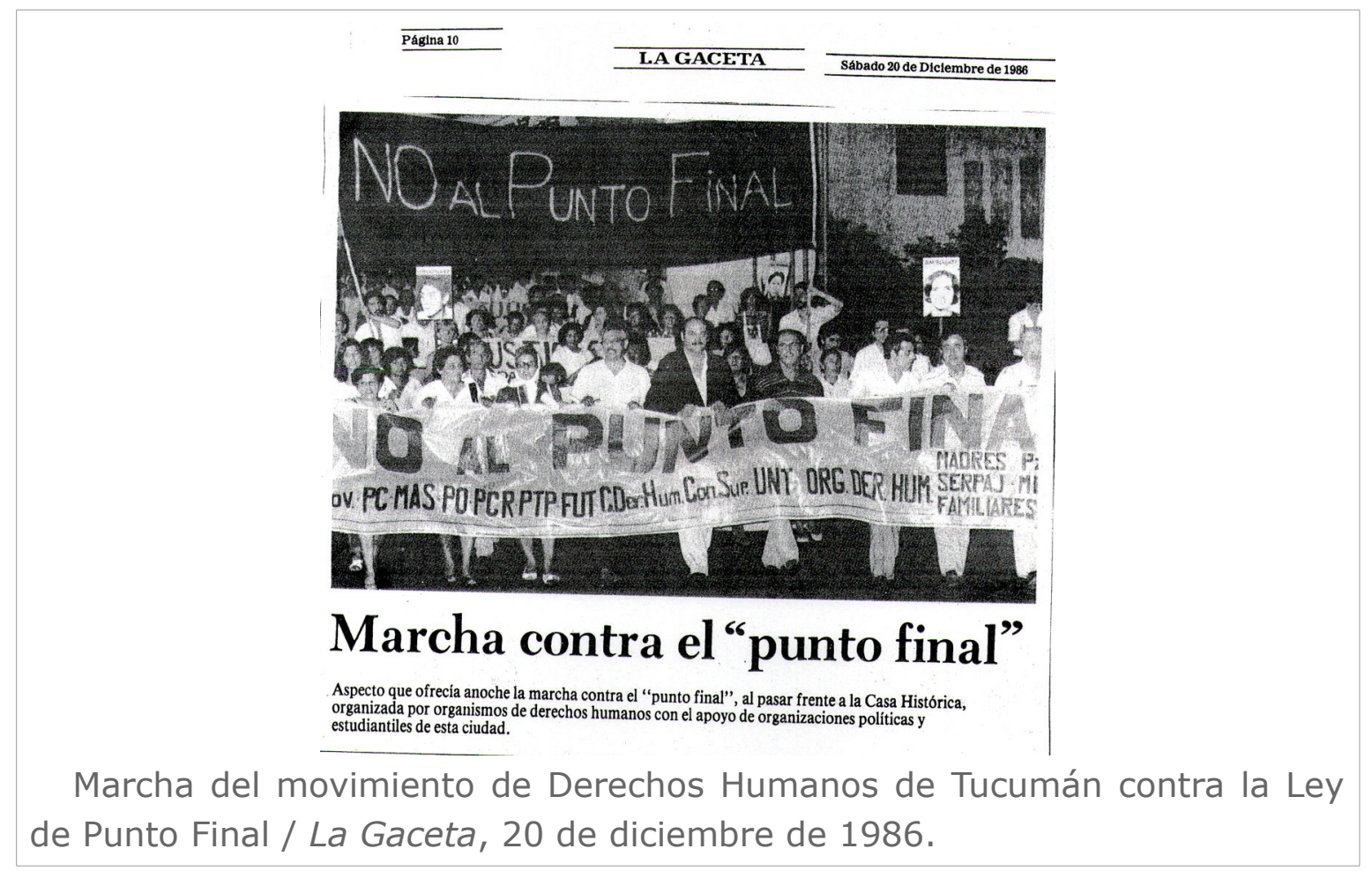

Jelín explica que, una vez sancionada la ley de Punto Final, la acción de los organismos se "volcó sobre el Poder Judicial, procurando que, dentro de los márgenes cada vez más estrechos (...) actuara con toda la firmeza posible. La sanción de la Ley de Punto Final produjo el resultado paradójico de las presentaciones masivas resueltas en la febril 441 Testimonio de Alicia Noli. 
actividad judicial de los primeros meses de 1987. Las delegaciones provinciales de los organismos de derechos humanos y la presión popular fueron factores importantes." ${ }^{\prime 42}$ Como afirman Díaz Colodrero y Abella, "las primeras medidas del gobierno -de Alfonsín- contenían en germen los elementos que irían a desarrollarse más tarde, en el transcurso de los acontecimientos. (...) la situación de la justicia y los ascensos a militares cuestionados por su participación en la represión. A esto vino a sumarse la falta de voluntad política del gobierno de investigar y castigar los delitos económicos y el no desmantelamiento del aparato represivo." ${ }^{443}$

Las sospechas de los organismos de derechos humanos sobre los límites y los alcances de los juicios sumadas a las propias limitaciones del gobierno de Alfonsín para ir más allá en el juzgamiento de los rangos inferiores, se ven entonces corroboradas con la sanción de las llamadas leyes de impunidad. Como es bien conocido, la Ley 23.492 de Punto Final, que fue promulgada el 23 de diciembre de 1986, estableció la paralización de los procesos judiciales contra los represores. Entre los beneficiados estaba Antonio Domingo Bussi.

Literalmente la ley expresaba que "se extinguirá la acción penal contra toda persona que hubiere cometido delitos vinculados a la instauración de formas violentas de acción política hasta el 10 de diciembre de 1983. Sólo quedaban fuera del ámbito de aplicación de la ley los casos de secuestro de bebés nacidos en cautiverio, un resquicio legal que permitiría años más tarde reabrir algunas causas contra los beneficiados por esta ley. En este sentido Hugo Quiroga afirma que "a partir del juicio a los responsables de la represión se abrió una tensa

\footnotetext{
442 Suriano, Juan, Nueva Historia Argentina, Op. Cit. P. 543.

${ }^{443}$ Díaz Colodrero, José L. y Abella Monica (1987): Punto Final. Amnistía o Voluntad Popular. Puntosur editores, Buenos Aires. Véase también Nino, Carlos (2006): Juicio al mal absoluto, Edit. Ariel, Buenos Aires.
} 
relación entre el gobierno radical y las Fuerzas Armadas, que estalló con el alzamiento militar de Semana Santa, en abril de 1987. La ley de Punto Final, sancionada cuatro meses antes, había salido al cruce de las presiones militares con la finalidad de evitar posibles rebeliones castrenses. El sentido de esa ley era evitar tanto la proliferación de los juicios como disipar el estado de sospecha que pesaba sobre la institución militar..." ${ }^{444}$

Alicia Noli es terminante al sostener:

«Confirmando estas dos leyes de impunidad ya sabemos que se suspende el juicio hasta que se vuelven a declarar ya insanablemente nulas...» $\gg^{445}$

El levantamiento militar de semana santa en 1987 había implicado un punto de inflexión en la transición vigilada a la democracia, a la vez que ponía a prueba la institucionalidad recuperada en diciembre de 1983. Miles de argentinos colmaron entonces la Plaza de Mayo en apoyo del gobierno de Raúl Alfonsín, quien mientras anunciaba el final del levantamiento militar, regresaba de negociar con los mismos militares la sanción de la Ley de Obediencia Debida, ley que beneficiaba a los rangos inferiores del ejército, quienes eran acusados de cumplir órdenes de la superioridad al mando de los operativos. Tanto la ley de Punto Final como la de Obediencia Debida fueron vividas por algunos militantes del MDHT como un segundo momento de capitulación por parte del presidente Alfonsín ante unas Fuerzas Armadas que seguían teniendo fuerza y capacidad de acción, esta vez, en pos de frenar la revisión de su actuación represiva durante la dictadura.

${ }^{444}$ Suriano, Juan dir. (2005): Nueva Historia Argentina T. 10: Dictadura y Democracia (1976 - 2001), edit. Sudamericana, Buenos Aires.

445 Testimonio de Alicia Noli. 
La claudicación del gobierno radical se sintió de manera particularmente dura en Tucumán, por cuanto su sanción suponía una vía libre para el ascenso político de Bussi, tal y como ocurrió en los años subsiguientes. Aunque en los días previos a la sanción de ambas leyes se sucedieron las manifestaciones públicas, los organismos nada pudieron hacer entonces para evitar su aprobación en el parlamento.

Laura Figueroa lo explica de la siguiente manera:

«Una vez aplicadas las leyes, fue un golpe muy fuerte porque entonces los Familiares y las organizaciones ¿Cómo íbamos a seguir esta lucha? Aquí yo creo que hubo una derrota, esto después habrá que evaluarlo, yo creo que si, que tenemos que hablar como una derrota política, con saldos bastante negativos porque hubo una diáspora, mucha gente en la derrota dejó de militar, dejó de reclamar por sus familiares y otros que no tenían familiares dejaron de ver que ese era un tema importante para ser reivindicado y pasó a ser un tema secundario el tema de los desaparecidos, porque tomó prioridad el tema económico, los saqueos, el hambre, etc etc.»446

Sara Mrad por su parte analiza:

«Este tipo de cosas lo primero que te produce es mucha bronca, indignación en realidad. Desde Madres siempre hemos dicho que esas leyes eran inconstitucionales, y yo recuerdo que hicimos un acto en la plaza acá en Tucumán, vino mucha gente, repudiando las leyes porque un caso emblemático como el de Bussi no podía quedar ahí, como en agua de borraja. Pero esos han sido los pasos de la impunidad.»

$\overline{446}$ Testimonio de Laura Figueroa. 
Pregunta: ¿Ustedes ya preveían esta posibilidad que Bussi participara en la vida institucional o ni siquiera lo planteaban?

«Nos imaginábamos cuando él empieza a tener contactos con Ávila Gallo, que fue el lo introduce en la vida política de la provincia con el Partido Bandera Blanca. Nosotros empezamos a trabajar, trabajamos muchísimo, hemos hecho una carta a la opinión pública que le hemos entregado a todos los partidos políticos $(\ldots) \gg^{447}$

Uno de los que se alejarán de la militancia en el movimiento una vez sancionadas las leyes de Obediencia Debida y Punto Final es Carlos Soldati. Cada vez concurría menos a las reuniones y veía con desánimo el proceso político provincial que conducía, inevitablemente, a que Bussi se encumbrara políticamente y fuera ganando espacio. Soldati asume entonces:

«Después el tiempo fue haciendo lo suyo, porque ya después de esa claudicación se hicieron unas cuantas movilizaciones más, pero el tiempo y estas claudicaciones fueron desalentando a la gente y después vino el indulto y aún más ahí decreció más la actividad de los organismos (...) con el tiempo sigo militando pero ya sin ir a la ciudad, lo hago aquí en Simoca, con menos frecuencia, colaborando solo en los grandes actos, ya no con la misma intensidad que uno tenía años anteriores». ${ }^{448}$

Otra que entiende que el movimiento fue golpeado con las leyes es Vilma Ribero:

«Y nos sentíamos re mal, imagínese usted, porque perdimos las esperanzas, porque hecha la ley, hecha la

\footnotetext{
447 Testimonio de Sara Mrad.

448 Testimonio de Carlos Soldati.
} 
trampa. Si bien es cierto que hubo declaraciones, que hubo investigaciones a las Juntas, pero quedó ahí no más.»449

Los años que siguieron a la sanción de las leyes de impunidad, como son denominadas por los organismos, estuvieron marcadas, de un lado, por el alejamiento de algunos militantes y por otro lado por el debilitamiento del conjunto del movimiento, debilidad que permitió, en contrapartida, que el Bussismo asomara con fuerza en el panorama político tucumano. Fortalecidos tras la paralización de las causas en su contra y con una imagen positiva en determinados sectores sociales, algunos dirigentes de la derecha tucumana no dudaron en encumbrarlo. Este fue sin lugar a dudas el golpe de gracia para el movimiento en Tucumán, mucho más que los indultos dictados en 1989 por el entonces presidente justicialista Carlos Menem, a los militares condenados. Menem había justificado los indultos en la necesidad de culminar con el proceso de reconciliación nacional, pero esta no era la idea que sostenían las organizaciones de derechos humanos y los partidos de izquierda. Sin embargo en Tucumán pesaba mucho más en el imaginario la Ley de Punto Final que los indultos, ya que veían como gracias a esta normativa sancionada por el congreso a la sazón del presidente Alfonsín, el "represor" local ascendía rápidamente en el horizonte político. Esta fue, sin duda, la derrota más dura desde los primeros años de la transición, de la que recuerdan los entrevistados, derrota política que golpea duramente en el movimiento pero que, paradójicamente, habría de servir en el transcurso de los '90 para producir reacomodamientos y el surgimiento de nuevos actores sociales, como H.I.J.O.S. A pesar de la debilidad, las organizaciones que componen al movimiento de derechos humanos en Tucumán nunca dejaron la calle y nunca abandonaron el espacio público como espacio de disputa y lucha.

\footnotetext{
449 Testimonio de Vilma Ibáñez.
} 


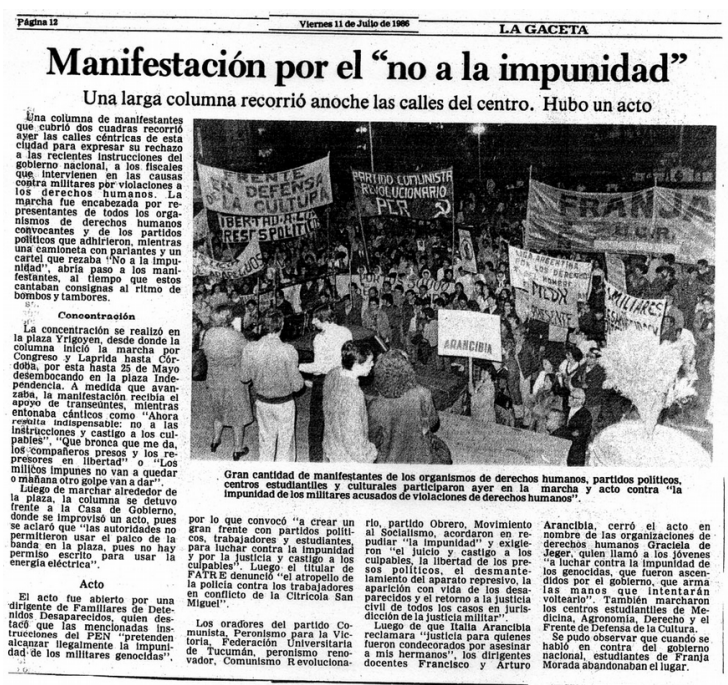

Marcha del movimiento de Derechos Humanos de Tucumán contra las leyes de impunidad / La Gaceta, 11 de julio de 1986.

\section{X.3 Del 24 de marzo al 10 de diciembre, lo ritual y lo simbólico}

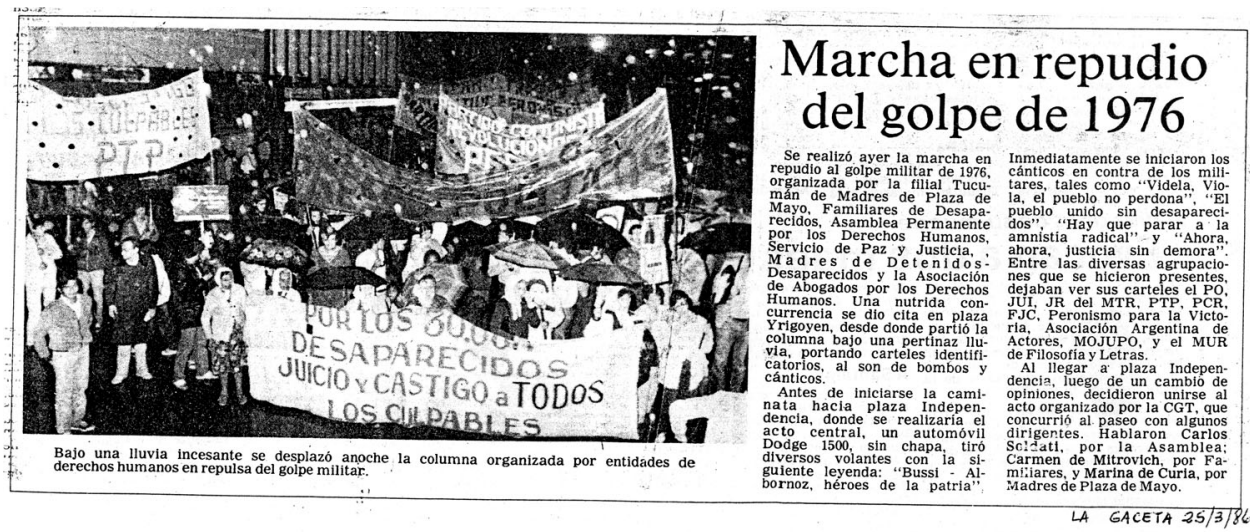

El ritual del 24 de marzo a 10 años del golpe militar en la ciudad de Tucumán / La Gaceta, 25 de marzo de 1986..

Si la participación de los integrantes de las organizaciones se retrae tras la sanción de las leyes de Punto Final, Obediencia Debida y los indultos, un ritual que no desapareció hasta el día de hoy y que congrega incluso a quienes se han alejado del movimiento o a quienes ni siquiera han participan en él, son los actos del 24 de marzo, cuando se recuerda 
el golpe militar de $1976^{450}$, y los actos del 10 de diciembre, día internacional de los derechos humanos. ${ }^{451}$ Algunos militantes han buscado incluso imponer en Tucumán como fecha central del recuerdo de los desaparecidos el 9 de febrero, día en que comienza el Operativo Independencia en 1975 y que, como ya dije, afectó particularmente a la provincia norteña.

Muy vinculado al tema de las memorias y al conflicto entre éstas, los rituales del movimiento de derechos humanos ocupan un lugar central por evitar que "la amnistía provoque amnesia". ${ }^{452} \mathrm{Si}$ el fortalecimiento del

450 Léase en el anexo documental número 6, el documento elaborado por las organizaciones de derechos humanos de Tucumán y leído el 24 de marzo de 2008. Presento dicho documento en razón de ser uno de los que tuve acceso en el momento de la búsqueda al resguardo de un militante. No he podido encontrar los documentos anteriores que den cuenta de la trayectoria de los mismos durante el periodo en estudio. Si cabe mencionar que la elaboración de los documentos a ser leídos cada 24 de marzo se elaboran sobre la base del documento del año anterior en el cual se incorporan los reclamos del año vigente. Hasta los primeros años del 2000 las marchas del 24 congregaban a las organizaciones de derechos humanos y a los partidos de izquierda en conjunto, por lo que los documentos tenían, según narran los militantes, cuestiones que tenían que ver, por ejemplo, con la impugnación al gobierno nacional de turno. En los últimos años dichas manifestaciones se hicieron por separado y mientras el movimiento de derechos humanos realzó el valor de lo actuado por el gobierno nacional en materia de revisión del pasado represivo, los partidos de izquierda, en sus respectivos documentos, siguieron impugnando al gobierno nacional en razón de los reclamos por los derechos humanos en el presente.

451 Incluso el 10 de diciembre en Argentina reviste de un doble valor simbólico ya que en esa fecha pero de 1983 se produjo la asunción del presidente democráticamente elegido, Raúl Alfonsín, tras la retirada de los militares del poder. El 10 de diciembre como fecha de manifestación tuvo sus altibajos: mientras que en los 80 congregaba casi tantos manifestantes como el 24 de marzo, a lo largo de los '90, la costumbre de marchar el 10 de diciembre se diluyó. En los últimos años, el actual gobierno retomó la fecha del 10 de diciembre y la hizo propia con la celebración del llamado "día de la democracia", dotándole de nuevas significaciones.

452 La idea de la amnistía sin amnesia es tomada del editorial de Le Monde, del 29 de abril de 1995 titulado justamente "Amnesia y Amnistía". Josefina Cuesta recupera la expresión para hablar de la transición del franquismo a la democracia en España. 
Bussismo en Tucumán cubría el pasado con un manto de silencio, el movimiento de derechos humanos pretendía continuar la batalla de la memoria contra el olvido y por la condena social en la plaza pública. A las consabidas consignas de los organismos, en Tucumán se sumaba el grito a viva voz sobre el rechazo a la propia persona de Bussi en una pugna por consolidar la memoria del pasado reciente del país.

Tal como lo entiende Elizabeth Jelin, "las fechas y los aniversarios son coyunturas de activación de la memoria." ${ }^{\prime 43}$ Pero no todos comparten las mismas memorias, y es aquí donde entran en juego los conflictos mencionados. Esto sucede no solamente en la lucha del movimiento contra la memoria oficial o en contrapartida a su olvido, sino también al interior del mismo de las organizaciones.

Durante los años de la dictadura los mensajes de la junta militar "al pueblo argentino" al cumplirse un aniversario del golpe, eran una constante, en un llamado por la unidad, la paz y sobre todo por explicar al conjunto de la sociedad los propósitos del gobierno de facto, como una manera de legitimarse permanentemente. Ante la falta ostensible de legalidad, los dictadores argentinos buscaron permanentemente los canales alternativos para legitimarse, sino en los hechos, al menos en los discursos, en los relatos. En este contexto dictatorial, sin embargo, algunos osaron desafiar a la memoria oficial. La Carta abierta a la Junta Militar del periodista Rodolfo Walsh, con motivo de cumplirse el primer año del golpe el 24 de marzo de 1977, operaba en este sentido. La introducción de la carta es una respuesta a esa memoria oficial que exaltaba y justificaba la esencia misma del gobierno de facto: "El primer aniversario de esta Junta Militar ha motivado un balance de la acción de gobierno en documentos y discursos oficiales, donde lo que ustedes

453 Jelin, Elizabeth, Los trabajos de la Memoria, Op. Cit. P. 52. 
llaman aciertos son errores, los que reconocen como errores son crímenes y lo que omiten son calamidades". ${ }^{454}$ Walsh contraponía entonces los aciertos considerados como tales por la dictadura a los errores que algunos intelectuales venían denunciando, y denominaban crímenes a los errores reconocidos por el mando militar en un claro intento de contraponer un relato y otro. ${ }^{455}$ Desde la Carta de Walsh hasta los actos públicos del movimiento es posible afirmar entonces como lo señala Jelín, que "las organizaciones (...) elaboraron una versión antagónica de lo ocurrido el 24 de marzo de 1976, y fueron quienes ocuparon la escena pública de la conmemoración a partir de la transición. El Estado estuvo ausente de las mismas durante muchos años...". 456

Uno de los cantos que acompañó durante los '80 y los '90 las manifestaciones del 24 de marzo consignaba: "Como a los nazis, les va a pasar, a donde vayan los iremos a buscar", en clara referencia a los juicios celebrados en Núremberg y que habían sentenciado a jerarcas nazis, pero también a la lucha por perseguir a los nazis ocultos tras el fin de la Segunda Guerra Mundial.

Una de las preguntas que se hizo a los entrevistados fue sobre el significado tanto del 24 de marzo como del 10 de diciembre en Tucumán. Para todos ellos son fechas de particular relevancia en las que aún estando alejados de la militancia, viven como una cita impostergable. Laura Figueroa, por ejemplo, analiza:

${ }_{454}$ Introducción de la Carta Abierta de Rodolfo Walsh en Vinelli, Natalia (2002): ANCLA, una experiencia de comunicación clandestina orientada por Rodolfo Walsh, edit. La Rosa Blindada, Buenos Aires.

${ }^{455}$ La escritura de la carta le valió al periodista su desaparición el mismo día en que Walsh se dirigía a los medios de prensa gráficos a entregar el mensaje epistolar. Sin lugar a dudas la propia desaparición de Walsh el 24 de marzo de 1977, es decir, un año después de producido el golpe, también jugaría como factor clave en las memorias enfrentadas en el intento del movimiento de derechos humanos por hacer suya también esta desaparición.

456 Jelín, Elizabeth, Los Trabajos de la Memoria, Op. Cit. P. 53. 
«Nosotros siempre teníamos dos fechas, el 24 de marzo y el 10 de diciembre. El 10 de diciembre era impresionante como se convocaba gente, sobre todo porque el 10 de diciembre había asumido Alfonsín, entonces los radicales en los primeros tiempos se volcaban a las calles, a las movilizaciones. Paulatinamente ese 10 de diciembre fue perdiendo fuerza y pasó a tener otra fuerza, que eran las organizaciones en conflicto que tomaban el 10 de diciembre para denunciar. Entonces como ya había demasiadas protestas y demasiadas banderas rojas, los sectores del PJ o el radicalismo abandonaron las marchas del 10 de diciembre y permanecían aunque formalmente para repudiar el golpe del 24 de marzo, pero bueno, se sintió la disminución de gente cuando fue la derrota alfonsinista y menemista, y el 10 de diciembre en Tucumán hace varios años que tiene una convocatoria raquítica porque la dirección, sobre todo de uno de los organismos de derechos humanos, no le da la importancia, porque bueno, casualmente está Kirchner en el gobierno.... ${ }^{457}$

Carlos Soldati concuerda con Figueroa tanto en lo que respecta al 24 de marzo y los comienzos de la represión en Tucumán, como a los primeros actos en los que participaban también los afiliados y votantes del Partido Radical en los primeros años de gobierno del presidente Alfonsín:

«En realidad siempre los 24 de marzo tenían el sentido grande que nos unificaba a todos en repudio al horror, al terrorismo de Estado, a la dictadura... pero claro, en los comienzos del gobierno de Alfonsín siempre estaban los grupos que valoraban también a la par o había una mención respecto de las cosas positivas que se venían haciendo y

457 Testimonio de Laura Figueroa. 
siempre la polémica entre los que estaban más afín al gobierno rescatando lo que hacían y los que estaban en una actitud crítica y de mayor confrontación, pero siempre la gran bandera fue el repudio a todo el horror que comienza el 24 de marzo, aunque en realidad se pone como una fecha, la noche larga del terrorismo de estado, pero en realidad ya comenzó un año antes con el Operativo Independencia en donde ya comienzan las desapariciones... $\gg^{458}$

Es decir que, además de la manifestación simbólica y ritual, el 24 de marzo los congregaba, los unía y, en definitiva, servía para reordenar unas organizaciones en constante movimiento. A veces servía incluso para que aquellos que habían abandonado la participación, retornaran a las organizaciones.

Sobre el tema de las fechas, en Tucumán se daba la particularidad de que el 9 de febrero era, para algunos militantes, tanto o más representativo que el 24 de marzo, fecha en que, como ya dije, había comenzado a operar el aparato represivo en la provincia en el llamado Operativo Independencia. Sin embargo, en esa pugna por las memorias nunca se pudo institucionalizar como efemérides. Esto lo explica Sara Mrad, quien desde Madres de Plaza de Mayo, insistió en variadas oportunidades en la necesidad de instituirlo:

«...es una fecha emblemática el 24 de marzo, nosotros siempre, y en Tucumán hemos intentado en algún momento y hemos hecho actividades, para nosotros la marcha más importante no tendría que ser el 24 de marzo sino el 9 de febrero, porque en realidad el golpe, el golpe así, institucionalizado empieza el 9 de febrero con el Operativo Independencia, pero cuesta trabajarlo al 9 de febrero, y

$\overline{458}$ Testimonio de Carlos Soldati. 
recién hace unos años que la gente empieza a manejar el tema del Operativo Independencia.

Pero nosotros, hemos hecho actos en Famaillá... y es una fecha emblemática a nivel nacional el 24 de marzo, entonces uno la toma y lo mismo el 10 de diciembre, pero con el tiempo por las diferencias que había con las otras organizaciones, las Madres dejamos de hacer cosas el 10 de diciembre para plantear las marchas de la resistencia que se las hacía, digamos, cerca del 10 de diciembre, un miércoles y un jueves anterior al 10 de diciembre... $\gg^{459}$

En todo caso, resulta emblemático que organizaciones como Madres de Plaza de Mayo no solamente manifiesten en fechas determinadas, sino que hayan podido ocupar aún en el imaginario social, el espacio público de cada jueves con las marchas en Plaza de Mayo en Buenos Aires y en cada plaza central en el interior del país. El jueves ha sido también el día elegido por la filial tucumana para marchar por la Plaza Independencia, marchas que con el paso del tiempo ha ido disminuyendo en número de asistentes, pero que no se han suspendido, contando el organismo con la colaboración de los grupos de apoyo locales. El ritualismo poco a poco se hizo costumbre y las mencionadas manifestaciones supusieron un intento de preservar la memoria viva del relato del movimiento. Con el tiempo, algunos miembros de las organizaciones se alejaron de las organizaciones, sin embargo, los 24 de marzo no dejaron de acudir a la cita en la Plaza Independencia, como evento impostergable. Aunque apartados de la militancia activa, se reconocen aún dentro del movimiento sólo por acudir a la manifestación cada año.

459 Testimonio de Sara Mrad. 
A mediados de los '90 con el surgimiento de H.I.J.O.S. y con el triunfo de Bussi en la gobernación de Tucumán en 1995, las marchas del 24 de marzo cobraron una renovada significación. La nueva generación de militantes, jóvenes, que hacían la entrada en la escena pública como organización y con banderas reconocibles, le imprimía al movimiento dinámicas distintas y por lo tanto acciones y representaciones de la memoria muy diferentes. Como lo expresa Jelín, "los primeros años de la década de los noventa fueron de escasa actividad, para reactivarse a partir de 1995, en los preparativos del 20 aniversario y en los años posteriores. Nuevos actores juveniles, nuevas formas de expresión y de participación (la agrupación H.I.J.O.S., las murgas) marcan transformaciones de la fecha." ${ }^{460}$

En Tucumán los actos del 24 de marzo posteriores al triunfo electoral de Bussi centraron mucho más la atención en la persona del general retirado, ahora gobernador elegido por medio de los votos, y, tanto el palco desde el cual hablaban las organizaciones, como los discursos, se veían reforzados al mismo tiempo en las consignas contra FR. Interpelaban una vez más al conjunto social sobre quién era Bussi y qué había hecho para merecer el repudio del movimiento. Además, los folletos distribuidos apuntaban todos contra la persona del propio militar. En uno de esos panfletos podía leerse: "Bussi asesino, la cárcel es tu destino, acabó el tiempo de la impunidad y comienza el de rendir cuentas".

Los integrantes de H.I.J.O.S. por su parte procuraban darle al 24 de marzo nuevos sentidos elaborados al interior de la organización. No se trataba de vivir ya el 24 de marzo como una fecha de luto permanente, trágica, de dolor y llanto, sino de buscar una nueva significación en la

\footnotetext{
460 Ibídem.
} 
cual no faltaron las murgas o los pasacalles en las movilizaciones hacia la plaza Independencia. Esta era una nueva forma de entender las conmemoraciones en los aniversarios del golpe.

Sobre su participación en los actos del 24 de marzo, Josefina Centurión recuerda:

«...es como que de cajón siempre estábamos ahí, y además porque comprendíamos la importancia de esas fechas, no por algo que hubiera que repetir mecánicamente, sino que era la oportunidad de concentrar la energía en eso que salía hacia afuera del trabajo de las organizaciones. No era lo único que hacían las otras organizaciones pero era algo que salía hacia a fuera y la oportunidad de convocar, como abrir a la sociedad el tema y la convocatoria, y que la gente se acerque, y eso, sabíamos que en esas fechas se acercaba mucha gente que no tenía una militancia organizada, pero que obviamente estaba comprometida con la causa...»

Pregunta: ¿Y qué diferencias había en el movimiento? Por ejemplo en la elaboración del documento...

«Las diferencias surgían siempre ahí, si...aunque en general no teníamos tantas diferencias con los otros organismos a nivel discursivo, sí a nivel operativo, organizativo de las cosas, porque al final nosotros sentíamos que los que terminábamos laburando éramos nosotros (los militantes de H.I.J.O.S) y además que era como que un poco cariñosamente y un poco también lavándose las manos, como que nos endilgaban la tarea pesada porque éramos jóvenes, pero era natural y nos reíamos de eso porque era lo que queríamos hacer, pero por ahí las principales diferencias surgían con las organizaciones de izquierda por las reivindicaciones que había que incluir o no en el documento, 
cuestiones que por ahí a nosotros nos parecía que excedían las exigencias de los organismos de derechos humanos, no porque no nos solidarizábamos con lo que pasara en Irak, sino porque nos parecía que se diluían las reivindicaciones concretas que a nosotros nos interesaba en ese marco del 24 de marzo...» ${ }^{461}$

Susana Salvatierra vincula la marcha de los 24 con la herencia que recibe H.I.J.O.S. de las organizaciones que le precedieron, sobre todo de Madres, aunque plantea las diferencias que buscaba el novel organismo en los actos:

«(...) la línea de la lucha era la misma, en lo que sí creo que nos hemos diferenciado sí es el cómo, a nosotros nos resultaba muy pesado continuar ese camino del reclamo de justicia desde el dolor, nos costaba muchísimo, nos despertaba mucha paranoia, nos hacía sentir culpables, yo al menos tenía esa cosa de sentir esa mirada de "pobrecitos" en lo que tuvo el padre, entonces el hecho de que los H.I.J.O.S. hayamos podido encontrarle la alegría, el humor... las marchas de H.I.J.O.S. son tan distintas a las marchas de Familiares como la de Madres, una cosa totalmente distinta, desde el hecho que estaba la murga, desde el hecho que cada vez que organizábamos un 24 de marzo y que H.I.J.O.S. se encargaba de hacer el 24, era organizar fiesta, o sea era fiesta, vamos a hacer una fiesta, en esta esquina van a estar los payasos, en la otra esquina las bailarinas, en la otra esquina van a estar los músicos y en la plaza había fiesta, recital...»

Pregunta: ¿No desde el dolor sino desde la alegría?

$\overline{461}$ Testimonio de Josefina Centurión [Entrevista realizada por el autor el 21 de diciembre de 2007]. 
«Sí, porque además también nos ha costado mucho esto de que los organismos entienden que sos culpable por haber sobrevivido, muchos en nuestras familias lo hemos sentido, vos estás acá... ese peso de que vos sí estas vivo... y al contrario, el sentirnos bien por eso, no sé, es como que por suerte nos ha salido así...» ${ }^{462}$

Sobre el significado del 24 de marzo H.I.J.O.S. Viviana Vicente concluye:

«El 24 de marzo siempre fue como la actividad principal, es ir en esa fecha a la plaza, convocar a la mayor cantidad de gente posible y decir: acá hubo un golpe, acá hay un asesino suelto, acá hay una continuidad del terrorismo de Estado, los que están en el gobierno son cómplices de todo lo que pasó... es una actividad de denuncia, sí, básicamente de denuncia y tratar de llevar tu mensaje a la mayor cantidad de gente posible... $\gg^{463}$

Si el 24 de marzo representa para el MDHT el espacio de la denuncia, también es el de la discusión, el debate, la lucha interna por ocupar el espacio en el palco, la pelea con los partidos de izquierda por el protagonismo ${ }^{464}$, es, en todo caso, el espacio donde se resuelven o se

462 Testimonio de Susana Salvatierra.

463 Testimonio de Viviana Vicente.

464 Nótese como hasta los primeros años de la primera década del 2000, la izquierda siempre caminó junto al movimiento de Derechos Humanos en Argentina cada 24 de marzo. A partir del acercamiento de las organizaciones que componen al movimiento al gobierno de Kirchner, los partidos de izquierda, críticos del mismo, se distanciaron y por lo general es posible ver en cada provincia argentina hoy dos marchas distintas cada 24 de marzo: las que congregan las organizaciones de Derechos Humanos y las que convocan los partidos de izquierda en una nueva fractura claramente visible en la puja por ocupar un lugar central en la plaza principal. En los primeros años de la transición, tal división era impensable, dado que como ya se explicó en este trabajo, la izquierda contribuía con el movimiento de Derechos Humanos desde los comienzos mismos de la última dictadura. 
profundizan las luchas de poder al propio interior del movimiento. Esto es percibido claramente por todos en un tema de mucha sensibilidad como es la elaboración del documento que será leído en el acto central.

Normalmente, como explican los militantes, el documento se elabora a partir del texto del año anterior, sin embargo, cada 24 de marzo, la propia coyuntura hace que ese original sea discutido una y otra vez y el nuevo documento diste mucho de parecerse a su antecesor. Con el dictáfono apagado, una integrante del movimiento de Madres de Plaza de Mayo filial Tucumán me comentaba un altercado entre los dirigentes de Familiares, APDH y ella misma. La discusión giraba en torno al documento final, que si bien había sido consensuado por todos, estaba escrito por la presidenta de Madres, que, según entendían los otros dirigentes, había cambiado la letra estipulada. Esta discusión se había producido el 23 de marzo de 2006, un día antes del acto central del 24. La presidenta de Madres en Tucumán había amenazado entonces con no concurrir a la manifestación del día siguiente y esto preocupaba a las otras organizaciones, que inmediatamente le pedían disculpas y le solicitaban rever la medida. La conclusión de esta militante de Madres es clara: «necesitan del pañuelo blanco en la plaza».

El MDHT necesita de la presencia del pañuelo blanco en la plaza, como símbolo externo de la lucha contra la dictadura, símbolo de las marchas de los jueves y de las marchas de los 24 de marzo. Lo que refleja en todo caso este incidente es que la conflictividad dentro del propio movimiento es tan fuerte como lo puede ser hacia fuera, produciéndose un enfrentamiento de las memorias de los propios militantes. 


\section{CAPÍtulo XI: El MDHT fRente al AsCenso del General ANTonio Domingo Bussi}

\section{XI.1 Palito "Ortega" o Antonio D. Bussi, y el Retroceso del MDHT}

Como concluye Crenzel "la emergencia y desarrollo del Bussismo como fuerza significativa en el ámbito de la provincia de Tucumán a partir de 1987 (...) hasta 1995 cuando alcanza la gobernación de la provincia, expresó un proceso múltiple de articulación de variadas formas de persistencia y emergencia de una memoria social favorable al gobierno dictatorial en la provincia en una importante porción de la población." ${ }^{465}$

Un paréntesis se hace necesario aquí para hablar de la primera elección que ha tenido a Bussi por protagonista en la lucha por ocupar la gobernación de Tucumán. El fortalecimiento de Bussi y su partido FR nacido del alejamiento del general retirado del partido que le sirvió de plataforma de lanzamiento, Bandera Blanca, serán producto de las llamadas leyes de impunidad, pero también de la incapacidad de la dirigencia política provincial, que no ha sabido articularse para satisfacer las demandas de grandes sectores de la sociedad. Estos sectores sociales que confiarían su voto a FR, veían en Bussi la alternativa al sistema bipartidista que se reproducía en Tucumán como fiel reflejo de todo el país, donde los partidos Justicialistas o Peronistas y Radicales, absorbían casi todo el espectro del electorado en el país.

El desencanto por los gobiernos peronistas y radicales, más una memoria de grandes sectores sociales acerca que la dictadura de los años '70 había supuesto orden, limpieza y cierta resolución de las demandas

465 Crenzel, Emilio (2001): Memorias enfrentadas, Op. Cit. P. 21. 
públicas, se manifestaba en la capacidad ejecutiva del ahora candidato a gobernador y se veía reflejada en obras públicas realizadas en los años en que Bussi había sido gobernador de facto.

Bussi no dudaba en mostrar su propia imagen de administrador eficaz frente al desgobierno del entonces gobernador justicialista José Domato, elegido en 1987 y quien tuvo que ser reemplazado un año antes de finalizar su mandato por una intervención federal dispuesta desde el gobierno central, en 1990. La gestión de Domato, además de verse agravada por la crisis económica que sacudía al país desde 1989, había levantado sospechas de corrupción. Por su parte, quienes más cuestionaban en todo caso la "supuesta" capacidad de administrar los bienes públicos y de ejecutar con eficacia obras públicas, por parte de Bussi, eran los propios militantes de las organizaciones de derechos humanos, que, en su afán de frenar el avance político del militar, ofrecían testimonio sobre las deficiencias de las obras públicas realizadas durante su gestión en los años de la dictadura.

Esto es lo que comentaba, por ejemplo, Carlos Soldati sobre las obras públicas realizadas por Bussi en tiempos de dictadura:

«Después está la impotencia de la democracia, porque hablamos de la democracia, de la libertad de expresión, pero para mucha gente eso no ha sido gran cosa... Más bien aparece como una burocracia impotente, que no pagaba los sueldos en términos y que no tenía respuesta. Entonces en medio de ese clima y con la categoría que organizaban con lo que había ocurrido mucha gente, o no lo sabía con precisión, o no sabían la magnitud, o decían, ah no! Fue contra los guerrilleros nada más, o contra la subversión (...) entonces se empieza a escuchar una voz con un discurso enérgico y simplificador, que traía todas las soluciones: Bussi. Y como en 
la Alemania previa al surgimiento de Hitler, empieza a crecer la figura de Bussi. Pero a partir del enorme poder que en la imaginación de la gente tenía Bussi, ¿pero ese poder por qué? Hasta por las cosas malas que había hecho, y era el único que podía revertir la crisis, y yo discutiendo con gente me dicen: pero mirá todo lo que hizo Bussi, ah claro! En eso vos tenés razón, pero es que yo lo quiero a Bussi con todo ese poder pero en democracia, y valoraban el poder que había tenido de lo malo que había hecho. Incluso lo bueno había sido mucha propaganda, porque en realidad había aumentado la desocupación con la cesantía a los empleados públicos, y las obras que se habían hecho eran en tiempo record y no eran $\tan$ buenas... ${ }^{466}$

Estas dos visiones en pugna serían las que catapultarían a Bussi a la gobernación, pues aún cuando hubiera podido cometer crímenes de Lesa Humanidad, el dictador, según los imaginarios sociales del momento, "hacía obras públicas" en contraposición con las autoridades del momento elegidas por medio del voto. ${ }^{467}$

Es así como, a comienzos de 1991, el crecimiento cuantitativo de los posibles votantes de FR hizo ver a los dos partidos más importantes de la provincia, el Justicialista y el Radical, que había que buscar una solución popular para canalizar en las urnas el descontento ciudadano. La alternativa llegó entonces de la mano de un cantante del pop tucumano, traído desde su lugar de residencia, Miami, en Estados Unidos, recalando en la provincia como candidato por el Partido Peronista local. Ramón Bautista Ortega, más popularmente conocido como "Palito Ortega", ${ }_{466}$ Testimonio de Carlos Soldati.

${ }^{467}$ No en pocos casos los votantes de Bussi o bien compartían la ideología del ex gobernador de facto y por lo tanto justificaban el accionar represivo o bien ponían en duda las imputaciones que desde las organizaciones de derechos humanos se hacían. Primaba, en todo caso, la eficiencia de Bussi, gobernador, para administrar la cosa pública. 
consiguió unificar a la oposición frente al horror que suponía la emergencia del Bussismo. Nunca mejor explicado el refrán que reza "no nos une el amor, sino el espanto" también mencionado en las entrevistas.

Muchos militantes del MDHT y de algunos partidos de izquierda, incluso aquellos que se encontraban lejos de la opción electoral, decidieron concurrir a las urnas en 1991 para votar por Ortega, ante una Fuerza Republicana que era favorita en todas las encuestas. El cantautor tucumano conseguiría de esta manera, desplazar a Bussi en las preferencias electorales. Proveniente de una familia humilde de la periferia rural de la provincia, Ortega había regresado a Tucumán después de haber triunfado en el espectáculo y en la empresa para disputar la gobernación a Bussi y se impuso por un escaso margen de sufragios al general retirado. San Miguel de Tucumán, la capital de la provincia, quedó, sin embargo, en manos de FR. ${ }^{468}$ Nótese, además que la Unión Cívica Radical (U.C.R), habiendo sido la primera fuerza en 1987, prácticamente desapareció del espectro político provincial en las elecciones de 1991. De algún modo, podría suponerse que la mayor parte de los votos ganados por Bussi provenían de viejos votantes de la U.C.R., pero en elecciones posteriores se puede observar que tanto este partido como el Justicialista perderían votantes en favor del Bussismo.

La estrategia del peronismo había sido exitosa en 1991, sin embargo, no pudo repetir la fórmula en 1995, oportunidad en que una feroz interna partidaria, resolvió la postulación de Olijela del Valle Rivas a la gobernación. La candidata oficialista llevaba sobre sus espaldas una tradición caudillista y clientelar, propia del partido justicialista, que no

\footnotetext{
${ }^{468}$ Véase los trabajos de Marcos, Dolores: Liderazgos autoritarios en el Noroeste argentino, el caso Bussi en Tucumán, Op. Cit y Aibar, Julio: El retorno del General. El Bussismo, la otra cara de la democracia argentina, en Perfiles Latinoamericanos No 26, FLACSO.
} 
contaba con la plena confianza ni la popularidad del electorado, ni siquiera dentro de su propio partido.

Prueba de esto es el triunfo de Bussi en la elección a gobernador en Octubre de 1995 producido por un margen importante de diferencia con el Partido Justicialista, aunque no supuso, sin embargo, el dominio por parte de FR del parlamento provincial. Asimismo, el Bussismo se volvía a adjudicar la alcaldía de la capital provincial, pero los municipios del interior, en su mayoría, fueron conquistados por el peronismo. Esto indica un importante corte de papeletas a favor de la figura de Bussi y contra la candidata justicialista, pero que implicaba al mismo tiempo, cierta confianza en los candidatos a la legislatura de los partidos tradicionales, una contradicción que suele repetirse casi como norma en algunos actos comiciales. Además, los estudios constatan que la procedencia del voto Bussista se concentraba en la capital y sus alrededores, y no en el sector rural que seguía respondiendo, como históricamente lo venía haciendo, al peronismo. ${ }^{469}$

\section{XI.2 ENTRE LO SIMBóliCO Y LO REAL: EL JUICIO ÉTICO Y EL RETORNO DEL General}

El 19 de junio de 1995, dos meses antes de las elecciones provinciales a gobernador que llevarían a Antonio Domingo Bussi como principal candidato a ocupar la casa de gobierno, según las principales encuestas, los organismos de Derechos Humanos de la provincia de Tucumán decidieron organizar un "Juicio Ético"470 contra el represor. El

469 Marcos, Dolores, Op. Cit. Y Aibar, Julio, Op. Cit. Véase Crenzel, Emilio, El voto a Bussi en Tucumán, Op. Cit.

470 En anexo presento un DVD que contiene una filmación amateur del Juicio Ético, documento que considero como un fundamental aporte al presente trabajo, no solo porque permite observar al movimiento de derechos humanos de Tucumán en acción, sino y sobre todo porque es uno de los pocos materiales audiovisuales disponibles de la época disponible, lo que sirve como referencia para cruzar este 
Juicio Ético a Bussi ${ }^{471}$ ha quedado entonces en el imaginario de los militantes del movimiento de derechos humanos de la provincia, como uno de los íconos en la lucha local por frenar el avance del Bussismo. Para algunas de estas organizaciones, el Juicio Ético implicó volver a la escena pública tras la serie de derrotas políticas que supusieron las leyes de Obediencia Debida, Punto Final, los indultos y el ascenso del propio Bussi en el escenario político local. Aunque lo simbólico del juicio no implicaba una condena real del represor, lo que buscaron las organizaciones de derechos humanos era la condena social. Cada organización participó aportando sus propios militantes y colocando sus propias fuerzas, la coordinación y la actuación conjunta hicieron visible que la figura del ex represor Bussi, conseguía la unidad de acción y criterios en la mayoría de las actividades públicas del conjunto.

Mientras que en 1991 las fuerzas políticas tradicionales habían conseguido frenar el avance del ex represor con la apuesta del Partido Justicialista, ubicando al cantante Ramón Ortega en el centro de la campaña electoral, en 1995 parecía que las estrategias para impedir tal avance se encontraban limitadas y con pocas posibilidades de éxito, dado el crecimiento sostenido del apoyo popular al general retirado. Desde 1987, año en que Bussi se catapultó como político en la provincia de Tucumán, detrás del Partido Bandera Blanca, que lideraba Ávila Gallo, las organizaciones de derechos humanos de la provincia venían sosteniendo

mismo con los testimonios y al mismo tiempo con las notas de prensa sobre el evento en cuestión. El video del Juicio Ético nos permite tener una visión del conjunto de las organizaciones de derechos humanos actuando desde lo colectivo, lo que además nos ayuda a confirmar que las mismas se constituyeron como un movimiento social amplio, aunque cada organización actuara de manera autónoma. Al mismo tiempo es una prueba irrefutable que nos permite valorar positivamente los testimonios orales al corroborar que lo narrado por los entrevistados es creíble en el cruce de fuentes.

${ }^{471}$ Véase el video citado sobe el Juicio Ético. 
la necesidad de obstruir dicho avance, aunque desde los partidos políticos se minimizaran las capacidades del ex gobernador de facto por armar una estructura capaz de llegar al poder.

El crecimiento paulatino de FR les hizo dar cuenta tanto a las organizaciones de derechos humanos como a los partidos políticos tradicionales que de ninguna manera se podía subestimar el poder de convocatoria del Bussismo y, para mediados de 1995, meses antes de las elecciones provinciales, la suerte parecía estar echada: la llegada de Bussi a la casa de gobierno era inminente y las perspectivas en el horizonte político local parecía signado por la presencia del represor.

Sobre el contexto político en el que se desarrolló el Juicio Ético, Emilio Crenzel postula que "más allá de la competencia electoral, pero aprovechando el "estado deliberativo" previo a las elecciones, los organismos de Derechos Humanos instrumentaron un "juicio ético" a Bussi con abogados, intelectuales, ex militantes, ex detenidos desaparecidos, sindicalistas y en el que también participó el ex gendarme Torres, quien declarara ante la CONADEP haber sido testigo de ejecuciones directas de prisioneros por parte del entonces General Bussi, dando su testimonio". 472

Es así como el 19 de junio de 1995, los organismos de derechos humanos de la provincia decidieron organizar el Juicio Ético y Popular, como se lo denominó, contra el represor y candidato a la gobernación de Tucumán. En dicha campaña, Bussi basaba sus discursos y solicitadas críticas "al 'gobierno empresarial' de Ortega y a 'los excesos de la libertad económica' que desatienden las necesidades de la gente, a la par de manifestarse reiteradamente como 'un buen amigo de Menem' y refrendar el plan económico llevado adelante por el gobierno nacional". 473 472 Crenzel, Emilio, Op. Cit. P. 54.

473 Ibídem. 
Por su parte los organismos de derechos humanos en 1995 se encontraban reagrupados ante una causa común: evitar que el ex represor ganara las elecciones como sugerían las principales encuestas de aquellos días. Aunque con ciertas discrepancias sobre la acción a llevar a cabo, la unidad de acción se manifestaba en determinadas oportunidades acompañados por referentes nacionales, quienes veían con sorpresa el ascenso del Bussismo.

Los reacomodamientos al interior del movimiento de derechos humanos ante el temor del triunfo de Bussi, hicieron que muchas organizaciones volvieran a resurgir con fuerza tras un decaimiento del movimiento en su conjunto en los últimos años de los ' 80 y los primeros años de los '90, procurando establecer fuertes vínculos entre todos para enfrentarse a al Bussismo político. ${ }^{474}$ Junto al surgimiento de H.I.J.O.S. en $1995^{475}$, el regreso de algunos actores sociales que se habían alejado de la militancia algunos años antes, como veremos luego, revive también en Tucumán; la Asamblea Permanente por los Derechos Humanos (APDH), que llevaba varios años desarticulada, sobre todo a partir del alejamiento de su presidente Atilio Castagnaro a fines de los '80, cuando emigra a España, vuelve a congregarse para contribuir con el JE. A finales de 1994 Castagnaro había regresado a Tucumán para reorganizar a la APDH local, dadas las perspectivas políticas de la provincia, el crecimiento del Bussismo y la posibilidad que el general retirado consiga un triunfo electoral al año siguiente.

\footnotetext{
${ }^{474}$ Sobre el crecimiento electoral del Bussismo léase Marcos, Dolores, Op. Cit. 475 Léase Kotler, Rubén (2009): "Los orígenes de H.I.J.O.S. en el movimiento de derechos humanos de Tucumán", en Memorias del Primer Congreso Nacional sobre Protesta Social, Acción Colectiva y Movimientos Sociales en Argentina, Buenos Aires.
} 
Castagnaro explica entonces:

"Hasta entonces la APDH estaba un poco desarticulada porque se habían ido mucho de los compañeros, Rovetta estaba en España, y vive actualmente en España, estaba bastante desarticulada, no solo la APDH sino también, digamos, los compañeros de la APDH estaban medio dispersos, quizás más metidos en organismos, en Familiares, pero Familiares también estaba medio disperso, era un año muy jodido, estamos hablando de un año antes que gane Bussi las elecciones, estaba muy desarticulado todo y..."

Pregunta: ¿Fue el ascenso del Bussismo lo que permitió volver a articular al movimiento?

"El acojone que nos produjo, sí, sí, seguro. Y acá ya nos empezamos a juntar y ahí si que venían Madres... por ejemplo, a las reuniones de la APDH venían un montón de Madres, la Pirucha se incorpora como una militante más de la APDH, la Pirucha de Campopiano, la Nelly de Bianchi, y bueno, refundamos la APDH..." ${ }^{\prime 476}$

El temor del que refiere Castagnaro, y que determinó la realización del Juicio Ético era el temor que recorría en esos meses a todos los organismos de derechos humanos pues el ascenso del ex represor y su triunfo electoral esta vez parecía inevitables. El ejemplo de la APDH sirve para ilustrar hasta qué punto el Bussi que estaba dispuesto llegar al poder, consiguió reactivar a un movimiento que venía desalentado. El temor a que el partido de Bussi finalmente accediera a la gobernación, determinó por otra parte que el movimiento de derechos humanos se reagrupara y pasara de la inacción a la protesta, como hiciera en años anteriores. Ya no se levantaban las consignas de la "aparición con vida" de los desaparecidos, pero el doble principio de $\overline{476}$ Testimonio de Atilio Castagnaro. 
"Verdad y Justicia" era enarbolado una vez más por las organizaciones. La verdad implicaba conocer qué había pasado en los años de la dictadura y la justicia marcaba al tiempo presente en la necesidad de anular las leyes de Punto Final, Obediencia Debida, dejar sin efecto los indultos y volver a poner en la agenda pública el juicio a los responsables de las desapariciones.

José "el macho" Luna ${ }^{477}$ había sido uno de los artífices del Juicio Ético. Exiliado en Venezuela, Luna había sido uno de los militantes setentistas que habían luchado contra el cierre de los comedores universitarios, en las revueltas de los Tucumanazos, mencionadas en otro capítulo de este trabajo. En 1995, meses antes de las elecciones, Luna volvió a Tucumán para colaborar en la organización del tribunal ético y fue uno de los artífices de esta actividad que mostraba, como vemos en los testimonios, al conjunto de las organizaciones de derechos humanos y partidos de izquierda, juntos alrededor de una causa. En la memoria de José Luna vuelve entonces la evaluación que él mismo hace de lo que fue el Juicio Ético, por una parte, y cuál era el clima de época en el enfrentamiento con el Bussismo en esos años, por otra:

«La presencia de ese energúmeno (por Bussi) hizo con que lo que uno pudiera hacer para denunciarlo, era la obligación. $Y$ en las campañas de gobernador de él yo vine con unos compañeros de Buenos Aires y otros compañeros de aquí, organizamos el juicio ético contra... el tribunal ético contra Bussi. Y, en realidad, todavía no había juicios legales, ni la justicia burguesa había hecho nada, es decir, todavía eran personas que tenía campo libre, que se podía presentar un genocida como un simple ciudadano con todos los derechos democráticos vigentes como si nunca hubiera hecho nada.

$\overline{477}$ Referencia al macho Luna. 
Entonces hicimos ese juicio, que fue muy importante, que lo declaramos culpable, que participó un grupo importante de compañeros, que en realidad queríamos sembrar los primeros embriones a ver si se podía aparecer con polos de agrupamientos pero el hecho como tal sirvió, tuvo su parte. En esos mismos días también, un compañero que estaba en el canal, Germán Valdez, me invitó a un debate contra Bussi, al final contra dos funcionarios, dos cuadros del Bussismo, Bussi no fue, pero fueron ellos, mientras yo los acusaba y les demostraba todos los crímenes de Lesa Humanidad que ellos habían hecho, ellos, la máxima acusación, porque bueno, de qué me pueden acusar, cuál ha sido nuestro delito, yo pagué cárcel, exilio, mi vida cambió, no tengo ni un futuro todavía para mí, porque voy, vengo, ando itinerante, estoy pagando un duro precio por haber luchado aquí, bueno, "ustedes", que son los artífices de la dictadura, cuáles son los cargos que me hacen, háganme los cargos delante de la cámara, díganme qué hemos hecho, lo único que se atrevió uno a decir que pintábamos las paredes, que ensuciábamos las paredes $(\ldots) \gg .478$

Si bien el Juicio Ético no ha sido cubierto mediáticamente, tuvo una repercusión en el tiempo y ha quedado grabado en la memoria de los militantes de las organizaciones de derechos humanos de Tucumán. Cuando uno indaga la historia del movimiento a partir de entrevistas con los dirigentes de las organizaciones descubre lo qué ha significado simbólicamente el juicio en tanto actividad conjunta en una manifestación plural y con una capacidad organizativa trascendente, mientras que la organización se tuvo que enfrentar a todo tipo de adversidades como, por ejemplo, la negativa de los clubes a prestar apoyo para su concreción. Es así que en la trayectoria histórica del

478 Testimonio de José Luna. [Entrevista realizada por el autor el 19 de diciembre de 2012]. 
movimiento el JE no ha quedado al margen $\mathrm{y}$ todos los militantes mencionan en algún momento de sus relatos las instancias de la mencionada manifestación pública. Ha implicado, por lo tanto, un acto que, más allá de su valor simbólico, ha generado un impacto de tal magnitud que es imposible que un militante no solo no lo mencione, sino que no realice una evaluación positiva, aún cuando solo haya sido un acto simbólico y a priori no haya logrado su cometido. Con la excepción de Laura Figueroa, abogada por los derechos humanos y principal querellante en la causa del Arsenal Miguel de Azcuénaga, quien, al día de hoy, hace un balance negativo, como veremos más adelante, todos los testimoniantes destacan el valor del acto celebrado en el club All Boys, analizando positivamente su concreción.

Es importante destacar esta cuestión ya que si bien la manifestación pública celebrada en el club no cumplió con el objetivo de frenar el avance de Bussi a la casa de Gobierno, sí mostró al movimiento de derechos humanos en conjunto, la capacidad en la organización de actos unitarios, independientemente de las diferencias políticas de cada organización, estos actos habían decaído por las debilidades del movimiento. Vemos aquí cuán importante son algunas manifestaciones públicas, aunque simbólicas, para el imaginario de los militantes y para balancear una falta ante determinadas demandas.

Los organismos buscaban, por medio de la organización del Juicio Ético, lanzar un mensaje, aunque sea alegórico, al conjunto de la sociedad sobre los crímenes de Lesa Humanidad cometidos por el general retirado, ahora candidato una vez más. A falta de una condena judicial, el movimiento de derechos humanos seguía buscando la condena social, esta vez por medio de la realización de un juicio simbólico, una forma de escrache público, manifestación popularizada unos meses más tarde por 
la organización H.I.J.O.S. que comenzaba a dar sus primeros pasos en la escena política nacional.

"El tribunal ético estuvo integrado por 22 miembros, entre ellos los legisladores provinciales Gurmesindo Parajón y Daniel Márquez; el sindicalista Carlos 'Perro' Santillán; los escritores David Viñas y León Rozichner y Emilio Mignone, de la organización de derechos humanos Centro de Estudios Legales y Sociales (CELS)"479, y tuvo lugar en el club All Boys próximo al centro de la ciudad, el que se vio colmado en su capacidad para dos mil personas. No sin dificultades de toda índole, el juicio demostró la capacidad de movilización con la que contaba en aquellos años el movimiento de derechos humanos, movilización que sin embargo no era constante ni permanente.

Según recuerda Sara Mrad, la organización en la que ella milita, Madres de Plaza de Mayo, participó del juicio:

«Participamos y lo organizamos con los otros organismos. Había acuerdo en organizarlo, porque además fue una movida muy importante, porque ha venido gente de Buenos Aires de diferentes agrupaciones, y se ha movilizado mucho la gente, y la verdad que ha sido una actividad muy importante... La patada inicial para el juicio la hace justamente Madres ya que en Buenos Aires ya se venían haciendo los juicios éticos a los médicos, a mucha gente, ahí en la Plaza, por eso surge acá también. La idea, la propuesta es de Madres y ha sido ampliamente aceptada, además que en esos años estaba la Asamblea Permanente que en ese momento tenía una línea acorde a la de Madres, entonces ha habido más gente que trabajaba...»480

\footnotetext{
479 Clarín, 20 de Junio de 1995.
}

480 Testimonio de Sara Mrad. 
Sobre la organización del Juicio Ético, Carlos Zamorano, referente del Partido Comunista Argentino y de la Liga Argentina por los Derechos del hombre, explicaba:

«Los organismos de derechos humanos locales, con mi humilde participación, porque yo viajé a ese efecto desde Buenos Aires, consideraron indispensable poner en escena un juzgamiento al genocida Bussi fundado en que para nosotros daba exactamente igual que sacara dos votos o que sacara dos millones de votos. El estigma por su obra histórica era irreversible, se trataban de crímenes de Lesa Humanidad y ahí no hay prescriptibilidad, ni amnistía ni amnesia, son inindultables, inasibles, etc, en consecuencia correspondía convocar a la opinión pública para hacer un juicio ético popular simbólico. La participación central, yo tengo la absoluta persuasión, fue de Gumersindo Parajón ${ }^{481}$. Gumersindo Parajón, procuró hallar de diversas fuentes el dinero indispensable, puso en movimiento el vasto espacio popular que en esa época lo apoyaba, con la participación de todos los organismos de derechos humanos que en el imaginario social suscitan un eco indudable y movilizaba en aquella época todavía a las masas, a pesar de estar decaído ya el movimiento de derechos humanos en cuanto al eco popular, porque obviamente los organismos de derechos humanos nunca han tenido masa propia, pero sí han tenido capacidad de convocatoria para las masas y ha habido actos muy grandes en épocas pretéritas. Bueno, todavía en el año '95 era creíble, pero realmente, cuando se hizo el juicio y hubo 1.500 personas presentes, llamó la atención... porque

$\overline{481}$ Gumersindo Parajón es un histórico dirigente político surgido del radicalismo. Una vez fuera del Partido Radical, Parajón fundó un partido propio: Pueblo Unido. Referente político que ha tenido una importante actividad referida al tema de los derechos humanos y ha sido activo participante en el Juicio Ético a Bussi. 
en otros lados se hizo un juicio ético con 300 personas a 400 personas, en diversos lugares del país, etc. De modo que lo extraordinario es que el Juicio Ético se realizó en la sede del club All Boys mientras la comisión directiva nos declaraba intrusos, nos ordenaba por resolución a evacuar, nosotros le dijimos que teniendo 1500 personas dentro esto era impracticable, que habíamos convenido junto con la subcomisión de Basquet, porque ellos necesitaban el ingreso de dinero, se alquiló la sede en nombre del club, y todo eso la comisión directiva no refrendó, al contrario, revocó por el terror, mientras los camiones con gente bussista circulaban alrededor del club All Boys profiriendo amenazas y todo eso... ya nos habían revocado en dos lugares anteriores que no puedo memorizar hoy, pero Gumersindo sin dudas lo recuerda perfectamente, después de haber puesto el dinero, porque se pagaba adelantado, luego revocaron y nos devolvieron el dinero, entonces se trajo incluso vehículos del interior de la provincia con gente para este Juicio Ético popular y bueno...»

Pregunta: ¿Cómo fue el funcionamiento del Juicio?

«Había un tribunal colegiado con muchas personas representativas que delegaron en el presidente para conducir, que era David Viñas, quien tenía de secretario a otro miembro del tribunal, que era Gumersindo Parajón, por su antigüedad como judicial, que podría ayudar en el sentido de dirigir la cosa, porque David Viñas puede entender de la historia de la literatura, pero sinceramente en esta cuestión era difícil. Además David Viñas debía cerrar al final del juicio e hizo alguna referencia a un líder y mártir de Tucumán, Bernardo Monteagudo. Entre la inmensa cantidad de gente y figuras, me costaría ahora intentar... por ejemplo, alguien que 
llegó a ser juez y creo que ministro de la Corte Suprema en Jujuy, que acaba de fallecer, un novelista destacado y cuentista, era uno de ellos, que tiene una hija desaparecida... eran como 25 jueces y lamento tanto no poder tener en este preciso instante memoria y me surgirá en cualquier instante... por ejemplo, estaba el capitán D'andrea Mor, entre los jueces, en determinado momento, después que se escuchan los alegatos, la fiscalía, que eran el "chino" Robles y yo, y después de haber escuchado el alegato de la defensa, se pasó a cuarto intermedio para dictar sentencia, ante 1.500 personas que estaban angustiadas y que no conocían en realidad que nos habían declarado intrusos y que estábamos usurpando, entonces es obvio que en diez minutos tienen que venir, porque el fallo ya estaba pre elaborado con acuerdo de los organismos...»

Pregunta: ¿Y no se repartió el texto del fallo entre el público?

«No, solamente los jueces, porque el juicio oral es así, al final del juicio se leen las sentencias y se disuelve... no se puede distribuir entre la gente porque quedaría más evidente que ya había fotocopias a granel, cosa absurda... pero sucede que no volvía el tribunal del lugar a donde estaba, supuestamente elaborando la sentencia, y me dice Gumersindo Parajón "andá y fijate porque no vuelven", y ahí se armó una discusión, y yo digo: pero yo soy fiscal, no puedo entrar a hablar con el tribunal, y yo un poquito obtuso por mi formación, y me dice, pero bueno, entrá de manera clandestina, y bueno, estaban discutiendo, porque parece que el capitán D'andrea Mor había dicho que se ponga como parte de la sentencia que queda habilitado el capitán (D'andrea Mor) para retarlo a duelo espada al general Bussi y para 
dirimir en el terreno del honor las cosas que había hecho, algo así era (...) el tema es que por fin volvieron y leyeron la sentencia. En este momento no me acuerdo quién la leyó...»

Carlos Soldati, quien había militado en Familiares y Madres, y había sido uno de los co fundadores de la APDH en Tucumán, para mediados de 1995, estaba alejado de la militancia en las organizaciones de Derechos Humanos. Cuando se organiza el JE participó como testigo dejando su testimonio en el juicio, aportando datos sobre la desaparición de sus hermanos y del secuestro que él mismo sufriera. Sin embargo, Carlos narra cómo ha vivido las instancias del JE que lo tuvo como uno de los "protagonistas":

«En el año 1995 gana Bussi. Unas dos semanas antes hicimos el juicio ético. Yo ahí brindé mi testimonio, otros sobrevivientes de campos de concentración también. Para nosotros ese juicio ético fue una satisfacción grande que con el apoyo de gente de Tucumán y de Buenos Aires, como David Viñas, por ejemplo, se hubiera hecho. Y quedó registrado. ${ }^{482}$ Uno de los que participó fue el ex gendarme Omar Eduardo Torres que brindó su testimonio. Aunque ha sido filmado hay que decir que la repercusión que tuvo en los medios ha sido escasa. $\mathrm{Y}$ juicio ético entre comillas, como no tomando enserio esto del juicio ético. Como acto fue algo muy importante por los testimonios, por la concurrencia, por el apoyo de gente de Tucumán, vino el militar D'Andrea Mohr, como decía, David Viñas, el actor Gerardo Romano, gente de los organismos... y fue muy emocionante, pero desde el punto de vista de la repercusión es como si hubiera sido boicoteado... $>^{483}$

\footnotetext{
482 Soldatti hace mención aquí a alguna de las tantas filmaciones que han registrado el juicio ético.

${ }^{483}$ Testimonio de Carlos Soldatti.
} 
Felicidad Carreras, militante desde los orígenes de Familiares de Detenidos Desaparecidos por Razones Políticas, fue una de las participantes más activas en la organización del Juicio Ético. Felicidad se había involucrado tempranamente en el movimiento y si bien venía de años de desazón por no haber podido encontrar a su hermano desaparecido, al igual que Carlos Soldati, Ilevaba mucho tiempo alejada de la militancia. El Juicio la convocó de la misma manera que había convocado a decenas de militantes que veían en él una nueva oportunidad de manifestarse públicamente para exigir el principio de Verdad y Justicia. Una anécdota recorre la historia que la propia Felicidad narra con entusiasmo y que la filmación del juicio se encarga de corroborar, una anécdota que parece superflua cuando uno la analiza fríamente en el marco de la manifestación, pero que confirma la veracidad de su testimonio al confrontarlo con el video en cuestión. Felicidad relata entonces un episodio que lejos de ser jocoso, demuestra al mismo tiempo cuán movilizada estaba la sociedad y sobre todo cuán expectantes estaban fuera de Tucumán los que veían con asombro el ascenso de Bussi:

«Sí, que fue toda una historia que te deben haber contado, que lo hacíamos en un lado, que lo hacíamos en otro lado, bueno por fin se lo hizo en el aquel club chiquito, pero una cosa muy importante que cuando lo veía a Carlos Zamorano me acordaba ${ }^{484}$ porque él fue uno de los jueces, $y$, pero yo no participe ni como testigo ni como nada porque estaba muy bien organizado, fue una cosa relativamente corta, me acuerdo que Carlos Soldati, vos sabes que no me acuerdo quien más, Gerardo Romano me acuerdo que estuvo

\footnotetext{
${ }^{484}$ Felicidad menciona a Carlos Zamorano ya que tuvo oportunidad de verlo unos días antes de la entrevista que le hiciera en el documental El Tucumanazo, en una de las proyecciones del largometraje en Tucumán.
} 
presente, estuvo presente porque yo lo invité, ¿te contaron? Fue muy gracioso... ${ }^{485}$

Pregunta: cuénteme, quiero que usted me lo cuente...

«Fue muy gracioso. Resulta que yo me entero por el diario que estaba Gerardo Romano poniendo una obra de teatro acá, en el teatro Alberdi, si no me equivoco, entonces digo, a este tipo hay que invitarlo, entonces hago una notita, que decía: Gerardo, soy fulana de tal, no me acuerdo exactamente, mañana en tal lugar, no me acuerdo el lugar porque iba a ser en este club que queda pasando la Avenida Sarmiento...»

Pregunta: ¿Estudiantes?

«Sí, creo que era ahí, vamos a hacer un juicio ético a Bussi como "sé cómo piensas" una cosa así, te espero, "Mimi" Carreras. Romano se alojaba en el Gran Hotel y me voy en el auto de una amiga con el sobre cerrado, lo dejo, bueno pasa; vos sabes que yo el día ese del juicio era tantas cosas que ni me he acordado de Gerardo Romano, sinceramente a mi él me encanta como actor, como hombre; proviniendo hacia el final, el locutor que no me acuerdo quien era, dice: porque acá contamos con la presencia, bueno estaba David Viñas, todos los que habían venido, el padre Farinello, Rozichner, el perro Santillán, y en un momento dice, contamos con la presencia del actor Gerardo Romano; estábamos en un grupo de gente y empiezo a mirar, a buscarlo, cuando lo veo estaba teñido de rubio, de pelo claro, no me olvido, era una cosa rarísima, en medio de toda la gente cruza y se sube al escenario, se para en el escenario y lo primero que dice: "¿Quién es Mimi?" ... dicen mis amigas que me tuvieron que hacer una camilla, casi me desmayo de la emoción y yo le

485 Testimonio de Felicidad Carreras. 
gritaba "yo, yo!" y me dice él "gracias por invitarme, porque por eso estoy acá" una cosa así, por supuesto el habló unas cuantas palabras muy lindas y después me acerqué al escenario para saludarlo cuando bajaba, le dije cuanto te agradezco porque la verdad el diario no sacaba nada. $\gg^{486}$

Más allá del gesto del actor al saludar a Felicidad, que se comprueba en la filmación que se ha podido rescatar de las instancias del juicio, lo que el testimonio deja para el análisis tiene que ver con la veracidad de lo narrado, aunque también sobre las percepciones que se tienen del valor del JE más allá de lo simbólico. En aquellos años, el movimiento de derechos humanos de Tucumán tenía necesidad de ver respaldada su lucha por referentes nacionales, aún de aquellos provenientes del ámbito de la cultura. Esto le daba legitimidad a la batalla del movimiento que procuraba, como ya dije, frenar el avance del Bussismo. Al mismo tiempo, corroborar que lo narrado por Felicidad no es una exageración y que Gerardo Romano la menciona en la filmación es una clara señal que el testimonio de la militante se vuelve creíble, no solamente el del JE, sino toda la entrevista, que aborda la historia personal y familiar que circunda a la desaparición de su hermano. Esta cuestión nos lleva a reflexionar sobre un tema en permanente debate en el campo de la Historia Oral, como ser la credibilidad del testigo ocular.

$\overline{486}$ Testimonio de Felicidad Carreras. 


\section{XI.3 La Lectura de LA "SENTENCIA": LO REAL Y LO Simbólico}

Tras la realización del juicio ético los manifestantes marcharon por las calles de la ciudad portando antorchas y coreando cánticos contra Bussi y la dictadura. Al llegar a la plaza Independencia los militantes se detuvieron frente a las escalinatas de la Casa de Gobierno desde donde el dirigente de la Liga por los Derechos del Hombre, Carlos Zamorano, leyó la sentencia del tribunal. Zamorano recuerda entonces:

«Al llega a la plaza, unos religiosos, abandonan el palco y nos dejan el campo libre para usar un palco que era inesperado como beneficio de "tata Dios", no en vano eran religiosos (risas) entonces subimos al palco y me dicen: "lee la sentencia", pero ¿icómo voy a leer la sentencia si la tiene en el bolsillo a la auténtica David Viñas!? Y me dicen: se ha quedado en el camino a tomar cerveza... uy!! Dios Mío... entonces yo agarré lo que tenía en el bolsillo, que salvo algunas palabras, era lo que se acababa de fallar y lo leí ahí, no se cómo habrá salido, lo cierto es que ha tenido un finiquito de lo más exitoso... inesperadamente exitoso, por esa ida a la Plaza Independencia. ${ }^{487}$

La sentencia entonces leída sostenía los siguientes puntos:

1. El tribunal entiende probado que entre los años 1975 y 1977 se ha ocasionado en la provincia de Tucumán un genocidio, del cual resulta - entre otros - muy especialmente imputado quien fuera Comandante de las operaciones antipopulares primero, y Gobernador de facto después Antonio Domingo Bussi.

2. En base a las probanzas introducidas en el decurso del juzgamiento ético, se resuelve CONDENAR a los planificadores y ejecutores del

$\overline{487}$ Testimonio de Carlos Zamorano. [Entrevista realizada por el autor en agosto de 2008 en la ciudad de Buenos Aires]. 
mencionado genocidio contra el pueblo tucumano y, en especial, a su principal mentor el citado Antonio D. Bussi.

3. Por ello el tribunal recomienda a los Concejos Deliberantes de todas las ciudades de la provincia y a la Universidad que declaren personas no gratas a los condenados por este fallo.

4. Asimismo, peticionar al Tribunal Electoral provincial que revise la errónea resolución que le confiriera en su momento al Gral. Bussi el reconocimiento jurídico para presentarse como candidato a cargos electivos.

5. Igualmente, este tribunal ético, en nombre de la vida, exhorta a la opinión pública de Tucumán a no reconocer como candidato a ningún cargo público al citado General ni a los demás acusados, conceptuando que no reúnen las condiciones éticos sociales compatibles con el grado de desarrollo de la civilización universal sobre el respeto al ser humano y sus derechos sustanciales.

6. El tribunal ético plantea al Congreso de la Nación que declare la nulidad de las leyes no 23.492 (punto final) y 23.521 (Obediencia debida), privándolas de cualquier efecto jurídico desde el momento mismo de su indebida sanción en los años 1986 y 1987 respectivamente, a efectos de procederse al juicio y castigo regular de los crímenes que en este enjuiciamiento ético se han demostrado.

7. Atento a que los aquí acusados por la Fiscalía se presentan ante la opinión pública como fervientes católicos, y a que jamás han expresado el menor arrepentimiento sino que, por el contrario, hacen apología de su anterior conducta, y a que han soslayado la penitencia invocando a su favor las leyes de impunidad, este Tribunal solicita a la Santa Sede de la Iglesia Católica Apostólica 
HISTORIA Y MEMORIA DEL MOVIMIENTO DE DERECHOS HUMANOS DE TUCUMÁN (1977 - 1999) CAPÍtulo XI: El MDHT frente al Ascenso del General Antonio Domingo Bussi

Romana, que estudie la posibilidad de realizar el proceso de excomunión.

8. Con iguales fundamentos que los expuestos en el punto anterior el tribunal CONDENA, por último, al principal imputado, a vivir, soportar y sufrir la vida del pueblo argentino en libertad, democracia y pluralidad de pensamiento; por degradar la condición humana y haber ejercido la suma del poder público y el derecho de vida y muerte, se lo acusa de infame traidor a la Patria por lo cual, exhorta a la sociedad, a las instituciones representativas y en especial a la prensa, a negar al acusado el derecho de ser nombrado; en caso de resultar necesario referir su actividad, mencionarlo como "el culpable", sin citar su nombre. ${ }^{488}$

Como podemos observar, entre otras acusaciones, la sentencia sostenía que en Tucumán había habido un genocidio y uno de sus máximos responsables había sido el general retirado Antonio Domingo

${ }^{488}$ Véase el anexo documental interactivo referido al DVD con la filmación del Juicio Ético, donde en su tramo final aparece el propio Carlos Zamorano leyendo la presente resolución, la cual si bien no fue repartida entre los manifestantes, fue impresa con posterioridad. Firmaban la sentencia Co-Presidentes: David Viñas (escritor) - Gumersindo Parajón (legislador); Miembros nacionales y extranjeros: León Rozitchner (filósofo) - Luis Farinello (sacerdote) - José D'Andrea Mohr (militar retirado, CEMIDA) - Carlos "perro" Santillán (dirigente gremial) - Patricio Rice (Coordinador general del MEDH) - Beatriz Sardina (Secretaria DDHH de la CTA) - Raúl Serrano ( director teatral) - Juan Ferrante (ex sacerdote) - Beverly Keene (coordinadora SERPAJ) - Elsa Ponce (DDHH Salta) - María Inés Morey (DDHH Salta) - Diana Kordon (psiquiatra); Por Tucumán: Eduardo Rosenzvaig (escritor) - José Luna (ex dirigente universitario) - Jorge Gigou (pastor metodista) - Rubén Amaya (escritor) Ricardo Somaini (movimiento cooperativo) - Graciela Jaeger (Madres de Plaza de Mayo) - Carme Mitrovich (Familiares de Desaparecidos) - Ana M. Medina (sec. Ejecutiva MEDH) - Luisa Vivanco (APDH) - Adelaida Campopiano (Madres de Plaza de Mayo Línea Fundadora) - Hugo J. Palacios (médico) - Daniel Márquez (hijo de legislador desaparecido) - Eduardo Joaquín (plástico) - Sergio Osorio (periodista) - Adriana Clérici (Hijos afectados por represión política); Fiscales: Dr. Juan Roberto Robles y Dr. Carlos Mariano Zamorano. 
Bussi. En un documento que se hizo circular con posterioridad se condenaba a "los planificadores y ejecutores" de ese genocidio al tiempo que se emitía un mensaje directo ya no sólo a la sociedad tucumana, sino a los poderes gobernantes, tanto a los distintos poderes legislativos como a todas las universidades del país, para declarar persona no grata al ex dictador. Al mismo tiempo se persuadía a la población en general para que no votaran por el candidato en las elecciones provinciales próximas a ocurrir.

Asimismo, la tribuna política servía para peticionar al parlamento nacional la nulidad de las leyes no 23.492 (Punto Final) y 23.521 (Obediencia Debida), "privándolas de cualquier efecto jurídico desde el momento mismo de su indebida sanción en los años 1986 y 1987 respectivamente". También la Iglesia Católica Apostólica Romana fue objeto de denuncia en el documento elaborado, solicitando a las autoridades del Vaticano la excomunión de los represores. ${ }^{489}$ Por último se condenaba a Bussi como "principal imputado, a vivir, soportar y sufrir la vida del pueblo argentino en libertad, democracia y pluralidad de pensamiento; por degradar la condición humana y haber ejercido la suma del poder público y el derecho de vida y muerte, lo acusa de infame traidor a la Patria". Esta última declaración ponía de manifiesto lo que entendían los promotores del juicio ético, implicaban las violaciones a los derechos humanos cometidos por Bussi.

${ }^{489}$ Estimo realizar aquí una digresión en lo que se refiere a la Iglesia Católica en Argentina, ya que si por una parte importantes sectores de esa Iglesia apoyaron y avalaron los crímenes cometidos por represión, al mismo tiempo, una sociedad profundamente católica, como la tucumana, no podía prescindir de mencionarla. Hay que recordar una vez más que alguno de los organismos de derechos humanos habían tenido fuertes vinculaciones con alguna de las iglesias que respondían a la Santa Sede en Roma, y si bien muchos de sus miembros se reconocían católicos, denunciaban las complicidades de los Obispos con el régimen. 
Al volver sobre el JE se hace imprescindible observar la evaluación que los militantes del movimiento de derechos humanos hace transcurridos tantos años desde su celebración. Como dije al comienzo de este capítulo, todos sacan conclusiones positivas con la sola excepción de Laura Figueroa, quien expone sus motivos para calificar de "fracaso absoluto" la organización de la manifestación:

«Casi ni les interesaba que yo me sume porque estaba orquestado por determinado grupo político de la época entre los que se encontraban Parajón, el "Chino" Robles, estaba el "Macho" Luna que venía con una fórmula mágica desde Venezuela, en ese momento él estaba en el movimiento cooperativista, que había sido dirigente en los '60 y '70 del comedor universitario, y fue el que trajo un poco el tema del juicio ético. La única voz en contra era la mía, ya les parecía que por lo menos nos teníamos que juntar y que el esfuerzo valía y que ese era un camino importante para que la gente se diera cuenta quien era Bussi; cuando yo les decía que si hubiera sido televisado por ejemplo, y que toda la población hubiera podido seguir el juicio todavía, pero no era eso, sino que era otra cosa y en un club chiquito en el que no entraban más de 2.000 personas y el eje era ese. Me parece que se puso demasiada energía y desgaste en testigos, y lo que más importaba para mi en esa época era dar la batalla política porque Bussi era candidato a gobernador, por ejemplo, ir a los barrios... aquí en 1995 es cuando gana Bussi, así que el juicio ético fue un fracaso absoluto. ${ }^{490}$

El resto de los entrevistados, no obstante, hacen una evaluación positiva del JE, como en el caso de Ángela Nassif, referente del Partido Comunista Revolucionario y co fundadora en 1984 de la APDH local:

490 Testimonio de Laura Figueroa. 
«Yo fui parte organizadora del juicio ético y fue un hecho muy importante en medio que políticamente los jueces del gobierno facilitaban su absolución y la impunidad, nosotros con ese juicio ético, que además, puso blanco sobre negro todo lo que había pasado, con pruebas, puso en evidencia frente a la sociedad con mayor claridad lo que era la política del alfonsinismo y el gobierno de mucho bla bla en relación a los derechos humanos porque en la práctica servía para absolver a los responsables. O sea que fue un hecho muy importante... Participan todos los organismos de derechos humanos y los de Buenos Aires mandan delegaciones. Vino gente como el "Perro" Santillán, que apoyó directamente, vino una delegación de Madres de Buenos Aires, de Santiago del Estero, y sobre todo padres, porque en Santiago del Estero, eran los padres los que se movían...» ${ }^{491}$

Por su parte Sara Mrad exponía:

«Ha sido algo impactante no solamente por el desarrollo del juicio, sino por todo lo que ha generado, los responsables del club han sido amenazados, había un montón de cosas así que no nos permitía comenzar a hacer el juicio y finalmente se hizo, eso ha sido bastante impactante. Para Tucumán ha sido una movida muy importante».

Pregunta: ¿Crees que la aparición del Bussismo con fuerza sirvió para que los organismos en esta época se juntaran y trabajaran más unidos salvando las diferencias?

«Yo creo que hay momentos y hay puntos que la realidad necesariamente te tiene que unir, porque no podes luchar contra Bussi, por ejemplo, de forma aislada, o no podes hacer un acto del 24 de marzo de forma aislada. ${ }^{492}$

\footnotetext{
491 Testimonio de Ángela Nassif.

492 Testimonio de Sara Mrad.
} 
También Felicidad expresaba su satisfacción por el resultado del JE aunque con ciertas reservas, pues entendía que una actividad de esa magnitud debía abrirse al conjunto de la sociedad. Esto queda claro cuando Felicidad afirma:

«A mí me ha parecido una cosa muy importante a pesar que yo en este momento de la historia, de todo esto te puedo decir algo: muchas de las cosas que se han hecho y que se siguen haciendo es como que sigue siendo para nosotros. Vos te acordás que la noche de la presentación del video ${ }^{493}$, a vos o no sé a quién le he dicho, esto hay que pasarlo en otro lugar, donde no venga gente como uno, porque no es que sea más de lo mismo ni tu video ni lo del Juicio Ético ni nada, no, no es eso, ni subestimo, ni desvalorizo mucho menos, pero es como que uno, no sé si por el miedo, por costumbre o por una modalidad que teníamos, organizábamos, todas estas cosas para adentro. $\gg^{494}$

Si bien en el balance final los militantes de los organismos hoy reconocen la importancia que en su momento tuvo la organización de este hecho simbólico, con el tiempo la llegada de Bussi al poder les haría darse cuenta de las limitaciones que suponía un acto de esta naturaleza. Si la convocatoria sirvió para algo, fue para reagrupar al movimiento de derechos humanos en su conjunto y volver a poner en el punto de mira al enemigo que dicho movimiento tenía en Tucumán. El periodista Horacio Verbitsky escribía el 6 de junio de 1999 en su columna semanal de Página 12: "cuando Bussi daba sus primeros pasos políticos había quienes trataban de entender cómo eso era posible. Hoy su presencia se acepta con tanta naturalidad como la de Hugo Banzer en Bolivia, ese otro

\footnotetext{
493 Felicidad hace mención aquí una proyección del documental El Tucumanazo, cuando tuve la oportunidad de conocerla y quedar con ella para la concreción de la entrevista.

494 Testimonio de Felicidad Carreras.
} 
espejo de la argentinidad en que los políticos ilustrados de Buenos Aires tampoco gustan mirarse. En 1989 el analista político Fernando Hevia escribió que "en ningún otro lugar del país la transición estuvo tan teñida de continuismo". ${ }^{495} \mathrm{Y}$ dicho continuismo se vio reflejado en las elecciones provinciales de octubre de 1995 que terminaron de catapultar a Bussi a la casa de gobierno. Ni las marchas, ni el Juicio Ético habían dado sus frutos, esos que espera el movimiento de derechos humanos de Tucumán, como si se tratara de un sortilegio y que el general fuera derrotado en las urnas como en 1991. Sin embargo, el ascenso del Bussismo era inevitable y los organismos comenzarían a centrar su eje de acción en la demanda pública y en lo que H.I.J.O.S. darían en llamar "la condena social" por medio del escrache, el cual sólo se llevaría a cabo en la provincia en octubre de 1998. El movimiento de derechos humanos de Tucumán tuvo que esperar otra década para ver sentenciado, esta vez por la justicia ordinaria a Bussi como autor de crímenes de Lesa Humanidad.

Los testimonios aparecen atravesados por las instancias del Juicio Ético en el que la valoración positiva del mismo contrasta con falta del cumplimiento de los objetivos propuestos. El apoyo de personalidades políticas e intelectuales nacionales fortaleció la lucha de las organizaciones que volvían a la carga tras las derrotas políticas de las llamadas leyes de impunidad. El Juicio Ético a Bussi no fue sino la primera de una serie de acciones que el movimiento de derechos humanos habría de enfrentar en el segundo lustro de la década del '90, en una batalla por la memoria respecto a la historia reciente de la provincia y del país.

495 Página 12, edición del 6 de junio de 1999. 
Algunas de las acciones unitarias consolidaron una forma de accionar e inauguraron una nueva metodología de lucha en procura de la condena social a falta de la condena real de la justicia ordinaria. Seguirá siendo materia de estudio el papel que jugó el Juicio Ético en el marco de las "memorias enfrentadas" y solo en el tiempo se podrán establecer los paralelismos necesarios con los juicios que actualmente se llevan a cabo contra los represores. Hoy las organizaciones de derechos humanos tienen una fisonomía muy distinta a la de la década del '90, sin embargo, la batalla parece ser la misma: en 1995, en el marco de un juicio simbólico, en 2008 y en 2010, en el marco de unos juicios emanados de la justicia federal. Aunque en perspectiva, hoy, con Bussi desaparecido físicamente tras su muerte a fines de 2011, la condena real de los represores que siguen con vida parece ser el nuevo eje vertebrador del movimiento. 


\title{
CAPÍtUlO XII: H.I.J.O.S., UNA NUEVA GENERACIÓN EN EL MDHT
}

\begin{abstract}
"Creo que HIJOS me ayudó a "democratizar" el dolor que había en mí, que yo suponía tan único, tan inigualable. Nadie es especial, porque las historias son todas parecidas. La sensación de estar todos juntos, de haber encontrado iguales, de yo no tengo que explicar porque todo está en tus ojos, es alucinante, y conmovedora, y peligrosa". ${ }^{496}$
\end{abstract}

\section{XII.1 El nacimiento de los "Hijos"}

Como afirma Luciano Alonso, en el marco de "conflictos sociales (de los '90) y de una vieja/nueva estructura de oportunidades políticas, H.I.J.O.S. se constituyó a inicios de 1995 en distintas ciudades del país." ${ }^{497}$ Asimismo el historiador santafesino agrega que "se fue formando la red de H.I.J.O.S. a partir de vinculaciones personales, convocatorias públicas y la promoción del nucleamiento por integrantes de otras agrupaciones de derechos humanos. Se concretó una primera reunión nacional en un campamento realizado en la provincia de Córdoba, aprovechando el trabajo previo del Taller Cortázar, que había atendido en esa ciudad a niños y jóvenes afectados por la violencia represiva." ${ }^{498} Y$ los "hijos" de Tucumán también van a participar de dicho campamento y se integrarán a la red nacional pero desde principios y estrategias que le serían propias, como veremos en el presente capítulo.

\footnotetext{
496 Testimonio de Josefina en Gelman, Juan y La Madrid Mara (1995): Ni el Flaco Perdón de Dios. Hijos de Desaparecidos. Edit. Planeta, Buenos Aires.

497 Alonso, Luciano (2011) Pp. 184 - 188.

498 Alonso, Luciano, Op. Cit.
} 
Si durante el primer lustro de la década del '90, el movimiento de derechos humanos en Tucumán había sufrido un retroceso, el horror que provocaba en sus militantes la posibilidad certera del triunfo de Bussi en 1995, propició las condiciones fundamentales para que las organizaciones se reagruparan y cerraran filas nuevamente en torno a una causa común. Al mismo tiempo, 1995 suponía la aparición de H.I.J.O.S., lo que le daría al movimiento en su conjunto, un nuevo empuje y nuevas dinámicas de lucha. H.I.J.O.S. implicaba al mismo tiempo la relación filiatoria de sus miembros con respecto a los represaliados por la dictadura, pero también emergía como una consigna con una carga identitaria mucho más amplia: H.I.J.O.S. que agrupaba, entre otros, a los hijos de los detenidos y desaparecidos, significaba en sus siglas "Hijos por la Identidad por la Justicia contra el Olvido y el Silencio".

Sobre la aparición de esta nueva organización en el marco de un movimiento más amplio, explica Susana Salvatierra:

«...H.I.J.O.S. hereda una tradición. H.I.J.O.S. no hubiera aparecido si antes no había Madres, es así, hasta biológico, es así, la lucha de Madres es como que marca la vía y a muchos de nosotros, por más que lo hemos pensado y teníamos ganas, se nos ocurrió organizarnos para salir a matar genocidas, entonces como que hay una vía de la lucha que si, han abierto las Madres, esto del reclamo, que ha habido muchas diferencias desde la organización, desde los fines, los principios desde lo político, siempre, y en cuanto a la lucha de nuestros padres, muchas veces me acuerdo que lo que nos planteábamos era eso, si tomábamos las banderas de los desaparecidos, y en muchas cosas sí, ellos no tomaban las banderas de los desaparecidos, tenían sus propias banderas, en donde es casi el mismo camino de lucha, es muy difícil que 
hagas una lucha social en otra dirección, los medios sí, son discutibles... ${ }^{499}$

Algunos testimonios sitúan el origen de H.I.J.O.S. en Tucumán en el año 1993, impulsado por Eva Urrutia, la hija de un desaparecido, quien congregó a otros hijos de afectados que ella conocía con la idea de hacer un documental. María Coronel lo recuerda:

«En realidad H.I.J.O.S. empieza en Tucumán... bueno, acá tiene un origen distinto que en otras provincias, la Red Nacional se arma en el '95, pero acá en Tucumán nosotros nos empezamos a juntar a partir de 1993, porque una hija de desaparecidos, de acá, de Tucumán, Eva Urrutia, quería hacer un documental sobre los hijos de desaparecidos. Entonces hace un trabajo de hormigas, de rastrearnos uno por uno en las facultades, a otros nos encontraba en la Plaza porque íbamos los jueves a la Plaza Independencia, y la verdad que hizo un laburo de hormiga, porque un día nos juntó y éramos tres pares de hermanos para las primeras reuniones. La idea era que cada uno contara su historia para que ella pudiera armar el documental. Las primeras reuniones han sido como muy fuertes porque uno empezaba a contar, y el otro contaba otra cosa y la típica cosa, que uno ha sentido que era único en el universo y empezábamos a compartir las historias, y empezamos a charlar de cada uno, hemos tenido prácticamente un año de charlas de todo lo que sentíamos sobre la desaparición de los viejos, la cuestión de la militancia, la lucha armada, la tortura, que también es un tema bastante movilizador, y eran temas que nunca lo habíamos hablado con nadie. La Eva nunca hizo el documental, nunca ha filmado nada (risas) pero justo en el momento que estábamos en esa cuestión de idas y vueltas de

499 Testimonio de Susana Salvatierra. 
encontrarte con otros H.I.J.O.S., compartir historias y las cosas que vos sentías surge de alguna manera la figura de Bussi, se empieza a candidatear y se empieza a hacer cada vez más fuerte. Y es una cuestión mas visceral que te pasa, que decís: no puede ser que este tipo esté saliendo a la vida política y no tenga ningún tipo de oposición. Entonces fue decir, venimos trabajando durante tanto tiempo cuestiones emocionales, empecemos a ver si podemos plantearnos ciertas cuestiones de militancia política de alguna manera en el lugar que tenemos. Y nos hemos armado como grupo, le hemos puesto nombre al grupo, que es más largo que el de H.I.J.O.S., grupo de H.I.J.O.S. de afectados directos por la represión política y hemos empezado a hacer pequeñas actividades, por ejemplo participar de marchas, hemos estado en la Expo Joven que era en la Escuela de Educación Física, todo esto en el año '94...»500

Por su parte, Susana Salvatierra resume este inicio desde su propia experiencia:

«En el '94, o '95 creo que fue, conozco a Virginia Vitale estudiando teatro en la Facultad de Artes, y me la presentan y ella me invita a una reunión, me dice que se estaban juntando varios hijos de desaparecidos a charlar sobre las cosas que les pasaban, además porque estaba todo el tema de las leyes nuevas que iban a salir por el tema de las indemnizaciones y ese tipo de cosas, un poco también por el pedido de las Madres para que las apoyemos un poco en el tema de las marchas de los jueves, de la organización de los actos, que ya estaban medio viejas, cansadas y todas esas cosas, y así nos empezamos a juntar.»

Pregunta: ¿Ya existía H.I.J.O.S. a nivel nacional?

500 Testimonio de María Coronel. 
«No. En realidad H.I.J.O.S. Tucumán es como que hace punta como organización y con una compañera nuestra, con la Evita Urrutia, es una de las que hace punta en esta cuestión, porque cuando se empiezan a juntar... organizan un primer encuentro, creo que fue un campamento en Córdoba, - algo así, entonces se juntan prácticamente así, los H.I.J.O.S. de la gente que se seguía viendo, pero todo movilizado alrededor de lo que Evita quería juntar para hacer un video, un documental... entonces se empezó a juntar todo ese tipo de gente... $>^{501}$

Susana confirma la impresión de María acerca que la semilla de H.I.J.O.S. Tucumán fue puesta por Urrutia en el intento de congregar a otros jóvenes en su misma situación. La coyuntura política de Tucumán, sumado el ascenso de Bussi y el retroceso de las organizaciones de derechos humanos, sirvieron de abono para que H.I.J.O.S. se conformara orgánicamente y llegaran al primer encuentro Nacional en 1995 con un trabajo previo en la provincia.

Sin embargo, al formar parte de la Red Nacional, empezaron a plantearse algunas cuestiones referidas a los integrantes de la agrupación, ya que uno de los temas de permanente discusión era si aceptaban o no integrantes que no fueran hijos de afectados por la represión. Entonces surgía la discusión según la cual algunos planteaban como opción hacer de H.I.J.O.S. un organismo, como ellos mismos le llaman, de "población abierta o población cerrada". En este sentido, la discusión giraba en torno a si cabía aceptar a jóvenes que no estuvieran vinculados a lo que Ilamaban los "cuatro orígenes". María Coronel explica la idea de los cuatro orígenes de H.I.J.O.S. vinculado a la idea de

$\overline{501}$ Testimonio de Susana Salvatierra. 
población abierta y población cerrada y cómo se discutió esta alternativa en Tucumán:

«La discusión tuvo que ver con las experiencias de cada provincia y las vivencias de cada uno. La mayoría de las regionales de H.I.J.O.S. eran en un principio solamente lo que era población cerrada, es decir que estaba integrada por gente que estaba vinculada a lo que llamamos los cuatro orígenes: hijo de desaparecido, hijo de asesinado, de preso político y exiliado. En realidad todas las regionales salvo nosotros tenían esa población cerrada, que incluso si alguien que tenía esos cuatro orígenes y quería entrar a militar, armaba algo que se llamaba grupo de apoyo, Capital por ejemplo tuvo un grupo de apoyo muy grande, en un momento el grupo de apoyo era más grande que H.I.J.O.S. en sí, durante mucho tiempo y con mucho laburo. A nosotros la verdad que nos parecía innecesario eso sobre todo por el análisis de la historia, si tenés un slogan "todos somos H.I.J.O.S. de una misma historia" nos parecía contradictorio ponerte a cerrar así en una cosa muy específica tuya, porque además que muy en lo subjetivo, muy en lo personal y no tenés la proyección biológico político de lo que querés hacer con la agrupación.... ${ }^{502}$

A nivel nacional, algunas regionales debatieron la cuestión de la población abierta y cerrada. ${ }^{503}$ La "discusión -que se dio en todas las regionales de la Red Nacional de H.I.J.O.S. y que cada una definió de

502 Testimonio de María Coronel.

503 Véase por ejemplo el caso de H.I.J.O.S. La Plata en el trabajo de Cueto Rua, Santiago "Nacimos en su lucha, viven en la nuestra". Identidad, justicia y memoria en la agrupación HIJOS-La Plata, en Atheleia N5 http://www.aletheia.fahce.unlp.edu.ar/numeros/numero-1/santiago-cueto-rua.201cnacimos-en-su-lucha-viven-en-la-nuestra201d.-identidad-justicia-ymemoria-en-la-agrupacion-hijos-la-plata [Consultado por última vez enero 2012]. 
manera autónoma- se estructuraba en tres posicionamientos distintos: En primer lugar, estaban quienes creían que a la organización debían entrar sólo los hijos de los desaparecidos y asesinados ("dos orígenes"). La segunda postura aceptaba también hijos de exiliados y ex presos políticos ("cuatro orígenes"). En último término estaban los que no querían hacer restricciones al ingreso ("población abierta"). 504

Mientras, en Tucumán, tal como expresa María, las ideas siempre estuvieron claras respecto de abrirle las puertas a quienes quisiera militar en la nueva organización. Es así como muchos jóvenes pasaron por H.I.J.O.S. sin pertenecer o sin estar incluidos en ninguno de los llamados cuatro orígenes. Una de ellas fue Valentina García que, sin ser hija de afectados, tuvo un breve pero intenso paso por la agrupación, invitada por una compañera de una agrupación cultural de la Facultad de Derecho, donde estudiaba:

«Cuando empiezo a estudiar y a averiguar qué había pasado es en la Facultad de Derecho, cuando conformamos un grupo que se Ilamaba La Ciega. Este era un grupo independiente de estudiantes de derecho quienes conformamos inicialmente La Ciega, que surge un poco desde el espanto a los partidos universitarios, como un espacio de poder expresarnos, sobre todo, teníamos una revista, todo esto desde el año '98 (...) Dentro de los miembros de La Ciega había compañeros que militaban en H.I.J.O.S., Vichi Vicente, Pablo Gargiulo, y varias personas más que ahora no me acuerdo patente. A raíz de un trabajo dentro de La Ciega,

${ }^{504}$ Ibídem. Según Cueto Rua la regional de H.I.J.O.S. de la ciudad de La Plata fue la única en la cual se impusieron quienes estaban a favor de cerrar la población a los "dos orígenes". Eran mayoría y lograron transformar en colectivo ese sentimiento de que H.I.J.O.S. debía ser sólo para quienes habían perdido a sus padres durante el terrorismo de Estado. Algunos de estos jóvenes tomaron como modelo la organización de las Madres de Plaza de Mayo, con cuya líder, Hebe de Bonafini tenían un fuerte vínculo personal. 
que también abordábamos el derecho como herramienta de cambio social desde una perspectiva estudiantil, empezamos a trabajar en promoción sobre todo de derechos humanos (...) uno de los ítems era la discusión Verdad y Justicia (...) y nos empezamos a relacionar con los distintos grupos que estaban trabajando también la temática. Dentro de esos grupos estaba H.I.J.O.S. que aparte algunos compartía con nosotros el espacio de La Ciega (...) así comenzamos a participar de algunas actividades junto con H.I.J.O.S., participamos de algunos escraches ${ }^{505}$, de los primeros escraches que se empiezan a realizar en Tucumán, primero a Bussi y después a Blanco, etc, después de un tiempo yo me empiezo a sentir cada vez más identificada con el tema y desde ese lugar me meto en H.I.J.O.S.. Me aceptan sin tener familiares desaparecidos, porque H.I.J.O.S. venía de un proceso plural de apertura, no de una apertura plena plena, pero ya había pasado la etapa de H.I.J.O.S. cerrados, ya estaban con la posibilidad que otra gente allegada se dirija».

Pregunta: ¿Entras en H.I.J.O.S. por una afinidad política o generacional? Porque así como entraste en H.I.J.O.S. podrías haber entrado en APDH, en Madres...

«Había sí una afinidad política e ideológica...»506

Uno de los aportes de esta nueva organización fue el haberle dado al movimiento en Tucumán una energía que partía de unos jóvenes que renovaron el espíritu de lucha, volviendo a levantar las consignas

${ }^{505}$ A los fines de la comprensión en este punto, solo diré que los escraches son una forma de protesta para señalar a algo o a alguien al conjunto de la sociedad. Sobre los escraches volveré más adelante, ya que merece un apartado especial tanto para explicar qué ha sido como el de relatar uno de los más importantes realizados en Tucumán.

506 Testimonio de Valentina García Salemi [Entrevista realizada por el autor el 30 de octubre de 2007]. 
históricas pero además venían a renovar los debates en torno al pasado reciente del país y la provincia.

Los militantes de H.I.J.O.S. Tucumán participaban de los campamentos nacionales de la red y de las reuniones en las que se discutían los ejes a seguir. Si bien el germen de lo que sería H.I.J.O.S. comienza con las reuniones convocadas por Eva Urrutia, la agrupación no haría su aparición pública hasta dos años después. Consciente o inconscientemente los jóvenes que conformarían la agrupación participaron del llamado Juicio Ético en junio de 1995.

¿Pero qué es H.I.J.O.S.? ¿Cómo lo definen sus militantes? María responde a esta pregunta, desde su percepción, del siguiente modo:

«Hay mucho de recuperación de tu identidad, no sólo ser los nietos de las madres de Plaza de Mayo, los H.I.J.O.S. de la generación de los desaparecidos, es como que siempre eras algo de alguien. Que también obviamente vos tenés una agrupación que se llama H.I.J.O.S., te estás identificando con algo en ese sentido, pero H.I.J.O.S. es una sigla también, que tiene que ver con la vivencia que vos tenés, con cosas que a vos te han pasado, la cuestión esta de tratar de identificarte con una generación en particular, que es la nuestra, no la generación de nuestros viejos. Nosotros tratamos de identificarnos con nuestra generación y qué vivencias hemos tenido... es como que hemos ido armando una mezcla de cosas para armar una lucha muy particular, creo que es muy nuestra, por eso te digo, creo que todavía nos queda muy grande la lucha de nuestros viejos como para... y también puede ser que nos quede grande o que sea distinta la lucha de lo que ha sido la de Madres o las Abuelas de la nuestra.»507

\footnotetext{
507 Testimonio de María Coronel.
} 
Según Gabriela Fried H.I.J.O.S es "una comunidad de memoria" porque comparte una historia y referentes comunes, basados en experiencias emocionales personales y/o colectivas profundas". ${ }^{508}$ En ese marco de experiencias compartidas la cuestión identitaria fue uno de los principales aspectos de diferenciación de H.I.J.O.S. respecto a las otras organizaciones. Si bien cada organización fue delineando su razón de ser con el tiempo, en la organización de estos jóvenes el preguntarse por sus propios orígenes tenía que ver con que muchos de ellos desconocían la militancia de sus padres desaparecidos y el conocer el pasado era una condición necesaria para la proyección en las historias de vida personales y, en última instancia, colectivas.

\section{XII.2 LA IDENTIDAD EN LA CONSTITUCIÓN DE H.I.J.O.S. TUCUMÁN}

Como afirma Cueto Rua "los H.I.J.O.S. heredaron la legitimidad de los organismos de derechos humanos, como Madres y Abuelas de Plaza de Mayo y también la de sus padres, cuyos sueños y valores eran reconocidos por algunos sectores de la sociedad. Los HIJOS retoman el camino de los organismos de "afectados directos". Al igual que ellos se juntan a partir de un lazo sanguíneo con las víctimas y además se incorporan a sus demandas de "verdad, memoria y justicia". A su vez pretenden inscribirse políticamente en el derrotero de las organizaciones en las que militaban sus padres. De allí el intento no sólo de recordarlos como luchadores políticos, sino de proyectar la propia militancia de HIJOS en línea directa con la de sus padres." ${ }^{\prime 509}$

Pedro Gómez sostiene que "la identidad es siempre una negociación entre una 'autoidentidad / endoidentidad' y una

\footnotetext{
508 Alonso, Luciano (2011): Luchas en plazas vacías de sueños, Edit. Prohistoria, Rosario, Pp. 185 - 188.

${ }^{509}$ Cueto Rua, Santiago "Nacimos en su lucha, viven en la nuestra"... Op. Cit.
} 
'exoidentidad', definida por los otros; las identidades son el resultado de procesos de asignación de sentido (identificaciones y diferenciaciones) elaborados en el interior de los grupos (endoidentidad) o asignaciones de sentido que recaen sobre el grupo desde su exterior, desde otros grupos o sectores sociales (exoidentidad). Ese otro en relación con el cual se construye la identidad puede ser postulado, entonces, como una doble alteridad: un otro-espejo, objeto de identificación y diferenciación, y otro-mirada, sujeto del cual provienen interpelaciones, dictados de ser y hacer. El otro-espejo puede ser aquel con el cual elaboro un "nosotros" constitutivo de grupo o aquel otro a cuya imagen me modelo; pero también ese otro del que me diferencio, el que queda del otro lado de la frontera de las grupalidades que integro, un otro que puede convertirse en objeto de recelo y odio. A su vez, el otro - mirada es aquel que proyecta sus categorías sobre mí y mi grupo desde un "afuera", un otro que puede materializarse en las instituciones, sus agentes y sus narrativas. Ambas definiciones identitarias pueden estar en tensión, entrar en conflicto o negociarse. Según la relación de fuerza entre los grupos en contacto (fuerza material, fuerza simbólica) la endoidentidad tendrá más o menos legitimidad que la exoidentidad. En una situación de dominación o hegemonía, la exoidentidad se manifiesta como estigmatización, pero los grupos pueden presentar resistencia transformando el estigma en emblema. Esto es lo que ocurre con las llamadas "identidades." 510

Por su parte, Roberto Grandi explica que "las identidades se forman en virtud de procesos discursivos, entendidos como lugares de

510 Gómez, Pedro A., "La identidad como fábrica de sentido", texto producido para la cátedra de Teoría de la Comunicación I, Facultad de Filosofía y Letras de la UNT, Tucumán http://ecaths1.s3.amazonaws.com/tc1unt/1894358758.Introducci \%C3\%B3n\%20Identidad\%20F\%C3\%A1brica\%20de\%20sentido.pdf [Consultado por última vez en diciembre de 2012]. 
producción y representación de experiencias, es decir, aquellos lugares en los que los textos y los contextos se vuelven a articular en relación al conjunto de las actividades sociales." ${ }^{\prime \prime 11}$

H.I.J.O.S. Tucumán articuló entonces tanto su discurso como su práctica en relación a diversos contextos históricos tanto pasados como presentes. Por una parte la identidad de H.I.J.O.S. se forjó dentro de una mirada crítica pero al mismo tiempo relacional con la generación de sus padres. Se platearon interrogantes sobre quiénes habían sido los desaparecidos, dónde habían militado, por qué estaban desaparecidos, llegando, en más de un caso, a reivindicar esa lucha y en cierto modo a hacerla propia. También se nutrió H.I.J.O.S. de la experiencia de la militancia de las otras organizaciones de $\mathrm{DDHH}$, sobre todo de aquellas que por su origen tenían una relación filiatoria con los desaparecidos, como ser Madres de Plaza de Mayo, Familiares de desaparecidos por razones políticas y Abuelas de Plaza de Mayo. Pero también se concibió la identidad de HIJOS Tucumán, en tanto agrupación, en relación a un "otro" estableciendo una frontera claramente delimitada entre un "nosotros" y un "ellos" encarnado en la figura del represor Bussi y su partido, Fuerza Republicana. Por lo tanto podemos afirmar que la construcción identitaria de la agrupación ha tenido un triple punto de confrontación:

1. Por un lado, con la generación que denominamos "setentista", la generación de sus padres quienes, por la militancia de los años '60 y '70, sufrirían la represión desde 1975 con el establecimiento del Operativo Independencia y ya desde 1976, tras el golpe de Estado con la aplicación sistemática del sistema de desaparición de personas.

$\overline{511}$ Grandi, R. (1995) "Los estudios culturales: entre texto y contexto, culturas e identidad" en Los medios de comunicación, Bosch, Barcelona. 
2. Por otro lado, con las organizaciones más antiguas de $\mathrm{DDHH}$, en particular aquellas cuyo origen se vinculaba directamente de manera filial con los desaparecidos y que si bien reconocen heredar la tradición de esas organizaciones, plantea una diferencia en cuanto a lecturas, tácticas y estrategias y prácticas cotidianas de lucha muy marcadas.

3. Finalmente, hacia el afuera, con el Bussismo y lo que representa la figura del propio gobernador de facto, devenido en democracia en gobernador elegido por medio del sistema de votos.

Lo que es plausible analizar entonces es que desde la "endoidentidad" H.I.J.O.S. Tucumán definió el nosotros en función de un largo proceso de discusión. El resultado fue que, para la regional local, la población abierta supusiera la integración de militantes en el seno de la agrupación que no estuvieran vinculados en relaciones de parentesco con las víctimas de la dictadura. El hecho de que plantearan que toda la sociedad era "hija de una misma historia" los colocaba en un lugar fuera de la centralidad del papel de víctimas. Al mismo tiempo, sentir que heredan una tradición como la de Familiares de desaparecidos o Madres de Plaza de Mayo, los hizo configurar ese otro-espejo al que alude Gómez.

Desde la "exoidentidad" prefiguraron un otro negativo, el Bussismo, no solo en la propia figura del ex gobernador de facto, sino también, en la idea o concepción que indicaba que el Bussismo en democracia representaba cierta continuidad de lo que había sido la dictadura. El otro-mirada sirvió para delimitar la aceptación, además, de quiénes podrían integrar el propio organismo. En este sentido el "todos somos hijos de una misma historia", excluiría por definición a Bussi, su entorno y sus votantes. Estas cuestiones que aquí se plantean fueron 
definidas por la organización en su interior, pero en discusión también con las otras regionales en el marco de los campamentos de la red nacional.

A su vez, la construcción de una identidad grupal forjada en el principio generacional hizo que éstos jóvenes inaugurasen nuevas formas de protesta y nuevas manifestaciones y prácticas sociales, nuevas modalidades discursivas y novedosas maneras de comunicar la memoria. En los testimonios de los militantes de H.I.J.O.S. hallamos que lo generacional resulta crucial para la constitución del grupo y el forjamiento de la identidad aludida.

La identidad tenía que ver entonces con el pasado, con la historia individual de cada uno de los integrantes de la agrupación, pero también con el presente que les tocaba vivir. En el nexo del pasado y el presente se configura una forma de ver el mundo $y$, en última instancia, de militar. Las antiguas organizaciones ya no satisfacían las necesidades de estos jóvenes que comenzaron a indagar en su propia historia buscando al mismo tiempo salidas diferentes a las tradicionales, nuevas formas de militancia, acciones propias y es en esa militancia donde se va conformando la nueva identidad que pronto será reconocida en las acciones que les serán propias, como por ejemplo los escraches. ${ }^{512}$ Una clara señal de cambio en las marchas públicas ha sido la incorporación de las murgas en los actos del 24 de marzo, que suponía romper con una estrategia solemne del recuerdo para buscar un elemento de alegría en la manifestación.

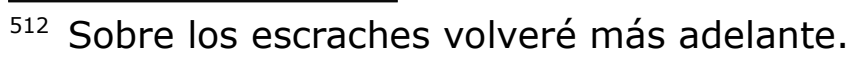




\section{XII.3 ¿ACEPTAR LAS REPARACIONES O NO ACEPTARLAS? TAMBIÉN ESA FUE LA CUESTIÓN}

El 8 de diciembre de 1994 el parlamento argentino sancionaba una ley para indemnizar a los "herederos directos o derecho habientes de los detenidos desaparecidos durante la última dictadura militar" ${ }^{\prime 513}$ conocida popularmente como la Ley de Reparación Económica. Uno de los temas que mayor conflictividad produjo en el movimiento de derechos humanos en Argentina fue la cuestión de la aceptación de las indemnizaciones a los familiares de las víctimas de la represión dictatorial. El único organismo que se opuso directamente a su cobro fue Madres de Plaza de Mayo y se pronunciaba contra su aceptación en la marcha de la resistencia de 1994 afirmando que: "La vida vale vida. La vida de un ser humano no puede valer dinero $y$, mucho menos, la vida de un revolucionario. Lo que hay que reparar con justicia no se puede reparar con dinero. Los radicales y los menemistas que perdonaron a los asesinos, ahora quieren tapar sus crímenes con dinero. Nadie le va a poner precio a la vida de nuestros hijos. ${ }^{\prime 514}$ La sentencia más concluyente del organismo sigue en la frase en la que afirmaba que "las Madres de Plaza de Mayo seguiremos afirmando que los que cobran las reparaciones económicas se prostituyen." ${ }^{515}$

Sobre la postura del organismo liderado a nivel nacional por Hebe de Bonafini, Sara Mrad sienta la posición desde Tucumán:

«El tema de la reparación económica dividió y mucho, dividió a las familias incluso porque la gente entendía que si el Estado había sido el represor tenía entonces que dar

\footnotetext{
513 Asociación Madres de Plaza de Mayo (2002): Luchar siempre. Las marchas de la resistencia, Ediciones de la Asociación de Madres de Plaza de Mayo, Buenos Aires, Pág. 95.

514 Ibídem.

${ }^{515}$ Ibídem.
} 
alguna reparación, pero para nosotros es todo lo que te ofrece el sistema, es la mercantilización de la lucha de los desaparecidos. El desaparecido entraba al mercado, porque ni siquiera te pagaban la plata sino que te pagaban con bonos que cotizaban en la bolsa... la vida del desaparecido estaba cotizada en la bolsa, esto es de terror, además, ¿cómo se puede pagar con plata lo que no existe con justicia? ...» ${ }^{516}$

Como afirman Kordon y Edelman "las posiciones personales y familiares estuvieron inexorablemente atravesadas por esta polémica. El hecho de asumir una posición, en sí mismo, iba acompañado de una alta carga emotiva y, a su vez, estos antagonismos reforzaban el componente emocional." ${ }^{\prime 517}$ Algunos organismos dejaron al libre arbitrio la decisión de cobrar la reparación del Estado en sus miembros y donde más debate y discusión generó, fue al interior de H.I.J.O.S. La juventud de sus militantes, la falta de empleo en muchos de ellos y la necesidad ante la crisis económica que afectaba a gran parte de la sociedad argentina desde mediados de los '90, hizo que muchos integrantes de la organización decidiera cobrar la indemnización para solventar sus gastos personales, no sin sentir cierta culpa por hacerlo y produciéndose en todos ellos conflictos internos, muchos de los cuales todavía no han sido resueltos. "La relación entre la pertenencia institucional y el margen de libertad personal en cuanto a la decisión también ha generado situaciones conflictivas (...) en algunos casos la institución exigía el cumplimiento del criterio que ésta asumía públicamente por parte de todos sus miembros, y en otros, aunque hubiera flexibilidad, resultaba muy difícil en el plano personal asumir y sostener una decisión que no se

\footnotetext{
516 Testimonio de Sara Mrad.

517 Kordon, Diana y Edelman, Lucila (2007): Por-venires de la memoria, Ediciones Madres de Plaza de Mayo, Buenos Aires, P. 137.
} 
correspondiera con la idea de la mayoría." ${ }^{518}$ Dentro de H.I.J.O.S. siempre se dejó el libre arbitrio para que cada militante decidiera si cobrar o no y no se juzgaba esta acción de ninguna manera. El señalamiento que desde Madres de Plaza de Mayo se hacía a quienes cobraban este estipendio otorgado por el Estado nacional sumaba conflictividad a un tema que de por sí era complejo para los militantes del novel organismo.

Sobre la visión de H.I.J.O.S., respecto a las indemnizaciones, Viviana Vicente explica:

«Se discutió mucho, había posiciones... es decir, H.I.J.O.S. nunca se puso en una posición de decir sí se cobra o no se cobra, como la Asociación Madres de Plaza de Mayo, jamás. Una porque estaban las posiciones, por ejemplo, de si vos tenés un accidente de tránsito y te indemnizan, te pagan una indemnización, de hecho era entender que el pago de esta indemnización tenía que ver con la política de reparación del Estado, y que efectivamente se hacía cargo que ellos había desaparecido personas, ellos habían asesinado... y que a vos te den eso, que además ni siquiera era que te deban la guita ${ }^{519}$ que te tendrían que dar si vos haces un juicio civil porque podrían haber dado mucha más plata, sino que sacan una ley para pagar menos y te lo pagan con bonos... $>^{520}$ María Coronel, por su parte, había decidido cobrarlo:

«Sobre las indemnizaciones yo entiendo por donde vienen las críticas y por donde viene lo positivo, yo lo he cobrado, porque había una realidad, estábamos en la lona ${ }^{521}$, es una realidad, no todos, pero es cierto que no tenías a alguien que

\footnotetext{
518 Kordon, Diana y Edelman, Lucila (2007): Por-venires de la memoria, Op. Cit.

519 Guita es la forma en que vulgarmente se denomina al dinero en Argentina.

520 Testimonio de Viviana Vicente.

${ }^{521}$ Estar en la lona es una expresión local que indica estar en problemas económicos.
} 
esté velando por vos, no éramos tan grandes tampoco y la pasábamos mal muchos, entonces, ponerte en crítico en el que alguien pueda cobrar un dinero que le pueda permitir hacer ciertas cosas de su vida tranquilo es muy egoísta, ponerte desde la militancia o lo ideológico en "no podes cobrar esa guita", pero si he visto lo que era el mecanismo, como que de alguna manera estaba muy bien pensado, y mucha gente que ha cobrado dejó de militar después, pero porque te genera todo un mecanismo de culpa increíble, a nivel subjetivo... vos por ejemplo, el trámite para cobrar primero que era agotador, yo era menor de edad cuando lo empecé y me he paseado por el juzgado de menores...»

Pregunta: ¿Pero todo eso lo discutían o lo hablaban en H.I.J.O.S.?

«No, no... no ha sido una cuestión hablada, bueno, cuando empiezan las críticas por parte de las Madres de la Hebe, que eran muy duras, nosotros dijimos: ¿Pero qué onda con esto? Que la cobre el que la quiera cobrar, vos no sos quien para decirle al otro que se tiene que morir en la miseria porque ideológicamente no da y no es así. A mi me ha costado una barbaridad cobrarlo, es la realidad... encima vos ibas a firmar un papel donde estaba el nombre de tu desaparecido y la cifra abajo, parecía de gusto encima, lo único que estaba en negrita era eso, es como que esa historia que decía la Hebe que lo estabas vendiendo, como que mirabas y decías... la verdad que puesto así es tremendo. $Y$ a los H.I.J.O.S. en particular, yo he visto H.I.J.O.S. a los que le ha pegado muy mal, entonces yo digo, que bien que la han hecho con lo de las indemnizaciones, que a muchos los han hecho mierda... $\gg^{522}$

$\overline{522}$ Testimonio de María Coronel. 
Si el tema de las indemnizaciones fue problemático y dividió aguas, sobre todo en H.I.J.O.S., otros temas no resultaron menos complejos como, por ejemplo, la militancia de los desaparecidos. Retomo aquí la idea de los dos demonios, en el sentido de que la discusión acerca de la vía usada para la lucha contra el régimen por los militantes setentistas, cobraba nueva significación en los '90. Claramente el debate acerca de la reivindicación o no de determinadas formas de lucha fueron discutidas en el seno del MDHT, y que en H.I.J.O.S. reaparece con fuerza, motivando incluso discusiones internas de relevancia. Sin embargo, ante un enemigo común como el Bussismo en ascenso, estos debates no llegaron a producir rupturas. Los militantes de H.I.J.O.S. entendían que debían mostrar cierta unidad hacia fuera, aunque hacia adentro se produjeran importantes discusiones. Josefina Centurión lo explica:

«... no se si se llegaba a identificar con qué o a qué organización había pertenecido... tu padre concretamente... era como que... hasta donde lo de la lucha armada era algo que generaba... bueno, medio una parálisis en el debate, y en principio como que tratábamos que las diferencias no atentaran contra la continuidad de H.I.J.O.S. y como que en ese punto se frenaba un poco la discusión.» ${ }^{523}$

El tema central del debate introducido por H.I.J.O.S. al MDHT (aunque también se dio a nivel nacional), es lo que la organización entiende por "la reconstrucción del tejido social", ampliando así el campo de visión del propio significado que los derechos humanos tienen para sus militantes, no porque las otras organizaciones no lo plantearan sino porque, hasta mediados de los '90, la preocupación casi exclusiva del movimiento tenía que ver con la revisión del pasado dictatorial, y no con

523 Testimonio de Josefina Centurión. 
el presente social, producto de ese pasado, por ende, tiene que ver con la aplicación de ciertas medidas económicas y sociales.

La definición más clara de este aspecto viene dada entonces por la consigna que levantaba H.I.J.O.S. y que aparecía como novedosa: "Todos somos hijos de una misma historia". Consigna que, al menos en Tucumán, les servía para permitir la entrada en la agrupación de militantes que no estuvieran vinculados con los cuatro orígenes explicados más arriba. Sobre la idea de la reconstrucción del tejido social, Josefina Centurión analiza críticamente la cuestión, ya que parecía tener una dimensión tan amplia que era difícil llevarse a cabo:

«Sí, era un pilar pero entendíamos cuando nos abocábamos a ver ese punto que era un poco abstracto de alguna medida, y cómo le dábamos concreción a eso, la reconstrucción del tejido social, como una tarea enorme (...) era como que hacía agua, y eso nos llevaba a ver cómo nosotros como organización nos integrábamos con las otras organizaciones que trabajaban en eso también aunque sin que fuera puesto expresamente como un punto pero lo que hacían, la tarea concreta que llevaban adelante tenía esa intensión, de generar lazos, de comunicar o de ir al mismo lado y no se hasta que punto nos integrábamos, esto te lo digo muy a nivel personal, yo veía como que teníamos la intensión de abrir pero que costaba mucho... $\gg^{524}$

Una de las principales diferencias del MDHT con respecto al movimiento que actuaba en Buenos Aires, es por un lado la inferioridad en la cantidad de militantes que ha llevado a establecer la segunda distinción, que es la cercanía de los militantes de una u otra organización. Como ya se dijo en otro apartado de este trabajo, si bien las diferencias políticas o las discrepancias en la acción, podían marcar una línea ${ }^{524}$ Testimonio de Josefina Centurión. 
divisoria entre un organismo y otro, el hecho de tener que movilizar gente un 24 de marzo o en algún otro evento, requería de cierta unidad, para no parecer un movimiento pequeño y donde las fuerzas de algunos de sus miembros, ya por edad, ya por cansancio de años de militancia, hacía que fuera necesario interactuar. Esto se vio claramente durante los años en el que el Bussismo llegaba inevitablemente al poder provincial por medio de los votos. La necesidad de frenar tal avance hizo que a mediados de 1995 todo el MDHT se conjugara para organizar lo que se llamó el Juicio Ético a Bussi, a mediados del mes de junio de ese año, dos meses antes de las elecciones a gobernador, que he tenido la ocasión de analizar. 


\section{CAPÍtULO XIII: LOS '90 y LAS MEMORIAS ENFRENTADAS}

\section{XIII.1 LA Justicia LLegA De ALLende LOS MARES}

Una breve pero necesaria mención merece la apertura de las causas en España y en Italia contra los represores argentinos. Cerradas las opciones legales en Argentina, los organismos de derechos humanos buscaron un resquicio que pudiera acorralar a los ex dictadores y encontraron esa veta en Europa donde, a partir de 1996, se abrieron algunas causas contra los dictadores por la desaparición de ciudadanos españoles o italianos. A Bussi le tocó la citación de la justicia española el 12 septiembre de 1996 quien junto a otros represores como Alfredo Astiz, Emilio Massera o Orlando Agosti, eran requeridos por el juez español Baltasar Garzón para ser juzgados en la península española. ${ }^{525} \mathrm{El}$ 28 de marzo de 1996, estimando que los crímenes cometidos en la Argentina durante la dictadura militar eran crímenes de Lesa Humanidad, y por lo tanto perseguibles en todo el mundo, la Unión Progresista de Fiscales de España, interpuso una denuncia ante la Audiencia Nacional. ${ }^{526}$ Las investigaciones de Garzón, habían comenzado en abril de ese año y consiguieron que se conociera la existencia de cuentas bancarias suizas a nombre de destacados miembros de las Fuerzas Armadas argentinas, como el vicealmirante Adolfo Mario Arduino, el ex capitán de corbeta Jorge Acosta y el general Antonio Domingo Bussi. ${ }^{527}$

El cerco a Bussi llegaba entonces desde el otro lado del Atlántico y comenzaba al mismo tiempo el debate sobre las competencias de

\footnotetext{
525 Véase Martín de Pozuelo, Eduardo y Tarín, Santiago: España Acusa, Op. Cit.

526 Diario Página 12 del 25 de enero de 1998.

527 Diario La Nación del 3 de marzo de 1998.
} 
terceros países para juzgar a los dictadores argentinos. Como los imputados no habrían de trasladarse a España para ser juzgados (muchos de ellos, como Bussi, no habían sido juzgados en Argentina por lo que era de prever que no habrían de viajar a Europa para ser juzgados y condenados allí), y conociendo lo arduo que sería la cuestión, Garzón declaraba entonces que tenía "la absoluta seguridad de que, dada la gravedad de los hechos y la importancia cualitativa de los hechos investigados", (Argentina) colaboraría "en el esclarecimiento de los mismos." ${ }^{2528}$ Como se afirma en una editorial del diario La Nación "el juicio fue idea de Adolfo Pérez Esquivel. Nació con una denuncia de Carlos Castresana, de la Unión de Fiscales Progresistas. Contó con el asesoramiento de algunos abogados progresistas italianos."

El MDHT tuvo alguna incidencia también para que esta instancia judicial se abriera tanto en España como así también en Italia. Lo explica Atilio Castagnaro cuando afirma:

«Después a lo que nos dedicamos fundamentalmente es ver cómo hacíamos para tratar de anular las Leyes de Obediencia Debida y Punto Final, o sea, para tratar de conseguir un resquicio que permita la justicia. $\mathrm{Y}$ bueno, primero buscamos todo lo que sea, en realidad esto era un by pass que era saltarnos la ley para que los juzguen en España con todas las vinculaciones que teníamos ahí, intentamos hacer eso, yo llevé las primeras carpetas originales, que dan origen al libro, que las llevé con Pirucha Campopiano a España, se las llevamos a Garzón, y ahí empieza toda la historia con Garzón, eso fue mucho antes del '98, entonces buscamos esa línea que desemboca en el pedido de captura

\footnotetext{
${ }^{528}$ Declaraciones del juez Baltasar Garzón reproducidas por el diario Página 12 en su edición del 13 de Septiembre de 1996.

${ }^{529}$ Diario La Nación del 19 de abril de 1998.
} 
internacional que interpone Garzón a INTERPOL y que hace que Bussi no se pueda ir a veranear al Uruguay... $>^{530}$

Si bien Bussi no había sido juzgado todavía en España, el proceso abierto en 1996 permitió, por un lado, dar ánimos a los organismos en su lucha por el reclamo de justicia y, por otro, puso al descubierto las cuentas secretas que el general tenía en Suiza y el incremento patrimonial no declarado en 1993 cuando fuera elegido diputado nacional.

Un hecho que cabe mencionar aquí es que, en medio de todo el proceso político y judicial que comienza a vivirse nuevamente con intensidad, se instala en los cerros tucumanos en diciembre de 1996 un Bosque de la Memoria impulsado por la propia APDH en conjunto con la Universidad Nacional. Motor de una persistencia por hacer frente al Bussismo, las organizaciones además de buscar un cauce legal siguen expresando la necesidad de la condena social la encuentran una vez más en lo simbólico, como es el erigir un bosque por la memoria, la forma más representativa de desafiar al gobierno, mostrando a la sociedad que, a veinte años del golpe militar, los desaparecidos seguían estando presentes y debían formar parte de la agenda política de la provincia. Esta tozudez por desafiar al Bussismo no llegará más que dos años después, con las distintas confrontaciones entre el MDHT y Bussi a lo largo de todo el año 1998.

530 Testimonio de Atilio Castagnaro. 


\section{XIII.2 MEMORIAS EN PUGNA EN LAS CALLES, EN LOS JUZGADOS Y EN LA PRENSA}

La memoria despierta para herir a los pueblos dormidos, que no la dejan vivir, libre como el viento. ${ }^{531}$

1998 puede ser considerado "el" año en que las protestas contra Bussi se consolidaron. Fue el año en el que las memorias se enfrentaban con más fuerza en la provincia de Tucumán. Las investigaciones judiciales llevadas adelante en España por parte del Juez Baltasar Garzón, si bien no podían por el momento sentar en el banquillo de los acusados a Bussi, al menos desataban una crisis política de la que Bussi, a pesar de todo, saldría bien parado.

El 13 de febrero de 1998 se conocía que el gobernador de Tucumán tenía una cuenta en Suiza. La información había sido dada por la fiscal Carla del Ponte a pedido del juez español Baltasar Garzón. "No lo niego ni lo afirmo", dijo llorando a la prensa el general retirado. ${ }^{532}$ Al día siguiente de la puesta en escena mediática de Bussi, la Legislatura tucumana aprobó la formación de una comisión investigadora. El 18 de febrero la Cámara de diputados de la Nación abrió la declaración que hizo Bussi al asumir a su banca en 1993 y, como se sospechaba, no figuraba la cuenta suiza. El 19, Bussi volvía a comparecer ante los medios de comunicación reconociendo la existencia de tal cuenta y afirmando que "se trató de una omisión sin intencionalidad." 533 El 5 de marzo la Legislatura tucumana aprobaba la puesta en marcha del juicio político contra el gobernador. El 12 de ese mes Bussi presentó su descargo ante el tribunal de honor formado por orden del jefe del Ejército, general Martín Balza. Bussi dijo entonces que al mentir actuó "como un político y

\footnotetext{
531 Gieco, León, La memoria, Op. Cit.

${ }^{532}$ La Gaceta de Tucumán, 14 de abril de 1998.

533 Página 12, 20 de Febrero de 1998.
} 
no como militar", lo que le valió la sanción por parte del Tribunal de Honor Militar con una amonestación grave. En un escrito confidencial, Bussi habría advertido al Tribunal de Honor del Ejército que era objeto de una supuesta campaña organizada por "políticos de reconocida ideología izquierdizante" que procuraban "reeditar los enfrentamientos del pasado en una nueva confrontación ideológica cuyo planteo final sería en las elecciones del año 1999". 534

El 24 de Marzo, con motivo de un nuevo aniversario del golpe de Estado de 1976, APDH e H.I.J.O.S. de Buenos Aires sacaba una solicitada en el diario Página 12 en la que el título ya sugería lo que habría de ser el reclamo del movimiento de derechos humanos, en lo que le quedaba de mandato a Bussi frente a la gobernación. Sin más, el título de la primera solicitada decía: "Fuera Bussi". Ésta convocaba a todos los organismos que quisieran participar de una solicitada mayor que sería publicada el 29 de marzo en el mismo diario. Estas publicaciones del movimiento se hacían en respuesta a una solicitada aparecida el 22 de marzo de ese año en el diario La Gaceta de Tucumán. En página impar completa, Bussi se dirigía a la opinión pública diciendo: "Juzgue Usted", a lo cual agregaba un extenso listado en el que enumeraba las "arbitrariedades" de la comisión de juicio político que seguiría su causa.

Mientras Bussi era suspendido el 13 de Abril de 1998 por 60 días en sus funciones como gobernador, a raíz del juicio político que la legislatura provincial llevaba en su contra, el MDHT aprovechaba la coyuntura para hacerle fuerza en las calles con distintas manifestaciones a los largo de todo 1998. En ese contexto, el 30 de Abril, la organización Madres de Plaza de Mayo Línea Fundadora decide realizar la ronda de los jueves en la Plaza Independencia de Tucumán, recordar el 21 aniversario

${ }^{534}$ Clarín, 26 de marzo de 1998. 
de su nacimiento como organización, y en señal de solidaridad con el MDHT. En una solicitada en el diario Página 12 la organización expresaba que «las Madres de Plaza de Mayo -Línea Fundadora-, a 21 años del Primer Encuentro en la Plaza de Mayo el 30 de abril de 1977, marcharemos en la Plaza Independencia de San Miguel de Tucumán, el jueves 30 de abril. Los invitamos a acompañarnos en ese lugar, que hemos elegido como repudio al represor Domingo Antonio Bussi, responsable de miles de desapariciones y asesinatos. ${ }^{535}$ Una de las que acompañaría la ronda es Adelaida de Campopiano, quien años antes se había ido de la Asociación de Madres de Plaza de Mayo liderada por Bonafini, para recalar en Línea Fundadora y era una de las promotoras de la protesta del 30 de abril. En una entrevista a un diario porteño, "Pirucha", como era apodada esta Madre de Plaza de Mayo tucumana, explicaba:

«Todo este tiempo lo viví como si fuera una película. Me parece imposible haber hecho todo lo que hice por mi hijo. No puedo olvidarme cuando en los primeros años de la dictadura le ofrecí a Bussi mi vida por la libertad de Julio César. Tampoco me olvido que en vísperas de Pascuas le escribí a un general para que aunque fuera de forma anónima me diera a conocer cuál era la suerte que había corrido mi hijo. Se lo suplicaba porque me sentía decaer y no quería morir sin saber qué pasó con él. Sólo recibí un par de panfletos de un tal Comando Larrabure. Éstos me anunciaban que mi hijo había sido ajusticiado por el Ejército. Ni aún así dejé de luchar por Julio.»536

535 Solicitada de Madres de Plaza de Mayo Línea Fundadora aparecida en el diario Página 12 el 30 de abril de 1998.

${ }^{536}$ Diario Página 12, 30 de abril de 1998. 
También los seguidores de Bussi se manifestaban públicamente. Convocados por FR días antes de la suspensión del gobernador en su cargo, unas 2.500 personas se congregaban frente a la presidencia de la Legislatura provincial con la consigna "Bussi no se va". Protestaban en la capital tucumana en apoyo a la posición del gobernador de desobedecer una posible acusación en su contra de la Comisión de Juicio Político de la Legislatura local. Ricardo Bussi, hijo del gobernador y orador en el acto decía, al imaginar un posible arresto de su padre: "Somos capaces de enfrentar a la Gendarmería". ${ }^{537}$

Laura Figueroa realiza un balance de lo que para ella significó el juicio legislativo y lo que considera una nueva derrota en el plano político para el conjunto de organizaciones de derechos humanos en la provincia:

«Esta etapa ha sido terrible, muy dura. Ahí reaparece Carmen de Mitrovich, como que vuelve a agarrar el rol de dirigente de Familiares con un grupo, aparece fuerte Asamblea, Madres de Línea Fundadora, Sarita Mrad. Como que este hecho político nuclea, nos vuelve a nuclear y ahí, una vez más mi voz era en disonancia, porque comienzan a surgir dentro de los organismos fisuras en cuanto a que la línea peronista de Antonio Guerrero y otros más dirigiendo el partido Justicialista, ellos estaban por el juicio político y los que estábamos en la izquierda decíamos: no queremos juicio político, no dejemos la Plaza y obliguémoslo a renunciar. Entonces el partido justicialista mete lo del juicio político sabiendo que no tenía mayoría de legisladores y que lo iban a perder, porque Fuerza Republicana tenía mayoría de legisladores, y así fue. Pudimos resistir hasta un punto pero

537 Diario Clarín, 8 de Abril de 1998. 
perdimos la fuerza y el juicio político salió a favor de Bussi, y fue una derrota espantosa... $\gg^{538}$

Aunque en el balance Figueroa reconoce la derrota política, valora positivamente el hecho de la condena social:

«Aunque fue una derrota espantosa, lo bueno del juicio fue que para un buen sector de la sociedad de Tucumán se vio un Bussi corrupto, que era la primera vez que lo veían...»539

A pesar de todo el esfuerzo de los legisladores de la oposición (oposición a la posición hegemónica en la provincia, que era la del Bussimo) y del MDHT por conseguir que Bussi fuera sancionado, el 5 de junio de 1998 la Comisión de Juicio Político absolvía al General retirado, quien regresaba triunfal a ocupar el sillón de gobierno. En un medido discurso desde el balcón de la casa de gobierno provincial y ante sus seguidores, Bussi afirmaba: "No hay vencedores ni vencidos"540 como si se tratara de una guerra, la misma que decía haber librado en los años de la represión.

Bussi, como pocas veces, aceptaba ser entrevistado por el periódico local, La Gaceta. En un fragmento de la entrevista el ahora restituido gobernador, al ser preguntado por las denuncias que llegaban desde España afirmaba: «es un pasado sobre el que no quiero opinar nunca más. Creo que hacemos muy mal quienes volvemos al pasado y no tenemos presente los problemas que hoy nos comprometen a dar soluciones. Que sea la historia la que juzgue los supuestos hechos que se denuncian. He trazado una raya definitiva que no es el olvido, y le dedico todo mi tiempo al bien común de los tucumanos». ${ }^{541}$ En sintonía con la actitud hacia el pasado propuesto de las leyes de Punto Final y con el

\footnotetext{
538 Testimonio de Laura Figueroa.

${ }^{539}$ Ibídem.

540 Diario La Gaceta, 6 de junio de 1998.

${ }^{541}$ Ibídem.
} 
"nunca más" pretendido por los distintos gobiernos nacionales, Bussi comprendía que la mejor forma de dar vuelta la página no consistía en defender lo actuado en los años '70 sino procurar no volver a mencionar el tema y que todo cayera nuevamente en el olvido. Sin embargo el MDHT no aceptaba cerrar el capítulo de la historia y se seguiría movilizando para continuar la batalla por la condena social.

Como vemos, es posible situar a 1998 como un año de intensa actividad política, un año de reacomodamientos, tanto en el MDHT como en el propio Bussismo, que procuraba no quedar expuesto a las denuncias que llegaban desde Madrid y que dejaban al descubierto que Bussi no sólo era responsable de crímenes de Lesa Humanidad, sino que detrás se escondía la cuestión moral, juego que hizo el propio Bussi en las distintas campañas electorales para desmarcarse de los políticos tradicionales, que también se diluía y ofrecía nuevos argumentos de denuncia a los organismos de derechos humanos locales y nacionales. 


\section{XIII.3 EL PRIMER ESCRACHE DE H.I.J.O.S. EN TUCUMÁN}

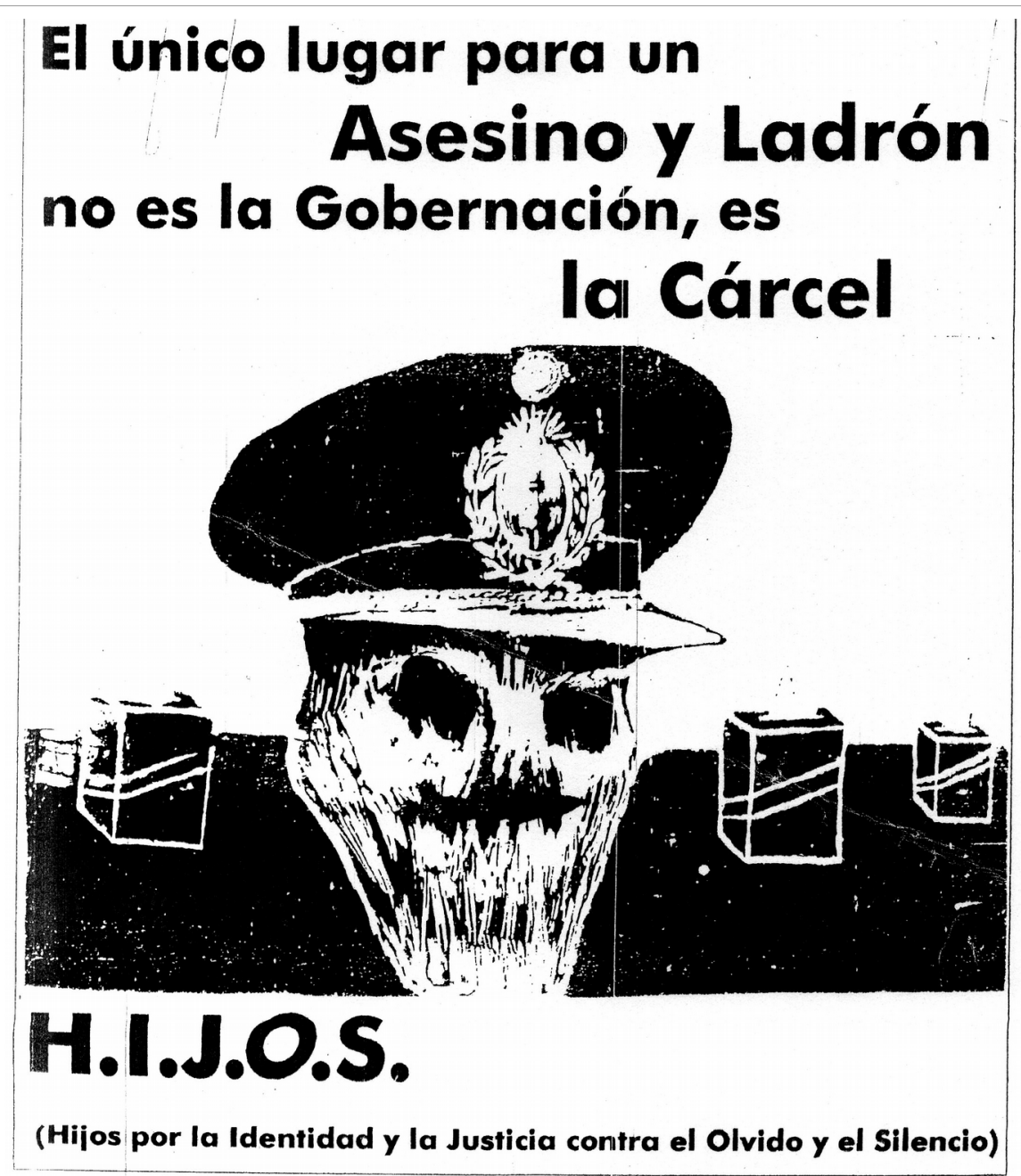

27. Representación de Bussi realizada por H.I.J.O.S. Tucumán con motivo del escrache del 12 de octubre de 1998 / Panfleto cedido por miembros de la organización.

Si la aparición de H.I.J.O.S. había supuesto, como ya dije, un nuevo impulso y le aportaba nuevas dinámicas a las manifestaciones del MDHT, los escraches aparecieron en el horizonte de la organización como una novedosa forma de expresión contra los represores de la dictadura, manifestaciones donde los jóvenes asumían un rol protagónico, buscando conseguir lo que el propio organismo había denominado como el "Castigo Social". La idea del castigo social no era nueva, como lo había 
demostrado la experiencia del Juicio Ético a Bussi en junio de 1995, pero adquiría en la práctica llevada adelante por H.I.J.O.S. una novedosa manera de manifestar la denuncia pública sobre la falta de la condena real.

Cerradas las instancias judiciales por medio de las leyes ya mencionadas, H.I.J.O.S. buscaba una forma de justicia simbólica y una condena social pero que, sin embargo, no se trataba una forma de justicia por manos propias, ya que de hecho la organización había heredado la tradición de Madres o de Familiares, organismos que no buscaban nunca salirse del cauce legal, o bien buscaban la trascendencia social por medio de manifestaciones públicas pero nunca atentatorias contra la persona física de los responsables de la dictadura. Los escraches le aportaron a la protesta nuevas dinámicas y nuevas simbologías, distintas a las expresadas en las marchas del 24 de marzo, por ejemplo, o a las marchas de la resistencia que anualmente venía realizando desde sus orígenes Madres de Plaza de Mayo en Buenos Aires y que reunía a multitudes de todo el país.

Pero el MDHT no olvidaba e H.I.J.O.S. recibía entonces la herencia de la memoria que le transmitían las organizaciones más antiguas. H.I.J.O.S. buscaba la condena social y es aquí donde agotará las instancias de la lucha, procurando dar a conocer por un lado los crímenes cometidos, y por otro, señalando a los responsables, muchos de los cuales permanecían recluidos en sus vidas privadas ocultando el pasado que les avergonzaba. Bussi y su entorno seguían justificando el accionar del ejército, seguían manteniendo la tesis de la guerra, y por lo tanto veían en las acciones de H.I.J.O.S. y de todo el movimiento un intento de revanchismo. ${ }^{542}$

${ }^{542}$ Bussi nunca negó su tesis sobre la existencia de una guerra en la llamada lucha contra la subversión, y puede incluso rastrearse la continuidad de su discurso a lo largo de todo el periodo en las notas de prensa aún siendo gobernador. Bussi, 
Una primera experiencia, lejos de Tucumán, más precisamente en la ciudad de Buenos Aires, había sido la concreción de una manifestación pública frente a la "Casa de la Provincia de Tucumán" en la capital del país, organizada por la Red Nacional, el día en que Bussi asumía la gobernación, el 29 de octubre de 1995. Como lo recoge de los testimonios surgidos de su propia investigación sobre H.I.J.O.S. La Plata, Santiago Cueto Rua entrevista a militantes de aquella regional que recuerdan entonces la actividad de repudio a Bussi en Buenos Aires.

Ramón, entrevistado por Cueto Rua, asocia el repudio a Bussi con el origen, al principio negado, de la práctica que luego será distintiva de HIJOS: «a partir de eso en HIJOS-La Plata surge, no sé si con la palabra "escrache", pero la idea de romper las bolas en la casa de Tucumán. El acto consensuado en particular con Capital era ir el jueves con las Madres, participar de la marcha alrededor del monumento, hacer un acto hablando del "día de la vergüenza nacional", de la aberración de que Bussi sea gobernador. Ahí La Plata va con la propuesta de después de ahí marchar a la casa de Tucumán. Creo que hasta ahí hubo un consenso, pero ya estaban los resquemores de quién impulsaba esa idea, qué

como otros ex represores tuvieron que sentarse años más tarde en el banquillo de los acusados, y es así como en el primer juicio por delitos de Lesa Humanidad llevado a cabo en Tucumán, en 2008, por la causa de la desaparición del ex senador Guillermo Vargas Aignase, en su alegato, Bussi volvió a levantar la hipótesis de la guerra para procurar convencer al tribunal sobre su inocencia. En un fragmento del mencionado alegato Bussi afirma: "Los tucumanos de la década del '70, son testigos insobornables de la guerra que vivió Tucumán y de la conducta de sus Fuerzas Armadas; muy pocos pueden negar hoy este "hecho" y de los miedos y horrores que producían las "bandas de delincuentes terroristas" que asolaban la Provincia, con su secuela de muertos, desaparecidos, secuestrados, atentados, etc". Véase en este sentido el anexo documental número 7 con el alegato de Bussi. Cabe mencionar que esta tesis de la guerra fue además esgrimida por otros ex represores, como el caso de Luciano Benjamín Menéndez, juzgado en varias causas en todo el país, quien también sostuvo dicho argumento para justificar la represión en los años de la dictadura. 
íbamos a hacer. Cuestión que llegamos a la casa de Tucumán, hay una pequeña refriega, piedras y que se yo, un grupo de HIJOS se coloca como columna delante de la casa de Tucumán. Fue feo porque había HIJOS contra HIJOS. $\gg^{543}$

Ya en Tucumán, la experiencia del escrache como manifestación de repudio ha sido breve y acotada, organizándose solamente dos a lo largo de los años '90. La más importante fue sin dudas en octubre de 1998, promediando el mandato de Bussi al frente de la gobernación cuando H.I.J.O.S. Tucumán había considerado conseguir el apoyo de la red nacional para su organización. Tras el regreso del general retirado a la gobernación, después de ser absuelto del Juicio Político de ese mismo año, H.I.J.O.S. había resuelto llevar a cabo su campamento nacional en la provincia norteña, seguido de un escrache que pretendía llegar a la Plaza Independencia, en las inmediaciones mismas de la casa de Gobierno provincial.

¿Pero qué son los escraches? Alejandro Medici aclara que "escrachar implica hacer público algo que alguien quiere mantener en el terreno de lo privado"544. Al mismo tiempo el escrache cumple con un triple objetivo: "llamar la atención de la comunidad hacia una reivindicación o un agravio, constituir una expresión de la unidad de los participantes y apelar a los no participantes a tomar posición." ${ }^{545}$

Si bien es cierto que en el caso de Bussi la organización de un escrache en su contra no equivalía a poner de manifiesto su existencia,

${ }^{543}$ Entrevista a Ramón, citada en "Nacimos en su lucha, viven en la nuestra" por Cueto Rua, Santiago en: Identidad, justicia y memoria en la agrupación HIJOSLa Plata. Tesis de maestría. Mimeo gentileza del autor.

544 Medici, Alejandro (2000): El movimiento de Derechos Humanos en Argentina y la lucha contra la impunidad: la estrategia del escrache, en Revista latinoamericana de política, filosofía y derecho, No 17.

545 Ibídem. 
pues el mismo ex represor se encontraba gobernando la provincia, sí suponía para el caso tucumano, la búsqueda de la condena social. Bussi, como dijimos, nunca negó su pasado y por el contrario, en más de una ocasión su actuación militar le había servido de plataforma política para ganar adeptos a partir de "su lucha contra la subversión" y sus "habilidades" en la gestión de la cosa pública. Simbólicamente, escrachar a Bussi en Tucumán tenía un objetivo muy distinto al de otras acciones similares en el país, donde la Red Nacional de H.I.J.O.S. o una regional querían poner al descubierto la existencia en tal sitio de un ex represor para que el conjunto social se enterara y condenara.

Julia Vitar, militante local de H.I.J.O.S. explica con sus propias palabras la significación del escrache:

«El escrache surge a partir de la imposibilidad de condenar a los milicos en la justicia por el hecho de las leyes de Obediencia Debida y Punto Final, entonces a parte de mostrar esta cuestión que todos sabemos, que los milicos ${ }^{546}$ están en todos lados y que caminan con impunidad en la calle porque nunca hubo justicia, es al mismo tiempo de develar este secreto, mostrarle a los vecinos, a la gente que convive, que va a la panadería, que va sube a los colectivos, seguramente los milicos no suben a los colectivos, pero bueno, que van a la farmacia y todo, que su vecino es esta persona, es esta persona, y generar en el ámbito de su cotidianeidad o de su laburo, por ejemplo, la condena social. Entonces es decir: ya que la justicia se niega a condenar a los milicos porque están estas leyes que son una basura y lo prohíben, nosotros lo que vamos a hacer es que la gente los repudie, sepa quiénes son, qué es lo que han hecho, de qué se los acusa, y que existe

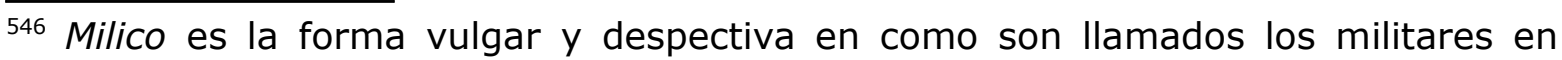
Argentina. 
una imposibilidad de condenarlo, pero que si no existiera esa imposibilidad, estos tipos deberían estar presos. ${ }^{547}$

La novedad de los escraches surgía no sólo de la necesidad de la condena social, que también era buscada por el movimiento en su conjunto, sino también en que rompía con el ritual de la manifestación en un momento determinado, en una fecha del calendario ritual. Hasta la aparición de H.I.J.O.S. el movimiento protestaba contra los represores y contra las leyes que imposibilitan el juzgamiento de los mismos, protestas que se expresaban en un contexto determinado, como lo eran las marchas organizadas para la rememoración del 24 de marzo o del 10 de diciembre, pero sin apuntar directamente al lugar de residencia o de trabajo del acusado. H.I.J.O.S. irrumpía de esta manera en la escena pública con una nueva forma de manifestación pública: se dirigía al domicilio o al lugar de trabajo del "escrachado" dejando una marca en la pared a modo de graffiti, mediante el desarrollo de un acto público de repudio y la entrega de panfletos, expresan la condena de quienes consideran eran los responsables de los crímenes cometidos por la última dictadura militar.

En Tucumán la realización de este tipo de protestas se vio limitada por un lado por el reducido número de militantes con que contaba H.I.J.O.S., y por otro lado con la realidad de la provincia, que, desde octubre de 1995, tenía al frente de la gobernación al dictador elegido por medio de los votos. Si la agrupación quería realizar una protesta por medio del escrache debía contar con una logística de movilización mayor y con una planificación del modo de concretarla muy organizada por cuanto no se estaba "escrachando" a un personaje oculto, sino a una figura pública y que además contaba desde su espacio de poder, con el monopolio del uso de la fuerza pública, reprimenda que ya ${ }^{547}$ Testimonio de Julia Vitar. 
habían sufrido algunos sindicatos y partidos de izquierda en innumerables manifestaciones que, por distintos motivos, se habían llevado a cabo en la provincia.

María comenta la imposibilidad de hacer estos escraches en provincias como Tucumán o lo complejo que resultaba dicho cometido:

«Con el escrache pasa que también marcaba una diferencia. Los escraches lo hacían solamente en Capital o en Córdoba, que eran las regionales más grandes, que tenían la contención de organismos también grandes como ellos, tenían, de alguna manera, el apoyo para llevarlo a adelante. Nosotros siempre éramos pocos, $y$ en todas las organizaciones, en una época en que H.I.J.O.S. Capital o H.I.J.O.S. Córdoba tenían cien militantes o ciento cincuenta, en Tucumán nunca hemos pasado más de veinte y obviamente es lo que les ha pasado a los otros organismos también, siempre hemos sido pocos (...) y estábamos en una situación con Bussi en la gobernación, con los organismos que éramos pocos, con la gente que sino lo había votado a Bussi, es el miedo de decir, antes era dictador y ahora es gobernador constitucional y puede hacer lo que quiera exactamente igual que en 1976, no tenías la base para poder hacer un escrache como podían hacer las regionales grandes...» ${ }^{548}$

Aún así H.I.J.O.S. Tucumán nunca dudó en buscar los medios de cumplir con esta novedosa protesta en la provincia y fue planteada como propuesta en el marco del décimo encuentro nacional de delegados de H.I.J.O.S, realizado entre el 15 y el 17 de agosto de 1998 en la ciudad de La Plata. A esta reunión asistieron Josefina Centurión y Susana Salvatierra llevando el mandato de Tucumán.

548 Testimonio de María Coronel. 
Josefina Centurión, recuerda de la reunión en Tucumán, previa al viaje a La Plata las discusiones que tuvo la regional local:

«Yo había entrado a H.I.J.O.S. ese año y como salió lo del encuentro de delegados en La Plata fuimos la Tuti y yo, entonces ahí como que los compañeros elegían quienes iban, elegíamos entre todos (...) entonces nos planteamos que para hacer el encuentro en Tucumán tenía que estar como organizado, tenía que valer la pena el esfuerzo y lo que iba a significar que los H.I.J.O.S. de desaparecidos se iban a juntar en esta provincia gobernada por un asesino de la dictadura y nos habíamos planteado que no fuera un encuentro como venía siendo hasta ese momento, que era una cuestión de juntarse entre nosotros en una casa grande o en una sede de algún gremio que te prestaba (...) habíamos decidido que si se hacía acá, si íbamos a asumir semejante esfuerzo tenía que hacerse con un acto público, con un hecho político, queríamos generar un hecho político, como parte de ese encuentro de H.I.J.O.S. (...) entonces ya fuimos al encuentro de delegados de La Plata con ese planteo...» ${ }^{549}$

De la reunión llevada a cabo en La Plata Susana Salvatierra cuenta:

«En la época de los encuentros de delegados se da que sube Bussi, que estaba Bussi en el poder en Tucumán, y con una compañera, Josefina Centurión, nos vamos al encuentro de La Plata y decidimos acá, en la asamblea, la propuesta de Tucumán era hacer el próximo encuentro de delegados en Tucumán, con la realización del escrache a Bussi. Y había que defender la postura porque además estaba Buenos Aires con la posibilidad de hacer el encuentro ahí con un escrache a Massera, en realidad ellos querían hacer un escrache a toda la

549 Testimonio de Josefina Centurión. 
junta, o algo así, un escrache groso. Entonces nosotros discutíamos y la postura era que, como coyunturalmente estaba el tipo en el poder, y tenía la posibilidad de seguir en el poder, y todo lo demás que el momento era hacerlo en Tucumán...» ${ }^{550}$

Después de tres días de discusiones, la reunión de delegados toma por fin la decisión de realizar el escrache en Tucumán y la regional provincial contaría con todo el apoyo de la Red Nacional, justamente para conseguir una manifestación importante que dé cuenta a todo el país quién estaba ocupando la casa de gobierno. Allí se decidió también la realización del Congreso Nacional de la agrupación en Tucumán entre el 10 y el 12 de Octubre de ese año. Fundamentaban la decisión en las circunstancias políticas que vivía la provincia "con las institucionalización del fascismo a través de un partido político, "Fuerza Republicana", expresada en el proyecto hegemónico del genocida Antonio Domingo Bussi $(\ldots)$, generan la necesidad de la realización de una abierta denuncia y repudio desde el conjunto de los miembros de la Red Nacional.."551

Es así como se llegó a octubre de 1998, buscando apoyos en los otros organismos, en la propia universidad, por medio de la cual H.I.J.O.S. conseguiría organizar su Congreso Nacional en un campus llamado la Quinta Agronómica, y que tenía gran valor simbólico, por cuanto los militantes de H.I.J.O.S. guardaban el recuerdo de los hechos que en ese predio habían sucedido en junio de 1972, los sucesos recordados como el "Quintazo", enfrentamientos estudiantiles con las fuerzas de la entonces dictadura dirigida por Lanusse. Muchos de los militantes que en los años '70 habían participado en el Quintazo, eran los

\footnotetext{
550 Testimonio de Susana Salvatierra.

551 Documento elaborado por la Red Nacional de H.I.J.O.S. en la 10a reunión de delegados en la Ciudad de La Plata. Léase el anexo documental número 2, el cual reproduce el documento íntegro.
} 
padres de esta generación de H.I.J.O.S., represaliados durante la última dictadura militar.

El tema del lugar era clave porque se esperaba la llegada de decenas de jóvenes más la cobertura de la prensa nacional, ya que tal nivel de movilización en la provincia era inédito. La Quinta agronómica surgía como espacio posible después de la gestión que Susana Salvatierra, por pedido de otros miembros, realizara directamente al rector de la Universidad Nacional de Tucumán, Mario Marigliano. De esto refiere Susana:

«Me habían pedido a mí que hiciera el pedido porque mi familia era amiga de Marigliano. Él estaba de rector en ese momento. Entonces yo hablé con Marigliano. Un día me lo encontré en el Centro Cultural, me fui a propósito, me dijeron, hoy hay un acto acá, y me fui a hablar con Marigliano directamente. Me lo presentaron, me abrazó y me dijo: yo fui, yo estuve porque lo conocí a tu viejo, porque mi papá era santiagueño, entonces le dije: mire, queremos hacer el encuentro de H.I.J.O.S. en Tucumán y necesitamos un lugar donde alojar más o menos a 200 chicos, y me dijo: ¿te parece la Quinta Agronómica, se acomodan ahí? Por su puesto...»

Pregunta: Además era un lugar emblemático la Quinta...

«Claro, después nos cae la ficha, en el tema de decir, La Quinta, ¿en dónde? Donde estaba el comedor universitario, justo en esa parte donde era el complejo Dickens y nos prestaban toda la Quinta, las asambleas las podíamos hacer dentro de los anfiteatros, era una cosa como demasiado simbólica...»552

$\overline{552}$ Testimonio de Susana Salvatierra. 
El escrache a Bussi sin embargo se enfrentó a todas las dificultades temidas por los organizadores del Encuentro Nacional: escuchas telefónicas, persecuciones a los militantes por medio de los servicios de inteligencias provinciales y el amedrentamiento de patotas que respondían al gobernador. Sin embargo durante los días en que transcurría el Congreso Nacional la Red Nacional había dispuesto un operativo de seguridad que incluía la entrega a los visitantes de las regionales que llegaban a provincia de una carta con recomendaciones sobre cómo actuar y qué hacer en caso de ser detenidos.

Josefina Centurión recuerda:

«La universidad nos prestó la sede del encuentro, que fue la Quinta Agronómica, y lo que había sido el comedor universitario o lo que quedaba que había sido parte de comedores universitarios aunque no exista tal cosa, es como que hay ahí un tipo que quedó de comedores universitarios, por lo menos de nombre, de una oficina, y quedaban unas cosas que todavía tiene la universidad y que se usan para los campamentos de algún colegio, como ollas, y cosas así, que sabíamos que quedaron de aquella época (...) Lo que sí que teníamos que hacer aquí como un esfuerzo adicional para que los que venían de afuera comprendieran la situación de Tucumán, en un sentido más amplio, desde tratar de ponerse en el lugar de los que estábamos aquí, que vivíamos aquí y militábamos aquí, entonces era difícil...»553

La mayor dificultad que tuvo H.I.J.O.S. Tucumán a la hora de recibir a los integrantes de la Red Nacional, era explicarles a muchos militantes la propia historia de Tucumán ya que muchos desconocían lo que había sido el Operativo Independencia y los riesgos que se corrían al organizar una protesta de la naturaleza de la que se organizaba en la 553 Testimonio de Josefina Centurión. 
provincia. Estas dificultades también fueron definidas por Susana Salvatierra:

«...Obviamente, obviamente que se despertó todo ese sistema de inteligencia, los mismos compañeros nos decían, los teléfonos están pinchados, seguramente los van a seguir, toda la mano de obra desocupada ${ }^{554}$ ha encontrado trabajo en el gobierno de Bussi y lo único que saben hacer es seguir gente, apretar gente, entonces esperen que vaya a pasar eso, tomen medidas de seguridad: no anden solos, no estén hablando por teléfono, o sea, un poco tratar de tener esos cuidados... $\gg^{555}$

De las recomendaciones que la red tucumana de H.I.J.O.S. daba a los visitantes, se enunciaban los cuidados de los que habla Susana. El documento entregado en mano a los que llegaban a Tucumán advertía la necesidad de permanecer unidos; en caso de ser reprimidos por la policía debían llamar rápidamente la atención de la gente y de la prensa; se debía evitar responder violentamente a las agresiones; si alguien resultaba detenido se debía llamar a los abogados y a la prensa (para tal fin se disponían los números de teléfonos de los abogados que trabajaban en materia de derechos humanos, como el de Laura Figueroa, entre otros).

Estimo aquí necesario una nueva digresión para explicar los fundamentos de tal temor en la organización de tamaña actividad, aún cuando dicha protesta se hiciera bajo un estado de derecho. ¿Había que

${ }^{554}$ Comúnmente se dice que la mano de obra desocupada son aquellas personas que durante la dictadura militar ocupaban algún cargo o tenían algún "trabajo" dentro del esquema represivo, muchos de los cuales habían formado parte de los llamados grupos de Tarea que secuestraban y torturaban a las víctimas. Los organismos de derechos humanos siempre denunciaron humanos que dicha mano de obra desocupada seguía activa y que en determinados momentos era usada para trabajos de inteligencia durante la democracia.

555 Testimonio de Susana Salvatierra. 
temer una posible represalia por parte de Bussi? ¿Habría de mostrar Bussi su rostro dictatorial sabiendo que la prensa nacional acompañaría a los manifestantes? Dos datos corroboran que el temor de los organizadores del escrache en Tucumán estaba fuertemente fundado. El primero es una noticia aparecida dos años antes en la prensa nacional. En su edición del 7 de febrero de 1996, el diario Clarín daba cuenta de una reunión realizada en el despacho del gobernador tucumano, entre Bussi y dos funcionarios de su gobernación, uno de ellos Osvaldo Morelli, alcalde de la ciudad de Concepción y Atilio Peluffo, Secretario del Interior de la Provincia. En la foto aparecen los tres hombres y en primer plano un revólver Mágnum 357. El matutino porteño daba la noticia afirmando que "ni Bussi ni su oficina de prensa explicaron por qué el gobernador da audiencias armado." ${ }^{1556} \mathrm{El}$ análisis de otro diario de la Capital expresaba en una nota editorial que "Bussi, como lo ha demostrado a diario desde que asumió como gobernador democrático, el último 29 de octubre, sigue siendo muy afecto a los gestos marciales." ${ }^{557}$

Si este hecho provocaba la repulsa de los medios nacionales y les hacía comprender que el Bussi de la democracia era el mismo de la dictadura, el operativo montado en la ciudad de San Miguel de Tucumán el día de la marcha de H.I.J.O.S. y del escrache demuestran hasta dónde el gobernador no sólo seguía viendo en los militantes de los organismos de derechos humanos a sus adversarios de "guerra", sino el grado de persecución que él mismo general retirado sentía sobre sus espaldas. Una nota de Página 12 define el operativo de seguridad el día de la marcha de H.I.J.O.S. es decir el 12 de Octubre de 1998, con el siguiente título: "En Tucumán hubo cinco policías por cada hijo de desaparecido."

\footnotetext{
556 Diario Clarín, 7 de febrero de 1996.

557 Diario Página 12, 8 de febrero de 1996.

558 Diario Página 12, 13 de Octubre de 1998.
} 
Felipe Yapur comenzaba la noticia sobre el escrache afirmando que "Antonio Domingo Bussi, el gobernador de Tucumán, fue escrachado en su propia provincia por los jóvenes de H.I.J.O.S.. Ésta debe haber sido la razón fundamental por la que el anciano general se ausentó de la provincia, pero antes dejó un impresionante operativo policial (alrededor de cinco mil efectivos) que tenía la orden de impedir, a como diera lugar, la llegada a la casa de gobierno de las más de mil personas que acompañaron a H.I.J.O.S.." ${ }^{\prime \prime 59}$

Si bien los manifestantes no pudieron ingresar al centro de la ciudad por estar custodiada por los efectivos de la policía, realizaron el acto público en presencia de los medios de prensa nacionales, en un parque ubicado a 700 metros de la Casa de Gobierno. El parque, días antes de la protesta, había sido rebautizado con el nombre de "Operativo Independencia", por lo que los manifestantes muñidos de aerosoles refundaron el espacio público con el nombre de "30.000 detenidos desaparecidos", en un acto de profundo desafío al poder Ejecutivo Provincial.

Susana explica cómo había sido vivida desde adentro la protesta:

«Para el encuentro, después del último día, después que hacemos las deliberaciones, decidimos hacer la marcha a pie, un tramo lo íbamos a hacer en colectivo, los compañeros habían conseguido algunos colectivos para acercarnos un poco y no tener que estar caminando, sobre todo para los que iban con H.I.J.O.S., y por las banderas y todo lo demás. El primer acto era cambiarle el nombre a las plazas que estaban en la Avenida Roca ${ }^{560}$, tenían el nombre Operativo Independencia, entonces cuando le explicamos a los chicos

\footnotetext{
559 Ibídem.

560 Se hace mención aquí al parque donde finalmente se llevaría a cabo el acto central al tener impedido el ingreso al centro.
} 
que era el Operativo Independencia, que muchos no sabían (...) para los chicos el '75, represión en Tucumán, muchos no sabían... muchos no sabían que este hijo de puta había sido educado y había venido a poner en práctica eso. No tenían ni idea. Y bueno, después llegamos a ese lugar, cuando íbamos caminando, un compañero que pinchaba la radio, nos dice: no es para que se asusten pero hay 5.000 policías. Entonces nos juntamos y dijimos: hagamos un operativo de seguridad como la gente para nosotros. Y había gente que nos estaba esperando en la Plaza (Independencia) y la policía había cerrado las cuatro avenidas. No podíamos llegar a la Plaza. Y se armó el desbande porque todo el mundo quería llegar a la Plaza (...) la prensa nos preguntaba que íbamos a hacer: y son cinco mil tipos y nosotros ciento veinte, ¿qué íbamos a hacer? Los Familiares que eran como ochenta personas... era como desmedido... $>^{561}$

En el folleto entregado por la organización del escrache a los vecinos y a los manifestantes ${ }^{562}$ se volvían a hacer públicas las denuncias que pesaban sobre Bussi, a las ya reiteradas por su pasado como gobernador de facto. Al recuerdo del pasado dictatorial más lejano se le agregaban las denuncias sobre el pasado reciente. Algunas de estas acusaciones afirmaban entonces que le habían descubierto "una abultada cuenta en Suiza que se presume conformada con fondos de "Botín de Guerra", se recordaba además el juicio político que meses antes lo había mantenido lejos de la casa de Gobierno por dos meses, entre otras imputaciones.

Claramente la escena mostraba un combate por la memoria. Nuevamente el espacio público era testigo del enfrentamiento entre una

\footnotetext{
561 Testimonio de Susana Salvatierra.

562 Véase la transcripción del panfleto en el anexo documental número 3.
} 
memoria oficial que destacaba el Operativo por medio del cual había comenzado el genocidio en Argentina, y una memoria de un sector importante de la sociedad, embanderada por el MDHT en general y por H.I.J.O.S. en este acto particular, y se encargaba de sostener por medio del escrache público la condena social buscada por los organismos durante tanto tiempo, una condena social que parecía llegar tarde, mientras que el general retirado ya ocupaba la casa de Gobierno de donde ni siquiera el juicio político había podido tumbarle.

En el balance de los organizadores el escrache había tenido éxito porque había permitido una vez más mostrar la cara visible del represor, la misma de 1975 cuando se hizo cargo del Operativo Independencia, la misma de 1996, recibiendo a funcionarios en su despacho con un revólver en la mesa. Pero, al mismo tiempo, la finalización de esta protesta puso al descubierto una vez más las debilidades propias de las organizaciones de derechos humanos que quedarían diezmadas, como había ocurrido a finales de la década del ' 80 . Nuevos reacomodamientos harían falta y nuevas estrategias para conseguir establecer en el tiempo una línea de trabajo eficaz en la consecución de los objetivos del movimiento.

\section{XIII.4 UN NUEVA CRISIS DEL MDHT Y EL PRINCIPIO DEL FIN DEL BUSSISMO. EL CAMINO A UNA NUEVA TRANSICIÓN}

Una vez finalizado el escrache del 12 de Octubre de 1998, los interrogantes sobre hacia dónde iba el MDHT eran múltiples. El desgaste producido después de casi tres años de enfrentamientos con Bussi ocupando la casa de Gobierno y, agotando todas las instancias posibles para su desplazamiento, volvía a producir un efecto de debilitamiento en las organizaciones. La organización H.I.J.O.S. quedaba marcada después 
del escrache, sobre todo al término del mismo y al retirarse de la provincia cada uno de los contingentes de la Red Nacional. Los militantes locales eran objeto de persecuciones y amenazas por parte de las fuerzas del gobernador que buscaban el amedrentamiento por distintas vías. Los activistas de H.I.J.O.S. Tucumán, como lo reconocen ellos mismos, no estaban preparados para continuar solos en la lucha contra un gobierno que había salido indemne de todos los intentos de condena judicial, política y social. Persecuciones, amenazas e intimidaciones a los militantes afectaron mucho en la psiquis de los jóvenes que se veían en soledad ante un Bussismo que se mantenía firme, pese a todo, en la casa de Gobierno. Este desgaste supuso el comienzo del final en esta etapa de H.I.J.O.S., pero también un final de época en todo el MDHT en su conjunto. La crisis en este lapso de H.I.J.O.S. es explicada por Susana Salvatierra:

«Me voy porque yo ya sentía que no daba mucho, como que por un lado se había perdido en mí, la confianza de que esa lucha iba a conseguir algo.»

Pregunta: ¿Qué creías que podía conseguir esa lucha antes de esto?

«El tema de la condena. Para mí el escrache fue como, hasta ahí llegué, hasta ahí llegué. Creo que va a ser mucho más difícil... después me volví a acercar a Familiares, no a H.I.J.O.S., H.I.J.O.S. quedó medio desorganizado, me acerqué a Familiares por el tema del Pozo de Vargas $^{563}$ y

${ }^{563}$ El Pozo de Vargas es un espacio en la periferia de la ciudad capital donde se encontró lo que ya quedó materialmente demostrado, ha sido una fosa de entierro común. La investigación del Pozo de Vargas comenzó en 2002, cuando un funcionario del entonces gobierno justicialista denunció su existencia. Al día de hoy todavía continúan las investigaciones aunque ya se encontraron los primeros restos mortales de detenidos desaparecidos durante la última dictadura militar. Dada la profundidad del pozo, las pesquisas por parte de los peritos continúan al día de hoy. 
estuve un tiempo y realmente extrañaba H.I.J.O.S., después de estar en Familiares, extrañaba H.I.J.O.S....»564

Susana no es la única que con el tiempo se aleja de H.I.J.O.S., lo harán casi todos sus miembros hasta entrado el 2001 en el que la agrupación queda desarticulada. Sin embargo, esta nueva derrota política de finales de los '90, no sólo se produjo al interior de H.I.J.O.S. Otras agrupaciones como Familiares y Madres también van a quedar desvencijadas y van a sufrir en su interior reacomodamientos, viendo nuevamente como alguno de sus militantes se alejaban, desilusionados una vez más por la falta de concreción de los objetivos. Los ejes de acción claramente cambiarán hasta bien entrado los años 2000, con la nueva administración política encabezada por el entonces presidente Néstor Kirchner. Sobre la crisis en Familiares y Madres, Laura Figueroa, realiza un balance que resulta al mismo tiempo una lectura política de su propia militancia hasta esos años:

«...la década del '80 para mí fue la década de oro desperdiciada, truncada, traicionada y violada por Alfonsín. Porque realmente ¿dónde se pinchan los familiares? Es con la Ley de Punto Final. Ya los agarra viejos en la década del '90, el indulto fue una derrota absoluta porque la marcha enorme de cien mil personas en Buenos Aires fue derrotada. Y Bussi que iba creciendo. Por supuesto que si los dirigentes hubieran tenido por ahí mayor claridad política de lo que significaba la herramienta del juicio hubiese habido mayor participación (...) Con el tiempo Familiares deja de ser lo que era. Carmen de Mitrovich comienza a enfermarse, se desintegra Familiares, se desorganiza mejor dicho Familiares, monopoliza la lucha el MEDH, Ana de Díaz pasa a ser el referente, ahí es donde se asesora sobre las indemnizaciones, los beneficios y el eje era

564 Testimonio de Susana Salvatierra. 
ese. Ya Madres tiene otra línea de trabajo, se mete más en lo social, la Línea Fundadora acá ha sido más bien débil, digamos, no tenía una sede, no tenía muchos familiares que las siguieran y más iban a la Iglesia Metodista (...) después de producirse una crisis dentro del MEDH y Ana de Díaz debe alejarse, ahí se produce una diáspora, muchos familiares cayeron en abogados particulares que directamente los dejaban en la calle, fue una desgracia absoluta, hasta que en el 2001 yo digo que no se podía seguir trabajando así y vuelvo a convocar para que nos reunamos... ${ }^{565}$

Las llamadas leyes de impunidad por esos años no habían podido ser derogadas y perdidas las batallas judiciales y políticas, era momento de la reclusión de los militantes y un retroceso en el espacio público. Quedaba sin embargo recorrer un largo año 1999 en el que tanto el Bussismo, como las organizaciones de derechos humanos, llegaban con gran desgaste.

Tanto Bussi como su partido parecían indemnes ante esta lucha de años. En las elecciones provinciales Bussi colocó como candidato a uno de sus hijos, Ricardo Argentino, mientras que el propio ex gobernador se presentaba como candidato a Diputado, demostrando una vez más el personalismo y el verticalismo de un partido que había sido creado a su imagen y semejanza. Mientras su vástago era derrotado en el cargo de gobernador en manos del candidato justicialista Julio Miranda, el general retirado conseguía una banca en la cámara de diputados de la nación, lo que le habría de garantizar la impunidad de continuar eludiendo a la justicia por medio de la inmunidad parlamentaria. La batalla entonces volvió a librarse en las esferas nacionales donde,

565 Testimonio de Laura Figueroa. 
después de un amplio debate, el congreso le cerraría las puertas a la obtención del diploma de diputado.

En la gobernación, Bussi no pudo imponer a su hijo como fiel continuador del proyecto de Fuerza Republicana ya que había perdido las elecciones provinciales por un margen muy pequeño, tan pequeño que el mismo día de los comicios, el 6 de junio de 1999 y sin que hubiera finalizado el recuento de los votos, los medios de prensa locales y nacionales anunciaban el triunfo de Bussi hijo, mientras que el conteo final daba la victoria a Julio Miranda, candidato justicialista. Felipe Yapur, describía el fracaso de FR afirmando que: "Antonio Bussi luce derrotado, lo demuestra su semblante y lo delatan sus declaraciones. En un intento por revertir el fracaso sufrido por su vástago y su partido, anunció y advirtió, en un tono marcial, que existen dos alternativas para destrabar el conflicto electoral: "O se hace un escrutinio voto por voto o se anula los comicios". De todas formas, el general se cuidó de pronunciar la palabra fraude y consideró que sus fiscales fueron engañados. Mientras, el escrutinio provisorio seguía adelante y ampliaba la estrecha victoria justicialista." ${ }^{\prime 566}$

Ante el cambio de signo político en el gobierno de Tucumán, la periodista Norma Morandini sintetizaba en una nota lo que dejaba tras cuatro años de gobierno la administración Bussi: "El general que prometía el orden de los cuarteles para la provincia, deja Tucumán con un gran desorden en sus cuentas públicas; el militar que imponía una idea de autoridad se despide del gobierno con lágrimas que derrama profusamente frente a los micrófonos; el gobernador que llegó con una escoba en la mano para simbolizar que iba a barrer con la corrupción, se va sospechado de enriquecimiento ilícito, varios de sus ministros

566 Página 12, 8 de junio de 1999. 
involucrados en negociados privados con las arcas del estado. Y la basura se acumula en las esquinas del Jardín de la República, donde las escobas de los municipales están en huelga por los meses de sueldo que les adeudan. El gobernador que pintaba todo de blanco, de los postes a los árboles, ocultaba los mendigos y hacia escudriñar la noche desde el aire con el potente haz de luz de los helicópteros, dejó en la Plaza Independencia, al frente de la Casa de Gobierno un paisaje urbano desolador: "la carpa del aguante". Los empleados acampados desde hace meses para reclamar el pago de sus salarios". ${ }^{567}$

Por fin el general perdía una batalla política. Pero no sería la única. El 1 de diciembre de 1999, la cámara de diputados de la nación impedía que Antonio Domingo Bussi asumiera en su banca legislativa. El cuerpo legislativo enviaba el diploma de Bussi a Comisión para determinar si le cabía al candidato la acusación de "inhabilidad moral y falsedad ideológica." ${ }^{\prime 568}$ En el recinto de diputados se llevó a cabo un extenso e intenso debate en el que el único defensor del general retirado había sido su propio hijo, Ricardo Bussi, quien ocupaba una banca por FR. Uno de los diputados, el socialista Alfredo Bravo, defendía la posición de la mayoría de elevar a Comisión el diploma de Bussi:

«Señor presidente: en ocasiones la vida nos pone ante circunstancias ineludibles; esto es lo que hoy le ocurre a esta Honorable Cámara, que enfrenta el inevitable destino de pasar a la historia del Poder Legislativo. Este pasaje lo realizará con dignidad o con oprobio, de acuerdo con lo que decida respecto a la incorporación de un diputado electo cuyo diploma venimos a impugnar. En ese sentido, quiero alertar a la Honorable Cámara sobre la situación que se podría presentar si el diputado electo que impugnamos llegase a

567 Clarín, 31 de Octubre de 1999.

568 Página 12, 2 de diciembre de 1999. 
prestar juramento. En ese momento se estaría incorporando a este seno al impugnado, que sigue cometiendo el delito permanente de desaparición forzada de personas. Por lo tanto, para evitar que se produzca un hecho bochornoso atentatorio contra la dignidad de esta Honorable Cámara, impugnamos la incorporación a este cuerpo del diputado electo por la provincia de Tucumán, Antonio Domingo Bussi. (Aplausos) Asimismo, solicito que se suspenda su juramento hasta que en una sesión ordinaria el cuerpo se expida sobre el requisito de idoneidad moral que se requiere para integrar la Honorable Cámara de Diputados de la Nación. ${ }^{569}$

Este nuevo paso en falso para el ex gobernador y su partido, después de la derrota electoral en junio de ese año, fue ratificado cuatro meses después cuando el parlamento finalmente decidía rechazar la incorporación de Bussi el 10 de mayo de 2000. 570

Otra historia comenzaría entonces a trazarse tanto en la trayectoria del movimiento de derechos humanos, como en la de su principal oponente, Bussi, clausurando una etapa de más de 20 años de memorias enfrentadas en todos los frentes posibles: el espacio público, el ámbito doméstico, las iglesias, los tribunales, etc. La última y definitiva batalla se daría en 2003, cuando en un último intento por prolongar la

\footnotetext{
569 Versión taquigráfica de la sesión ordinaria de la Cámara de Diputados de la Nación del 1 de diciembre de 1999. Véase en http://www.hcdn.gov.ar/dependencias/dtaquigrafos/frames.html [Consultado por última vez en marzo de 2010]. Véase en el anexo documental número 4 un extracto del debate parlamentario.

570 De la votación para el rechazo del diploma de Bussi como diputado nacional sobre 191 diputados presentes, 179 han votado a favor del rechazo y 7 en contra, entre los que se encontraban Ricardo Bussi, hijo del ex militar, registrándose además 2 abstenciones. Versión taquigráfica de la sesión ordinaria de la Cámara de Diputados de la Nación del 3 y del 10 de mayo de 2000. Véase en http://www.hcdn.gov.ar/dependencias/dtaquigrafos/frames.html [Consultado por última vez en marzo de 2010].
} 
"inmunidad" el ex gobernador volvía a presentarse como candidato a alcalde de la ciudad de Tucumán derrotando por apenas 17 votos a Gerónimo Vargas Aignase quien, paradójicamente, era el hijo de un senador desaparecido durante el mandato de facto de Bussi en 1976. Sin embargo, en lo que sería la última acción de este periodo, dos de las organizaciones de derechos humanos que habían logrado sobrevivir a la crisis de 1999, ANDHES y la APDH, en compañía con el CELS de Buenos Aires, presentaban la impugnación a la candidatura de Bussi a la intendencia de la ciudad capital. El pedido llegaría a la justicia tras esas elecciones y Bussi, como había sucedido en el año 2000 en la cámara de Diputados, tampoco podía asumir la alcaldía de San Miguel.

Entre los fundamentos de las organizaciones para pedir se revea la posible asunción de Bussi a la intendencia de la Capital tucumana se impugnaba a Bussi en "la causal de falta de idoneidad (...) --en el caso, idoneidad ética-moral-- requisito sustancial exigido por el artículo 16 de la Constitución Nacional como única condición para acceder a cualquier tipo de cargo público. Motiva esta causal, la participación y responsabilidad del impugnado en las graves violaciones a los derechos humanos cometidas en Argentina durante el período 1975-1983 (...)". . $^{571}$

Los nuevos tiempos presagiaban entonces nuevas disputas y nuevos actores sociales en lo que todavía hoy sigue siendo historia presente y que deberá ser revisada en un futuro por la historiografía local. Sin embargo desde 1999 y hasta 2003, se terminaba de cerrar un círculo en la historia de la provincia de Tucumán, abierto incluso mucho antes del golpe de Estado de 1976. Las memorias enfrentadas entre el campo del movimiento de los derechos humanos locales y el Bussismo clausuraba un nuevo capítulo donde por un lado, las organizaciones que

571 Véase la presentación de la impugnación a la candidatura de Bussi a la alcaldía de San Miguel de Tucumán en el anexo documental número 5. 
nucleaba al movimiento no habían podido cumplimentar sus objetivos y por otro, Bussi, objeto central de la disputa del movimiento, si bien era derrotado esta vez políticamente, dicha derrota no se condecía con la necesidad de condena judicial por partes de los familiares de los desaparecidos. El 2003 abrirá en este terreno nuevas instancias y producirá nuevos reacomodamientos que como expresé, deberán ser materia de revisión futura. 
Conclusiones 
A lo largo del presente trabajo he procurado establecer la relación del surgimiento y devenir del movimiento de derechos humanos en Tucumán, a partir del testimonio y la memoria de sus militantes, con el proceso político abierto en la provincia desde el último golpe militar hasta el periodo de la larga transición vigilada. Desarrollo que, en la provincia norteña de Argentina, tuvo que ver con cuestiones claramente locales, no sin la verificación de los vínculos entre las organizaciones que componen el movimiento y a su vez entre éstas con otras organizaciones de similares características en todo el país.

El nacimiento, evolución, desarrollo y crisis del movimiento de derechos humanos de Tucumán respondió a los avatares propios de la historia política local y al mismo tiempo a las experiencias de los propios actores sociales que componen el conjunto de organizaciones. Tal como pudimos apreciar, Tucumán fue duramente golpeada por las dos últimas dictaduras militares en la imposición de políticas económicas y sociales que impactaron en vastos sectores sociales, los que a su vez respondieron desde la resistencia a dichas coacciones determinando al mismo tiempo la respuesta duramente represiva del establishment gobernante por medio de las Fuerzas Armadas.

Tras la llegada al poder del General Juan C. Onganía el 28 de junio de 1966 por medio de un golpe militar contra el gobierno de Arturo Ilia, la provincia de Tucumán se vio afectada de forma exclusiva tanto en la implementación de políticas económicas que afectaron su estructura social y la intervención en la autonomía universitaria que conmovió a sectores medios integrantes de la casa de estudios. La respuesta a dicha dictadura desembocó en la consiguiente réplica represiva, la que a su vez se profundizó a partir de 1975 con la puesta en marcha del llamado Operativo Independencia. La operación militar ordenada por el gobierno 
constitucional de Isabel Martínez de Perón, fue la prueba de ensayo en la que los militares argentinos experimentarían el esquema represivo desatado un año después tras el golpe de Estado el 24 de marzo de 1976.

Directamente relacionado con estos dos golpes militares, el aparato represivo fustigó a importantes sectores sociales contestatarios lo que determinó no sólo la resistencia de obreros y estudiantes, sino el consecuente aumento represivo sobre estos dos sectores, lo que se tradujo en unas maneras de violencia estatal que trajo aparejado el secuestro y posterior desaparición de personas, ultrajando así, los más elementales derechos humanos. El círculo de la violencia política había sido abierto claramente y así como los sectores populares legitimaron el uso de la violencia para responder a la violencia estatal, los mencionados regímenes dictatoriales profundizaron el terror para conseguir la sumisión del pueblo en su conjunto.

De ese contexto surgió en la segunda mitad del año 1977 la primera organización que congregó a Familiares de Detenidos y Desaparecidos por Razones Políticas, agrupación que habría de sentar las bases del movimiento de derechos humanos de Tucumán. Los primeros pasos de "Familiares" consolidaron en poco tiempo un espacio desde el cual se reclamaba de manera conjunta por la aparición con vida de los desaparecidos. Dicha consigna si bien con el tiempo se vio ampliada y hasta fue abandonada en los primeros años de la transición, fue el eje vertebrador desde el cual Familiares comenzó su andadura durante los primeros tiempos.

Como pudimos apreciar, la falta de una acción pública más concreta y decidida del colectivo congregado en la Iglesia del Sagrado Corazón de Jesús, liderado por Carmen de Mitrovich, determinó que un 
grupo de mujeres sintiera que la "mera reunión" se volvía ineficaz para las demandas que exigía el conjunto, y la respuesta debía ser una salida a la calle para manifestarse públicamente contra el régimen en una actitud desafiante más contundente. Guiadas por las acciones de las Madres de Plaza de Mayo en Buenos Aires, pero con autonomía en su formación, decidieron romper con Familiares y armar una organización propia hacia finales de 1981 e instituyeron la costumbre de marchar alrededor de la plaza principal de la ciudad, la Plaza Independencia, emulando las rondas de las madres porteñas.

Aunque durante los años en que gobernaron las Fuerzas Armadas, las dos organizaciones que hasta 1983 conformaban el movimiento de derechos humanos tuvieron un rol protagónico en la resistencia y por el reclamo de aparición con vida de los desaparecidos, con la crisis del régimen provocada, entre otros factores por la derrota en la guerra de Malvinas en 1982, aparecieron en los albores de la transición institucionalizada del país nuevas organizaciones que irrumpieron en la escena política local y que contribuyeron a la ampliación del movimiento tucumano.

La primera de estas organizaciones, inédita por su composición, fue la Asociación de Abogados por los Derechos Humanos que reunió a especialistas en materia jurídica para la colaboración con los familiares de víctimas de la dictadura. Este agrupamiento de letrados contribuyó con Familiares y Madres en la presentación de habeas corpus, la recogida de testimonios de afectados, la colaboración con la Comisión Bicameral Investigadora de las violaciones a los derechos humanos de Tucumán. Este último acontecimiento resultó una de las conquistas más significativas del movimiento local durante los primeros años de transición. La conformación, en el ámbito local, de una comisión 
parlamentaria provincial ordenada por el Poder Ejecutivo para la investigación de los crímenes de Lesa Humanidad cometidos por la dictadura, marcó una diferencia sobre todo cualitativa con respecto a la nación, porque implicó en última instancia, la asunción por parte del gobierno los crímenes cometidos por el propio aparato estatal. Si en Tucumán se dio dicha conformación se debió, entre otras razones, al accionar del movimiento de derechos humanos local, constituido hasta ese momento por "Familiares" y "Madres", y como respuesta que el gobierno provincial dio en función de satisfacer dichas demandas. Vuelvo entonces sobre la idea de la determinación de Raymond Williams para observar cómo a los límite impuestos por el régimen, el movimiento de derechos humanos le respondió con las presiones a los fines de romper el cerco represivo, que en última instancia tampoco se terminó el 10 de diciembre de 1983 con la entrada en vigor del Estado de derecho, pero en el cual comenzaron a aparecer grietas.

Ya en los primeros meses de la transición, se había conformado también en Tucumán la Asamblea Permanente por los Derechos Humanos, organización que en Buenos Aires venía actuando desde 1975, pero que en la provincia norteña recién pudo hacerlo en enero de 1984. El motivo de tan tardío surgimiento se explica por la profundización de la misma oleada represiva en Tucumán mencionada anteriormente. Como vimos, parte de la composición de la APDH local estuvo dada por miembros de partidos políticos de centro izquierda, pero también con algunos militantes desencantados de las organizaciones de Familiares y Madres, como Carlos Soldati, quien no cejó en la búsqueda de un espacio que satisficiera sus necesidades en función de la búsqueda de sus hermanos desaparecidos. 
Lo que observamos entonces para el caso tucumano es que desde la experiencia local algunos activistas transitaron de organización en organización, siendo que las limitaciones de las actuaciones colectivas chocaban con las necesidades personales de quienes componían el movimiento. En torno a la APDH local, y según pudimos ver, las discusiones y debates se dieron entre los activistas tucumanos que la conformaban, en el marco de sus propias necesidades y disputas que, en no pocas oportunidades, se vieron envueltas en colisión con los criterios de la central de Buenos Aires y que dirigía entonces el ex presidente Raúl Alfonsín.

En los años subsiguientes a la transición, los andamiajes locales jugaron un factor decisivo nuevamente en la conducta del movimiento de derechos humanos, correspondiéndose su permanente movilización entre mediados y fines de los '80 en rechazo a la sanción de las leyes de Obediencia Debida y Punto Final. Las Ilamadas "leyes de impunidad" jugaron en beneficio del ascenso político en la provincia de quien fuera el gobernador de facto al momento de producirse el último golpe militar. Fue así como emergió en 1987 la figura de Antonio Domingo Bussi una vez más, como lo había hecho en diciembre de 1975 al hacerse cargo del Operativo Independencia en reemplazo del General Acdel Vilas. En un contexto absolutamente distint, esta aparición en la escena política local, le permitió a Bussi la creación de un partido político propio, el cual sintetizó el espíritu autoritario del Bussismo como modalidad propiamente tucumana.

Desde esta coyuntura local las organizaciones de derechos humanos centraron entonces sus acciones directas desde 1987 hasta 1999 (e incluso en los años subsiguientes), contra la propia figura de Bussi, su partido Fuerza Republicana y el Bussismo, generándose una 
lucha entre unos y otros que tuvo sus picos de tensión, los cuales pude ubicar temporalmente a lo largo del trabajo. El ascenso y crecimiento del Bussismo le dio al propio Bussi la posibilidad de presentarse como candidato a la gobernación de la provincia en 1991, siendo frenada su llegada a la gobernación por la aparición de un cantante popular como postulante como estratagema de algunos sectores políticos para impedir que el ex militar consiga el triunfo electoral. Ramón Ortega, candidato del peronismo local finalmente le arrebató la elección a Bussi.

En este proceso que continuaría durante la segunda mitad de los '90, se produjo la irrupción de H.I.J.O.S. en 1995, irrupción que planteará nuevas cuestiones, debates y desafíos que se dieron al interior de dicha organización pero que al mismo tiempo contribuyeron a renovar el repertorio de las prácticas de todo el movimiento de derechos humanos, producto de las necesidades con la que estos jóvenes conquistaban la escena pública. Uno de los aspectos centrales en este sentido fue el de la búsqueda de una identidad que respondiera a los interrogantes del quiénes somos, de dónde venimos y hacia dónde caminamos, propio de la consigna que levantaron desde H.I.J.O.S.: "todos somos hijos de una misma historia". Las cuestiones vinculadas a la identidad, como problemática, no se dio en organizaciones como "Familiares" o "Madres" cuyos integrantes no desconocían la militancia de los desaparecidos y que si bien no reivindicaban abiertamente, reconocían como motivo esencial en el secuestro por parte del régimen. Si en el vínculo sanguíneo de los familiares que salieron a buscar a sus desaparecidos se establecieron las primeras pautas organizativas del movimiento, en el caso de H.I.J.O.S. dicho círculo se cerró y la reivindicación de la lucha de los padres desaparecidos, implicó al mismo tiempo posicionamientos que, en lo local, se sintetizaron en consignas tales como "somos de la gloriosa 
juventud tucumana, la del Tucumanazo", que se escuchaba en las manifestaciones de las jóvenes generaciones de militantes. H.I.J.O.S. Tucumán además de distinguirse de las otras organizaciones de familiares de víctimas, se diferenciaron al mismo tiempo de otras regionales del país de la propia agrupación al plantearse organizativamente como "población abierta" y permitir la militancia dentro del colectivo a jóvenes sin vínculos con los represaliados. Nuevamente observamos aquí que no hubo una subordinación de la organización local a principios de tipo nacionales y que en definitiva valió más la experiencia local que la mera imitación de fórmulas venidas de fuera. Incluso, en aquellos problemas medulares que atravesaron al conjunto de las organizaciones por igual, como lo fue la decisión de cobrar o no las indemnizaciones dispuestas por el gobierno nacional en 1994, se resolvió desde la propia experiencia de cada militante y no por un tipo particular de mandato superior.

Retornando al año 1995, pude verificar también, que la nueva candidatura de Bussi, esta vez arribando irremediablemente a la gobernación por medio de los votos populares, hizo que el movimiento de derechos humanos se reagrupara y como acción concreta, en los meses previos a las elecciones provinciales, organizara el Juicio Ético a los fines de exponer a la sociedad quién era el candidato de Fuerza Republicana. El Juicio Ético sin embargo no pudo frenar el triunfo de Bussi quien desde entonces y hasta 1999 ocupó la gobernación, dando comienzo entonces al enfrentamiento directo entre el Bussismo y el movimiento de derechos humanos. Confrontación que tuvo su punto sobresaliente en 1998, año que he definido como el de las memorias enfrentadas tanto en las calles como en los tribunales. Bussi debió afrontar entonces, por un lado, un Juicio Político, producto del descubrimiento de unas cuentas secretas en Suiza, Juicio Político del que salió airadamente indemne; por otro lado la 
acción concreta que H.I.J.O.S. delineó con el llamado escrache, como novedosa manifestación pública, concretado finalmente en octubre de ese año. Aquí vemos que la idea de las memorias enfrentadas, aludida por Elizabeth Jelín, determinó la relación entre el campo de los derechos humanos y el Bussismo en el parlamento, en el palacio de gobierno y en las calles, llevando la pulseada por el recuerdo del pasado a su máxima expresión con acciones directas.

En el proceso de desarrollo de la organización H.I.J.O.S. Tucumán, el campamento nacional llevado a cabo en la provincia, previo al mencionado escrache de 1998, supuso la puesta en juego de una revisión en la construcción identitaria del grupo local, toda vez que se llevó a cabo en un predio universitario donde la lucha sentetista había tenido un capítulo particular con el llamado Quintazo en junio de 1972. Sin proponérselo el campamento nacional y el escrache a Bussi terminó fortaleciendo esa construcción identitaria referida en concreto a la militancia de los padres desaparecidos. Dicha cuestión es imposible de trasladarse al conjunto de la red nacional por lo que observamos nuevamente cómo los clivajes locales jugaron un rol preponderante en la andadura del movimiento local.

Hasta el final del mandato de Bussi al frente de la gobernación en 1999, se produjo un desgaste propio del enfrentamiento entre las dos memorias en pugna por un pasado inconcluso. Dicho deterioro hizo que tanto el Bussismo como las organizaciones derechos humanos entraran en una crisis que desembocaría en nuevas rupturas y reacomodamientos propios de un final de época. Este conjunto de problemáticas que envolvió al movimiento local, se debió a cuestiones meramente particulares que solo pueden explicarse desde el proceso provincial, lo que dio como resultado la emergencia de una experiencia 
reconociblemente tucumana y que llevó a los integrantes de las organizaciones a desarrollar estrategias de acción también propias de acuerdo a sus objetivos.

A lo largo de todo el periodo en estudio, pudimos contemplar también, que los momentos de auge y crisis del movimiento no se debieron a razones externas a los propios militantes, como sí a cuestiones personales y subjetivas, donde la vivencia sobre las implicancias del Bussismo en relación con la política local, hizo que los activistas del movimiento de derechos humanos de Tucumán sintieran como verdaderas derrotas políticas los retrocesos en relación a la revisión del pasado reciente de la provincia. En contra partida los logros del periodo se consolidaron como victorias también políticas, las que dieron impulso a nuevas acciones y repertorios.

Pude además establecer las pautas de las particularidades del caso tucumano a partir de observar las estructuras del sentir, modo en que Raymond Williams llama a las formaciones específicas y que nos impiden entonces ubicar al conjunto de organizaciones locales como parte de un movimiento nacional mayor que estaría subordinado a las actuaciones en la capital del país. En este sentido un amplio conjunto de realizaciones particulares se manifestaron durante todo el lapso de tiempo que desplegaron desde el gobierno militar propiamente hasta la aparición en escena del Bussismo como expresión política local. Toda experiencia de los militantes, traducidas en sus memorias sobre el pasado reciente, está atravesada por ese mismo devenir histórico imposible de ser explicado desde una relación macro-nacional en el que las prácticas locales hayan sido mera imitación de lo actuado en Buenos Aires. Por el contrario, las prácticas locales contribuyeron a complejizar los análisis y a enriquecer un vasto movimiento que se dio también en 
otras regiones periféricas de Argentina como en Rosario, Santa Fe, Córdoba o Neuquén.

La memoria que mana de los testimonios recogidos, indica que la experiencia de los activistas fue un factor determinante para la acción en cada momento histórico, no pudiéndose explicar el proceso político vivido en Tucumán, lejos del derrotero propio vivenciado desde la individualidad y producto de un trauma colectivo que afectó a cada familiar de manera exclusiva. En esas particularidades es que pude situar una historia colectiva desde la última dictadura militar hasta finales de los años '90, que mantuvo como protagonista de una lucha por la imposición de una memoria del pasado reciente a un movimiento que no se permitió nunca el abandono en la búsqueda de la verdad y la justicia por los cauces de la institucionalidad, jamás desde el revanchismo del que fuera objeto de acusación por parte del propio Bussi, como si se tratara de la continuidad de "su propia" guerra iniciada a fines de 1975.

La triple consigna de "memoria, verdad y justicia" guió el accionar de todo el colectivo tucumano y si bien en esto no difirió con lo que sucedió en otras regiones del país, sí se dieron distintas estrategias y prácticas de resistencia a los límites impuestos por los férreos controles de la dictadura en Tucumán con acciones públicas concretas hacia el final del periodo dictatorial, como las rondas alrededor de la plaza principal, con la ritualidad de las marchas del 24 de marzo y 10 de diciembre y con acciones que, siendo menos frecuentes, tuvieron mayor ingenio para desafiar la coyuntura política durante la larga transición vigilada y que todas ellas tuvieron su blanco de ataque a la figura central de Antonio D. Bussi.

La lucha por las memorias enfrentadas, tal como vimos, no se dio solo en oposición al Bussismo y a la narración discursiva sobre la 
interpretación del pasado, sino también al interior mismo del propio movimiento social con periodos de ruptura, de crisis y peleas, natural de toda organización colectiva humana. Estos cambios los pudimos apreciar en las actitudes de algunos militantes que fueron cambiando de organización en la búsqueda permanente por encontrar el espacio más adecuado desde el cual canalizar las demandas. Sin embargo, como reconoció uno de los entrevistados, el espanto ante la llegada de Bussi al poder, fue lo que unió en determinados momentos a todas las organizaciones en acciones concretas y bien definidas, claramente reconocibles dentro de un campo de acción que les era propio. Subordinando lo individual a lo colectivo o a los intereses de la propia organización, dicha actuación conjunta nos permite hablar de un movimiento social en el sentido sociológico del término, con sus formas y expresiones, con sus debates internos y sus conflictos, pero ante todo sobre la base de un horizonte de acción común. Las divisiones internas y discusiones tuvieron siempre su punto de confrontación en el momento de concretar una acción común entre todas las organizaciones, como la elaboración de un documento o el replanteo de las acciones a seguir. $Y$ fue en esas diferencias donde se alojaron las debilidades y fortalezas del movimiento. Los mecanismos y dinamismos propios de todo colectivo demarcó el camino y sus transformaciones. Claro ejemplo de esto fue la introducción de H.I.J.O.S. de nuevas formas de intervención en el ritual no ya desde el dolor sino desde la alegría, como lo reconocen sus militantes, al proponer el desarrollo de las murgas y los bailes en las solemnes marchas del 24, rompiendo con unas formas de acción propias de Familiares y Madres. El espacio de disputa no se dio solo con el Bussismo sino también a partir de planteos interiores del propio movimiento social en estudio. El hecho de plantear miradas distintas hizo que muchas veces las acciones fueran más inútiles y con un menor 
campo de acción; por el contrario, cuando "el espanto les unió", tras la inminente llegada de Bussi al poder, concretaron acciones colectivas de trascendencia aunque no siempre la concreción de los objetivos fuera su resultado, como vimos ante la asunción del ex dictador a la gobernación.

Pero como la memoria subjetiva de los actores sociales forma parte del entramado que propone la historia oral para la reconstrucción del complejo proceso en examen, retomo aquí la idea de Portelli sobre lo que nos ofrece la retro reflexión del testigo: no sólo se desliza aquí lo ocurrido sino también lo que los propios militantes quisieron que ocurriera y lo que creyeron estaba ocurriendo. La memoria, como vimos a lo largo del trabajo, está atravesada en el caso tucumano por el trauma del pasado represivo del cual incluso algunos militantes del propio movimiento se vieron afectados. Sin embargo, las expectativas y las esperanzas se fijaron en la coyuntura abierta en 2003. Entre el pasado que recuerdan los militantes y el presente en el que viven al momento de ser entrevistados, las percepciones individuales reflejan sentimientos colectivos sobre la experiencia vivida. Pasado y presente se conjugan entonces para que los militantes de las organizaciones recuesten sus esperanzas sobre el futuro de ver concretadas las consignas de verdad y justicia. Es justamente en ese cruce donde las estructuras del sentir del movimiento pueden ser detectadas y se convierten en encuadres que le son propios.

Sobre las marcas espaciales, también en Tucumán se fue configurando un modo particular en las disputas de esas memorias. El señalamiento de lo que fueron los Centros Clandestinos de Detención, la colocación de placas rememorativas, la disputa del espacio público al Bussismo, entre otras cuestiones, definieron también lo local como propio y dicha demarcación emanó incluso de los mismos testimonios. Lo 
espacial se configuró entonces en lo particular de ver señalado cada lugar allí donde el horror fue parte de la vida de la sociedad, pero también en aquellos espacios donde la lucha política por la ocupación del espacio público se dio en terrenos propios, como ser la Plaza Independencia, uno de sus principales escenarios de confrontación pero no el único. Un club barrial o un predio universitario sirvieron, para el caso tucumano, de "teatro" de la disputa por el recuerdo de aquello que nunca más debería suceder, más como denuncia sobre quien fue el principal responsable del horror que como intento por la disputa del poder mismo, nunca planteada al interior del movimiento de derechos humanos en los años abordados.

\section{A MODO DE EPÍLOGO}

Al comenzar esta investigación hace aproximadamente siete años, el Movimiento de Derechos Humanos de Tucumán se encontraba en su última etapa de reacomodamientos surgidos después de 2003, cuando la administración Kirchner, y tras varios años de crisis en Argentina, disponía un giro de 180 grados en materia de revisión del pasado. Ante el debilitamiento del conjunto de organizaciones a fines de 1999, el MDHT se enfrentaba al nuevo desafío planteado por la coyuntura política que, entre otros aspectos, promovía un cambio importante en la justicia, la cual anulaba las leyes de Obediencia Debida y Punto Final y permitía reabrir nuevas instancias judiciales contra los represores.

El quiebre de la política estatal en materia de revisión del pasado estuvo dado en un acto público en la Escuela de Mecánica de la Armada en 2004, en la ciudad de Buenos Aires, allí donde justamente había funcionado el principal Centro Clandestino de Detención del país durante la última dictadura. En dicho acto, el entonces presidente Néstor Kirchner 
dispuso descolgar un cuadro de Jorge Rafael Videla, quien había sido el primer presidente de facto de la junta que gobernara Argentina entre 1976 y 1983 . En su discurso inaugurando el espacio de la ESMA como Museo de la Memoria, Kirchner expresaba "que la enseñanza de la historia no encuentra sustento en el odio o en la división en bandos enfrentados del pueblo argentino, sino que por el contrario busca unir a la sociedad tras las banderas de la justicia, la verdad y la memoria en defensa de los derechos humanos, la democracia y el orden republicano (...) $)^{\prime \prime 572}$ Las palabras de Kirchner se habían hecho eco también en Tucumán y repercutían, al menos simbólicamente, en lo que quedaba de las organizaciones de derechos humanos que, ante la nueva coyuntura, planteaba nuevos desafíos. Las palabras del presidente se hacían eco incluso en aquellos activistas ya alejados de la militancia que entendían que se abría una nueva posibilidad de concreción de antiguos objetivos, aquellos por los que habían luchado toda la vida, principalmente los de la verdad y la justicia.

Cuando en septiembre de 2007 comencé a realizar las entrevistas me di con dos realidades distintas: por un lado, la conformación de una nueva configuración del MDHT y por otro, el imaginario que recorría y aún recorre en parte de la sociedad tucumana sobre ese movimiento. Cuando pregunté a históricos militantes acerca de quién me recomendaban para entrevistar, muchos me decían, por ejemplo, que H.I.J.O.S. Tucumán ya no existía y que dentro de Familiares de Desaparecidos de Tucumán, llamado ahora FADETUC ${ }^{573}$, pocos quedaban de la vieja guardia. Sin embargo H.I.J.O.S. existía y Familiares encabezaba tanto las presentaciones judiciales como las protestas, de

\footnotetext{
572 Discurso reproducido en Dutrénit Bielous, Silvia y Varela Petito, Gonzalo (2011): Tramitando el pasado", Clacso, Buenos Aires. P. 321.

573 Por sus siglas: Familiares de Desaparecidos de Tucumán.
} 
acuerdo a lo que se podía observar en la prensa local. Por su parte Madres de Plaza de Mayo había quedado visiblemente diezmada, ya que muchas de sus integrantes habían fallecido o se habían alejado de la organización por diferencias políticas, siendo la cara visible de la organización liderada por Hebe de Bonafini en la filial tucumana, Sara Mrad que junto al grupo de apoyo local seguía militando prácticamente en soledad. Igualmente, volver a entrevistar a Sara me resultaba complejo, pues su testimonio no remitía ya a la organización en Tucumán, como habían sido otros testimonios que ella me había dado años atrás, sino que se referenciaba en la historia de las Madres en Buenos Aires. De repente la historia de Sara en Madres era la historia de las Madres en Buenos Aires y ya no más en Tucumán, siendo una de las frases recurrentes en su testimonio: «Porque nosotras, las madres en Buenos Aires...».

Algo profundo entonces se había modificado también en la percepción de los militantes del MDHT tras las primeras señales que enviaba desde la ESMA el presidente Kirchner. Por su parte, nuevas organizaciones de derechos humanos habían surgido en los últimos años, como ANDHES, una ONG que si bien tiene un campo de acción mucho más amplio en lo que la materia de derechos humanos se refiere, heredaba cierta tradición de la Asociación de Abogados creada allá por 1983. Si bien alguno de los integrantes de ANDHES, entrevistados por mí, habían formado parte de la agrupación H.I.J.O.S., evidentemente aquella militancia ya no les convencía y ahora se encontraban en una agrupación novedosa que se abría paso dentro del movimiento, buscando ser, al mismo tiempo, reconocida como una organización de derechos humanos más. 
De esta manera, comprendía que el MDHT que yo procuraba estudiar era muy distinto de este otro con el que me encontraba en el momento de concretar las entrevistas y que, al mismo tiempo, es hoy muy diferente, dado los avatares de los últimos años, donde los tres juicios por delitos de Lesa Humanidad llevados a cabo en la provincia configuran nuevas expectativas al mismo tiempo que generan novedosas experiencias en el campo estudiado.

Será entonces materia de futuros estudios pensar si esta nueva configuración del movimiento de derechos humanos de Tucumán y sus nuevas estrategias, nos hablan de un movimiento social distinto al que enfrentó al Bussismo durante más de 25 años, o si por el contrario, estamos en presencia de una continuidad del mismo pero con características renovadas.

Lo que queda claro, en todo caso, es que la actual coyuntura política y jurídica del país ha transformado las configuraciones locales tanto del MDHT como de la propia fuerza política del Bussismo y a su partido, Fuerza Republicana, que en las últimas elecciones provinciales, ya sin la figura central de Bussi padre, su mentor, consiguió apenas superar los 25.000 sufragios en dos listas divididas, representadas, cada una de ellas, en los hijos del general ahora fallecido. El fallecimiento de Bussi a fines de 2011 tras una prolongada enfermedad que le impidió ser juzgado en el juicio de Jefatura en 2010 implicó no sólo la desaparición física del máximo responsable de la represión en Tucumán sino que desaparecía también quien había sido el blanco elegido por el movimiento de derechos humanos local para señalar al conjunto social sus demandas de "memoria, verdad y justicia".

Es posible que ahora los militantes de los organismos de derechos humanos de Tucumán estén en condiciones de afirmar que de la derrota 
política de los años '80 y '90, se ha conseguido, gracias a la perseverancia y a las fuerzas de las nuevas generaciones, concretar algunos objetivos específicos: desplazar políticamente a Bussi, sentarlo en el banquillo de los acusados junto a otros responsables del plan sistemático de represión, etc. Pero como en historia no se pueden hacer predicciones futuristas, el tiempo dirá hasta dónde el MDHT ha triunfado en sus históricos objetivos y hasta dónde seguirá transitando, pues resuelta la consigna de juicio y castigo, quedará como objetivo central el de sostener la memoria de lo ocurrido para que "nunca más suceda".

En este mismo lapso de tiempo han comenzado también a ser descubierto algunos cuerpos en fosas comunes en aquellos sitios denunciados históricamente como lugares de destino final de los desaparecidos con lo que otro de los objetivos del movimiento comienza a ser saldado, el del conocer el sitio dónde han sido depositados los detenidos y asesinados del régimen militar. Recordemos que la consigna de aparición con vida había sido abandonada ya en los primeros años de la transición y ante la presunción de muerte de los desaparecidos quedaba la imperiosa necesidad de saber qué habían hecho con sus cuerpos los verdugos, no sólo para poder elaborar un duelo inconcluso sino también para poder demostrar al conjunto social que las denuncias eran ciertas. Las primeras sentencias condenatorias a los responsables de la represión sirvieron de confirmación de aquello sobre lo que las agrupaciones venían denunciando históricamente desde los tiempos mismos de la última dictadura.

Repensar el presente a partir del análisis de la historia de los últimos 40 años en Tucumán, es una apuesta por aprehender mucho más que un objeto de estudio e historizarlo. Por $\mathrm{mi}$ parte, existe la preocupación de aquello que mencionaba cuando citaba a Pablo Dreizik 
sobre que estamos llamados a responder por acciones que no hemos cometido y que tuvieron lugar en un tiempo que no ha sido el nuestro, ${ }^{574}$ y es aquí donde considero que la labor de los historiadores resulta fundamental, no sólo para establecer el principio de verdad, sino, y sobre todo, por contribuir a que la sociedad conozca qué pasó y evitar que nuevamente triunfen, ya sea en elecciones o por otros medios, posiciones claramente autoritarias.

$\mathrm{Si}$ considero al movimiento de derechos humanos en su configuración actual, la misma es muy distinta a aquella que he estudiado. Será materia de futuros estudios el buscar y establecer las nuevas rupturas, diferencias y continuidades con aquel otro movimiento que entre 1977 y 1999 irrumpió en la escena política planteando un serio desafío al Bussismo. En este sentido, el presente trabajo se propone dejar plasmado apenas un capítulo con más interrogantes que respuestas pero estimo que con el valor agregado de aquello que testimonia. Si finalmente el sistema judicial argentino permite dictar sentencia $y$ esclarecer lo ocurrido castigando al mismo tiempo a los responsables de la dictadura, el movimiento habrá visto cumplidas sus históricas demandas y entonces podremos decir que un capítulo de la historia tucumana, abierto el 24 de marzo de 1976, y aún antes, ha sido, por fin, clausurado. De lo contrario, la deuda pendiente seguirá estando impaga hacia quienes fueron las víctimas directas de la represión como así también a sus familiares, pero sobre todo a la sociedad tucumana que, en definitiva, también fue víctima de aquello porque, como sostenía una de las principales consignas de H.I.J.O.S., está claro que en Tucumán, al menos, "todos somos hijos de una misma historia".

574 Dreizik, Pablo M. Op. Cit. 
La propuesta que sigue a la presentación y defensa de la tesis, será la de difundir todo el material documental recolectado que excede ampliamente los plasmado en los anexos y que como fuente servirá a otros historiadores e historiadoras para la continuidad en la investigación del presente campo elegido. Pero también se hará esta difusión con el firme propósito de que todo aquel que lo desee pueda indagar, pueda escuchar de primera mano los testimonios que aquí se recogen y repasar la historia reciente de nuestra provincia que hereda, sin lugar a dudas, los alcances de la represión setentista, pero también la lucha obstinada de la memoria histórica de todo aquello que no debe volver a suceder nunca más.

Tucumán, Mayo de 2013. 


\section{ÍnDICE DE ABREVIATURAS}

- AAA: Triple A o Alianza Anticomunista Argentina.

- APDH: Asamblea Permanente por los Derechos Humanos.

- CIDH: Comisión Interamericana de Derechos Humanos.

- CONADEP: Comisión Nacional sobre la Desaparición de Personas.

- ERP: Ejército Revolucionario del Pueblo.

- ESMA: Escuela de Mecánica de la Armada

- FEDEFAM: Federación Latinoamericana de Asociaciones de Familiares de Detenidos-Desaparecidos

- FFAA: Fuerzas Armadas

- FR: Fuerza Republicana.

- H.I.J.O.S.: Hijos por la Identidad y la Justicia contra el Olvido y el Silencio.

- ICBI: Informe de la Comisión Bicameral Investigadora de las Violaciones de los Derechos Humanos en Tucumán.

- MAS: Movimiento al Socialismo

- MDTH: Movimiento de Derechos Humanos de Tucumán.

- MEDH: Movimiento Ecuménico por los Derechos Humanos.

- OEA: Organización de Estados Americanos

- PEN: Poder Ejecutivo Nacional.

- PI: Partido Intransigente.

- PJ: Partido Justicialista.

- PRN: Proceso de Reorganización Nacional.

- SERPAJ: Servicio de Paz y Justicia.

- UCR: Unión Cívica Radical.

- UNT: Universidad Nacional de Tucumán 
ANEXO 1 EXtRACTO DEL EXPEDIENTE JUDiCIAL CON LA CAUSA SOBRE EL

\section{"Cuerpo de Delegados" de la Facultad de Bioquímica, Química Y}

FARMACIA DE LA UNIVERSIDAD NACIONAL DE TUCUMÁN 575

Merece un título especial el Cuerpo de Delegados de esta Facultad, pues las personas secuestradas que estuvieron en cautiverio en Arsenal Miguel de Azcuénaga, por su participación gremial estudiantil, como delgados de las carreras de Bioquímica, Química y Farmacia, pues constituye prueba acabada sobre el plan de extermino a opositores al régimen, previa tarea de inteligencia y persecución, contra los que realizaban alguna actividad calificada por las fuerzas de Seguridad de "subversiva".

Como lo señalara el Dr. Víctor Alderete, en su declaración ante la Comisión de Derechos Humanos de la U.N.T.: "le manifestaron los secuestradores que la intensión era "limpiar la Universidad".

$\overline{575}$ A modo de ejemplo, sobre el blanco elegido por la dictadura en la represión a la población estudiantil universitaria, mostramos en este anexo un extracto del legajo sobre la presentación judicial acerca de la desaparición de los miembros del "Cuerpo de Delegados de la facultad de Bioquímica". El cuerpo de delegados, como se explicó anteriormente era el órgano de representación estudiantil en las distintas facultades. Hoy el lugar que le cupo al cuerpo de delegados le corresponde a los Ilamados "centros de estudiantes" donde los alumnos eligen a sus representantes siendo distinto de la representación ante la propia universidad como ser el Consejo Directivo de cada facultad y de la propia universidad. Los consejos directivos son el órgano de mayor representación y conforman el claustro universitario. Los centros estudiantiles por su parte se encargan de la resolución de cuestiones vinculadas al estudiantado en lo cotidiano pero no tiene voz ni voto en el consejo. Para éste últimos los estudiantes, como los demás sectores universitarios eligen sus consejeros (claustrales). Lo que se ofrece aquí como prueba en relación al trabajo son los casos de Enrique Sánchez, esposo de Alicia Noli y Juan Carreras, hermano de Felicidad Carreras, ambas desapariciones relacionadas entre sí. El listado completo de los estudiantes desaparecidos en este caso, no solo forman parte del juicio que se lleva a cabo por la mega causa del Arsenal Miguel de Azcuénaga, sino que simbólicamente ha sido uno de los más signficativos en el ámbito universitario, al punto que en el patio de la Facultad de Bioquímica, Química y Farmacia, una placa los recuerda en la consigna sobre "quienes pudieron haber sido sus egresados". 
Esta Comisión constató que: "todos los secuestrados son una prueba fehaciente de que los secuestros no eran al azar, obedecían a un plan de destruir toda organización estudiantil, en este caso sindical".

Ellos son:

CANo, José Antonio: delegado por 3er. Año de la Bioquímica fecha del secuestro 20-02-76, tenía 23 años de edad. Primero estuvo detenido en el centro clandestino de detención ubicado en La Escuela de Educación Física de la UNT, y luego fue trasladado al Arsenal Miguel de Azcuénaga.

Morales, Humberto ReYes: delegado, secuestrado el 14-04-76 y fue llevado a la Escuela de Educación Física y luego fue trasladado a Arsenal Miguel de Azcuénaga.

SÁnCHEZ, EnRIQUe Alberto: delegado de 3er. Año, secuestrado el 14-09-76j y fue visto en Arsenal Miguel de Azcuénaga.

Del Castillo, Julio Arnaldo: delegado, secuestrado el 15-04-76, fue visto en Arsenal Miguel de Azcuénaga

BIANCHI, RAMÓn OSCAR: delegado de 1er. Año de la Carrera de Bioquímica, secuestrado el 15-04-76 y llevado a la Escuela de Educación Física y luego fue trasladado a Arsenal Miguel de Azcuénaga.

CARRERAS, JUAN Francisco: delegado de 3er. año de la carrera de Bioquímica, secuestrado el 16-09-76 al finalizar un examen. Fue visto en Arsenal Miguel de Azcuénaga.

Borda, Nely YolandA ${ }^{576}$ : delegada de50 año de Química, fue secuestrada en Belén, Catamarca el 27-01-77, fue vista en Arsenal Miguel de Azcuénaga.

LERNER, RODOLFO HUGO

Estudiantes liberados

ALDERETE, VÍctor FERnANDo

576 Yolanda Borda, si bien perteneció al Cuerpo de Delegados, fue secuestrada en la localidad catamarqueña de Belén, de donde era oriundo también Juan Carreras. Cabe mencionar que ambos casos resultan inéditos, pues el secuestro de la primera es el único caso registrado en la ciudad de Belén, mientras que el caso de Carreras, como ya se mencionó en el cuerpo del trabajo, es el único caso del secuestro desde dentro de una sede universitaria. 
Corral, Carlos

\section{Los casos de Juan Carreras y Enrique Sánchez}

Causa Comisión Bicameral Legajo No 126-P-84:

Víctima: Carreras, Juan Francisco

Fecha del Hecho: 16 de Setiembre de 1976

Profesión: estudiante de Bioquímica

Hechos: La Sra. Delia Enriqueta Pernasetti de Carreras, madre de la víctima, dijo que se encontraba rindiendo examen de Fisiología, cuando se presentó en la sala un individuo que le preguntó a los examinadores, si allí se encontraba Juan Francisco Carreras, quienes asintieron. Aquel individuo esperó afuera hasta que terminó el examen, y junto a otros (4 o 6) secuestraron a su hijo. Cuando se lo llevaban, se cruzaron con el Profesor Dr. Francisco Barbieri, entonces Juan Francisco Carreras comenzó a pedirle que lo ayudara, pero igual lo introdujeron en un automóvil.

La profesora Elsa Braudkmann vio a los secuestradores rodeando el aula o sala donde se tomaba el examen, además ella habló con uno de ellos. También dijo que, había un auto detenido en la cuadra de la Facultad y en su interior había varias personas, entre las cuales había una muy parecida al estudiante Enrique Sánchez, que había sido secuestrado un día y medio antes. Fue asentada la denuncia en la Comisaría $2^{\mathrm{a}}$ y en la Policía Federal y otros organismos.

Prueba Testimonial: 10) El testimonio del Dr. Francisco Domingo Barbieri, está agregado a fs. 13: "El grupo estaba integrado por unos 4 o 6 individuos, todos vestidos con camperas, menos uno que la tenía en el brazo. Carreras iba en el medio de los desconocidos, no lo agarraban, y cuando se encontraron en la puerta del Instituto de Biología, aquel le gritó pidiendo ayuda. Fue tal su sorpresa e impresión y posiblemente temor, que no atinó a hacer nada; que en la puerta estaban estacionados dos automóviles, uno de ellos quizás se trataba de un Ford Falcon color claro, donde subió Carreras, apenas lo había hecho empezó nuevamente a pedir a gritos que lo auxiliasen. 
$2^{\circ}$ ) El testimonio de la bioquímica Sofía Braudkmann, se encuentra agregado a fs. 16 y 17: "El día 16 de Setiembre de 1976 estaba tomando una prueba escrita a los alumnos entre los que se encontraba Juan Francisco Carreras, cuando se abrió la puerta del local, un hombre preguntó por Carreras; luego de recibir la respuesta procedió a esperar en la terraza, estaba vestido de civil, con campera ligeramente calvo. También comprobó que había dos hombres mas, sentados en la escalera; uno de ellos era alto, cutis blanco, delgado y llevaba campera en la mano como si estuviese ocultando algo. Cuando todos los alumnos salieron -Carreras fue el último en salir- lo hicieron por la puerta que da al Instituto de Bioquímica, y ella lo hizo por la puerta que da a la terraza, de donde se asomó y vio que esos hombres acompañaban a Juan Francisco Carreras.

$\left.3^{\circ}\right)$ El testimonio de Juan Martín está agregado en el Legajo No 440 de la CONADEP, dijo: "haber visto en abril de 1977 en el campo clandestino "El Arsenal" a Juan Francisco Carreras.

40) Prueba Testimonial: Declaración ante la Comisión Investigadora de la U.N.T (Res.No 02408 fecha 4-12-84): de Víctor Fernando Alderete, bioquímico (L.E. No 8.446.818):

"Fue secuestrado y estuvo en cautiverio en Arsenal Miguel de Azcuénaga y Escuela de Educación Física, declaró ante la comisión investigadora de la UNT: "...le manifestaron que la intención era limpiar la Universidad en medio de tormentos físicos y psíquicos... y se lo interrogaba sobre las actividades del cuerpo de delegados y los miembros que lo componían a pesar que los interrogatorios demostraban un conocimiento bastante profundo de las actividades que se desarrollaba el Cuerpo de Delegados. Que compartió el cautiverio con los delegados José Antonio Cano, alumno de 3er año de Bioquímica secuestrado el 20-0276, con Ramón Oscar Bianchi de 1er año secuestrado el 15-04-76, Humberto Reyes Morales secuestrado el 14-04-76, que todos estuvieron en la Escuela de Educación Física y luego en Arsenal Miguel de Azcuénaga".

"Que allí también se encontraba el delegado de $4^{\circ}$ año de Bioquímica Carlos Corral, secuestrado el 18-04-76 y liberado a fines de mayo del mismo año.. que todas estas personas que mencionó fueron 
llevadas allí por sus actividades en el Cuerpo de Delegados, que así le manifestaron los interrogadores y en ese sentido iban dirigidos los interrogatorios".

"Posteriormente, el 29 de Mayo de 1976...un grupo de 14 personas armadas se dirigió al domicilio de Adolfo Pateterlini (liberado), quien fuera delegado por $5^{\circ}$ año de Farmacia...(luego) fueron secuestrados los delegados de $3^{\circ}$ año, Enrique Alberto Sánchez el 14-0976 y Juan Francisco Carreras el 16-09-76... dentro de las dependencias de la Universidad."

El informe dice: "Esta Comisión constató que todos los datos vertidos en esta denuncia coinciden con los presentados ante la CONADEP, la Comisión Bicameral y los Organismos de Derechos Humanos. Los estudiantes Bianchi, Borda, Cano, Carreras, Del Castillo, Morales y Sánchez, secuestrados en menos de un año, son una prueba fehaciente de que los secuestros no eran al azar, obedecían a un plan de destruir toda organización estudiantil".-

$\left.5^{\circ}\right)$ Prueba Testimonial de Lerma, Andrés Héctor Lorenzo, dijo: "En un momento dado, los secuestradores le dijeron: "tenés un amigo a tu lado", le sacaron la bolsa y vio a Juan Carreras al frente de él. Le preguntaron si lo conocía, y respondió que sí, aunque, casi no lo reconoció por que tenía completamente negro alrededor de los ojos. Días después, Juan Carreras le dijo: que le habían prometido soltarlo, y se iba le dejaría su saco. Efectivamente una mañana, sintió en el pecho un cosa que le pegó, era el saco de Juan; se iba. Era un saco gris espigado. Jamás supo de él. Dijo que Juan vivía en Catamarca. Esa mañana lo bañaron, le pusieron otra ropa, le cortaron el pelo y sintió que hablaba con los guardias. Ese procedimiento les hacía a los que los liberaban.

\section{No 46}

Causa Comisión Bicameral Legajo No 201-N-84:

Víctima: Sánchez, Enrique Alberto

Fecha del Hecho: 14 de Setiembre de 1976

Profesión: estudiante de bioquímica 
Hechos: La víctima fue secuestrada de su domicilio en presencia de su esposa, Alicia Noli, quien efectuó la denuncia. Posteriormente, fue saqueada la casa, se llevaron desde el calefón hasta la ropa del bebé. La Sra. María Alicia Noli de Sánchez dijo que varios estudiantes de la Facultad de Bioquímica fueron secuestrados, los que se encontraban vinculados al Cuerpo de Delegados.

Prueba Testimonial: 10) Juan Martín declaró "que Luis Falú le dijo que había estado detenido en Arsenales Miguel de Azcuénaga".

$2^{\circ}$ ) La Sra. María Cristina Rodríguez Román de Fiad, declaró ante la Fiscalía Federal No 1, quien dijo: "Que estuvo detenido en el mismo lugar que ella (Arsenal Miguel de Azcuénaga) ya que, una vez transcurrido el tiempo, empezaron a conocerse y conversar entre sí en los momentos en que no estaba la guardia y los grupos de tareas. Que Enrique hablaba acerca de su esposa Alicia y su bebé y que incluso, el día en que ella fue dejada en libertad, que fue el último momento en que lo vio, Enrique le pidió que se llegase hasta la calle 24 de Setiembre y Catamarca y le haga decir a Alicia, que él estaba bien, y que los quería mucho. Que Enrique estaba muy ilusionado en salir por que no tenía nada que ver con el tema de la subversión."

30) Prueba Testimonial: Declaración ante la Comisión Investigadora de la U.N.T (Res.NO 02408 fecha 4-12-84): de Víctor Fernando Alderete, bioquímico (L.E. No 8.446.818):

"Fue secuestrado y estuvo en cautiverio en Arsenal Miguel de Azcuénaga y Escuela de Educación Física, declaró ante la comisión investigadora de la UNT: "...le manifestaron que la intención era limpiar la Universidad en medio de tormentos físicos y psíquicos... y se lo interrogaba sobre las actividades del cuerpo de delegados y los miembros que lo componían a pesar que los interrogatorios demostraban un conocimiento bastante profundo de las actividades que se desarrollaba el Cuerpo de Delegados. Que compartió el cautiverio con los delegados José Antonio Cano, alumno de 3er año de Bioquímica secuestrado el 20-0276, con Ramón Oscar Bianchi de 1er año secuestrado el 15-04-76, Humberto Reyes Morales secuestrado el 14-04-76, que todos estuvieron en la Escuela de Educación Física y luego en Arsenal Miguel de Azcuénaga". 
"Que allí también se encontraba el delegado de $4^{\circ}$ año de Bioquímica Carlos Corral, secuestrado el 18-04-76 y liberado a fines de mayo del mismo año.. que todas estas personas que mencionó fueron llevadas allí por sus actividades en el Cuerpo de Delegados, que así le manifestaron los interrogadores y en ese sentido iban dirigidos los interrogatorios".

"Posteriormente, el 29 de Mayo de 1976...un grupo de 14 personas armadas se dirigió al domicilio de Adolfo Pateterlini (liberado), quien fuera delegado por $5^{\circ}$ año de Farmacia...(luego) fueron secuestrados los delegados de $3^{\circ}$ año, Enrique Alberto Sánchez el 14-0976 y Juan Francisco Carreras el 16-09-76... dentro de las dependencias de la Universidad."

El informe dice: "Esta Comisión constató que todos los datos vertidos en esta denuncia coinciden con los presentados ante la CONADEP, la Comisión Bicameral y los Organismos de Derechos Humanos. Los estudiantes Bianchi, Borda, Cano, Carreras, Del Castillo, Morales y Sánchez, secuestrados en menos de un año, son una prueba fehaciente de que los secuestros no eran al azar, obedecían a un plan de destruir toda organización estudiantil". 


\title{
Anexo 2 Reproducción del documento elaborado por la Red Nacional De H.I.J.O.S. el 17 de agosto de 1998 en la CiUdad de La Plata
}

\author{
$10^{\circ}$ ENCUENTRO NACIONAL DE DELEGADOS
}

A los compañeros:

En el marco del Xo Encuentro Nacional de Delegados de H.I.J.O.S. (H.I.J.O.S. por la Identidad y la Justicia contra el Olvido y el Silencio), las regionales presentes a través de sus respectivos compañeros:

- BAHIA BANCA: Facundo Vasquez

- CAPITAL FEDERAL: Verónica Lara - Facundo Martínez

- CORDOBA: Agustín Di Toffino - Sebastián Soulier

- LA PLATA: Daniel Bellingeri - Juan Pedro Váldez

- MENDOZA: Alba Vega

- TUCUMÁN: Josefina Centurión - Susana Salvatierra

- ZONA SUR - GRAN BUENOS AIRES: Pablo Blasco - Ernesto Darío Boris

Con el objetivo de cumplir con el temario propuesto nos reunimos los días 15, 16 y 17 de agosto llegamos a los siguientes acuerdos:

- Realizar el CONGRESO NACIONAL en la provincia de Tucumán los días 10,11 y 12 de octubre del corriente año. Fundamos esta decisión en el hecho de que las circunstancias políticas de esta provincia con la institucionalización del fascismo a través de un partido político, "Fuerza Republicana", expresada en el proyecto hegemónico del genocida Antonio Domingo Bussi (actual gobernador provincial) generan la necesidad de la realización de una abierta denuncia y repudio desde el conjunto de los miembros de la Red Nacional.

- Comprometerse con el mayor espíritu militante a realizar el esfuerzo necesario para organizar este congreso que evidentemente nos fortalecerá como Red Nacional. Para ello se hace imprescindible el hacer una campaña financiera de envergadura que logre reunir los fondos necesarios para tal fin. 
A partir del día de la fecha hasta el 29 del corriente mes comenzar la campaña financiera de acuerdo a las posibilidades de cada regional. Resaltamos que la principal fuente de recursos para la realización del Congreso es responsabilidad del trabajo de base de cada regional (venta de periódicos, fiestas, donaciones, etc.)

Asimismo en este encuentro se redactó una carta que será enviada a los diferentes organismos nacionales e internacionales solicitando los fondos necesarios para la realización del Congreso (ONG, sindicatos, Centros de Estudiantes, etc.).

El día 29 de agosto nos comunicaremos para evaluar los recursos efectivos al momento y los recursos a obtener por medio de préstamos y compromisos futuros.

- La regional TUCUMÁN centralizará la información (...) 
Anexo 3 Transcripción del Panfleto entregado por H.I.J.O.S. DURANTE EL ESCRACHE A BUSSI EN OCTUBRE DE 1998

\section{Escrache a Bussi}

Organizado por H.I.J.O.S. red nacional en Tucumán, tras el campamento realizado en la provincia.

Volante de H.I.J.O.S.: Lunes 12 de Octubre de 1998

Profesión: ASESINO, TORTURADOR, MENTIROSO Y LADRÓN

\section{Cargos que le permitieron abusar del poder:}

- Jefe de la subzona 32 que abarcaba a la provincia de Tucumán.

- Gobernador de la provincia bajo la dictadura militar

- Comandante del III Cuerpo del Ejército y jefe de la zona 3 por lo que fue el máximo responsable de los crímenes cometidos en el marco del terrorismo de estado.

- Actual gobernador de la provincia.

\section{Responsable de:}

- 306 causas por desaparición y tortura denunciadas y probadas.

- Más de 14 Centros Clandestinos de Detención a su cargo.

- Desaparición y Robo de menores.

- Por haber sido oficial del ejército, responsable de a Zona 1, deberá declarar sobre el destino final de los desaparecidos en los Tribunales de esa jurisdicción

\section{Durante su gestión:}

- Quiso implementar el uso de comida deshidratada en los comedores escolares.

- La provincia aumentó considerablemente su deuda por la agudización de los préstamos.

- Utiliza "Cheques diferidos" para el pago de salarios

- Se suscribió al plan menemista del "Canal Federal", que quitaría el agua destinada a los riegos. 
- Se descubrió que posee una abultada cuenta en Suiza que se presume conformada con fondos de "Botín de Guerra".

- Se le inició Juicio político por: Enriquecimiento ilícito, evasión fiscal, falseamiento de documentos públicos, falta a los deberes de funcionario público.

\section{Comunicado:}

La Agrupación H.I.J.O.S. comunica que el 12 de octubre del corriente año ${ }^{577}$ a $11 \mathrm{hs}$, en avenida Roca y Buenos Aires se llevará a cabo la concentración que dará inicio a la "Marcha - Escrache" a Bussi y los represores cómplices que actualmente viven en la provincia amparados por el marco de impunidad que les da las leyes de Obediencia Debida, Punto Final y los Indultos presidenciales.

Esta actividad encarada por H.I.J.O.S. de todo el país, es una de las formas de denuncia que proponemos ante la falta de justicia verdadera por parte del gobierno.

Consideramos que procurar la condena social a los genocidas es el método que nos queda ante el incumplimiento de una condena legal, ya que rechazamos cualquier metodología violenta de venganza o justicia por mano propia (lo que se evidencia en nuestra trayectoria y la de cualquier otro organismo de Derechos Humanos) así como la propuesta absurda de una "Reconciliación Nacional" que nos obliga a convivir con los criminales responsables del Terrorismo de estado sobre la basa de la no justicia, el olvido, el silencio y el ocultamiento de la verdad.

Creemos que la democracia no se puede construir sobre la impunidad, pero también advertimos que esta ilegalidad (que viola los pactos internacionales de Derechos Humanos firmados por Argentina y por lo tanto de jerarquía constitucional), no se mantiene por capricho o ingenuidad. Hay una lógica para que esto se mantenga: el gobierno militar de la dictadura y el de Menem y Bussi tienen en común el mismo proyecto económico de exclusión y por lo tanto el mismo aparato represivo que defiende estos objetivos.

$\overline{577} 12$ de octubre de 1998. 
Convocamos a la sociedad en general a sumarse a nuestra propuesta que considera que la movilización popular y los proyectos que surgen del pueblo y con el pueblo, son los que podrían fortalecer la democracia llevando a cabo los cambios profundos que necesita incluirnos a todos. 
AneXo 4 EXtracto del debate PARLAMENTARIO Del PRIMERO De Diciembre DE 1999 QUe tRató en Cámara de Diputados la impugnaCión deL DIPLOMA DE ANTONIO DOMINGo BUSSI Y QUE FINALMENTE LE IMPIDIÓ ASUMIR COMO LEGISLADOR NACIONAL ${ }^{578}$

Palabras del diputado socialista Alfredo Bravo.

Sr. PRESIDENTE (Juri).- Tiene la palabra el señor diputado por la Capital.

Sr. BRAVO.- Señor presidente: en ocasiones la vida nos pone ante circunstancias ineludibles; esto es lo que hoy le ocurre a esta Honorable Cámara, que enfrenta el inevitable destino de pasar a la historia del Poder Legislativo. Este pasaje lo realizará con dignidad o con oprobio, de acuerdo con lo que decida respecto a la incorporación de un diputado electo cuyo diploma venimos a impugnar.

En ese sentido, quiero alertar a la Honorable Cámara sobre la situación que se podría presentar si el diputado electo que impugnamos llegase a prestar juramento. En ese momento se estaría incorporando a este seno al impugnado, que sigue cometiendo el delito permanente de desaparición forzada de personas.

Por lo tanto, para evitar que se produzca un hecho bochornoso atentatorio contra la dignidad de esta Honorable Cámara, impugnamos la incorporación a este cuerpo del diputado electo por la provincia de Tucumán, Antonio Domingo Bussi. (Aplausos.)

Asimismo, solicito que se suspenda su juramento hasta que en una sesión ordinaria el cuerpo se expida sobre el requisito de idoneidad moral que se requiere para integrar la Honorable Cámara de Diputados de la Nación.

578 Léase en este mismo sentido la nota firmada por Felipe Yapur del 2 de diciembre de 1999 aparecida en Página 12 bajo el título: "El único que lo defendió fue su hijo". http://www.pagina12.com.ar/1999/99-12/99-12-02/pag03.htm [Última consulta: 10 de marzo de 2011) Asimismo consúltese la resolución de la Corte Suprema de Justicia de la Nación: http://www.derhuman.jus.gov.ar/pdfs/fallobussi.pdf 
La Constitución Nacional otorga a las Cámaras legislativas la facultad de sancionar a sus miembros, ya que el artículo 64 de la Carta Magna les reconoce la condición de jueces para expedirse sobre la validez de las elecciones, derechos y títulos de sus integrantes.

Además, el artículo 66 de la Constitución establece que cada Cámara hará su reglamento y podrá corregir a cualquiera de sus miembros por desorden de conducta en el ejercicio de sus funciones, 0 removerlos por inhabilidad física $o$ moral sobreviniente a su incorporación, y hasta excluirlo de su seno.

El tema de la inhabilidad moral es un concepto sobre el que mucho se ha escrito. La mayoría de los hombres de derecho que abordaron el tema la relacionan con lacarencia de dignidad, es decir, con la condición de quien comete o tolera actos vergonzosos o humillantes.

En 1991 la Honorable Cámara de Diputados de la Nación analizó y debatió el comportamiento de uno de sus miembros: Luis Angel Luque, quien había hecho pública su inhabilidad moral al jactarse en declaraciones periodísticas de su presunto poder para hacer desaparecer el cuerpo de la joven asesinada María Soledad Morales, y luego negar en el recinto, de manera mendaz, que hubiese formulado tales declaraciones.

Ante estas actitudes la Cámara lo consideró indigno de seguir formando parte de ella y lo excluyó de su seno. La decisión fue una muestra de salud institucional de parte de la Cámara. Con ella los diputados enviaron un mensaje positivo a la sociedad; se negaron a mantener como par a quien exhibiera su incapacidad para comprender que provocar la desaparición del cadáver de un ser humano y mentir son expresiones de lo malo, de lo opuesto a la moral pública.

Cuando la Constitución otorga a las Cámaras la potestad para separar de ellas a quienes manifiesten inhabilidad moral, reconoce que tal condición es un impedimento para integrarlas y en consecuencia para incorporarse a ellas. Las Cámaras Legislativas son instituciones de la Nación Argentina, y como tales tienen por ley fundamental a la Constitución Nacional. Precisamente, uno de los artículos de la Constitución, el 16, dice que todos los habitantes de la Nación son admisibles en los empleos sin otra condición que la idoneidad. 
Quiero citar un ejemplo de inhabilidad. En la Ciudad Autónoma de Buenos Aires sólo son idóneos para ejercer la docencia quienes reúnan ciertas condiciones, entre ellas sustentar los principios establecidos por la Constitución Nacional, inculcar a sus alumnos el respeto por los derechos humanos y el sentido de justicia, y también observar una conducta acorde con los principios de la moral. De este modo, no podría ser docente quien negase el derecho a la vida que tienen todas las personas, ni quien con cualquier excusa aceptase el genocidio o la tortura, ya que en ambos casos violaría principios que la Constitución Nacional consagra a través de los tratados internacionales, que afortunadamente fueron incorporados en la Constitución en 1994.

Asimismo, el docente estaría expuesto a la cesantía o exoneración si ejerciendo su cargo observase una conducta no acorde con la moral, como es el hecho de mentir, especialmente si con esa mentira lesiona a su institución educativa o al sistema en su conjunto.

$\mathrm{Si}$ estas son condiciones exigibles para acceder o mantener la condición de docente, consideramos que lo son mucho más para ocupar una banca en la Cámara de Diputados de la Nación como representante del pueblo. Al ser esta Cámara una institución de la democracia creada por la Constitución Nacional, debería al menos requerir a quienes deban incorporarse a la tarea legislativa un compromiso con esa democracia y con los principios constitucionales, como así también el ejercicio de una conducta acorde y comprobable antes y durante su mandato.

Luego de una etapa en que las instituciones de la República sufrieron un permanente bastardeo que las desprestigió ante la ciudadanía, y después de que el veredicto popular del 24 de octubre evidenció que esa ciudadanía reclamaba instituciones cuidadosas de su decoro, venimos hoy a requerir de esta Cámara que asuma la decisión política de responder a esa demanda y rechace el diploma de un diputado electo cuyos antecedentes antidemocráticos y su conducta lo hacen indigno de integrar este cuerpo.

Nos referimos a Antonio Domingo Bussi, responsable de la detención y desaparición forzada de centenares de personas, de haber cometido el delito de reivindicar el terrorismo de Estado y el de falsedad ideológica en el propio ámbito de esta Cámara, a la que intenta regresar. 
En efecto, Bussi es responsable de la detención y desaparición de centenares de personas. Entre diciembre de 1975 y diciembre de 1977 comandó la Brigada de Infantería $\mathrm{V}$ con asiento en Tucumán, y con jurisdicción en esa provincia y en las de Salta y Jujuy, que constituían la Subzona 32 del Tercer Cuerpo de Ejército. Sustituyó en el cargo al general Acdel Edgardo Vilas, quien cumpliendo órdenes emanadas del Poder Ejecutivo nacional a través de los decretos 256 y 260 -éste es de carácter secreto- había anulado en su capacidad de combate y prácticamente extinguido a la compañía de monte Ramón Rosa Giménez del Ejército Revolucionario del Pueblo, que según un documento que el propio Ejército atribuyó al ERP, contaba con treinta y cinco efectivos.

La asunción de Bussi se produjo cuando estaba en marcha el golpe de Estado del 24 de marzo de 1976, y en abril de ese año sumó a su cargo militar el de interventor de la provincia de Tucumán. Ambas posiciones lo transformaron en responsable de todos los centros clandestinos de detención que funcionaron en su jurisdicción y del control operativo de las fuerzas armadas y de seguridad, como comandante de la Subzona 32. Fue responsable de los centros clandestinos de detención que funcionaron en la Jefatura de Policía de Tucumán y en la Penitenciaría de Villa Urquiza, Sección E, como interventor y/o gobernador de facto de Tucumán.

En los dos años que estamos considerando se produjeron en la jurisdicción que política y militarmente controlaba Bussi la detención y desaparición forzada de 590 personas. En poder de la Secretaría existen cinco anexos con la presentación de la impugnación, donde se detallan los nombres de las personas detenidas y desaparecidas, la fecha en que ellas se produjeron y la zona y el momento en que actuaba Antonio Domingo Bussi. Esas 590 personas representan a un equivalente de un detenido desaparecido cada treinta horas.

Entre enero de 1978 y enero de 1979 fue segundo comandante y jefe del Estado Mayor del Comando de Institutos Militares. Ejerciendo tales cargos se produjo la detención y desaparición forzada de setenta y siete personas, un número que representa en promedio a más de cinco desapariciones mensuales. 
Entre febrero y diciembre de 1980 Bussi comandó el Tercer Cuerpo de Ejército, que abarcaba a las provincias de Córdoba, San Luis, Mendoza, San Juan, La Rioja, Catamarca, Santiago del Estero, Tucumán, Salta y Jujuy.

Sr. PRESIDENTE (Juri).- Señor diputado Bravo: han transcurrido los quince minutos de que se dispone, por lo que le ruego que redondee su exposición.

Sr. BRAVO.- Con mucho gusto, señor presidente. Esta es una sesión en la que estamos hablando de un diputado electo y recordando una historia que los argentinos no debemos olvidar: la que ocurrió durante ese período. (Aplausos.)

Esta exposición se centra, tiene su meollo y esencia, en algo que representa para los argentinos un objetivo que debemos tener presente permanentemente.

Como balance de todo esto -y lo que omito en honor al pedido que me ha hecho el señor presidente- digamos que entre diciembre de 1975 e igual mes de 1981 se produjeron 680 desapariciones forzadas de personas en jurisdicción comandada por Bussi. Aquí viene la esencia de la impugnación, por lo menos de una parte, porque otros pares van a hablar sobre diversos aspectos de la actitud y el perfil de Antonio Domingo Bussi. Al respecto cabe recordar que en diciembre de 1992 las Naciones Unidas aprobaron una declaración en la que taxativamente se consideraba que la desaparición forzada de personas es un delito que no prescribe y que se repite permanentemente. Del mismo modo caracteriza a este delito la Convención Interamericana sobre Desaparición Forzada de Personas suscripta por la República Argentina, ratificada por el Congreso Nacional e incorporada al texto de la Constitución Nacional. Más recientemente la Cámara Federal en lo Criminal y Correccional de la Capital Federal consideró que el delito de desaparición forzada de personas cometido por el Estado es de carácter permanente y no admite prescripción, pues se sigue cometiendo mientras no aparece la víctima. Igual criterio sostuvo la Procuración General de la Nación.

Por estas razones decíamos al principio que, si Bussi se incorporara a esta Cámara, se daría la inconcebible situación de que un 
cuerpo legislativo estaría admitiendo a uno de sus miembros en el preciso instante en el que está cometiendo ese delito.

En mérito al pedido que se me ha formulado no me extenderé en la exposición haciendo referencia a las 814 causas sobre homicidios, tormentos, privaciones ilegítimas de la libertad y falsificación documental. Tampoco voy a hablar de ese fallo lamentable de la Corte Suprema de Justicia después de la controversia entre la Cámara Federal de Tucumán y la Cámara Federal de Córdoba donde, por una interpretación formal de la prescripción del término en que debían ser enjuiciados, a raíz de la ley de punto final resultaron absueltos Benjamín Menéndez y Antonio Domingo Bussi. Y tampoco me referiré a la forma en que reivindicó permanentemente al terrorismo de Estado. Solamente voy a decir algo que es muy caro para todos nosotros, porque resolver esta situación entraña -como dije anteriormente- pasar a la historia, ya sea porque ratificamos la posición de rechazo del diploma del diputado electo o por el oprobio de conceder su permanencia en esta Cámara.

Por ello, señor presidente y señores diputados, en nombre de la Constitución de la Nación Argentina, de la justicia universal, del "nunca más", de los treinta mil detenidos desaparecidos que hoy no tienen voz, y de la propia dignidad de esta Cámara y de sus integrantes, solicito a mis pares que rechacen el diploma del diputado electo Antonio Domingo Bussi. (Aplausos en las bancas y en las galerías. Varios señores diputados rodean y felicitan al orador.) 


\section{ANeXo 5 EXtRACTOS de La IMPUgnación de LA CANDIDATURA A INTENDENTE de San Miguel de Tucumán de Antonio D. Bussi por parte de ORGANISMOS DE DERECHOS HUMANOS ${ }^{579}$}

\section{4 de Mayo de 2003}

Sr. Presidente de la Junta Electoral de la Pcia. de Tucumán.

Gabriel Pereira, representante legal de la fundación de Abogados y Abogadas del Noroeste Argentino en Derechos Humanos y Estudios Sociales (ANDHES), Atilio Castagnaro, representante legal de la Asamblea Permanente por los Derechos Humanos-delegación Tucumán (APDH), en nombre y representación de APDH Central-Buenos Aires y por derecho propio en el carácter de ciudadanos habilitados para participar de las próximas elecciones para Intendente de San Miguel de Tucumán; junto a Horacio Verbitsky, presidente del Centro de Estudios Legales y Sociales (CELS), constituyendo todos domicilio legal en Av. 24 de Septiembre $N^{\circ} 1021,3^{\circ}$ piso, oficina " $A^{\prime}$ de esta ciudad, nos presentamos respetuosamente y decimos:

\section{Legitimación}

Como se acredita con copia certificada de la resolución No 436/02 de la Dirección de Personas Jurídicas de Tucumán y con copia certificada del estatuto social, Gabriel Pereira ha sido designado Presidente del Consejo de Administración de ANDHES, y en tal calidad ejerce la representación legal de dicha entidad; como se acredita en copia fiel del poder general, que adjuntamos y cuya validez y vigencia declaramos, Atilio Castagnaro es Apoderado de la APDH Central-Buenos Aires a los fines de esta presentación; por su lado, Horacio Verbitsky es Presidente del CELS, y en tal calidad ejerce la representación legal de dicha entidad, tal como se acredita con copia certificada del estatuto social y del acta de reunión de la Comisión Directiva de dicho organismo.

(...)

\footnotetext{
579 Véase el

documento

completo

en

http://www.derechos.org/nizkor/arg/doc/andhes1.html [Consultado por última vez en Marzo de 2011].
} 


\section{Objeto}

Que en debido tiempo y forma venimos a plantear formal impugnación a la candidatura oficial para intendente de la Municipalidad de San Miguel de Tucumán del general retirado ANTONIO DOMINGO BUSSI del partido político "Fuerza Republicana". Fundamos esta impugnación en la causal de falta de idoneidad del antes mencionado --en el caso, idoneidad ética-moral-- requisito sustancial exigido por el artículo 16 de la Constitución Nacional (CN) como única condición para acceder a cualquier tipo de cargo público. Motiva esta causal, la participación y responsabilidad del impugnado en las graves violaciones a los derechos humanos cometidas en Argentina durante el período 19751983, todo en concordancia con lo dispuesto por los artículos 36 y 75 inc. $22 \mathrm{CN}$ y los instrumentos internacionales de derechos humanos y de conformidad con las razones de hecho y de derecho que a continuación pasamos a exponer.

\section{Hechos}

Para una mayor comprensión, hemos dividido el relato de los hechos en tres partes: en la primera haremos referencia a la situación de la República Argentina, antes y durante el golpe militar de 1976; en la segunda, a lo acontecido en la provincia de Tucumán en igual período de tiempo. Finalmente destinaremos la tercera parte de este acápite a la actuación de Antonio Domingo Bussi en la misma época referida anteriormente, como así también se destacarán algunos hechos ocurridos en democracia.

\section{ARGENTINA ENTRE LOS AÑOS 1975-1983.}

\subsection{Los años previos al golpe militar del '76.}

Durante la primera mitad de la década del setenta --en especial a partir del año '75-- sucedieron en nuestro país una serie de acontecimientos políticos y sociales que impulsaron a determinado sector de la extrema derecha argentina a confabular un plan criminal tendiente a aplicar, en pos de la ideología "occidental y cristiana", la Doctrina de la Seguridad Nacional. Es así que los responsables militares de las Fuerzas Armadas (FFAA), con la ayuda de las fuerzas policiales, los servicios de Inteligencia y el apoyo de grupos de civiles, tomaron la decisión de 
derrocar a la presidenta constitucional María Estela Martínez de Perón. La toma del poder será, en definitiva, la puerta que abrió el desarrollo a gran escala del plan de eliminación y desaparición sistemática de personas de diferentes bloques de población, con el fin último de imponer la propia ideología de estos grupos.

La debilidad e inestabilidad del gobierno constitucional de esa época permitieron que los militares dirigieran la situación nacional, dando cobertura "legal" a la represión ya iniciada. En ese sentido, la mencionada represión legalmente comenzó con el dictado del Decreto $\mathrm{N}^{\circ}$ $261 / 75$, del 5 de febrero de 1975, en el que se estableció una estructura funcional para todos los organismos de inteligencia y por el que se autorizó al Ejército a ejecutar las operaciones necesarias para neutralizar y/o aniquilar el accionar de los elementos subversivos que actuaban en la provincia de Tucumán. Asimismo, también determinó este inicio, la Orden secreta del 5 de febrero del mismo año del General Jorge Rafael Videla, en la que se dió luz verde a las operaciones de represión en esa provincia y al Ilamado "Operativo Independencia", que comenzó a ejecutarse como tal a partir del 9 de febrero de 1975. Será esta "Operación" la que formalmente dará el inicio de lo que un año después desembocará en el peor golpe militar sufrido en la historia argentina.

El golpe militar en virtud del cual se instauró el llamado Proceso de Reorganización Nacional, fue elaborado minuciosamente con antelación y en complicidad con diferentes sectores de la sociedad. Es así que las graves violaciones a los derechos humanos que se perpetraron a partir de entonces serán parte esencial de ese plan, y nada quedará librado al azar: cada una de las persecuciones, asesinatos, detenciones ilegales, desapariciones forzadas, apropiaciones de niños, torturas y demás delitos cometidos por miembros de las FFAA, de seguridad, organismos de inteligencia y colaboradores civiles no serán más que la concreción del mismo.

\subsection{El golpe militar de 1976.}

El 24 de marzo de 1976 se produjo el golpe de Estado que se extendió hasta fines de 1983. En ese período, las FFAA usurparon ilegalmente el gobierno y pusieron en marcha el llamado "Proceso de Reorganización Nacional" y la denominada "Lucha contra la subversión" 
cuya finalidad no fue otra que la destrucción sistemática de personas que se opusieran a ese régimen.

Es así que la coordinación y jerarquía de la represión violenta pasó a estar directamente en manos de las Fuerzas Armadas, a quienes correspondió la última decisión sobre el destino de las personas que se consideraron contrarias a la ideología que se buscaba imponer.

Desde esa fecha se produjo un exterminio masivo de ciudadanos/as y se impuso un régimen de terror generalizado a través de la muerte, el secuestro, la desaparición forzada de personas y las torturas inferidas con métodos "científicos", reducción a servidumbre, apropiación, ocultamiento y sustitución de identidad de niños, de los que son víctimas decenas de miles de personas en todo el país. Tal proceder implicó la derogación de las normas constitucionales y legales en vigor y la implementación de planes aprobados y ordenados a sus respectivas fuerzas por los comandantes militares. Las disposiciones de las Juntas Militares se tradujeron en la implantación de un organigrama de grupos de tareas, organizaciones y bandas armadas, que subvirtiendo el orden constitucional y alterando gravemente la paz pública, cometieron una cadena de hechos delictivos que desembocaron en una feroz represión.

Con este sentido, las FFAA dividieron al país geográficamente en seis zonas militares, dentro de las cuales se habilitaron dependencias militares y civiles que a lo largo de la dictadura llegaron a configurar un número aproximado de 340 centros clandestinos de detención (CCD), en los cuales se alojaron a miles de personas cuya eliminación, en la mayoría de los casos, ya estaba prevista.

En todas las zonas, y de acuerdo con las directivas emanadas de los altos mandos militares, se procedió al secuestro y detención ilegales de aproximadamente 30.000 personas; a la práctica sistemática de tortura; al abuso sexual; al trato cruel, inhumano y degradante; al exterminio generalizado; al enterramiento en fosas comunes; al lanzamiento de detenidos desde aeronaves --conocidos como "vuelos de la muerte"--; a la cremación y desaparición de los cuerpos; y, por último, a la sustracción, ocultamiento y sustitución de identidad de cientos de niños arrebatados a sus madres al ser detenidas-desaparecidas --como "botín de guerra"--, entre otros delitos. 
Estas violaciones a los derechos humanos no fueron acciones aisladas e inconexas. Ni siquiera una pluralidad de acciones meramente coincidentes en el tiempo. Absolutamente todas fueron consecuencia de una acción coordinada y planificada hasta en sus más mínimos detalles contra una gran parte de los habitantes de nuestro país.

Es a partir de este tremendo plan de exterminio que en la Argentina se violaron derechos humanos fundamentales de decenas de miles de personas, tales como el derecho a la vida, la libertad personal, seguridad e integridad personal, al acceso a la justicia, derechos todos garantizados por nuestra Constitución Nacional, la Declaración Americana de Derechos y Deberes del Hombre y por la Convención Americana sobre Derechos Humanos, violación que ha generado la responsabilidad internacional del Estado argentino.

\section{Lo acontecido en Tucumán}

Previo al golpe militar de 1976, y tal como ya lo señaláramos, el "Operativo Independencia" se había desatado en Tucumán. Su accionar represivo estaba a cargo del general Acdel Edgardo Vilas quien, en cumplimiento de las funciones encomendadas y aún antes de asumir Antonio Domingo Bussi como interventor de Tucumán --abril de 1976--, ya había anulado en su capacidad de combate y prácticamente extinguido a la Compañía de Monte "Ramón Rosa Jiménez", del Ejército Revolucionario del Pueblo (ERP), que operó en la zona selvática de Tucumán con un contingente compuesto, conforme a un documento que el propio Ejército atribuye al ERP, por 35 efectivos y que, de acuerdo con lo estimado por la Jefatura de Inteligencia del Estado Mayor General del Ejército, estaba integrado por un número que variaba entre 120 y 160 personas.

A partir del 24 de marzo de 1976 que el plan represivo se incrementó en forma alarmante en la provincia, llegando a su punto más álgido durante el mandato de Bussi.

Dentro del esquema represivo del '76, Tucumán se identificó como la Sub-zona 32-Área 312, comprendida en la $3^{a}$ Zona y bajo jurisdicción del III Cuerpo del Ejército, con sede en la provincia de Córdoba. 
Al frente de las actividades represivas en la provincia de Tucumán se encontraba el Comando de Subzona 32 a cargo de la $V^{\circ}$ Brigada de Infantería del Ejército dirigida por el General Antonio Domingo Bussi desde diciembre de 1975 a diciembre de 1977, y por el General Luis Santiago Martella, desde diciembre de 1977.

En la Subzona 32 funcionaron, bajo el mando del jefe de la $5^{a}$ Brigada del Ejercito, no menos de 18 Centros Clandestinos de Detención (C.C.D.): 15 de ellos correspondieron a la provincia de Tucumán (área 321), y 3 a la provincia de Jujuy (área 323).

Los C.C.D que dependían del Regimiento de Infantería del Ejército, bajo responsabilidad de Bussi en tanto interventor-gobernador eran:

Jefatura Central de Policía Tucumán, San Miguel de Tucumán: funcionó entre 1974 y agosto de 1978. Estuvo a cargo, en distintas épocas, de los Tenientes Coroneles Arrechea y Zimmerman, Teniente $1^{\circ}$ Félix González Naya e Inspector Roberto Heriberto Albornoz.

Cuartel de Bomberos, San Miguel de Tucumán.

Comando Radioeléctrico de la Policía de Tucumán, San Miguel de Tucumán.

Escuela de Educación Física, San Miguel de Tucumán: funcionó entre marzo y mayo de 1976.

"EI Reformatorio", barrio El Palomar, de San Miguel de Tucumán.

Escuela "República del Perú", San Miguel de Tucumán.

"Sección E" de la Penitenciaria de Villa Urquiza, San Miguel de Tucumán: funcionó durante 1976.

"El Motel" frente al predio de la Compañía de Arsenales Vo "Miguel de Azcuénaga", Ruta nacional Nº 9.

"El Arsenal", ubicado en el predio de la Compañía de Arsenales Vo "Miguel de Azcuénaga", Ruta Nacional 9, Km 1307 - San Miguel de Tucumán: funcionó entre marzo de 1976 y mayo de 1977, aproximadamente.

Los CCD que dependían directamente de Antonio Domingo Bussi, en tanto comandante de la Subzona 32, entre diciembre del año '75 y diciembre del año 77 fueron los siguientes: 
Ex Ingenio Lules, Ingenio Lules: funcionó entre febrero de 1975 y mayo de 1976 en la localidad de Famaillá.

Conventillos de Fronterita, en Ingenio Fronterita (Famaillá).

Escuela "Diego de Rojas" ó "Escuelita de Famaillá" Famaillá. Sus responsables fueron: General Acdel Edgardo Vilas y el primer Alferez Montes de Oca, "SOWINSKI".

Ingenio Nueva Baviera (Famaillá): funcionó de marzo de 1976 a agosto de 1977. A su cargo estuvo el cabo de la policía tucumana Héctor Domingo Calderón, bajo mando directo de Antonio Arrechea.

Ingenio Bella Vista (Famaillá).

Comisaría de Monteros.

Los tres restantes CCD funcionaron en la provincia de Jujuy:

Jefatura de Policía de Jujuy.

Penitenciaria Villa Gorriti.

Escuela de Policía ubicada en la Ruta Nacional No 9, "Guerrero".

Durante la dictadura militar, en Tucumán, se encuentran registradas judicialmente como desaparecidas más de 600 personas, estimándose que en toda la provincia el número real de víctimas sería más de 2.000 .

\section{Antecedentes de Antonio Domingo Bussi}

\subsection{Bussi ocupa altos cargos militares. "Represor y} Genocida"

A Tucumán le cupo el triste y doloroso papel de ser el primer campo de experimentación de aberrantes técnicas represivas aplicadas por jefes militares y policiales.

En este marco, es importante señalar como ineludible punto de partida la participación de Antonio Domingo Bussi y su responsabilidad en la detención ilegal y desaparición forzada de centenares de argentinos. A saber:

Entre diciembre de 1975 y diciembre de 1977 el por entonces general de Brigada Antonio D. Bussi se desempeñó como comandante de la VBrigada de Infantería, con asiento en Tucumán y con jurisdicción en 
la provincia homónima, y en las de Salta y Jujuy, que en conjunto constituían la subzona 32 del Tercer Cuerpo del Ejército, sustituyendo en el cargo al ya mencionado general Acdel Edgardo Vilas.

Cuando ya estaba en marcha el golpe de Estado del '76, en abril de ese año, sumó a su cargo militar el de interventor de la provincia de Tucumán. Ambas posiciones lo transformaron en responsable de todos los centros clandestinos de detención (CCD) que funcionaron en su jurisdicción y del control operativo de las fuerzas armadas y de seguridad, en tanto comandante de la subzona 32.

En los dos años considerados se produjeron en la jurisdicción controlada por Bussi --conforme registro judicial-- las detenciones ilegales y desapariciones forzadas de 590 personas. Las desapariciones producidas mientras Bussi comandaba la subzona 32 y gobernaba a Tucumán equivalen a un caso cada 30 horas.

Entre enero de 1978 y enero de 1979, Bussi fue $2^{\circ}$ comandante de Institutos Militares y jefe del Estado Mayor del Comando de Institutos Militares. En ejercicio de tales cargos tuvo jurisdicción en los partidos bonaerenses de Escobar, General Sarmiento, General San Martín, Pilar, San Fernando, Tigre, Tres de Febrero y Vicente López.

En este período se produjo la detención ilegal y la desaparición forzada de 77 personas: un número que representa un promedio de 5,1 desapariciones mensuales.

Entre febrero y diciembre de 1980, Bussi fue comandante del III Cuerpo del Ejército, que abarcaba las provincias de Córdoba, San Luis, Mendoza, San Juan, La Rioja, Catamarca, Santiago del Estero, Tucumán, Salta y Jujuy.

En esta etapa, continuaron las desapariciones de personas:

Entre diciembre de 1980 y diciembre de 1981, Bussi comandó el I ${ }^{\circ}$ Cuerpo del Ejército, que comprendía la Capital Federal y la provincia de Buenos Aires con excepción de 14 partidos sureños integrantes del Vo Cuerpo y de los 8 partidos que estaban bajo la jurisdicción del Comando de Institutos Militares.

Durante ese período se produjo en jurisdicción del $\mathrm{I}^{\circ}$ Cuerpo la detención ilegal y desaparición forzada de 10 personas más. 
De acuerdo con lo antes mencionado, entre diciembre de 1975 e igual mes de 1981 se produjeron --y constan judicialmente--, más de 680 detenciones ilegales y desapariciones forzadas de personas en las jurisdicciones comandadas por Bussi.

Asimismo, resaltamos que en los párrafos precedentes sólo nos circunscribimos al delito de desaparición forzada de personas --delito de lesa humanidad--, omitiendo asesinatos, torturas, apropiación, retención y ocultamiento de niños y otros gravísimos delitos que se le adjudicaron a Bussi y que éste siempre quiso hacer pasar como "acciones de guerra".

Debemos señalar que de todos los delitos imputados --más de 680 casos, sólo de desapariciones forzadas-- llegaron a la justicia únicamente los cometidos entre diciembre de 1975 e igual mes de 1977, mientras Bussi comandó la subzona 32 del III Cuerpo del Ejército. Cabe acotar que en esta cifra se encuentran incluidas las 171 personas pertenecientes a la comunidad universitaria de Tucumán, desaparecidas y asesinadas durante la gestión militar de Bussi.

En el año 1984, la Comisión Bicameral Investigadora de Violaciones de Derechos Humanos de la Honorable Legislatura de la Provincia de Tucumán se pronunció en estos términos sobre los hechos acontecidos en nuestra provincia, y en los que Bussi se encuentra directamente implicado:

"[...] La militarización creciente de la sociedad tucumana aumentó cuando la policía local pasó a depender directamente de la autoridad militar de la provincia, incrementándose la escala represiva con el accionar conjunto de las fuerzas militares, policiales y de seguridad.

[...] En este marco, merece especial mención la furia represiva que se desató luego del golpe militar de 1976, contra las autoridades constitucionales de la provincia. Cárceles, torturas, asesinatos, desapariciones, persecuciones y vejámenes de toda clase, fueron moneda corriente en el trato que dispensó la dictadura a esos funcionarios del gobierno justicialista.

[...] Pese a las dificultades a las que hemos aludido y a las que vamos a hacer mención más adelante (...) debemos señalar que se han sustanciado un total de 450 expedientes que comprenden a 600 
presuntas víctimas las que, ahora, podrán ejercer por sí o por sus representantes legales, ante la justicia administrada por jueces constitucionales, los roles que la ley les acuerda".

Ante lo expuesto, surge claramente que Antonio Domingo Bussi se vio implicado en violaciones a los derechos humanos cometidas en los períodos mencionados. Los altos cargos que ocupaba en esos tiempos y muchas de las declaraciones que constan en diferentes instrumentos nos llevan a concluir, ya sea por acción u omisión, su responsabilidad directa en cada una de estas violaciones

\subsection{La situación de Bussi durante la democracia}

a) La impunidad de Bussi.

El 4 de agosto de 1991, desde Madrid, España, el Instituto de Estudios Políticos para América Latina y África (IEPALA) escribía en ocasión de homenajear a Monseñor E. Angelelli (Obispo de La Rioja), a tres lustros de su martirio:

"[...] en Tucumán, la situación todavía es más crítica. En ningún momento se sancionó a los responsables de tales hechos. Por el contrario, los que implementaron la Doctrina de la Seguridad Nacional en esta provincia, amparados por la impunidad y abusando de las instituciones de la democracia, comenzaron una inesperada carrera política, como huída hacia adelante. Y lo más patético es que se vieron beneficiados por un alto porcentaje del voto popular".

El caso de Bussi en Tucumán es paradigmático de esa "huída hacia adelante" que emprendieron muchos de los responsables del terrorismo de Estado argentino. Esto así, pese a que los tribunales federales--a comienzos de la restauración de la democracia-- acumularon en su contra 814 causas referidas a homicidios, tormentos, privación ilegítima de la libertad y falsificación documental. Sobran los testimonios de ex detenidos-desaparecidos y gendarmes que lo involucran directamente en graves delitos, como de familiares de sus víctimas que aún continúan con la búsqueda de justicia. Tampoco puede pasar desapercibido el hecho de que la justicia federal haya sido la que estableció su directa responsabilidad en los hechos que se le imputan, al negarle su pretensión 
de beneficiarse con la hoy derogada Ley de Obediencia Debida (ley $\mathrm{N}^{\circ}$ 23.521). No podía ser de otro modo: él impartía las órdenes.

En 1987, la Corte Suprema de Justicia de la Nación lo colocó --junto con Luciano Benjamín Menéndez, Luis Santiago Martella y otros represores-- al amparo de la hoy también derogada Ley de Punto Final (ley $\mathrm{N}^{\circ}$ 23.492), aduciendo que se habían vencido los plazos excepcionales para enjuiciarlo, situación que de ningún modo excluye su culpabilidad.

Así eludió Bussi la labor de la justicia argentina.

En igual sentido, conviene tener en cuenta las expresiones de la Asamblea Permanente por los Derechos Humanos (APDH) en una presentación efectuada ante la Cámara de Diputados de la Nación en el año 2000, en ocasión de la impugnación de sus pliegos:

"de hecho, el diputado electo Antonio Domingo Bussi es, a este efecto, una persona que cometió delitos y está impune por la consecuencia de sus actos, simplemente porque una ley determinó límites para instrumentar la acusación penal y un fallo judicial convalidó, en el marco de una crisis política, esta impunidad que nunca le hubiera correspondido por sus niveles de mando que incluso lo excluían de la ley de Obediencia Debida... no pudo ser juzgado, ni castigado. Sus crímenes subsisten $y$, sin responsabilidades penales aparentes, sus responsabilidades morales son tan graves como las formales".

Pero lo que no pudo evitar fue la condena social por los crímenes cometidos. Así, la sociedad tucumana en oportunidad del "Juicio Ético Popular por la Memoria y la Dignidad" en contra de Antonio Domingo Bussi, lo acusó de "...degradar la condición humana, haber ejercido la suma del poder público y el derecho de vida y muerte", y lo condenó como infame traidor a la Patria, exhortando a la sociedad, a las instituciones representativas y en especial a la prensa a negar al acusado el derecho a ser nombrado. El mismo Tribunal Ético Popular peticionó al Tribunal Electoral Provincial la revisión de la errónea resolución que confiriera en su momento a Bussi el reconocimiento jurídico para presentarse como candidato a cargos electivos. 
Con idéntica finalidad --condena ética social-- Antonio Domingo Bussi fue declarado por el Honorable Consejo Superior de la Universidad Nacional de Tucumán, "Persona No Grata" en el ámbito universitario local. En esa misma resolución, este órgano repudió la candidatura de Bussi a la gobernación de la provincia

"... por ser uno de los notorios representantes del período más nefasto de la historia de nuestro país..." , sosteniendo también que su candidatura "constituye una provocación a la sociedad democrática que ha repudiado ese pasado y sus perversos autores".

Bussi, si bien es impune ante la ley fue declarado culpable por la sociedad.

b) Reivindicación pública del terrorismo de Estado.

Abusando de su impunidad, Antonio D. Bussi jamás mostró arrepentimiento por su actuación durante el terrorismo de Estado que implementó la dictadura militar. Al contrario, cada vez que pudo, reivindicó en forma pública la violencia y los delitos de lesa humanidad de los que es responsable y a los que prefiere incluir en el contexto de una victoriosa "guerra" librada contra el enemigo subversivo:

"En la guerra no existe represión, existen operaciones militares. Muertos por asesinato no existen en la guerra, existen muertos por combate. En la guerra no hay ese tipo de figuras delictivas. En la guerra hay operaciones militares... hay persecución. En la guerra el límite de las armas no es de carácter jurídico, es de carácter táctico porque en la guerra, el que no mata, muere....

Se confunde una operación de captura de un delincuente subversivo con un secuestro y se pretende presentar como desaparecidos a quienes no son tales, ya que son víctimas del accionar de la subversión. En la guerra no hay desaparecidos en los términos en que se los quiere reclamar: hay muertos en combate".

Respondiendo a esta forma de justificar los delitos cometidos, Bussi jugó un rol central para evitar que los tribunales civiles actuaran frente a las graves violaciones de los derechos humanos denunciadas, y para que fuera la propia justicia militar la que resolviera en definitiva sobre lo denunciado. Así, acusó al propio titular del Ejército, general 
Héctor Ríos Ereñú, de no ejercer la responsabilidad de su jerarquía a fin de preservar lo que Bussi consideraba la única victoria militar indiscutible del Ejército (el "Operativo Independencia"). En este sentido, solicitó que el Consejo Supremo de la FFAA sancionara, con un Tribunal de Honor, a Ríos Ereñú. Sus fundamentos fueron, textualmente, entre otros:

"La Operación Independencia fue la expresión más acabada de la guerra llevada a cabo por el Ejército Argentino contra la agresión marxista-leninista...; su preservación y exaltación es un derecho y una obligación de todas las jerarquías y niveles de conducción...

Aceptar su juzgamiento por los vencidos de ayer y en el mismo campo de combate, cualquiera sea su cobertura jurídica, es una afrenta al Ejército, y cada uno de sus integrantes "http://www.derechos.org/nizkor/arg/doc/andhes1.html - N_20.

Esta propuesta le valió un arresto militar de 20 días en la provincia de La Pampa.

En julio de 1987, Bussi rechazó la candidatura a gobernador propuesta por el partido "Defensa Provincial (Bandera Blanca)", oferta que finalmente aceptó el 24 de agosto de ese año en un contexto de marcado cuestionamiento jurídico-social hacia el terrorismo de Estado implementado. En esa coyuntura comenzó su carrera política en la provincia. Nótese la vinculación entre esta decisión y la reinvindicación del accionar represivo como estrategia para sustraerse a la justicia. En un discurso pronunciado días antes de dar a conocer la aceptación final, el mismo Bussi lo deja entrever diciendo que su presencia en Tucumán era:

"una muestra de reconocimiento a Tucumán, en un país de sordos, de mudos y de ciegos, donde la mayoría ha perdido la memoria de lo que fue la Argentina hace 10 años... como hombre, como ciudadano y como soldado (dijo que) esto es una patriada que apunta a reivindicar al Ejército que operó en Tucumán... no soy el hombre nuevo que irrumpe en la política tucumana, ni el novicio que viene a convencer a la gente con un programa difícil de entender...".

Terminó su discurso señalando que:

"es hoy el militar de hace 10 años, que no tiene nada nuevo que decir a Tucumán... la subversión aún no ha renacido físicamente. Eso sí, 
se están creando las condiciones económicas y sociales que la harán posible".

Las últimas palabras de Bussi antes transcriptas, resultarían un macabro anuncio de cómo intentaría éste justificar lo que ocurriera dos semanas después: tres jóvenes que protestaban contra un acto de Bandera Blanca, realizado en Tafí Viejo, fueron baleados por personal de seguridad de Bandera Blanca. Uno de ellos, Fernando (Fredy) Rojas, moriría tras agonizar tres meses, producto de los dos balazos que recibiera en su cabeza.

A finales de 1987, Antonio D. Bussi continuó públicamente con sus dichos --de neto corte autoritario--, esta vez refiriéndose a un miembro de su propio partido "Defensa Provincial (Bandera Blanca)", el concejal Carlos Cóceres que había votado por un candidato del Partido Justicialista. Aquí Bussi propone volver a aplicar métodos que implican un desconocimiento total de la dignidad humana:

"Vamos a ser muy severos con los tramposos como Carlos Cáceres... vamos a invitarlo a que deje la provincia, porque no puede tener presencia física en el Concejo Deliberante... individuos de las actitudes del señor Cóceres no tienen cabida no ya en la estructura política, sino en la provincia".

En 1998, esta vez frente a la decisión del juez federal Adolfo Bagnasco de procesar a jerarcas de la dictadura militar en la causa que tramita por apropiación de menores, Bussi --imputado en dicha causa y en otras tres más, una de ellas de carácter internacional y con pedido de captura de igual índole-- nuevamente se "defendió" en forma pública afirmando que:

"...en la guerra, el hombre enfrentado a matar o morir puede cometer algún error, pero la causa que lo anima es superior a la vida o a la muerte (. . .); pero estoy convencido de que hicimos lo mejor que pudimos".

Viene al caso destacar que, con referencia a la causa internacional reseñada --y a otras más, como ser la abierta en Italia-- Bussi no dudó en desacreditar subjetivamente lo realizado por el juez Baltazar Garzón aduciendo que era "... un disparate", y que el magistrado español era "un 
pobre juez... " y "un lunático, que pierde el tiempo conmigo". Sin embargo, nótese que desde el momento en que tomó estado público la medida judicial de Garzón, Bussi restringió sus viajes al extranjero o bien a países que tuviesen tratados de extradición con España. Esta situación fue resaltada por los medios de prensa nacionales.

El 12 de octubre de 1998, la Agrupación H.I.J.O.S. de Tucumán organizó un "escrache" pacífico contra el entonces gobernador de la provincia, Antonio Domingo Bussi, en la plaza Independencia. Un impresionante operativo policial --más de 5.000 efectivos-- cercó la mencionada plaza y sus alrededores, impidiendo el paso hacia ese lugar público a casi 1.000 personas que participaban de la protesta. Pese a que no hubo ningún tipo de disturbio en esa ocasión, dos jóvenes integrantes de H.I.J.O.S. de Mendoza fueron detenidos sin mediar motivo legal alguno en la Comisaría $1^{\circ}$ de esta ciudad. Otra vez, Bussi demostró que en épocas de democracia mantiene vicios propios de la dictadura: implementar políticas destinadas a generar un clima de terror para anular a sectores claramente opositores que lo vinculan con su accionar represivo pasado.

El 20 de noviembre de 1999, ante las impugnaciones de sus pliegos como diputado de la Nación por la Cámara respectiva, Bussi no dudó en declarar que:

"...las impugnaciones constituyen una campaña psicológica... No se puede desconocer que la Operación Independencia es el único éxito de las armas de la Argentina en el siglo que finaliza... He sido electo por millares de tucumanos, a través del voto popular y con el aval de las justicias electorales provincial y nacional, para ocupar los más altos cargos y funciones, y sólo reconozco en el soberano, después de Dios, a mi juez supremo... Sólo una ignorancia supina o una ideología perversa, que descarto, puede llevarla [a la diputada Inés Pérez Suárez, PJ] al equívoco sobre las únicas responsabilidades que me tocaron llevar a cabo en Tucumán en 1976 y 1977",

c) Otras causas en contra de Antonio Domingo Bussi.

Hasta aquí nos referimos al Bussi represor y genocida, partícipe y ejecutor directo de un plan sistemático de exterminio masivo, en virtud del cual hoy continúan desaparecidas más de 2.000 personas, más de 
680 registradas judicialmente en las jurisdicciones que estuvieron a su cargo --600 de estas últimas, víctimas tucumanas-- y que son de su principal responsabilidad. Impune por la ley de Punto Final, ya derogada y declarada inconstitucional por varios jueces y tribunales de todo el país, pero con causas penales pendientes en el país por apropiación de niños --delito de lesa humanidad que quedó "fuera" del alcance de la ley mencionada-- y con un pedido de captura internacional que le impide salir legalmente del territorio argentino.

Ése es el rasgo característico de la "moral" pública de quien intenta hoy ser candidato a la intendencia de San Miguel de Tucumán en las próximas elecciones provinciales, y causal directa de la inhabilidad ética aquí planteada.

Pero a lo dicho, debe también sumarse el hecho de que en el año 1994 Antonio Domingo Bussi falseó la declaración jurada de bienes presentada ante la Cámara de Diputados de la Nación, al omitir el hecho de ser titular de cuentas bancarias secretas en el exterior, ilícito que le fuera descubierto en el año 1998.

Esta situación fue expresamente reconocida públicamente por Bussi. Ello lo llevó en febrero de 1998, no sólo a los estrados judiciales y a la impugnación de sus pliegos como diputado electo por parte de la referida Cámara, sino incluso a ser sancionado, el 3 de abril de ese año, por el Tribunal Superior de Honor de las FFAA --a requerimiento del entonces jefe del Estado Mayor del Ejército, Teniente General Martín A. Balza--, correspondiéndole una amonestación por "falta grave al honor" al "haber perjudicado el prestigio de la institución". Baste recordar que Antonio D. Bussi, al ser sancionado por el Tribunal de Honor del Ejército por "faltas morales", se defendió manifestando que cuando él miente no lo hace en su condición de militar, sino de político. Esto evidencia el profundo desprecio que tiene el impugnado por la política en sí y por las instituciones democráticas.

Diez días después, el 13 de abril de 1998, la Legislatura de Tucumán entendió que Bussi había incurrido en desorden de conducta y falta de cumplimiento de los deberes de funcionario público. En ese sentido, lo suspendió en el ejercicio de su cargo de gobernador por 60 días y lo sometió a un juicio político, en el cual, escandalosamente, la 
fuerza del número pudo más que las evidencias acumuladas, lo que posibilitó que Bussi volviera a asumir la gobernación.

Como ya fuera dicha, el 1 de diciembre de 1999, la Cámara de Diputados de la Nación se negó a incorporar al diputado electo Antonio Domingo Bussi, rechazando sus pliegos el 10 de mayo de 2000, por considerarlo, en virtud de los artículos 64, 36, 16 y 75 inc. 22 de la Constitución Nacional, inhábil moralmente tanto por las gravísimas violaciones de derechos humanos atribuidas a Bussi en épocas de dictadura, como por "mentirle" en su oportunidad a la Cámara a nivel patrimonial en épocas de democracia.

En esta ocasión, cobra especial relevancia mencionar el contenido del conteste de Bussi tras el traslado de las impugnaciones realizadas, ya que en ningún momento Antonio Domingo Bussi negó los hechos imputados, sino que limitó su defensa a argumentaciones formales, de carácter meramente procesal, tales como la falta de jurisdicción y de acción de la Cámara y la consecuente nulidad del proceso impugnatorio. En la actualidad, este rechazo fue recurrido por Bussi y se encuentra en instancia judicial.

El 24/10/02 fue elevado --por apelación del sobreseimiento dictado por el Juzgado de Instrucción de la Vo Nominación, a la Excma. Cámara Penal, Sala VI del Poder Judicial de la Provincia de Tucumán, la causa penal seguida en contra de Antonio D. Bussi por peculado (malversación de caudales públicos), delito presuntamente cometido durante su gestión como gobernador de la provincia en el período 19951999, impulsada por la Fiscalía Anticorrupción de Tucumán. En el mes de abril de 2003, la Cámara citada revocó el sobreseimiento dictado y ordenó la realización del juicio oral y público en esos actuados. 


\section{AneXo 6 Documento del 24 De mARZO de 2008 CONSENSUAdo entRe}

\section{TODAS LAS ORGANIZACIONES DE DERECHOS HUMANOS DE TUCUMÁN}

Mientras el pasado no sea saldado, lo que pasó sigue pasando, día tras día, sigue pasando. Pasa todo el tiempo, es tiempo presente. Si no hay Justicia vuelve a pasar. A 32 años del golpe genocida en que el Poder Económico y su brazo ejecutor, las Fuerzas Armadas, instauraron a sangre y fuego el Estado Genocida, los hechos nos dan la razón.

Hace 32 años en nuestro país comenzó el proceso de recomposición de un sistema que se encontraba en crisis mediante un siniestro plan de apropiación de la riqueza del pueblo argentino a manos del monopólico capital financiero nacional e internacional. Para garantizar su efectiva realización se implementó el plan represivo más sangriento en la historia de la nación, que significó la generalización de la práctica del terrorismo de estado, a partir de la metodología de la desaparición forzada de personas cuyas víctimas fueron obreros, estudiantes, políticos, dirigentes, militantes populares y todos aquellos que planteaban de manera critica y activa la transformación del país. Se reemplazó la Constitución Nacional por el Estatuto de Reorganización Nacional de la dictadura oligárquica militar pro-imperialista; se violentaron todos los derechos constitucionales; se intervinieron militarmente las organizaciones sociales como sindicatos, agremiaciones de pequeños y medianos empresarios, universidades; se prohibió el accionar de los partidos políticos; desapareció la libertad de pensamiento, de expresión y de libre circulación.

Los militares y los grupos económicos nacionales y extranjeros, que financiaron y dirigieron económicamente el terrorismo de Estado y la dictadura, contaron con la complicidad de algunos dirigentes políticos, la cúpula de la Iglesia y la burocracia sindical.

En Tucumán el Genocidio tuvo su primera implementación con El Operativo Independencia que inició en febrero de 1975, en pleno Gobierno Constitucional de Estela Martínez de Perón. El Ejército Argentino ocupó el territorio de la provincia, y puso en marcha un Plan Sistemático de Violaciones Masivas de los Derechos Humanos, que luego se iría 
extendiendo a diferentes provincias, hasta alcanzar todo el país una vez consumado el del Golpe Militar. Así es como Tucumán tuvo el primer Centro Clandestino de Detención del país denominado "La Escuelita" que funcionó en la ciudad de Famaillá. Sin embargo la violencia, amparada por el Estado, ya había tenido sus primeras armas con la Triple A (Alianza Anticomunista Argentina), organización ilegal y paramilitar, comandada por López Rega, Ministro de Bienestar Social de Isabel, que atentó contra cientos de dirigentes políticos y organizaciones populares.-

Una vez más estamos en esta plaza para denunciar cómo la impunidad de ayer ve su continuidad en la impunidad de hoy. Porque JULIO LÓPEZ, continúa desaparecido.

Hoy 24 de marzo, son 18 meses y 6 días de su ausencia. Contamos los días, porque un día sin Julio López es un día más de IMPUNIDAD.

La impunidad de ayer, la impunidad de hoy, que entorpece la Justicia que exigimos. Julio López desapareció por segunda vez un día de democracia, que quedó grabado como un día de terror, del mismo terror que se desató con la dictadura que calló las voces de 30.000 argentinos que pensaban y accionaban por un país con trabajo, justicia social, equitativa distribución de la riqueza, salud, educación, para todos y todas.

Quedó demostrado que con declamaciones no basta, pues el APARATO REPRESIVO SE MANTIENE INTACTO, manifestándose en los casos de gatillo fácil, en los crímenes impunes amparados por el silencio ensordecedor del Gobierno, en las detenciones arbitrarias por contravenciones, en la represión a las luchas populares, en los servicios de seguridad privada al mando de represores. Hace un año y medio que exigimos su aparición con vida, y no recibimos una sola respuesta cierta por parte del Gobierno y de todas las instituciones del Estado.

Su desaparición, su segunda desaparición forzada nos grita, nos reclama, como espantoso ejemplo de la NATURALIZACIÓN DE LA IMPUNIDAD que trajeron aparejados tantos años de injusticia, de pretender meter la mugre bajo la alfombra. La sociedad no se apropió de esa desaparición escandalosa. Nuevamente la figura del desaparecido pretende la idea de que desapareció solo. 
Pero la mugre aflora en todas partes, como el asesinato del prefecto Febres, pocos días antes del momento en que se iba a leer la sentencia en el juicio oral en su contra. Su muerte borró la posibilidad, aunque más no sea pequeña, de que tal vez revelare donde están los H.I.J.O.S. de los Compañeros, apropiados y ocultados bajo otros nombres.

Estos dos hechos vinculados a los juicios, que se están llevando a cabo treinta años después, nos permite decir que hoy, en nombre del terrorismo de Estado de los '70, hay quienes siguen matando. La muerte del genocida Febres significa esto, que siguen haciendo lo que hicieron siempre. Lo único que saben hacer. Su atroz arte de matar por la espalda, que actúan buscando la impunidad de los culpables del GENOCIDIO, generando temor, confusión y pretendiendo amedrentar a los que luchamos por Justicia.

Pero los Organismos de Derechos Humanos y demás organizaciones sociales y políticas no transitaron en vano este largo y doloroso período caracterizado por la negación de Justicia.

La impunidad de ayer, la impunidad de hoy. A la violencia no sólo represiva, sino Económica ejercida por el Estado Genocida la vemos instaurada y enquistada aún hoy, a través de la reproducción de la pobreza y la desigual distribución de la riqueza, las cuales día a día se siguen incrementando.

El gobierno de CFK y Alperovich, en defensa de su alianza con los sectores económicos dominantes, reprime a los que no claudican en la lucha. Así sucedió con los trabajadores del Casino Flotante de BSAS, los docentes en Salta, Santa Cruz y Neuquén, con los jubilados, con los desocupados y a los que se movilizan en defensa de los intereses populares, como en la lucha contra el aumento del boleto en Tucumán.

La represión se manifiesta no solo a través de los aparatos del estado como en el asesinato de Carlos Fuentealba por la policía neuquina, sino también mediante organizaciones y patotas paraestatales como en el de Lázaro Duarte. Quien fuera un militante del MST de Neuquén que murió en febrero de este año, a causa de un ataque perpetrado por una patota que ingresó a la madrugada al local del MST. 
En Tucumán la Impunidad se manifiesta también, en la ausencia de justicia para los más de 150 casos que desde hace 100 martes continúan denunciando que en esta provincia la justicia ejerce derecho de admisión con los pobres. $Y$ que hoy en plena democracia siguen desapareciendo personas, víctimas de la trata de personas u otros delitos.

La impunidad ayer y hoy continúa cobrándose sus víctimas entre los adolescentes y jóvenes de nuestros barrios, acosados por la represión o las víctimas de la desnutrición visible y oculta.

iBasta de represión a los adolescentes y jóvenes y de la judicialización de la pobreza!. El Hambre es un Crimen. Ni un pibe menos.

A pesar de la coyuntura internacional favorable a la valorización de las materias primas, que reportan grandes dividendos a las arcas del estado nacional, a través de las retenciones, los grandes problemas de los trabajadores y del pueblo no han sido resueltos.

El estado sella nuevos aumentos en las tarifas públicas, mantiene las privatizaciones y las leyes laborales del menemismo y los salarios deprimidos, a través de pactos con el empresariado y la burocracia sindical.

El gobierno de Alperovich a través de los principales medios de comunicación financiados por él, pretende que el pueblo crea que se genera trabajo digno, que se combate el trabajo en negro, cuando en realidad, solo se aumenta la precarización, y el estado es el principal empleador en negro, instaurando así el envilecimiento laboral. Los jubilados son dejados morir literalmente, sin ver resuelta su demanda por el $82 \%$ móvil a pesar de existir disposiciones judiciales que así lo disponen. La destrucción del medio ambiente también es consentida por el gobierno, debido a su complicidad con las empresas, podemos mencionar el caso de las contaminación por la explotación minera en Aguas Ricas y La alumbrera, donde además se cuenta con complicidad de la UNT; o la aceptación de la existencia de industrias contaminantes, tales como los ingenios, las citrícolas, etc. 
La impunidad de ayer, la impunidad de hoy. El Plan Cóndor elaborado por los EE.UU. para sostener a las dictaduras latinoamericanas encuentra su correlato contemporáneo en el Plan Colombia y su sucedáneo el Plan Patriota. Repudiamos la intromisión de Colombia en territorio Ecuatoriano respaldada por el imperialismo yanqui, así como cualquier intromisión del imperialismo genocida.

El Estado Genocida que no respetó la vida se ve perpetuado y continuado en democracia con la participación en las instituciones de funcionarios de la dictadura con la totalidad complicidad del actual gobierno; tal el caso de Pablo Baillo, Mauricio Guzman y los reconocidos ex bussistas, hoy acoplados a la lista oficial.

El Estado provincial al parecer no tan sólo aloja entre sus filas a represores y ex funcionarios de la dictadura sino que ahora los asciende, poniéndolos en sitios estratégicos, pretendiendo que la Justicia que perseguimos se vea postergada aún más. Repudiamos enérgicamente la vergonzosa decisión de Alperovich de proponer al abogado Sassi Colombres, como Vocal de la Corte Suprema de Justicia, aunque 24 horas después, presionado, diese marcha atrás. Como también denunciamos a la Legislatura, obsecuente y cómplice, que aprobó el pliego.

Aunque porqué nos extrañaría esto de un gobernador con prácticas tan autoritarias como dictatoriales, ya que es el mismo que maneja el presupuesto, la justicia y los negocios a su antojo, para favorecer a empresas propias y las del selecto círculo de privilegiados amigos.

Mientras nosotros esperamos más de 30 años para comenzar a ver a los asesinos en la cárcel y vemos cómo la falta de presupuesto y personal ven bostezar las causas por delitos de lessa humanidad en los Tribunales de todo el país, paradójicamente los represores cuentan con abogados y grupos de contención bien pagados por Estado.

El Poder Judicial ha dado muestras acabadas de cuál es su criterio para administrar justicia, de los cientos de casos por delitos de lesa humanidad en la provincia, el primer caso a elevar a juicio oral es el de Vargas Aignasse, un caso sin querella. Existen causas como la de Arsenales, paradigma del Genocidio en Tucumán que cuenta con un 
increíble caudal probatorio, que duerme el sueño de los justos, mientras espera algún día ser elevada a juicio oral.-

Por esto Exigimos la inmediata elevación a juicio oral de las causas por delitos de lesa humanidad, el Juzgamiento por Centro Clandestino de detención, evitando así la revictimización de los testigos y sobrevivientes en los juicios.

Porque una Justicia lenta no es Justicia.

\section{Por esto Exigimos:}

Aparición con Vida Ya de Julio López! El esclarecimiento de su desaparición, y certezas sobre la investigación. Que el gobierno asuma la responsabilidad por su desaparición y la DECISIÓN POLÍTICA de investigar su secuestro.

Celeridad en la investigación y la tramitación de las causas por violaciones a los derechos humanos y su unificación por Centro Clandestino de Detención. Juicios orales ya!!!!

Basta de IMPUNIDAD. Exigimos el desmantelamiento del aparato represivo YA!!.

Por la restitución de la identidad de los más de 400 niños apropiados durante la Dictadura Militar.

La apertura de los archivos secretos de la SIDE, el Ejército y la Policía.

Por una Justicia independiente y una política de estado eficaz para la protección de los ciudadanos, que garantice la plena vigencia de derechos humanos para todos.

Desprocesamiento y libertad a los luchadores populares. No a la criminalización de la protesta social.

El esclarecimiento del asesinato de Paulina Lebbos y de los más de 150 casos de víctimas de la impunidad en Tucumán.

No a la ley Antiterrorista.

A 20 años de su asesinato continuamos exijiendo justicia por el compañero Fredy Rojas, asesinado por la custodia de Bussi. 
Repudiamos la represión y las persecuciones y amenazas a los militantes políticos y sociales.

Juicio y Castigo a los responsables políticos y materiales de los asesinatos de Carlos Fuentealba y el compañero Lázaro Duarte.

Exijimos la nulidad de los Indultos a los Genocidas.

Protección a los testigos y víctimas de violaciones a los Derechos Humanos.

CÁRCEL COMÚN, PERPETUA, EFECTIVA E INMEDIATA para todos Ios GENOCIDAS y sus cómplices civiles y eclesiásticos.

LA IMPUNIDAD solo genera MÁS IMPUNIDAD

NO OLVIDAMOS-NO PERDONAMOS-NO NOS RECONCILIAMOS

30.000

COMPAÑEROS

DETENIDOS

DESAPARECIDOS

PRESENTES!!!

AHORA Y SIEMPRE!!! 


\section{ANEXO 7 CAUSA: G. VARGAS AIGNASSE S/DESAPARICIÓN: "ALEGATO" DE ANTONIo D. BUSSI ${ }^{580}$}

Sres. Jueces:

Estamos cerrando el último capítulo de la historia tucumana de la década del 70.

Ustedes serán -Honorable Tribunal- los protagonistas principalísimos de un fallo -cualquiera sea su SENTENCIA- que pasará a la posteridad, signando un antes y un después en la vida política tucumana.

Usted también Sr. Fiscal tendrá su "espacio" en la historia que comenzará a escribirse, con posterioridad inmediata a este juicio histórico, donde no tendrán cabida sus falsas incriminaciones -sin fundamento jurídico alguno- avaladas por delincuentes comunes manifiestamente asesorados, sino por su pretendido "vedetismo" publicitario y su transfiguración pública, develando públicamente -usted mismo- un secreto "a voces", rogando ayer asiduamente en mi propia sede partidaria, negociar mis electores en el Colegio Electoral de 1987, en su beneficio personal y la de su jefe político, a cambio de cargos públicos, y acusándome hoy de los delitos más atroces que, más que una acusación, me da derecho a pensar producto de una venganza, incompatible con su carácter de Fiscal de la República.

Usted ha cambiado Sr. Fiscal, de "pedigüeño a vengativo" yo NO, sigo siendo el Bussi de toda mi vida -con sus más y sus menosasí fui conocido y reconocido por la inmensa mayoría de los tucumanos.

Finalmente, mi protagonismo en los hechos enjuiciados donde, sin duda alguna, aflorarán imperfecciones propias de mi naturaleza

${ }^{580}$ El presente anexo tiene por objeto presentar la visión de Bussi, expresada en distintas oportunidades y medios. El valor testimonial del presente documento es el marco donde el propio Bussi hace su descargo sobre los hechos que le imputaron como responsable de la desaparición del ex senador Guillermo Vargas Aignase en la primera causa por delitos de Lesa Humanidad llevada a cabo en Tucumán. El sostenimiento del argumento de la guerra ha sido la constante no solo en Bussi sino en todos los ex militares juzgados. 
humana pero si, la consideración y el respeto de mis conciudadanos tucumanos en $\mathrm{mi}$ doble condición de soldado y gobernante, sobradamente demostradas en multitudinarias expresiones y por el voto popular.

Para esa historia no escrita pero vivida están orientadas las presentes palabras, condicionado y limitado por mis dolencias físicas y psíquicas que no me permiten librar éste "último combate" con la plenitud de mis fuerzas.

\section{Sr(s) JUECES:}

He servido al País, a través del Ejército y de la Política, durante más de sesenta años. Mi "foja de servicios" es ilustrativa sobre mi trayectoria militar y pública. Tuve la oportunidad de instruir y educar a generaciones de argentinos, incluyendo a mi propia "clase", en el amor a la Patria y en la defensa de sus instituciones, exclusivamente.

En mi vida militar tuve oportunidad de estudiar, investigar y enseñar el fenómeno de los "conflictos ideológicos", que transcurrieron y transcurren en el Mundo y en la Región, y de presenciar -en Vietnam- una de las mayores confrontaciones armadas en ambiente subversivo, y ver derrotar a los ejércitos de la democracia mas poderosa de la tierra, vencedores en todos los combates, por no comprender y dar respuesta a los problemas de la gente, a quienes pretendían defender (derrumbamiento del frente interno).

La experiencia adquirida me permitió comprender este horroroso fenómeno de la guerra, para enfrentar al flagelo de la subversión en el "epicentro" mismo del accionar subversivo nacional (Tucumán), acompañado y apoyado por la inmensa mayoría del pueblo tucumano -"objetivo inicial" y víctima de la agresión apátridaque vio y sufrió, en vivo y en directo, más que ningún otro argentino, el temor y el terror; la seguridad de sus vidas; y la pérdida de sus patrimonios; convirtiéndose -de hecho- en el factor determinante de la victoria político- militar de mi gestión.

Los TUCUMANOS DE LA DECADA DEL 70, son testigos insobornables de la GUERRA que vivió Tucumán y de la conducta de sus FFAA; muy pocos pueden negar hoy este "hecho" y de los miedos y 
horrores que producían las "bandas de delincuentes terroristas" que asolaban la Provincia, con su secuela de muertos, desaparecidos, secuestrados, atentados, etc.

El "fusilamiento" de la familia del Cap. Viola, a metros del actual domicilio del Sr. Fiscal de ésta causa -que niega enfáticamente la guerra- fue la "carta de presentación del ERP", declarando abiertas las hostilidades contra la sociedad tucumana y sus instituciones, con proyección nacional -por similitud a Montoneros, con el secuestro y asesinato del Grl. Aramburu-.

Las mujeres y hombres de cuarenta años y menores fueron sometidos a escuchar permanentemente una sola campana y ver a la Patria a través de un retrovisor. Los padres no contaron a sus hijos y éstos no preguntaron a sus progenitores lo realmente acontecido en la década del 70; unos y otros, comprometidos con sus propias problemáticas, intentando sobrevivir en la Argentina de las crisis permanentes que no garantiza futuro cierto a la mayoría de sus habitantes $y$, en particular, A LA JUVENTUD.

Las nuevas generaciones tienen un conocimiento distorsionado de la guerra sufrida por sus mayores, por no haber vivido la agresión, sometidas a tremendas campañas de acción psicológica, de que fueron y son objeto permanente, en todos los medios de comunicación y en todos los ámbitos, con particular énfasis en el educativo.

Estas campañas fueron elaboradas y llevadas a cabo por el erpiano y fundador del "ejército revolucionario del pueblo" (ERP) Luis Eduardo Duhalde, con la complicidad de delincuentes terroristas liberados; funcionarios expulsados de sus instituciones por inconducta e inmoralidad; etc.

También se incorporaron -a estas campañas psicológicas- como nuevos denunciantes, los familiares de los muertos en combate que no denunciaron, en su oportunidad, la ausencia de los suyos, por desconocimiento o miedo y hoy se presentan, sin pruebas ni testigos valederos en procura de indemnizaciones. 
Corresponde señalar que solo el Tte. Gral. Alzogaray fue la excepción de una regla generalizada de no denunciar los muertos en combate; poco después de la muerte de su hijo reclamó su cadáver. Veinte años después su hermano reconoció que el mismo había muerto en combate, luciendo el uniforme de "oficial montonero" y con el fusil en la mano.

Finalmente, fueron parte importantísima y eje de esas campañas psicológicas, los subversivos muertos en combate y los individuos comprometidos con el accionar subversivo, incorporados a las bandas de delincuentes terroristas - voluntaria o compulsivamente; con conocimiento o desconocimiento de familiares y amigos - para cubrir sus fajas de combate ("pasaje a la clandestinidad"), denunciándolos como desaparecidos, secuestrados, etc. imputando su autoría a las FFAA, mediante intensas campañas de acción psicológica; la "industria de las indemnizaciones" implementada por el ex Pte. Alfonsín, alentando y financiando la formulación de falsas denuncias; y la de letrados patrocinantes, inescrupulosos profesionales que se beneficiaron con cuantiosos honorarios provenientes de compensaciones reconocidas a sus representados.

No me sorprende la "supuesta falta de información" de algunos funcionarios llamados a administrar justicia, sobre el horroroso drama de la guerra subversiva que vivió Tucumán y sus consecuencias.

Otros no llegaron a comprender el fenómeno de los conflictos ideológicos, menos aún hoy como producto de las campañas de acción psicológica, con apoyo oficial; algunos por ignorancia supina, otros por intereses personales o identificación ideológica; cabe preguntar con cuál de estas categorías se identifica el Sr. Fiscal.

Necesito creer que fue su ignorancia sobre el fenómeno de la guerra lo que lo llevo a confundir instalaciones militares de uso internacional, tales como lugares de reunión de detenidos con campos de concentración, sin descartar la posibilidad de una revancha por mi negativa de facilitarle la constitución de un gobierno que lo contuviera, penalmente castigado por la ley. 
No faltaron a ésta "confusión" algunos militares llamados a prestar testimonio, como consecuencia de la presión, subestimación, menoscabo, etc. de que hizo gala el Fiscal que contrasta con el conjunto de este Alto Tribunal.

La omisión deliberada e intencional de la guerra y de sus actos universalmente reconocidos, tales como bajas de combate, prisioneros de guerra, desaparecidos, etc. fue llevada a cabo para encuadrar a sus protagonistas en CONVENIOS, TRATADOS y LEYES PARA TIEMPOS DE PAZ, (DERECHOS DE PAZ) QUE, OBVIAMENTE, NO CONTEMPLAN EL FENOMENO DE LA GUERRA Y SUS CONSECUENCIAS.

EL ESTATUTO DE ROMA, INCORPORADO A LA LEGISLACION NACIONAL, OMITIDO ARBITRARIA E INTENCIONALMENTE, ESTABLECE TAXATIVAMENTE LAS LEYES DE LA GUERRA Y LA RESPONSIBILIDAD DE LOS COMBATIENTES (DERECHOS DE GUERRA).

En su articulado, debieron encuadrarse - si los hubo - "las circunstancias y los hechos" imputados a los combatientes de la guerra justa.

He sido y soy -hasta el límite de mi conciencia- un militar y político del "común denominador", apasionado y comprometido con el ejercicio de mis responsabilidades públicas.

Como MILITAR, he sido formado para defender a la Nación, encuadrado en la doctrina, leyes y reglamentos militares de los que jamás me aparté.

En aquellas circunstancias, fui convocado por un gobierno constitucional para conducir -SIN SOLUCION DE CONTINUIDAD- las operaciones específicamente militares en desarrollo en la Zona de Operaciones "Tucumán" contra las bandas de delincuentes terroristas que mantenían fuerte presencia en el monte y ciudades, con capacidad para destinar efectivos de su organización para participar en el ataque del Arsenal "Viejo Bueno" -Bs.As. (24/XII/75) reforzadas con la presencia encubierta de Montoneros que, a partir de principios de 1976, pasó a la lucha abierta y de superficie (Sierra de Medina, El Cadillal, Choromoro, calle Azcuenaga, etc..) en coordinación y apoyo del ERP. 
Al respecto, me permito rescatar párrafos de una carta reciente, publicada en los medios locales, de una madre relatando la muerte de su hijo, víctimas del accionar subversivo:

EL "GOLPE MILITAR" DEL 24/III/ 76 NO MODIFICÓ NI INTERFIRIÓ LAS actividades militares $y$, posteriormente, político-militares en la EN LA ZONA DE OPERACIONES.

La unificación del gobierno provincial con la conducción militar bajo un solo comando- respondió a exigencias operacionales exclusivamente, orientada a atacar en forma coordinada -política y militarmente- las causas reales que dieron origen y vigencia al fenómeno subversivo, y proveer el máximo de seguridad a la población, objetivo primario de mi preocupación y acción.

Como POLITICo, he sido evaluado y juzgado reiteradamente por una inmensa mayoría de tucumanos que me encumbraron electoralmente, en todos los cargos públicos de la Provincia y su representación ante la Nación, constituyendo un hecho inédito en la historia militar contemporánea, que un comandante de tropas que libró combates, sea elegido por el voto popular, en el mismo campo de batalla (Provincia de Tucumán).

EN EL EJERCICIO DE LOS CARGOS PUBLICOS, he sido investigado "a fondo", por similitud a mis dolencias físicas, recurriendo a personajes desconocidos ajenos al medio -ignotos contadores y médicos- que excedieron el límite de la ética profesional, en menoscabo de las excelencias profesionales Tucumanas, cuyo prestigio superó las fronteras comarcanas y aún del País; hurgando en mi vida desde la tumba de mis padres, toda mi existencia privada y la de mis hijos CON RESULTADOS NEGATIVOS, no descartando que llegarán hasta mis nietos.

\section{RESPECTO A LA DETENCIÓN DEL EX SENADOR GUILERMO} VARGAS AIGNASSE, debo señalar -una vez más - que la orden impartida y cumplida, inexcusable e insoslayable, pormenorizada hasta en sus menores detalles conducentes a la detención del causante, sin opción alguna de cambio, estaba dirigida sólo a prevenir cualquier tipo de reacción inmediata de potenciales opositores, para lograr el tiempo necesario de consolidación de la Junta Militar en el ejercicio del poder. 
La medida debía durar solo unos días, pero no tenía - ni en su letra ni en su espíritu - intención alguna de mortificación y, mucho menos, de la eliminación física de persona alguna, terminantemente prohibida por la Constitución, las Leyes y Reglamentos, aún en situación de guerra y bajo estado de sitio.

La lista de personas a detener, ordenada por la Junta Militar, debió ser confeccionada -probablemente- por algunos de los Organismos de Inteligencia de la CONDUCCION NACIONAL, con asiento permanente en la jurisdicción.

El régimen carcelario y las autoridades que debió "soportar" el citado Vargas Aignasse, hasta su liberación ordenada por la Junta Militar, fueron instituídas por el gobierno democrático del señor Juri, sin modificación alguna de mi parte, atento al poco tiempo trascurrido desde mi asunción al cargo, y el ejercicio pleno de mis nuevas responsabilidades de conducir los Operativos "Lamadrid".

Reitero, hasta donde alcanza mi memoria que solo en 2 oportunidades visité la unidad carcelaria de Villa Urquiza; la primera, interesándome en el alojamiento de los detenidos políticos. En la segunda, en oportunidad de mi despedida de la Provincia y de los cargos asumidos, con la misma intencionalidad, el 12 de diciembre de 1977.

Hasta donde es de mi conocimiento, ningún liberado de la cárcel de Villa Urquiza - durante mi mandato - denunció ni hizo constar por profesionales de la salud, signos de tortura alguna.

Tampoco la esposa del ex Senador - en las dos oportunidades que tuvo de contactarse con su esposo, observó ni denunció maltrato alguno; solo "nerviosismo", quizás propio de quién se sabe delator de sus "compañeros de ruta" ante quienes -tarde o temprano- debía "dar la cara" porque conocía que su "colaboración", había trascendido el ámbito carcelario.

El traslado del citado Vargas Aignasse, en un vehículo de la unidad carcelaria a su domicilio, fue a su expreso pedido; todo hace suponer producto del temor por las consecuencias de su delación, por parte de sus delatados. 
El "primer secuestro", como lo denominara el señor Fiscal a la detención del causante, no se compadecería, de manera alguna, con el tiempo dispensado al citado para vestirse despaciosamente, despedirse de cada uno de sus cinco hijos y de su señora esposa, según testimonios ofrecidos por un testigo del Fiscal.

Hablan los testigos vivos y muertos sobre la excarcelación del citado Vargas Aignasse; algunos, presenciales del "hecho", según consta en autos de la Justicia Federal y Militar y en ámbitos policiales (comisarías); solo el Fiscal "baraja" otras hipótesis, explotando el tiempo transcurrido, la avanzada edad y formación de algunos testigos, pretendiendo influir en la opinión pública lo que no pudo probar en este estrado, como una expresión mas de su resentimiento para con mi persona.

El Juez Federal interviniente en oportunidad del "hecho", me notificó oficialmente y poco tiempo después del mismo, los resultados obtenidos de sus diligencias, concordantes con la Justicia Militar, según obra en autos.

Al señor Vargas Aignasse no lo vi ni traté en mi vida, y no obraba en mi poder ni en los organismos que comandaba, antecedente alguno sobre sus actividades.

CONSECUENTEMENTE, NO HABÍA RAZÓN POLÍTICA, MILITAR O PERSONAL ALGUNA PARA PROLONGAR SU DETENCIÓN.

Descarto la posibilidad de haber agraviado su persona; los términos utilizados son propios del lenguaje popular y jerga de los montoneros para con sus delatores; si así no fue entendido, mis sinceras disculpas.

A LOS JUECES QUE HOY TOCA LA RESPONSABILIDAD DE JUZGAR MIS CONDUCTAS -A PESAR DE NO SER MIS JUECES NATURALES- ME PERMITO SEÑALAR QUE, MAS ALLA DEL ALTISIMO HONOR DE SER JUECES DE LA NACION, TAMBIEN LES CABE EL PRIVILEGIO DE SER JUECES DE LA "CUNA DE LA INDEPENDENCIA" EN PELIGRO CIERTO DE SER CONVERTIDA - DESDE LOS MONTES TUCUMANOS - EN "LA SIERRA MAESTRA ARGENTINA" POR LA AGRESION MARXISTA-LENINISTA QUE PROCURABA CONVERTIR A LA ARGENTINA HISTORICA EN UN NUEVO 
SATELITE DEL COMUNISMO INTERNACIONAL, RECLAMANDO SU SOBERANIA A NIVEL MUNDIAL.

SOY UN PERSEGUIDO POR LOS DERROTADOS DE AYER EN LA GUERRA JUSTA $Y$ NECESARIA $Y$ EN LAS URNAS TUCUMANAS, HOY ENCUMBRADOS -EBRIOS DE RENCOR Y DE VENGANZA- EN LOS MAS ALTOS CARGOS DEL GOBIERNO NACIONAL Y PROVINCIAL -EXPLOTANDO EL CALOR OFICIAL- PRESIONANDO A LA JUSTICIA, CON LA PRESENCIA PERMANENTE DE PERSONAJES DE ELEVADO PODER POLITICO, EN AMBITOS JUDICIALES, VIOLENTANDO TODOS LOS PRINCIPIOS DEL DERECHO PENAL, NACIONAL Y UNIVERSAL, COMO INSTRUMENTO DE SUS INCONFESABLES FINES DE DESTRUIRME COMO CIUDADANO, MILITAR Y POLITICO. 


\section{Anexo 8 Mapa del Noroeste argentino (NOA)}

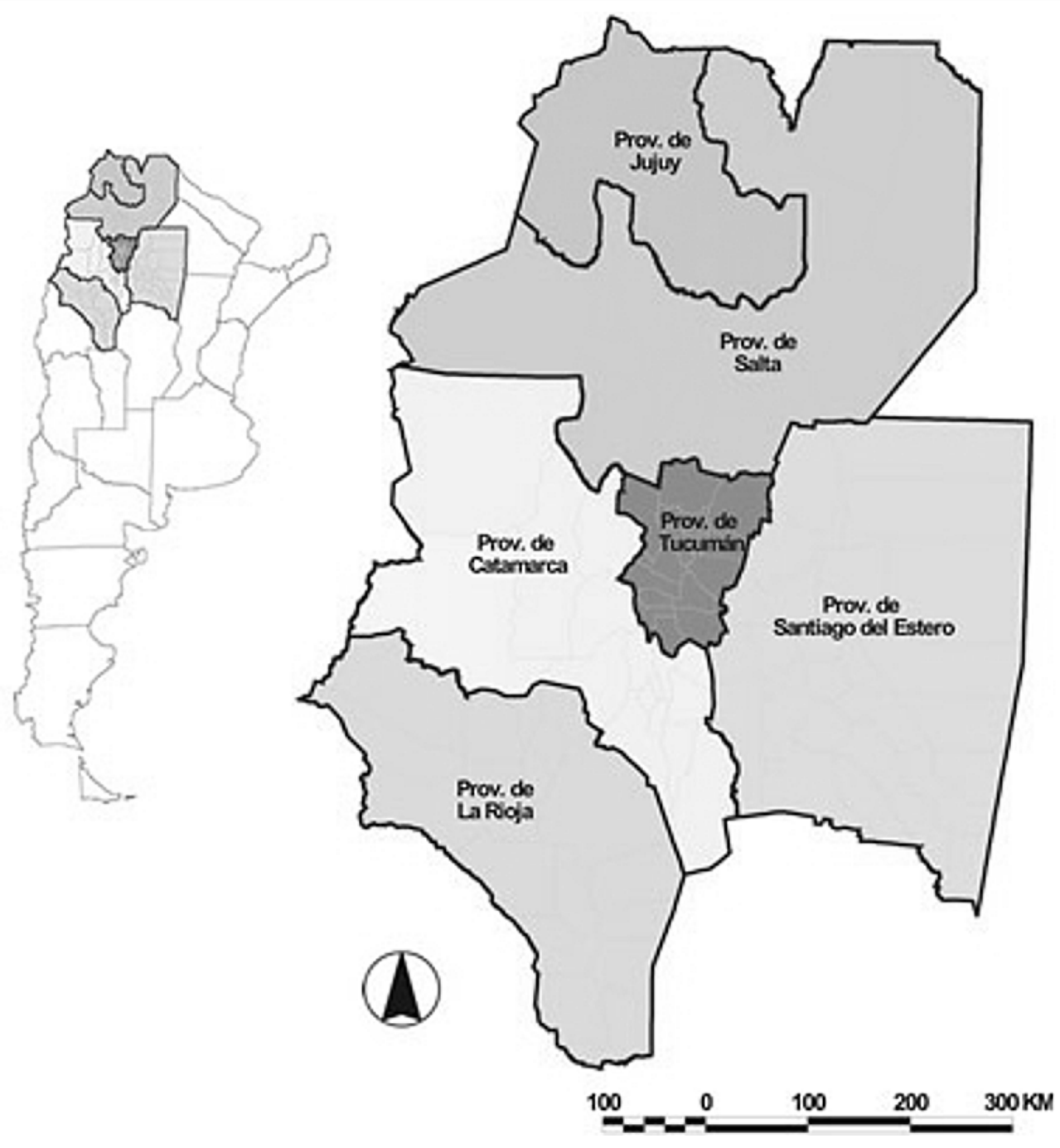


FUENTES 


\section{LAS ENTREVISTAS}

Entre los anexos del presente trabajo, presentamos un DVD con el audio de las entrevistas completas a los militantes del movimiento de derechos humanos de Tucumán. En referencia al conjunto de testimonios ofrecemos aquí las fichas por orden alfabético de quiénes han sido los entrevistados. Me ha parecido oportuno en lugar de ofrecer la transcripción completa de cada una de ellas, ofrecer los audios para su escucha, atendiendo que la producción de las fuentes orales, merecen ser "escuchadas", ya que en la transcripción, se pierde parte del espíritu de lo que los entrevistados quisieron decir, dijeron o expresaron. Asimismo en el cuerpo del trabajo se presentan los fragmentos que considero más relevantes de los testimonios aunque la totalidad de los audios consiguen aportar una mayor solidez a la percepción de los propios entrevistados sobre el pasado vivido y el presente mismo de la entrevista.

Lo que sigue entonces son las fichas que acompañan al DVD con cada una de las referencias:

Relación entrevistas en Orden alfabético.

Entrevistado: ABDALA, Darío

Entrevistador: Rubén Kotler

Fecha de la Entrevista: 12 de noviembre de 2007

Lugar de la entrevista: Tucumán

Organización a la que perteneció: HIJOS

Entrevistada: CARRERAS, Felicidad

Entrevistador: Rubén Kotler

Fecha de la Entrevista: 2009

Lugar de la entrevista: Tucumán 
Organización a la que perteneció: Familiares de Detenidos Desaparecidos por Razones Políticas de Tucumán

Entrevistado: CARRIZO, Raúl

Entrevistador: Rubén Kotler

Fecha de la Entrevista: 15 de octubre de 2007

Lugar de la entrevista: Tucumán

Organización a la que perteneció: Grupo de apoyo a Madres de Plaza de Mayo

Entrevistado: CASTAGNARO, Atilio

Entrevistador: Rubén Kotler

Fecha de la Entrevista: 13 de noviembre de 2007

Lugar de la entrevista: Tucumán

Organización a la que perteneció: Asamblea Permanente por los Derechos Humanos

Entrevistada: CENTURIÓN, Josefina

Entrevistador: Rubén Kotler

Fecha de la Entrevista: 21 de diciembre de 2007

Lugar de la entrevista: Tucumán

Organización a la que perteneció: HIJOS

Entrevistada: CORONEL, María

Entrevistador: Rubén Kotler

Fecha de la Primera Entrevista: 31 de Octubre de 2007

Fecha de la Segunda Entrevista: 29 de noviembre de 2007

Lugar de la entrevista: Tucumán

Organización a la que perteneció: HIJOS 
Entrevistada: FIGUEROA, Laura

Entrevistador: Rubén Kotler

Fecha de la Entrevista: 13 de octubre de 2007

Lugar de la entrevista: Tucumán

Organización a la que perteneció: Asociación de Abogados por los Derechos Humanos

Entrevistad: GARCÍA SALEMI, Valentina

Entrevistador: Rubén Kotler

Fecha de la Entrevista: 30 de octubre de 2007

Lugar de la entrevista: Tucumán

Organización a la que perteneció: HIJOS

Entrevistado: JEAGER, Pablo

Entrevistador: Rubén Kotler

Fecha de la Entrevista: 21 de noviembre de 2007

Lugar de la entrevista: Tucumán

Organización a la que perteneció: Asamblea Permanente por los Derechos Humanos

Entrevistada: MAZZAMUTO, Alicia

Entrevistador: Rubén Kotler

Fecha de la Entrevista: 13 de noviembre de 2007

Lugar de la entrevista: Tucumán

Organización a la que perteneció: Asamblea Permanente por los Derechos Humanos

Entrevistada: MRAD, Sara 
Entrevistador: Rubén Kotler

Fecha de la Primera Entrevista: 2 de noviembre de 2007

Fecha de la Segunda Entrevista: 5 de diciembre de 2007

Lugar de la entrevista: Tucumán

Organización a la que perteneció: Madres de Plaza de Mayo, Filial Tucumán

Entrevistada: NASSIF, Ángela

Entrevistador: Rubén Kotler

Fecha de la Entrevista: 6 de diciembre de 2007

Lugar de la entrevista: Tucumán

Organización a la que perteneció: Partido Comunista Revolucionario. Desde el partido apoyó y colaboró con Madres de Detenidos Desaparecidos de Tucumán y fue co-fundadora de la Asamblea Permanente por los Derechos Humanos de Tucumán

Entrevistada: NOLI, Alicia

Entrevistador: Rubén Kotler

Fecha de la Entrevista: 28 de noviembre de 2007

Lugar de la entrevista: Tucumán

Organización a la que perteneció: Asociación de Abogados por los Derechos Humanos

Entrevistada: PEREYRA, Carolina

Entrevistador: Rubén Kotler

Fecha de la Entrevista: 8 de noviembre de 2007

Lugar de la entrevista: Tucumán

Organización a la que perteneció: HIJOS

Entrevistada: RIVERO, Vilma 
Entrevistador: Rubén Kotler

Fecha de la Primera Entrevista: 22 de noviembre de 2007

Fecha de la Segunda Entrevista: 5 de diciembre de 2007

Lugar de las entrevistas: Tucumán

Organización a la que perteneció: Familiares de Detenidos Desaparecidos por Razones- Políticas de Tucumán

Entrevistada: SALVATIERRA, Susana

Entrevistador: Rubén Kotler

Fecha de la Entrevista: 29 de noviembre de 2007

Lugar de la entrevista: Tucumán

Organización a la que perteneció: HIJOS

Entrevistada: SOLDATI, Carlos

Entrevistador: Rubén Kotler

Fecha de la Entrevista: 1 de diciembre de 2007

Lugar de la entrevista: Localidad de Simoca (Tucumán)

Organización a la que perteneció: Familiares de Detenidos Desaparecidos de Tucumán, Madres de Detenidos Desaparecidos de Tucumán y co fundador de la Asamblea Permanente por los Derechos Humanos en Tucumán en 1984. Además tuvo una destacada participación en el Juicio Ético que le hicieron a Bussi las organizaciones de derechos humanos en junio de 1995, donde simbólicamente prestó testimonio sobre la desaparición de sus hermanos y su propia detención.

Entrevistada: VELASCO, Ilda

Entrevistador: Rubén Kotler

Fecha de la Entrevista: 4 de octubre de 2007

Lugar de la entrevista: Buenos Aires 
Organización a la que perteneció: Familiares de Detenidos Desaparecidos por Razones Políticas de Buenos Aires

Entrevistada: VICENTE, Viviana

Entrevistador: Rubén Kotler

Fecha de la Entrevista: 12 de noviembre de 2007

Lugar de la entrevista: Tucumán

Organización a la que perteneció: HIJOS

Entrevistado: VIDELA, Ramón

Entrevistador: Rubén Kotler

Fecha de la Entrevista: 4 de octubre de 2007

Lugar de la entrevista: Buenos Aires

Organización a la que perteneció: Familiares de Detenidos Desaparecidos por Razones Políticas de Buenos Aires

Entrevistada: VITAR, Julia

Entrevistador: Rubén Kotler

Fecha de la Entrevista: 31 de octubre de 2007

Lugar de la entrevista: Tucumán

Organización a la que perteneció: HIJOS

$---$

Entrevistado: ZAMORANO, Carlos

Entrevistador: Rubén Kotler

Fecha de la Entrevista: 8 de agosto de 2008

Lugar de la entrevista: Buenos Aires

Organización a la que perteneció: Partido Comunista - Liga por los Derechos Humanos (Organización cuya antigüedad se remonta a 1937 y está vinculada al Partido Comunista). 


\section{FUENTES AUDIO-VISUALES}

- Filmación casera del Juicio Ético a Bussi. Formato VHS digitalizado.

- Audios completos del Juicio de Jefatura, año 2010. Archivo cedido por el Tribunal Oral Federal de Tucumán.

\section{OTRAS FUENTES CONSULTADAS}

\section{EN INTERNET}

- www.madres.org

- www.madres-lineafundadora.org.ar

- www.cels.org.ar

- www.derechos.org/serpaj

- www.apdh.com.ar

- www.famdescba.org.ar/H.I.J.O.S.

- www.nuncamas.org.ar

- www.ddhhtucuman.com

- www.desaparecidos.org

\section{FILMOGRAFÍA}

Aliverti, Eduardo (1996): Malajunta. Eduardo Aliverti y Crears producciones, Buenos Aires.

APDH (2008): El juicio a los genocidas en Neuquén y Alto Valle. APDH Neuquén.

Blaunstein, David (1996): Cazadores de Utopía.

Bruck, Violeta; Jaime, Gabi y Gabino, Javier (2012): Memoria para reincidentes. Lucha y militancia obrera en los 70 , Contraimagen.

Calcagno, Eduardo (1995): El Censor. Eduardo Calcagno - INCAA. 
Cartoy Díaz, Emilio (2000): "20 años, 20 poemas, 20 artistas. Vídeo homenaje a las Madres de Plaza de Mayo". Página 12 y asociación Madres de Plaza de Mayo.

Heluani, Diego (2007): El Tucumanazo. Cine Independiente producciones.

Lejtman, Roman (2001): El Proceso. Roman Lejtman y Editorial Perfil.

Magliocca, Eugenio (2009): Arderá la memoria, hasta que todo sea como lo soñamos. Grupo de apoyo a Madres de Rosario.

Meerapfel, Jeanine (1988): La Amiga. Jorge Mora Estrada Producciones S.A. (Buenos Aires)/ Journal Film KG (Berlín)/ Alma Film (Berlín).

Milstein, Pablo y Ludin , Norberto (2003): Sol de Noche. Con la investigación y relatos del periodista Eduardo Aliverti

Olivera, Héctor (1986): La noche de los Lápices. Aries Cinematográfica Argentina S.A., Buenos Aires.

\section{FUENTES ESCRITAS}

\section{Periódicos}

- La gaceta de Tucumán

- La Tarde de Tucumán (Edición vespertina del diario La Gaceta de Tucumán)

- El Periódico de Tucumán

- Clarín

- La Nación

- Página 12

- El País de Madrid 


\section{REVISTAS}

- Colección revista Voces Recobradas

- Cuadernos de emancipación (1996): "Cultura, música popular y luchas de clases". Dirigido por Bossi, F. Ramón, No 11, Bs. As.

- Historia, Antropología y Fuentes Orales. No 24: Recordar el Olvido. Año 2002. Editado por la Universidad de Barcelona.

- Locas. Cultura y Utopía. Nº, 1, 2, 3, 4.

- Puentes. N 1 - Agosto 2000.

- Revista de Clarín VIVA: N 1356, 28 de Abril de 2002.

- Revista de la Fundación Plural no 9. "Tucumán: el caso Bussi", dirigida por H. López Echagüe.

- Revista Prohistoria 11: Historia Reciente y Dictadura. Argentina, 1976-1983, Primavera 2007.

- Todo es Historia. No 394 - Mayo 2000.

- Tres Puntos. N 33/ Febrero, 1998 - N49/ Junio 1998.

\section{DOCUMENTOS E INFORMES CONSULTADOS}

- Informe de la CIDH, Comisión Interamericana de Derechos Humanos, 14 de Diciembre de 1979.

- Report of an Amnesty Internacional Misión to Argentina, 6 - 13 November 1976 en www.amnesty.org

- Informe de la Comisión Nacional sobre la Desaparición de Personas, EUDEBA, Bs. As., 1995.

- Informe de la Comisión Bicameral Investigadora de las Violaciones de Derechos Humanos en la Provincia de Tucumán. IEPALA, Salamanca, 1991.

- Grabación del Juicio Ético de Bussi realizado el 19 de Junio de 1995 en la provincia de Tucumán.

- Acta Fundacional del Movimiento de Madres de Detenidos Desaparecidos de Tucumán. 
- Libro de Actas del Movimiento de Madres de Detenidos Desaparecidos de Tucumán.

- Sentencia del Juicio Ético a Bussi del 19 de junio de 1995.

- Presentación de la Impugnación de la Candidatura de Bussi a la Intendencia de San Miguel de Tucumán (2003).

- Fallo contra el cura castrense Christian Federico Von Wernich en el que se le sentencia a reclusión perpetua por el crimen de genocidio en la ciudad de La Plata. Causa 2506/07.

http://www.apdhlaplata.org.ar/Fundamentos\%20VW

$\% 20$ chico.pdf

- Documento con la elevación a juicio de la causa "Operativo Independencia" del 27 de diciembre de 2012 (1975/marzo de 1976) Expte. $401015 / 04$ y $401016 / 04$ y conexas

http://www.cij.gov.ar/adj/pdfs/ADJ-0.602312001356710481.pdf

- Sentencia del Juicio sobre Desaparición del ex senador Guillermo Vargas Aignase:

http://www.pjn.gov.ar/Publicaciones/Fijo/TOF_TUC_VARGAS.Pdf

- "JEFATURA DE POLICIA CCD S/Secuestros y Desapariciones (2do Grupo) Expte. n 795/04 y conexos":

http://www.cij.gov.ar/nota-4681-Lesa-humanidad--procesan-enTucuman-a-ocho-ex-policias.html

- Diario de campaña de Acdel Vilas: Tucumán, enero a diciembre 1975. Mimeo 


\section{FUENTES FOTOGRÁFICAS}

\section{MESA DEBA'TE DESAPARICION FORZADA DE PERSONAS Y LEY DE AMNISTIA \\ PARTICIPAN}

ORGANISMOS DE DEFENSA DE DERECHOS HUMANOS

FAMILIARES DE DESAPARECIDOS Y DETENIDOS POR RAZONES POLITICAS

CELS (CENTRO DE ESTUDIOS LEGALES Y SOCIALES)

LIGA ARGENTINA POR LOS DERECHOS DEL HOMBRE

ORGANIZAN

DE DETENIDOS-DESAPARECIDOS DE TUCUMAN ADHIEREN

MADRES DE PLAZA DE MAYO

SABADO 30 DE JULIO Hs. 17

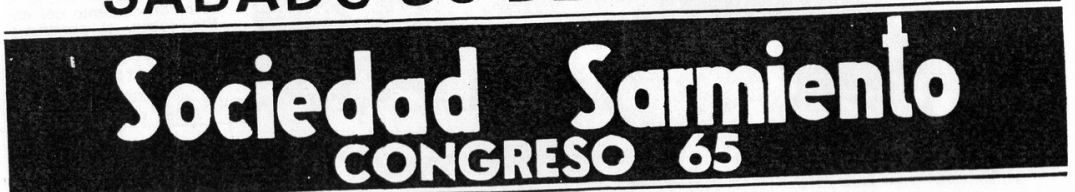

Invitación a Mesa debate pública sobre el tema "Desaparición Forzada de Personas". Convocaba el movimiento de derechos humanos en el "deshielo" de la dictadura / Panfleto del 30 de julio de 1983.

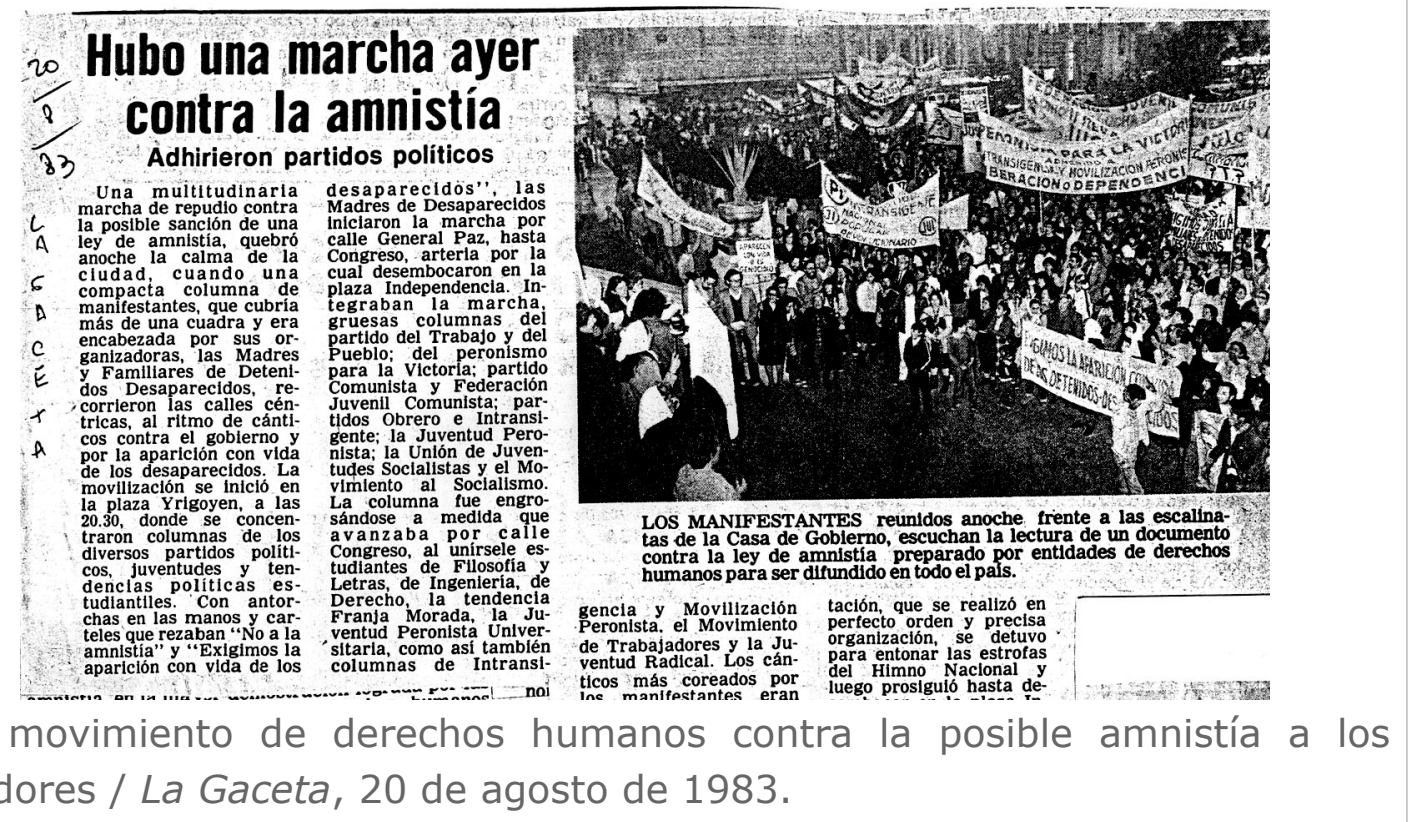




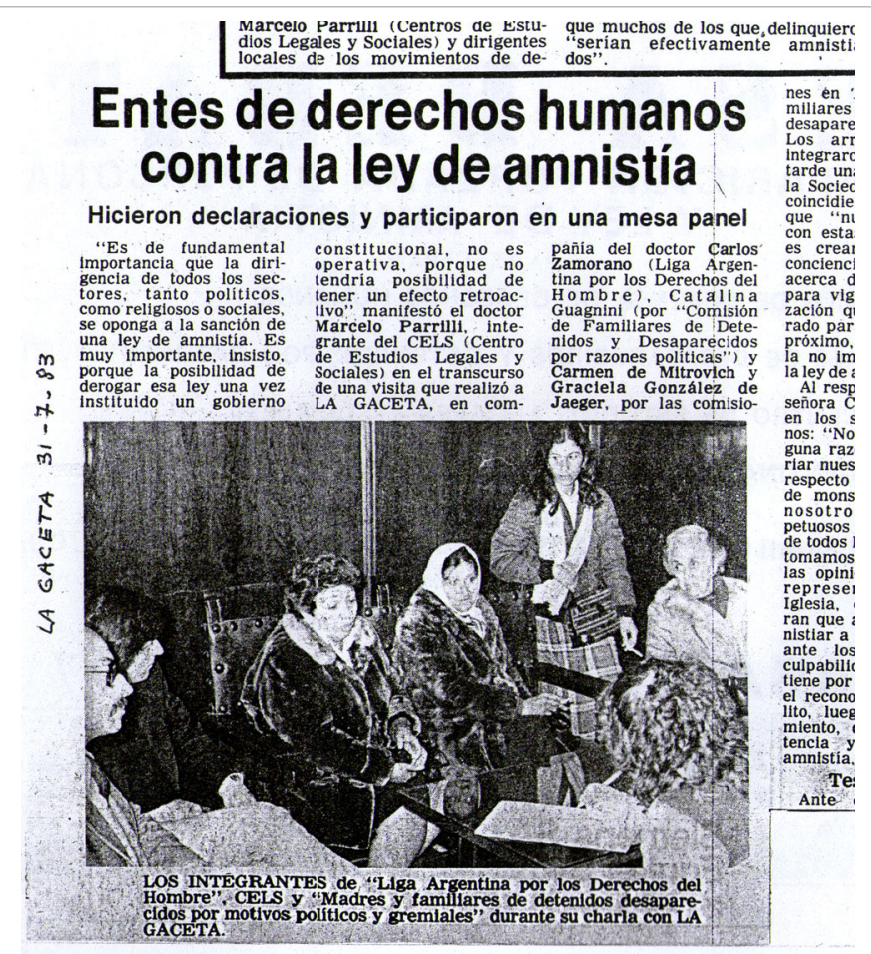

Organizaciones de derechos humanos contra la ley de amnistía. Noticia sobre la mesa panel convocada el día anterior / La Gaceta, 31 de julio de 1983.

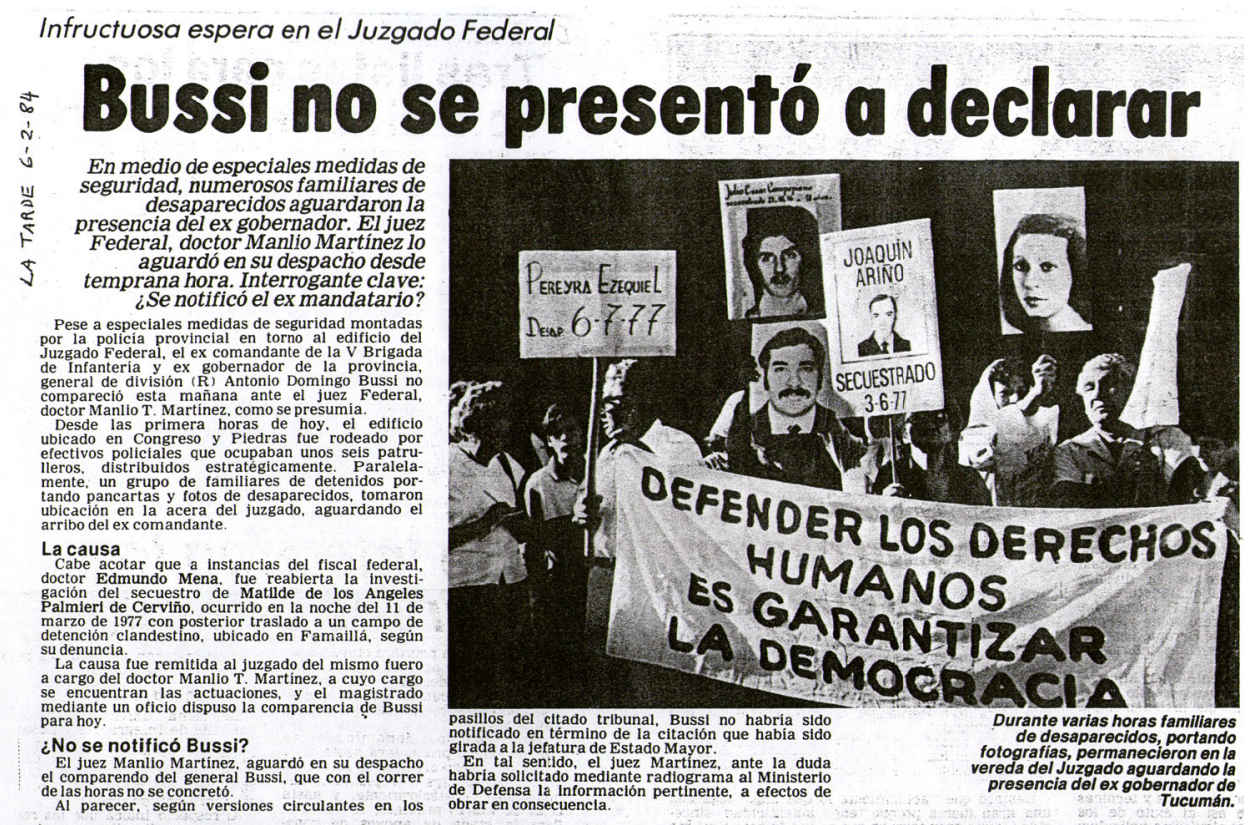

Negativa de Bussi a declarar en el proceso del enjuiciamiento en los albores de la transición / La Tarde, 6 de febrero de 1984. 


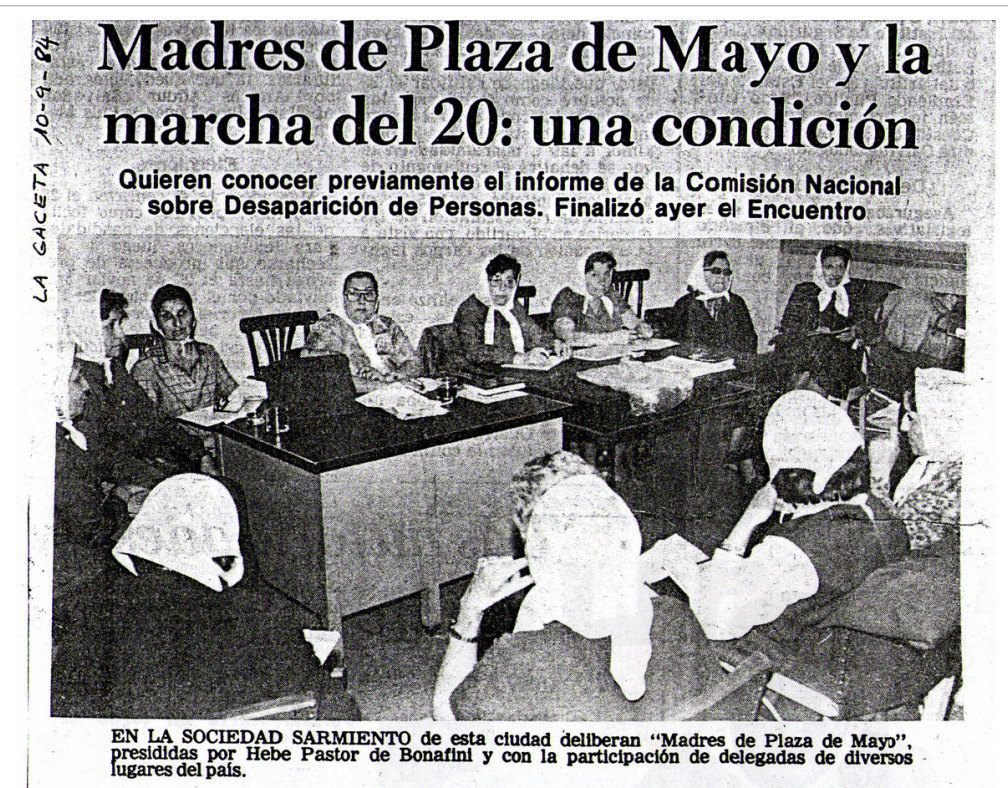

Las Madres de Detenidos-desaparecidos de Tucumán ya como filial de M. de Plaza de Mayo reciben a su presidenta, Hebe de Bonafini / La Gaceta, 10 de septiembre de 1984.

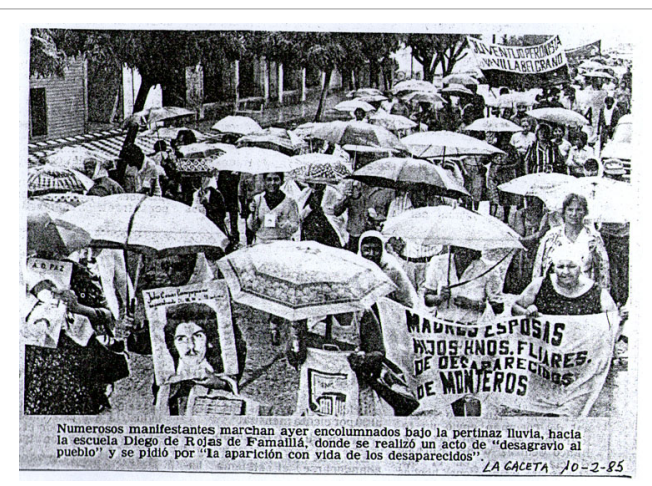

Marcha del movimiento de Derechos Humanos de Tucumán en la "Escuelita" de Famaillá, donde funcionó el primer Centro Clandestino de Detención en la provincia / La Gaceta, 10 de febrero de 1985. 


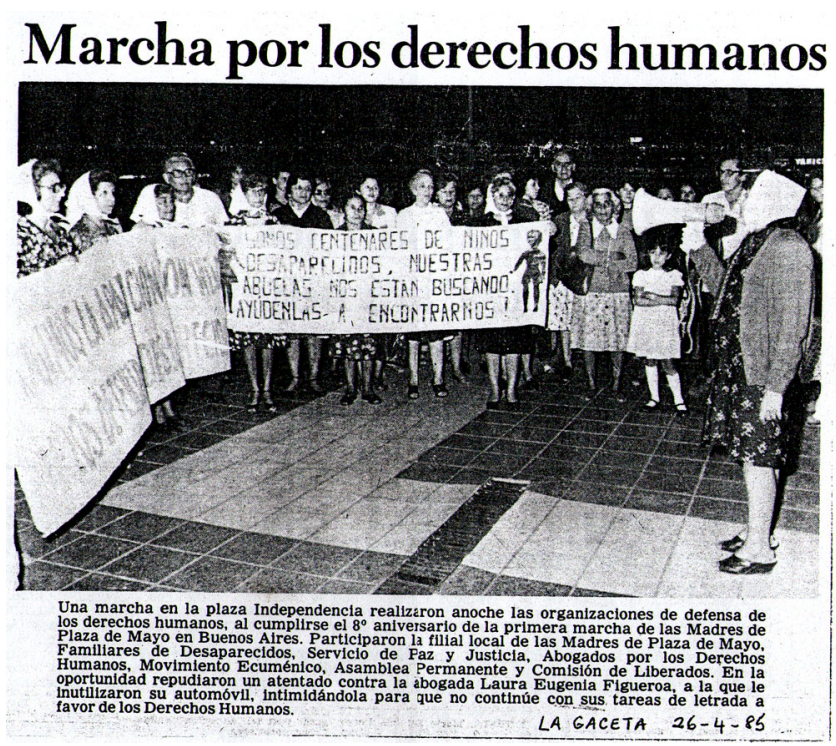

Marcha del movimiento de Derechos Humanos de Tucumán exigiendo la "aparición con vida" de los desaparecidos / La Gaceta, 26 de abril de 1985.
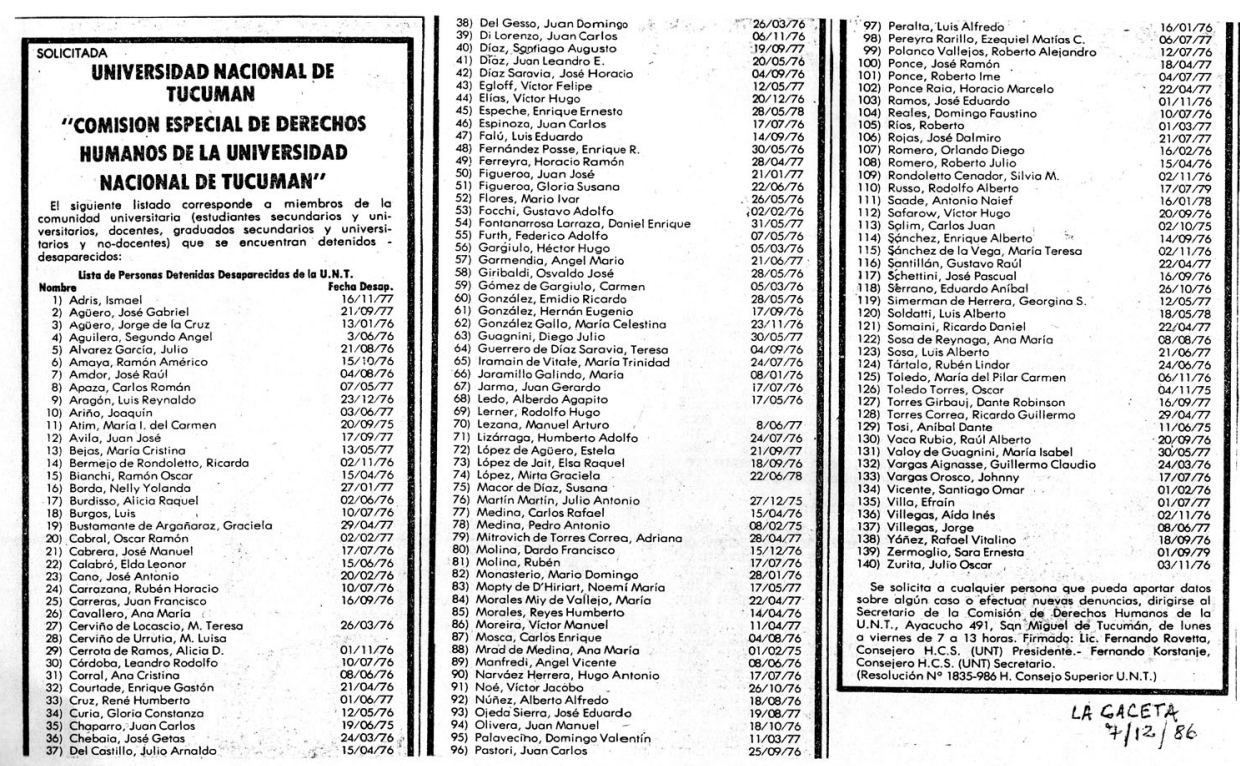

Solicitada de la Universidad Nacional de Tucumán con la nómina de los miembros de la comunidad universitaria desaparecidos / La Gaceta, 7 de diciembre de 1986. 


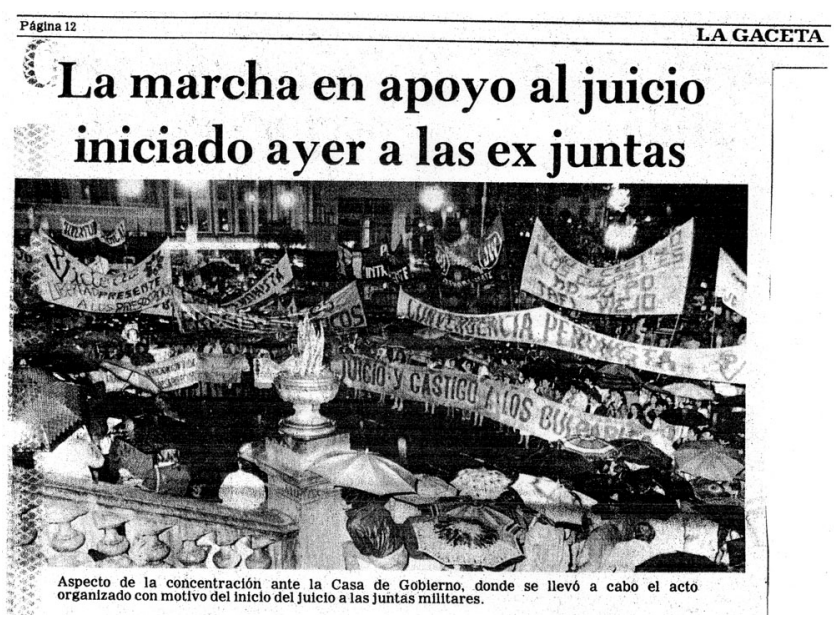

Marcha del movimiento de Derechos Humanos de Tucumán en apoyo al juicio a las Juntas / La Gaceta, (sin registro del día) de 1985.

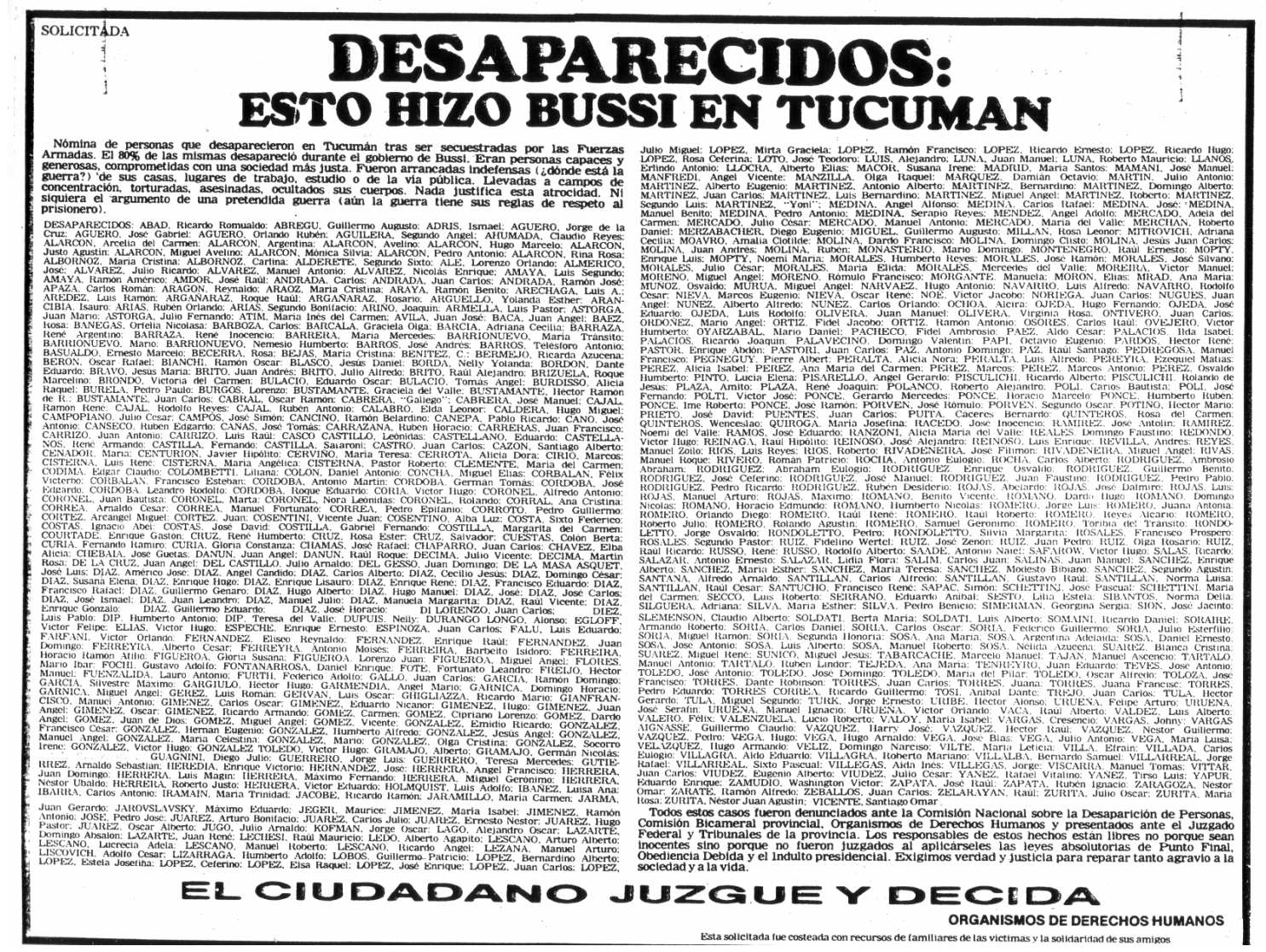

Nómina de desaparecidos de Tucumán. Aparecido en una gigantografía que fue pegada en distintos puntos de la ciudad. 
que habia sido premiado en el concurso Jacques Prévert. Para la oportunidad llegaba a la provincia el agregado cultural de la embajada de Francia. Al escenario del teatro San Martín subió uno de sus hermanos, para recibir el premio.

"Mi hijo era un estudiante, pero por sobre todas las cosas amaba la vida, pero en un esquema diferente al que se estaba viviendo o al que se vive hoy. Es el más inteligente y el más sensible de todos mis hijos y jamás lo recuerdo ni torturado ni asesinado. Sólo lo recuerdo creciendo. Hoy tendría 41 años", reflexionó Adelaida. do a todos sus adversarios políticos como "llevar de las orejas o de las pestañas a esos enanos de la política para que paguen por sus culpas". Hoy será un día agitado en Tucumán. La actividad de las Madres comenzará temprano. Durante la maf̃ana entregarán a los legisladores provinciales y nacionales de Tucumán un preproyecto de ley sobre el Arsenal Miguel de Azcuénaga para rescatar el edificio como un monumento a la memoria de los desaparecidos. Cerca del mediodía las $\mathrm{Ma}$ dres estarán en la peatonal San Miguel de Tucumán entregando mate-

\section{7 - 30 de abril - 1998}

Las Madres de Plaza de Mayo -Línea Fundadora-, a 21 años del Primer Encuentro en la Plaza de Mayo el 30 de abril de 1977, marcharemos en la Plaza Independencia de San Miguel de Tucumán, el jueves 30 de abril. Los invitamos a acompañarnos en este lugar, que hemos elegido como repudio al represor Domingo Bussi, responsable de miles de desapariciones y asesinatos.

Nos reuniremos junto a las Madres y Familiares de Desaparecidos del país para repudiar los crímenes de ayer y de hoy.

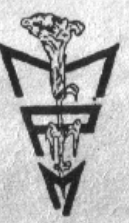

$$
\begin{gathered}
\text { Madres de Plaza de Mayo. } \\
\text { Sinea Fundadera }
\end{gathered}
$$

Página 6 Jueves 30 de abril de 1998

Solicitada de Madres de Plaza de Mayo, Línea Fundadora, convocando a su marcha en Tucumán en apoyo al movimiento de derechos humanos local para repudiar al gobernador Antonio D. Bussi / Página 12, 30 de abril de 1998. 


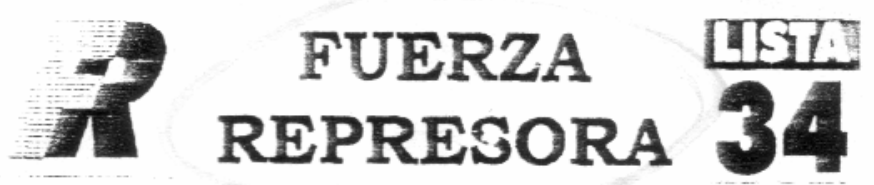

ELECCIONES NACIONALES DEL 26 DE OCTUBRE DE 1997

-DISTRITO TUCUMÁN-

(LA TIERRA DEL NOMEACUERDO)

No doy mi voto para perpetuar al asesino en s sitio de poder, a través de su engendro

\section{TITULARES}
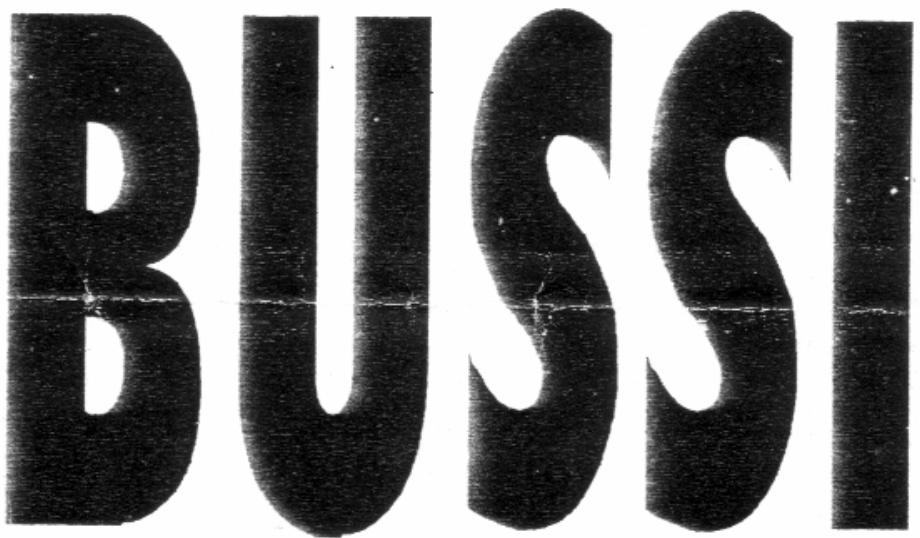

Ricardo Argentino (futuro genocida)
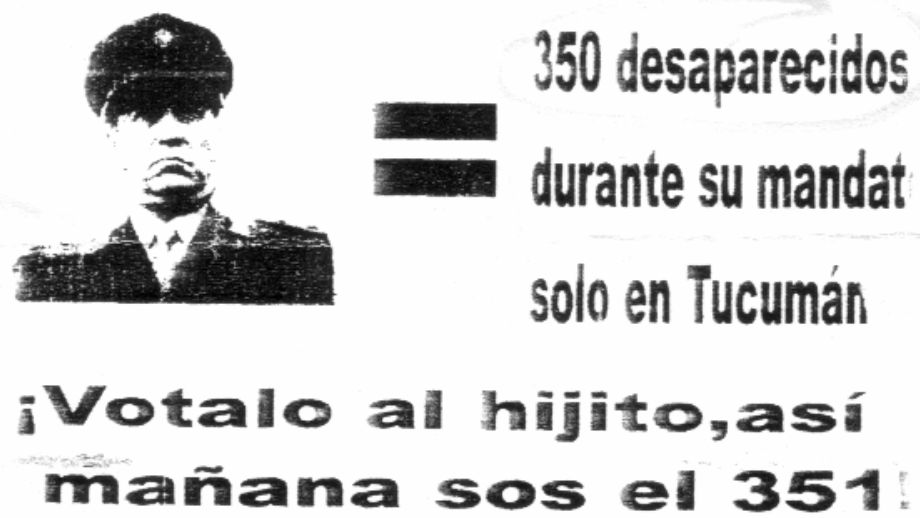

Un panfleto en el que se emula la papeleta electoral en el que se denuncia al partido de Bussi, Fuerza Republicana. 


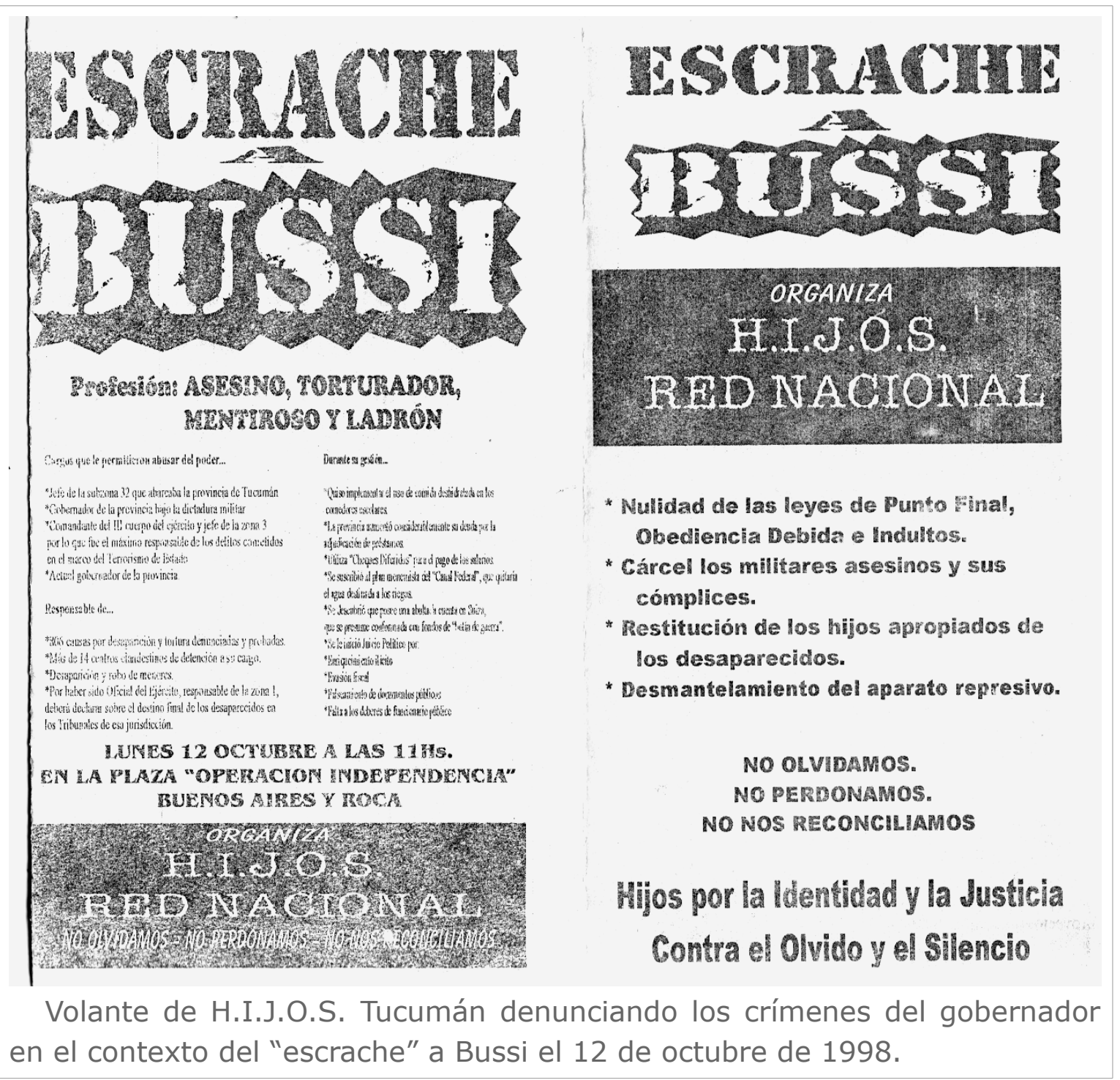


Bibliografía TemÁtica 


\section{MOVIMIENTOS SOCIALES}

AAVV (1992): Los Nuevos movimientos sociales: un reto al orden político. Eds. Alfons el Magnànim, Valencia.

BIANCHI, Susana (1992): "Historia de las mujeres o mujeres en la historia", en Reynoso, N., Sampaolasi, A., Sommer, Susana (comp.). Feminismo, Editorial Humanitas. Buenos Aires.

CALDERÓN Fernando (1986): "Los movimientos sociales ante la crisis". Editado por la Universidad de las Naciones Unidas (UNU) y CLACSO. Bs. As.

CANO, Inés (1982): "La mujer en la Historia Argentina", en Todo es Historia, Buenos Aires.

FEIJOÓ, María del Carmen: "La trampa del afecto: Mujer y democracia en Argentina".

FEIJOÓ, María del Carmen; GoGNA, Mónica (1986): "Las Mujeres en la transición a la democracia". En E. Jelín (ed) Los nuevos movimientos sociales. CEAL. Bs. As.

FERNÁNDEZ, Arturo (1991): "Movimientos Sociales en América Latina". Aique Grupo Editor. Bs. As.

FILC, Judith (1997): "Entre el parentesco y la política. Familia y dictadura, 1976-1983". Ed. Biblos. Buenos Aires.

GINGOLD, Laura; Vázquez, Inés (1998): "Madres de Plaza de Mayo", en Nueva Sociedad, No 93, Caracas.

IBARRA Pedro y TEJERINA Benjamín comps. (1998): Los Movimientos Sociales. Transformaciones políticas y cambio Cultural. Editorial Trotta, Valladolid.

JELÍN, Elizabeth comp. (1987): Movimientos Sociales y democracia emergente, T. 1. Centro Editor de América Latina, Buenos Aires. 
JELÍN, Elizabeth comp. (1987): Movimientos Sociales y democracia emergente, T. 2. Centro Editor de América Latina, Buenos Aires.

LARAÑA, Enrique (1999): La construcción de los Movimientos Sociales. Edit. Alianza, Madrid. (H/con FF-7 428 facultad geografía e historia USAL)

MAIER, Elizabeth (2001): Las madres de los desaparecidos. ¿Un nuevo mito materno en América Latina?, Cultura Universitaria, Serie Ensayo No 70, México.

MC ADAM, Dough; D. MACCARTHY, John y ZALD, Mayer eds. (1999): Movimientos Sociales: perspectivas comparadas. Edit Istmo, Madrid.

MEDICI, Alejandro (2000): El movimiento de Derechos Humanos en Argentina y la lucha contra la impunidad: la estrategia del escrache, en Revista latinoamericana de política, filosofía y derecho, No 17.

RIECHMANN, Jorge y FERNÁNDEZ BUEY, Francisco (1994): Redes que dan libertad. Introducción a los nuevos movimientos sociales. Edit PAIDÓS, Barcelona.

RUBIO, María Amalia comp. (2005): Espacios de Género, Colegio de Michoacán.

SZTOMPKA, Piotr (1995): "Sociología del Cambio Social". Ed. Alianza, Madrid.

TARROW, Sidney (1997): El poder en movimiento. Los movimientos sociales, la acción colectiva y la política. Edit. Alianza, Madrid.

TOURAINE, Alain (1984): "Los Movimientos Sociales". Ed. Almagesto. Buenos Aires.

TOURAINE, Alain (1989): "América latina. Política y Sociedad". Ed. Espasa Calpe, Madrid.

TOURAINE, Alain (1995): ¿Qué es la democracia? FCE, Montevideo. 


\section{Movimiento de DeReChos Humanos}

ABUELAS de Plaza de Mayo (2007): Niños desaparecidos, jóvenes localizados en la Argentina desde 1975 a 2007, Abuelas de Plaza de Mayo, Buenos Aires.

ARROSAGARAY, Enrique (1993): Los Villaflor de Avellaneda, Ediciones de la Flor, Buenos Aires

ARROSAGARAY, Enrique (2011): Biografía de Azucena Villaflor, CEA, Avellaneda.

ARROSAGARAY, Enrique (2011): Josefina pepa de Noia. Una Madre de la primera hora, Hombre Nuevo Editoria, Buenos Aires.

ALONSO, Luciano (2011): Luchas en plazas vacías de sueños. Movimiento de derechos humanos, orden local y acción antisistémica en Santa Fe, Prohistoria Ediciones, Rosario.

ALONSO, Luciano (2008): El surgimiento del movimiento argentino por los derechos humanos en perspectiva comparada, en revista digital de la escuela de historia - unr / año $1-n^{\circ} 1$ / Rosario, 2008.

AZCONEGUI, Cecilia (2009): Madres, militantes o resistentes. La definición de identidades en el movimiento de derechos humanos en el Alto Valle de Río Negro y Neuquén (1976-1983), presentado en Primer Congreso Nacional Sobre Protesta Social, Acción Colectiva y Movimientos Sociales, Buenos Aires, Mimeo

ASOCIACIÓN Madres de Plaza de Mayo (1995): Historia de las Madres de la Plaza de Mayo, Ediciones Asociación Madres de Plaza de Mayo. Buenos Aires.

ASOCIACIÓN Madres de Plaza de Mayo (1999): "Massera. El genocida." Ed. La Página. Buenos Aires.

ASOCIACIÓN Madres de Plaza de Mayo (2002): Luchar siempre. Las marchas de la resistencia 1981 - 2001, Ediciones Asociación Madres de Plaza de Mayo. Buenos Aires.

BIANCHI, Susana y SANCHÍS, Norma (1987): "Las madres de la Plaza de Mayo: la politización de lo doméstico", Deslinde no 17, 
Vol. VI, Facultad de Filosofía y Letras de la Universidad Autónoma de Nuevo León. México.

BOUSQUET, Jean Pierre (1983): "Las Locas de la Plaza de Mayo".

El Cid Editor, Buenos Aires.

CASTRO, Reynaldo (2008): Con vida los llevaron. Memorias de Madres y Familiares de detenidos - desaparecidos de San Salvador de Jujuy, Argentina, Edi. UNJU, Jujuy.

DIOGO, Alejandro (1988): Conversando con las Madres de Plaza de Mayo. Hebe, Memoria y Esperanza, Ediciones Dialéctica, Buenos Aires.

ECKSTEIN, Susan coordinadora (2001): Poder y Protesta Popular. Movimientos Sociales Latinoamericanos. Edit. Siglo XXI, México.

EHLSTEIN, Jean (1991): "Mothers against the authoritarian state", XV Congreso Internacional de la Asociación de Ciencia política, Buenos Aires.

FAMILIARES de Detenidos por Razones Políticas (2006): La lucha que reivindica la lucha. Testimonios de nuestra historia, 1976 2006.

FERNÁNDEZ, Arturo (1994): "El testimonio de una Madre". En: Movimientos de mujeres y pobreza en América Latina. Homo Sapiens Ediciones. Rosario.

GELMAN, Juan y La Madrid, Mara (1996): Ni el Flaco Perdón de Dios. H.I.J.O.S. de Desaparecidos. Editorial Planeta, Buenos Aires.

GORINI, Ulises (2011): La rebelión de las Madres. Historia de las Madres de Plaza de Mayo, T.I (1976 - 1983), Edit. Norma Página 12, Buenos Aires.

GORINI, Ulises (2011): La rebelión de las Madres. Historia de las Madres de Plaza de Mayo, T.II (1983 - 1986), Edit. Norma Página 12, Buenos Aires. 
JEGER, Graciela (2010): A boca de jarro. Escritos en el Periódico de Madres y otros textos, Ediciones Madres de Plaza de Mayo, Buenos Aires.

KOTLER, Rubén (2006): Los Movimientos Sociales: Formas de resistencia a la dictadura. Madres de Detenidos - Desaparecidos de Tucumán, Facultad de Filosofía y Letras de la UBA; Buenos Aires.

MORALES, Ma. Virginia (2010): De la cocina a la plaza. La categoría "madre" en el discurso de las Madres de Plaza de Mayo, Eduvim, Córdoba.

SCOCCO, Marianela (2012): "La historia de una búsqueda. Darwinia Gallicchio, Madre y Abuela de Plaza 25 de Mayo de Rosario", en Revista Aletehia, vol. 3, núm. 5, La Plata, diciembre 2012

SITUACIONES (2002): Genocida en el barrio. Mesa de escrache popular. Ediciones De mano en mano, Buenos Aires.

SOLÍs, Ana Carol (2011): Los derechos humanos en la inmediata posdictadura. (Córdoba, 1983-1987) en Revista Estudios - $\mathrm{N}^{\circ}$ 25 -ISSN 0328-185X (Enero-Junio 2011) 83- 100.

VEIGA, Raúl (1985): Las organizaciones de derechos humanos. Biblioteca Política Argentina, Centro Editor de América Latina, Buenos Aires.

\section{GENOCIDIO}

CALVEIRO, Pilar (2012): Violencias de estado. La guerra antiterrorista y la guerra contra el crimen como medios de control global, Edit. S XXI, Buenos Aires.

CHALK, Frank y JONASSOHN, Kurt (2010): Historia y sociología del genocidio. Análisis y estudio de casos, Prometeo EDUNTREF, Buenos Aires. 
LACAPRA, Dominick (2008): Representar el holocausto. Historia, teoría y trauma, Prometeo, Buenos Aires.

FEIERSTEIN, Daniel (2007): El genocidio como práctica social. Entre el nazismo y la experiencia argentina. Edit. Fondo de Cultura Económica, Buenos Aires.

FEIERSTEIN, Daniel comp. (2005): Genocidio: La administración de la muerte en la modernidad, Edit. Eduntref, Buenos Aires.

FEIERSTEIN, Daniel comp. (2009): Terrorismo de estado y Genocidio en América Latina, Prometeo - EDUNTREF, Buenos Aires.

MÁNTARAS, Mirta (2005): Genocidio en Argentina, Buenos Aires.

\section{HISTORIA ARgENTINA}

ANDÚJAR, A., D'ANTONIO, D., GIL LOZANO, F. y otros comps. (2009): De minifaldas, militancias y revoluciones. Exploraciones sobre los 70 en la Argentina, Ediciones Luxemburg, Buenos Aires.

BAYER, Osvaldo (1994): "Rebeldía y Esperanza". Ediciones B Grupo Z. Buenos Aires.

CAVAROZZI, Marcelo (1993): El sentido de la democracia en la América Latina contemporánea, en Perfiles Latinoamericanos, FLACSO, No 2, México.

CRENZEL, Emilio A (1996): "Crisis social y transformación de la subjetividad social: la emergencia de fuerzas políticas autoritarias de masa. Tucumán, 1995: el Bussismo". En Actas del $1^{\circ}$ Congreso de Investigación Social, región y sociedad en Latinoamérica. Su problemática en el NOA. Tucumán.

CRENZEL, Emilio A. (1991): "El Tucumanazo 1969 - 1964" Tomos I y II. Centro Editor de Latinoamérica, Bs. As.

DE RIZ, Liliana (2000): "Historia Argentina: La política en suspenso. 1966/1976". Ed. Paidós. Buenos Aires. 
GALEANO, Eduardo (1988): "Memoria del fuego". T.III. Ed. S. XXI, Buenos Aires.

GIUSSIANI, Pablo (1997): "Montoneros, la soberbia armada". Ed. Planeta Bolsillo. Buenos Aires.

GONZÁLEZ JANZEN, Ignacio (2a Edición): La Triple A. Edit. Contrapunto, Buenos Aires.

HOBSBAWM, Eric (1996): "Historia del Siglo XX". Ed. Crítica. Barcelona.

HOROWIKZ, Alejandro (1985): Los cuatro Peronismos. Editorial Legasa, Buenos Aires.

JAMES, Daniel (2010): Resistencia e integración, el peronismo y la clase trabajadora argentina, Edit. S XXI, Buenos Aires.

JANZEN, Ignacio G. (1987): "La Triple A". Ed. Contrapunto. Buenos Aires.

JAURATA, Francisco Comp. (1998): "Escenarios de la Globalización. Una mirada crítica desde las Ciencias Sociales". Ed. Homo Sapiens. Rosario, Santa Fé.

LONGONI, Ana y MESTMAN, Mariano (2008): Del Di tella a "Tucumán Arde". Vanguardia artística y política en el 68 argentino, EUDEBA, Buenos Aires.

MUCHNIK, Daniel (1998): "Argentina Modelo. De la furia a la resignación. Economía y política entre 1973 y 1998". Ed. Manantial, Buenos Aires.

NASSIF, Silvia (2012): Tucumanazos. Una huella histórica de luchas populares, 1969-1972, Inst. de Investigaciones históricas R. L. Pinto, Facultad de Filosofía y Letras de la Univ. Nac. De Tucumán.

NECOECHEA GRACIA, Gerardo y PENSADO L., Patricia Comps. (2010): Voltear el mundo de cabeza. Historias de militancia de izquierda en América Latina, Imago Mundi, Buenos Aires. 
NECOECHEA GRACIA, Gerardo y MONTENEGRO, Antonio Comps (2011): Caminos de historia y memoria en América Latina, RELAHO - Imago Mundi, Buenos Aires.

NOVARO, Marcos (2010): Historia de Argentina, 1955 - 2010, Edit. S. XXI, Buenos Aires.

O'Donnell, Guillermo (1997): Contrapuntos. Ensayos escogidos sobre autoritarismo y democratización. Paidós. Buenos Aires.

OSZLAK, Oscar comp. (1984): "Proceso", crisis y transición democrática / 1. Biblioteca Política Argentina, Centro Editor de América Latina, Buenos Aires.

OSZLAK, Oscar comp. (1984): "Proceso", crisis y transición democrática / 2. Biblioteca Política Argentina, Centro Editor de América Latina, Buenos Aires.

PAEZ DE LA TORRE, Carlos (1987): Historia de Tucumán, Edit. Plus Ultra, Buenos Aires.

PETRAS, James (1993): "Clase, Estado y poder en el tercer mundo. Casos de conflictos de clases en América Latina". Fondo de Cultura Económica. Buenos Aires.

PETRAS, James (1999): "América Latina. De la globalización a la Revolución". Homo Sapiens Ediciones. Rosario.

PONZA, Pablo (2010): Intelectuales y violencia política 1955 1973, Editorial Babel, Córdoba.

POZZI, Pablo (2004): "Por las sendas argentinas...", El PRT-ERP, la guerrila marxista, Imago Mundi, Buenos Aires.

POZZI, Pablo y Schneider, Alejandro (2000): Los Setentistas, Izquierda y clase Obrera (1969 - 1976), EUDEBA, Buenos Aires. POZZI, Pablo (2008): La oposición obrera a la dictadura (1976 1983), Imago Mundi, Buenos Aires.

PUCCI, Roberto (2007): Historia de la destrucción de una provincia. Tucumán 1966, Ediciones del Pago Chico, Buenos Aires. 
ROMERO, Luis Alberto (1998): Breve Historia contemporánea Argentina. Fondo de Cultura Económica, Buenos Aires.

ROUQUIÉ, Alain (1990): Extremo Occidente. Introducción a América Latina. Ed. EMECE. Buenos Aires.

ROUQUIÉ, Alain Comp. (1982): "Argentina Hoy". Ed. Siglo XXI. México.

SADER, Emir y GENTILLI, Pablo Comps. (1999): "La trama del neoliberalismo. Mercado, crisis y exclusión social". Eudeba. Buenos Aires.

SERVETTO, Alicia (2010): 73/76, el gobierno peronista contra las "provincias montoneras", Edit. S XXI, Buenos Aires.

SURIANO, Juan Comp. (2005): Dictadura y democracia (1976 2001). Edit. Sudamericana, Buenos Aires.

TAIRE, Marcos (2008): El último grito. 1974: Crónica de la huelga de los obreros tucumanos de la FOTIA, Ediciones del Pago Chico, Buenos Aires.

TELES, Janaína (2000): Mortos e desaparecidos políticos: Reparaçao ou Impunidadade? Edit. Humanitas, São Paulo.

TORRADO, Susana (1992): "Estructura Social de la Argentina, 1945-1983". Ediciones la Flor. Buenos Aires.

VERBITSKY, Horacio (1986): "Ezeiza." Ed. Contrapunto. Buenos Aires.

VEZZETI, Hugo (2009): Sobre la violencia revolucionaria. Memorias y Olvidos, Edit. S XXI, Buenos Aires.

\section{DICTADURA Y TRANSICIÓN EN ARGENTINA}

AAVV (1987): La desaparición. Crimen contra la humanidad. APDH ediciones, Buenos Aires.

ÁGUILA, Gabriela (2008): Dictadura, represión y sociedad en Rosario, 1976/1983. Un estudio sobre la represión y los 
comportamientos y actitudes sociales en dictadura, Prometeo, Buenos Aires.

AIBAR, Julio (2005): El retorno del general. El Bussismo, la otra cara de la democracia, en Perfiles latinoamericanos No 26, Facultad Latinoamericana de Ciencias Sociales México.

ANDERLE, Ádám y GIRÓN, José Eds. (1997): "Estudios sobre transiciones democráticas en América Latina. Universidad de Oviedo, Oviedo.

ANDREOZZI, Gabriele Coord. (2011): Juicios por crímenes de Lesa Humanidad en Argentina, Edit. Cara o Ceca, Buenos Aires

ANGUITA, Eduardo (2001): Sano Juicio. Baltasar Garzón, algunos sobrevivientes y la lucha contra la impunidad en Latinoamérica. Edit. Sudamericana, Buenos Aires.

APDH (1987): La desaparición. Crimen contra la humanidad. Editada por APDH, Buenos Aires.

ARENDT, Hannah (2006): Entre el pasado y el futuro. Ocho ejercicios sobre la reflexión política, Ediciones Península, Barcelona.

ARENDT, Hannah (1998): La condición humana, Edit. Paidós, Barcelona.

ARENDT, Hannah (2002): Los orígenes del Totalitarismo T1: Antisemitismo. Edit. Alianza, Madrid.

ARENDT, Hannah (2002): Los orígenes del Totalitarismo T2: Imperialismo. Edit. Alianza, Madrid.

ARENDT, Hannah (2002): Los orígenes del Totalitarismo T3: Totalitarismo. Edit. Alianza, Madrid.

AVELLANEDA, Andrés (1986): Censura, autoritarismo y cultura: Argentina 1960-1983. Centro editor de América Latina, Bs. As.

BARQUET, Lucrecia y ADET, Raquel (2010): La represión en Salta (1970 - 1983). Testimonios y documentos, EUNSA, Salta. 
BAUD, Michiel (2001): "El padre de la novia. Jorge Zorreguieta, la sociedad argentina y el régimen militar". Ed. Fondo de Cultura Económica. Buenos Aires.

BIGNONE, Reynaldo (1992): "El último defacto. La liquidación del proceso. Memoria y Testimonio". Ed. Planeta. Buenos Aires.

BONASSO, Miguel (1994): "Recuerdo de la Muerte". Ed. Planeta. Buenos Aires.

BONASSO, Miguel (2000): "Diario de un Clandestino". Ed. Planeta. Buenos Aires.

BONAVENA, Pablo, MAAÑón Mariana y otros (1998): "Orígenes y desarrollo de la Guerra Civil en la Argentina, 1966-1976". Eudeba. Bs. As.

BOUSQUET, Jean Pierre (1994): Las Locas de la Plaza de Mayo. El Cid Editor. Buenos Aires.

CABRAL, David (1995): "Dictadura militar en Tucumán: terror de Estado y consenso social; efectos psicosociales (marzo diciembre, 1976). Mimeo.

CALVEIRO, Pilar (1998): Poder y desaparición. Los campos de concentración en Argentina, Edit. Colihue, Buenos Aires.

CALVO, Pablo (2011): Los mendigos y el tirano. Bussi y la emboscada a los vagabundos de Tucumán, Aguilar, Buenos Aires.

CANELO, Paula (2008): El proceso en su laberinto. La interna militar de Videla a Bignone, Prometeo - UNSAM, Buenos Aires.

CARABALLO, Liliana, CHARLIER, Noemí y GARULLI, Liliana (1998): La dictadura (1976 - 1983). Testimonios y documentos. EUDEBA, Buenos Aires.

CERRUTI, Gabriela (1997): "Herederos del silencio". Ed. Planeta, Bs. As..

CIANCAGLINI Sergio, GRANOVSKY Martín (1995): "Nada más que la verdad. El juicio a las Juntas. La guerra sucia desde el golpe hasta las autocríticas militares". Ed. Planeta. Buenos Aires. 
CRENZEL, Emilio (2001): Memorias Enfrentadas: El voto a Bussi en Tucumán, Colección Diálogos, Universidad Nacional de Tucumán, Tucumán.

CRENZEL, Emilio (2008): La historia política del Nunca Más. La memoria de las desapariciones en Argentina, Edit. S XXI, Buenos Aires.

D'ANDREA MOR, José Luis (1999): "Memoria Debida". Ed. Colihue, Buenos Aires.

DÍAZ COLODRERO, José y ABELLA Mónica (1987): Punto Final. Amnistía o voluntad popular. Puntosur Editores, Buenos Aires.

DRI, Rubén (2011): La hegemonía de los cruzados. La iglesia católica y la dictadura militar, Editorial Biblos, Buenos Aires.

FEINMANN, José P. (1998): "La sangre derramada. Ensayo sobre la violencia política". Ed. Ariel. Buenos Aires.

FERNÁNDEZ MEIJIDE, Graciela (1988): Las cifras de la guerra sucia. Editado por la Asamblea Permanente por los Derechos Humanos, Buenos Aires.

FERRARI, Germán (2009): Símbolos y Fantasmas. Las víctimas de la guerrilla: de la amnistía a la "justicia para todos", Edit. Sudamericana, Buenos Aires.

FINCHELSTEIN, Federico (2008): La Argentina fascista. Los orígenes ideológicos de la dictadura, Editorial Sudamericana, Buenos Aires.

FOUCALT, Michel (2003): Vigilar y Castigar. El nacimiento de la prisión. Edit. XXI, Buenos Aires.

GOÑI, Uki (1996): "La verdadera historia de Alfredo Astiz. El infiltrado." Ed. Sudamericana. Buenos Aires.

IZAGUIRRE, Inés Comp. (2010): Lucha de clases, Guerra civil y Genocidio en la Argentina 1973 - 1983. Antecedentes, desarrollo, complicidades. EUDEBA, Buenos Aires. 
JENSEN, Silvina Inés (2007): La provincia flotante. El exilio argentino en Cataluña (1976 - 2006), Edit. Casa Amèrica Catalunya, Barcelona.

KOTLER, Rubén Isidoro y SOSA, María Belén (1999): "El Movimiento de Rock Nacional durante el período de la Dictadura (1976-1983)". Inédito.

LABRUNE, Noemí (1988): Buscados. Represores del Alto Valle y Neuquén. Papeles Políticos, colección del Centro Editor de América Latina, Buenos Aires.

LAUDANO, Claudia Nora (1997): "Las mujeres en los discursos militares (1976-1983)". Papeles de Investigación, Ed. La Página S.A., Buenos Aires.

LEFRANC, Sandrine (2004): Políticas del perdón, Frónesis Cátedra PUV, Madrid.

LIDIA, Claudia, CRESPO Horario y YANKELEVICH, Pablo Comps (2007): Argentina, 1976. Estudios en torno al golpe de Estado. Fondo de Cultura Económica - Colegio de México, Buenos Aires.

LIPIS, Guillermo (2010): Zikarón - Memoria. Judíos y militares bajo el terror del Plan Cóndor, Edit. Del nuevo extremo, Buenos Aires.

LÓPEZ ECHAGÜE, Hernán (1991): El enigma del general Bussi: de la Operación Independencia a la Operación Retorno. Editorial Sudamericana, Buenos Aires.

LORENZETTI, Ricardo y KRAUT, Alfredo (2011): Derechos Humanos: justicia y reparación. La experiencia de los juicios en la Argentina, crímenes de Lesa Humanidad, Edit. Sudamericana, Buenos Aires.

MARCOS, Dolores (2005): Liderazgos autoritarios en el noroeste argentino: el caso Bussi en Tucumán, en Revista Reflexión Política, No 13, Universidad Autónoma de Bucaramanga, Colombia. 
MARCOS, Dolores (2006): Asedio a la democracia. Perfiles del autoritarismo en el NOA, Facultad de Filosofía y Letras de la UNT, Tucumán.

MARTÍN DE POZUELO, Eduardo y TARÍN Santiago (1999): "España Acusa". Ed. Plaza Janés. Barcelona.

MARTÍNEZ, Juán Carlos (1995): "La Abuela de Hierro. El reencuentro de Carla con la vida, el amor y la libertad." SERPAJ. Buenos Aires.

MIGNONE, Emilio (1999): Iglesia y Dictadura. Editorial de la Universidad Nacional de Quilmes y Edit. La Página, Buenos Aires.

MIGNONE, Emilio y CONTE MC DONNELL, Augusto (2006): Estrategia represiva de la dictadura militar. La doctrina del paralelismo global. Edit. Colihue, Buenos Aires.

MOREIRA ALVES, Maria Helena (1984): Estado e Oposiçao no Brasil (1964 - 1984). Edit. Vozes, Petrópolis.

MORENO, Sergio (1996): "La noche de los bastones largos, 30 años después". Ed. La Página. Buenos Aires.

NINO, Carlos (2006): Juicio al mal Absoluto. Edit. Ariel, Buenos Aires.

NOSIGLIA, Julio (1999): "Botín de guerra". Ed. La Página. Buenos Aires.

NOVARO, Marcos y PALERMO Vicente (2003): La Dictadura Militar 1976 / 1983. Del golpe de Estado a la restauración democrática. Edit. Paidós, Buenos Aires.

Nunca Más (1985): informe de la CONADEP. Eudeba, Bs. AS.

O'Donnell, Guillermo (2009): El estado burocrático autoritario, Prometeo, Buenos Aires.

O'Donnell, Guillermo y Schmitter, Philippe (2010): Transiciones desde un gobierno autoritario, Prometeo, Buenos Aires. 
OSZLAK, Oscar comp. (1984): "Proceso", crisis y transición democrática, T. 1, Centro Editor de América Latina, Buenos Aires.

OSZLAK, Oscar comp. (1984): "Proceso", crisis y transición democrática, T. 2, Centro Editor de América Latina, Buenos Aires.

PACHECO, Hernán y CARRERA, Pablo (2008): Los que no están. Desaparecidos y dictadura cívico - militar en Florencio varela (1976 - 1983), Dialektik, Avellaneda.

PEDRO, Joana M., SCHEIBE WOLF, Cristina y VEIGA, Ana María Comps. (2011): Resistencias, género y feminismos contra las dictaduras en el cono sur, Editora Mulheres, Florianópolis.

POZZI, Pablo (2007): La oposición obrera a la dictadura (1976 1982), Imago Mundi, Buenos Aires.

QUIROGA, Hugo (1994): El tiempo del proceso. Conflictos y coincidencias entre políticos y militares, 1976 - 1983. Editorial Fundación Ross, Buenos Aires.

ROCK, David (1991): "La Argentina Autoritaria. Los nacionalistas, su historia y su influencia en la vida pública". Ed. Ariel.

ROUQUIÉ, Alain (2011): A las sombras de las dictaduras. La democracia en América Latina, Fondo de Cultura Económica, Buenos Aires.

ROSEMBERG, Tina (1998): "Astiz: La estirpe de Caín." Ed. La página. Buenos Aires.

ROSENZVAIG, Eduardo (1993): "La Oruga sobre el pizarrón". Ediciones del Pensamiento Nacional. Buenos Aires.

ROSENZVAIG, Eduardo; Lobo, Horacio: "Quimeras y pesadillas." Ediciones Letra Buena, Bs. As., 1993.

VÁZQUEZ, Enrique (1985): PRN, La última: origen, apogeo y caída de la dictadura militar. EUDEBA, Bs. As., 1985.

VERBITSKY, Horacio (1995): "El vuelo". Editorial Planeta. Espejo de la Argentina. Buenos Aires. 
VEZZETTI, Hugo (2003): Pasado y Presente. Guerra, dictadura y sociedad en la Argentina, Siglo Veintiuno, Buenos Aires.

VINELLI, Natalia (2002): ANCLA, una experiencia de comunicación clandestina orientada por Rodolfo Walsh, Edit. La Rosa Blindada, Buenos Aires.

WALDMANN, Peter y GARZÓN VALDEZ, Ernesto Comp. (1983): "EI poder militar en la Argentina. 1976 - 1981. Ed. Galerna. Buenos Aires.

\section{DICTADURAS Y TRANSICIONES EN AMÉRICA LATINA}

AAVV (2010): Problemas de historia reciente del Cono Sur, Vol. I, Prometeo - UNGS, Buenos Aires.

BOHOSLAVSKY, E.; FRANCO M.; IGLESIAS, M. y LVOVICH, D. (2010): Problemas de historia reciente del Cono Sur, Vol. II, Prometeo - UNGS, Buenos Aires.

CARRIÓ, Alejandro (2008): Los crímenes del Cóndor. El caso Prats y la trama de conspiraciones entre los servicios de inteligencia en el Cono Sur, Edit. Sudamericana, Buenos Aires.

CHAVES PALACIOS, Julián comp. (2010): La larga memoria de la dictadura en Iberoamérica, Prometeo, Buenos Aires.

DUTRNIT BIELOUS, Silvia y VARELA PETITO, Gonzalo (2010): Tramitando el pasado. Violaciones de los derechos humanos y agendas gubernamentales en casos latinoamericanos, FLACSO CLACSO, Buenos Aires.

FEIERSTEIN, Daniel comp. (2009): Terrorismo de estado y Genocidio en América Latina, Prometeo - EDUNTREF, Buenos Aires.

MACDOWELL SANTOS, Cecília; TELES, Edson y DE ALMEIDA TELES, Janaína Comps (2009): Desarquivando a ditadura. Memória e Justiça no Brasil, Volume I, editora Hucitec, San Pablo 
MACDOWELL SANTOS, Cecília; TELES, Edson y DE ALMEIDA TELES, Janaína Comps (2009): Desarquivando a ditadura. Memória e Justiça no Brasil, Volume II, editora Hucitec, San Pablo.

MOREIRA ALVES, Maria Helena (2005): Estado e Oposição no Brasil, 1964 - 1984, EDUSC, San Pablo.

MOREIRAS, Alberto y RICHARD, Nelly Edits (2001): Pensar en la posdictadura, Edit. Cuarto Propio, Santiago, Chile.

POZZI, Pablo y PÉREZ, Claudio Edit. (2012): Historia oral e historia política. Izquierda y lucha armada em América Latina, 1960-1990, Universidad Academia de Humanismo Cristiano, LOM Ediciones, Santiago de Chile.

\section{MEMORIA}

AAVV (2003): Construcción de la Memoria. EUDEBA, Buenos Aires. AAVV (2004): Usos de la Historia y políticas de la Memoria. Edit. Prensas Universitarias de Zaragoza, Zaragoza.

CANDAU, Joël (2008): Memoria e Identidad, Ediciones del Sol, Buenos Aires.

CARNOVALE, Vera; LORENZ, Federico y PITTALUGA, Roberto comps. (2006): Historia, Memoria y Fuentes orales. Edits. Memoria Abierta y CEDINCI editores, Buenos Aires

CARRIZO, Raúl (1994): Elisabeth o sobre la justicia. Edición del Autor.

CARRIZO, Raúl (2005): Condición humana y enunciación ética. Su expresión en las prácticas y discursos de la Asociación Madres de Plaza de Mayo, Mimeo.

CHARTIER, Roger (1992): El mundo como representación. Historia cultural: entre práctica y representación, Edit. Gedisa, Barcelona. 
COLMEIRO, José (2005): Memoria histórica e identidad cultural. De la Postguerra a la Postmodernidad, Anthropos, Barcelona.

CRENZEL, Emilio (2001): "Memorias enfrentadas: el voto a Bussi en Tucumán, Colección Diálogos, Facultad de Filosofía y Letras de la Universidad Nacional de Tucumán.

CRENZEL, Emilio (2007): Dictadura y Desapariciones en Argentina: Memoria, conocimiento, $y$ reconocimiento del crimen, en Intersticios, Revista Sociológica de Pensamiento Crítico, Vol. 1, No 2, en www.intersticios.es

CRENZEL, Emilio (2008): Historia Política del Nunca Más. La memoria de las desapariciones en la Argentina, Edit. S. XXI, Buenos Aires.

CUESTA BUSTILLO, Josefina (1985): "La Historia del tiempo Presente: estado de la cuestión", en Estudia Histórica, Historia Contemporánea, Vol. 4, ediciones de la Universidad de Salamanca.

CUESTA BUSTILLO, Josefina (1996): "De la Memoria a la Historia", en Entre el pasado y el presente. Historia y memoria, Universidad Nacional de Educación a distancia, Madrid.

CUESTA BUSTILLO, Josefina Comp. (1998): Memoria e Historia, Colección Ayer, Madrid.

CUESTA BUSTILLO, Josefina (2008): La odisea de la Memoria. Historia de la memoria en España. S. XXI, Alianza Editorial, Madrid.

DALMASSO, María T. y BORIA, Adriana (1999): "El discurso social argentino. T. 1 Memoria: 70/90. Colección El Hijo del Discurso". Ed. Topo Grafía. Bs. As.

DE LA PEZA, María del Carmen comp. (2009): Memoria(s) y política. Experiencia, poéticas y construcciones de nación, Prometeo, Buenos Aires.

DEMARCHI, Marina y BROWARNIK, Graciela (1997): "Historias detrás de la puerta. Una exploración a través del universo de los 
secretos, de los silencios, de las medias palabras. 1976 -1982". Inédito.

DREIZIK, Pablo M. Comp. (2001): "La Memoria de las cenizas". Editado por la Dirección Nacional de Patrimonios, Museos y Artes. Buenos Aires.

FLEURY, Béatrice y WALTER, Jacques Comps. (2011): Memorias de la piedra. Ensayos en torno a lugares de detención y masacre, Ejercitar la Memoria Editores, Buenos Aires.

FRASER, Ronald (2007): Recuérdalo tú, y recuérdalo a otros. Historia oral de la guerra civil española, Edit. Crítica, Madrid.

HALBWACH, Maurice (2004): Los marcos sociales de la memoria. Edit. Anthropos, Barcelona.

JELÍN, Elizabeth (2002): "Los trabajos de la Memoria, Edit. Siglo XXI, Madrid.

JELÍN, Elizabeth, DA SILVA CATELA, Luzmila comps. (2002): "Los archivos de la represión: documentos, memoria y verdad. Edit. S. XXI, Madrid.

KORDON Diana y EDELMAN Lucila (2007): Por - Venires de la Memoria. Ediciones Madres de Plaza de Mayo, Buenos Aires.

KORDON, Diana y EDELMAN, Lucila y otros (1986): "Efectos psicológicos de la represión política". Ed. Sudamericana / Planeta. Buenos Aires.

LACAPRA, Dominick (2005): Escribir la historia, escribir el trauma, Nueva Visión, Buenos Aires.

LACAPRA, Dominick (2006): Historia en tránsito. Experiencia, identidad, teoría crítica, Fondo de Cultura económica, Buenos Aires.

LACAPRA, Dominick (2008): Historia y memoria después de Auschwitz, Prometeo - UNTREF, Buenos Aires.

LEVI, Primo (2005): Si esto es un hombre, Edit. El Aleph, Barcelona. 
MESSINA, Rina Comp. (2000): Donde anida la memoria. Reflexiones acerca del uso de las fuentes en la investigación histórica, Ferreyra Editor, Córdoba.

RICOEUR, Paul (2003): La memoria, la historia, el olvido, Edit. Trotta, Madrid.

SAMUEL, Rapahel (2008): Teatros de la Memoria, V. I. Pasado y presente de la cultura contemporánea, Universitat de Valencia, Valencia.

TRAVERSO, Enzo (2012): La historia como campo de batalla. Interpretar las violencias del S XX, Fondo de Cultura Económica, Buenos Aires.

TODOROV Tzvetan (2000): "Los abusos de la memoria". Editorial Paidós - Asterisco.

TODOROV Tzvetan (2002): Memoria del mal, tentación del bien. Indagación sobre el S XX, Edit. Península, Barcelona.

YERUSHALMI, Yosef (1998): Usos del olvido, Edit. Nueva Visión, Buenos Aires.

\section{HISTORIA ORAL Y METOdOLOGÍA}

AAVV (2005): VII Jornadas de Historia Oral y I Congreso Internacional de Historia Oral, CD Memoria de las jornadas.

AAVV: Entre la palabra y el texto. Problemas en la interpretación de fuentes orales y escritas, Colección de Antropología y Literatura, Madrid.

BARELA, Liliana, MIGUEZ, Mercedes, CONDE Luis García (1999): Algunos apuntes sobre historia oral. Publicación del Instituto Histórico de la Ciudad de Buenos Aires. Buenos Aires.

BENADIBA, Laura (2007): Historia Oral, Relatos y Memoria. Edit. Maipue, Buenos Aires. 
CARNOVALE, Vera, LORENZ, Federico y PITTALUGA, Roberto comps. (2006): Historia, Memoria y Fuentes orales. Edits. Memoria Abierta y CEDINCI editores, Buenos Aires.

CERNADAS, jorge y LVOVICH, Daniel Comps. (2010): Historia ¿Para qué? Revisitas a una vieja pregunta, Prometeo - UNGS, Buenos Aires.

FOLGUERA, Pilar: Cómo se Hace Historia Oral, Eudema.

FRANCO Marina y LEVÍN Florencia Comps. (2007): Historia Reciente. Perspectivas y desafíos para un campo en construcción, Paidós, Buenos Aires.

GALASSO, Giuseppe (2001): Nada más que historia. Teoría y Metodología. Edit. Ariel, Barcelona.

HOBSBAWM, Eric (1998): Sobre la Historia, Edit. Crítica, Barcelona.

LARA MESA, Ada Marina; MACÍAS G. Felipe y CAMARENA O. Mario coords. (2011): Los oficios del historiador. Taller y prácticas de la Historia Oral, Universidad de Guanajuato, México.

LLONA, Miren Coord. (2012): Entreverse. Teoría y metodología práctica de las fuentes orales, Argitalpen Zerbitzua Servicio Editorial, Gipuzkoa.

MESSINA, Rina Comp. (2000): Donde anida la memoria. Reflexiones acerca del uso de las fuentes en la investigación histórica, Ferreyra Editor, Córdoba.

MORAES FERREIRA, Marieta y AMADO, Janaína Comps. (2010): Usos y abusos da história Oral, Fundación Getulio Vargas Editora, Río de Janeiro.

NECOECHEA, Gerardo y POZZI Pablo (2008): Cuéntame cómo fue. Introducción a la historia oral, Imago Mundi, Buenos Aires.

PASQUALI, Laura Comp (2008): Historia social e historia oral. Experiencias en la historia reciente de Argentina y América Latina, Edic. Homo Sapiens, Rosario. 
PORTELLI, Alessandro (2004): La orden ya fue ejecutada. Roma, las Fosas Ardeatinas, la Memoria, Fondo de Cultura Económica, Buenos Aires.

SCHWARTZEIN, Dora Comp. (1991): "La Historia Oral". Colección, Los fundamentos de las Ciencias del Hombre. Centro Editor de América Latina. Buenos Aires.

SEGURA GRAIÑO, Cristina edit. (1993): La Voz del silencio II. Historia de las mujeres: Compromiso y método, Asociación Cultural AL-MUDAYNA, Madrid.

THOMPSON, Paul (1988): Historia Oral, Edicions Alfons el Magnánim, Valencia.

VALLES, Miguel (1997): Técnicas Cualitativas de Investigación Social, Edit. Síntesis, Madrid.

WILLIAMS, Raymond (1997): Marxismo y Literatura, Ediciones Península, Barcelona. 